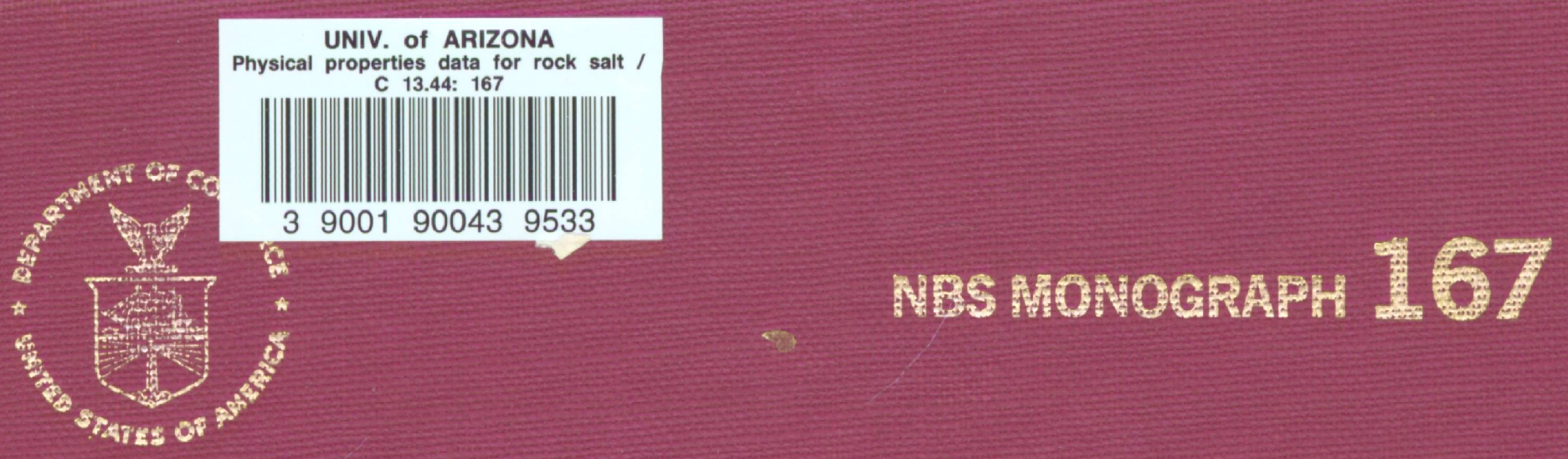

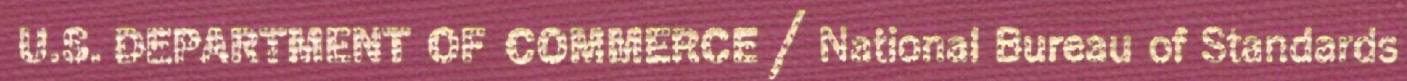
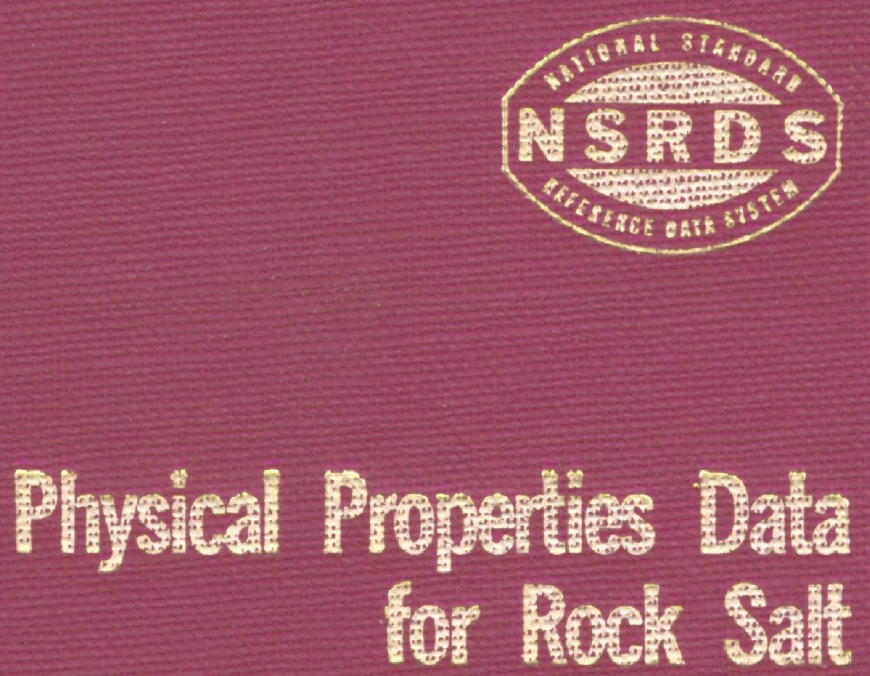
$1 / 3.44$
167

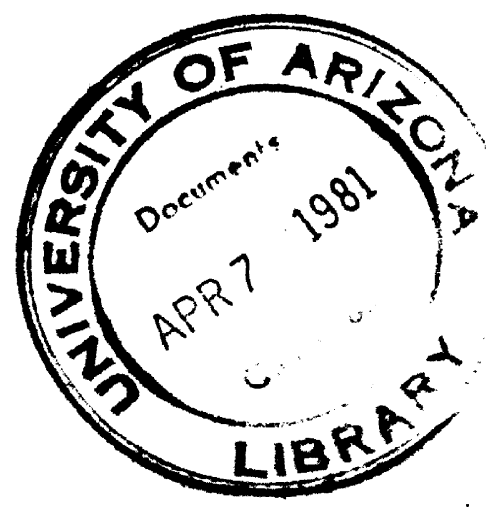




\section{$C, 3,44$ $16>$ estata.}

Errata Sheet to accompany NBS Monograph 167

Physical Properties Data for Rock Salt

L. H. Gevantman, Editor

Page 232, left-hand column, line 20:

Eq. 5.4 should be replaced by $\underline{5.19}$

line 32:

$\checkmark$ substitute absorption coefficient for absorption index.

line 37 (in table):

$\checkmark$ Change eq. 5.3 to 5.18

line 39 (in table):

$\checkmark$ Change eq. $\underline{5.4}$ to $\underline{5.19}$

Page 233, Figure 5.4

Title of figure should be

Experimental Absorption Coefficient of Rock Salt

ordinate title should be

$\mathrm{V}$

done $4 / 22 / 81$

SITY OF

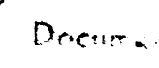

Deene.

(1) $1: 1981$

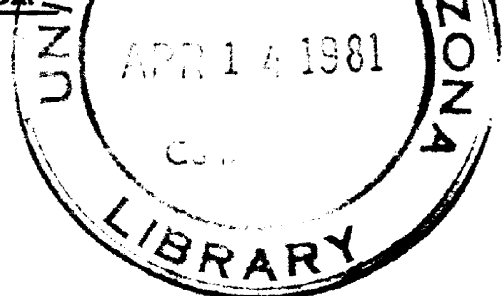




\section{Physical Properties Data for Rock Salt}

\section{H. Gevantman, Editor}

National Bureau of Standards

Washington, D.C. 20234

J. Lorenz, J. L. Haas, Jr., M. A. Clynne, R. W. Potter, II, and C. M. Schafer

National Center for the Thermodynamic Data of Minerals

U.S. Department of the Interior, Geological Survey

Reston, Virginia 22092

J. L. Haas, Jr., Director

R. P. T. Tomkins

New Jersey Institute of Technology

Newark, New Jersey 07102

in association with

Molten Salts Data Center

Rensselaer Polytechnic Institute

Troy, New York 12181

G. J. Janz, Director

A. Shakoor, H. R. Hume, J. M. Yang, H. H. Li, and R. A. Matula

Center for Information and Numerical Data Analysis and Synthesis

Purdue University

West Lafayette, Indiana 47906

Y. S. Touloukian, Director

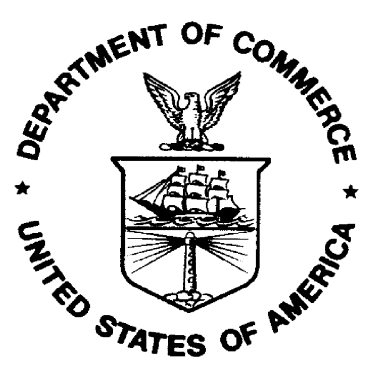

U.S. DEPARTMENT OF COMMERCE, Philip M. Klutznick, Secretary

Luther H. Hodges, Jr., Deputy Secretary

Jordan J. Baruch, Assistant Secretary for Productivity, Technology, and Innovation NATIONAL BUREAU OF STANDARDS, Ernest Ambler, Director 


\section{Library of Congress Cataloging in Publication Data}

Main entry under title:

Physical properties data for rock salt.

(National Bureau of Standards monograph; 167)

Supt. of Docs. no.: C 13.44:167

1. Rock-salt-Handbooks, manuals, etc.

2. Radioactive waste disposal in the ground-Handbooks, manuals, etc. I. Gevantman, L. H. II. Series: United States. National Bureau of Standards

Monograph: 167

QC100.U556 no. 167 [TN900] 602'.18s

[620.1'98]

$80-607096$

\section{National Bureau of Standards Monograph 167}

Nat. Bur. Stand. (U.S.), Mono. 167, 288 pages (Jan. 1981)

CODEN: NBSMA6

\section{U.S. GOVERNMENT PRINTING OFFICE}

WASHINGTON: 1981

For sale by the Superintendent of Documents, U.S. Government Printing Office, Washington, D.C. 20402 Price \$12. (Buckram)

(Add 25 percent for other than U.S. mailing) 


\section{Preface}

The Office of Standard Reference Data of the National Bureau of Standards is responsible for a broad-based program to provide reliable physical and chemical reference data to the U.S. technical community. Under this program a number of data evaluation centers both at NBS and at universities and other private institutions are supported and coordinated; these activities are collectively known as the National Standard Reference Data System (NSRDS). Important areas of the physical sciences are covered systematically by NSRDS data centers, and data bases with broad utility are prepared and disseminated. These centers can also take on special compilations of data addressing specific applications such as those frequently required by other Federal Agencies in carrying out their mission responsibilities. The existence of an ongoing program permits the collection of data for these special compilations to be carried out in an efficient and timely manner.

This Monograph on Properties of Rock Salt was prepared by the Office of Standard Reference Data in response to needs of the Department of Energy for reliable data in connection with nuclear waste disposal. The resources and experience of several NSRDS data centers were enlisted to produce a compilation of the various relevant properties of rock salt. We hope that the Monograph will be a useful source of reference data and serve as a model for other compilations of data required by Government agencies and private institutions.

David R. Lide, Jr., Chief

Office of Standard Reference Data 


\section{Acknowledgement}

I wish to acknowledge the sponsorship and financial support of the Office of Nuclear Waste Isolation and to thank Dr. G. Raines for his sound advice and support. I also appreciate the individual efforts of Drs. W. C. McClain and J. E. Russell, formerly of that office, for their encouragement and support during the execution of this project. I also wish to thank the individual authors for their technical contributions and Drs. Y. S. Touloukian, G. J. Janz, and J. L. Haas, $\mathrm{Jr}$., for their aid and cooperation in making available the facilities of their individual data centers to the authors. The efforts of Dr. D. Isherwood and her colleagues who served as technical reviewers are gratefully acknowledged. Finally, I deeply appreciate the assistance of Mrs. M. E. Schlager, of the Office of Standard Reference Data, who helped me with all of the many tasks leading to the publication of this Monograph.

L. H. Gevantman 


\section{Contents}

Preface

D. R. Lide, Jr., Office of Standard Reference Data, National Bureau of Standards,

W ashington, DC 20234

Acknowledgement

Introduction

L. H. Gevantman, Office of Standard Reference Data, National Bureau of Standards,

Washington, DC 20234

Chapter 1. Geology, Mineralogy, and Some Geophysical and Geochemical Properties of Salt Deposits ...

J. L. Haas, Jr., J. Lorenz, M. A. Clynne, R. W. Potter, II, and C. M. Schafer.

United States Department of the Interior Geological Survey, Reston, VA 22092

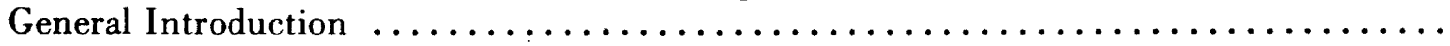

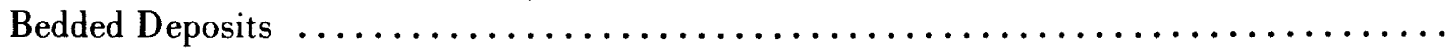

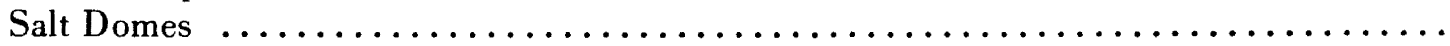

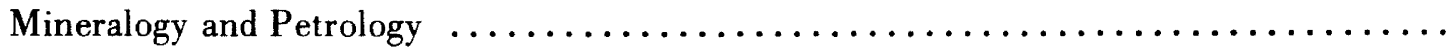

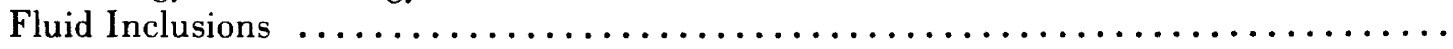

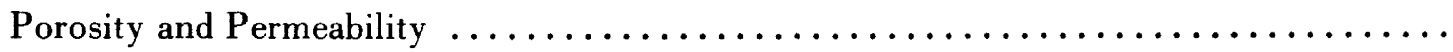

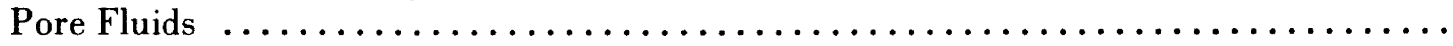

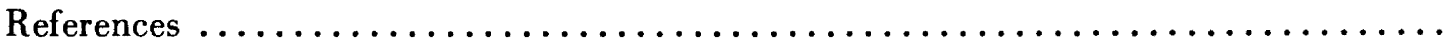

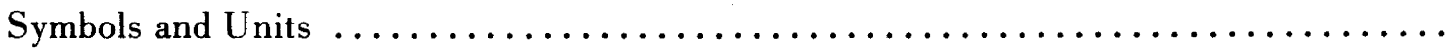

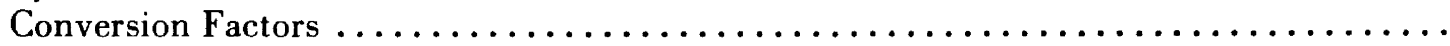

Chapter 2. Physical and Chemical Properties of Components in Salt Deposits ............. 45

R. P. T. Tomkins. New Jersey Institute of Technology, Newark, NJ 07102

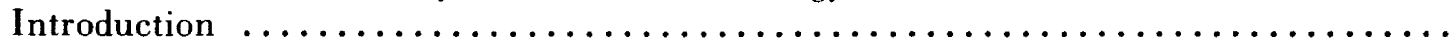

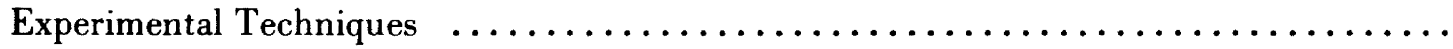

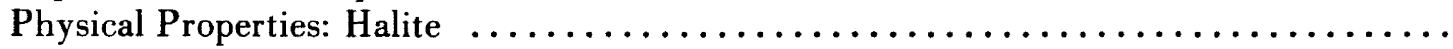

Physical Properties of Major Impurities in Halite $\ldots \ldots \ldots \ldots \ldots \ldots \ldots \ldots \ldots \ldots \ldots \ldots$

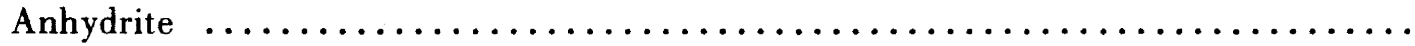



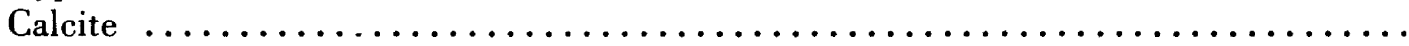

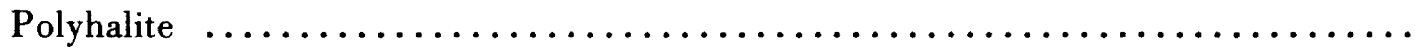

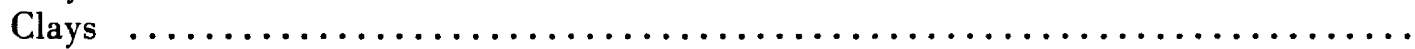

Chemical Properties Among Components in Salt Deposits $\ldots \ldots \ldots \ldots \ldots \ldots \ldots \ldots$

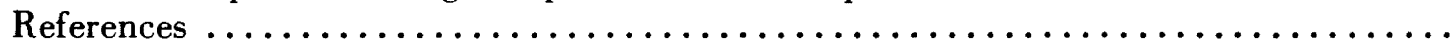

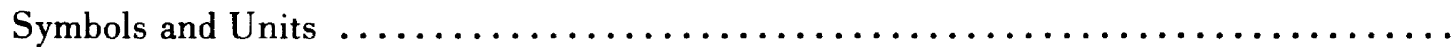

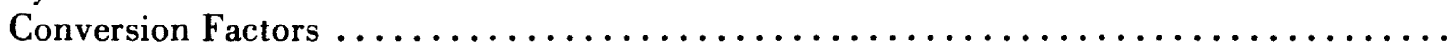

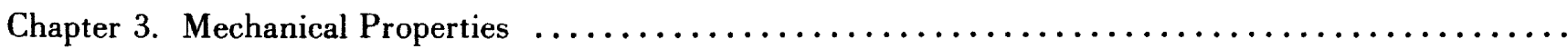

A. Shakoor and H. R. Hume. Center for Information and Numerical Data Analysis and Synthesis, Purdue University, West Lafayette, IN 47906

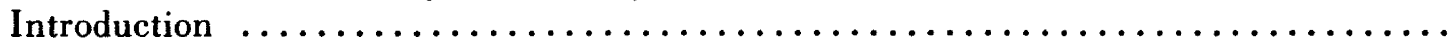

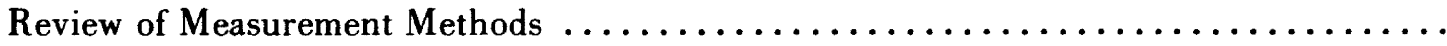

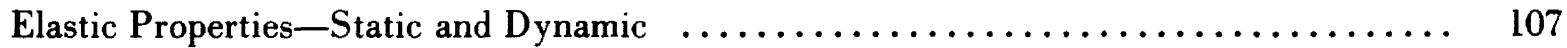

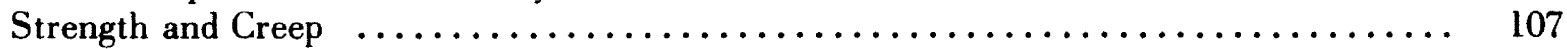

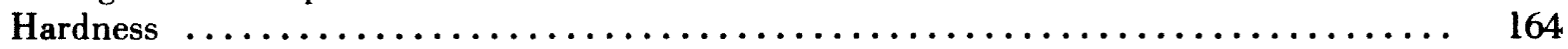

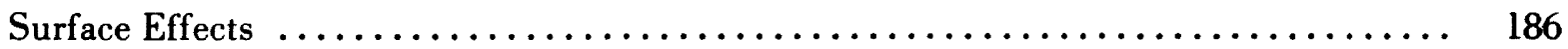

Effect of Nuclear Irradiation on Mechanical Properties of Rock Salt $\ldots \ldots \ldots \ldots \ldots \ldots$

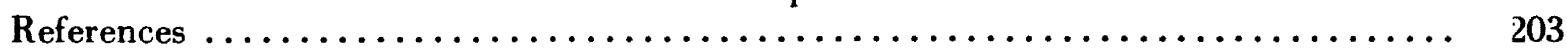

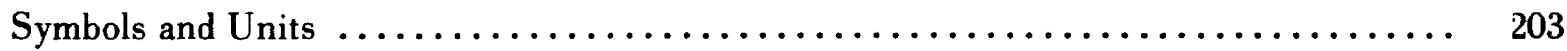

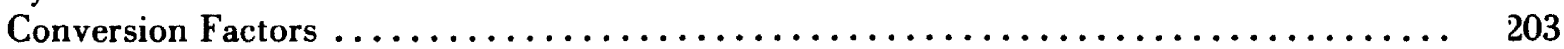




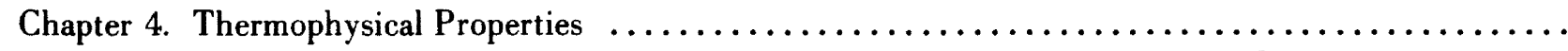

J. M. Yang. Center for Information and Numerical Data Analysis and Synthesis,

Purdue University, West Lafayette, IN 47906

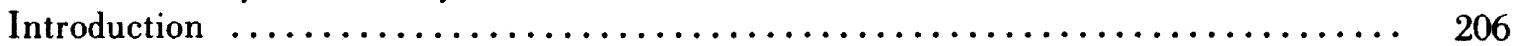

Review of Measurement Methods for Thermophysical Properties $\ldots \ldots \ldots \ldots \ldots \ldots \ldots 206$

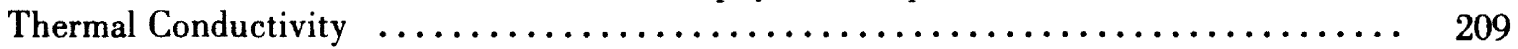

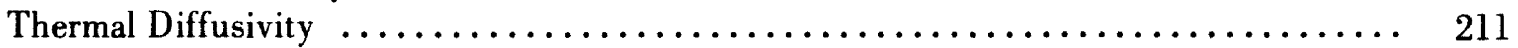

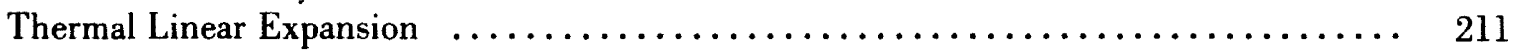

Effect of Nuclear Irradiation on Thermophysical Properties $\ldots \ldots \ldots \ldots \ldots \ldots \ldots \ldots \ldots, 212$

References ............................................ 217

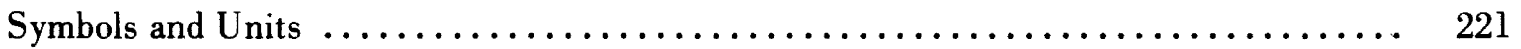

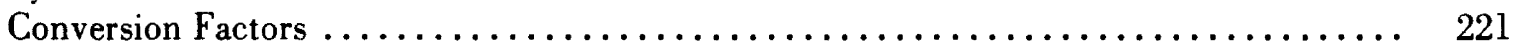

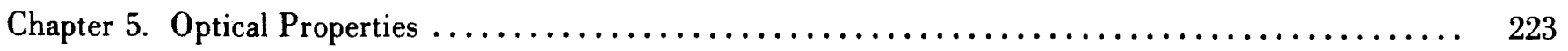

H. H. Li. Center for Information and Numerical Data Analysis and Synthesis,

Purdue University, West Lafayette, IN 47906

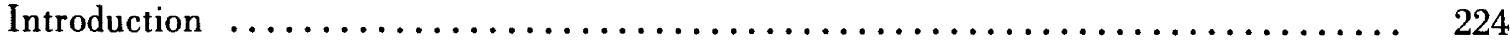

Measurement Methods for Optical Properties ......................... 224

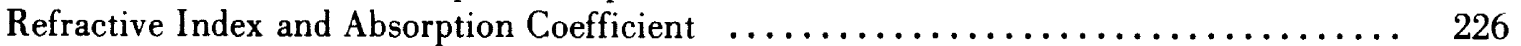

Effect of Nuclear Irradiation on the Optical Properties .................... 232

References ........................................... 238

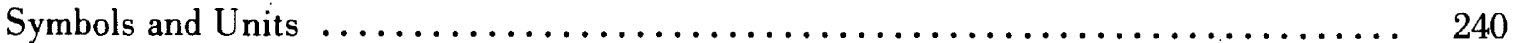

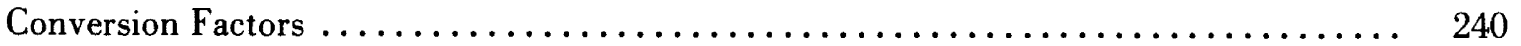

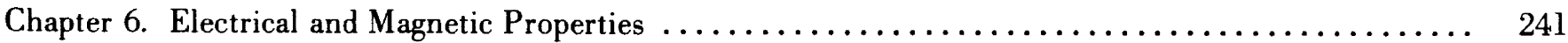

R. A. Matula. Center for Information and Numerical Data Analysis and Synthesis,

Purdue University, West Lafayette, IN 47906

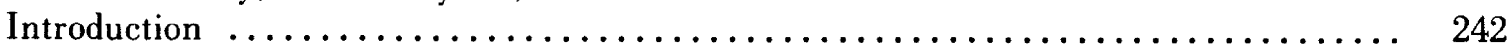

Methods of Measuring Electrical and Magnetic Properties $\ldots \ldots \ldots \ldots \ldots \ldots \ldots \ldots . \ldots . \ldots 242$

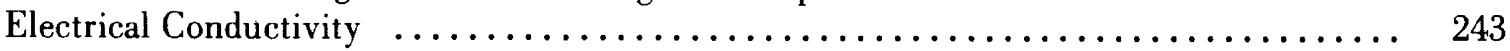

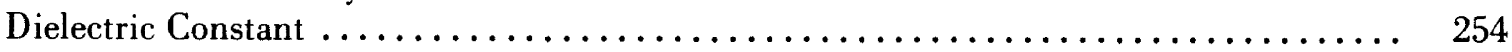

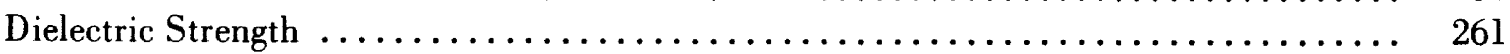

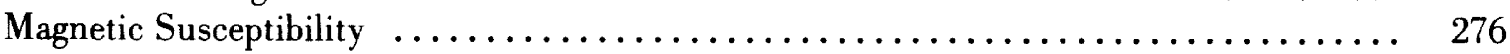

Effect of Nuclear Irradiation on Electrical and Magnetic Properties ............ 276

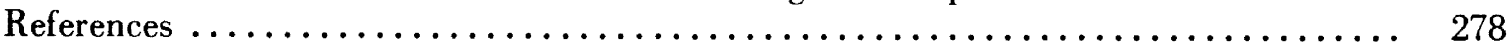

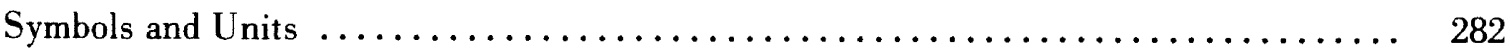

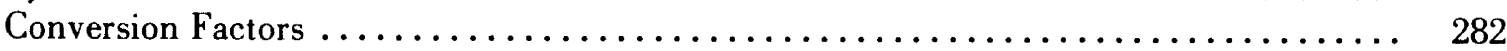




\title{
Physical Properties Data for Rock Salt
}

\author{
L. H. Gevantman, Editor \\ Office of Standard Reference Data, National Bureau of Standards, Washington, D.C. 20234
}

\begin{abstract}
Rock salt and pure sodium chloride properties data are assembled into a single source. The properties covered include geological, mechanical, optical, thermal, radiation damage, electrical, magnetic, chemical, and physical. A concerted attempt has been made to present the best data consistent with their availability in the literature. Recommended values for data are given where possible. A brief discussion of measurement techniques is included for each property.
\end{abstract}

Key words: Chemical; electrical; geological; monograph; magnetic; mechanical; optical; physical; properties data; radiation damage; rock salt; sodium chloride.

\section{Introduction}

This effort was begun at the direction of the Office of Waste Isolation (OWI), Oak Ridge National Laboratory, Department of Energy, ${ }^{*}$ to answer a pressing need for a single source of data on rock salt properties. This need arose from the possibility that rock salt deposits provide an acceptable medium for the permanent storage of high level radioactive wastes. While a considerable body of data exists in the literature [references $1,2,3$, and 4] on the physical properties of rock salt, it is not readily available in a single, easily identified source. Nor are the data in a form that permits designers of waste burial facilities to extract the variety of numerical values for use with any degree of confidence in these values. As a consequence, the Office of Standard Reference Data (OSRD) was asked to undertake a data evaluation project which would produce a data book on rock salt properties. These data also were to be evaluated, wherever possible, for reliability consistent with the measurement state-ofthe-art.

While the principal reasons for assembling this Monograph are nuclear-waste-storage inspired, the data for most of the properties cited would also apply to the burial of other types of waste where long-term stable facilities are required. It is intended that the data will serve as a source of generalized information to the salt industry. No attempt is made to argue the advantages or disadvantages for burial of nuclear wastes in rock salt formations. Such discussions are available elsewhere [references 5, 6, and 7].

\footnotetext{
* This project was funded in part by the Office of W aste Isolation, Oak Ridge National Laboratory, Department of Energy.

Now the Office of Nuclear Waste Isolation, Battelle Memorial Institute, 505 King Avenue, Columbus, Ohio 43201.
}

\section{History of the Project}

In organizing and defining the scope of this project the Office of Standard Reference Data recognized the need for two types of input. One was the viewpoints and criteria for information as represented by the sponsor. The second was the need for expertise in data assembly and evaluation, particularly the specific properties of interest. It was therefore the Office's role to bring these functions together to implement the project. In the first instance, the OSRD was fortunate in having excellent representation and advice from the Office of Nuclear Waste Isolation, which furnished an outline of the properties desired. After some consultation the OSRD was able to identify and designate three data centersthe Center for Information and Numerical Data Analysis and Synthesis (CINDAS), the Molten Salts Data Center, and the National Center for Thermodynamic Data of Minerals-to evaluate the data. An ad hoc committee, consisting of representatives from the Office of Standard Reference Data, the Office of Nuclear W aste Isolation, and each of the data center designates, met and reviewed the outline of the physical properties data to be contained in the Monograph. After some minor changes, work assignments based on the final version of the outline were distributed, and the work got under way. The OSRD assumed full responsibility for coordinating the efforts and for assembling and publishing the final product.

\section{Monograph Organization}

The Monograph is in six chapters covering the geological, mechnical, optical, thermal, radiation damage, electrical, magnetic, chemical, and physical properties of rock salt and pure $\mathrm{NaCl}$. Each chapter has been written by a different author, or authors, consistent with 
his field of expertise. Some attempt at uniformity of presentation has been made not only in the order of presentation of the data but also in content. In some instances exchanges of data among data centers have taken place so that the data given in one chapter also represent the efforts of other center contributors.

In general, each chapter attempts to present the best data available on the subject property in both tabular and graphic form. Wherever possible, recommended values and error limits are given. If this is not possible because the data are in disarray or are insufficient for subject judgment, a full review of the useful data and a rationale for working with the data are presented. Experimental methods for data measurement are given in brief form with precision limits on the measurement capability where possible. Brief reviews of error analysis are also included where applicable. In sum, every aspect of the particular property has been compiled, evaluated, and recorded when the data are available from the literature. The lack of a recommended value means the data are either lacking or too imprecise to permit evaluation. Nevertheless it is felt that a useful attempt has been made to present the better data now available in a single source.
As in all publications of this type, errors and omissions of one kind or another are bound to occur. Corrections and additions to the data by readers are solicited.

\section{References}

[1] Kaufman, D.W., Ed., "Sodium Chloride, the Properties of Salt and Brine," ACS Monograph Series, Reinhold Publishing Corporation, New York (1960).

[2] "The Sterling Brine Handbook," International Salt Comparıy, (1972).

[3] Potter, K.W., II, Babcock, R.S., and Brown, D.L., J. Res., U.S. Geological Survey, 5, 389, 1977.

[4] Stull, D.R. and Prophet, H., Ed., JANAF Thermochemical Tables, 2nd Edition, NSRDS-NBS 37, June, 1971.

[5] Bradeholft, J.D., England, A.W., Stewart, D.B., Trask, N.J., and Winograd, I.J., "Geologic Disposal of High Level Radioactive Waste-Earth Science Perspective," U.S. Geological Survey Circular 779, 1978.

[6] "Subgroup Report on Alternative Technology Strategies for the Isolation of Nuclear W aste," Interagency Review Group, TID 28818 (Draft), October 1978.

[7] "State of Geological Knowledge Regarding Potential Transport of High Level Radioactive Waste from Deep Continental Repositories," The Ad-Hoc Panel of Earth Sciences, EPA/520/4-78-004, June 1978. 


\title{
Chapter 1
}

\section{Geology, Mineralogy, and Some Geophysical and Geochemical Properties of Salt Deposits}

\author{
John Lorenz*, John L. Haas, Jr. ${ }^{*}$, Michael A. Clynne**, Robert W. Potter, II**, and Constance M. Schafer*
}

\section{Contents}

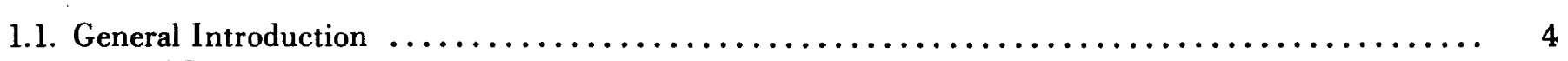

1.2. Bedded Deposits $\ldots \ldots \ldots \ldots \ldots \ldots \ldots \ldots \ldots \ldots \ldots \ldots \ldots \ldots \ldots \ldots \ldots \ldots \ldots \ldots \ldots \ldots \ldots \ldots, 4$

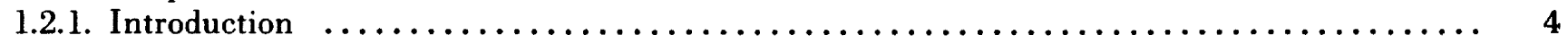

1.2.2. Depositional Models $\ldots \ldots \ldots \ldots \ldots \ldots \ldots \ldots \ldots \ldots \ldots \ldots \ldots \ldots \ldots \ldots \ldots \ldots \ldots \ldots \ldots \ldots$

1.2.3. The Precipitation Sequence Predicted from Sea $\mathbb{W}_{\text {ater }} \ldots \ldots \ldots \ldots \ldots \ldots \ldots \ldots \ldots \ldots \ldots \ldots$

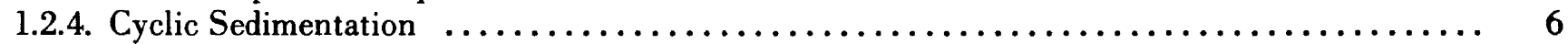

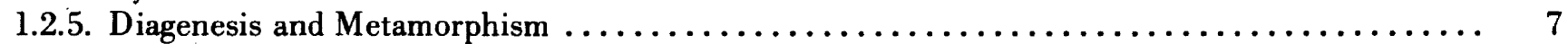

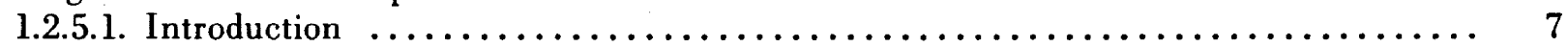

1.2.5.2. Dynamic metamorphism $\ldots \ldots \ldots \ldots \ldots \ldots \ldots \ldots \ldots \ldots \ldots \ldots \ldots \ldots \ldots \ldots$

1.2.5.3. Thermal metamorphism $\ldots \ldots \ldots \ldots \ldots \ldots \ldots \ldots \ldots \ldots \ldots \ldots \ldots \ldots \ldots \ldots \ldots$

1.2.5.4. Solution metamorphism $\ldots \ldots \ldots \ldots \ldots \ldots \ldots \ldots \ldots \ldots \ldots \ldots \ldots \ldots \ldots \ldots$

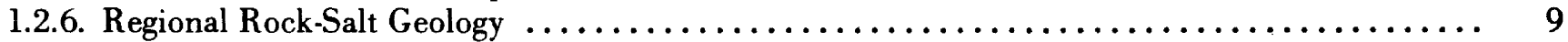

1.2.7. The variability within Salt Beds $\ldots \ldots \ldots \ldots \ldots \ldots \ldots \ldots \ldots \ldots \ldots \ldots \ldots \ldots \ldots \ldots \ldots$

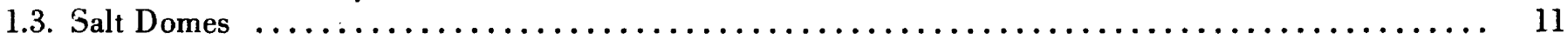

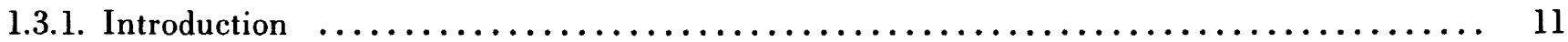

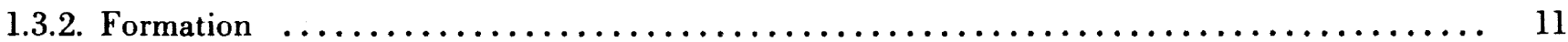

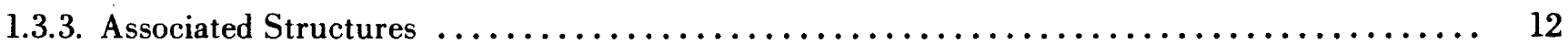

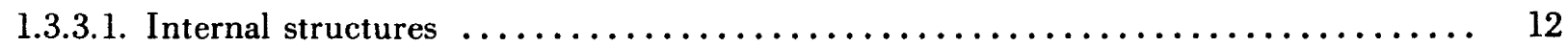

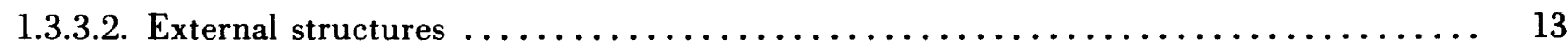

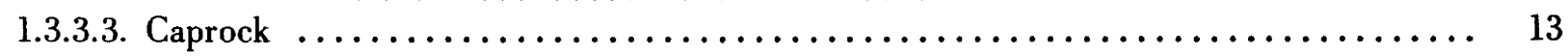

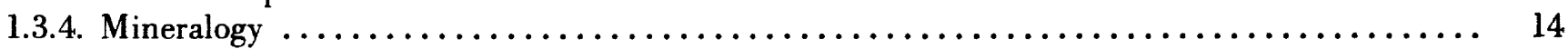

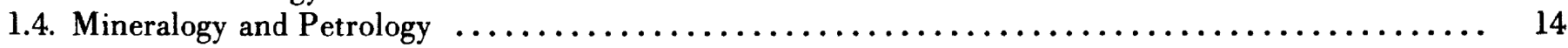

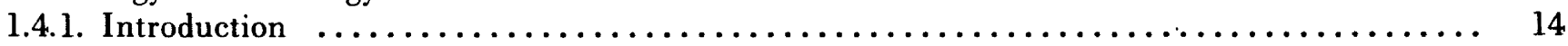

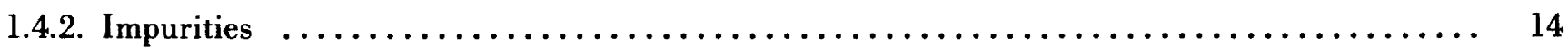

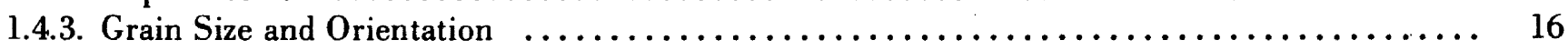

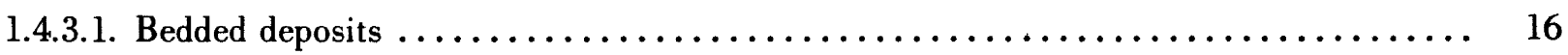

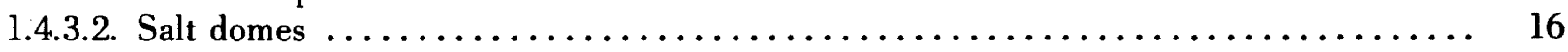

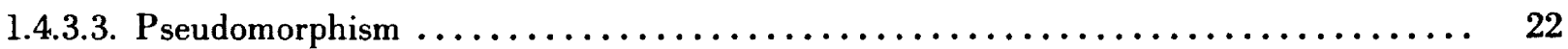

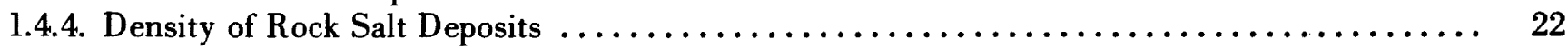

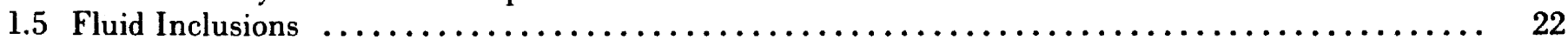

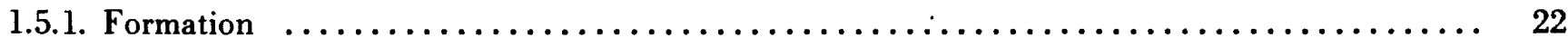

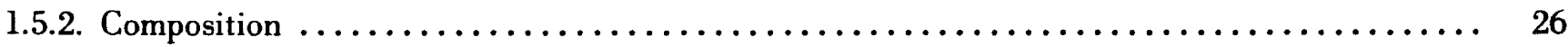

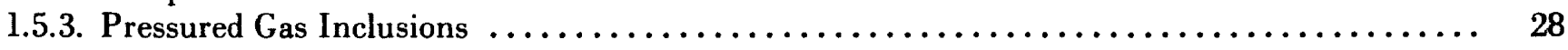

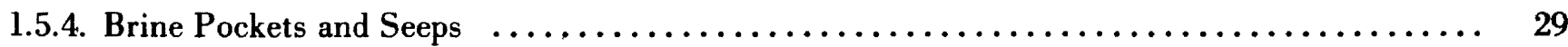

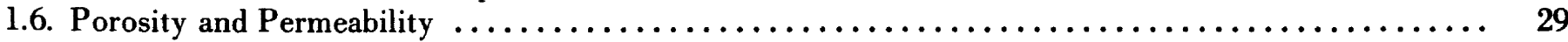

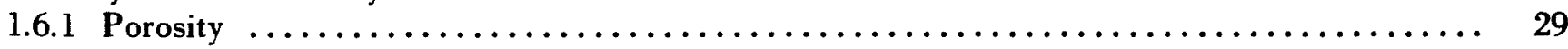

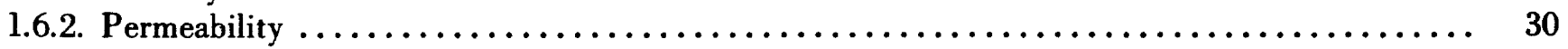

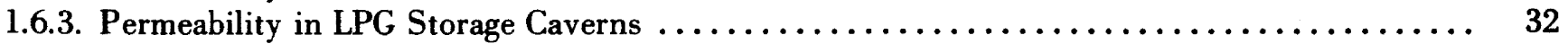

*U.S. Geological Survey, Reston, VA 22092.

**Occidental Research Corporation, Irvine, CA 92713. 


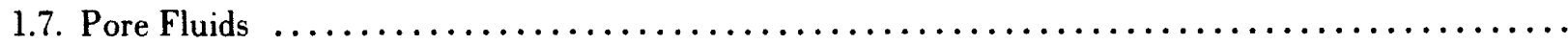

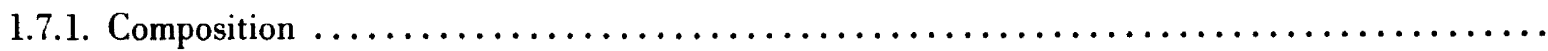

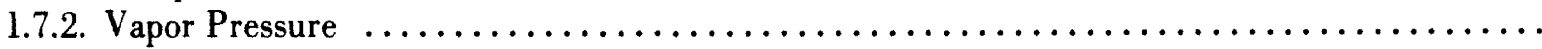

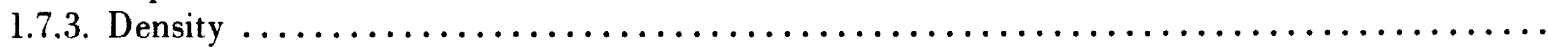

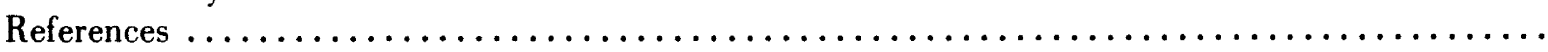

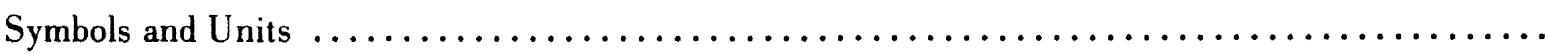

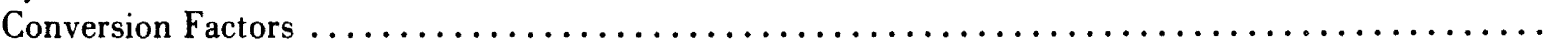

\subsection{General Introduction}

Rock salt is a coarsely crystalline, sedimentary rock containing massive, fibrous, or granular aggregates. Rock salt occurs in extensive beds, or in domes and plugs. Rock salt is the result of evaporation of saline water and is a member of a suite of related rocks, the evaporite series. Rock salt is dominantly halite, but other minerals are present such as calcite, dolomite, anhydrite, gypsum, and potash minerals. (Potash is an industrial term for the complex potassium and magnesium evaporites. A more complete list of minerals commonly found in evaporite deposits is given in chapter 2.) These minerals may be deposited contemporaneously in adjacent parts of a basin. The mineralogy is dependent on variations in topography, water depth, salinity, and other factors. Because these factors can change during geologically short periods of time, beds of different evaporite minerals overlie and overlap each other in sequences reflecting the changes in equilibrium that occur locally during the subsidence and sedimentary filling of basins.

Given the right conditions, halite can be the dominant mineral that accumulates. Halite, the chloride of sodium $(\mathrm{NaCl})$, can form rare, pure beds as much as 80 meters thick. Once deposited and buried by succeeding layers of sediments, halite and associated minerals are susceptible to a variety of changes brought about by the effects of the elevated temperatures and pressures that are found at depths. Beside actual changes in mineralogy of the accessory minerals, the most dramatic changes are due to the lowered viscosity of halite and the increased contrast between its density and that of the surrounding sediments. Deeply buried salt commonly forms diapirs (domes or anticlinal folds, the overlying rocks of which have been bent or ruptured by the squeezing out of the plastic core) $1-6$ kilometers in diameter by flowing plastically from original bedding horizons up thousands of meters through the sediments and sometimes to the surface.

Some of the characteristics of rock salt deposits change when the rock salt flows into domes. Domes contain generally purer halite, and rock salts in domes lose most of their primary sedimentary structures. Fluid inclusions in domed rock salt are more apt to contain foreign substances, such as oil. Other characteristics of rock salt, specifically porosity and permeability, do not necessarily change on intrusion. Both porosity and permeability are minimal in bedded and diapiric rock salt deposits. Salt domes are discussed more fully in section 1.3 below.

Thick halite and associated evaporite deposits are found in four large sedimentary basins in the United States (figure 1.1). Several smaller deposits exist, and the major deposits themselves can be subdivided by age and stratigraphy. Primary sedimentary thickness of the deposits ranges from some 1300 to $1400 \mathrm{~m}$ in the Ochoan evaporite sequence of Permian age (see Appendix 1.1 for geologic time scale) [1] in the Delaware basin of Texas and New Mexico [2] to surficial veneers now being deposited in the playa lakes of the western States. Diapiric rock salt is found only in the Gulf Coast area, though secondary thickening at the crests of anticlines has been described in the Paradox basin in Utah.

\subsection{Bedded Deposits}

\subsubsection{Introduction}

Ionic ratios suggest that most salt deposits were originally derived from evaporated sea water. Average sea water contains $38,450 \mathrm{ppm}$ (parts per million) dissolved solids, of which about three quarters will precipitate as halite on evaporation. The evaporation rate of water is a function of the temperature of both the air and the water and of such things as the turbulence of the water surface. The rate of evaporation decreases as salinity of the remaining brine increases. In addition, Kinsman [3] has indicated that, for the precipitation of halite, the relative humidity must be less than 76 percent and, for the potash minerals, less than 67 percent. Most ancient evaporite deposits are formed in warm and arid climates. Another common feature of rock salt deposits is that they contain very little silt, sand, or other coarse, granular sediment; apparently only small amounts of these sediments were supplied to the basin during the evaporation of the brine. Such impurities as are found 


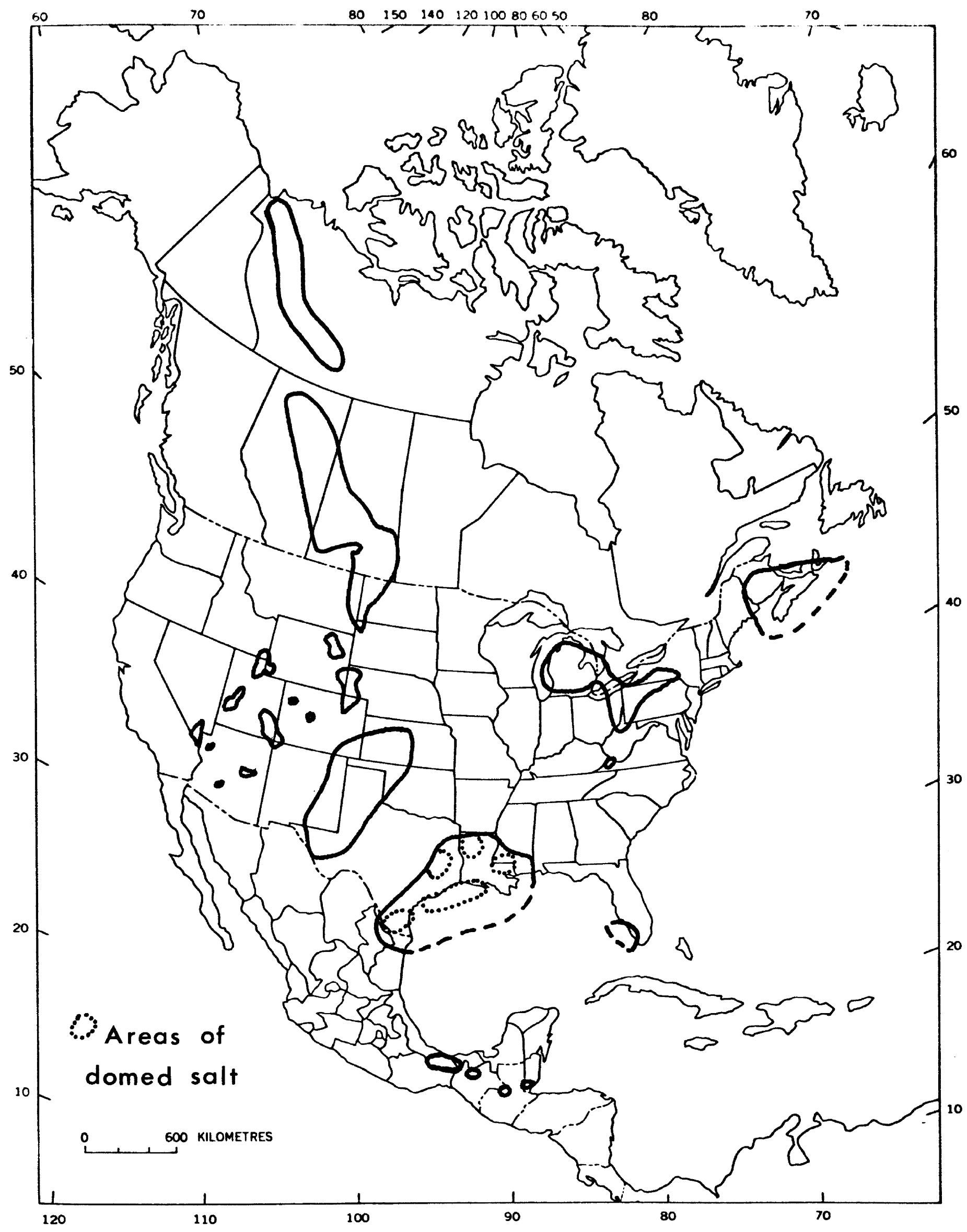

FIGURE 1.1 Areas of rock-salt deposits in North America. Modified from [140, 141]. 
are usually clay sized and are rarely larger than silt. The rate of supply of the fine-grained debris relative to the rate of accumulation of the chemical precipitates is also low for the beds of rock salt.

\subsubsection{Depositional Models}

Probably the most widely accepted theory to explain formations of bedded rock salt has been the "bar theory" originally proposed by Ochsenius [4]. This model in its simplest form hypothesizes an arm of the sea in which circulation is restricted (by a bar, ridge, or reef across the mouth); water in the arm is concurrently evaporated and replenished, and its dissolved salt is precipitated into basin-wide beds (figure 1.2). A large number of observed primary sedimentary structures in evaporites may be explained by this model: clay-filled desiccation cracks, ripple marks, and crossbedding in halite [5]; the presence of preferentially oriented hopper crystals [6]; dissolution horizons, unconformities, and halite conglomerates [7]; and cyclic deposition.

A variation on this model that has gained many adherents is Scruton's hypothesis [8] of constant water volume in a basin and reflux of final-stage brines to the sea (figure 1.3). This theory, which may have a modern analog in the Gulf of Kara Bogaz off the Caspian Sea, involves a subsea-level restriction that allows partial circulation in and out of the basin. The sea adds water over the restriction as it is evaporated from the basin. This restricted addition of sea water creates a salinity gradient; the water in the basin becomes progressively concentrated away from the sea and precipitates its various components in a lateral continuum of minerals. The final-stage brines either precipitate their contents at the far end of the basin or are cycled back out of the basin along the sea floor. This theory accounts for the large-scale lateral facies variations seen in many evaporite deposits.

Other theories have been formulated in attempts to explain characteristics of one or more salt deposits $[9,10]$. A model of separate basins attempted to account for some observed monomineralic accumulations of limestone, gypsum, and halite. Various theories about nonmarine or semimarine desert basins attempted to explain the lack of fossils in some salt deposits; at the other extreme, theories of subaqueous deposition from dense, deep-sea brines [11,12] were suggested to explain the apparent correlations between unfossiliferous deposits and their topographically low setting. The uniform and laterally extensive character of some bedding in salt deposits might also be explained by variations of these models of subaqueous deposition.
The most recently proposed theory is based on the discovery of salt deposits flooring the Mediterranean Sea. Labeled "the theory of desiccating deep basins" by Hsũ [9], it involves episodic cutoff and desiccation of large bodies of water such as the Mediterranean Sea or the Gulf of Mexico and evaporite deposition in the remnant salt lakes. Kirkland and Evans [13] assembled a collection of papers dealing with the origin of marine evaporites.

\subsubsection{The Precipitation Sequence Predicted from Sea Water}

Usiglio [14] in 1849 studied the precipitation sequence from evaporating sea water experimentally. His and other experimentally determined proportions of minerals from a fixed volume of sea water do not correspond well with those found in typical rock salt deposits (figure 1.4 and table 1.1), but several theories account for the discrepancies. If Scruton's reflux model is accepted, then the sea water need not be evaporated completely and the components of certain minerals may be retained in solution even though the preceding mineral in the series is extensively precipitated. The more soluble a mineral is, the less likely it is to be precipitated and preserved. The abundance of an individual evaporite mineral in the entire sedimentary rock record is inversely proportional to its solubility.

Another reason for the difference between observed sequences and the ideal sequence described by Borchert and Muir [15] is that the ideal sequence was precipitated at a constant temperature.

A discrepancy present in actual deposits that have reached the potash phase of deposition is the deficiency of sulfate minerals with respect to the ideal sequence. This deficiency is most often said to result from the destruction of sulfate minerals by sulfate-reducing anaerobic bacteria that derive their oxygen from the $\mathrm{SO}_{4}{ }^{2-}$ ion [16].

The mineral bischofite, which composes a sizeable part of the ideal precipitation sequence, is rarely found in the geologic record. The end brines containing this mineral are hydroscopic; that is, they are stable, resist evaporation, and usually find their way back to the sea.

\subsubsection{Cyclic Sedimentation}

Jones [17] described bedded-sediment cycles in the Salado Formation of New Mexico that approximate Usiglio's predicted sequence [14]. The cycles are represented by beds 0.7 to $10 \mathrm{~m}$ thick; basal "clastic stratum" (green, brown clays) grades up into a "sulfate" (usually anhydrite) then to a "halite," and finally to a mixed "halite-clastic stratum." Similar cycles described 


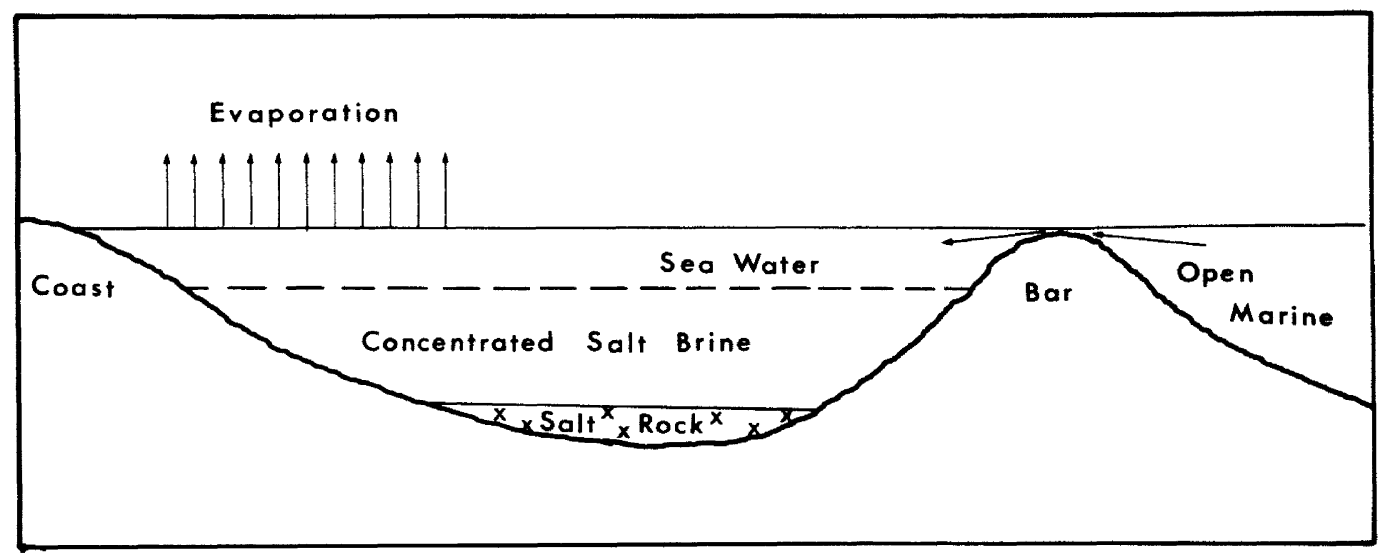

FIGURE 1.2. Ochsenius' bar theory [4] of rock-salt deposition as illustrated by Hsü [142].

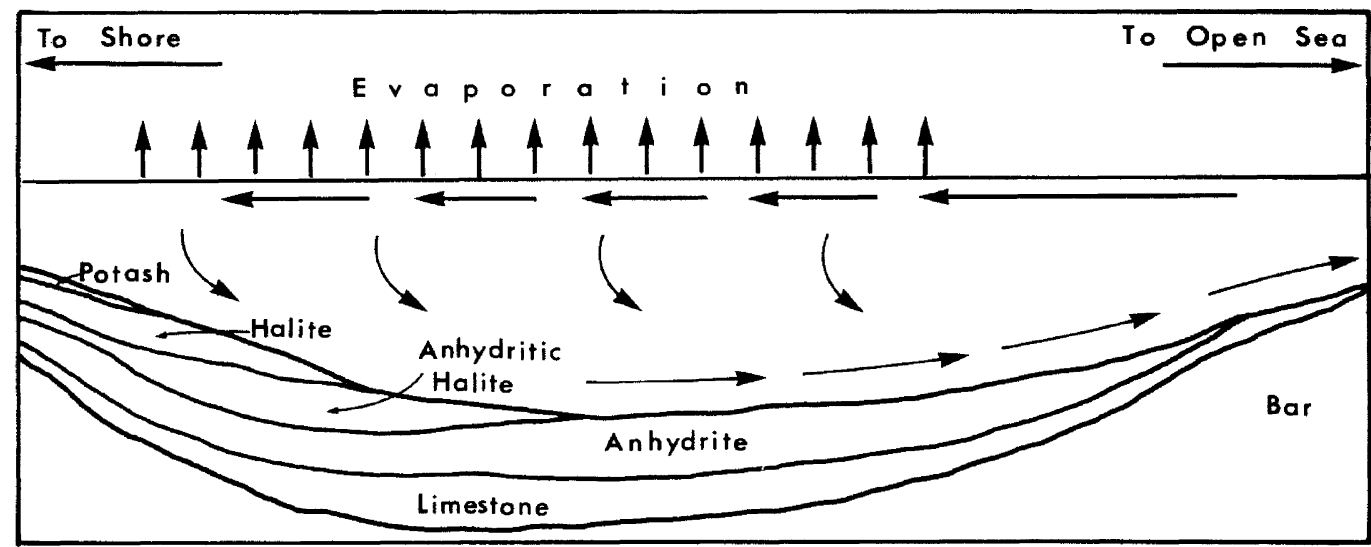

FIGURE 1.3. Scruton's reflux hypothesis [143]-restricted marine basin showing stratigraphic sequence precipitated during lateral increase of brine salinity. Final stage brines may precipitate their contents at the shore end of the basin or may flow back to the sea along the basin floor. Modified from [143].

for the Hutchinson Salt Member of the Wellington Formation in Kansas [18] contain very thin carbonate beds above the basal shales. The basal clays in such cycles are often interpreted as resulting from solution lags caused by new influxes of fresh water that redissolve some of the clay-rich rock salt and set the precipitation sequence back to the anhydrite/gypsum phase.

Cyclic layering is common in Gulf Coast salt domes, where 2.4 to $25 \mathrm{~cm}$-thick layers of anhydritic halite alternate with layers of pure halite, but these layers are not necessarily of depositional origin. The Castile Formation of southeast New Mexico also contains cyclic banding of calcite rich in organic matter alternating with pure anhydrite layers on a very small scale. These layers can be correlated for many kilometers across the Delaware basin [19] and may represent seasonal variations in climate during the Permian age.

\subsubsection{Diagenesis and Metamorphism}

\subsubsection{Introduction}

In this book, no distinction is made between "diagenesis" and "metamorphism." The Glossary of Geology [20, p. 192, 446] defines the terms as follows:

"diagenesis [sedimentary] All the chemical, physical, and biologic changes, modifications, or transformations undergone by a sediment after its initial deposition (i.e., after it has reached its final resting place in the current cycle of erosion, transportation, and deposition), and during and after its lithification, exclusive of surficial alteration (weathering) and metamorphism. ${ }^{* * * "}$

"metamorphism The mineralogical and structural adjustment of solid rocks to physical and chemical conditions which have been imposed at depth below the 


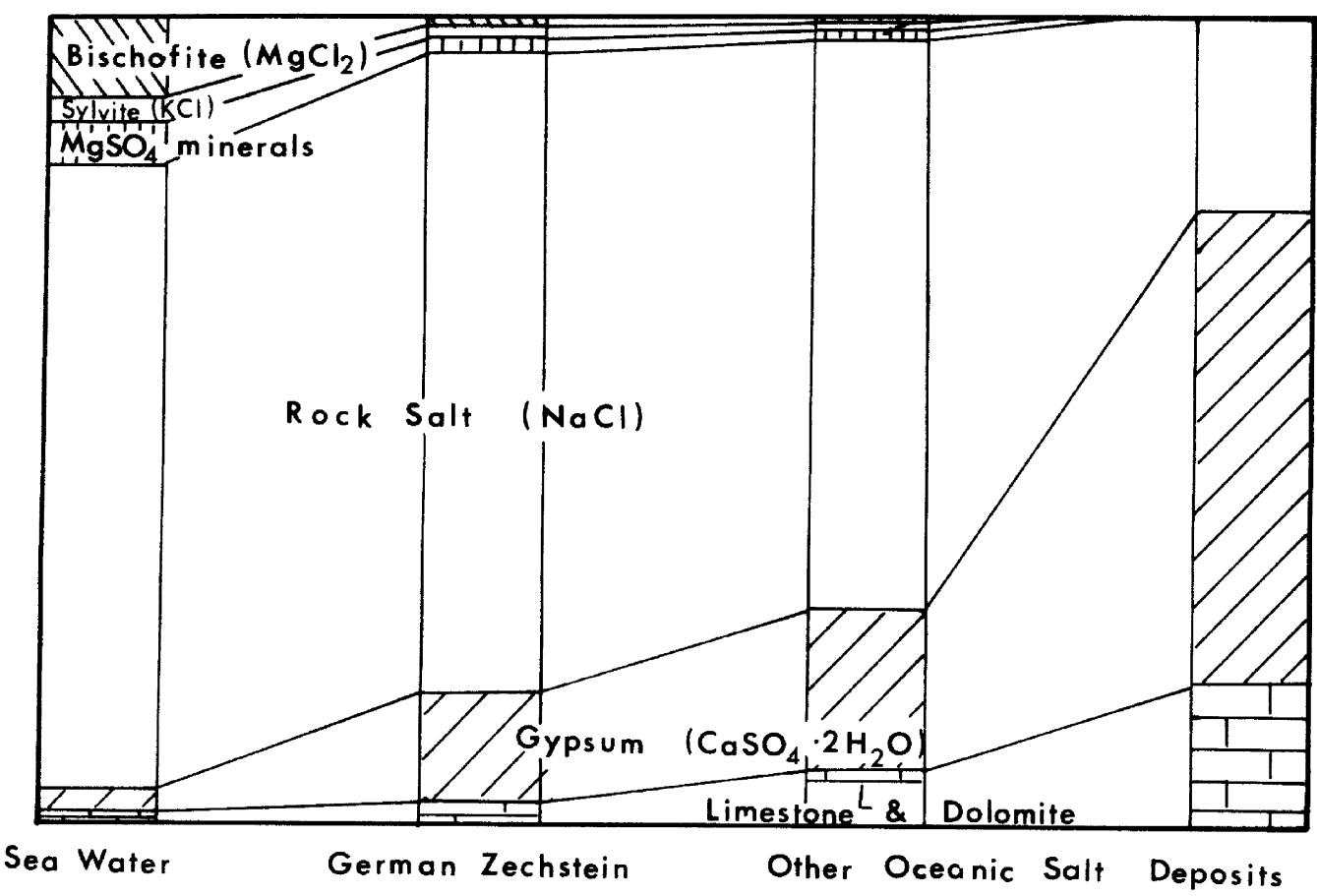

FigURE 1.4. Proportions of minerals experimentally precipitated from sea water compared with those found in natural rock-salt deposits. Modified from [144].

Table 1.1

Minerals that Precipitate from Increasing Brine Concentrations at Constant Temperature. Modified from [123]

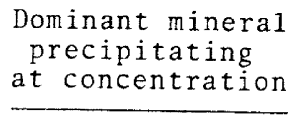

Limestone/dolomite

Gypsum

Halite

$M g$ and $K$ salts (potash

minerals)

Bischofite

$\begin{gathered}\text { Brine concentration } \\ \text { (multiples of } \\ \text { sea-water } \\ \text { concentration })\end{gathered}$
$1-4$
$4-12$
$12-64$
$64-120$

$120-240$ surface zones of weathering and cementation, and which differ from the conditions under which the rocks in question originated ${ }^{* * *}$."

In an evaporite deposit, the distinction between diagenesis and metamorphism would be arbitrary at best because the contained minerals are responsive to small changes in temperature and pressure above the ambient conditions for deposition. Some changes that are considered metamorphic take place before others that are considered diagenetic.

The minerals most susceptible to change are those precipitated from the most concentrated brines. Gypsum is the dihydrate of calcium sulfate that usually forms as a primary precipitate, but anhydrite, its dewatered equivalent, is the mineral most common in the rock record. Minerals of the potash phase are rarely found in their primary states. Some potash minerals do not form except after burial. Evidences for changes in evaporite deposits are the presence of minerals that do not form at normal surface temperature, abrupt lateral mineralogy changes, and irregular trace-element profiles (especially the profile for bromine). Braitsch [21] listed three types of change-dynamic, thermal, and solution-and classified them as metamorphic processes.

\subsubsection{Dynamic Metamorphism}

Dynamic metamorphism is the simplest type of metamorphism and the one that most readily affects the mineral halite. Braitsch [21] described it as the mechanical plastic deformation of salts under low stress and the associated isochemical and isophase recrystallization. Kupfer [22] indicated that the segregation of anhydrite from halite in salt domes probably took place during this type of deformation. Effects of dynamic metamorphism include (1) textures characterized by large, uniformly oriented crystals and (2) the folding of original bedding. It is caused by overburden pressures and tectonic stresses that produce movement of the rock salt. 


\subsubsection{Thermal Metamorphism (Including Load Metamorphism)}

As sediments subside with a basin, they are subjected to the elevated temperatures and pressures associated with the temperature gradient of the earth's crust and the increased pressure of the overlying sediments. These temperatures and pressures dewater the loosely hydrated minerals in the early stages of burial. Dehydration of most evaporite minerals is easily accomplished and usually takes place at temperatures below $100^{\circ} \mathrm{C}[23]$. The most important of these reactions is $\mathrm{CaSO}_{4} \cdot 2 \mathrm{H}_{2} \mathrm{O}=$ $\mathrm{CaSO}_{4}+2 \mathrm{H}_{2} \mathrm{O}$, which occurs at depths of 100-175 m [24]. Carnallite $\left(\mathrm{KCl} \cdot \mathrm{MgCl}_{2} \cdot 6 \mathrm{H}_{2} \mathrm{O}\right)$ is often dewatered to produce sylvite $\mathrm{KCl}$ and a $\mathrm{MgCl}_{2}$ brine. The brine liberated from these reactions is important in solution metamorphism as described below.

Thermal metamorphism also causes extensive recrystallization in monomineralic beds, specifically halite beds, though the resulting textures are not oriented as in dynamic recrystallization. In beds containing more than one primary mineral, the ionic components of minerals are mobile and new minerals are often formed at the expense of primary ones. This complex process is described by Braitsch [21].

\subsubsection{Solution Metamorphism}

The dehydration of a cubic meter of gypsum produces slightly less than $1 / 2$ cubic meter of water. During dehydration, a 10 m-thick bed of gypsum will decrease in thickness to a $6.2 \mathrm{~m}$-thick bed of anhydrite [25]. Because gypsum is one of the first minerals to precipitate in the evaporation of sea water, most evaporite deposits include a thick basal anhydrite sequence that provided brines for solution metamorphism during the formation of the anhydrite. In certain other deposits, brines may have originated as magmatic or artesian ground waters [26].

The brines created by these processes flow through "tectonically created permeability" [27], dissolving the more soluble minerals and depositing less soluble minerals from solution. (Some of the mobility of the fluid may be due to this differential solubility of the host rock rather than to its actual permeability.) Dissolution and redeposition of the components available in the rock result in a continuously changing composition in the brines; the changes are directed towards the same end composition as that of end brines in an evaporation sequence [28].

The complex changes in mineralogy due to solution metamorphism are most important in potash deposits, where the secondary minerals are often more abundant than the primary precipitates. Variations in metamor- phic mineralogy are due to changes in temperature and composition of the intruding fluids and intruded rocks. Brines can cause temporary cavities, brecciation, and collapse structures, as well as mineral changes. However, the brines quickly become saturated with respect to halite and anhydrite, and "further migration ... can usually produce no further effects within a pure rock salt deposit" [29].

\subsubsection{Regional Rock Salt Geology}

Summary discussions or tne rock salt deposits in the United States are given by Pierce and Rich [2] and by Johnson and Gonzales [30]. The reader is referred there for both further information and bibliographies on the siratigraphy of individual deposits. The variability of salt deposits is exemplified by the differences in the data supplied by Pierce and Rich for many of the basins; presumably the data are derived from different authors or different parts of a basin. However, much of the variability may be real. Variability in salt depositis can be a response to the shape of the basin, the topography within the basin, the rate of subsidence of the various parts of the basin, the location of freshwater or unsaturated marine water input, and the different rates of evaporation within the basin. Because rock salt has been significantly changed by various chemical and physical stresses after burial, studies of modern surficial evaporite deposits are not as applicable to an understanding of rock salt as studies of subsurface deposits that only can be obtained in situ from well logs and mines. We often only have a limited and localized knowledge of subsurface deposits.

Rock salt deposits range greatly in size. The most widespread deposits in the United States, excluding the probable extension of the Louann Salt of Jurassic age under the Gulf of Mexico, are the Permian evaporite sequences of Texas, New Mexico, Colorado, Oklahoma, and Kansas. Table 1.2 shows the correlation between geologic ages and time before the present. These deposits (figure 1.1) cover an area about $1000 \mathrm{~km}$ long, north to south, and about 240 to $320 \mathrm{~km}$ wide. They are subdivided by age and stratigraphy into at least five local basins [31]. In New Mexico and Texas, the salt-bearing Castile and Salado Formations, approximately 600 and 70 meters thick, respectively, are Late Permian in age and are found in the Delaware basin. The Salado Formation extends into the Midland basin. The approximately $250 \mathrm{~m}$-thick Wellington Formation, best known in the Wellington basin of Kansas, is of early Permian age. These salt deposits are part of the same general depositional and tectonic province, called the Permian basin, but are loosely related products of 


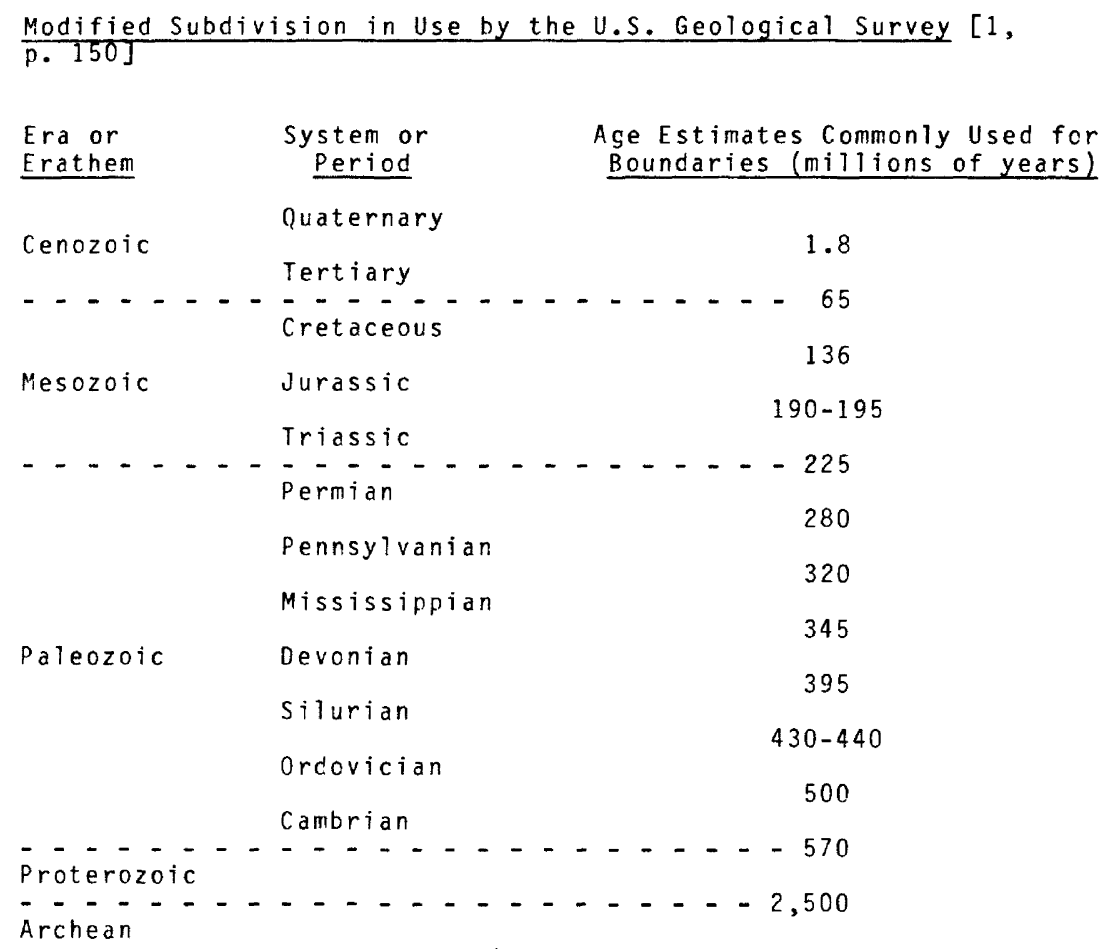

different localities in it and thin or wedge out between subdivisions of the basin.

The Silurian salt-bearing Salina Formation of Michigan, northern Ohio, Ontario, New York, Pennsylvania, and West Virginia covers a maximum linear distance of $880 \mathrm{~km}$. The formation is a thin $(0-100 \mathrm{~m})$ blanket across most of Ohio, Pennsylvania, and West Virginia bu thickens to $300 \mathrm{~m}$ in parts of New York and to $600 \mathrm{~m}$ in Michigan where the subsidence of the Appalachian and Michigan basins allowed thicker accumulations.

The Williston basin in North Dakota, Montana, and Saskatchewan is unique in that it had four episodes of rock-salt accumulation in the same geographic location (during Devonian, Mississippian, Permian, and Triassic time). In an area about $500 \mathrm{~km}$ long and $500 \mathrm{~km}$ wide, the salt-bearing formations range from 30 to $50 \mathrm{~m}$ in thickness, though they are buried deeply and are poorly known.

The Louann Salt and the associated formations of the United States Gulf Coast are also poorly known. Most oilwell drilling is terminated when the salt beds are reached so that estimates of thickness are highly speculative, ranging from 170 to $1700 \mathrm{~m}$. The Louann Salt extends well into the Gulf of Mexico to the Sigsbee knolls, which are considered to be salt domes. Thus, it has great areal extent, despite an area in central Louisiana that may be salt free.

\subsubsection{The Variability within Salt Beds}

The percentage of a given formation that is bedded rock salt ranges from 0 to 100 percent, though most deposits shown in figure 1.1 are less than 50 percent other minerals. The distribution of other minerals within a formation is irregular, reflecting depositional changes, subsequent metamorphism, and ground-water leaching.

The thickest individual monomineralic halite beds that might exist in a formation cannot be identified from the literature. Deciding the thickness and number of clay or anhydrite partings that must be in a rock salt bed before it is no longer considered to be halite is a subjecttive process. Pierce and Rich [32] stated: 
The normal bedded rock salt deposit is composed of a number of separate beds that have slight to large variations in composition. A forty-foot vertical section, selected at random in a salt sequence, might consist of:

\begin{tabular}{lcc} 
& Feet & Inches \\
\cline { 2 - 2 } Salt & 9 & \\
Anhydrite & & 0 \\
Salt & & 6 \\
Shale & & 2 \\
Salt & & 6 \\
Shale & 2 & 0 \\
Salt & 12 & 0 \\
Shale and anhydrite & & 8 \\
Salt & $\underline{8}$ & $\underline{0}$ \\
\multicolumn{1}{c}{ Total } & 40 & 0
\end{tabular}

Some authors would tend to call the above section a pure halite bed if the 2 foot $(0.6 \mathrm{~m})$ shale break were thinner. Impurities in bedded rock salt may also be present as finely disseminated intracrystalline particles and blebs, especially of clay or anhydrite.

Gleaned from Pierce and Rich [2], the following are estimates of the maximum thicknesses of "pure" individual halite beds in some formations.

\begin{tabular}{lc}
\multicolumn{1}{c}{ Formation } & $\begin{array}{r}\text { Thickness, } \\
\text { in meters }\end{array}$ \\
Salina (Michigan) & 80 \\
Salina (Ohio) & 20 \\
Salina (Pennsylvania) & 70 \\
Lucas (Michigan) & 30 \\
Castile (New Mexico) & 210 \\
Salado (New Mexico) & 20 \\
Rustler (New Mexico) & 70 \\
Wellington (Kansas) & 10 \\
Supai (Arizona) & 70 \\
Charles (South Dakota) & 50 \\
Opeche (South Dakota) & 50
\end{tabular}

Average bed thickness ranges are well below 50 percent of the above-given maximum thicknesses. The Louann Salt of southern Louisian is perhaps one of the purer rock salt deposits, but it is poorly known. Andrews [33] described it as very white to grey, clear, coarsely crystalline and containing anhydrite streaks, and very pure without clastic material. The Hermosa Formation of Utah, on the other hand, is described by Pierce and Rich [34] as containing "many shale and anhydrite beds," despite its flowage into great accumulated thicknesses at anticline crests.
Gross-scale composite sections of some salt-bearing formations in the United States are given by Lefond [35] and can be found in the Northern Ohio Geological Society Salt Symposia volumes.

\subsection{Salt Domes}

\subsubsection{Introduction}

Only the rock salt deposits of the Gulf Coast embayment have produced salt domes in the United States, though incipient doming is present in the Paradox basin salt deposits. More than 300 salt domes have been recognized, onshore and offshore, in Texas, Louisiana, and Mississippi.

These domes have risen from great depths. Their source, the bedded Louann Salt, is approximately $5000 \mathrm{~m}$ deep north of the area in central Louisiana that may be salt free. South of the area, the depth estimates range from $11,700 \mathrm{~m}$ to as much as $20,000 \mathrm{~m}$, though the generally accepted figures are from 13,000 to $15,000 \mathrm{~m}$. The domes rise above the source bed from local thickenings of the bed all the way up to present-day land surfaces. In the United States, the salt beds are not exposed at the surface; however, the locations of many domes are marked by solution and collapse that produced lakes. Some of the lakes contain central islands that may be the result of continued doming.

Domes may be circular to broadly elliptical, and their diameter may either increase or decrease downwards. Some domes may even have detached from their source bed. Domes commonly have a mushroom shape near the top, on any or all sides, termed "overhang" (figure 5). The average diameter at the top of Gulf Coast domes is about $3.2 \mathrm{~km}$, though they range from 1 to $6 \mathrm{~km}$ in diameter [36a and b]. The upper surfaces may be flat, convex upward, or irregular and are usually but not always covered by "caprock."

\subsubsection{Formation}

Salt-dome formation is related to the incompressible and plastic characteristics of salt. As shown by figure 1.6, halite has a greater density than clastic sediments at surface conditions. Pore spaces in forming rock salt are quickly filled by halite on recrystallization. In clastic sedimentary rocks, pore space is filled by water; only gradually is the water forced out and the pore space reduced by the increasing pressure of thickening overburden. The result is that the density of clastic rocks, usually sandstone and shale, increases as depth of burial increases whereas that of halite remains constant. At a depth from $130 \mathrm{~m} \mathrm{[37]} \mathrm{to} 700 \mathrm{~m}$ [38], the density of 


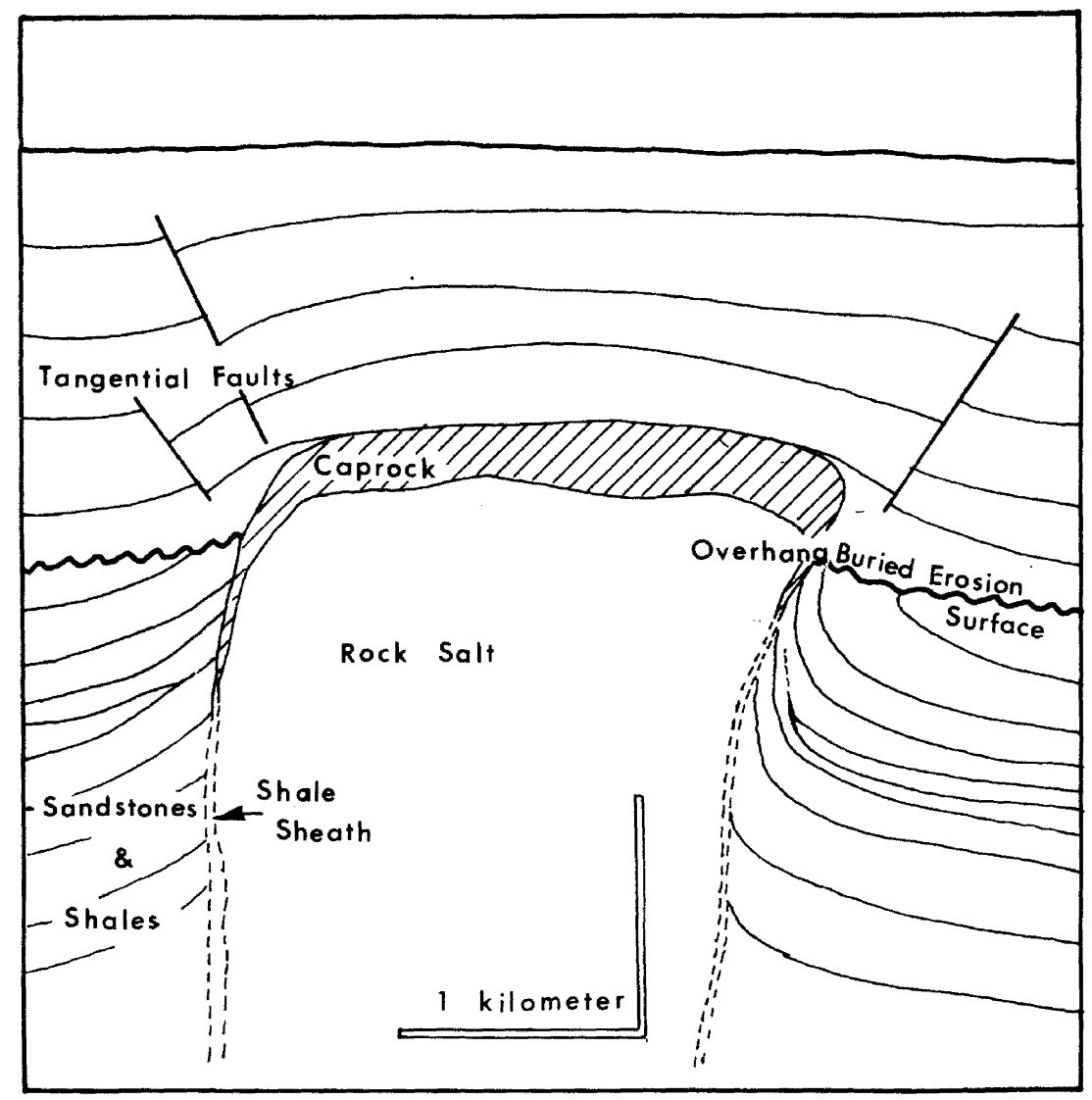

FIGURE 1.5. Idealized stratigraphic cross section of upper part of an intermediate depth Gulf Coast salt dome.

salt equals that of average sedimentary rocks; below that, an unstable density inversion is present because denser clastic sediments overlie lighter rock salt. (The incipiently domed rock salt of the Paradox basin is covered by about $700 \mathrm{~m}$ of overburden, but the deep salts of the Williston basin are undomed.)

Added to this density inversion is the plasticity of halite, which increases as temperature and pressure increase. "At depths of between 2500 and 3000 meters, the temperature is about $100^{\circ} \mathrm{C}$ and the pressure over $600 \mathrm{~kg} / \mathrm{cm}^{2}$ [58.84 MPa]. Under these conditions, salt is very plastic; it is in fact about as soft as butter on a hot summer's day" [39]. While this is an overstatement, it must be recognized that rock salt, alone among the common rock types, flows readily in response to small gradients in pressure and temperature.

Salt flows toward sedimentary and tectonic irregularities in the overburden. Folded strata are especially conducive to rock salt flowage because of the differential stresses. Salt accumulates at the crests of folds. The greater the depth of burial, the larger the local accumulation of rock salt, and the greater the tendency towards penetration of the overlying sediments. The mobility of rock salt is such that its original site of deposition may be as far as $25 \mathrm{~km}$ from the dome where it is presently found [41].

Salt flows to and within domes in pulses, not continuously. This pulsing flow is indicated by the different episodes of folding (refolded folds) found within domes and the irregular effects the rising dome has had on the adjacent stratigraphy (described below). Estimates of the actual rates of flow are on the order of a few millimeters per year [42]. In contrast with the Persian domes that are pushed up to some $1300 \mathrm{~m}$ above the surrounding plain and are still rising [43], most of the Gulf Coast domes seem currently to be in a state of equilibrium. Sediment deposition on top of them would probably remobilize them. Borchert and Muir [44] stated "salt will normally continue to flow into the dome until the supply from the surrounding area is exhausted. So the height of the dome is largely governed by the thickness of the original bed of salt."

\subsubsection{Associated Structures}

\subsubsection{Internal Structures}

The internal structure of salt domes is visible in the contortions of the ubiquitous banding of pure halite and 


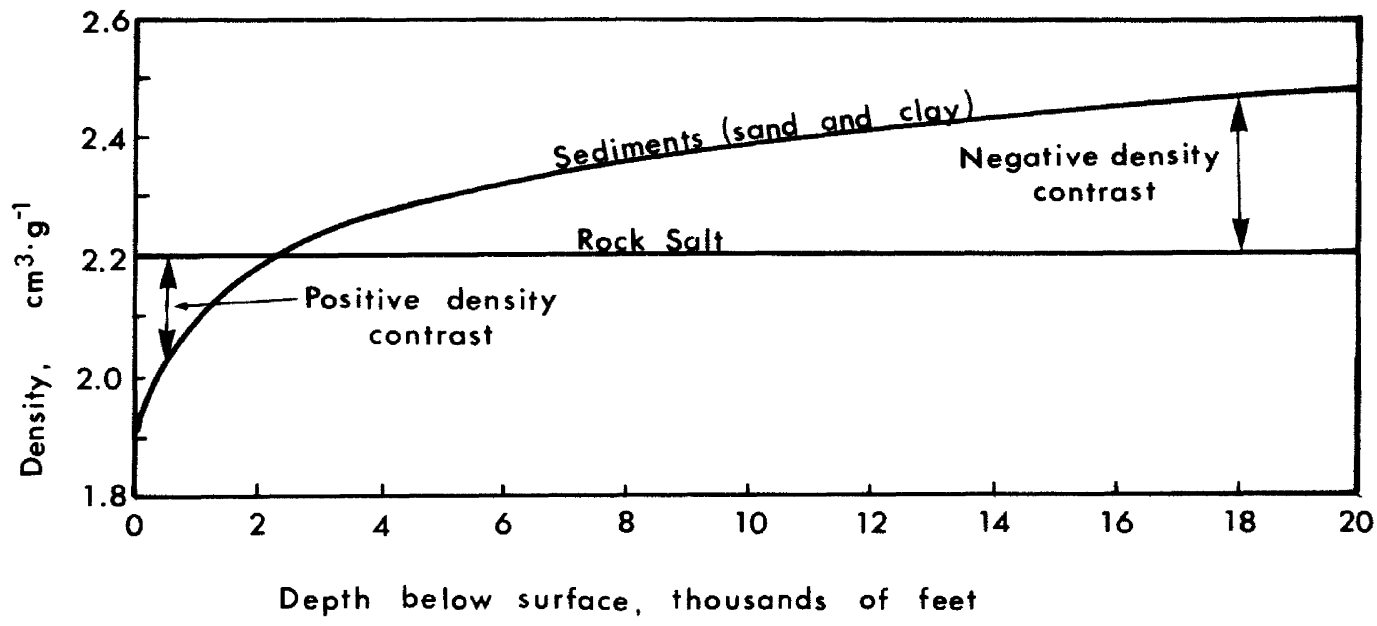

FIGURE 1.6. Density-depth relationship for Gulf Coast sediments and rock salt. Modified from Nettleton [145]

anhydritic halite. This layering is usually 0.025 to $0.25 \mathrm{~m}$ thick and is tacitly assumed to be the original sedimentary layering. The anhydrite rarely makes up more than 5 percent of the impure layers but gives them a distinctively darker coloration.

Folding of the bands in domes of northern Louisiana is relatively simple because of the short distance that they have risen, but the folding in southern Louisiana is complex. The overall pattern of folding is one of radially distributed vertical folds. Because the major vector of flow in domes is vertical, vertical cross-sections within the domes rarely show more than parallel near-vertical lineations. A horizontal section, however, shows complex ellipses and concentric and ptygmatic (disharmonic) folding. Shearing and attenuation of folds, in many places to elimination, are also common. Rare but more competent anhydrite bands may show boudinage, a set of regular extensional partings. All these folds have axes that are near vertical and are continuous vertically for as far as the exposure (usually a mining face) is available. Kupfer [45] stated "folding in domes is due to minor lateral drift of adjacent elements during vertical motion." As such, it is secondary in importance as a record of movement to the vertical lineations. The multiple episodes of refolding were probably caused by varying components of this lateral drift. Generally, the bedding is parallel to the side of the dome near the edges and becomes more complex inward.

Differential vertical movement within the dome produces "spines" of salt that rise higher than adjacent parts of the dome. Spines are usually cited as the cause of shear zones noted within salt domes. The structure in shear zones has been homogenized and looks deceptively simple, though pieces of the rock surrounding the dome are sometimes incorporated into these zones. Rare highangle and more common bedding-slip faulting may also be produced by spine movement [46].

\subsubsection{External Structures}

The rock salt of the Louisiana domes is rimmed by an external shear zone called the "shale sheath." In the Weeks Mine, Louisiana, this sheath is a chaotic shale/salt mixture, 130-330 m thick. Sedimentary layers pierced by salt domes may be abruptly truncated against a dome-margin shear zone, but more commonly they are upturned or even overturned against the shale sheath.

Other adjacent sedimentary layers were directly created by the doming action. As rock salt was withdrawn from the beds peripheral to the dome, the overlying sediments subsided into a "rim syncline," while the central rocks were pushed upward by the dome. Sediments eroded from the central high were redeposited in the rim syncline, creating both a local unconformity over the top of the dome and adjacent sedimentary strata that dip away from the dome and pinch out against it. In other circumstances, a bed that was being deposited regionally concurrent with doming would be thinner over the dome. The local stratigraphy records the relationship between episodic growth of the dome and the regional deposition.

Two sets of faults in the overlying sediments are usually associated with domes: 1) tear faults radial to the dome and 2) tension faults tangential to the dome (figure 1.7). The latter often create a "central graben" over the center of the dome.

\subsubsection{Caprock}

Some salt domes are covered by "caprock," a sequence of a basal, granular anhydrite, an intermediate layer of gypsum, and a covering of calcite (which in many places contains minable quantities of native sulfur). Hawkins and Jirik [118] noted that 181 of the some 330 known salt 


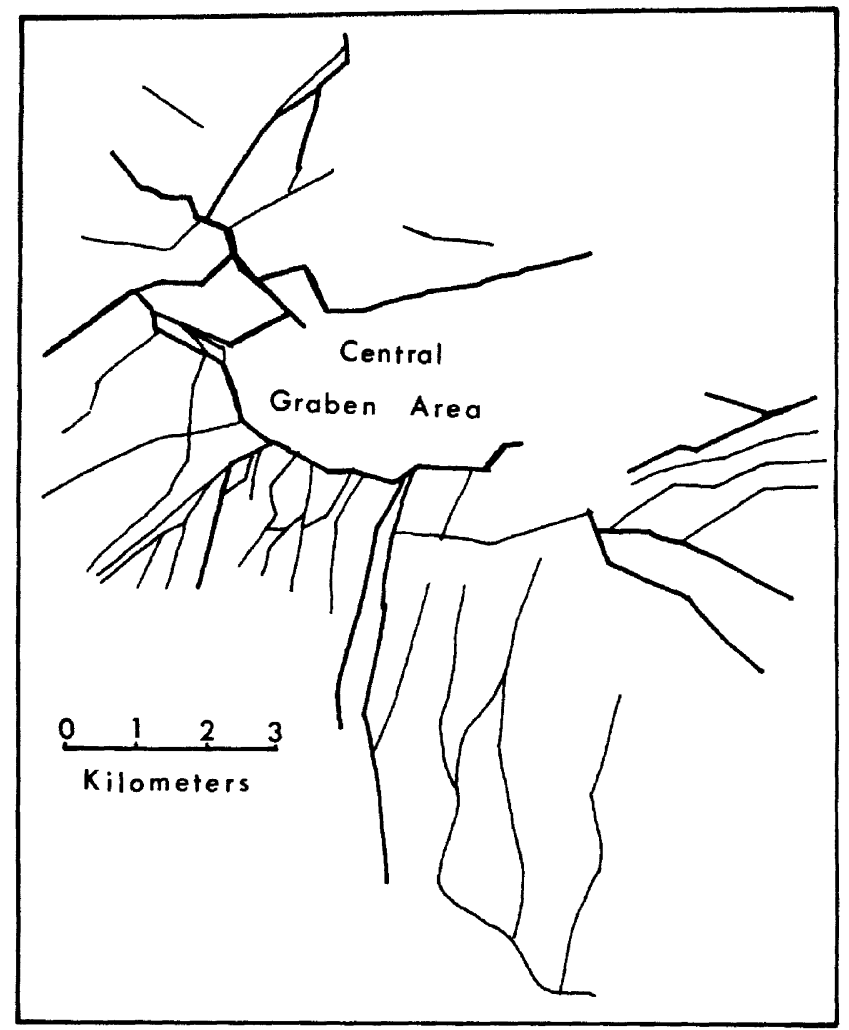

FigurE 1.7. Example of the fault pattern in sediments overlying a salt dome near Galveston County, Texas. Modified from [146].

domes along the Gulf Coast are known to have caprock and that it is usually thicker on domes that are closer to the surface. Uncapped domes are also known. The thickness of caprock ranges from less than $3 \mathrm{~m}$ to greater than $500 \mathrm{~m}$ and averages $130 \mathrm{~m}$ [47].

The origin of caprock is probably a combination of a solution lag of anhydrite, as the anhydrite-bearing rock salt of the dome intruded into the freshwater horizon [48], and an in-place alteration of the upper zones of that anhydrite to gypsum and calcite. Given the low percentage of anhydrite in dome rock salt, a large volume of the rock salt must have been dissolved in order to leave some of the thicker layers of caprock.

Arguments for the in-place origin of caprock are largely based on the presence of authigenic minerals not found within the dome rock salt and isotopic ratios indicating organic activity. The $\mathrm{S}^{34} / \mathrm{S}^{32}$ ratios of the sulfur pockets found in the calcite are reflections of the preference of certain anaerobic bacteria for one of those isotopes [49] in their conversion of $\mathrm{CaSO}_{4}$ to $\mathrm{H}_{2} \mathrm{~S}$ and ultimately to $\mathrm{S}$ in order to obtain oxygen. These bacteria feed on the hydrocarbons associated with domes. The remaining $\mathrm{Ca}$ combines with $\mathrm{CO}_{2}$, also bacterially produced, to produce the top layer of calcite (which is enriched in $\mathrm{C}^{12}$, also indicative of an organic origin).

The general sequence of events in the formation of caprock is:
1. Solution lag of anhydrite $\left(\mathrm{CaSO}_{4}\right)$.

2. Hydration of anhydrite to gypsum

$\left(\mathrm{CaSO}_{4}+2 \mathrm{H}_{2} \mathrm{O}=\mathrm{CaSO}_{4} \cdot 2 \mathrm{H}_{2} \mathrm{O}\right)$.

3. Bacterial reduction of gypsum and methane $\left(\mathrm{CH}_{4}\right)$ to produce $\mathrm{H}_{2} \mathrm{~S}, \mathrm{CO}_{2}$, and $\mathrm{Ca}^{2+}$.

4. Inorganic oxidation of $\mathrm{H}_{2} \mathrm{~S}$ to $\mathrm{S}$, and combination of $\mathrm{Ca}^{2+}$ and $\mathrm{CO}_{2}$ to form calcite $\left(\mathrm{CaCO}_{3}\right)$.

\subsubsection{Mineralogy}

Gulf Coast salt dome deposits are generally more than 97 percent halite. The major impurity is anhydrite, which makes up from 1 to 10 percent of the darker beds $[50,51]$. The bedding style is termed "graded" in that, above a sharp basal contact, the impure bed gradually grades to pure halite. More precise rock salt analyses and descriptions of crystal habit are given in section 1.4.

The mineralogy can change during diapirism (saltdome formation). Some evidence indicates that "differential purification may occur during diapirism" [52]. Halite-rich layers respond to stress and flow more readily than the less plastic impurities such as the anhydrite or clay layers. Though the Louann Salt is reported to be a relatively pure halite deposit, the domes formed from it probably contain even fewer impurities.

The rock salt in some domes in Louisiana is incompetent. Hand specimens tend to fall apart readily along crystal boundaries [53]. An inverse relationship between competency and the vertical distance of piercement may be present.

\subsection{Mineralogy and Petrology}

\subsubsection{Introduction}

Halite has a cubic crystal shape, but it may also be found in a massive, granular, or fibrous habit. It may break with perfect right-angle cleavage or, to a lesser extent, it may fracture conchoidally. Its hue, dependent on the amount and type of impurities, may be colorless, grey, white, or red. In certain instances, it is a deep blue. Summaries of the optical and physical properties of halite and other evaporite minerals have been published by Borchert and Muir [54] and by Braitsch [55]. They are also discussed in other chapters of this book.

\subsubsection{Impurities}

Rock salt contains a variety of accessory or minor minerals. The accessory minerals in salt domes (the type of deposit that is most pure) are summarized in table 1.3. These minerals are also found in bedded deposits, where 


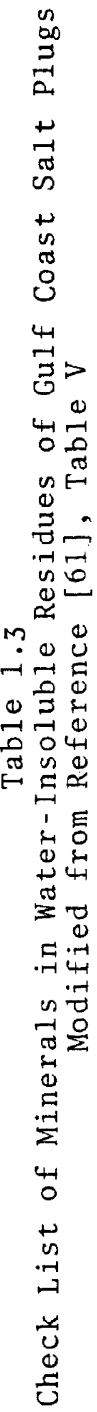

\begin{tabular}{|c|c|c|c|}
\hline 'sstw 'KzunoJ xeuret & $x \times x \quad x \times$ & & \\
\hline sexəL 'punow suṭsoH & $x \times x \times x \quad x \quad x$ & & \\
\hline 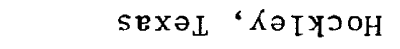 & $\succ x \times x \times x$ & & \\
\hline 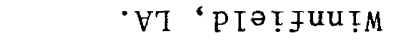 & $x \times x \times x \times x \quad x \quad x$ & & $x$ \\
\hline 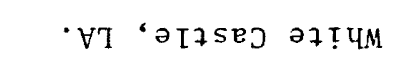 & $x \times x \times x$ & & 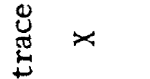 \\
\hline • $\forall$ T 'pueIsI sуәәм & $x \nsim x \nsim x x \times \quad x$ & & $x x \times x$ \\
\hline 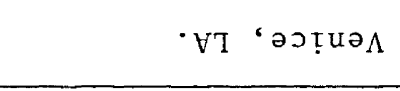 & $x x \quad x$ & & 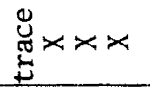 \\
\hline$\cdot \forall T$ 'Inप⿺dns & $x \times x \quad x \quad x \quad x$ & & $x \times$ \\
\hline • $\forall T$ 'səyts & $x x x>$ & & \\
\hline • $\forall T$ 'uozoutusem әҮeT & $x \times x \times x \times x \times x \quad x$ & & $x \quad x x$ \\
\hline • $\forall T$ 'әภี & $x x x \quad x$ & & $\succ x$ \\
\hline • $\forall T$ 's sิuțuuər & $x \times x \times x$ & & \\
\hline$\cdot \forall T \cdot P I$ uosxafzər & $x \times x \times x \times x \times x \quad x \times x$ & & $x \times x \times$ \\
\hline$\cdot \forall T$ 'Keg ·PI uәpıeD & $x x \quad x x$ & & $x$ \\
\hline$\cdot \forall T \cdot K x\lrcorner ә q$ ' & $x \times x \times x$ & & $\times$ \\
\hline • $\forall 1$ 'moxied & $x \times x \times x$ & & 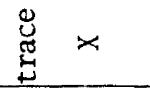 \\
\hline 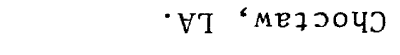 & $x \times x \times x \times x \times x \quad x$ & & $x \times x \times$ \\
\hline • $\forall T$ 'nәtg nokeg & $x \times x \times x$ & & $x_{1}$ \\
\hline 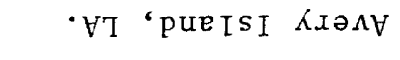 & $x \times x \times x \times x \times x \quad x$ & & $x \times x \times$ \\
\hline$\cdot \forall T \cdot \partial \neg 7 n g$ et əsur & $x \times x \times x \times x$ & & 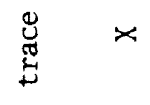 \\
\hline 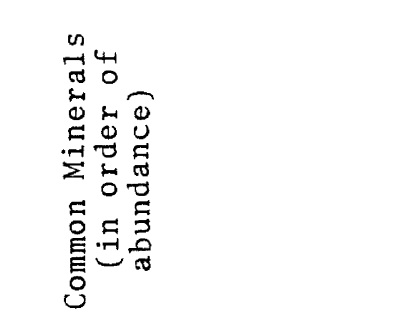 & 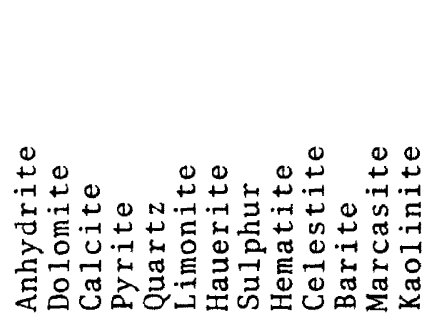 & 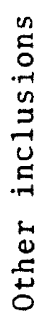 & 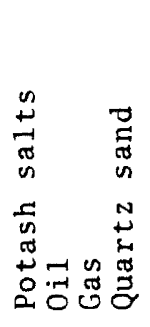 \\
\hline
\end{tabular}


their volume and distribution range from 0 to 100 percent of a formation or sample and from thick intercalated beds to disseminated intercrystalline grains. Jones [18, p. A1] summarized the small-scale occurrence of impurities in rock salt beds of the Wellington Formation in Kansas as follows:

"Anhydrite and detrital argillaceous clay materials are the main accessory constituents of the rock and commonly form angular interstitial patches and irregular veinlike masses. Other minor constituents-such as polyhalite, dolomite, magnesite, hematite, celestite, marcasite, and pyrite-occur as single crystals or as groups of crystals that project into halite from the edges of argillaceous patches and from small lensic or veinlike masses of anhydrite. Small pseudomorphs after gypsum, outlined by crystals and fine-grained masses of anhydrite, are scattered irregularly through the rock."

Representative analyses of hand samples from United States salt domes are given in table 1.4.

To illustrate the typical composition of rock salt containing more impurities, Jones [18] gave the following breakdown for the entire Salado Formation of New Mexico: rock salt, 38.6 percent; clay-rich rock salt, 45.0 percent; sulfate rocks, 12.5 percent; and clastic rocks, 3.9 percent. These percentages vary across the basin, and the formation becomes principally anhydrite and dolomite on the southern edges. To the north, the percentage of clay, sand, and silt in the Salado Formation increases to dominance. Salt-percentage maps show that rock salt composes the greatest percentage of most saltbearing formations near the center of a basin.

Impurities in the Gulf Coast salt domes are very irregularly distributed, and the composition and grade of rock salt are often different in adjacent spines of a dome. The overall impurity percentage estimates vary between 1 and 2 percent for domes in southern Louisiana [56] and up to 15 percent for northern Louisiana and Texas [57].

The percentage of impurities also varies across the complete spectrum at the intermediate scale of the 30 $\mathrm{cm}$ - to 8-m-thick beds that make up bedded formations. As a rule, rock salt is purer in the upper parts of beds, especially the thicker ones. In the Salina Formation in New York, "halite makes up 85 to 95 percent of the laminated salt by weight" $[58$, p. 41$]$; in the same formation in northeastern Ohio, impurities (mostly dolomite and anhydrite) range from 0 to 30 percent, the percentage being greatest near contacts with beds of anhydrite [59]. In the Salado Formation of New Mexico, most salt beds contain from 1 to 10 percent impurities including anhydrite, polyhalite, and clay [60] as disseminated intercrystalline blebs. A composite sample of the Hutchinson Salt Member of the Wellington from Kansas yielded 5.7 percent insoluble material, mostly anhydrite [61].

\subsubsection{Grain Size and Orientation}

\subsubsection{Bedded Deposits}

The crystal size of halite in bedded deposits varies from a few millimeters to more than $0.1 \mathrm{~m}$ on a side. Most often the crystals of a bed are of roughly the same size, though gradations from a zone of one size to a zone of another size are common. Larger crystals tend to be found where fewer impurities are present to inhibit their growth during recrystallization.

Where rock salt has not been extensively recrystallized, hopper crystals may be preserved in bedded salt. These pyramidal, originally open-ended crystals, 0.005 to $0.01 \mathrm{~m}$ on a side, grow point down at the evaporation surface of a brine until their weight overcomes surface tension and they settle to the bottom [62]. In some instances, sheets of uniformly oriented hopper crystals are found in rock salt beds, indicating that they grew together at the surface and settled as a unit. These crystals of ten serve as nucleation sites for cubic crystals, which grow in crystallographic continuity during recrystallization or periods of supersaturation of brines at the bottom of the basin or both. Hopper crystals can be recognized by the abundant, minute fluid inclusions that outline successive growth planes of the crystal and show characteristic "chevron" patterns in thin section.

Another of the few remnant primary crystalline textures in salt deposits is that displayed by gypsum. Gypsum commonly grows as crystals attached to the basin floor, in a distinctive "swallow-tail" configuration, centimeters in length. This texture is commonly preserved even though the gypsum may be changed to anhydrite or replaced by other minerals (usually halite). The texture may be used to tell the "up" direction of a piece of core.

\subsubsection{Salt Domes}

The size of halite crystals in salt domes usually ranges from 0.005 to 0.01 meters on a side, though some domes contain rare zones of finer grained crystals. More common "pods" of coarse grained crystals 0.025 to 0.05 meters on a side commonly cut across bedding and may be the result of resolution and deposition caused by ground-water intrusion [64]. These coarsely crystalline pods are often associated with water seepages, oil inclusions, and shear zones between spines.

Halite crystals elongated preferentially in the vertical direction, that is, parallel to the direction of flow, have been reported [41, 42, 51, 65]. The length ratios of vertical to horizontal axes are commonly about 1.5 and, in some crystals, are as much as 6.0. The elongation is thought to be caused by a combination of mechanical 


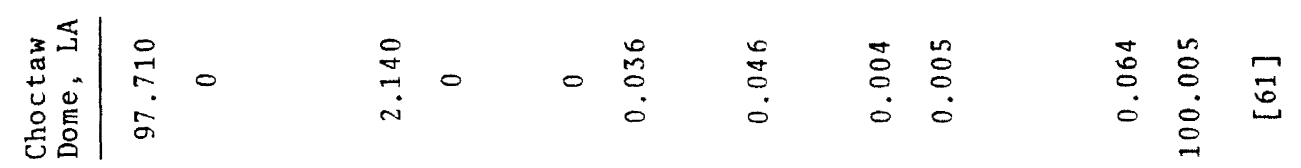

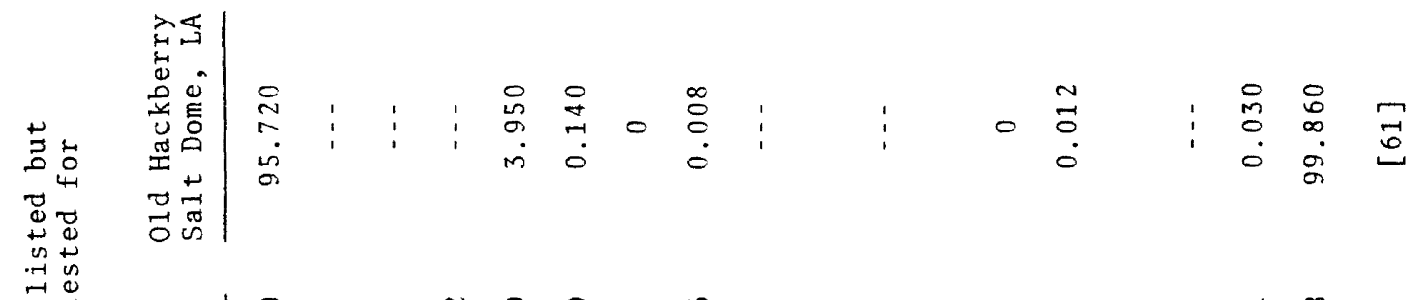

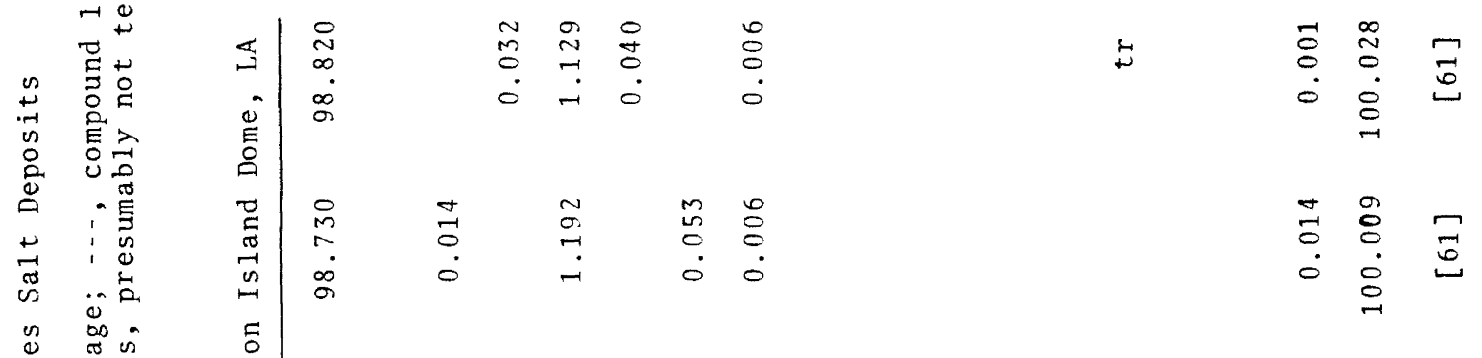

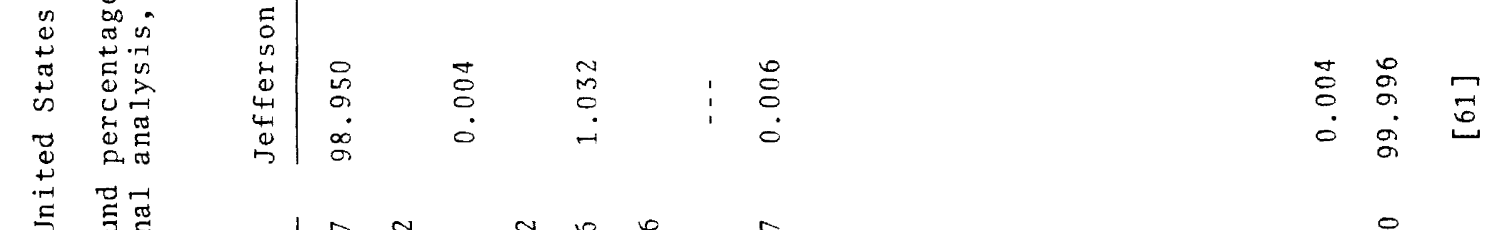

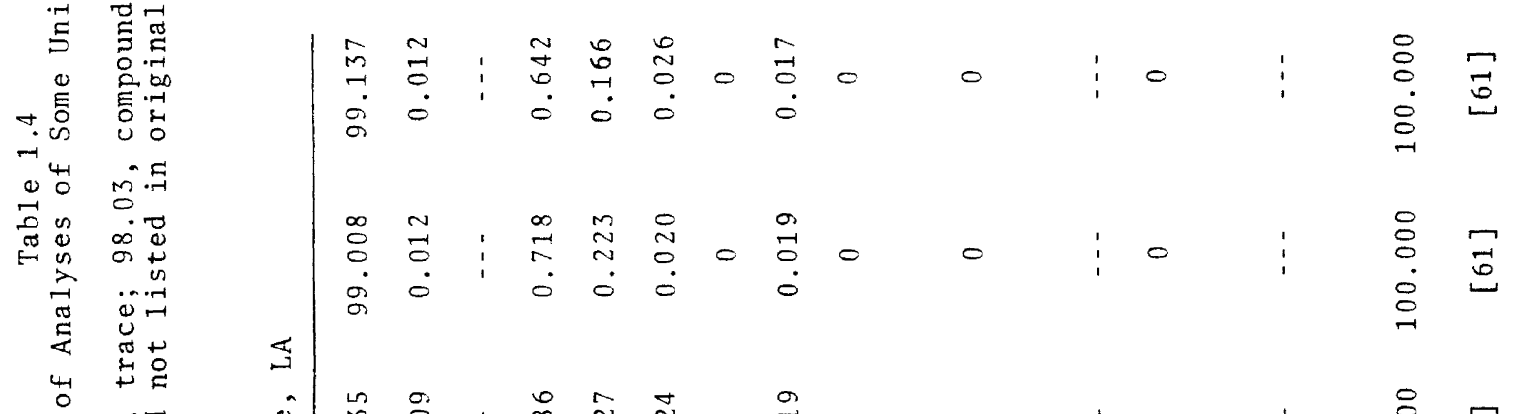

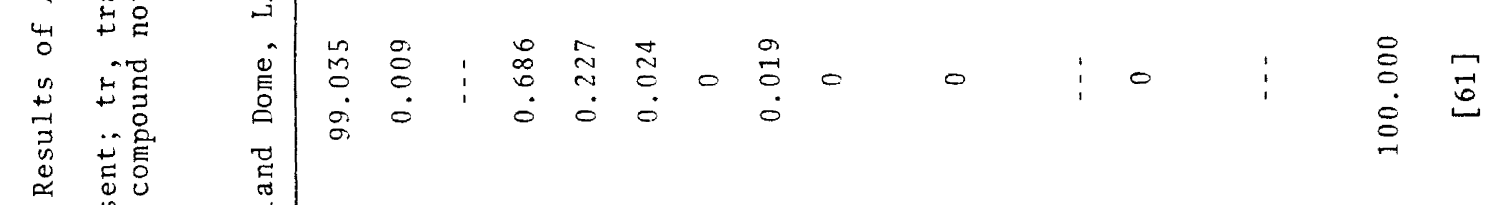

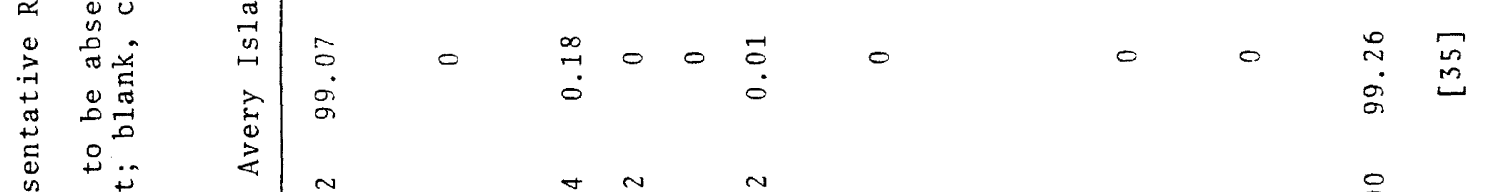

$$
\begin{aligned}
& \stackrel{0}{0}
\end{aligned}
$$

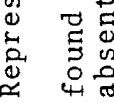

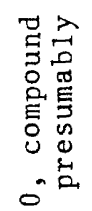

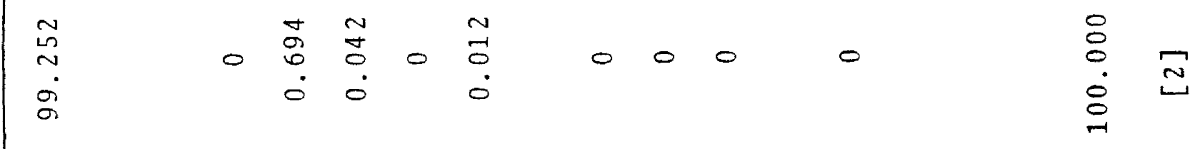

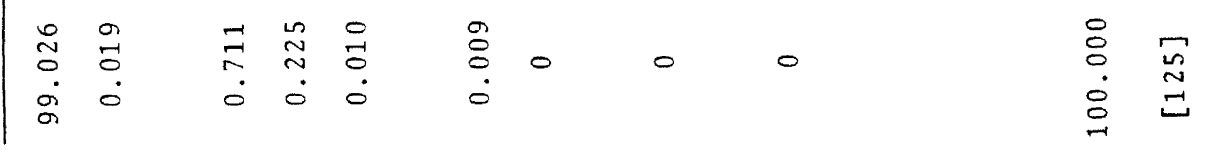

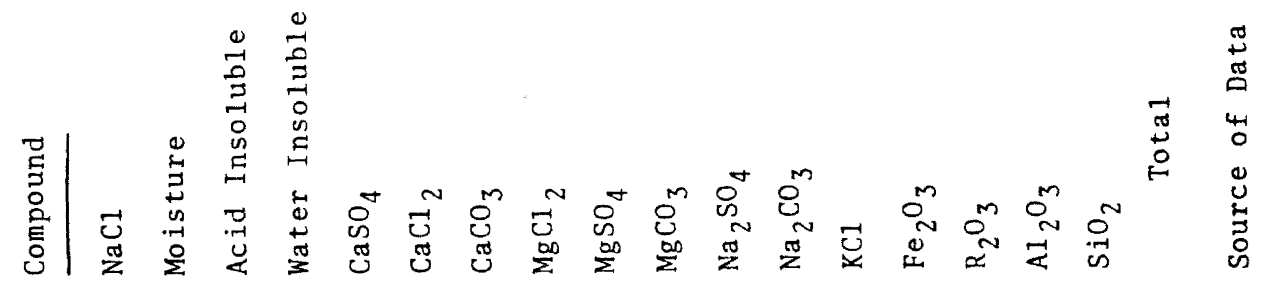




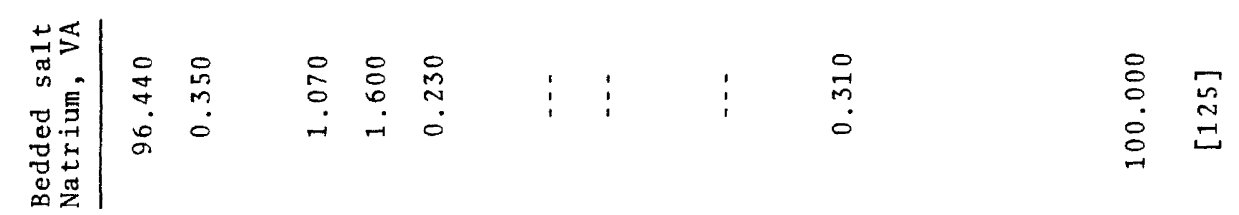

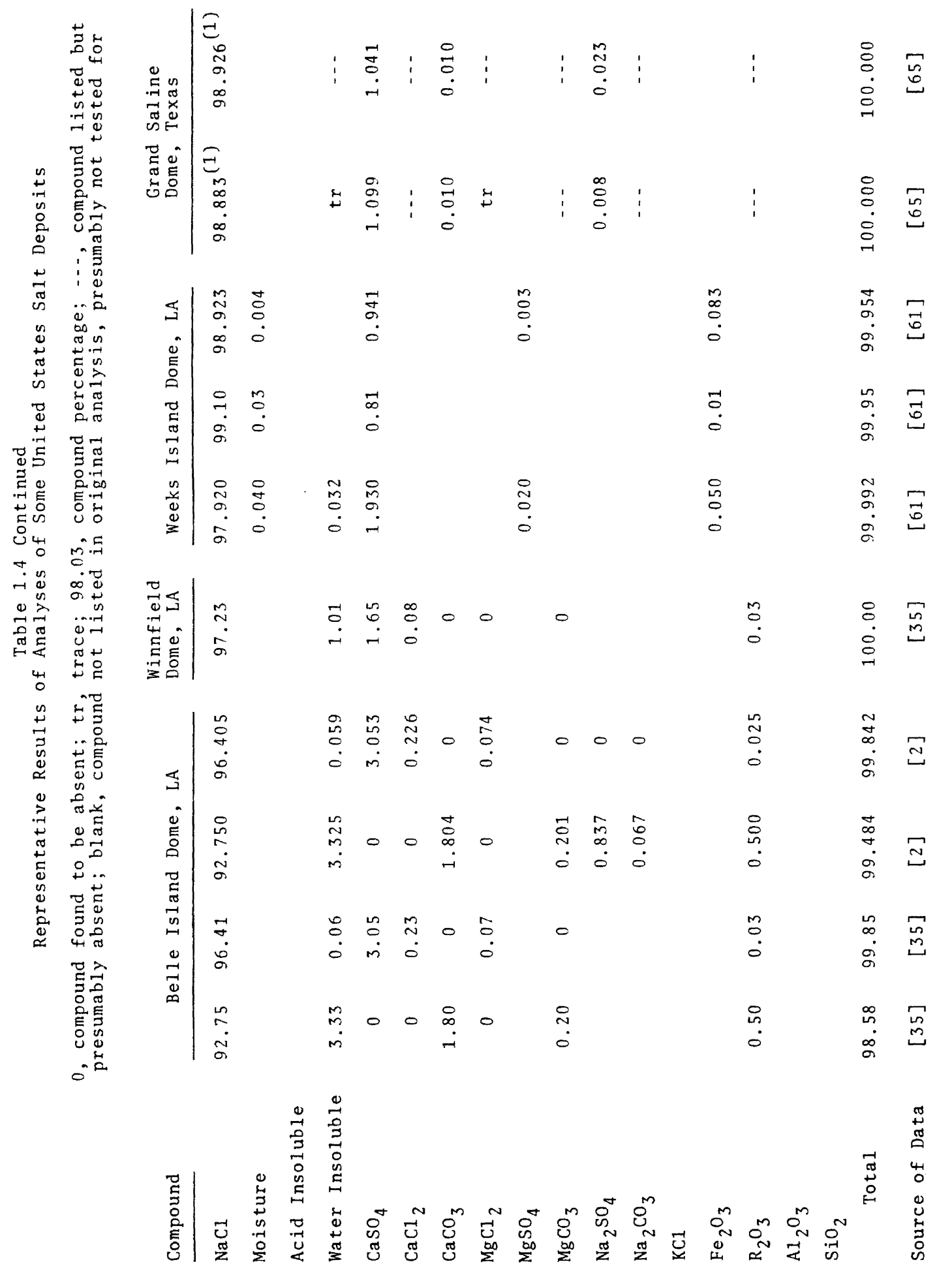




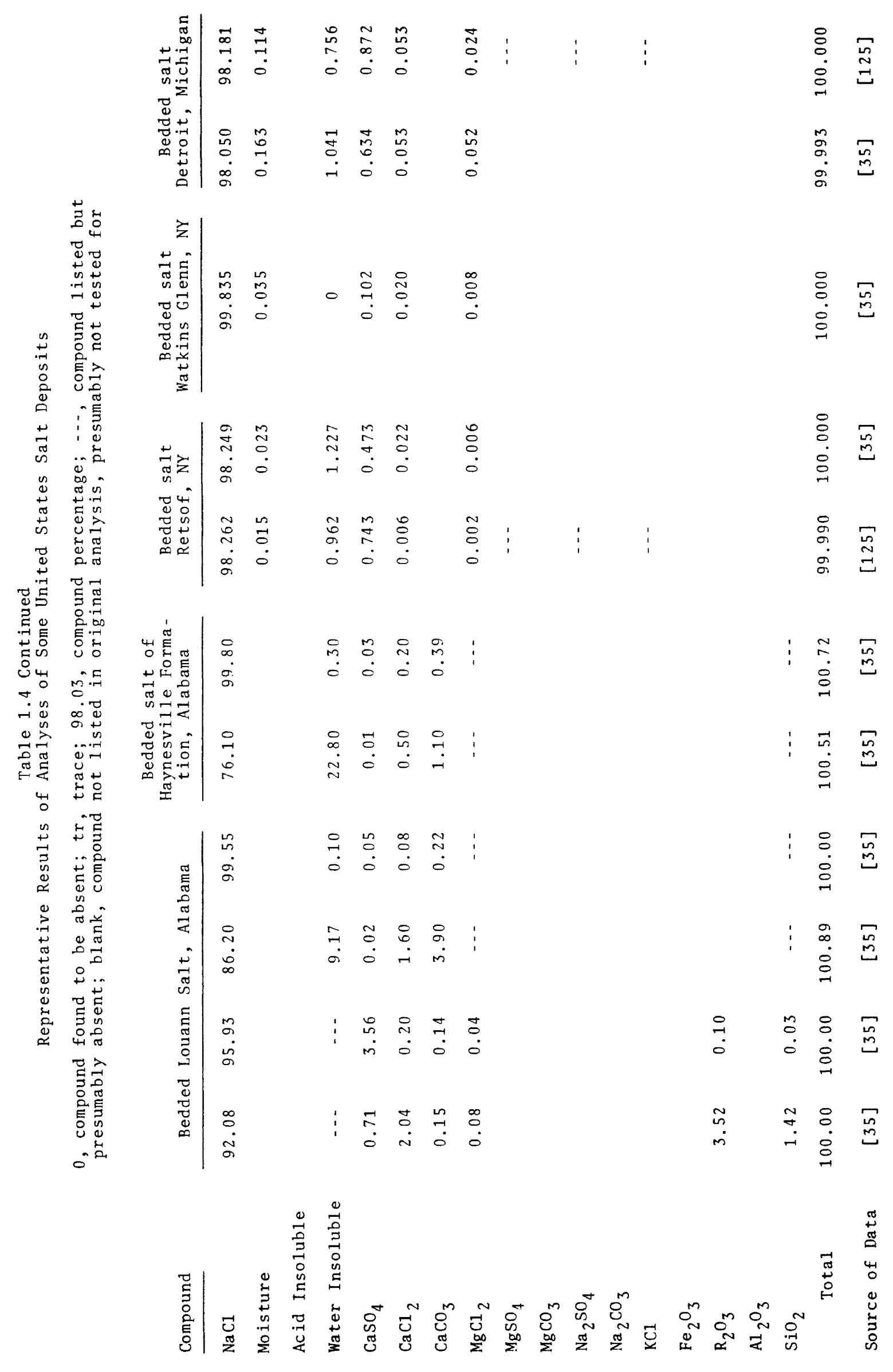




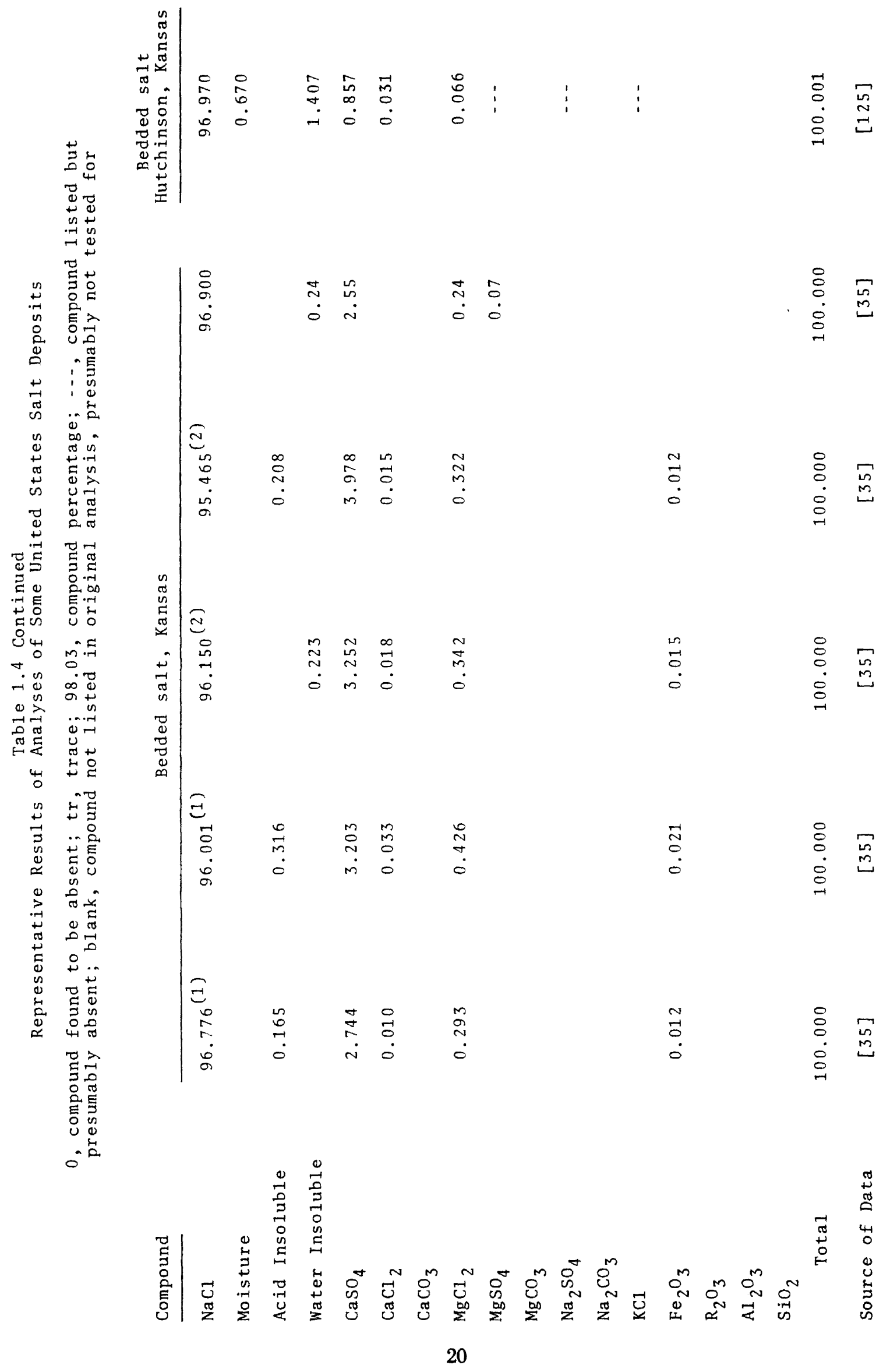




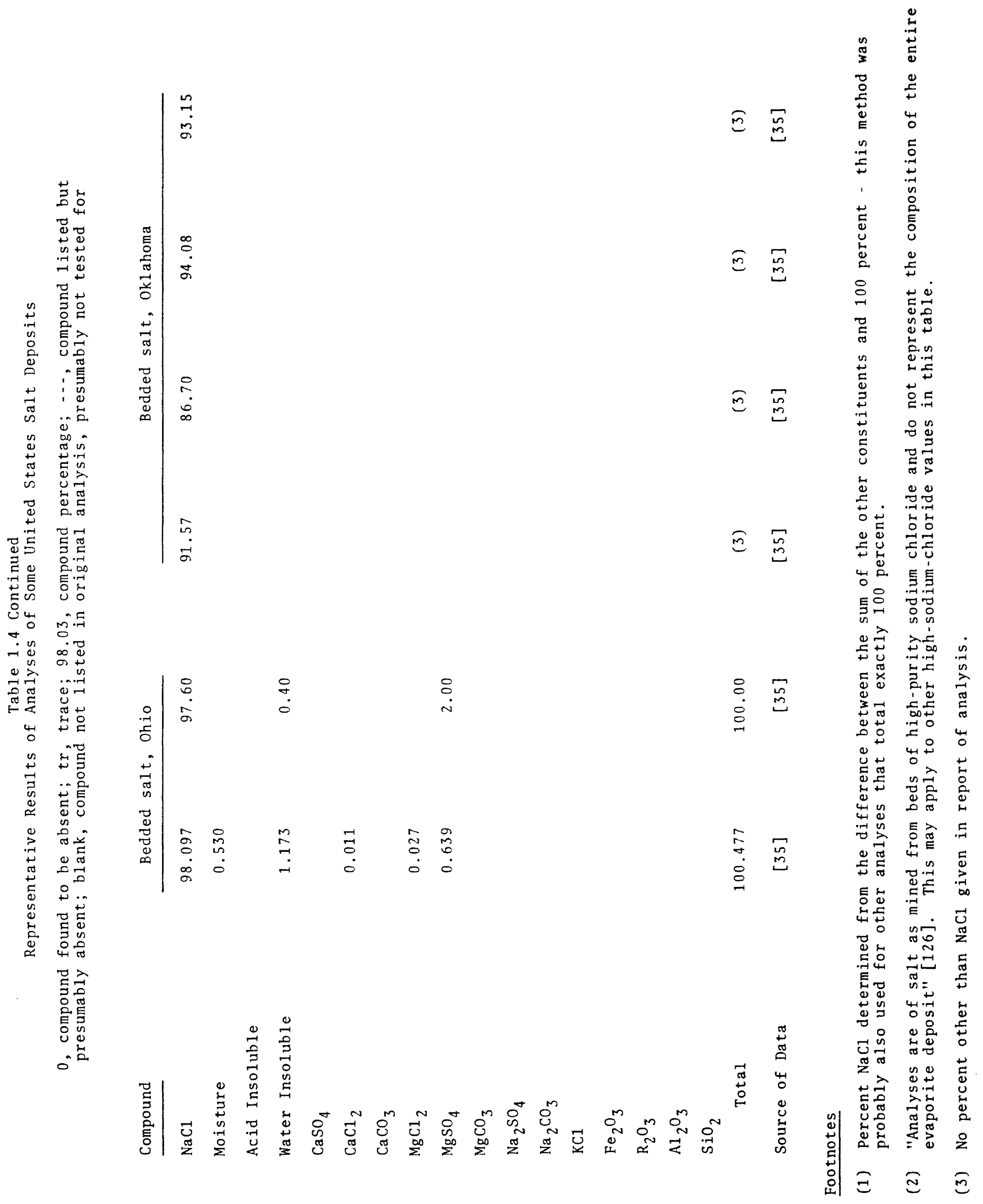


rotation of the entire crystal and translation gliding within it during flow. The rotation and translation are counteracted by the effects of recrystallization during periods of quiescence or contemporaneously with flow. In the deeper parts of domes, higher temperatures increase diffusion rates, and recrystallization processes keep pace with those causing crystal elongation.

Anhydrite stringers are commonly vertically aligned in domes, where linear concentrations of small aligned crystals form "pencil anhydrite." This alignment is well shown in the Grand Saline Dome in Texas [65].

\subsubsection{Pseudomorphism}

Minerals may be entirely replaced several times by other minerals more stable at varying temperature and pressure conditions because the salts deposited from the brines are only stable at low temperatures or because the phases precipitated are metastable and increased temperature permits the recombination of the chemical components. Schaller and Henderson [63] cited many examples of such pseudomorphism, which is the replacement of the mineral but the retention of its crystal form. Among the more common, besides the above-mentioned halite-for-gypsum replacement, are polyhalite replacing anhydrite, kainite replacing langbeinite, and sylvite replacing carnallite. In some crystals, where the physical properties of the replacement mineral are similar to those of the original, $\mathrm{x}$-ray diffraction tests are necessary to determine which mineral is present, though the crystal form is distinctive of only the original mineral.

\subsubsection{Density of Rock Salt Deposits}

At $15^{\circ} \mathrm{C}$, the average density of pure $\mathrm{NaCl}$ is 2.165 $\mathrm{g} / \mathrm{cm}^{3}[66]$. The density of the rock salt in most natural deposits is close to this. But, as the percentage of dense anhydrite impurity increases, so does the density of the sample. A rock that is 20 percent anhydrite and 80 percent halite rock would have a density of $2.32 \mathrm{~g} / \mathrm{cm}^{3}$ and a specific volume of $0.431 \mathrm{~cm}^{3} / \mathrm{g}$. Odé [67, p. 685] stated "the density of rock salt aggregates varies roughly between 2.16 and 2.25 . The variations are usually caused by anhydrite." Compaction is a negligible variable in changing the density of salt, even to depths of 18,300 meters [68]. Tables 1.5b and 1.5a list published densities and specific volumes of rock salt and other evaporites from some United States deposits and of individual constituent minerals in their pure form.

In the few cases where the type of density (table $1.5 b$ ) was indicated by the primary source, the bulk density was measured. This includes the volume of the pore space in the rock. The bulk density is relevant to geophysical measurements of the rock in place, whereas the grain densities as listed in table 1.5a are useful for laboratory work on individual crystals. In most salt deposits, the pore space is minimal, and only a slight difference exists between bulk and grain densities of rock salt. Guido and Warner [69] gave the following comparison of density values for one sample from the Winnfield Dome of Louisiana:

$$
\begin{array}{lll}
\text { Bulk } 2.163 \pm 0.018 \mathrm{~g} / \mathrm{cm}^{3} & \text { (7 tests) } \\
\text { Grain } 2.191 \pm 0.010 \mathrm{~g} / \mathrm{cm}^{3} & \text { (4 tests) }
\end{array}
$$

The procedures used in the measurement of the densities were as follows:

\section{Grain Density}

a. Specimens powdered, dried, and weighed.

b. Specimen volumes determined by kerosene displacement.

c. Specimen densities averaged.

\section{Bulk Density}

a. Specimen stripped clean and weighed to 0.1 gram.

b. Specimen volume determined to $0.1 \mathrm{~cm}^{3}$ by $\mathrm{Hg}$ displacement.

The more variable the mineralogy of a salt deposit, the more variable will be the bulk densities. Where potash beds are present and where diagenetic or metamorphic changes have occurred, abrupt changes in mineralogy and, therefore, density are common. In the potash deposits of New Mexico, horizontal sylvite and langbeinite beds commonly are abruptly truncated by zones of massive halite that were deposited from secondary migrating fluids. The replacement of sylvite (density $\left.1.98 \mathrm{~g} / \mathrm{cm}^{3}\right)$ by halite $\left(2.16 \mathrm{~g} / \mathrm{cm}^{3}\right)$ would produce an anomalously dense zone, whereas the replacement of langbeinite $\left(2.83 \mathrm{~g} / \mathrm{cm}^{3}\right)$ by halite would cause a minor decrease in relative density.

\subsection{Fluid Inclusions}

\subsubsection{Formation}

Fluid inclusions in rock salt deposits range in volume from fractions of microliters to centiliters. They are formed when fluid is trapped in irregularities of growing crystals or in rehealed fractures. As such, they are records of the composition, temperature, and pressure of the fluid medium that was present during crystal growth or fracturing.

Ionic ratios in primary inclusions in bedded halite have been used to document the unchanged composition of sea water since Paleozoic time. Because neither 
Table $1.5 a$

Reported Densities of Selected Pure Evaporite Minerals

\begin{tabular}{|c|c|c|c|c|}
\hline Sample & Formula & $\begin{array}{c}\text { Grain Density } \\
\mathrm{g} / \mathrm{cm}^{3}\end{array}$ & $\begin{array}{c}\text { Specific Volume } \\
\mathrm{cm}^{3} / \mathrm{g}\end{array}$ & $\begin{array}{l}\text { Source } \\
\text { of Data }\end{array}$ \\
\hline \multirow[t]{4}{*}{ Anhydrite } & \multirow[t]{4}{*}{$\mathrm{CaSO}_{4}$} & $2.89-2.98$ & $0.346-0.336$ & {$[127]$} \\
\hline & & 2.90 & 0.345 & {$[57]$} \\
\hline & & 2.963 & 0.337 & [ 128$]$ \\
\hline & & $2.9-3.0$ & $0.345-0.333$ & [ 129$]$ \\
\hline \multirow[t]{2}{*}{ Calcite } & \multirow[t]{2}{*}{$\mathrm{CaCO}_{3}$} & 2.72 & 0.368 & {$\left[\begin{array}{ll}1 & 27\end{array}\right]$} \\
\hline & & 2.712 & 0.369 & [ 128$]$ \\
\hline \multirow[t]{4}{*}{ Carnallite } & \multirow{4}{*}{$\mathrm{KMgCl}_{3} \cdot \mathrm{H}_{2} \mathrm{O}$} & 1.6 & 0.625 & {$\left[\begin{array}{lll}1 & 2 & 7\end{array}\right]$} \\
\hline & & 1.60 & 0.625 & {$[57]$} \\
\hline & & 1.598 & 0.626 & {$[128]$} \\
\hline & & 1.6 & 0.625 & [ 1229 ] \\
\hline \multirow[t]{2}{*}{ Dolomite } & \multirow{2}{*}{$\mathrm{CaMg}\left(\mathrm{CO}_{3}\right)_{2}$} & 2.85 & 0.351 & [ 127$]$ \\
\hline & & 2.866 & 0.389 & [ 128$]$ \\
\hline \multirow[t]{4}{*}{ Gypsum } & \multirow[t]{4}{*}{$\mathrm{CaSO}_{4} \cdot \mathrm{H}_{2} \mathrm{O}$} & 2.32 & 0.431 & [ 1227 ] \\
\hline & & 2.31 & 0.433 & {$[57]$} \\
\hline & & 2.317 & 0.432 & [ 1128 ] \\
\hline & & $2.3-2.4$ & $0.435-0.417$ & [ 129$]$ \\
\hline \multirow[t]{4}{*}{ Halite } & \multirow[t]{4}{*}{$\mathrm{NaCl}$} & 2.16 & 0.463 & {$[127]$} \\
\hline & & 2.16 & 0.463 & {$[57]$} \\
\hline & & 2.163 & 0.462 & {$[128]$} \\
\hline & & $2.1-2.2$ & $0.467-0.455$ & [ 129$]$ \\
\hline \multirow[t]{2}{*}{ Langbeinite } & \multirow[t]{2}{*}{$\mathrm{K}_{2} \mathrm{SO}_{4} \cdot \mathrm{MgSO}_{4}$} & 2.77 & 0.361 & {$\left[\begin{array}{lll}1 & 28\end{array}\right]$} \\
\hline & & $2.82-2.83$ & $0.357-0.353$ & [ 129$]$ \\
\hline \multirow[t]{3}{*}{ Polyhalite } & \multirow[t]{3}{*}{$\mathrm{K}_{2} \mathrm{Ca}_{2} \mathrm{Mg}\left(\mathrm{SO}_{4}\right)_{4} \cdot 2 \mathrm{H}_{2} \mathrm{O}$} & 2.78 & 0.360 & [ 127 ] \\
\hline & & 2.78 & 0.360 & {$[128]$} \\
\hline & & 2.78 & 0.360 & {$[129]$} \\
\hline \multirow[t]{4}{*}{ Sylvite } & \multirow[t]{4}{*}{$\mathrm{KC} 1$} & 1.99 & 0.503 & {$[127]$} \\
\hline & & 1.98 & 0.505 & {$[57]$} \\
\hline & & 1.987 & 0.503 & {$[128]$} \\
\hline & & 1.98 & 0.503 & [ 129$]$ \\
\hline
\end{tabular}


Table $1.5 \mathrm{~b}$

Measured Densities of Natura1 Salt Deposits

\begin{tabular}{|c|c|c|c|c|}
\hline $\begin{array}{l}\text { Sample } \\
\text { Composition }\end{array}$ & $\begin{array}{l}\text { Sample } \\
\text { Location }\end{array}$ & $\begin{array}{l}\text { Bulk Density } \\
\mathrm{g} / \mathrm{cm}^{3}\end{array}$ & $\begin{array}{c}\text { Specific Volume } \\
\mathrm{cm}^{3} / \mathrm{g}\end{array}$ & $\begin{array}{c}\text { Source of } \\
\text { data }\end{array}$ \\
\hline \multicolumn{5}{|l|}{ Anhydrite } \\
\hline Caprock & $\begin{array}{l}\text { Grand Saline } \\
\text { Dome, Texas }\end{array}$ & $2.37-2.64$ & $0.422-0.379$ & {$[130]$} \\
\hline \multirow{4}{*}{$\begin{array}{l}\text { Anhydrite } \\
\text { banded } \\
\text { with salt } \\
\text { "rock" }\end{array}$} & \multirow{4}{*}{$\begin{array}{c}\text { Hockley Salt } \\
\text { Dome, Texas }\end{array}$} & $2.35-2.89$ & $0.426-0.346$ & [131] \\
\hline & & $2.89-2.91$ & $0.346-0.344$ & {$[131]$} \\
\hline & & $2.84-2.97$ & $0.352-0.337$ & [131] \\
\hline & & $2.60-2.90$ & $0.385-0.345$ & {$[131]$} \\
\hline Anhydrite & $\begin{array}{l}\text { average from } \\
\text { several } \\
\text { localities. }\end{array}$ & 2.9 & 0.345 & [132] \\
\hline \multicolumn{5}{|l|}{ Gypsum } \\
\hline $\begin{array}{c}\text { Weathered } \\
\text { gypsum }\end{array}$ & $\begin{array}{l}\text { Grand Saline } \\
\text { Dome, Texas }\end{array}$ & $2.26-2.36$ & $0.442-0.424$ & {$[130]$} \\
\hline Gypsum & $\begin{array}{l}\text { Hockley Salt } \\
\text { Dome, Texas }\end{array}$ & 2.07 & 0.483 & [131] \\
\hline Gypsum & $\begin{array}{l}\text { average from } \\
\text { several } \\
\text { localities. }\end{array}$ & $2.2-2.6$ & $0.455-0.385$ & [132] \\
\hline \multicolumn{5}{|c|}{ Rock salt - Isolated Measurements } \\
\hline "Clear salt" & $\begin{array}{l}\text { Grand Saline } \\
\text { Dome, Texas }\end{array}$ & $2.13-2.16$ & $0.469-0.463$ & [130] \\
\hline "Dark salt" & $\begin{array}{l}\text { Grand Saline } \\
\text { Dome, Texas }\end{array}$ & $2.22-2.25$ & $0.450-0.444$ & [130] \\
\hline Salt & $\begin{array}{l}\text { Winnfield Salt } \\
\text { Dome, LA. }\end{array}$ & 2.17 & 0.461 & [130] \\
\hline Salt & $\begin{aligned} & \text { Hockley } \text { Salt } \\
& \text { Dome, Texas }\end{aligned}$ & $2.20-2.21$ & $0.455-0.452$ & {$\left[\begin{array}{lll}1 & 30\end{array}\right]$} \\
\hline Sa $1 t$ & $\begin{array}{r}\text { Hockley Salt } \\
\text { Dome, Texas }\end{array}$ & $2.19-2.20$ & $0.457-0.455$ & [1 30] \\
\hline Salt & $\begin{array}{c}\text { Hockley } \text { Salt } \\
\text { Dome, Texas }\end{array}$ & $2.15-2.18$ & $0.456-0.459$ & [1 30] \\
\hline Bedded salt & $\begin{array}{l}\text { Eddy County, } \\
\text { New Mexico }\end{array}$ & 2.16 & 0.463 & [130] \\
\hline \multicolumn{5}{|c|}{ Rock salt - Variation within Domes } \\
\hline "Rock salt" & $\begin{array}{l}\text { Hockley Dome, } \\
\text { Texas }\end{array}$ & 2.38 & 0.420 & [131] \\
\hline "Rock salt" & $\begin{array}{l}\text { Hockley Dome, } \\
\text { Texas }\end{array}$ & 1.92 & 0.521 & {$\left[\begin{array}{lll}1 & 3 & 1\end{array}\right]$} \\
\hline "Rock salt" & $\begin{array}{r}\text { Hockley Dome, } \\
\text { Texas }\end{array}$ & 2.20 & 0.455 & {$[131]$} \\
\hline
\end{tabular}


Table 1.5b--Continued

\begin{tabular}{|c|c|c|c|c|c|}
\hline "Rock & salt" & $\begin{array}{l}\text { Hockley Dome, } \\
\text { Texas }\end{array}$ & 2.39 & 0.418 & [131] \\
\hline "Rock & salt" & $\begin{array}{l}\text { Hockley Dome, } \\
\text { Texas }\end{array}$ & 2.23 & 0.448 & [ 131$]$ \\
\hline "Rock & sa1t" & $\begin{array}{l}\text { Hockley Dome, } \\
\text { Texas }\end{array}$ & 2.18 & 0.457 & [131] \\
\hline "Rock & sa1t" & $\begin{array}{l}\text { Hockley Dome, } \\
\text { Texas }\end{array}$ & 2.18 & 0.457 & [131 ] \\
\hline "Rock & salt" & $\begin{array}{l}\text { Hockley Dome, } \\
\text { Texas }\end{array}$ & 2.19 & 0.457 & [ 131 ] \\
\hline "Rock & salt" & $\begin{array}{l}\text { Hockley Dome, } \\
\text { Texas }\end{array}$ & 2.21 & 0.453 & [1 31 ] \\
\hline "Rock & salt" & $\begin{array}{l}\text { Hockley Dome, } \\
\text { Texas }\end{array}$ & 2.26 & 0.442 & [1 31 ] \\
\hline "Rock & salt" & $\begin{array}{l}\text { Hockley Dome, } \\
\text { Texas }\end{array}$ & 2.28 & 0.439 & [131] \\
\hline $96.3 \%$ & $\mathrm{NaCl}$ & $\begin{array}{l}\text { Winnfield } \\
\text { Dome, LA }\end{array}$ & 2.14 & 0.467 & [133] \\
\hline $97.7 \%$ & $\mathrm{NaC} 1$ & $\begin{array}{l}\text { Winnfield } \\
\text { Dome, LA }\end{array}$ & 2.15 & 0.465 & {$[133]$} \\
\hline $87.5 \%$ & $\mathrm{NaCl}$ & $\begin{array}{l}\text { Winnfield } \\
\text { Dome, LA }\end{array}$ & 2.16 & 0.463 & [133] \\
\hline $93.4 \%$ & $\mathrm{NaCl}$ & $\begin{array}{l}\text { Winnfield } \\
\text { Dome, LA }\end{array}$ & 2.23 & 0.448 & [133] \\
\hline $99.3 \%$ & $\mathrm{NaCl}$ & $\begin{array}{l}\text { Winnfield } \\
\text { Dome, LA }\end{array}$ & 2.15 & 0.465 & [1 133$]$ \\
\hline $95.0 \%$ & $\mathrm{NaCl}$ & $\begin{array}{l}\text { Winnfield } \\
\text { Dome, LA }\end{array}$ & 2.12 & 0.472 & [133] \\
\hline $78.4 \%$ & $\mathrm{NaCl}$ & $\begin{array}{l}\text { Winnfield } \\
\text { Dome, LA }\end{array}$ & 2.19 & 0.457 & [133] \\
\hline $99.1 \%$ & $\mathrm{NaCl}$ & $\begin{array}{l}\text { Winnfield } \\
\text { Dome, LA }\end{array}$ & 2.14 & 0.467 & [133] \\
\hline $97.1 \%$ & $\mathrm{NaCl}$ & $\begin{array}{l}\text { Winnfield } \\
\text { Dome, LA }\end{array}$ & 2.16 & 0.463 & [133] \\
\hline Dome $s$ & salt & $\begin{array}{l}\text { Avery Island } \\
\text { Salt Dome, LA }\end{array}$ & 2.14 & 0.467 & [134] \\
\hline Dome $\mathrm{s}$ & salt & $\begin{array}{l}\text { Avery Island } \\
\text { Salt Dome, LA }\end{array}$ & 2.11 & 0.474 & [134] \\
\hline Dome $s$ & salt & $\begin{array}{l}\text { Avery Island } \\
\text { Salt Dome, LA }\end{array}$ & 2.12 & 0.472 & [134] \\
\hline Dome $\mathrm{s}$ & salt & $\begin{array}{l}\text { Avery Island } \\
\text { Sa1t Dome, LA }\end{array}$ & 2.14 & 0.467 & {$[134]$} \\
\hline Dome & salt & $\begin{array}{l}\text { Avery Island } \\
\text { Salt Dome, LA }\end{array}$ & 2.10 & 0.476 & [134] \\
\hline
\end{tabular}


bromine nor magnesium is a significant constituent of any of the minerals formed prior to the halite phase in the precipitation sequence, the $\mathrm{Br} / \mathrm{Mg}$ ratios of primary fluid inclusions are similar to those of the original brines. Holser [70] stated that:

"Most of the $\mathrm{Br} / \mathrm{Mg}$ ratios in the brine inclusions from Hutchinson are close to that of sea water and to modern bitterns. This indicates both that the inclusions are virtually unchanged samples of the bitterns left behind in Permian time and that the $\mathrm{Br} / \mathrm{Mg}$ ratio of the sea has remained constant since the Permian. . . . Brine inclusions from the Silurian of Michigan have a similar composition ..."

Ionic ratios in fluid inclusions also record the stage of evaporation or concentration of the brine at the time of halite crystallization. Kramer [71] indicated that the brines that precipitated the salt of the Salina Formation in Ohio and Michigan had concentrations 12 to 14 times that of normal sea water. Holser [70] believed that the brines that deposited the salt of the Hutchinson Salt Member of the Wellington Formation in Kansas were concentrated almost to the potash phase (a concentration factor of almost 64 times).

Because halite contains essentially zero magnesium and very little bromine, secondary inclusions formed during resolution, and precipitation of halite can be distinguished from primary inclusions by low $\mathrm{Br} / \mathrm{Cl}$ and very low $\mathrm{Mg} / \mathrm{Cl}$ ratios.

The temperature of formation of inclusions is also considered to be recorded in the vapor bubble that is present in some fluid inclusions. Assuming that the crystal formed at the earth's surface (at ambient pressure) in a purely aqueous medium, the vapor bubble must have formed in response to the vacuum created as the fluid enclosed within the crystal subsequently cooled and contracted. Unless some fluid has leaked from the inclusion, temperatures of formation can be experimentally determined by heating the inclusion to the point where the fluid expands to eliminate the bubble [72].

Dreyer and others [73] determined these temperatures for halite to be between $70^{\circ}$ and $100^{\circ} \mathrm{C}$ and concluded that these high temperatures were records of the exothermic heat of crystallization localized at the crystal surface and not the overall temperatures of the precipitating brines. Peach [74], however, believed that these temperatures recorded overall formation temperatures and pressures during secondary recrystallization at depth.

\subsubsection{Composition}

Data on the composition of fluid inclusions is minimal; many publications give only comparative ionion ratios rather than absolute parts per million. Tables 1.6a and 1.6b list some of the published data, many of them coming from Roedder [75]. In general, fluid inclusions are at saturation with respect to $\mathrm{NaCl}$ because their host mineral is halite. Metamorphism and recrystallization can cause the other ionic constituents of inclusions to vary greatly, even in adjacent inclusions. The major cations are $\mathrm{Na}^{+}, \mathrm{Ca}^{2+}$, and $\mathrm{Mg}^{2+}$; the dominant anion is $\mathrm{Cl}^{-}$, and some $\mathrm{SO}_{4}{ }^{2-}$ is present.

Kramer [76] stated "obviously secondary inclusions from Ontario (the Salina Formation) were almost pure $\mathrm{NaCl}$ brine." Roedder [77] noted that other inclusions from the same formation contain concentrated calcium brines. He also stated that most of the fluid inclusions at one locality of the Hutchinson Salt Member in Kansas are nearly pure $\mathrm{NaCl}$ brine.

Inclusions in domed rock salt have been subjected to recrystallization and, at least, mechanical deformation. At best, these inclusions can be considered to be only residues of the precipitating liquors or samples of secondary metamorphic brines. The methane gas and liquid oil inclusions in many of the Louisiana salt domes are certainly of secondary origin, having been incorporated into the salt contemporaneously with the dome formation.

Kramer [78] detailed a procedure for preparing and analyzing fluid inclusions, a summary of which follows:

1. $30 \mathrm{mg}$ samples of inclusion-rich salt were first examined for inclusion morphology.

2. A $30 \mathrm{mg}$ sample of inclusion-free salt from the same specimen was selected as a blank.

Parts per Million of Total Inclusion Fluid

\begin{tabular}{|c|c|c|c|c|c|c|c|c|c|}
\hline $\begin{array}{l}\text { Sample } \\
\text { Number }\end{array}$ & $\mathrm{Na}^{+}$ & $k^{+}$ & $\mathrm{Ca}^{2+}$ & $\mathrm{Mg}^{2+}$ & $\mathrm{Cl}^{-}$ & $\mathrm{SO}_{4}{ }^{2-}$ & $\mathrm{F}^{-}$ & Concentration & Location of Sample \\
\hline 1 & 69,100 & 3,500 & 13,700 & 1,600 & 110,000 & 44,800 & 58 & 242,600 & $\begin{array}{c}\text { Salina salt beds (Silurian) } \\
\text { Goderich, Ontario }\end{array}$ \\
\hline 2 & 88,200 & 4,700 & 16,400 & 2.050 & 145,000 & 38,100 & 63 & 294,500 & $\begin{array}{c}\text { Salina salt beds (Silurian) } \\
\text { Cleveland, Ohio }\end{array}$ \\
\hline
\end{tabular}




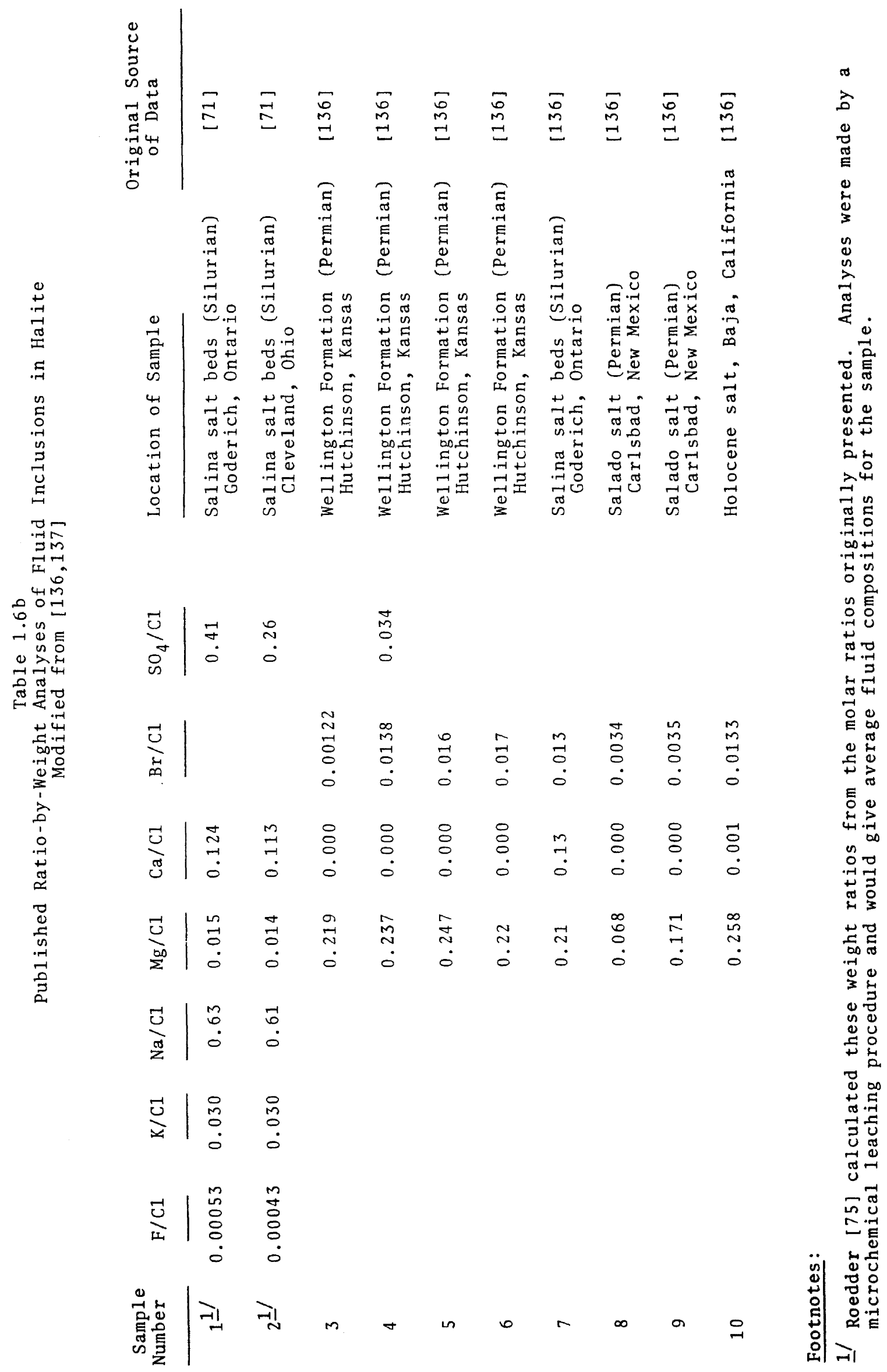


3. Samples were weighed to \pm 2 micrograms.

4. Samples were dried to a constant weight at $125^{\circ} \mathrm{C}$.

5. Samples were ground with mortar and pestle and again dried to constant weight at $125^{\circ} \mathrm{C}$.

6. Loss of weight between steps 4 and 5 was taken as the loss of inclusion water.

7. Ground samples were dissolved in water, and the solution was analyzed chemically. Ionic values greater than those of the blank sample were considered to have been derived from the inclusion fluids.

8. "The methods employed were flame emission for $\mathrm{Na}$ and $\mathrm{K}$, chloranilate calorimetry and thorin titration for sulfate, potentiometric titration with $\mathrm{AgNO}_{3}$ for $\mathrm{Cl}$, alizarin calorimetry for $\mathrm{F}$, fluorescence titration with calcein and EDTA for $\mathrm{Ca}$, and EBT titration with EDTA for $\mathrm{Ca}$ and $\mathrm{Mg}$ " [78].

Fluid inclusions in halite are irregularly distributed and in many places are abundant adjacent to uther zones where they are absent. They may be spherical, minimizing surface area, or cubic "negative" crystals, minimizing surface potential. Shuman and Fiedelman [79] found that, in artificially grown crystals, round inclusions formed in highly agitated water whereas cubic inclusions formed in quiet water. The number of inclusions in a sample is a "function of crystal size, concentration of solid particles in suspension in the brine, and particle size of the inclusions" [79]. Their irregular distribution is probably due to secondary metamorphism or recrystallization.

Inclusion volumes in some laboratory-grown halite crystals range from 0.23 to 0.45 percent of the total volume [79]. Roedder [80] stated that commercial reagent-grade halite contains abundant fluid inclusions that constitute about 0.5 percent of the total weight and that the inclusions in the bedded rock salt investigated constituted 0.44 weight percent of the rock.

The reported water content of rock salt is often well below this 0.5-percent figure. Aufricht and Howard [81] gave the following percentages of total volume occupied by water in rock-salt samples: rock salt in central Kansas, 0.05-0.08 percent; salt mines in Detroit, 0.1-0.15 percent; Louisiana salt domes, $0.003-0.008$ percent. Odé [82] listed typical weight percentages of moisture from Hutchinson and Lyons Mines, Kansas, as 0.127-0.293 percent and 0.090-0.100 percent, respectively. Although Odés analyzed samples were heated in excess of $250^{\circ} \mathrm{C}$, most moisture analysts do not heat their sampes above $125^{\circ} \mathrm{C}$. All moisture analyses in which the sample was heated above $125^{\circ} \mathrm{C}$ must be suspect. At $125^{\circ} \mathrm{C}$, rock salt will still contain a residual calcium-magnesium-chloride brine from which the water will not be removed.

As indicated by figure i.8, 100 percent of the moisture is not released by salt during normal laboratory heating times until the sample is heated in excess of $625^{\circ} \mathrm{C}$.
Shuman and Fiedelman [83] stated that, in order to remove 100 percent of the moisture in brine inclusions in salt within 1 hour, the sample must be heated to $801^{\circ} \mathrm{C}$ $\left(1474^{\circ} \mathrm{F}\right)$, close to its melting point. Aufricht and Howard [84] also observed this. Roedder [85] found his 0.44 percent weight loss (attributed to vaporized fluid inclusions) on decrepitation of salt heated to incipient fusion [86].

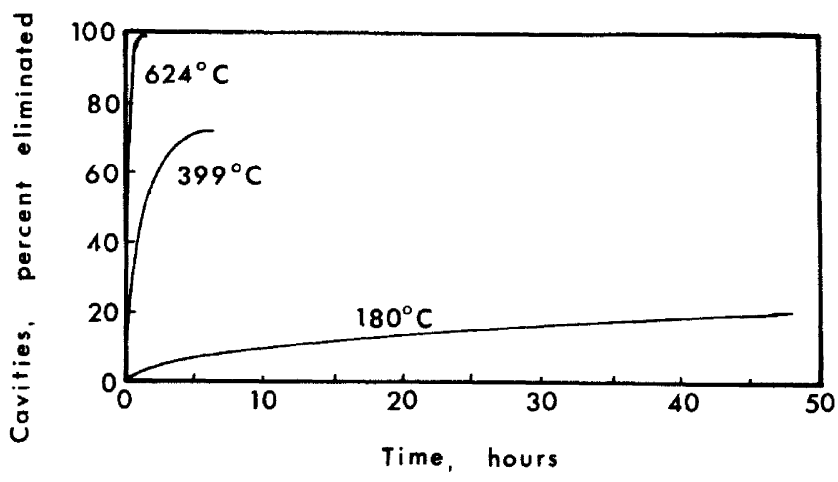

Figure 1.8. Rate of moisture release from brine inclusions in halite heated to various temperatures. Modified from [147].

\subsubsection{Pressure Gas Inclusions}

Although the vapor bubbles associated with fluid in primary inclusions are theoretically under a vacuum, other inclusions of gas are under considerable pressures. Baar [87] attributed some of these pressures to plastic deformation of rock salt by thick overburden and the resulting compression of the gas-filled cavities.

In East Germany, $\mathrm{CO}_{2}$ gas associated with Tertiary volcanic activity was trapped under pressure when it was magmatically injected into buried salt deposits, partially melting them. Solidification and recrystallization enclosed the gas as inclusions and as microscopic flaws at crystal boundaries [88]. A diabase dike [89] is known to cut through the New Mexico rock salt deposits, though no association has been made between it and pressured gas inclusions.

Gas inclusions are often associated with potash beds [90], and suggestions have been made that they are accumulations of argon, derived from the radioactive potassium isotope found in such minerals as sylvite (KCl) and langbeinite $\left(\mathrm{K}_{2} \mathrm{Mg}_{2}\left(\mathrm{SO}_{4}\right)_{2}\right)$. Hoy and others [91] have noted that carbon dioxide pockets and blowouts in Texas and Louisiana salt domes usually are near the dome boundaries. The gas probably has organic origins and may have been entrapped in processes related to the shearing and disruption of the salt during doming. Another possible source for $\mathrm{CO}_{2}$ gas [92] is the 
breakdown of the unstable magnesium chlorocarbonate $\left(\mathrm{MgCl}_{2} \cdot \mathrm{MgCO}_{3} \cdot 7 \mathrm{H}_{2} \mathrm{O}\right)$.

Pressures of gas inclusions are variable and difficult to measure. A common mining measurement is the weight of the rock salt that was shattered by the violent degassing of numerous concentrated inclusions. This weight often measures in the thousands of tons, and the estimates of gas released can range in the hundreds of thousands of cubic meters (at ambient surface pressures). Some rock salt deposits are capable of yielding 3 to 20 cubic meters of gas per ton [88] although the volume of the gas as inclusions is small under pressure.

Other pressure measurements are rare and scattered. Hoy and others [93] reported estimated pressures of 50 to $100 \mathrm{MPa}$ in $\mathrm{CO}_{2}$ blowouts in the Winnfield salt dome in Louisiana. McClain and others [94] noted that the steady shut-in pressure after a blowout in the AEC (Atomic Energy Commission) No. 7 well, drilling through the Permian Salado and Castile Formations of New Mexico, was $0.79 \mathrm{MPa}$, a measurement made after a considerable amount of uncontrolled gas venting. Roedder [92] cited examples of gas inclusions in Mexican and German salt that expanded their volumes 250 times after release from the confining pressures.

The most common gas inclusions in rock salt contain methane $\left(\mathrm{CH}_{4}\right)$, carbon dioxide $\left(\mathrm{CO}_{2}\right)$, and nitrogen $\left(\mathrm{N}_{2}\right)$ [95]. Methane and nitrogen have been reported in the potash mines of New Mexico [96,97]. The weight percent of constituents of blowout gases in the AEC No. 7 well, where six samples were collected for anlyses during a 1 month period [98], was given as:

$$
\begin{aligned}
& \mathrm{CO}_{2}-0 \text { to } 0.54 \text { percent } \\
& \mathrm{O}_{2}-0 \text { to } 0.81 \text { percent } \\
& \mathrm{CH}_{4}-0 \text { to } 2.14 \text { percent } \\
& \mathrm{CO}-0 \text { percent } \\
& \mathrm{C}_{2} \mathrm{H}_{6}-0.031 \text { to } 0.05 \text { percent } \\
& \mathrm{N}_{2}-97.08 \text { to } 99.904 \text { percent }
\end{aligned}
$$

Analyses have also been made on the gases associated with the Winnfield Dome in Louisiana. Belchic [99] reported the presence of $\mathrm{H}_{2} \mathrm{~S}$ and $\mathrm{CO}_{2}$. Hoy and others [100] reported:

$$
\begin{aligned}
& \mathrm{CO}_{2}-46.9 \text { percent } \\
& \mathrm{H}_{2} \mathrm{O}-17.3 \text { percent } \\
& \mathrm{N}_{2}-18.4 \text { percent } \\
& \mathrm{CO}-4.8 \text { percent } \\
& \mathrm{O}_{2}-4.4 \text { percent } \\
& \mathrm{SO}_{2}-3.7 \text { percent } \\
& \mathrm{H}_{2}-1.8 \text { percent } \\
& \mathrm{CH}_{4}-1.5 \text { percent } \\
& \mathrm{Ar}-0.4 \text { percent } \\
& \mathrm{C}_{2} \mathrm{H}_{2}-0.4 \text { percent } \\
& \text { Other hydrocarbons-0.4 percent }
\end{aligned}
$$

\subsubsection{Brine Pockets and Seeps}

Pockets and seeps of brine in rock salt deposits are commonly associated with pressured gas inclusions. Some of these brines may be large-scale entrapments of the original fluids that precipitated the deposits, but many are of secondary origin, remnants of metamorphic brines, or ground waters that became saturated with respect to the adjacent minerals and lost the ability to migrate by solution. Large but rare pockets containing " a few gallons" [85] of Ca-rich brines are found in the Goderich, Ontario, salt mine and the potash mines of Saskatchewan. Baar [101] has suggested that large pockets of Ca-rich solutions result from reactions of $\mathrm{MgCl}_{2}$ brines (the liquors left in the last stages of precipitation) with Ca-bearing rocks, in the reaction:

$\mathrm{MgCl}_{2}$ (brine) $+\mathrm{CaSO}_{4}$ (anhydrite) $=\mathrm{CaCl}_{2}$ (brine) + ( $\mathrm{MgSO}_{4}$ or any number of magnesium sulfate minerals).

Brine seeps and associated gases (usually $\mathrm{CO}_{2}$ ) are often found in the salt domes of the Gulf Coast. Belchic [102], citing the facts that brine seeps come up from the floor of mines more often than down from the roof and that they never freshen, believe that their source is deep within the dome rather than from ground water. The seeps are usually associated with anhydrite bands and tend to move vertically along the banding, perhaps at the anhydrite-salt contacts.

The salt mine in Winnfield Dome, Louisiana, contains the best-known examples of brine seeps. Most of these gas and brine seeps are found nearer the outer walls of the dome, though they are irregular in distribution. Flow rates are greatest just after exposure by excavation in the mine and dwindle to cessation during a period of a few years [103] either because of the sealing of the fractures or the eventual draining of the pocket of brine. Small gas and brine pockets are also found by horizontal drill holes into mining faces, but the flow from them ceases after a few hours [104]. Exploratory wells in the Winnfield Dome have penetrated pressured gas and brine pockets. Taylor [105] reported brine and gas under a pressure of $1.55 \mathrm{MPa}$ at a depth of 180 meters below the mine level, and Belchic and others $[99$, p. 34] noted a pressure of $0.90 \mathrm{MPa}$ in a cavity full of water at the anhydrite-salt contact.

\subsection{Porosity and Permeability}

\subsubsection{Porosity}

Most of the porosity in rock salt is quickly filled in by crystal growth and plastic flowage during deposition. Baar [106] listed porosity as a function of depth as follows: 
40 percent at the surface

30 percent under 0.15 meters of overburden

20 percent under 0.30 meters of overburden

15 to 20 percent under 0.60 meters of overburden

5 to 10 percent at depths of 6 to 12 meters

gradually approaches 0 percent below 12 meters

Guido and W arner [69] calculated porosity in rock salt from the Winnfield Dome at 1.28 percent by using the formula

$$
\text { porosity }(\theta)=1-\frac{\text { bulk density }}{\text { grain density }} .
$$

Aufricht and Howard [107] measured porosity in three salt domes and one deposit of bedded rock salt by using both gas expansion and brine resaturation tests performed on 2.5 to $5 \mathrm{~cm}$ cubic samples as follows:

"For the gas-expansion determinations, the bulk volume of the samples was determined in a mercury pycnometer. Pore volumes then were measured directly. In determining the resaturation porosities, the bulk volumes were also determined in a mercury pycnometer. The dry samples were weighed, evacuated, pressure saturated with brine and reweighed. The pore volumes were taken as the weight gains occurring upon saturation."

Table 1.7 gives Aufricht and Howard's porosity data. The range of individual samples was from 0.62 to 7.17 percent porosity, that of the averages from the four localities from 1.0 to 6.0 percent. Reynolds and Gloyna [108] gives average porosity values of 1.71 percent and 0.59 percent for rock salt from Grand Saline Dome, Texas, and the bedded salt of the Hutchinson Salt Member of the Wellington Formation, Kansas. The laboratory procedure used for measurement was not detailed.

Stevens [109] measured porosities in Permian anhydrite beds associated with salt deposits in the upper Brazos region of Texas. In 14 anhydrite samples, porosity varied from 0.3 to 4.4 percent, averaging 1.9 percent.

Using Guido and Warner's bulk-to-grain density proportion method for calculating porosity [69], the volume of fluid inclusions as well as the intercrystalline pore spaces would be measured as porosity. Using the brine resaturation method, however, only the intercrystalline voids in communication with the surface of the sample would contribute to the total porosity figure.

\subsubsection{Permeability}

Under low confining pressures, that is at shallow depths, dry halite allows fluid flow along crystal boundaries and cleavage planes. Laboratory tests on rock salt cores have measured these permeabilities with respect to various fluids and gases (table 1.8). Reynolds and Gloyna's data [108] illustrate the direct correlation between permeability of rock salt and the confining pressure. Baar [110] stated that the presence of trapped gases in salt deposits testifies to their absolute impermeability at depth, though Aufricht and Howard [111] noted significant permeability still present in rock salt samples at confining pressures less than $55 \mathrm{MPa}$.

Aufricht and Howard detailed their permeability measurement procedures which are summarized below:

1. Samples were cut into cores $7.5 \mathrm{~cm}$ in diameter and about $20 \mathrm{~cm}$ long.

2. Cores were cast in plastic or in bismuth alloy metal or were jacketed in copper to seal lateral surfaces.

3. Samples were placed in a pressure vessel, and simulated overburden pressures were created by injecting nitrogen gas into the vessel.

4. The sample was saturated with nitrogen or degassed saturated brine or liquid hydrocarbon.

5. The fluid was passed through the sample, and the flow was allowed to stabilize.

6. Pressure drops across the sample, flow rates, and the core dimensions were measured and used to calculate permeability by Darcy's law.

Table 1.7

Average Porosities of Salt Samples Modified From References [138]

Average porosity

percent bulk volume

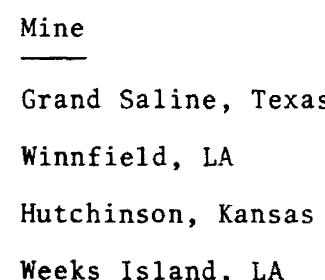

Weeks Island, LA

$\begin{gathered}\text { Number } \\ \text { of samples }\end{gathered}$
3
3
8
3

By

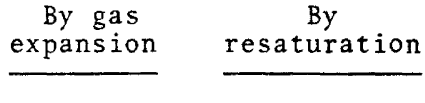

1.7

1. 8

1. 0

1.8

0.8

6.0 
Table 1.8

Permeability of Rock Salt

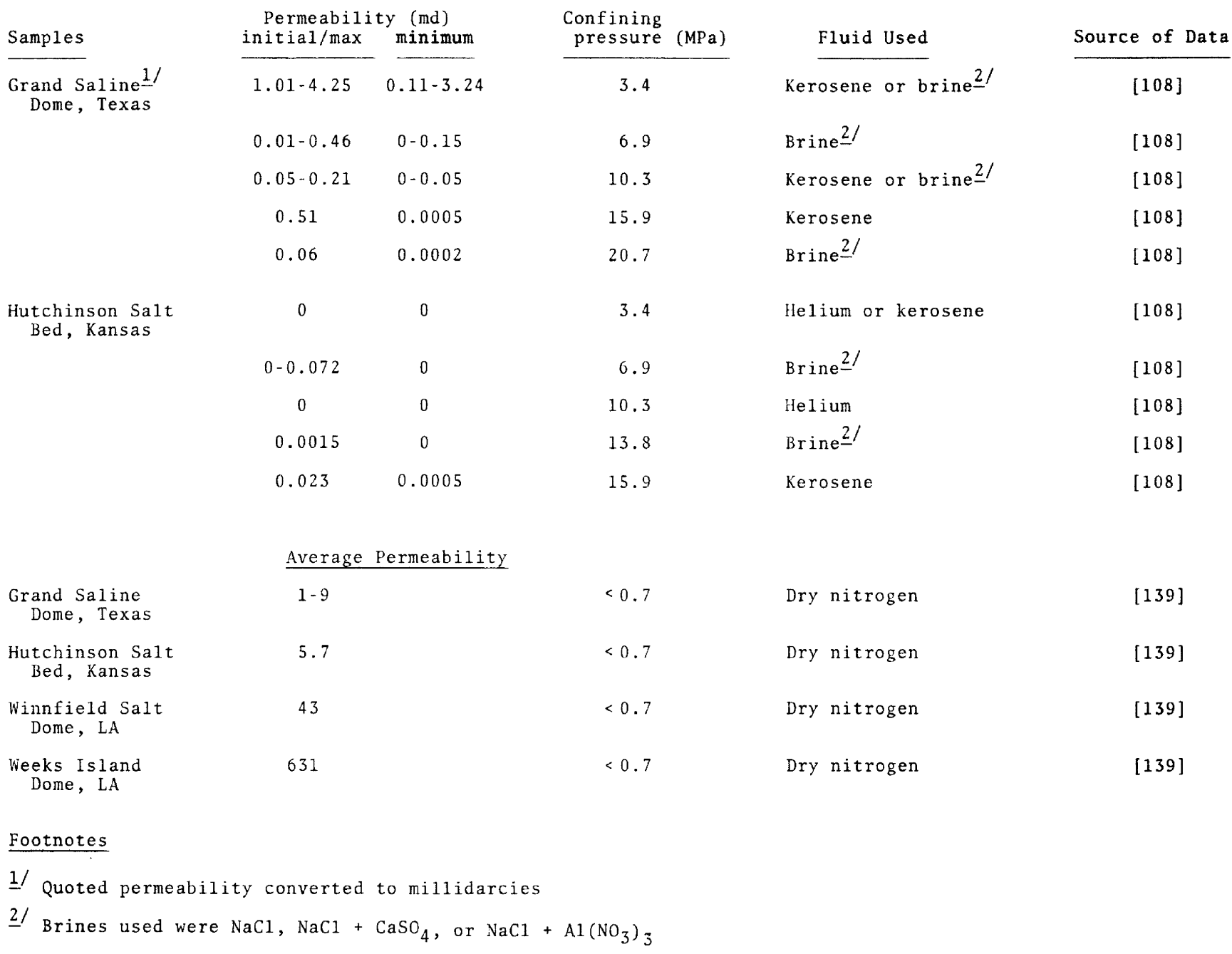

The permeability of halite is effectively zero when the pressure is sufficient to deform the halite plastically and close off the passageways at crystal interfaces. Observed permeability in rock salt samples at high confining pressures then, must be due to the presence of impurities or must be artifacts of laboratory techniques. Baar [112] asserted that "standard permeability tests on rock salt cores are usually of no use, for the cores are damaged when taken out of their tri-axial in-situ stress field. Such damage may be caused by stress relief deformation that results in intergranular loosening."

Another variable is the solution flowing through the sample. Fluids "inert" with respect to halite, such as hydrocarbons, flow more quickly and for longer periods of time than do saturated brines. (Fresh water would, of course, dissolve halite and enhance permeability until the fluid reached saturation.) Permeability using saturated brine decreases rapidly with time (figure 1.9a), probably owing to recrystallization of halite in the passageways and the enhanced plasticity of halite in the presence of water. Aufricht and Howard [111] believed that, after a certain time, however, stabilization may

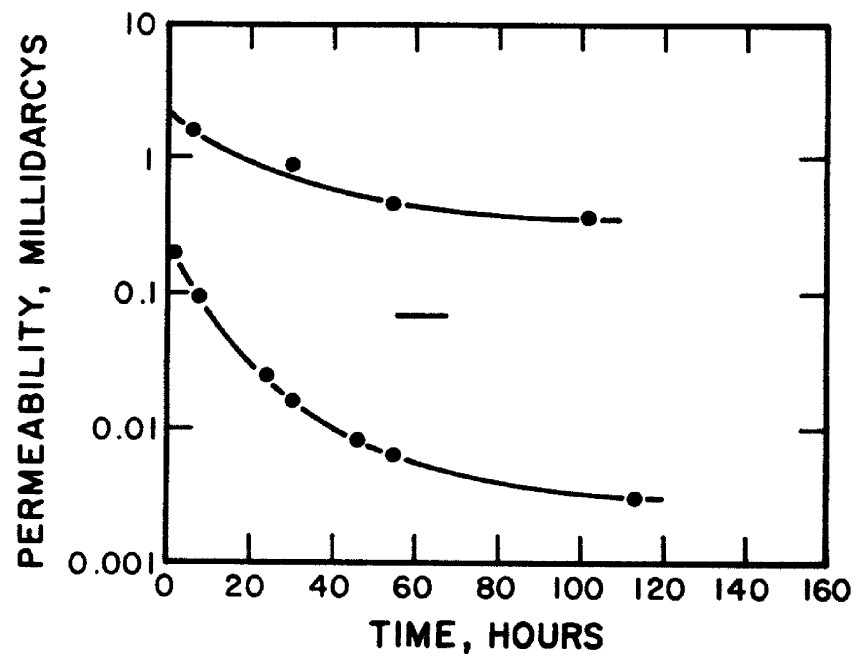

Figure 1.9a. Laboratory permeability of rock-salt samples to saturated brine at one atmosphere. Modified from [148]. 
occur in the brine/rock salt system, would stabilize, and would contain a small remnant permeability.

The presence of brine also inhibits permeability through the shale partings and anhydrite lenses often found in rock salt deposits. Water may hydrate anhydrite stringers and the clays of shale partings and increase their volume, squeezing off permeability. The resolution and deposition of $\mathrm{CaSO}_{4}$ caused by brine in anhydrite also helps choke off the permeability.

Laboratory permeability of rock salt to nitrogen, oil, and brine under a simulated overburden pressure of 5.51 $\mathrm{MPa}$ [149] is shown in figure 1.9b.

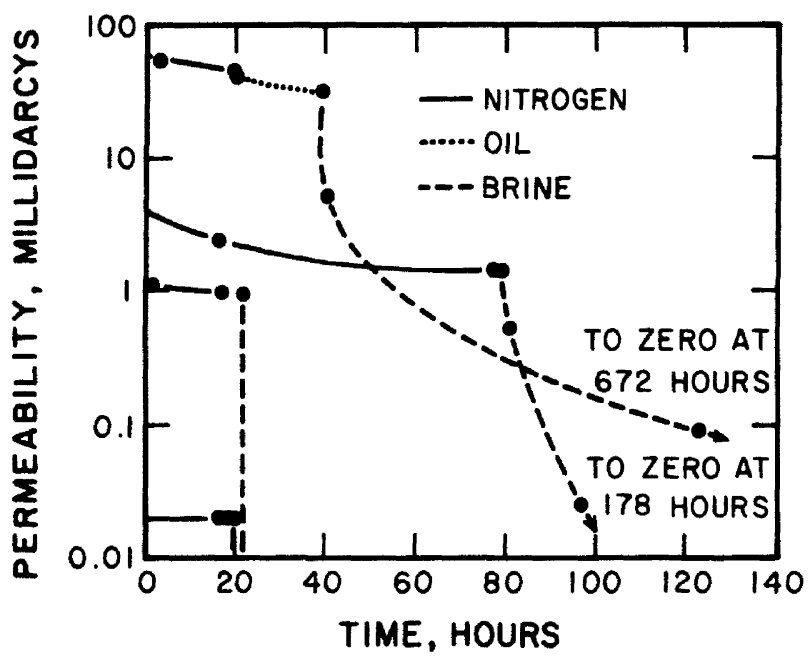

FIGURE 1.9b. Laboratory permeability of rock salt to nitrogen, oil, and brine under simulated overburden pressure of $5.51 \mathrm{MPa}$. Modified from [149].

In spite of these theoretical and laboratory results, evidence for local movement of quantities of water through rock salt deposits is not uncommon. Anhydrite banding in salt domes is "variably porous and permeable, and often partially saturated with brine and $\mathrm{CO}_{2}$ gas" [113]. Seeps and drips are known in most salt and potash mines, though those that come down from the roof may be ground water that has found its way down manmade passages.

The interfaces between halite and shale or halite and anhydrite are often suspected of having greater permeability than the beds themselves $[114,115]$. Permeability is greater parallel to bedding than it is perpendicular to it. The $W$ innfield Dome salt mine has numerous seeps of brine and gas from the floor and ceiling, yet "little or no brine or gas flow from the walls" [104].

The sheared "shale sheath" zone that encircles Gulf Coast salt domes is avoided by salt miners because of severe water leakage problems found there [116]. These leakage problems imply abundant and mobile water and high permeability. On the other hand, this zone is also avoided by well drillers because of overpressured gas pockets commonly associated with it, implying nonpermeable zones.

\subsubsection{Permeability in LPG Storage Caverns}

The fluid integrity of many rock salt deposits with respect to hydrocarbons has been tested by oil companies who store liquid petroleum gas (LPG) in cavities artificially dissolved out of the rock salt. Beds of halite are rarely thick enough to enclose a full-scale storage cavern, but the associated anhydrite bands and other impurities seem to be largely impermeable in these caverns [60] . Aufricht and Howard [117], using gasoline as a fluid, found a range of permeabilities through salt from 0 to $6 \mathrm{md}$, the average permeability was $0.3 \mathrm{md}$. Table 1.9 gives estimated recovery percentages for storage caverns in the Salado Formation in New Mexico and several other locations.

Hawkins and Jirik [118, p. 17] stated "with some exceptions, the recovery of stored LPG products (from caverns in Louisiana salt domes) has been good, generally above 90 percent." The 1956 Interstate Oil Compact Commission [119] also puts the recovery figure at generally greater than 90 percent, and some of the loss is probably due to above-ground handling losses. The lowest recovery percentage given was 57 percent, but the circumstances for this low figure were not described. Recovery percentages usually increase after the initial withdrawal from the cavern, prior losses being contributed to by infilling of cavern irregularities with nonrecoverable oil. Aufricht and Howard [120], however, noted a slight decrease in permeability of salt with respect to oil (and nitrogen) with time. Table 1.9 shows a fair inverse correlation between storage pressure and percent recovery.

\subsection{Pore Fluids}

\subsubsection{Composition}

The character of pore fluids is a function of the composition and history of the rock salt. The only generalization that is possible is that the $\mathrm{NaCl}$ content of the pore fluid is saturated or nearly saturated in the mineral halite. Tables 1.10 through 1.19 give the concentration of $\mathrm{NaCl}$ that is in the aqueous solution containing $\mathrm{KCl}, \mathrm{MgCl}_{2}, \mathrm{CaCl}_{2}$, and combinations of $\mathrm{CaCl}_{2}$ with $\mathrm{KCl}$ between 0 and $100^{\circ} \mathrm{C}$ [121]. Table 1.21 gives the solubility of $\mathrm{NaCl}$ in halite saturated water above $100^{\circ} \mathrm{C}$.

\subsubsection{V'apor Pressure}

Table 1.20 gives the experimentally measured vapor pressures for various synthetic, halite-saturated brines 
Table 1.9

Percent Recovery of Stored Liquid Petroleum Gas Stored in Solution Cavities in Salt Deposits. Adopted from Reference [119], table 13

\begin{tabular}{|c|c|c|c|c|}
\hline Location & Formation & $\begin{array}{l}\text { Capacity of } \\
\text { Cavern (gallons) }\end{array}$ & $\begin{array}{l}\text { Storage } \\
\text { Pressure (MPa) }\end{array}$ & $\begin{array}{l}\text { Estimated } \\
\text { Recovery }\end{array}$ \\
\hline New Mexico & Sal ado & 781,200 & 4.1 & 90 \\
\hline New Mexico & Salado & $1,500,000$ & 2.1 & 90 \\
\hline New Mexico & Sal ado & $1,848,672$ & 1.4 & 98.0 \\
\hline New Mexico & Salado & $1,000,000$ & 1.5 & 97 \\
\hline New Mexico & Sal ado & $1,456,980$ & 1.4 & 98 \\
\hline New Mexico & Salado & $2,000,000$ & 2.1 & 90.0 \\
\hline New Mexico & Salado & $2,005,580$ & 3.6 & $95 \frac{1}{\prime}$ \\
\hline New Mexico & Salado & $2,422,000$ & 3.8 & 92.0 \\
\hline New Mexico & Salado & $2,216,000$ & 4.1 & 90.0 \\
\hline New Mexico & Sal ado & $1,000,000$ & 1.6 & 97 \\
\hline New Mexico & Salado & $1,000,000$ & 1.6 & 97 \\
\hline Louisiana & $\begin{array}{c}\text { Pine Prairie } \\
\text { Salt Dome }\end{array}$ & $\cdots$ & $\cdots$ & 93.3 \\
\hline Kansas & Permian salt & $\cdots$ & $\cdots$ & 92.86 \\
\hline Kansas & Permian salt & $\cdots$ & $\cdots$ & 95 \\
\hline Kansas & Permian salt & $\cdots$ & $\cdots$ & 92.5 \\
\hline
\end{tabular}

1/ Originally shown in Table 13 as 9.7 percent - personal communication to Warren Petroleum Corp., Hobbs, N.M., indicated 95 percent as an approximate figure.

Table 1.10

Solubility of $\mathrm{NaCl}$ (weight percent) in KCl solutions as given. Data in parentheses, ( ), are extrapolated; the solution may be supersaturated in one or more solid phases other than halite. Precision ( 3 sigma) is given in brackets, [ ], for the $0^{\circ}, 50^{\circ}$, and $100^{\circ} \mathrm{C}$ isotherms.

Temperature

$\underline{\text { KCl concentration in weight percent }}$

\begin{tabular}{rccccccc}
$\left({ }^{\circ} \mathrm{C}\right)$ & 0 & 2 & 4 & 6 & 8 & 10 & 12 \\
\hdashline 0 & - & - & - & - & - & - & - \\
& $(25.94)$ & $(24.84)$ & $(23.75)$ & $(22.65)$ & $(21.56)$ & $(20.46)$ & $(19.37)$ \\
10 & {$[.13]$} & {$[.13]$} & {$[.14]$} & {$[.14]$} & {$[.15]$} & {$[.15]$} & {$[.16]$} \\
20 & $(26.07)$ & $(24.98)$ & $(23.88)$ & $(22.79)$ & $(21.69)$ & $(20.60)$ & $(19.50)$ \\
30 & $(26.23)$ & $(25.13)$ & $(24.04)$ & $(22.94)$ & $(21.85)$ & $(20.75)$ & $(19.66)$ \\
40 & 26.39 & 25.30 & 24.20 & 23.11 & 22.01 & 20.92 & 19.82 \\
50 & 26.57 & 25.48 & 24.38 & 23.29 & 22.10 & 21.10 & 20.00 \\
& 26.77 & 25.68 & 24.58 & 23.49 & 22.39 & 21.30 & 20.20 \\
60 & {$[.05]$} & {$[.04]$} & {$[.04]$} & {$[.05]$} & {$[.06]$} & {$[.07]$} & {$[.09]$} \\
70 & 26.99 & 25.89 & 24.80 & 23.70 & 22.61 & 21.51 & 20.42 \\
80 & 27.22 & 26.12 & 25.03 & 23.93 & 22.84 & 21.74 & 20.65 \\
90 & 27.46 & 26.37 & 25.27 & 24.18 & 23.08 & 21.99 & 20.89 \\
100 & 27.73 & 26.63 & 25.54 & 24.44 & 23.35 & 22.25 & 21.16 \\
& 28.00 & 26.91 & 25.81 & 24.73 & 23.62 & 22.53 & 21.43 \\
& {$[.08]$} & {$[.07]$} & {$[.07]$} & {$[.08]$} & {$[.08]$} & {$[.09]$} & {$[.10]$}
\end{tabular}


Table 1.11

Solubility of $\mathrm{NaCl}$ (weight percent) in $\mathrm{MgCl}_{2}$ solutions as given. Data in parentheses, ( ), are extrapolated; the solution may be supersaturated in one or more solid phases other than halite. Precision ( 3 sigma) is given in brackets, [ ], for the $0^{\circ}, 50^{\circ}$, and $100^{\circ} \mathrm{C}$

isotherms.

\begin{tabular}{|c|c|c|c|c|c|c|c|c|c|c|}
\hline pera & & & $\mathrm{MgC}$ & $12 \mathrm{cos}$ & ration & in we $i$ & $t$ perc & & & \\
\hline$\left({ }^{\circ} \mathrm{C}\right)$ & 0 & 2 & 4 & 6 & 8 & 10 & 12 & 14 & 16 & 18 \\
\hline & - & - & - & - & - & - & - & - & - & - \\
\hline 0 & $\begin{array}{c}(25.94) \\
{[.13]}\end{array}$ & $\begin{array}{c}(23.62) \\
{[.13]}\end{array}$ & $\begin{array}{c}(21.37) \\
{[.13]}\end{array}$ & $\begin{array}{c}(19.17) \\
{[.13]}\end{array}$ & $\begin{array}{c}(17.04) \\
{[.14]}\end{array}$ & $\begin{array}{c}(14.96) \\
{[.14]}\end{array}$ & $\begin{array}{c}(12.95) \\
{[.15]}\end{array}$ & $\begin{array}{c}(10.99) \\
{[.16]}\end{array}$ & $\begin{array}{l}(9.09) \\
{[.17]}\end{array}$ & $\begin{array}{l}(7.26) \\
{[.19]}\end{array}$ \\
\hline $\begin{array}{l}10 \\
20 \\
30 \\
40 \\
50\end{array}$ & $\begin{array}{c}(26.07) \\
26.23 \\
26.39 \\
26.57 \\
26.77 \\
{[.05]}\end{array}$ & $\begin{array}{c}(23.77) \\
23.93 \\
24.11 \\
24.30 \\
24.51 \\
{[.04]}\end{array}$ & $\begin{array}{c}(21.53) \\
21.70 \\
21.89 \\
22.09 \\
22.32 \\
{[.05]}\end{array}$ & $\begin{array}{c}(19.34) \\
19.53 \\
19.73 \\
19.94 \\
20.18 \\
{[.06]}\end{array}$ & $\begin{array}{l}(17.22) \\
17.41 \\
17.63 \\
17.85 \\
18.10 \\
{[.07]}\end{array}$ & $\begin{array}{c}(15.15) \\
15.36 \\
15.58 \\
15.82 \\
16.08 \\
{[.07]}\end{array}$ & $\begin{array}{c}(13.15) \\
13.37 \\
13.60 \\
13.85 \\
14.12 \\
{[.06]}\end{array}$ & $\begin{array}{c}(11.20) \\
11.43 \\
11.68 \\
11.94 \\
12.22 \\
{[.06]}\end{array}$ & $\begin{array}{c}(9.32) \\
9.56 \\
9.82 \\
10.09 \\
10.38 \\
{[.07]}\end{array}$ & $\begin{array}{c}(7.49) \\
7.75 \\
8.01 \\
8.30 \\
8.60 \\
{[.08]}\end{array}$ \\
\hline $\begin{array}{r}60 \\
70 \\
80 \\
90 \\
100\end{array}$ & $\begin{array}{l}26.99 \\
27.22 \\
27.46 \\
27.73 \\
28.00 \\
{[.08]}\end{array}$ & $\begin{array}{l}24.74 \\
24.98 \\
25.24 \\
25.51 \\
25.80 \\
{[.07]}\end{array}$ & $\begin{array}{l}22.55 \\
22.81 \\
23.07 \\
23.36 \\
23.66 \\
{[.08]}\end{array}$ & $\begin{array}{l}20.43 \\
20.69 \\
20.97 \\
21.27 \\
21.58 \\
{[.09]}\end{array}$ & $\begin{array}{l}18.36 \\
18.63 \\
18.92 \\
19.23 \\
19.56 \\
{[.10]}\end{array}$ & $\begin{array}{l}16.35 \\
16.64 \\
16.94 \\
17.26 \\
17.59 \\
{[.11]}\end{array}$ & $\begin{array}{l}14.40 \\
14.70 \\
15.01 \\
15.34 \\
15.69 \\
{[.12]}\end{array}$ & $\begin{array}{l}12.51 \\
12.82 \\
13.15 \\
13.49 \\
13.85 \\
{[.13]}\end{array}$ & $\begin{array}{l}10.69 \\
11.01 \\
11.34 \\
11.70 \\
12.06 \\
{[.15]}\end{array}$ & $\begin{array}{r}8.92 \\
9.25 \\
9.60 \\
9.96 \\
10.34 \\
{[.17]}\end{array}$ \\
\hline
\end{tabular}

Table 1.12

Solubility of $\mathrm{NaCl}$ (weight percent) in $\mathrm{CaCl}_{2}$ solutions as given. Data in parentheses, ( ), are extrapolated; the solutions may be supersatured in one or more solid phases other than halite. Precision ( 3 sigma) is given in brackets, [ ], for the $0^{\circ}, 50^{\circ}$, and $100^{\circ} \mathrm{C}$ isotherms.

\begin{tabular}{|c|c|c|c|c|c|c|c|c|}
\hline Temperature & & & $\mathrm{CaC}$ & conce & tion & weight & rcent & \\
\hline$\left({ }^{\circ} \mathrm{C}\right)$ & 0 & 2 & 4 & 6 & 8 & 10 & 12 & 14 \\
\hline 0 & $\begin{array}{c}(25.94) \\
{[.13]}\end{array}$ & $\begin{array}{c}(23.01) \\
{[.13]}\end{array}$ & $\begin{array}{c}(21.91) \\
{[.13]}\end{array}$ & $\begin{array}{c}(19.94) \\
{[.14]}\end{array}$ & $\begin{array}{c}(18.01) \\
{[.14]}\end{array}$ & $\begin{array}{c}(\overline{16.12}) \\
{[.14]}\end{array}$ & $\begin{array}{c}(\overline{14.26}) \\
{[.14]}\end{array}$ & $\begin{array}{l}(\overline{12.43}) \\
{[.15]}\end{array}$ \\
\hline $\begin{array}{l}10 \\
20 \\
30 \\
40 \\
50\end{array}$ & $\begin{array}{c}(26.07) \\
(26.23) \\
26.39 \\
26.57 \\
26.77 \\
{[.05]}\end{array}$ & $\begin{array}{c}(24.06) \\
(24.22) \\
24.40 \\
24.60 \\
24.81 \\
{[.05]}\end{array}$ & $\begin{array}{l}(22.07) \\
(22.25) \\
22.44 \\
22.65 \\
22.88 \\
{[.06]}\end{array}$ & $\begin{array}{l}(20.12) \\
(20.31) \\
20.52 \\
29.75 \\
20.99 \\
{[.07]}\end{array}$ & $\begin{array}{c}(18.21) \\
(18.41) \\
18.63 \\
18.87 \\
19.13 \\
{[.07]}\end{array}$ & $\begin{array}{c}(16.32) \\
(16.55) \\
16.78 \\
17.03 \\
17.30 \\
{[.07]}\end{array}$ & $\begin{array}{c}(14.48) \\
(14.71) \\
14.96 \\
15.23 \\
15.51 \\
{[.07]}\end{array}$ & $\begin{array}{l}(12.67) \\
(12.92) \\
13.18 \\
13.46 \\
13.76 \\
{[.08]}\end{array}$ \\
\hline $\begin{array}{r}60 \\
70 \\
80 \\
90 \\
100\end{array}$ & $\begin{array}{l}26.99 \\
27.22 \\
27.46 \\
27.73 \\
28.00 \\
{[.08]}\end{array}$ & $\begin{array}{l}25.04 \\
25.28 \\
25.54 \\
25.82 \\
26.11 \\
{[.08]}\end{array}$ & $\begin{array}{l}23.12 \\
23.38 \\
23.66 \\
23.95 \\
24.25 \\
{[.08]}\end{array}$ & $\begin{array}{l}21.24 \\
21.52 \\
21.80 \\
22.11 \\
22.43 \\
{[.09]}\end{array}$ & $\begin{array}{l}19.40 \\
19.68 \\
19.99 \\
20.30 \\
20.64 \\
{[.09]}\end{array}$ & $\begin{array}{l}17.59 \\
17.89 \\
18.20 \\
18.53 \\
18.88 \\
{[.09]}\end{array}$ & $\begin{array}{l}15.81 \\
16.12 \\
16.45 \\
16.80 \\
17.16 \\
{[.10]}\end{array}$ & $\begin{array}{l}14.07 \\
14.40 \\
14.74 \\
15.10 \\
15.48 \\
{[.12]}\end{array}$ \\
\hline
\end{tabular}


Table 1.13

Solubility of $\mathrm{NaCl}$ (weight percent) in a solution containing 2 weight percent $\mathrm{CaCl}_{2}$ plus the $\mathrm{KCl}$ concentration as given. Data in parentheses, ( ), are extrapolated; the solution may be supersaturated in one or more solid phases other than halite. Precision ( 3 sigma) is given in brackets, [ ], for the $0^{\circ}, 50^{\circ}$, and $100^{\circ} \mathrm{C}$ isotherms.

Temperature

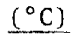

0

$\begin{array}{ll}10 & (24.06) \\ 20 & (24.22) \\ 30 & 24.40 \\ 40 & 24.60 \\ 50 & 24.81 \\ & {[.05]}\end{array}$

$\begin{array}{rl}60 & 25.04 \\ 70 & 25.28 \\ 80 & 25.54 \\ 90 & 25.82 \\ 100 & 26.11 \\ & {[.08]}\end{array}$

KCl concentration in weight percent

$\begin{array}{cccccc}\underline{2} & \underline{4} & \underline{6} & \underline{8} & \underline{10} & \underline{12} \\ (22.88) & (21.86) & (20.83) & (19.81) & (18.78) & (17.76) \\ {[.13]} & {[.13]} & {[.13]} & {[.14]} & {[.14]} & {[.15]} \\ (23.03) & (22.01) & (20.98) & (19.96) & (18.93) & (17.91) \\ (23.20) & (22.17) & (21.15) & (20.12) & (19.10) & (18.07) \\ 23.38 & 22.35 & 21.33 & 20.30 & (19.29) & (18.25) \\ 23.57 & 22.55 & 21.52 & 20.50 & 19.47 & 18.45 \\ 23.78 & 22.76 & 21.74 & 20.71 & 19.69 & 18.66 \\ {[.04]} & {[.04]} & {[.05]} & {[.06]} & {[.07]} & {[.09]} \\ 24.01 & 22.99 & 21.96 & 20.94 & 19.91 & 18.89 \\ 24.26 & 23.23 & 22.21 & 21.18 & 20.16 & 19.13 \\ 24.52 & 23.49 & 22.47 & 21.44 & 20.42 & 19.39 \\ 24.79 & 23.77 & 22.74 & 21.72 & 20.69 & 19.67 \\ 25.09 & 24.06 & 23.04 & 22.01 & 20.99 & 19.96 \\ {[.07]} & {[.07]} & {[.08]} & {[.09]} & {[.10]} & {[.11]}\end{array}$

Table 1.14

Solubility of $\mathrm{NaCl}$ (weight percent) in a solution containing 4 weight percent $\mathrm{CaCl}_{2}$ plus the $\mathrm{KCl}$ concentration as given. Data in parentheses, ( ), are extrapolated; the solution may be supersaturated in one or more solid phases other than halite. Precision ( $3 \mathrm{sigma}$ ) is given in brackets, [ ], for the $0^{\circ}, 50^{\circ}$, and $100^{\circ} \mathrm{C}$ isotherms.

Temperature

$\mathrm{KCl}$ concentration in weight percent

$\begin{array}{cccccccc}\left({ }^{\circ} \mathrm{C}\right) & \underline{0} & \underline{2} & \underline{4} & \underline{6} & \underline{8} & \underline{10} & \frac{12}{1} \\ 0 & (21.91) & (20.89) & (19.88) & (18.87) & (17.86) & (16.84) & (15.83) \\ & {[.13]} & {[.13]} & {[.13]} & {[.13]} & {[.13]} & {[.14]} & {[.14]} \\ 10 & (22.07) & (21.06) & (20.04) & (19.03) & (18.02) & (17.01) & (15.99) \\ 20 & (22.25) & (21.24) & (20.22) & (19.21) & (18.20) & (17.19) & (16.17) \\ 30 & 22.44 & 21.43 & 20.42 & 19.41 & 18.39 & (17.38) & (16.37) \\ 40 & 22.65 & 21.64 & 20.63 & 19.62 & 18.60 & 17.59 & 16.58 \\ 50 & 22.88 & 21.87 & 20.86 & 19.84 & 18.83 & 17.82 & 16.80 \\ & {[.05]} & {[.04]} & {[.04]} & {[.04]} & {[.05]} & {[.06]} & {[.08]} \\ 60 & 23.12 & 22.11 & 21.10 & 20.08 & 19.07 & 18.06 & 17.05 \\ 70 & 23.38 & 22.37 & 21.36 & 20.34 & 19.33 & 18.32 & 17.30 \\ 80 & 23.66 & 22.64 & 21.63 & 20.62 & 19.60 & 18.59 & 17.58 \\ 90 & 23.95 & 22.93 & 21.92 & 20.91 & 19.89 & 18.88 & 17.87 \\ 100 & 24.25 & 23.24 & 22.23 & 21.21 & 20.20 & 19.19 & 18.17 \\ & {[.08]} & {[.08]} & {[.07]} & {[.07]} & {[.08]} & {[.09]} & {[.10]}\end{array}$


Table 1.15

Solubility of $\mathrm{NaCl}$ (weight percent) in a solution containing 6 weight percent $\mathrm{CaCl}_{2}$ plus the $\mathrm{KCl}$ concentration as given. Data in parentheses, ( ), are extrapolated; the solution may be supersaturated in one or more solid phases other than halite. Precision ( 3 sigma) is given in brackets, [ ], for the $0^{\circ}, 50^{\circ}$, and $100^{\circ} \mathrm{C}$ isotherms.

Temperature

KCl concentration in weight percent

$\begin{array}{ccccccc}\left({ }^{\circ} \mathrm{C}\right) & \underline{0} & \underline{2} & \underline{4} & \underline{6} & \underline{8} & \underline{10} \\ 0 & (19.94) & (18.95) & (17.95) & (16.96) & (15.96) & (14.97) \\ & {[.13]} & {[.13]} & {[.13]} & {[.13]} & {[.13]} & {[.14]} \\ 10 & (20.12) & (19.13) & (18.13) & (17.13) & (16.14) & (15.14) \\ 20 & (20.31) & (19.32) & (18.32) & (17.33) & (16.33) & (15.34) \\ 30 & 20.52 & 19.53 & 18.53 & 17.54 & 16.54 & (15.54) \\ 40 & 20.75 & 19.75 & 18.76 & 17.76 & 16.76 & 15.77 \\ 50 & 20.99 & 19.99 & 19.00 & 18.00 & 17.01 & 16.01 \\ & {[.06]} & {[.05]} & {[.04]} & {[.05]} & {[.06]} & {[.08]} \\ 60 & 21.24 & 20.25 & 19.25 & 18.26 & 17.26 & 16.27 \\ 70 & 21.52 & 20.52 & 19.52 & 18.53 & 17.53 & 16.54 \\ 80 & 21.80 & 20.81 & 19.81 & 18.82 & 17.82 & 16.83 \\ 90 & 22.11 & 21.11 & 20.13 & 19.12 & 18.13 & 17.13 \\ 100 & 22.43 & 21.43 & 20.44 & 19.44 & 18.45 & 17.45 \\ & {[.09]} & {[.08]} & {[.07]} & {[.08]} & {[.09]} & {[.10]}\end{array}$

Table 1.16

Solubility of $\mathrm{NaCl}$ (weight percent) in a solution containing 8 weight percent $\mathrm{CaCl}_{2}$ plus the $\mathrm{KCl}$ concentration as given. Data in parentheses, ( ), are extrapolated; the solution may be supersaturated in one or more solid phases other than halite. Precision ( 3 sigma) is given in brackets, [ ], for the $0^{\circ}, 50^{\circ}$, and $100^{\circ} \mathrm{C}$ isotherms.

Temperature KC1 concentration in weight percent

$\begin{array}{ccccccccc}\left({ }^{\circ} \mathrm{C}\right) & \underline{0} & \underline{1} & \underline{2} & \underline{3} & \underline{4} & \underline{5} & \underline{6} & \underline{7} \\ 0 & (18.01) & (17.53) & (17.05) & (16.57) & (16.08) & (15.60) & (15.12) & (14.63) \\ & {[.14]} & {[.14]} & {[.13]} & {[.13]} & {[.13]} & {[.13]} & {[.13]} & {[.13]} \\ 10 & (18.21) & (17.72) & (17.24) & (16.76) & (16.27) & (15.79) & (15.31) & (14.82) \\ 20 & (18.41) & (17.93) & (17.45) & (16.90) & (16.48) & (16.00) & (15.51) & (15.03) \\ 30 & 18.63 & 18.15 & 17.67 & 17.19 & 16.70 & 16.22 & 15.74 & 15.25 \\ 40 & 18.87 & 18.39 & 17.91 & 17.42 & 16.94 & 16.46 & 15.97 & 15.49 \\ 50 & 19.13 & 18.64 & 18.16 & 17.68 & 17.19 & 16.71 & 16.23 & 15.74 \\ & {[.07]} & {[.06]} & {[.06]} & {[.05]} & {[.05]} & {[.05]} & {[.05]} & {[.06]} \\ 60 & 19.40 & 18.91 & 18.43 & 17.95 & 17.46 & 16.98 & 16.50 & 16.02 \\ 70 & 19.68 & 19.20 & 18.72 & 18.23 & 17.75 & 17.27 & 16.78 & 16.30 \\ 80 & 19.99 & 19.50 & 19.02 & 18.54 & 18.05 & 17.57 & 17.09 & 16.60 \\ 90 & 20.30 & 19.82 & 19.34 & 18.85 & 18.37 & 17.89 & 17.40 & 16.92 \\ 100 & 20.64 & 20.15 & 19.67 & 19.19 & 18.70 & 18.22 & 17.74 & 17.25 \\ & {[.10]} & {[.09]} & {[.08]} & {[.08]} & {[.08]} & {[.08]} & {[.08]} & {[.09]}\end{array}$


Tab1e 1.17

Solubility of $\mathrm{NaCl}$ (weight percent) in a solution containing 10 weight percent $\mathrm{CaCl}_{2}$ plus the $\mathrm{KCl}$ concentration as given. Data in parentheses, ( ), are extrapolated; the solution may be supersaturated in one or more solid phases other than halite. Precision (3 sigma) is given in brackets, [ ], for the $0^{\circ}, 50^{\circ}$, and $100^{\circ} \mathrm{C}$ isotherms.

\begin{tabular}{cccccccc} 
Temperature & \multicolumn{7}{c}{$\mathrm{kCl}$ concentration in weight percent } \\
$\begin{array}{ccc}\left({ }^{\circ} \mathrm{C}\right) \\
0\end{array}$ & $\underline{0}$ & $\underline{1}$ & $\underline{2}$ & $\underline{3}$ & $\underline{4}$ & $\underline{5}$ & $\underline{6}$ \\
0 & $(16.12)$ & $(15.66)$ & $(15.20)$ & $(14.73)$ & $(14.27)$ & $(13.81)$ & $(13.35)$ \\
& {$[.14]$} & {$[.14]$} & {$[.13]$} & {$[.13]$} & {$[.13]$} & {$[.13]$} & {$[.14]$} \\
10 & $(16.32)$ & $(15.86)$ & $(15.40)$ & $(14.94)$ & $(14.48)$ & $(14.02)$ & $(13.55)$ \\
20 & $(16.55)$ & $(16.08)$ & $(15.62)$ & $(15.16)$ & $(14.70)$ & $(14.24)$ & $(13.77)$ \\
30 & 16.78 & 16.32 & 15.86 & 15.40 & 14.93 & 14.47 & 14.01 \\
40 & 17.03 & 16.57 & 16.11 & 15.65 & 15.19 & 14.73 & 14.26 \\
50 & 17.30 & 16.84 & 16.38 & 15.92 & 15.46 & 14.99 & 14.53 \\
& {$[.07]$} & {$[.06]$} & {$[.05]$} & {$[.05]$} & {$[.05]$} & {$[.05]$} & {$[.06]$} \\
60 & 17.59 & 17.13 & 16.66 & 16.20 & 15.74 & 15.28 & 14.82 \\
70 & 17.89 & 17.43 & 16.96 & 16.50 & 16.04 & 15.58 & 15.12 \\
80 & 18.20 & 17.74 & 17.28 & 16.82 & 16.36 & 15.89 & 15.43 \\
90 & 18.53 & 18.07 & 17.61 & 17.15 & 16.69 & 16.23 & 15.76 \\
100 & 18.88 & 18.42 & 17.96 & 17.50 & 17.04 & 16.57 & 16.11 \\
& {$[.09]$} & {$[.09]$} & {$[.08]$} & {$[.08]$} & {$[.08]$} & {$[.09]$} & {$[.09]$}
\end{tabular}

Table 1.18

Solubility of $\mathrm{NaCl}$ (weight percent) in a solution containing 12 weight percent $\mathrm{CaCl}_{2}$ plus the $\mathrm{KCl}$ concentration as given. Data in parentheses, ( ), are extrapolated; the solution may be supersaturated in one or more solid phases other than halite. Precision (3 sigma) is given in brackets, [ ], for the $0^{\circ}, 50^{\circ}$, and $100^{\circ} \mathrm{C}$ isotherms.

Temperature

$\mathrm{KCl}$ concentration in weight percent

$\begin{array}{ccccccc}\left({ }^{\circ} \mathrm{C}\right) & \underline{0} & \underline{1} & \underline{2} & \underline{3} & \underline{4} & \underline{5} \\ 0 & \begin{array}{cccccc}(14.26) \\ {[.14]}\end{array} & \begin{array}{c}(13.83) \\ {[.14]}\end{array} & \begin{array}{c}(13.39) \\ {[.13]}\end{array} & \begin{array}{c}(12.96) \\ {[.13]}\end{array} & \begin{array}{c}(12.53) \\ {[.13]}\end{array} & \begin{array}{c}(12.10) \\ {[.14]}\end{array} \\ 10 & (14.48) & (14.05) & (13.61) & (13.18) & (12.75) & (12.32) \\ 20 & (14.71) & (14.28) & (13.85) & (13.42) & (12.98) & (12.55) \\ 30 & 14.96 & 14.53 & 14.10 & 13.67 & 13.23 & 12.80 \\ 40 & 15.23 & 14.80 & 14.36 & 13.93 & 13.50 & 13.07 \\ 50 & 15.51 & 15.08 & 14.65 & 14.21 & 13.78 & 13.35 \\ & {[.07]} & {[.06]} & {[.05]} & {[.04]} & {[.05]} & {[.05]} \\ 60 & 15.81 & 15.38 & 14.95 & 14.51 & 14.08 & 13.65 \\ 70 & 16.12 & 15.69 & 15.26 & 14.83 & 14.39 & 13.96 \\ 80 & 16.45 & 16.02 & 15.59 & 15.16 & 14.72 & 14.29 \\ 90 & 15.80 & 16.37 & 15.94 & 15.50 & 15.07 & 14.64 \\ 100 & 17.16 & 16.73 & 16.30 & 15.86 & 15.43 & 15.00 \\ & {[.10]} & {[.09]} & {[.09]} & {[.09]} & {[.09]} & {[.09]}\end{array}$


Table 1.19

Solubility of $\mathrm{NaCl}$ (weight percent) in a solution containing 14 weight percent $\mathrm{CaCl}_{2}$ plus the $\mathrm{KCl}$ concentration as given. Data in parentheses, ( ), are extrapolated; the solution may be supersaturated in one or more solid phases other than nalite. Precision ( 3 sigma) is given in brackets, [ ], for the $0^{\circ}, 50^{\circ}$, and $100^{\circ} \mathrm{C}$ isotherms.

Temperature $\quad K C 1$ concentration in weight percent

\begin{tabular}{|c|c|c|c|c|c|c|}
\hline$\left({ }^{\circ} \mathrm{C}\right)$ & $\underline{0}$ & 1 & $\underline{2}$ & $\underline{3}$ & $\underline{4}$ & $\underline{5}$ \\
\hline 0 & $\begin{array}{c}(12.43) \\
{[.15]}\end{array}$ & $\begin{array}{c}(12.04) \\
{[.14]}\end{array}$ & $\begin{array}{c}(11.64) \\
{[.14]}\end{array}$ & $\begin{array}{c}(11.25) \\
{[.14]}\end{array}$ & $\begin{array}{c}(10.85) \\
{[.14]}\end{array}$ & $\begin{array}{c}(10.46) \\
{[.14]}\end{array}$ \\
\hline $\begin{array}{l}10 \\
20 \\
30 \\
40 \\
50\end{array}$ & $\begin{array}{c}(12.67) \\
(12.92) \\
13.18 \\
13.46 \\
13.76 \\
{[.08]}\end{array}$ & $\begin{array}{l}(12.27) \\
(12.52) \\
12.78 \\
13.07 \\
13.36 \\
{[.07]}\end{array}$ & $\begin{array}{c}(11.88) \\
(12.12) \\
12.39 \\
12.67 \\
12.97 \\
{[.05]}\end{array}$ & $\begin{array}{l}(11.48) \\
(11.73) \\
11.99 \\
12.27 \\
12.57 \\
{[.05]}\end{array}$ & $\begin{array}{l}(11.08) \\
(11.33) \\
11.60 \\
11.88 \\
12.17 \\
{[.05]}\end{array}$ & $\begin{array}{l}(10.69) \\
(10.94) \\
11.20 \\
11.48 \\
11.78 \\
{[.06]}\end{array}$ \\
\hline $\begin{array}{r}60 \\
70 \\
80 \\
90 \\
100\end{array}$ & $\begin{array}{l}14.07 \\
14.40 \\
14.74 \\
15.10 \\
15.48 \\
{[.12]}\end{array}$ & $\begin{array}{l}13.67 \\
14.00 \\
14.35 \\
14.71 \\
15.08 \\
{[.11]}\end{array}$ & $\begin{array}{l}13.28 \\
13.61 \\
13.95 \\
14.31 \\
14.69 \\
{[.10]}\end{array}$ & $\begin{array}{l}12.88 \\
13.21 \\
13.55 \\
13.91 \\
14.29 \\
{[.10]}\end{array}$ & $\begin{array}{l}12.49 \\
12.81 \\
13.16 \\
13.52 \\
13.89 \\
{[.10]}\end{array}$ & $\begin{array}{l}12.09 \\
12.42 \\
12.76 \\
13.12 \\
13.50 \\
{[.10]}\end{array}$ \\
\hline
\end{tabular}




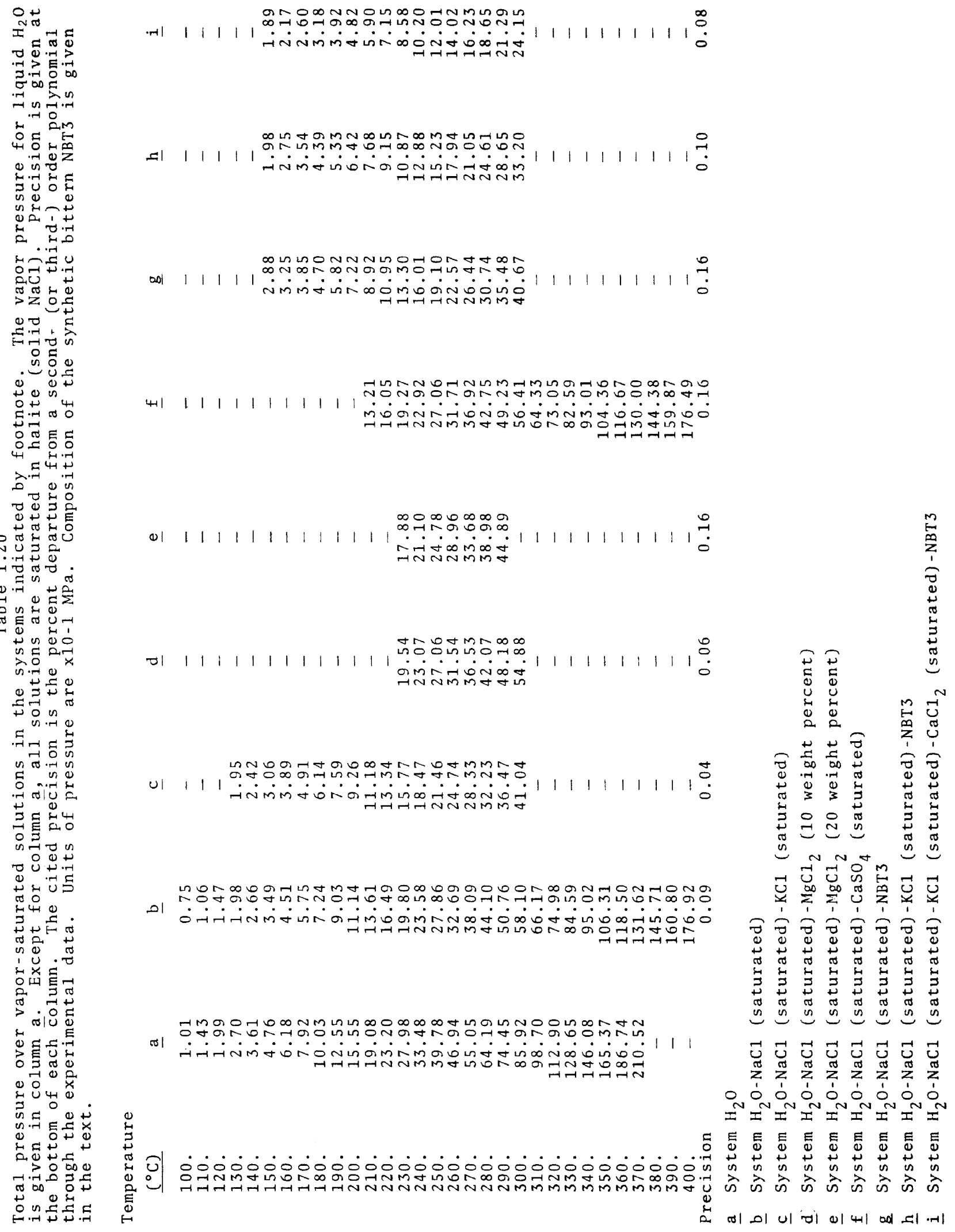


Table 1.21

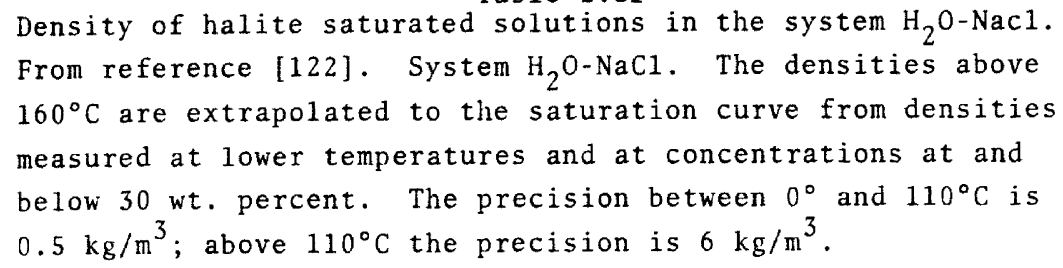

\begin{tabular}{|c|c|c|}
\hline Temperature & Concentration & Density \\
\hline$\left({ }^{\circ} \mathrm{C}\right)$ & (wt. percent) & $\left(\mathrm{kg} / \mathrm{m}^{3}\right)$ \\
\hline 0 & 25.99 & 1208.9 \\
\hline 10. & 26.11 & 1204.5 \\
\hline 20 . & 26.24 & 1200.1 \\
\hline 30 . & 26.40 & 1195.8 \\
\hline 40 . & 26.57 & 1191.5 \\
\hline 50 . & 26.76 & 1187.2 \\
\hline 60. & 26.97 & 1182.9 \\
\hline 70 & 27.19 & 1178.7 \\
\hline 80 . & 27.44 & 1174.4 \\
\hline 90 . & 27.70 & 1170.3 \\
\hline 100. & 27.99 & 1166.1 \\
\hline 110. & 28.29 & 1162.0 \\
\hline 120. & 28.61 & 1158. \\
\hline 130 . & 28.95 & 1153. \\
\hline 140. & 29.31 & 1148. \\
\hline 150. & 29.69 & 1143. \\
\hline 160 . & 30.10 & 1138. \\
\hline 170. & 30.52 & 1132 . \\
\hline 180. & 30.96 & 1127 . \\
\hline 190. & 31.42 & 1122. \\
\hline 200 . & 31.90 & 1116 . \\
\hline 210. & 32.40 & 1111 . \\
\hline 220. & 32.93 & 1106. \\
\hline 230 . & 33.47 & 1101. \\
\hline 240 . & 34.04 & 1097. \\
\hline 250 . & 34.62 & 1092 . \\
\hline 260 . & 35.23 & 1088 . \\
\hline 270 . & 35.86 & 1084 . \\
\hline 280 . & 36.51 & 1080 \\
\hline 290 . & 37.18 & 1077 . \\
\hline 300 . & 37.87 & 1073 . \\
\hline
\end{tabular}

between $100^{\circ}$ and $400^{\circ} \mathrm{C}$. The precision of the data is given at the bottom of each column. NBT3 is a synthetic bittern having the following composition:

\begin{tabular}{|c|c|}
\hline Component & Concentration \\
\hline $\mathrm{KCl}$ & 0.200 wt. pct. \\
\hline $\mathrm{MgCl}_{2}$ & 9.366 \\
\hline $\mathrm{CaCl}_{2}$ & 37.821 \\
\hline
\end{tabular}

\subsubsection{Density}

The data for the densities of pore fluids are unreliable because the composition and the sampling temperature vary widely. The concentrations are higher than those usually used in research studies on solutions of inorganic salts. Table 1.21 gives the density of halite-saturated solutions as a function of temperature [122]. Pore fluids, containing less dissolved $\mathrm{NaCl}$ but more of the other components such as $\mathrm{KCl}, \mathrm{MgCl}_{2}, \mathrm{MgSO}_{4}$, or $\mathrm{CaCl}_{2}$, would be denser than the fluids in the system $\mathrm{H}_{2} \mathrm{O}-\mathrm{NaCl}$ for which data are tabulated.

[1] Bishop, E.E., Eckel, E.B., and others, Suggestions to Authors of the Reports of the United States Geological Survey, 6th Edition, 273 pp., United States Government Printing Office, W ashington, DC (1978).

[2] Pierce,W.G., and Rich, E.I., Summary of Rock Salt Deposits in the United States as Possible Storage Sites for Radioactive Waste Materials: United States Geological Survey Bulletin 1148, 91 pp. (1962).

[3] Kinsman, D.J.T., Evaporites: Relative Humidity Control of Primary Mineral Facies: Journal of Sedimentary Petrology 46, 273-279 (1976).

[4] Ochsenius, C., Die Bildung der Steinsalzlager und ihrer Mutterlangensalze, 172 pp., C.E.M. Pfeffer, Halle (1877).

[5] Dellwig, L.F., "Primary Sedimentary Structures of Evaporites," in The Geology of Saline Deposits, G. Richter-Bernberg, Editor, pp. 53-60, UNESCO Symposium, Paris (1972).

[6] Dellwig, L.F., Origin of the Salina Salt of Michigan: Journal of Sedimentary Petrology 25, 83-110 (1955).

[7] Richter-Bernberg, G., "Sedimentological Problems of Saline Deposits," in The Geology of Saline Deposits, G. FichterBernberg, Editor, pp. 33-37, UNESCO Symposium, Paris (1972). 
[8] Scruton, P.C., Deposition of Evaporites: American Association of Petroleum Geologists Bulletin 37, 2498-2512 (1953).

[9] Hsü, K.J., Origin of Saline Giants: A critical Review after the Discovery of the Mediterranean Evaporite: Earth Science Reviews 8, 371.396 (1972).

[10] Stewart, F.H., Marine Evaporites: United States Geological Survey Professional Paper 440-Y, 52 pp. (1963).

[11] Sloss, L.L., Evaporite Deposition from Layered Solutions: American Association of Petroleum Geologists Bulletin 53, 776-789 (1969).

[12] Schmalz, R.F., Deep-water Evaporite Deposition: A Genetic Model: American Association of Petroleum Geologists Bulletin 53, 798-823 (1969).

[13] Kirkland, D.W., and Evans, Robert, Editors, Marine Evaporites: Origin, Diagenesis, and Geochemistry, 426 pp., Dowden, Hutchison, and Ross Inc., Stroudsberg, PA (1973).

[14] Usiglio, J., Analyse de l'eau de la Mediterranee sur les cotes de France: Ann. Chem. Phys., 3rd ser. 28, 92-107, 172-191 (1849).

[15] Borchert, Herman, and Muir, R.O., Salt Deposits: The Origin, Metamorphism, and Deformation of Evaporites, 338 pp., D. Van Nostrand Co. Ltd., New York (1964).

[16] Borchert, Herman, Principles of Oceanic Salt Deposition and Metamorphism: Geological Society of America Bulletin 80, 821-861 (1969).

[17] Jones, C.L., "The Occurence and Distribution of Potassium Minerals in Southeastern New Mexico," in Guidebook of Southeastern New Mexico, Fifth Field Conference, 107.112, New Mexico Geological Society (1954).

[18] Jones, C.L., Petrology of the Evaporites from the Wellington Formation near Hutchinson, Kansas, United States Geological Survey Bulletin 1201-A, 70 pp. (1964).

[19] Anderson, R.Y., and Kirkland, D.W., Intrabasin Varve Correlation: Geological Society of America Bulletin 77, 241-255 (1966).

[20] Gary; Margaret, McAfee, Robert, Jr., and Wolf, C.L., Editors, Glossary of Geology, 805 pp., American Geological Institute, Washington, DC (1972).

[21] Braitsch, Otto, Salt Deposits, Their Origin and Composition, 297 pp., Springer-Verlag, New York (1971).

[22] Kupfer, D.H., "Mechanism of Intrusion of Gulf Coast Salt," in Symposium on the Geology and Technology of Gulf Coast Salt, Baton Rouge, LA 1967, Proceedings, D.H. Kupfer, Editor, 25-66, Louisiana State University School of Geoscience, Baton Rouge, LA (1970).

[23] Reference [21], p. 108.

[24] Lees, G.M., "Salt-Some Depositional and Deformational Problems," in Symposium on Salt Domes, Vol. 17. 259-280, Journal of the Institute of Petroleum Technologists, London (1931).

[25] Reference·[15], p. 133.

[26] Reference [15], p. 108

[27] Baar, C.A., Applied Salt-rock Mechanics I, The In-situ Behavior of Salt Rocks: Developments in Geotechnical Engineering 16A, Elsvier, Amsterdam, 294 pp. (1977).

[28] Reference [15], p. 294.

[29] Reference [15], p. 109.

[30] Johnson, K.S., and Gonzales, Serge, Salt Deposits in the United States and Regional Geologic Characteristics Important for Storage of Radioactive Waste: Earth Resource Associates, Inc., Athens, GA, 188 pp. (March 1978) (Prepared under U.S. Government contract W-7405-eng-26 with the Department of Energy, The Office of $W$ aste Isolation.)
[31] Reference [30], figure ?.

[32] Reference [2], p. 69.

[33] Andrews, D.I., The Louann Salt and Its Relationship to Gulf Coast Salt Domes: Gulf Coast Association Geological Societies Transactions 10. 215-240 (1960).

[34] Reference [2], p. 71.

[35] Lefond, S.J., Handbook of World Salt Resources: 384 pp., Plenum Press, New York (1969).

[36a] Halbouty, M.T., Salt Domes, Gulf Coast Region, United States and Mexico, 425 pp., Gulf Publishing Co., Houston, TX (1967).

[36b] Hurlbut, C.S. Jr., Dana's Manual of Mineralogy, 17th Edition, 609 pp., John Wiley and Sons Inc., New York (1959).

[37] Odé, Helmer, Review of Mechanical Properties of Salt Relating to Salt Dome Genesis: Geological Society of America Special Paper 88, 544-595 (1968).

[38] Nettleton, L.L., Fluid Mechanics of Salt Domes: American Association of Petroleum Geologists Bulletin 18, 1175-1204 (1934).

[39] Reference [15], p. 243.

[40] Romanes, James, "Salt Domes of North Germany," in Symposium on Salt Domes, Vol. 17, 252-258, Journal of the Institute of Petroleum Technologists, London (1931).

[41] Kupfer, D.H., Louisiana Salt Domes and the Mississippi Deltaic Plain: 60 pp., New Orleans Geological Society Guidebook (1972).

[42] Schwerdtner, W.M., "Preferred Orientation of Halite in a 'Salt Seismogram," in Second Symposium on Salt, Jon L. Rau, Editor, Vol. 1, 70-84, Northern Ohio Geological Society, Inc., Cleveland, OH (1966).

[43] Reference [24] p. 276.

[44] Reference [15], p. 244.

[45] Reference [41], p. 20.

[46] Reference [41], p. 24.

[47] Walker, C.W., "Nature and Origin of Caprock Overlying Gulf Coast Salt Domes," in Fourth Symposium on Salt, Alan H. Coogan, Editor, Vol. 1, 169-195, Northern Ohio Geological Society, Inc., Cleveland, OH (1974).

[48] Taylor, R E., "Caprock Genesis and Occurrence of Sulfur Deposits," in The Geology of Saline Deposits, G. RichterBernberg, Editor, 253-254, UNESCO Symposium, Paris (1972).

[49] Jenson, M.L., Isotopic Geology and the Origin of Gulf Coast and Sicilian Sulfur Deposits: Geological Society of America Special Paper 88, 525-536 (1968).

[50] Reference [41], p. 9.

151] Kupfer, D.H., "Structure of Salt in Gulf Coast Domes," Symposium on Salt, Cleveland, 1962, A.E. Bersticker, Editor, 104-123, Northern Ohio Geological Society, Inc., Cleveland, $\mathrm{OH}$ (1963).

[52] Reference [22], p. 55.

[53] Reference [22], p. 45.

[54] Reference [15], pp. 4-7.

[55] Reference [21], pp. 8-15.

[56] Reference [22], p. 45.

[57] Reference [37], p. 550.

[58] Treesch, M.I., and Friedman, G.M., "Sabkha Deposition of the Salina Group (Upper Silurian) of New York State," in Fourth Symposium on Salt, Alan H. Coogan, Editor, Vol. 1, 35-46, Northern Ohio Geological Society, Inc., Cleveland, $\mathrm{OH}$ (1974).

[59] Hall, J.F., "Distribution of Salt in Ohio," in Symposium on Salt, Cleveland, 1962, A.C. Bersticker, Editor, 27-30, Northern Ohio Geological Society, Inc., Cleveland, OH (1963). 
[60] Reference [2], p. 70.

[61] Taylor, R.E., Water Insoluble Residues in Rock Salt of Louisiana Salt Plugs: American Association of Petroleum Geologists Bulletin 21, 1268-1310 (1937).

[62] Reference [6], p. 89.

[63] Schaller, W.T., and Henderson, E.P., Mineralogy of drill cores from the Potash Field of New Mexico and Texas: United States Geological Survey Bulletin 833, 124 pp. (1932).

[64] Reference [41], p. 18.

[65] Balk, R., Structure of Grand Saline Salt Dome, Van Zandt County, Texas: American Association of Petroleum Geologists Bulletin 33, 1791-1820 (1949).

[66] Reference [37], p. 549.

[67] Odé, Helmer, "Physical Properties Work Sessions," led by Helmer Odé, Geological Society of America Special Paper 88, 683-701 (1968).

[68] Reference [37], p. 551.

[69] Guido, R.S., and Warner, S.E., Project Cowboy, Physical Properties of Salt Samples: University of California, Lawrence Radiation Laboratory, U.C.R.L. 6069, 14 pp. (1960).

[70] Holser, W.T., Chemistry of Brine Inclusions in Permian Salt from Hutchinson, Kansas [abs.], Geological Survey of America Special Paper 88, 537 (1968).

[71] Kramer, J.R., History of Sea Water, Constant Temperaturepressure Equilibrium Models Compared to Liquid Inclusion Analyses: Geochimica et Cosmochimica Acta 29, 921-945 (1965).

[72] McCulloch, D.S., Vacuole Disappearance Temperatures of Laboratory-Grown Hopper Halite Crystals: Journal of Geophysics Research 64, 849-854 (1959).

[73] Dreyer, R.M., Garrels, R.M., and Howland, A.L., Liquid Inclusions in Halite as a Guide To Thermometry: American Mineralogist 34, 26-34 (1949).

[74] Peach, P.A., Liquid Inclusions in Geothermometry: American Mineralogist 34, 460-461 (1949).

[75] Roedder, Edwin, Composition of Fluid Inclusions: United States Geological Survey Professional Paper 440-JJ, 164 pp. (1972).

[76] Reference [71], p. 940.

[77] Roedder, Edwin, Studies of Fluid Inclusions II: Freezing Data and Their Interpretation: Economic Geology 58, 167-211 (1963).

[78] Reference [71], pp. 938-940.

[79] Shuman, C.A., and Fiedelman, H.W., "Gross Imperfections and Habit Modification in Salt Crystals," in Second Symposium on Salt, Jon L. Rau, Editor, Vol. 2, 246-253, Northern Ohio Geologic Society, Inc., Cleveland, OH (1966).

[80] Reference [77], p. 182.

[81] Aufricht, W.F., and Howard, K.C., Salt Characteristics as They Affect Storage of Hydrocarbons: Journal of Petroleum Technology 13, 733-738 (1961).

[82] Reference [67], Table 1.

[83] Reference [79], p. 249.

[84] Reference [81], p. 733.

[85] Reference [77], p. 183.

[86] Roedder, Edwin, United States Geological Survey, Reston, VA, personal communication (1978).

[87] Reference [27], p. 168.

[88] Giesel, W., "Outbursts of Carbon Dioxide in Potash MinesFundamentals and Possibilities of Forecast," in The Geology of Saline Depostts, G. Richter-Bernberg, Editor, 235-239, UNESCO Symposium, Paris (1972).
[89] Calzia, James, and Hiss, W.L., Igneous Rocks in the Northern Delaware Basin: New Mexico Bureau of Mines and of Mineral Resources Circular 159 (1978, in press).

[90] Refernece [27], p. 34.

[91] Hoy, R.B., Foose, R.M., and O'Neil, B.J., Structure of the Winnfield Salt Dome, Winn Parish, Louisiana: American Association of Petroleum Geologists Bulletin 46, 1444-1459 (1962).

[92] Reference [75], p. 43.

[93] Reference [91], p. 1458

[94] McClain, W.C., Lomenick, T.F., and Lowrie, R.S., Geologic Disposal Evaluation Program Semi-annual Report, United States Atomic Energy Commission, Oak Ridge National Laboratory, ORNL .5052, 135 pp. (1975).

[95] Reference [27], p. 35.

[96] Reference [91], p. 1459.

[97] Reference [61], p. 1283.

[98] Reference [94], Table 2.3

[99] Belchic, H.C., "The Winnfield Salt Dome, Winn Parish, Louisiana," in Interior Salt Domes and Tertiary Stratigraphy of North Louisiana, 29-47, Shreveport Geological Society Guidebook (1960).

[100] Reference [91], p. 1458

[101] Reference [27], p. 44.

[102] Reference [99], p. 38.

[103] Atwater, G.I., Gulf Coast Salt Dome Field Area: Geological Society American Special Paper 88, 29-40 (1968).

[104] Reference [99], p. 39.

[105] Reference [61], p. 1278.

[106] Reference [27], p. 36.

[107] Reference [81], p. 735

[108] Reynolds, T.D., and Gloyna, E.F., Permeability of rock salt and creep of underground cavities: United States Atomic Energy Commission Report TD 12383, 121 pp, as cited in Robertson, E.C., Physical Properties of Evapórite Minerals: United States Geological Survey Report TEI-821, 99 pp. (1962).

[109] Stevens, P.R., United States Geological Survey, Reston, VA, personal communication (1978).

[110] Reference [27], p. 89.

[111] Reference [81], p. 736.

[112] Reference [27], p. 88.

[113] Reference [99], p. 37.

[114] Reference [81], p. 734.

[115] Parker, F.L., Hemphill, L., and Crowell, J., Status Report on Waste Disposal in Natural Salt Formations: United States Atomic Energy Commission, Oak Ridge National Laboratory, ORNL 2560, 58 pp. (1958).

[116] Reference [41], p. 41.

[117] Reference [81], p. 738.

[118] Hawkins. M.E., and Jirik, C.J., Salt Domes in Texas, Louisiana, Mississippi, Alabama, and Offshore Tidelands, A Survey: United States Department of the Interior, Bureau of Mines Information Circular 8313, 78 pp. (1966).

[119] Interstate Oil Compact Commission, Kesearch and Coordinating Committee, Underground Storage of Liquid Petroleum Hydrocarbons in the United States: Oklahoma City, OK (April 1956).

[120] Reference [81], figure 12.

[121] Clynne, M.A. and Potter, R.W., United States Geological Survey, Menlo Park, CA, unpublished data (1978).

[122] Haas, J.L., Jr., Physiçal Properties of the Coexisting Phases and the Thermochemical Properties of the $\mathrm{H}_{2} \mathrm{O}$ Component in Boiling $\mathrm{NaCl}$ Solutions: United States Geological Survey Bulletin 1421-A, 73 pp. (1976). 
[123] Borchert, Herman, "Secondary Replacement Processes in Salt and Potash Deposits of Oceanic Origin," inThe Geology of Saline Deposits, G. Richter-Bernberg, Editor, 61-67, UNES. CO Symposium, Paris (1972).

[124] Reference [61], table V.

[125] Looker, C.D., "Salt," in Encyclopedia of Chemical Technology, R.E. Kirk and D.F. Othmer, Editors, Vol. 12, 67-82, Interscience Encyclopedia, Inc., New York (1954).

[126] Reference [108], p. 12.

[127] Reference [36b], pp. 597-609.

[128] Reference [108], pp. 14-17.

[129] Reference [15], pp. 4-7.

[130] Peters, J.W., and Dugan, A.F., Gravity and Magnetic Investigation at the Grand Saline Salt Dome, Van Zandt Co., Texas: Geophysics 10, 376-393 (1945).

[131] Allen, W.E., Caillouet, H.J., and Stanley, L., Gravity Investigations in the Hockley Salt Dome, Harris County, Texas: Geophysics 20, 829-840 (1955).

[132] Jakosky, J.J., Exploration Geophysics, 1195 pp., Trija Publishing Co., Los Angeles, CA (1950).

[133] Reference [69], p. 8.

[134] Moore, J.G., Thermal Conductivity Measurement and Development: United States Department of Energy, Office of Waste Isolation, Progress Report Y/OWI/TM-43/6, 13-15 (1978).

[135] Reference [75], Table 6.

[136] Holser, W.T., "Chemistry of Brine Inclusions in Permian Salt from Hutchison, Kansas," in Symposium on Salt, Cleveland, 1962, A.C. Bersticker, Editor, 86-95, Northern Ohio Geologic Society, Inc., Cleveland, OH (1963).

[137] Reference [71], table 5 and [75], table 4.

[138] Reference [81], table 1.

[139] Reference [81], table 2.

[140] Landes, K.K., "Origin of Salt Deposits," in Symposium on Salt, Cleveland, 1962, A.C. Bersticker, Editor, 3-9, Northern Ohio Geological Society, Inc., Cleveland, OH (1963).

[141] Reference [30], p. 10, figure 1.

[142] Reference [9], figure 1.

[143] Reference [8], figure 4.
[144] Reference [14], figure 5.

[145] Reference [38], figure 1.

[146] Reference [36a], figure 6-3.

[147] Reference [79], figure 4.

[148] Reference [81], figure 11.

[149] Reference [81], figure 12.

\section{Symbols and Units}

\begin{tabular}{cll}
\hline \hline Symbol & \multicolumn{1}{c}{ Name } & Unit \\
\hline$p$ & Density & $\mathrm{kg} / \mathrm{m}^{\mathbf{3}}$ \\
$t$ & Temperature, degrees Celsius & ${ }^{\circ} \mathrm{C}$ \\
$T$ & Temperature, kelvins & $\mathrm{K}$ \\
$P$ & Pressure, pascals & $\mathrm{Pa}$ \\
$\phi$ & Porosity & \\
$m$ & Permeability & $\mathrm{md}$ \\
\hline
\end{tabular}

\section{Conversion Factors}

\begin{tabular}{|c|c|c|}
\hline $\begin{array}{l}\text { Length } \\
\text { To convert from } \\
\text { feet }\end{array}$ & $\begin{array}{l}\text { to } \\
\text { meters }\end{array}$ & $\begin{array}{l}\text { Multiply by } \\
3.048\end{array}$ \\
\hline $\begin{array}{l}\text { Temperature } \\
\text { To convert from } \\
{ }^{\circ} \mathrm{C}\end{array}$ & $\begin{array}{l}\text { to } \\
\mathrm{K}\end{array}$ & $\begin{array}{l}\text { Add } \\
273.15\end{array}$ \\
\hline $\begin{array}{l}\text { Density } \\
\text { To convert from } \\
\mathrm{kg} / \mathrm{m}^{3} \\
\end{array}$ & $\begin{array}{l}\text { to } \\
\mathrm{g} / \mathrm{cm}^{3}\end{array}$ & $\begin{array}{l}\text { Multiply by } \\
1 \times 10^{-3}\end{array}$ \\
\hline $\begin{array}{l}\text { Pressure } \\
\text { To convert from } \\
\mathrm{MPa}\end{array}$ & $\begin{array}{l}\text { to } \\
\text { bar }\end{array}$ & $\begin{array}{l}\text { Multiply by } \\
10^{-1}\end{array}$ \\
\hline
\end{tabular}





\title{
Chapter 2
}

\section{Physical and Chemical Properties of Components in Salt Deposits}

\author{
Reginald P. T. Tomkins*
}

Contents

2. Physical and Chemical Properties of Components in Salt Deposits $\ldots \ldots \ldots \ldots \ldots \ldots \ldots \ldots \ldots \ldots .46$

2.1. Introduction ................................................ 46

2.2. Experimental Techniques $\ldots \ldots \ldots \ldots \ldots \ldots \ldots \ldots \ldots \ldots \ldots \ldots \ldots \ldots \ldots \ldots \ldots \ldots \ldots \ldots, 46$

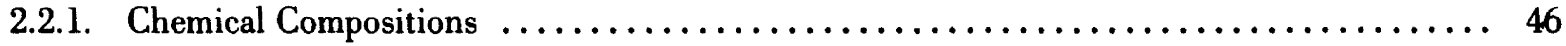

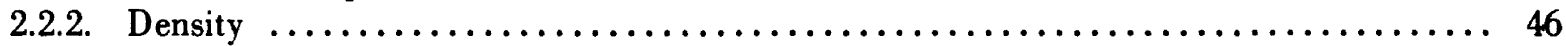

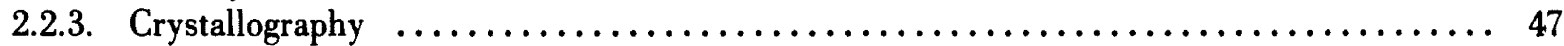

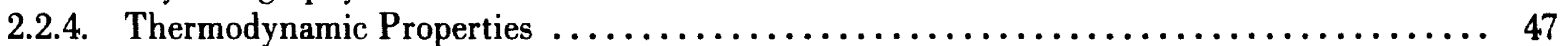

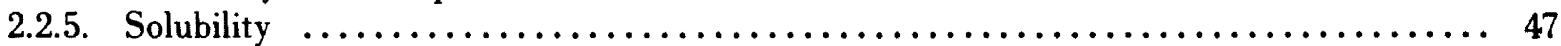

2.2.6. Accuracy and Precision $\ldots \ldots \ldots \ldots \ldots \ldots \ldots \ldots \ldots \ldots \ldots \ldots \ldots \ldots \ldots \ldots \ldots \ldots$

2.3. Physical Properties: Halite ........................................ 49

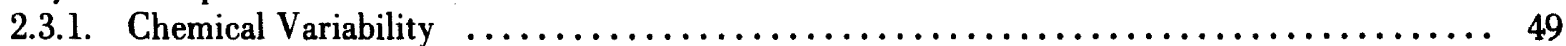

2.3.2. Density ............................................ 49

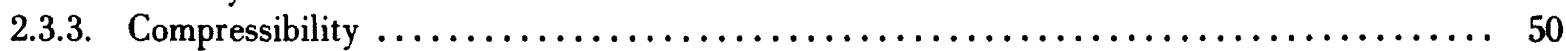

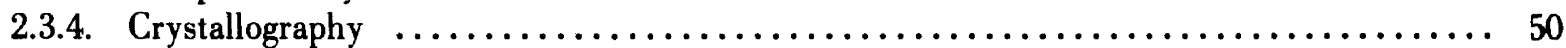

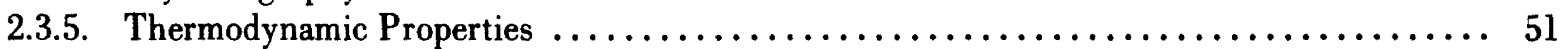

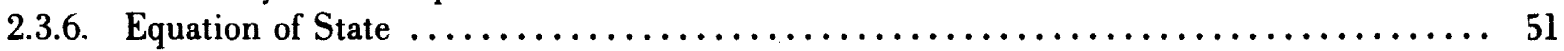

2.4. Physical Properties of Major Impurities in Halite $\ldots \ldots \ldots \ldots \ldots \ldots \ldots \ldots \ldots \ldots \ldots \ldots \ldots$. 51

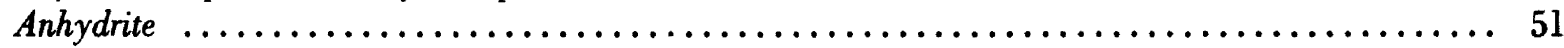

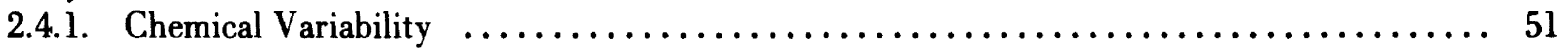

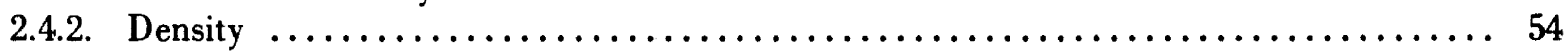

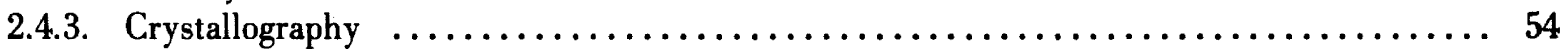

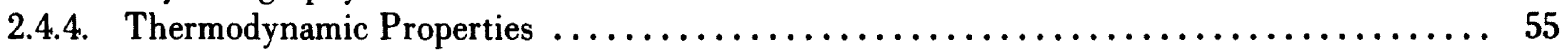

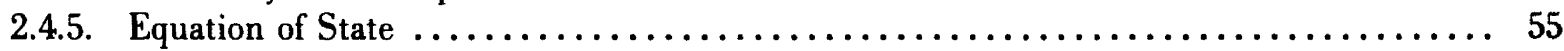

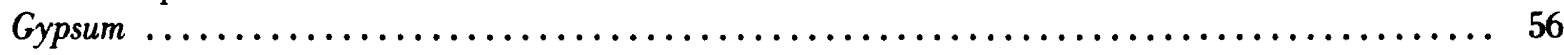

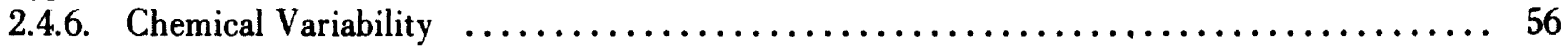

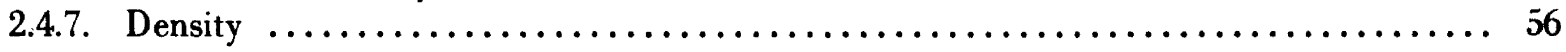

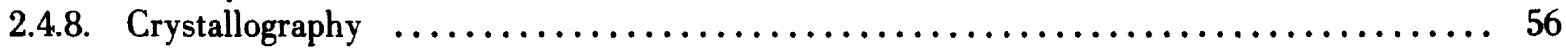

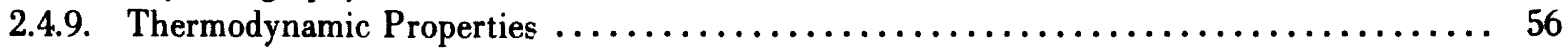

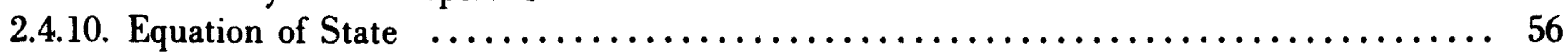

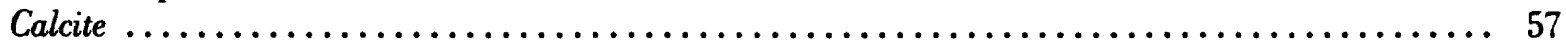

2.4.11. Chemical Variability .................................... 57

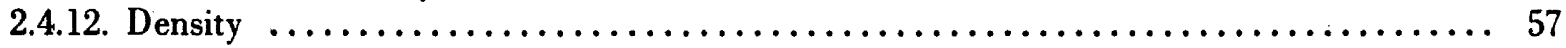

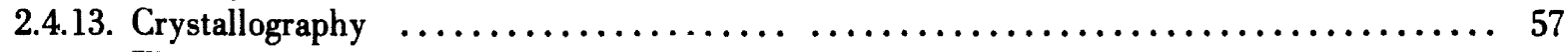

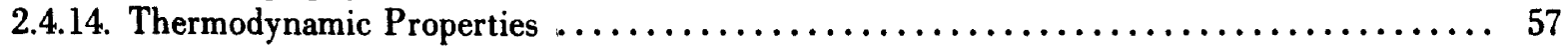

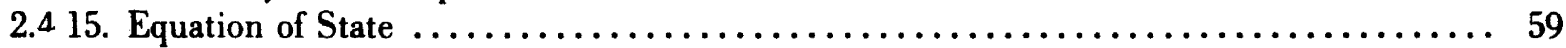

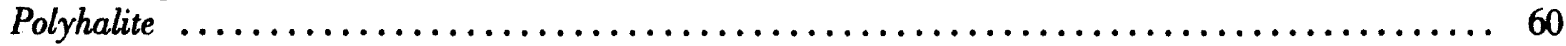

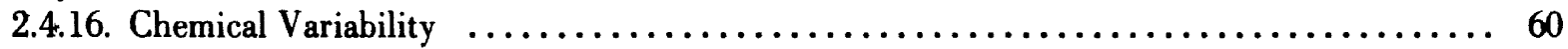

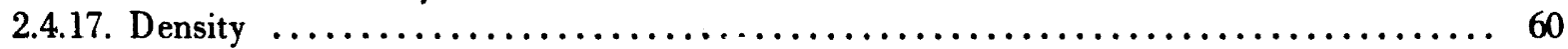

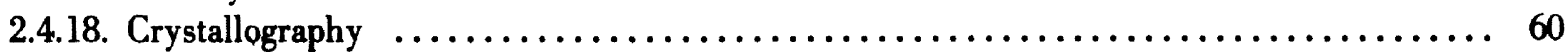

*Department of Chemical Engineering and Chemistry, New Jersey Institute of Technology, Newark, New Jersey 


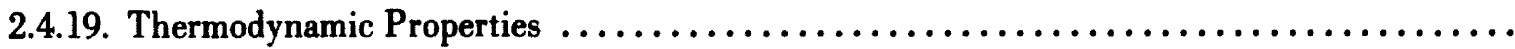

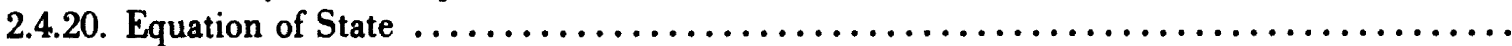

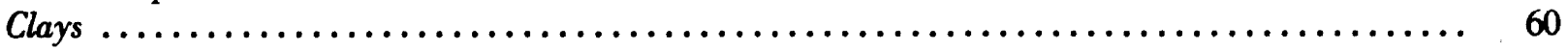

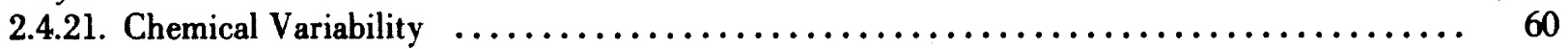

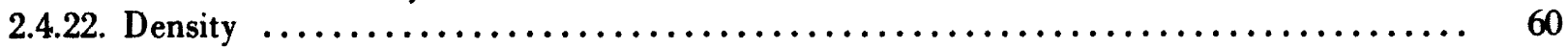

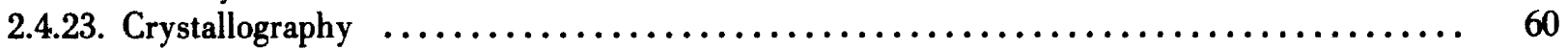

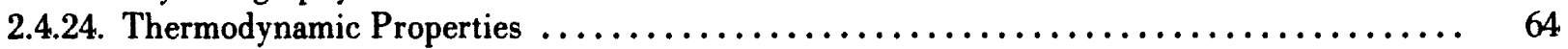

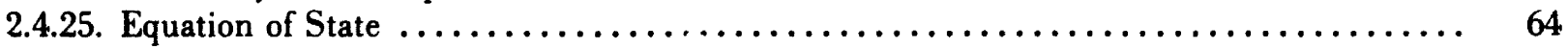

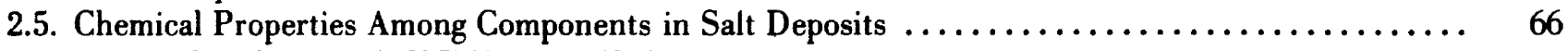

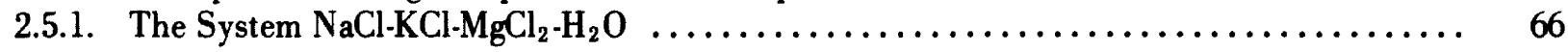

2.5.2. The System Anhydrite-Water-NaCl $\ldots \ldots \ldots \ldots \ldots \ldots \ldots \ldots \ldots \ldots \ldots \ldots \ldots \ldots \ldots . \ldots \ldots$

2.5.3. The System Gypsum-Water-NaCl $\ldots \ldots \ldots \ldots \ldots \ldots \ldots \ldots \ldots \ldots \ldots \ldots \ldots \ldots \ldots \ldots$

2.5.4. Comparison of the Systems Anhydrite-Water and Gypsum + Water $\ldots \ldots \ldots \ldots \ldots \ldots$

2.5.5. The System Calcite-Water $+\left(\mathrm{NaCl}, \mathrm{CaCl}_{2} \ldots\right) \ldots \ldots \ldots \ldots \ldots \ldots \ldots \ldots \ldots \ldots \ldots \ldots$

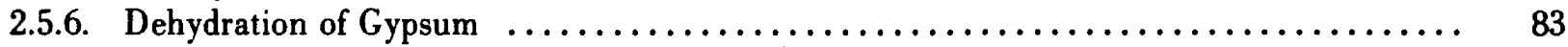

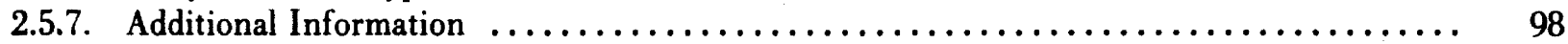

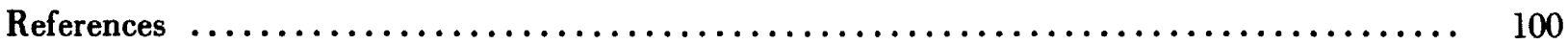

Symbols and Units $\ldots \ldots \ldots \ldots \ldots \ldots \ldots \ldots \ldots \ldots \ldots \ldots \ldots \ldots \ldots \ldots \ldots \ldots \ldots \ldots \ldots \ldots \ldots, 101$

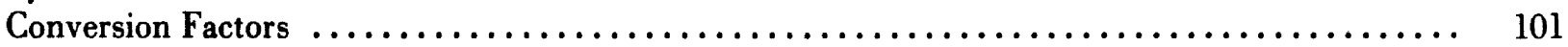

\section{Physical and Chemical Properties of Components in Salt Deposits}

\subsection{Introduction}

The physical and chemical properties of the components found in salt deposits are presented in this chapter. The concern is largely with the principal constituent of such deposits, namely halite and some of the more common impurities, particularly anhydrite, $\mathrm{CaSO}_{4}$; gypsum, $\mathrm{CaSO}_{4} \cdot 2 \mathrm{H}_{2} \mathrm{O}$; calcite, $\mathrm{CaCO}_{3}$; polyhalite, $\mathrm{K}_{2} \mathrm{Ca}_{2} \mathrm{Mg}\left(\mathrm{SO}_{4}\right)_{4} \cdot 2 \mathrm{H}_{2} \mathrm{O}$, and various types of clay minerals.

The properties of chemical variability, density, crystallography, and thermodynamic parameters (entropy, enthalpy of formation and free eneigy of formation) have been evaluated and are reported herewith. An equation of state has been included if available. An assessment of the chemistry among the components $\mathrm{H}_{2} \mathrm{O}-\mathrm{NaCl}-\mathrm{CaSO}_{4}-\mathrm{CaCO}_{3}-\mathrm{KCl}-\mathrm{MgCl}_{2}$ was also undertaken. The results for data on aqueous solubility, dehydration reactions, formation of solid solutions and phase diagrams for the systems indicated above are also reported in this chapter. A brief discussion of the techniques used for such measurements, together with remarks on the experimental accuracy, and precision is first given since an appreciation of this is basic to the data tabulations that follow.

\subsection{Experimental Techniques}

The experimental aspects for property measurements, such as chemical compositions, density, crystallography, thermodynamic properties, and solubility are considered in this section. References to recommended experimental investigations, in which the various techniques have been used, are included.

\subsection{Chemical Compositions}

Most of the analyses of the components of salt deposits have been performed using atomic absorption spectroscopy. The limits of detection for the analysis of rock salt varied from $0.0025-0.00005 \mathrm{ppm}$.

An example of the experimental approach is that by Bloomberg [1]. The salt was dissolved in water and allowed to stand overnight, then filtered. The residue was washed with several portions of distilled water and the filter paper and insolubles were dried overnight at $383 \mathrm{~K}$. The paper was separated and ashed, then the residue was added to the ash and the total weighed as insolubles. This portion was ground in an agate mortar and analyzed spectrographically.

The trace elements in the soluble fraction were precipitated with $\mathrm{H}_{2} \mathrm{~S}$ from slightly alkaline brine, using high purity lead as a carrier. The precipitate was allowed to settle overnight and was then separated from the alkaline brine by centrifuging, and washed several times with slightly alkaline $\mathrm{H}_{2} \mathrm{~S}$-saturated distilled water. The washed precipitate was then transferred to a crucible, dried at $383 \mathrm{~K}$, and analyzed spectrographically.

\subsubsection{Density}

Methods available for the determination of the densities of solids are described in detail by Bauer and Lewin [2]. Most of the commonly used methods depend on immersing the solids in some inert fluid of known 
density. The methods may be conveniently divided into displacement methods (pycnometric, dilatometric) and buoyancy methods (Archimedean principle).

A common displacement method uses a pycnometer where the volume of a known mass of the solid is found by determining the changes in weight when the pycnometer is successively filled with a liquid of known density, solid plus air, and solid plus liquid. With due precautions an accuracy of about \pm 0.0005 or $\pm 0.1 \%$ for the density can be achieved.

Hydrostatic weighing appears to be the most commonly employed buoyancy method, in which the apparent loss of weight is obtained by weighing the solid first in air and then immersed in the liquid. The accuracy of this method is about \pm 0.001 or $\pm 0.2 \%$. The main difficulty in these methods is that of completely removing all the air trapped by the solid. Variations of up to 5 percent have been obtained for individual crystals taken from the same source.

\subsubsection{Crystallography}

$\mathrm{X}$-ray diffraction techniques have been used to obtain the crystallographic parameters. The various techniques for determination of the structure of minerals are described by G $\mathrm{G}$ mhaw [3]. Large crystals are examined by means of a single crystal goniometer, with a GeigerMüller counter attachment to accurately detect the positions and relative intensities of the spots. Interlattice spacings accurate to $\pm 10^{-14} \mathrm{~m}$ are attainable using $x$-ray methods.

In cases where single crystal specimens are not available a powder sample can be used successfully. Most minerals lend themselves to the powder technique. However, it should be noted that the information obtained from a powder diffraction pattern is less complete compared to the single crystal pattern due to accidental overlap of powder lines with approximately the same Bragg angle. Another problem that is encountered with powder diffraction patterns is the existence of a stronger background leading to the possiblity of some weaker reflections being overlooked.

For measurements at higher pressures Jamieson [4] has described a new technique using "amorphous" boron as a pressure vessel for studies up to $10^{10}$ pascal pressure. The cell consists of a boron water sandwiched between two carboloy platens. The x-rays are collimated so that the beam traverses the wafer normal to its axis. The use of a Bridgman-anvil high pressure apparatus has been reported by Sato [5], which adapts the $x$-ray Debye-Scherrer system using a high pressure cell of boron, solidified with a polyester resin. Readings accurate to $\pm 0.02^{\circ}$ were attainable with this technique.
There are two important methods for measuring $x$-ray intensities. In the photographic or densitometric method, $\mathrm{I}_{0}$ is the intensity of the incident light scanning the densitometer trace and consequently $I_{0}>I$. The geiger method involves a direct measurement of $x$-ray scattering and accomplishes a comparison of the incident and scattered $x$-ray beam intensities. It is always advisable to check on the technique employed before using the reported values of intensities.

\subsubsection{Thermodynamic Properties}

The thermodynamic properties have been measured (or derived from) either low temperature adiabatic calorimetry (heat capacities) or combustion bomb calorimetry (heats of combustion). A detailed discussion of these methods is given by Sturtevant [6]. Additional discussion of the precision and accuracy attainable with adiabatic calorimeters is reported by Staveley [7]. Depending on the temperature range the precisions expected for heat capacity data are as follows: $0.7 \%$ $(10-30 \mathrm{~K}), 0.2 \%(30-100 \mathrm{~K})$, and $0.1 \%(100-300 \mathrm{~K})$. The expected accuracy is about $0.16 \%$.

Heat capacities are obtained using the Nernst method, in which the material under investigation is contained in a metal calorimeter which is equipped with a heater and a temperature measuring device such as a resistance thermometer, thermocouple, or thermistor. The calorimeter is supported inside a jacket of large heat capacity and accurately measurable temperature. The jacket is contained within another vessel, such as a Dewar flask, which is cooled by liquid air or liquid hydrogen. Several adiabatic calorimeters exist in which the jacketcalorimeter temperature difference is kept so small that thermal leakage is negligible.

The enthalpies and free energies of formation reported in this chapter have been obtained from heats of combustion data using bomb calorimetry. Data having an accuracy of a few hundredths of a percent may be obtained using the bomb calorimeter. A detailed description of the bomb calorimeter is given by Sturtevant [6].

The selection of the best values for the thermodynamic parameters has been based on four major critical compilations, namely: The JANAF tables [31], the tabulations of Barin and Knacke [53], the NBS Circular 500 [55], and the U.S. Geological Survey Bulletin [117].

\subsubsection{Solubility}

Methods for measuring solubilities and phase diagram data have been described concisely by Potter et al. [8] Three major categories of experimental techniques exist for the determination of the solubility of a salt in an 
aqueous solution as a function of temperature. These are quench methods, visual methods, and so-called indirect methods. Quench methods involve separating a representative sample of the saturated solution from the salt crystals at a certain temperature, quickly cooling the separated solution to room temperature, and finally analyzing its salt content using atomic absorption spectrophotometry or titration methods. Studies employing the visual method involving viewing a mixture of solution plus salt crystals plus vapor of known bulk composition as temperature is increased slowly until the last salt crystal dissolves. Solubility is determined with the indirect methods by utilizing changes in the intensive properties of a system of salt crystals plus saturated solution plus vapor of known bulk composition to detect the dissolution of the last salt crystal.

The quench method has been developed to obtain data at higher temperatures than were possible in earlier studies. Basically the modification consists of a "bomb in bomb" method, in which an empty bomb is sealed in a bomb filled with salt crystals plus solution in such a way that the inner bomb can be opened and closed. Some of the difficulties that are encountered with the quench method include density, stratification, super-saturation, analytical problems, precipitation on quench, and the criteria for establishing equilibrium. With the visual method, limiting factors include visibility during heating, density stratification, and the effect of devitrification on the ultimate strength of the glass.

Most of the geological solubility data have been obtained via indirect methods. An example of an indirect method consists of measuring the pressure as a function of volume of a known bulk composition at constant temperature. The dissolution of the last salt crystal is detected by discontinuities in the pressure-volume curves. Another indirect method used for solubility measurements is to measure vapor pressure of the solution as a function of the composition at constant temperature. The composition at which the pressurecomposition curve becomes constant is taken as the solubility of the salt at the temperature of the measurement. A limiting factor (with respect to the accuracy) is the spacing of the compositions; the more closely spaced, the greater the accuracy.

Potter et al. [8] have recently devised a new method for measuring the solubility of simple salts in water at elevated temperatures involving heating assemblages of salt crystals plus solution vapor at a constant rate in a platinum-lined bomb. The dissolution of the last salt crystal is evidenced by a distinct discontinuity in the pressure-temperature curve. The uncertainty of the solubility data obtained by this method was estimated to be \pm 0.1 weight percent of salt.
The preceding observations on accuracies and precision of the various techniques are summarized in table 2.1.

\subsubsection{Accuracy and Precision}

The accuracy estimates are based on experimental details including method of measurement. techniques, analytical characterization of materials and, wherever possible, intercomparisons with results from different investigators. Where precision estimates were advanced by the investigators, these are reported accordingly; where the data were subjected to further analyses, the precisions advanced are based on the statistical analyses.

Temperature-dependent or pressure-dependent equations are reported wherever possible. The statistical analysis was performed on the computer facilities at Rensselaer Polytechnic Insititue. The criterion for choosing the equation of best fit using a least-squares one-dimensional analysis is the standard error of estimate defined by

$$
s=\frac{\sum^{n}\left(\gamma_{e}-\gamma_{c}\right)^{2}}{n-q}
$$

where $\gamma_{\mathrm{e}}=$ the experimental value at each temperature, $\gamma_{\mathrm{c}}=$ the value calculated from the least squares equation at the same temperature as $\gamma_{\mathrm{e}}, n=$ the number of experimental data points, and $q=$ the number of coefficients in the least squares equation ( 2 for linear, 3 for quadratic). Alternatively, in the case of a linear regression analyses, the measure of the precision of the data is $r^{2}$, defined as:

$$
r^{2}=\frac{\left[\Sigma x_{i} y_{i}-\frac{\sum x_{i} \Sigma y_{i}}{n}\right]^{2}}{\left[\Sigma x_{i}{ }^{2}-\frac{\left(\Sigma x_{i}\right)^{2}}{n}\right]\left[\Sigma y_{i}{ }^{2}-\frac{\left(\Sigma y_{i}\right)^{2}}{n}\right]}
$$

where $x_{i}$ and $y_{i}$ are the data pairs and $\mathrm{n}$ the number of data pairs. For an exponential curve fit, $r^{2}$ is given by:

$$
r^{2}=\frac{\left[\Sigma x_{i} \ln y_{i}-\frac{1}{n} \Sigma x_{i} \Sigma \ln y_{i}\right]^{2}}{\left[\Sigma x_{i}{ }^{2}-\frac{\left(\Sigma x_{i}\right)^{2}}{n}\right]\left[\Sigma\left(\ln y_{i}\right)^{2}-\frac{\left(\Sigma \ln y_{i}\right)^{2}}{n}\right]}
$$

The closer the value of $r^{2}$ is to unity the more precise is the data. 


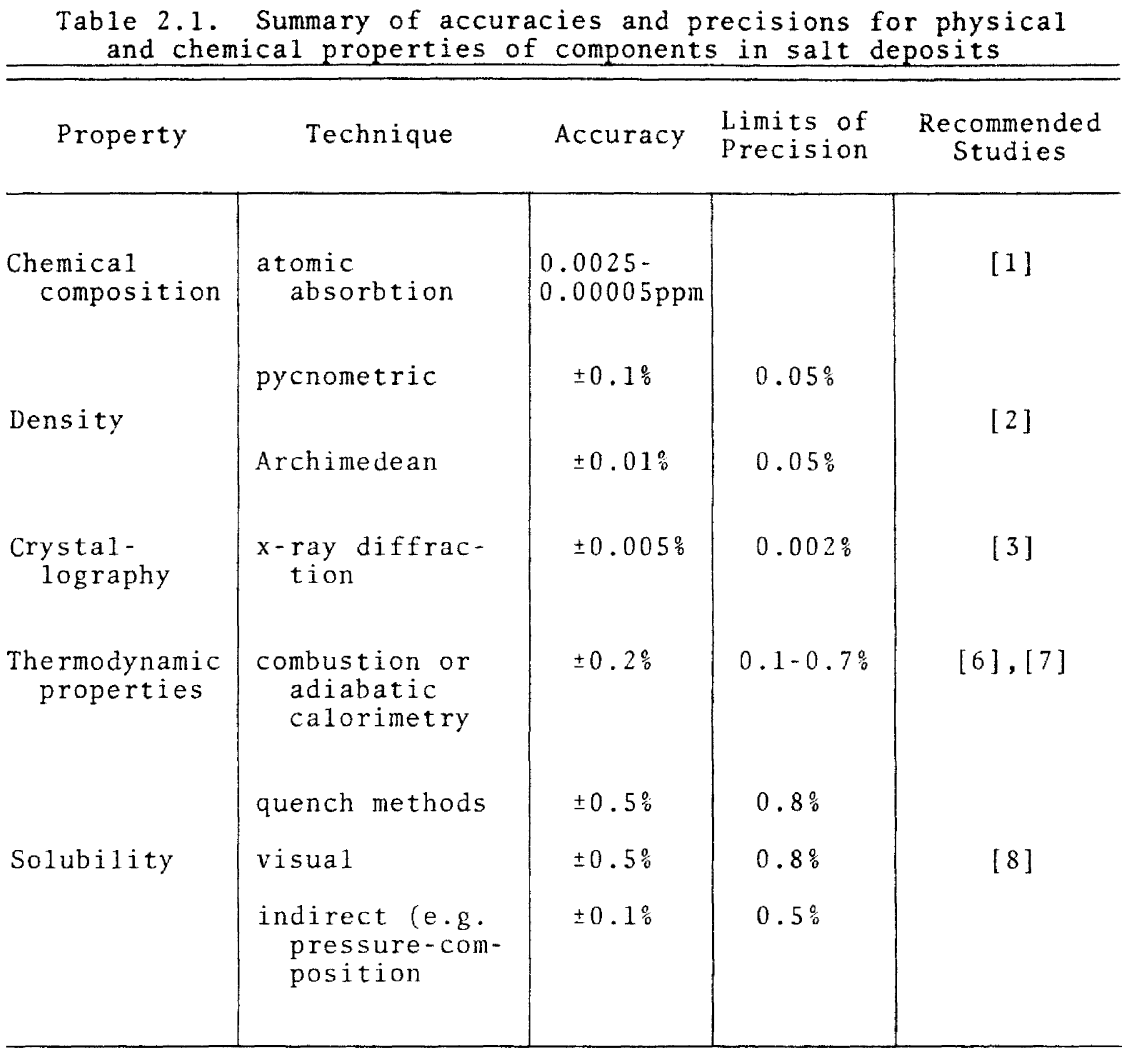

\subsection{Physical Properties: Halite}

\subsubsection{Chemical Variability}

The most common insoluble impurities in halite [9] are anhydrite, gypsum, dolomite, calcite, pyrite, quartz, and iron oxides. The most common soluble impurities include the following ions: $\mathrm{Ca}^{+2}, \mathrm{Mg}^{+2}, \mathrm{~K}^{+}, \mathrm{Cl}, \mathrm{CO}_{3}^{-2}$, and $\mathrm{SO}_{4}^{-2}$; in addition, $\mathrm{Ba}^{+2}, \mathrm{Sr}^{+2}, \mathrm{~B}^{+3}$ and $\mathrm{Br}$ may be present in minor amounts. In some deposits associated minerals are present. These minerals include the following:

Sylvite, $\mathrm{KCl}$

Carnallite, $\mathrm{KMgCl}_{3} \cdot 6 \mathrm{H}_{2} \mathrm{O}$

Tachydrite, $2 \mathrm{MgCl}_{2} \cdot 12 \mathrm{H}_{2} \mathrm{O}$

Bischofite, $\mathrm{MgCl}_{2} \cdot 6 \mathrm{H}_{2} \mathrm{O}$

Kainite, $\mathrm{MgSO}_{4} \cdot \mathrm{KCl} \cdot 3 \mathrm{H}_{2} \mathrm{O}$

Anhydrite, $\mathrm{CaSO}_{4}$

Vanthoffite, $\mathrm{MgSo}_{4} \cdot 3 \mathrm{Na}_{2} \mathrm{SO}_{4}$

Glaserite, $\mathrm{K}_{3} \mathrm{Na}\left(\mathrm{SO}_{4}\right)_{2}$

Langbeinite, $2 \mathrm{MgSO}_{4} \cdot \mathrm{K}_{2} \mathrm{SO}_{4}$

Syngenite, $\mathrm{CaSO}_{4} \cdot \mathrm{K}_{2} \mathrm{SO}_{4} \cdot \mathrm{H}_{2} \mathrm{O}$

Leonite, $\mathrm{MgSO}_{4} \cdot \mathrm{K}_{2} \mathrm{SO}_{4} \cdot 4 \mathrm{H}_{2} \mathrm{O}$

Picromerite, $\mathrm{MgSO}_{4} \cdot \mathrm{K}_{2} \mathrm{SO}_{4} \cdot 6 \mathrm{H}_{2} \mathrm{O}$

Gypsum, $\mathrm{CaSO}_{4} \cdot 2 \mathrm{H}_{2} \mathrm{O}$

Kieserite, $\mathrm{MgSO}_{4} \cdot \mathrm{H}_{2} \mathrm{O}$

Epsomite, $\mathrm{MgSO}_{4} \cdot 7 \mathrm{H}_{2} \mathrm{O}$
Glauberite, $\mathrm{CaSO}_{4} \cdot \mathrm{Na}_{2} \mathrm{SO}_{4}$

Bloedite, $\mathrm{MgSO}_{4} \cdot \mathrm{Na}_{2} \mathrm{SO}_{4} \cdot 4 \mathrm{H}_{2} \mathrm{O}$

Loeweite, $\mathrm{MgSO}_{4} \cdot \mathrm{Na}_{2} \mathrm{SO}_{4}$

Polyhalite, $2 \mathrm{CaSO}_{4} \cdot \mathrm{MgSO}_{4} \cdot \mathrm{K}_{2} \mathrm{SO}_{4} \cdot 2 \mathrm{H}_{2} \mathrm{O}$

Krugite, $4 \mathrm{CaSO}_{4} \cdot \mathrm{MgSO}_{4} \cdot \mathrm{K}_{2} \mathrm{SO}_{4} \cdot 2 \mathrm{H}_{2} \mathrm{O}$

In natural halite there does not appear to be much replacement of $\mathrm{Na}$ by $\mathrm{K}$, although sylvite $(\mathrm{KCl})$ is isomorphous with halite. Moisture is normally present as saturated brine inclusions within the salt crystals. Gas bubbles are sometimes found within the inclusions and consist mainly of air, $\mathrm{CO}_{2}$ and hydrocarbons. Some typical analyses of halite are listed in table 2.2. These analyses [10] cover samples found in Michigan, New York, Ohio, Louisiana and Kansas, which account for the bulk of production of rock salt in the United States. Commercial rock salt (halite) varies in purity from about 97\% (Kansas) to about $99 \%$ (Louisiana).

\subsubsection{Density}

The summary of density values advanced by Doelter and Leitmeier in 1929 [11] still appears authoritative. Later values are given for halite from several sources [12-16] at one temperature with accuracies of about $\pm 0.1 \%$. The samples varied from recrystallized salt to halite samples from various sources. 


\begin{tabular}{|c|c|c|c|c|c|}
\hline \multirow{4}{*}{ Component } & \multicolumn{5}{|c|}{ Source } \\
\hline & \multicolumn{5}{|c|}{ USA } \\
\hline & Louisiana & New York & Michigan & Ohio & Kansas \\
\hline & \multicolumn{5}{|c|}{ Weight Percent $(\%)$} \\
\hline $\mathrm{NaCl}$ & 99.01 & 98.24 & 98.08 & 97.87 & 97.27 \\
\hline $\mathrm{CaSO}_{4}$ & 0.84 & 1.48 & 1.55 & 1.84 & 2.22 \\
\hline $\mathrm{CaCO}_{3}$ & 0.10 & 0.05 & 0.11 & 0.11 & \\
\hline $\mathrm{MgCO}_{3}$ & 0.01 & 0.06 & 0.06 & 0.06 & 0.19 \\
\hline $\mathrm{SiO}_{2}$ & 0.02 & 0.11 & 0.03 & 0.04 & 0.23 \\
\hline $\mathrm{Fe}_{2} \mathrm{O}_{3}$ & 0.00 & 0.04 & 0.01 & 0.01 & 0.01 \\
\hline $\mathrm{H}_{2} \mathrm{O}$ & 0.02 & 0.02 & 0.16 & 0.07 & 0.08 \\
\hline
\end{tabular}

Hunt [12] used the buoyancy method with oil of turpentine, whereas Moseley [14] reported the density of halite as part of a calibration experiment for the determination of the $\mathrm{x}$-ray spectra of some elements. Retgers [13] used a carefully calibrated pycnometer for the measurement of density, but no other information was provided. The publications by Spencer [15] and Spannenberg [16] are both review articles. There have been no more recently determined values for the density of halite. In 1960 Kaufmann [17] undertook a further critical assessment of the density data for halite using the references cited in the 1929 compilation. The results of Kaufmann's assessment are recommended as the best values for density of halite. The densities are in table 2.3.

\subsubsection{Compressibility}

The values of the compressibility of halite are in table 2.4. These are based on the work of Richards and Jones [19] and Slater [20]. Some details of these studies follow.

In the low pressure study by Richards and Jones [19] a Cailletet compression pump was used to attain the pressures and the apparatus was immersed in a constant temperature bath which was maintained at $\pm 0.005^{\circ} \mathrm{C}$. The essential feature of the method was the comparison of the unknown compressibility with the known compressibility of mercury, by first compressing mercury in a given apparatus, measuring both pressure and change of volume and then displacing most of the mercury by the substance to be studied, and again noting the relationship of pressure to volume. The experiments were performed on both sodium chloride precipitated from reagent grade salt and on two specimens of clear, natural halite. The pressure gauge used in the experiments was calibrated by using the difference between the compressibility of water and mercury at $293 \mathrm{~K}$.

Slate [20] used sodium chloride samples grown from the melt and reported that the error in the values of compressibility at zero pressure was less than $1 \%$. The values obtained for variation with pressure and temperature were stated to be of the order of $5 \%$ and $20 \%$ respectively.

\subsubsection{Crystallography}

The crystal symmetry of halite is cubic hexoctahedral; this symmetry class is represented as $4 / \mathrm{m} \overline{3} 2 / \mathrm{m}$ [Hermann-Mauguin (International) symbols].

$\mathrm{X}$-ray crystallographic data for halite have been reported by several investigators [22-30]. The radiation sources used in these investigations were either molybdenum [22-24, 27] or copper [25, 28-30]. In view of several discrepancies in the intensities published on the ASTM cards, a critical analysis of existing data was undertaken by Swanson [30] in 1953, together with a redetermination of the crystal parameters using sodium chloride, twice recrystallized from hydrochloric acid. The results are in table 2.5. These values are recommended as the best values. 
Table 2.3. Halite: Density $\left(\mathrm{kg} / \mathrm{m}^{3}\right)$

\begin{tabular}{|c|c|}
\hline $\begin{array}{c}\mathrm{T} \\
(\mathrm{K}) \\
\end{array}$ & $\begin{array}{c}\rho \\
( \pm 2) \\
\end{array}$ \\
\hline 273 & 2168 \\
\hline 283 & 2165 \\
\hline 293 & 2163 \\
\hline 298 & 2161 \\
\hline 303 & 2160 \\
\hline 313 & 2158 \\
\hline 323 & 2155 \\
\hline
\end{tabular}

Temperature-dependent equation, and precision $\rho=2237.2057-0.254286 \mathrm{~T}:\left(\mathrm{r}^{2}=0.995\right)$

\subsubsection{Thermodynamic Properties}

Table 2.6 reports the recommended values for the entropies, standard enthalpies of formation, standard Gibbs free energies of formation and standard heat capacities as a function of temperature. These are the values advanced by Stull, Prophet et al. [31] from the JANAF thermochemical tables, and are recommended as the best values. The heat of formation is based on $\Delta H_{f}^{\circ},{ }_{298.15}=-240.12$ and $-167.15 \mathrm{~kJ} / \mathrm{mol}$ for $\mathrm{Na}^{+}$ $\left({ }^{\infty} \mathrm{H}_{2} \mathrm{O}\right)$ and $\mathrm{Cl}^{-}\left({ }^{\infty} \mathrm{H}_{2} \mathrm{O}\right)$, respectively, and on the heat of solution $\Delta H_{\infty}^{\circ}, 298.15=3857.6 \mathrm{~J} / \mathrm{mol}$ for $\mathrm{NaCl}$.

The heat capacities were obtained by high temperature precision calorimetry [32-42]. Temperature drift was reduced to a value less than $0.1 \% / \mathrm{min}$ during a temperature measurement. $\mathrm{Pt} / 10 \%$ Rhodium thermocouples were calibrated against the melting points of NBS samples of lead, tin and zinc. The sample container was fabricated from $\mathrm{Pt} / 10 \%$ Rhodium and contained a thermocouple well. The results were estimated to be accurate to $\pm 0.3 \%$ with a standard deviation of $54 \mathrm{~J} / \mathrm{mol}$.

\subsubsection{Equation of State}

No information on an equation of state is available for halite.

\subsection{Physical Properties of Major Impurities in Halite}

The major impurities in halite considered here are anhydrite, gypsum, calcite, polyhalite and clays. The properties of chemical variability, density, crystallography, thermodynamic properties and equation of state have been evaluated and are reported herewith.

Anhydrite, $\mathrm{CaSO}_{4}$

\subsubsection{Chemical Variability}

Anhydrite occurs as a monomineralic rock in many textural varieties and grain sizes [43]. It is found mixed

Table 2.4. Coefficient of compressibility, $\beta$, for halite

Low Pressures

\begin{tabular}{cccc}
$\begin{array}{c}\text { Temp } \\
(\mathrm{K})\end{array}$ & $\begin{array}{c}\text { Pressure Range } \\
\mathrm{Pa} / \mathrm{m}^{2}\left(\mathrm{x} 10^{-4}\right)\end{array}$ & $\begin{array}{c}\beta \times 10^{-3} \\
\mathrm{~m} 2 / \mathrm{Pa}\end{array}$ & Ref. \\
\hline 273 & $9.8-1471.0$ & 4.13 & {$[18]$} \\
293 & $980.7-4903.3$ & 4.11 & {$[19]$} \\
303 & 0 & 4.20 & {$[20]$}
\end{tabular}

High Pressures [21]

\begin{tabular}{cccc}
$\begin{array}{c}\text { Pressure } \\
\mathrm{Pa}\left(\mathrm{x} 10^{-7}\right)\end{array}$ & $B(293 \mathrm{~K})$ & $\begin{array}{c}\text { Pressure } \\
\mathrm{Pa}\left(\mathrm{x} 10^{-7}\right)\end{array}$ & $\beta(293 \mathrm{~K})$ \\
\hline 50 & 0.0196 & 300 & 0.0932 \\
100 & 0.0371 & 350 & 0.1043 \\
150 & 0.0531 & 400 & 0.1145 \\
200 & 0.0677 & 450 & 0.1239 \\
250 & 0.0810 & 500 & 0.1325
\end{tabular}

Pressure-dependent equation, and precision

$$
B=5.2008 \times 10^{-4}+3.9836 \times 10^{-4} \mathrm{P}-3.4203 \times 10^{-7} \mathrm{P}^{2}+1.4663 \times 10^{-10} \mathrm{p}^{3}(\mathrm{~s}=0.10 \%)
$$


Cubic system

$a=b=c=5.6402 \times 10^{-10} \mathrm{~m} \pm 0.0001 \times 10^{-10} \mathrm{~m}$

$a=\beta=\gamma=90^{\circ}$

\begin{tabular}{lrl}
$\mathrm{d}^{\mathrm{a}}$ & \multicolumn{1}{c}{$\mathrm{I}^{\mathrm{b}}$} & $\mathrm{hk} 1^{\mathrm{C}}$ \\
\hline 3.258 & 13 & 111 \\
2.821 & 100 & 200 \\
1.994 & 55 & 220 \\
1.701 & 2 & 311 \\
1.628 & 15 & 400 \\
1.410 & 6 & 400 \\
1.294 & 1 & 331 \\
1.261 & 11 & 420 \\
1.1515 & 7 & 422 \\
1.0855 & 1 & 511 \\
0.9969 & 2 & 440 \\
0.9533 & 1 & 531 \\
0.9401 & 3 & 600 \\
0.8917 & 4 & 620 \\
0.8601 & 1 & 533 \\
0.8503 & 3 & 622 \\
0.8141 & 2 & 444 \\
\hline
\end{tabular}

a) $\mathrm{d}$ is the interlattice spacing, in $\mathrm{mx} 10^{10}$.

b) I isthe intensity scaled to the strongest line which was assigned a value of 100

c) hkl are the Miller indices 
Table 2.6. Thermodynamic parameters for halite

(a) Entropy, enthalpy of formation and free energy of formation

\begin{tabular}{cccc}
$T(\mathrm{~K})$ & $\mathrm{S}^{\circ}(\mathrm{J} / \mathrm{mol} \mathrm{K})$ & $\Delta \mathrm{H}_{\mathrm{f}}^{\circ}(\mathrm{kJ} / \mathrm{mol})$ & $\Delta \mathrm{G}_{\mathrm{f}}^{\circ}(\mathrm{kJ} / \mathrm{mol})$ \\
\hline 298 & 72.115 & -411.260 & -384.212 \\
300 & 72.429 & -411.107 & -384.005 \\
400 & 87.228 & -413.461 & -374.837 \\
500 & 99.081 & -413.024 & -365.229 \\
600 & 109.052 & -412.352 & -355.730 \\
700 & 117.729 & -411.456 & -346.356 \\
800 & 125.499 & -410.352 & -337.136 \\
900 & 132.629 & -409.064 & -328.064 \\
1000 & 139.298 & -407.593 & -319.133 \\
\hline
\end{tabular}

Temperature-dependent equations, and precision

$$
\begin{aligned}
\mathrm{S}^{\circ} & =47.211+0.096428 \mathrm{~T} ;\left(\mathrm{r}^{2}=0.982\right) \\
\Delta \mathrm{G}_{\mathrm{f}}^{\circ} & =-411.863+0.093137 \mathrm{~T} ;\left(\mathrm{r}^{2}=0.999\right)
\end{aligned}
$$

(b) Heat capacity $\mathrm{C}_{\mathrm{p}}^{\circ}$

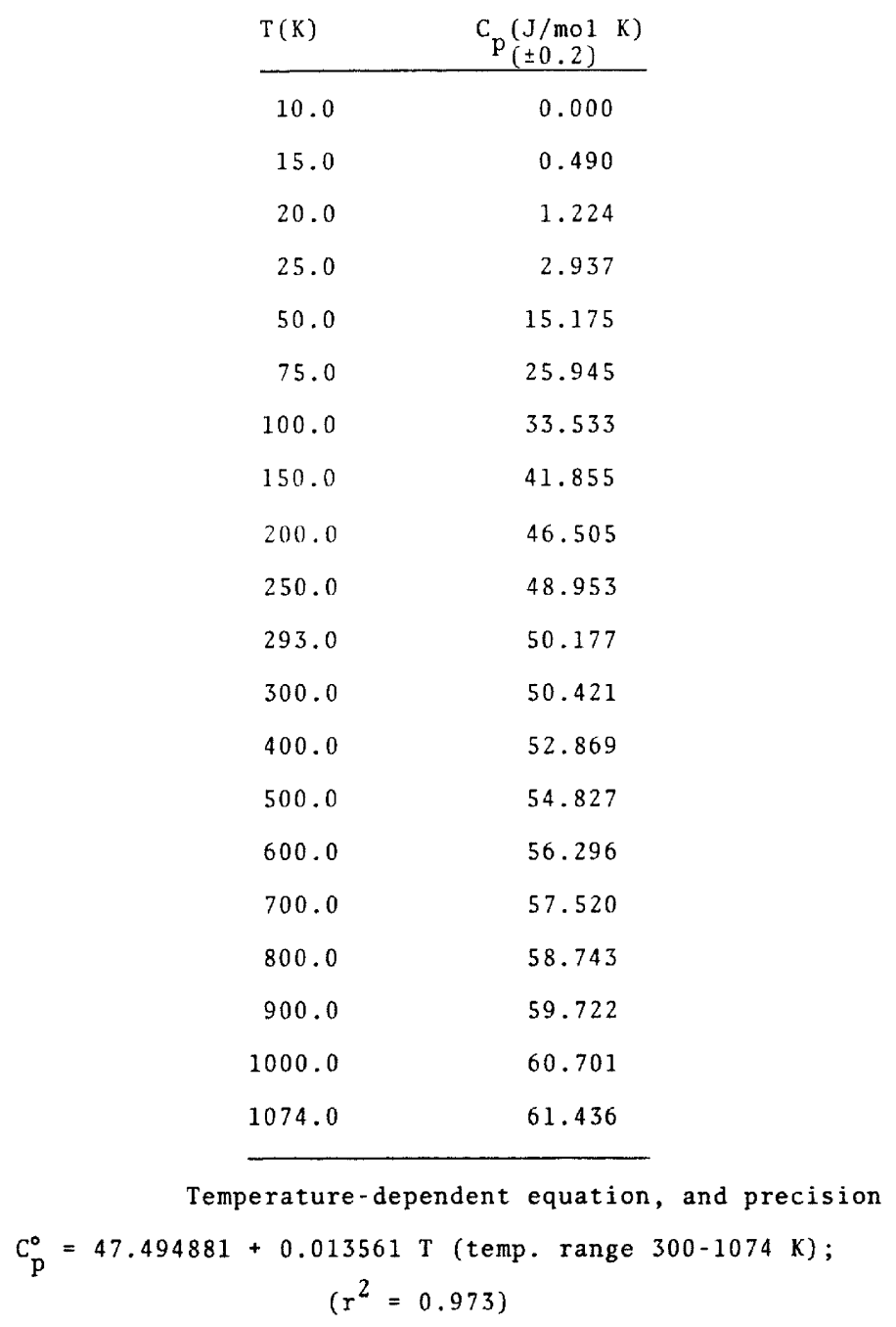


with calcite, dolomite, magnesite, clay and many other minerals, including halite. Anhydrite frequently occurs in bands alternating with massive fibrous gypsum. Table 2.7 gives the chemical analyses for several samples of anhydrite. It is apparent that only minor variations occur in its composition. Small amounts of strontium and barium sometimes occur replacing calcium; oxides are probably present as impurities and $\mathrm{H}_{2} \mathrm{O}^{+}$, when present, is mainly due to the presence of gypsum.

\subsubsection{Density}

Density data for anhydrite have been reported in two investigations $[44,45]$. Both sets of density data for anhydrite are in table 2.8. There is insufficient information for value judgements. No information on the experimental technique or sample preparation was given by Braitsch [44]. Ludwig and Müller [45] used a pycnometer, which was calibrated with n-heptane. Due precautions were taken to eliminate air from the apparatus. The pressure was normal atmospheric pressure.

\subsubsection{Crystallography}

The unit cell of anhydrite is orthorhombic. The structure of anhydrite is very different from that of the barytes group of sulfates and shows more similarity with the zircon type of structure. Sulfur atoms, (which are at the centers of regular tetrahedra of oxygen) and calcium atoms, lie on the lines of intersection of the two sets of mirror planes. Planes containing evenly spaced $\mathrm{Ca}$ and $\mathrm{SO}_{4}$ ions lie parallel to $(100)$ and $(010)$, whereas layering is not so well defined parallel to (001). X-ray crystallographic data for anhydrite have been reported by several investigators $[24,46-52]$. The radiation sources used in these investigations were either molybdenum [24, 46, $51,52]$ or copper $[47,50]$. In view of several discrepancies in the intensities published on the ASTM cards, Swanson [50] undertook a critical analysis of

\begin{tabular}{|c|c|c|c|c|c|c|}
\hline \multirow{4}{*}{ Component } & \multicolumn{6}{|c|}{ Source } \\
\hline & \multirow{2}{*}{$\begin{array}{c}\text { USA } \\
\text { I } 11 \text { ino is }{ }^{a}\end{array}$} & \multirow{2}{*}{$\begin{array}{l}\text { Japan } \\
\text { Kano }^{\circ}\end{array}$} & \multirow{2}{*}{$\mathrm{USSR}^{\mathrm{C}}$} & \multicolumn{2}{|c|}{ Germany } & \multirow{2}{*}{ Australia } \\
\hline & & & & Stassfurt & Celle & \\
\hline & \multicolumn{6}{|c|}{ Weight Percent $(\%)$} \\
\hline $\mathrm{SiO}_{2}$ & 0.50 & & 2.73 & & 0.01 & \\
\hline $\mathrm{Al}_{2} \mathrm{O}_{3}$ & 0.10 & 0.06 & 1.06 & 0.04 & 0.03 & \\
\hline $\mathrm{Fe}_{3} \mathrm{O}_{3} \mathrm{~J}$ & 0.10 & 0.00 & 1.00 & 0.04 & & \\
\hline $\mathrm{MgO}$ & 0.60 & & 0.17 & & 0.03 & \\
\hline $\mathrm{CaO}$ & 40.86 & 41.13 & 39.12 & 41.22 & 41.08 & 40.47 \\
\hline Sro & & & 0.00 & 0.01 & & 0.71 \\
\hline $\mathrm{BaO}$ & & & 0.00 & & & 0.05 \\
\hline $\mathrm{Na}_{2} \mathrm{O}$ & & & & ]$_{0} 02$ & 7 & \\
\hline $\mathrm{K}_{2} \mathrm{O}$ & & & & 0.02 & 0.07 & \\
\hline $\mathrm{SO}_{3}$ & 57.10 & 58.37 & 56.63 & 58.95 & 58.50 & 58.94 \\
\hline $\mathrm{CO}_{3}$ & 0.37 & 0.17 & & & & \\
\hline $\mathrm{H}_{2} \mathrm{O}^{+}$ & 0.69 & & 0.10 & 0.01 & 0.04 & \\
\hline $\mathrm{H}_{2} \mathrm{O}^{-}$ & 0.01 & & 0.68 & & & 0.40 \\
\hline Total & 100.61 & 99.75 & 100.49 & 100.25 & 99.76 & 100.57 \\
\hline
\end{tabular}

\footnotetext{
a) Includes $0.38 \mathrm{NaCl} ; \mathrm{SiO}_{2}$ figure includes insoluble residue.

b) Includes $\mathrm{FeS}_{2} 0.02$.

c) Fibrous anhydrite, dolomite rock.
} 


\begin{tabular}{lll}
$\begin{array}{l}\text { Density } \\
\left(\mathrm{kg} / \mathrm{m}^{3}\right)( \pm 2)\end{array}$ & $\mathrm{T}(\mathrm{K})$ & Ref. \\
\hline $2960-2980$ & 298 & {$[44]$} \\
$2920-2950$ & 298 & {$[45]$} \\
\hline
\end{tabular}

existing data and redetermined the crystal parameters using calcium sulfate prepared from the reaction between potassium sulfate and calcium chloride solu. tions, the product being heated at $973 \mathrm{~K}$ for 16 hours. Spectrographic analysis showed the following impurities: 0.01 to $0.1 \%$ each of $\mathrm{Bi}, \mathrm{Sr}$ and $\mathrm{Ti} ; 0.001$ to $0.01 \%$ each of $\mathrm{Ag}, \mathrm{Al}, \mathrm{Fe}, \mathrm{Mg}, \mathrm{Ni}$ and $\mathrm{Sn} ; 0.0001$ to $0.001 \%$ each of $\mathrm{Ba}, \mathrm{Cr}, \mathrm{Cu}$ and $\mathrm{Pb}$, and less than $0.0001 \%$ of $\mathrm{Mn}$. The values reported by Swanson [50] are recommended as the best values; the results are in table 2.9.

\subsubsection{Thermodynamic Properties}

The critical assessment of Barin and Knacke [53] is regarded as the most reliable. The results are advanced herewith as the recommended values in table 2.10 for entropies, standard enthalpies of formation, standard Gibbs free energies of formation and standard heat capacities for anhydrite. Temperature dependent equations and precisions are also included in table 2.10. For earlier studies, refer to references [54-57].

\subsubsection{Equation of State}

Müller and Siemes [114] carried out compression tests to examine the dependence of strength, ductility, and preferred orientation of polycrystalline anhydrite upon confining pressure (up to $5 \mathrm{kbar}$ ), temperatures (up to $300^{\circ} \mathrm{C}$ ) and strain (up to $30 \%$ ). It was observed that as the mantle pressure was increased at room temperature the strength and the ductility increased. Anhydrite was found to be brittle up to $1 \mathrm{kbar}$ with failure occurring by tension and shear fractures. Between 1 and $3 \mathrm{kbar}$ pressure homogeneous flow occurs, this being due to intercrystalline slip which is sensitive to pressure. Beyond the elastic limit it was found that the stressstrain curves were nearly horizontal, with no preferred orientation developing. However, the intracrystalline mechanisms become noticeable between 3 and 4 kbar. Under these conditions the stress-strain curves show a weak strain hardening and the (210) planes exhibit a weak preferred orientation perpendicular to the axis of compression.

As the temperature is increased the strength of anhydrite decreases at low strains $(<5 \%)$, and intracrystalline mechanisms become more dominant. At high strains $(>15 \%)$ both strength and ductility increase at
Table 2.9. Crystallographic parameters for anhydrite

Orthorhombic system

$$
\begin{aligned}
& a=6.238 \times 10^{-10} \mathrm{~m} ; b=6.991 \times 10^{-10} \mathrm{~m} ; c=6.996 \times 10^{-10} \mathrm{~m} \\
& \left( \pm 0.0001 \times 10^{-10}\right) \\
& \alpha=B=\gamma=90^{\circ}
\end{aligned}
$$

\begin{tabular}{ccc}
$\mathrm{d}^{\mathrm{a}}$ & $\mathrm{I}^{\mathrm{b}}$ & $\mathrm{hkl}^{\mathrm{c}}$ \\
\hline 3.873 & 6 & 111
\end{tabular}

$3.498 \quad 100 \quad 002,020$

$3.118 \quad 3 \quad 200$

$2.849 \quad 33 \quad 210$

$2.797 \quad 4 \quad 121$

$2.473 \quad 8 \quad 022$

$2.328 \quad 22 \quad 202,220$

$2.208 \quad 20 \quad 212$

$\begin{array}{lll}2.183 & 8 & 103\end{array}$

$\begin{array}{lll}2.086 & 9 & 113\end{array}$

$1.993 \quad 6 \quad 301$

$\begin{array}{lll}1.938 & 4 & 222\end{array}$

$\begin{array}{lll}1.869 & 15 & 230\end{array}$

$\begin{array}{lll}1.852 & 4 & 123\end{array}$

$1.749 \quad 11 \quad 004$

$1.748 \quad 10 \quad 040$

$\begin{array}{lll}1.648 & 14 & 232\end{array}$

$1.594 \quad 3 \quad 133$

$1.564 \quad 5 \quad 024,042$

$1.525 \quad 4 \quad 204,240$

$1.515 \quad 1 \quad 313,331$

$\begin{array}{lll}1.490 & 5 & 214\end{array}$

$1.424 \quad 3 \quad 402,420$

$\begin{array}{lll}1.418 & 1 & 323\end{array}$

$\begin{array}{lll}1.398 & 3 & 242\end{array}$

$\begin{array}{lll}1.396 & 2 & 412\end{array}$

$\begin{array}{lll}1.365 & 1 & 143\end{array}$

$\begin{array}{lll}1.319 & 4 & 422\end{array}$

$\begin{array}{lll}1.296 & 2 & 430\end{array}$

$\begin{array}{lll}1.277 & 5 & 234\end{array}$

$\begin{array}{lll}1.237 & 2 & 044\end{array}$

$\begin{array}{lll}1.216 & 4 & 432\end{array}$

$\begin{array}{lll}1.1993 & 2 & 252\end{array}$

$1.1781<1 \quad 135$

$\begin{array}{lll}1.1663 & 4 & 006\end{array}$

$\begin{array}{lll}1.1651 & 1 & 060\end{array}$

$\begin{array}{lll}1.1483 & 1 & 414\end{array}$

$1.1062 \quad 5 \quad 026$

$\begin{array}{lll}1.1044 & 4 & 424,442\end{array}$

$1.0785 \quad 2 \quad 216$

a) $d$ is the interlattice spacing, in $m \times 10^{10}$.

b) $I$ is the intensity scaled to the strongest line which was assigned a value of 100 .

c) hkl are the Miller indices.

\author{
(1)
}


Table 2.10. Thermodynamic properties of anhydrite

\begin{tabular}{ccccc}
$\mathrm{T}(\mathrm{K})$ & $\mathrm{S}^{\circ}(\mathrm{J} / \mathrm{mol} \mathrm{K})$ & $\Delta \mathrm{H}_{\mathrm{f}}^{\circ}(\mathrm{kJ} / \mathrm{mol})$ & $\Delta \mathrm{G}_{\mathrm{f}}^{\circ}(\mathrm{kJ} / \mathrm{mol})$ & $\left.\mathrm{C}_{\mathrm{p}}^{(\mathrm{J} / \mathrm{mol})} \mathrm{K}\right)$ \\
\hline 298 & 106.692 & -1434.110 & -1321.696 & 99.646 \\
300 & 107.307 & -1434.418 & -1320.803 & 99.830 \\
400 & 137.382 & -1436.727 & -1282.908 & 109.704 \\
500 & 162.920 & -1437.948 & -1244.262 & 119.579 \\
600 & 185.594 & -1438.205 & -1205.527 & 129.453 \\
700 & 206.292 & -1437.601 & -1166.775 & 139.327 \\
800 & 225.543 & & & 149.201 \\
900 & 243.685 & & & 159.076 \\
1000 & 260.956 & & & 168.950 \\
\hline
\end{tabular}

Temperature-dependent equations and precisions

$\mathrm{S}^{\circ}=46.736846+0.2211239 \mathrm{~T} ;\left(\mathrm{r}^{2}=0.992\right)$

$\Delta \mathrm{G}_{\mathrm{f}}^{\circ}=-1436.80866+0.3854957 \mathrm{~T} ;\left(\mathrm{r}^{2}=0.999\right)$

$\mathrm{C}_{\mathrm{p}}^{0}=70.206518+0.048744 \mathrm{~T} ; \quad\left(\mathrm{r}^{2}=1.000\right)$

higher temperatures. As the strain is increased further, strain hardenıng ceases once again and the stress-strain curves become nearly horizontal.

Gypsum, $\mathrm{CaSO}_{4}: 2 \mathrm{H}_{2} \mathrm{O}$

\subsubsection{Chemical Variability}

Gypsum shows very little variation in chemical composition. Table 2.11 gives the analyses of several samples of gypsum [43]. Most gypsum deposits contain clay minerals and fine sands as well as chemical sediments such as limestones and dolomites.

\subsubsection{Density}

Density data for gypsum have been reported in two studies $[45,58]$. There is insufficient information for value judgements. No information on the experimental technique or sample preparation was given by Appleyard [58]. Ludwig and Muller [45] used a pycnometer, which was calibrated with $n$-heptane. Due precautions were taken to eliminate air from the apparatus. In both cases the measurements were at room temperature. The pressure was normal atmospheric pressure. Both sets of density data for gypsum are in table 2.12.

\subsubsection{Crystallography}

The crystal structure of gypsum was determined by Wooster [59] from two dimensional x-ray diffraction data with Fourier methods. It was further refined by Atoji and Rundle [60] using neutron diffraction data.
Gillery [61] undertook a further refinement of the crystallographic data, the details of which are in agreement with conclusions drawn by other workers from spectroscopic data. The values advanced by Gillery [61] are regarded as the best values and are given in table 2.13 .

\subsubsection{Thermodynamic Properties}

The critical assessment of Barin and Knacke [53] is considered still to be valid. The results are advanced herewith as the recommended values in table 2.14 for the entropies, standard enthalpies of formation, standard Gibbs free energies of formation and standard heat capacities for gypsum. Temperature dependent equations and precisions are also included in table 2.14. For earlier studies refer to [62].

\subsubsection{Equation of State}

Heard and Rubey [115] have examined the stressstrain behavior of gypsum. The effect of dehydration on the strength of gypsum was investigated because of the known occurence of evaporites along many thrust faults. A series of stress-strain curves were obtained at a $5 \mathrm{kbar}$ confining pressure and at different temperatures. The resulting curves showed large reductions in strength over a relatively narrow temperature range $\left(100^{\circ}-150^{\circ} \mathrm{C}\right)$, which was attributed to the transformation of gypsum to metastable hemihydrate (anhydrite plus water). The stress-strain data at 2 kbar confining pressure showed identical results but at slightly lower 
Table 2.11. Chemical variability of gypsum

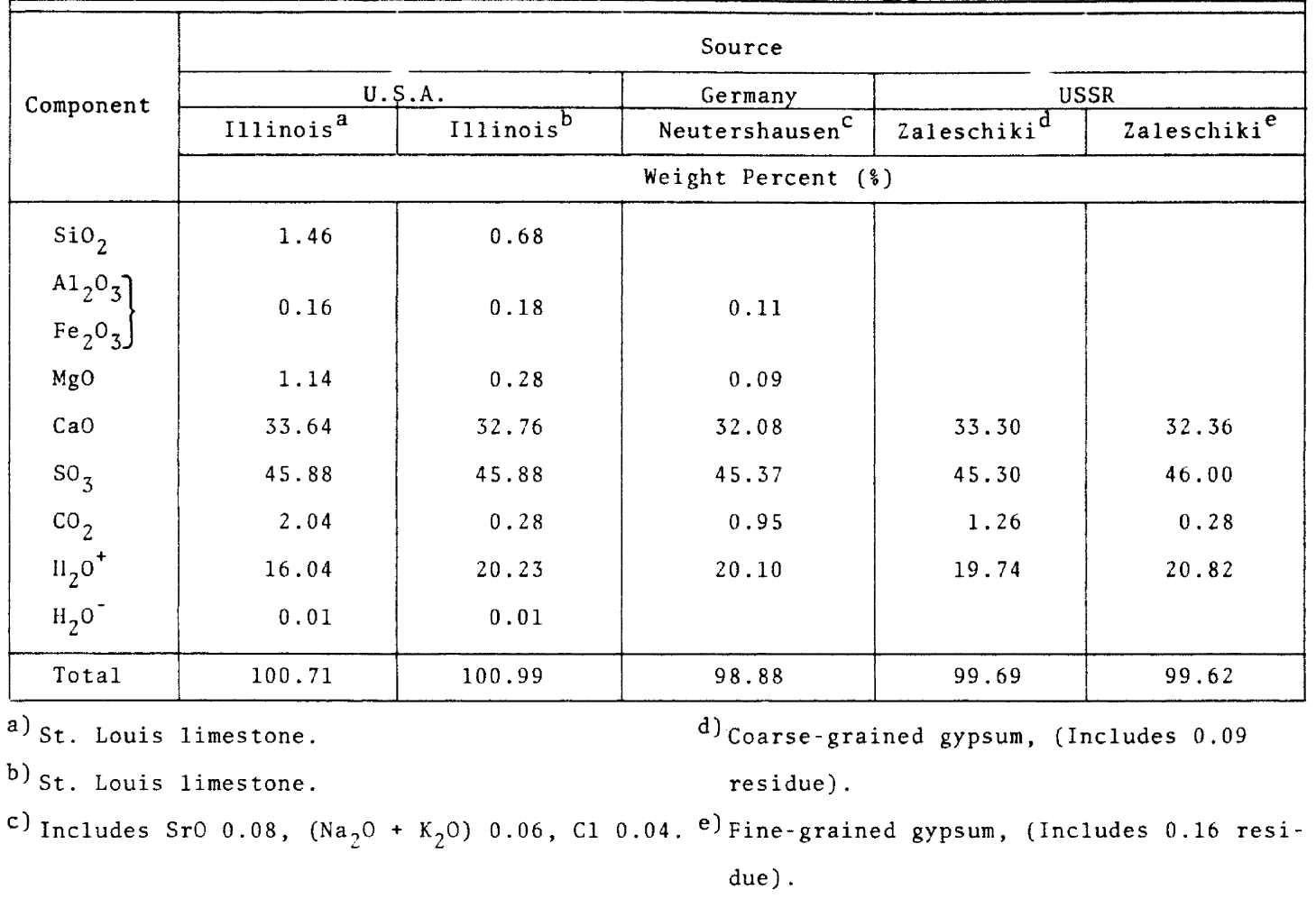

Table 2.12. Density of gypsum

\begin{tabular}{lll}
\hline $\begin{array}{l}\text { Density } \\
\left(\mathrm{kg} / \mathrm{m}^{3}\right)\end{array}$ & $\mathrm{T}(\mathrm{K})$ & $\operatorname{Ref.}$ \\
\hline $2320-2330$ & 298 & {$[45]$} \\
$2200-2400$ & 298 & {$[58]$} \\
\hline
\end{tabular}

temperatures. In addition it was observed that with increased preheating periods $\left(80^{\circ}-130^{\circ} \mathrm{C}\right)$ and a thousand-fold decrease in the strain rate (to $3 \times 10^{-7} \mathrm{~s}^{-1}$ ) the strength sensitive region was depressed further.

Calcite, $\mathrm{CaCO}_{3}$

\subsubsection{Chemical Variability}

Some analyses of calcite [43] to show compositional variations are given in table 2.15. A common substitution is that of $\mathrm{Mg}$ for $\mathrm{Ca}$ giving magnesian calcites. Barium and strontium may also substitute for calcium in calcite. Although many divalent cations may partially replace $\mathrm{Ca}$ in calcite, most calcite is relatively free from other ions and is fairly close in composition to pure $\mathrm{CaCO}_{3}$.

\subsubsection{Density}

The value for the density of calcite reported by Humbert and Plicque [63] was calculated from x-ray diffraction data. There is insufficient information for a value judgement. No information was provided on sample preparation. The value reported is given in table 2.16.

\subsubsection{Crystallographic Properties}

The crystallographic structure of calcite is analogous to that of halite, where the $\mathrm{Na}$ and $\mathrm{Cl}$ ions are replaced by $\mathrm{Ca}$ and $\mathrm{CO}_{3}$ ions, respectively, and the unit cell is distorted by compression along a triad axis to yield a facecentered rhomobohedral cell. X-ray crystallographic data for calcite have been reported by several investigators $[24,25,64-68]$. The radiation sources used in these investigations were either molybdenum $[25,64,66]$ or copper $[24,68]$. In view of several discrepancies in the intensities published on the ASTM cards, a critical analysis of existing data was undertaken by Swanson [68] in 1953, together with a redetermination of the crystal parameters of calcite. These values are recommended as the best values and the results are in table 2.17.

\subsubsection{Thermodynamic Properties}

The critical assessment of Barin and Knacke [53] is regarded as the most reliable. The results are advanced herewith as the recommended values in table 2.18 for the entropies, standard enthalpies of formation, standard Gibbs free energies of formation and standard heat 
Table 2.13. Crystallographic parameters for gypsum

Monoclinic system

$a=5.68 \times 10^{-10} \mathrm{~m} ; \mathrm{b}=15.18 \times 10^{-10} \mathrm{~m} ; \mathrm{c}=6.51 \times 10^{-10} \mathrm{~m}$

$\alpha=\gamma=90^{\circ} ; \beta=118^{\circ} 23^{\circ}$

$-\frac{\mathrm{d}^{\mathrm{a}}}{7.56} \quad \mathrm{I}^{\mathrm{b}} \quad \mathrm{hkI}^{\mathrm{C}}$

$4.27 \quad 51 \quad 12 \overline{1}$

3.79

21031,040

3.163

$11 \overline{2}$

3.059

$57 \quad 14 \overline{1}$

2. 867

2.786

002

2.679

2. 591

2. 530

2. 495

2.450

2.400

2. 216

2.139

2.080

2.073

1.990

1.953

1.898

1.879

1.864

1.843

1.812

1.796

1. 778

1. 711

1.684

1.664

1.645

1.621

1.599

1.584

1.532

1. 522

$27 \quad 002$

$5 \quad 21 \overline{1}$

$28 \quad 022,051$

$4 \quad 150,20 \overline{2}$

$<1 \quad 060$

6200

$4 \quad 22 \overline{2}$

$4 \quad 141$

$6 \quad 15 \overline{2}$

1024

$10 \quad 12 \overline{3}$

$8 \quad 112,25 \overline{1}$

$4 \quad 170$

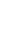

2

211

080,062

$10 \quad 14 \overline{3}$

$4 \quad 31 \overline{2}$

$\begin{array}{ll}4 & 312 \\ 1 & 231\end{array}$

$10 \quad 26 \overline{2}$

$432 \overline{1}$

$10 \quad 260$

$125 \overline{3}$

$132 \overline{3}$

$4 \quad 34 \mathrm{i}$

$216 \overline{3}$

6

$20 \tilde{4}, 181,053$

$35 \overline{2}, 190$

$2 \quad 22 \overline{4}$

$128 \overline{2}$

a) $\mathrm{d}$ is the interlattice spacing, in $\mathrm{mx} 10^{10}$.

b) I is the intensity scaled to the strongest line which was assigned a value of 100 .

c) hkl are the Miller indices. 
Table 2.14. Thermodynamic properties of gypsum

\begin{tabular}{lcccc}
\hline $\mathrm{T}(\mathrm{K})$ & $\mathrm{S}_{( \pm 0.2)}^{\circ}(\mathrm{J} / \mathrm{mol} \mathrm{K})$ & $\Delta \mathrm{H}_{\mathrm{f}}^{\circ}(\mathrm{kJ} / \mathrm{mol})$ & $\Delta \mathrm{G}_{\mathrm{f}}^{\circ}(\mathrm{kJ} / \mathrm{mol})$ & $\mathrm{C}_{\mathrm{p}}^{(\mathrm{J} / \mathrm{mol} \mathrm{K})}$ \\
\hline 298.15 & 193.970 & -2022.628 & -1797.197 & 250.521 \\
300 & 195.523 & -2022.023 & -1796.024 & 250.705 \\
400 & 268.998 & -2041.700 & -1746.756 & 260.580 \\
500 & 328.206 & -2068.548 & -1699.288 & 270.454 \\
600 & 378.384 & -2088.364 & -1653.940 & 280.328 \\
700 & 422.341 & -2110.387 & -1610.566 & 290.202 \\
800 & 461.738 & & & 300.076 \\
900 & 497.649 & & & 309.951 \\
1000 & 530.816 & & & 319.825 \\
\hline
\end{tabular}

Temperature-dependent equations and precisions

$\mathrm{S}^{\circ}=68.397727+0.48417 \mathrm{~T} ; \quad\left(\mathrm{r}^{2}=0.983\right)$

$\Delta \mathrm{G}_{\mathrm{f}}^{\circ}=-1934.894425+0.46659241 \mathrm{~T} ;\left(\mathrm{r}^{2}=0.999\right)$

$\mathrm{C}_{\mathrm{p}}^{0}=221.08187+0.098743 \mathrm{~T} ;\left(\mathrm{r}^{2}=1.000\right)$

Table 2.15. Chemical variability of calcite

\begin{tabular}{|c|c|c|c|c|}
\hline \multirow{3}{*}{ Component } & \multicolumn{4}{|c|}{ Source } \\
\hline & $\begin{array}{l}\text { Australia } \\
\text { Mariatrost }\end{array}$ & $\begin{array}{l}\text { Poland }_{b} \\
\text { Vistuea }\end{array}$ & Rujevac ${ }^{c}$ & $\underset{\text { Hokkaido }}{\text { Japan }}$ \\
\hline & \multicolumn{4}{|c|}{ Weight Percent $\left(\frac{\%}{0}\right)$} \\
\hline $\mathrm{MgO}$ & 0.04 & & 1.13 & 0.32 \\
\hline $\mathrm{FeO}$ & 0.00 & & & 0.29 \\
\hline $\mathrm{MnO}$ & $\operatorname{tr}$. & & & 3.19 \\
\hline $\mathrm{CaO}$ & 55.92 & 54.56 & 54.43 & 52.83 \\
\hline $\mathrm{NiO}$ & & & 0.65 & \\
\hline $\mathrm{CO}_{2}$ & 43.95 & 44.37 & 44.13 & 42.78 \\
\hline Tota 1 & 99.91 & 100.08 & 100.58 & 99.91 \\
\hline
\end{tabular}

a) Colorless or pale yellowish calcite.

${ }^{b)}$ Calcite, occurring as "rock-milk" (1ublinite), (Includes $\mathrm{Fe}_{2} \mathrm{O}_{3}+$ $\mathrm{Al}_{2} \mathrm{O}_{3} 0.18$, insol. 0.76, ign. loss 0.21).

c) Ni-Mg calcite, as yellowish or greenish rhombohedra associated with altered serpentine and marble, (Includes $\mathrm{Al}_{2} \mathrm{O}_{3} 0.11$, insol. $0.13)$.

d) Pale pink manganoan calcite, (Includes insol. 0.50). 


\section{Density}

$\left(\mathrm{kg} / \mathrm{m}^{3}\right)$

$\mathrm{T}(\mathrm{K})$

$\operatorname{Ref}$.

2712

299

[63]

capacities for calcite. Temperature-dependent equations and precisions are also included in table 2.18. For earlier studies, refer to [54-57].

\subsubsection{Equation of State}

Vaidya et al. [116] examined the compressibility of calcite up to 45 kilobars pressure. The data were fitted to an equation of the form:

$$
V / V_{0}=a_{0}+a P+b P^{2}+c P^{3}+d P^{4}
$$

where $V$ is the volume of the material at a given pressure and $V_{0}$ the volume at normal atmospheric pressure.

The values of the coefficients obtained in this study for the pressure range $0-15 \mathrm{kbar}$ were $a_{0}=0 ; a \times 10^{4}=$ $7.906 ;-b \times 10^{5}=14.580 ; c \times 10^{7}=58.756$; and for the pressure range 20-45 kbar were $a_{0}=0.02814 ; a \times 10^{4}=$ $28.653 ;-b \times 10^{5}=3.177 ; c \times 10^{7}=1.205$.

Polyhalite, $\mathrm{K}_{2} \mathrm{Ca}_{2} \mathrm{Mg}\left(\mathrm{SO}_{4}\right)_{4} \cdot 2 \mathrm{H}_{2} \mathrm{O}$

\subsubsection{Chemical Variability}

The main impurity in polyhalite is Kieserite $\left(\mathrm{MgSO}_{4}\right.$. $\mathrm{H}_{2} \mathrm{O}$ ). An analysis of a polyhalite-Kieserite rock [69] is given in table 2.19 . When polyhalite is heated to $573 \mathrm{~K}$ it loses its water of hydration and the residual salts form a heterogeneous mixture comprising at least two phases.

\subsubsection{Density}

Density data for polyhalite have been reported in two studies $[44,70]$. There is insufficient information for value judgements. No information on the experimental technique, sample preparation or temperature range was given in either study. Both sets of density data for polyhalite are in table 2.20 .

\subsubsection{Crystallography}

$\mathrm{X}$-ray crystallographic data for polyhalite have been reported by several investigators [71-73]. In view of the discrepancies occurring in the earlier studies, a critical analysis of existing data was undertaken by Braitsch [71] in 1961 together with a redetermination of the crystal parameters of polyhalite using more carefully designed optical orientation methods. These values are recommended as the best values. The results are in table 2.21 .

\subsection{Thermodynamic Properties}

No information is available on the thermodynamic properties of polyhalite.

\subsubsection{Equation of State}

No information is available on the equation of state for polyhalite.

Clays

The main types of sheet silicates found in salt deposits are talc, $\mathrm{Mg}_{3} \mathrm{Si}_{4} \mathrm{O}_{10}(\mathrm{OH})_{2}$; chlorites; amesite, $\left(\mathrm{Mg}_{2} \mathrm{Al}\right)$ $(\mathrm{Al}, \mathrm{Si})_{2} \mathrm{O}_{5}(\mathrm{OH})_{4}$; daphnite, $\left(\mathrm{Fe}_{2} \mathrm{Al}\right)(\mathrm{Al}, \mathrm{Si})_{2} \mathrm{O}_{5}(\mathrm{OH})_{4}$; penninite, $(\mathrm{Mg}, \mathrm{Fe}, \mathrm{Al})_{3}(\mathrm{Al}, \mathrm{Si})_{2} \mathrm{O}_{5}(\mathrm{OH})_{4}$; corrensite (chlorite-vermiculite clay mineral); and muscovite, $\mathrm{KAl}_{2}\left(\mathrm{AlSi}_{3}\right) \mathrm{O}_{10}(\mathrm{OH})_{2}$; and serpentines (antigorite, $\mathrm{Mg}_{3} \mathrm{Si}_{2} \mathrm{O}_{5}(\mathrm{OH})_{4}$; ferroantigorite, $\left.\mathrm{Fe}_{3} \mathrm{Si}_{2} \mathrm{O}_{5}(\mathrm{OH})_{4}\right)$; chrysotile, $\left.\mathrm{Mg}_{3} \mathrm{Si}_{2} \mathrm{O}_{5}(\mathrm{OH})_{4}\right)$. The properties of chemical variability, density, crystallographic parameters, thermodynamic data, and equation of state are reported for the clay minerals given above.

\subsubsection{Chemical Variability}

The principal impurities in talc are carbonates (magnesite, breunnerite), chlorites, and quartz. An analysis of a talc-carbonate rock [74] is given in table 2.22 .

Chlorite is the predominant clay mineral of many salt clays and many chloridic salt rocks. There are two varieties: normal chlorite (penninite-clinochlorite group) and chlorite (amesite-berthierite group). Both forms are normally found together. The chemical composition of dioctahedral chlorite [75] is given in table 2.23.

Corrensite is the predominant clay mineral in rock salt. It is always associated with varying amounts of a penninite-like chlorite.

Muscovite strongly predominates in the carbonate part of the salt clays, but in the noncarbonate salt clays its abundance relative to the other clay minerals diminishes.

\subsubsection{Density}

Grimshaw [3] has determined the density of several clay minerals using a pycnometric technique. There is insufficient information provided for value judgments. The density data are in Table 2.24 .

\subsubsection{Crystallography}

Grimshaw [3] undertook a critical analysis of existing data in 1971 and the values advanced in that study are still considered to be authoritative. The values reported by Grimshaw [3] include the three principal lines and are 
Table 2.17. Crystallographic parameters for calcite

Rhombohedral axes and hexagonal axes

$$
a=4.989 \times 10^{-10} \mathrm{~m} ; c=17.062 \times 10^{-10} \mathrm{~m}\left( \pm 0.001 \times 10^{-10}\right)
$$

$\alpha=\beta=\gamma=90^{\circ}$

\begin{tabular}{crr}
$\mathrm{d}^{\mathrm{a}}$ & $\mathrm{I}^{\mathrm{b}}$ & $\mathrm{hk} \mathrm{I}^{\mathrm{c}}$ \\
\hline 3.86 & 12 & 102 \\
3.035 & 100 & 104
\end{tabular}

$2.845 \quad 3 \quad 006$

$2.495 \quad 14 \quad 110$

$2.285 \quad 18 \quad 113$

$2.095 \quad 18 \quad 202$

$1.927 \quad 5 \quad 204$

$1.913 \quad 17 \quad 108$

$1.875 \quad 17 \quad 116$

$\begin{array}{lll}1.626 & 411\end{array}$

$\begin{array}{lll}1.604 & 8 & 212\end{array}$

$\begin{array}{lll}1.587 & 2 & 1.0 .10\end{array}$

$\begin{array}{lll}1.525 & 5 & 214\end{array}$

$\begin{array}{lll}1.518 & 408\end{array}$

$\begin{array}{lll}1.510 & 3 & 119\end{array}$

$\begin{array}{lll}1.473 & 215\end{array}$

$1.440 \quad 5 \quad 300$

$\begin{array}{lll}1.422 & 3 & 0.0 .12\end{array}$

$\begin{array}{lll}1.356 & 1 & 217\end{array}$

$\begin{array}{lll}1.339 & 2 & 2.0 .10\end{array}$

$1.297 \quad 218$

$\begin{array}{lll}1.284 & 1 & 306\end{array}$

$\begin{array}{lll}1.247 & 1 & 220\end{array}$

$\begin{array}{lll}1.235 & 2 & 1.1 .12\end{array}$

$\begin{array}{lll}1.1795 & 3 & 2.1 .10\end{array}$

$\begin{array}{lll}1.1538 & 3 & 314\end{array}$

$\begin{array}{lll}1.1425 & 1 & 226\end{array}$

$1.1244<1 \quad 2.1 .11$

$\begin{array}{lll}1.0613 & 1 & 2.0 .14\end{array}$

$\begin{array}{lll}1.0473 & 3 & 404\end{array}$

$1.0447 \quad 4 \quad 138$

$1.0352 \quad 2 \quad 0.1 .16,1.1 .15$

$1.0234<1<1.2 .13$

$\begin{array}{lll}1.0118 & 2 & 3.0 .12\end{array}$

$0.9895<1 \quad 231$

$\begin{array}{lll}0.9846 & 1 & 322\end{array}$

$\begin{array}{lll}0.9782 & 1 & 1.0 .17\end{array}$

$\begin{array}{lll}0.9767 & 3 & 2.1 .14\end{array}$

$0.9655 \quad 234$

a) $d$ is the interlattice spacing, in $m \times 10^{10}$.

b) I is the intensity scaled to the strongest line which was assigned a value of 100 .

c) hkl are the Miller indices. 
Table 2.18. Thermodynamic properties of calcite

\begin{tabular}{lcccc}
$\mathrm{T}(\mathrm{K})$ & $\mathrm{S}^{\circ}(\mathrm{J} / \mathrm{mol} \mathrm{K})$ & $\Delta \mathrm{H}_{\mathrm{f}}^{\circ}(\mathrm{kJ} / \mathrm{mol})$ & $\Delta \mathrm{G}_{\mathrm{f}}^{\circ}(\mathrm{kJ} / \mathrm{mol})$ & $\mathrm{C}_{\mathrm{p}}^{\circ}(\mathrm{J} / \mathrm{mol})$ \\
\hline 298.15 & 92.885 & -1207.370 & -1128.842 & \\
300 & 95.324 & -1206.871 & & \\
323 & & & & 86.734 \\
400 & 115.035 & -1206.301 & -1102.155 & 97.073 \\
500 & 137.633 & -1204.822 & -1076.292 & 105.102 \\
600 & 157.293 & -1203.276 & -1050.723 & 110.466 \\
700 & 174.640 & -1201.719 & -1025.427 & 114.570 \\
800 & 190.171 & -1201.145 & -1000.238 & 118.001 \\
900 & 204.246 & -1199.789 & -975.195 & 121.047 \\
1000 & 217.145 & -1198.689 & -950.299 & 123.846 \\
1100 & 229.074 & & & 126.491 \\
1200 & 240.191 & & & 129.022 \\
\hline
\end{tabular}

Temperature-dependent equations and precisions

$\mathrm{S}^{\circ}=51.38356+0.1652209 \mathrm{~T} ; \quad\left(\mathrm{r}^{2}=0.986\right)$

$\Delta G_{f}^{0}=-1203.759955+0.2541190 \mathrm{~T} ;\left(\mathrm{r}^{2}=0.999\right)$

$C_{p}^{\circ}=80.3668348+0.0436905 ; \quad\left(r^{2}=0.925\right)$

Table 2.19. Analysis of polyhalite-Kieserite rock

\begin{tabular}{lc}
\hline Mineral & \\
\hline Polyhalite & 85.2 \\
Kieserite & 3.6 \\
Magnesite & 4.4 \\
Dolomite & 0.2 \\
Halite (from excess chlorine) & 1.3 \\
Siliceous material & 5.3 \\
& 100.00 \\
\hline
\end{tabular}

Table 2.20. Density of polyhalite

\begin{tabular}{lc}
$\begin{array}{l}\text { Density } \\
\left(\mathrm{kg} / \mathrm{m}^{3}\right)\end{array}$ & $\operatorname{Ref}$. \\
\hline 2780 & {$[44]$} \\
2800 & {$[70]$} \\
\hline
\end{tabular}




\section{Triclinic system}

$a=6.962 \times 10^{-10} \mathrm{~m} ; \mathrm{b}=6.974 \times 10^{-10} \mathrm{~m} ; \mathrm{c}=8.967 \times 10^{-10} \mathrm{~m}\left( \pm 0.001 \times 10^{-10}\right)$

$\alpha=104.5^{\circ} ; \beta=101.5^{\circ} ; \gamma=113.9^{\circ}$

\begin{tabular}{|c|c|c|}
\hline $\mathrm{d}^{\mathrm{a}}$ & $I^{b}$ & $\mathrm{hk} 1^{\mathrm{c}}$ \\
\hline 6.0 & 12 & 100 \\
\hline 5.95 & 8 & $0 \overline{1} \overline{1}$ \\
\hline 5.82 & 6 & $1 \overline{1} 0$ \\
\hline 4.802 & 6 & 111 \\
\hline 4.15 & 4 & $01 \overline{2}$ \\
\hline 4.04 & 2 & $10 \overline{2}$ \\
\hline 3.48 & 6 & $2 \overline{1} 0,1 \overline{2} 1$ \\
\hline 3.406 & 12 & 211 \\
\hline 3.353 & 2 & $02 \overline{1}, 20 \overline{1}$ \\
\hline 3.175 & 70 & $2 \overline{1} 1$ \\
\hline 2.97 & 6 & 102 \\
\hline 2.943 & 12 & $2 \overline{2} 0$ \\
\hline $\begin{array}{l}2.912 \\
2.89\end{array}$ & 100 & 012 \\
\hline 2.846 & 16 & $10 \overline{3}$ \\
\hline 2.766 & 4 & $111,11 \overline{3}$ \\
\hline 2.404 & 6 & $2 \overline{2} 2,1 \overline{2} 3$ \\
\hline 2.350 & 6 & $\overline{1} 22$ \\
\hline 2.334 & 6 & $\overline{2} 22, \overline{2} 13$ \\
\hline 2.25 & 4 & $120,12 \overline{3}$ \\
\hline 2.213 & 4 & $1 \overline{3} 0,103$ \\
\hline 2.18 & 4 & $01 \overline{4}, 013$ \\
\hline 2.035 & 4 & 004 \\
\hline 1.948 & & $21 \pi$ \\
\hline 1.904 & 6 & $3 \overline{3} 1, \overline{2} 14$ \\
\hline 1.897 & 6 & $22 \overline{2}$ \\
\hline 1.873 & 6 & $3 \overline{2} 2,2 \overline{3} 3$ \\
\hline 1.859 & 4 & $22 \overline{1}$ \\
\hline 1.810 & 6 & 232 \\
\hline 1.806 & 6 & $\overline{3} 23$ \\
\hline
\end{tabular}

a) $\mathrm{d}$ is the interlattice spacing, in $\mathrm{m} \times 10^{10}$.

b) I is the intensity scaled to the strongest 1 ine which was assigned a value of 100 .

c) hkl are the Miller indices. 
Table 2.22. Chemical analysis of talc

\begin{tabular}{lccc}
\hline Component & $\begin{array}{c}\text { Weight } \\
\text { Percent }(q)\end{array}$ & Component & $\begin{array}{c}\text { Weight } \\
\text { Percent (q) }\end{array}$ \\
\hline $\mathrm{SiO}_{2}$ & 31.04 & $\mathrm{TiO}_{2}$ & 0.08 \\
$\mathrm{MgO}$ & 35.15 & $\mathrm{CaO}$ & 0.23 \\
$\mathrm{Al}_{2} \mathrm{O}_{3}$ & 0.54 & $\mathrm{~K}_{2} \mathrm{O}$ & 0.01 \\
$\mathrm{Fe}_{2} \mathrm{O}_{3}$ & 3.02 & $\mathrm{Na}_{2} \mathrm{O}$ & 0.01 \\
$\mathrm{FeO}$ & 4.32 & $\mathrm{Cr}_{2} \mathrm{O}_{3}$ & 0.33 \\
\hline
\end{tabular}

Table 2.23. Chemical analysis of chlorite

\begin{tabular}{lccc}
\hline Component & $\begin{array}{c}\text { Weight } \\
\text { Percent }(\xi)\end{array}$ & Component & $\begin{array}{c}\text { Weight } \\
\text { Percent }(\xi)\end{array}$ \\
\cline { 2 - 4 } $\mathrm{SiO}_{2}$ & 35.63 & $\mathrm{CaO}$ & 1.13 \\
$\mathrm{TiO}_{2}$ & 34.87 & $\mathrm{Na}_{2} \mathrm{O}$ & 0.24 \\
$\mathrm{Al}_{2} \mathrm{O}_{3}$ & 5.01 & $\mathrm{~K}_{2} \mathrm{O}$ & 0.46 \\
$\mathrm{Fe}_{2} \mathrm{O}_{3}$ & 0.43 & $\mathrm{H}_{2} \mathrm{O}$ & 1.91 \\
$\mathrm{FeO}$ & 0.05 & $\mathrm{Ign} .10 \mathrm{ls}$. & 12.24 \\
$\mathrm{MnO}$ & 8.63 & $\mathrm{~S}$ & \\
$\mathrm{MgO}$ & & &
\end{tabular}

Table 2.24. Density of clay minerals

\begin{tabular}{lc}
\hline \multicolumn{1}{c}{ C1ay } & $\begin{array}{c}\text { Density } \\
\mathrm{kg} / \mathrm{m}^{3}( \pm 2)\end{array}$ \\
\hline ta1c & 2750 \\
antigorite & 2570 \\
amesite & 2800 \\
daphnite & 3000 \\
ferro-antigorite & 3200 \\
penninite & 2700 \\
chrysotile & 2550 \\
muscovite & 2900 \\
\hline
\end{tabular}

recommended as the best values; the results are in table 2.25 .

\subsubsection{Thermodynamic Properties}

Robie et al. [117] has tabulated the thermodynamic parameters for several sheet silicates. In addition Tardy and Garrels [118] have discussed a method of estimating the Gibbs energies of formation of layer silicates. The thermodynamic parameters for a selection of sheet silicates are given in table $2.25 \mathrm{~A}$.

\subsubsection{Equation of State}

No information on equation of state is available for the clay minerals.

Tab1e 2.25, Crystallographic parameters for clays

\begin{tabular}{|c|c|c|c|}
\hline Clay & Crystal System & $d^{a}$ & $\mathrm{I}^{\mathrm{b}}$ \\
\hline \multirow[t]{3}{*}{ talc } & monoclinic & 9.30 & 80 \\
\hline & & 3.10 & 100 \\
\hline & & 1.53 & 80 \\
\hline \multirow[t]{3}{*}{ antigorite } & orthorhombic & 7.14 & 90 \\
\hline & & 3.59 & 100 \\
\hline & & 2.52 & 70 \\
\hline \multirow[t]{3}{*}{ amesite } & monoclinic & 7.00 & 100 \\
\hline & & 3.50 & 100 \\
\hline & & 2.47 & 90 \\
\hline \multirow[t]{3}{*}{ daphnite } & monoclinic & 6.9 & 80 \\
\hline & & 3.51 & 100 \\
\hline & & 4.69 & 50 \\
\hline \multirow{3}{*}{$\begin{array}{l}\text { ferro- } \\
\text { antigorite }\end{array}$} & monoclinic & 7.12 & 100 \\
\hline & & 3.50 & 100 \\
\hline & & 2.63 & 40 \\
\hline \multirow[t]{3}{*}{ penninite } & monoclinic & 14.30 & 60 \\
\hline & & 7.17 & 100 \\
\hline & & 4.78 & 100 \\
\hline \multirow[t]{3}{*}{ chrysotile } & orthorhombic & 7.07 & 40 \\
\hline & & 3.59 & 100 \\
\hline & & 2.45 & 60 \\
\hline \multirow[t]{3}{*}{ muscovite } & monoclinic & 9.98 & 100 \\
\hline & & 3.33 & 90 \\
\hline & & 2.57 & 100 \\
\hline
\end{tabular}

Table 2.25. Crystallographic parameters for clays

a) $\mathrm{d}$ is the interlattice spacing, in $\mathrm{mx} 10^{10}$

b) I is the intensity scaled to the strongest line which was assigned a value of 100 
Table 2.25A. Thermodymamic properties of sheet silicates

\begin{tabular}{|c|c|c|c|c|c|}
\hline Substance & $\mathrm{T}(\mathrm{K})$ & $\begin{array}{c}\mathrm{S}^{\circ}(\mathrm{J} / \mathrm{mol} \mathrm{K}) \\
( \pm 0.2)\end{array}$ & $\begin{array}{c}\Delta \mathrm{H}_{\mathrm{f}}^{\circ}(\mathrm{kJ} / \mathrm{mol}) \\
( \pm 0.5)\end{array}$ & $\begin{array}{c}\Delta \mathrm{G}_{\mathrm{f}}^{\circ}(\mathrm{kJ} / \mathrm{mol}) \\
\end{array}$ & $\begin{array}{c}\mathrm{C}_{\mathrm{p}}^{\circ}(\mathrm{J} / \mathrm{mol} \mathrm{K}) \\
( \pm 0.2)\end{array}$ \\
\hline Talc & 298.15 & 260.83 & -5915.900 & -5536.048 & 321.70 \\
\hline \multirow[t]{5}{*}{$\mathrm{Mg}_{3} \mathrm{Si}_{4}{ }^{0}{ }_{10}(\mathrm{OH})_{2}$} & 400 & 365.30 & -5917.050 & -5405.971 & 386.59 \\
\hline & 500 & 455.61 & -5914.990 & -5278.425 & 420.63 \\
\hline & 600 & 534.40 & -5911.596 & -5151.383 & 444.26 \\
\hline & 700 & 604.91 & -5906.844 & -5024.997 & 475.20 \\
\hline & 800 & 669.80 & -5898.951 & -4898.009 & 525.95 \\
\hline
\end{tabular}

emperature-dependent equations and precisions

$S^{\circ}=36.46201+0.8101748 \mathrm{~T}\left(\mathrm{r}^{2}=0.992\right)$

$\Delta G_{f}^{\circ}=-5914.45145+1.27097788 \mathrm{~T} ;\left(\mathrm{r}^{2}=0.999\right)$

$\mathrm{C}_{\mathrm{p}}^{0}=223.666881+0.3736424 \mathrm{~T}:\left(\mathrm{x}^{2}=0.977\right)$

\begin{tabular}{llllll}
\hline Chrysotile & 298.15 & 221.30 & -4361.660 & -4034.024 & 273.70 \\
$\mathrm{Mg}_{3} \mathrm{Si}_{2} \mathrm{O}_{5}(\mathrm{OH})_{4}$ & 400 & 309.13 & -4362.729 & -3921.820 & 323.22 \\
& 500 & 385.05 & -4360.883 & -3811.788 & 356.33 \\
& 600 & 452.14 & -4357.294 & -3702.258 & 378.95 \\
& 700 & 511.78 & -4352.759 & -3593.454 & 394.26 \\
& 800 & 565.13 & -4347.832 & -3485.318 & 404.32 \\
& 900 & 613.14 & -4342.911 & -3377.752 & 410.47 \\
\hline
\end{tabular}

Temperature-dependent equations and precisions

$\mathrm{S}^{\circ}=48.9012637+0.6467995 \mathrm{~T} ;\left(\mathrm{r}^{2}=0.990\right)$

$\Delta G_{f}^{o}=-4357.940316+1.09075860 \mathrm{~T}\left(\mathrm{r}^{2}=0.999\right)$

$C_{p}^{0}=232.449813+0.21773908 \mathrm{~T} ;\left(\mathrm{r}^{2}=0.901\right)$

\begin{tabular}{llllll}
\hline $\begin{array}{l}\text { Muscovite } \\
\mathrm{KA}_{2}\left[\mathrm{AlSi}_{3}{ }_{10}\right](\mathrm{OH})_{2}\end{array}$ & 298.15 & 306.40 & -5976.740 & -5600.671 & 326.10 \\
& 400 & 411.12 & -5981.048 & -5471.333 & 385.54 \\
& 500 & 501.73 & -5979.503 & -5344.043 & 425.67 \\
600 & 582.02 & -5975.746 & -5217.261 & 454.42 \\
700 & 653.74 & -5970.644 & -5091.248 & 475.56 \\
800 & 718.32 & -5964.809 & -4965.994 & 491.35 \\
900 & 776.92 & -5958.697 & -4841.485 & 503.24
\end{tabular}

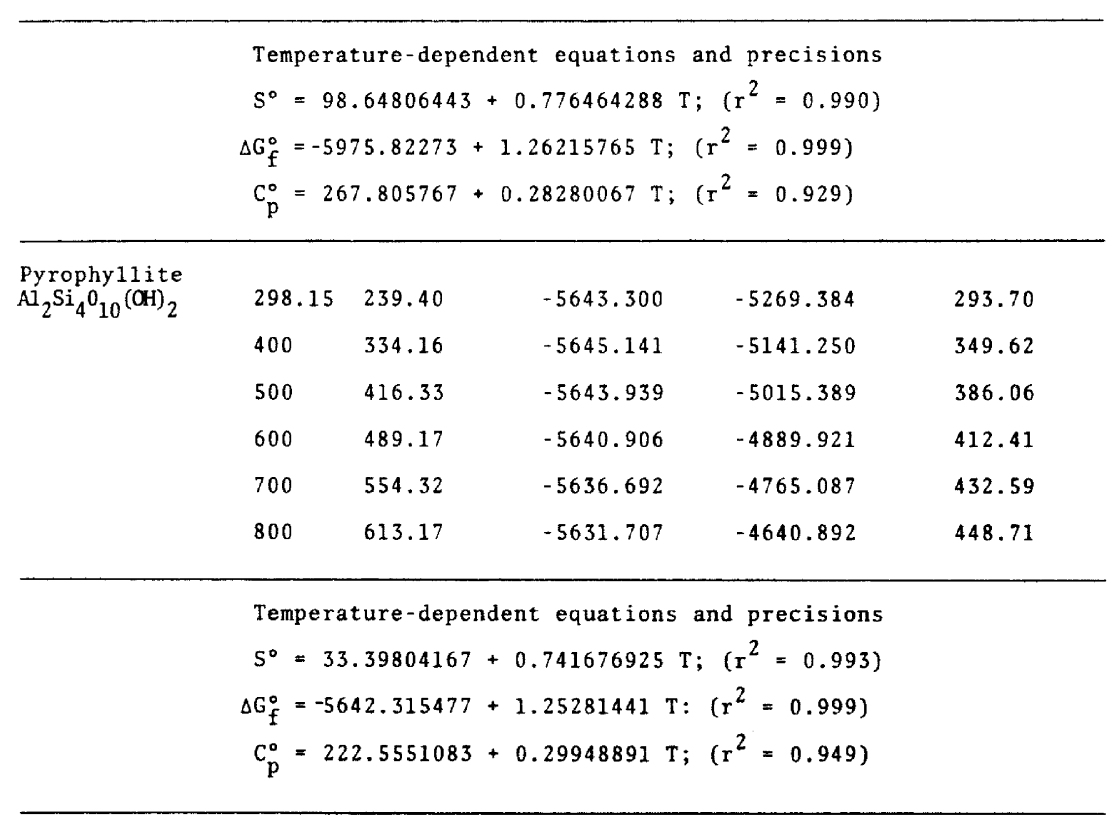




\subsection{Chemical Properties Among Components in Salt Deposits}

The chemistry among components in salt deposits includes data on aqueous solubility, dehydration reactions, formation of solid solutions and vapor phases and includes phase diagrams.

\subsubsection{The Systems $\mathrm{NaCl}-\mathrm{KCl}-\mathrm{MgCl}_{2}-\mathrm{H}_{2} \mathrm{O}$}

The determination of the solubility of sodium chloride in water has been the subject of several investigations [8, 76-80]. The earlier measurements were subject to an error of \pm 0.1 weight percent of salt below $373 \mathrm{~K}$ and \pm 0.3 weight percent salt above $373 \mathrm{~K}$. Potter et al. [8] undertook a redetermination of the solubility using a specially designed bomb lined with platinum (see section 2.2.5) and attained a precision of \pm 0.01 or \pm 0 . 1 weight percent of salt over the entire temperature range. A comparison of the solubilities obtained by various investigators is shown in figure 2 . 1 . The data reported by Potter et al. [8] have been reanalyzed and values of the solubility of sodium chloride at rounded temperatures are advanced as recommended values in table 2.26 , together with a temperature-dependent equation.

A temperature-composition phase diagram for the $\mathrm{NaCl}-\mathrm{H}_{2} \mathrm{O}$ system is shown in figure 2.2. As indicated three solid phases exist in this system namely: $\mathrm{NaCl}$,
$\mathrm{NaCl} \cdot 2 \mathrm{H}_{2} \mathrm{O}$ (hydrohalite) and ice. The solubility of $\mathrm{NaCl}$ increases slightly with increasing pressure, reaching a maximum at about $4053 \times 10^{2} \mathrm{~Pa}$ and decreases slowly until at around $1266562 \mathrm{~Pa}$ it has the same value as at atmospheric pressure. At $298 \mathrm{~K}$ between 800467 and 1175370 pascals hydrohalite is the stable form. A temperature-pressure-composition model for the $\mathrm{NaCl}-\mathrm{H}_{2} \mathrm{O}$ system is presented in figure 2.3.

This figure shows the compositions of gas in equilibrium with solid, the melting surface with coexisting gases, liquids, and solids, the envelope of curves relating the composition of the two fluid phases and the critical composition and pressure for each temperature studied. The system was studied to pressures of 1240 bars and through the temperature interval $250-700^{\circ} \mathrm{C}$.

The temperature coefficient for the solubility of $\mathrm{KCl}$ in water is strongly positive and this effect is also found for the $\mathrm{NaCl}-\mathrm{KCl}-\mathrm{H}_{2} \mathrm{O}$ system as shown in figure 2.4. The addition of similar ions reduces the actual solubility but has no marked effect on the temperature coefficient. The solubility of $\mathrm{NaCl}$ in the presence of $\mathrm{KCl}$ is similarly reduced and in fact below $373 \mathrm{~K}$ the temperature coefficient for the solubility of $\mathrm{NaCl}$ becomes negative. Absolute solution concentrations can be gained using figure 2.4 directly for this system. At any given temperature the unsaturated solutions lie between the

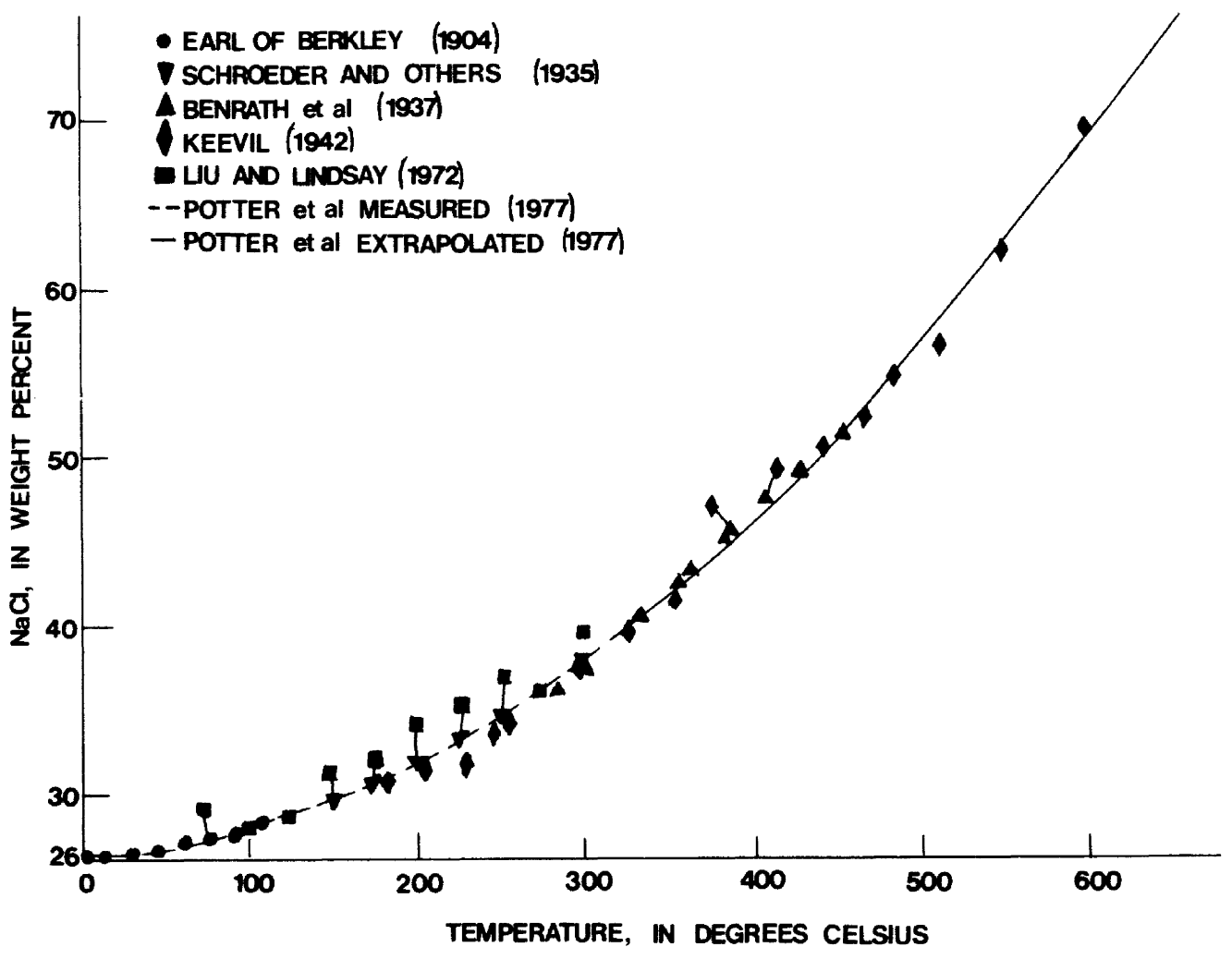

Figure 2.1. A comparison of the solubilities of sodium chloride in water. 
zero point and the appropriate isotherm. At points $P$ and $\mathrm{N}$ in figure 2.4, there are five phases: i.e., solid phases.

P: halite, hydrohalite, sylvite

$\mathrm{N}$ : hydrohalite, sylvite, ice and at both points also liquid solution and vapor phases.

When the solution is evaporated the composition changes linearly. For example sylvite precipitates first when at $20^{\circ} \mathrm{C}$ the point $a$ is reached. On further evaporation point $b$ is eventually attained. After this $\mathrm{NaCl}$ and $\mathrm{KCl}$ precipitate simultaneously and the composition of the solution remains constant. At $60^{\circ} \mathrm{C}, \mathrm{NaCl}$ precipitates (point c) and the solution composition changes along the $60^{\circ}$ isotherm in the direction of a lower $\mathrm{NaCl}$ concentration. After reaching the curve RP (at point d) the concentration remains constant until completely evaporated.

The four component system $\mathrm{NaCl}-\mathrm{KCl}-\mathrm{MgCl}_{2}-\mathrm{H}_{2} \mathrm{O}$ is characterized by the existence of a ternary compound, carnallite, $\mathrm{KCl} \cdot \mathrm{MgCl}_{2} \cdot 6 \mathrm{H}_{2} \mathrm{O}$. In figure 2.5 are the solubility isotherms for $\mathrm{KCl}$ at various temperatures and the $\mathrm{NaCl}$ isotherm at $293 \mathrm{~K}$. In this figure the carnallite isotherms have been extrapolated using the saturation concentrations at the boundaries between the sylvite and bischofite fields. Figures 2.6 and 2.7 present information on the temperature coefficients of solubility of $\mathrm{NaCl}$ at different temperatures at either $\mathrm{KCl}+\mathrm{NaCl}$ saturation or as a function of $\mathrm{MgCl}_{2}$ concentration. It is observed that the temperature coefficient of solubility is negative at low $\mathrm{MgCl}_{2}$ concentrations, while at medium and high concentrations it is positive. Also from about $50 \mathrm{~mol}$ $\mathrm{MgCl}_{2} / 1000 \mathrm{~mol} \mathrm{H}_{2} \mathrm{O}$ it remains approximately constant and independent of temperature.

\subsubsection{The System Anhydrite-Water-NaCl}

Several studies have been undertaken on the solubility of anhydrite in water [82-88]. With the exception of two studies $[85,87]$, all of the previous work was carried out at atmospheric pressure at temperatures above $373 \mathrm{~K}$ or at the vapor pressure of the system at temperatures above $373 \mathrm{~K}$.

Dickson, Blount and Tunell [82] used a special hydrothermal solution apparatus to determine the solubility of anhydrite in water from $373 \mathrm{~K}$ to $548 \mathrm{~K}$ and from $10^{5}$ to $10^{8}$ pascals pressure. The equipment consisted of a deformable teflon sample cell held in a stainless steel pressure vessel and sealed in such a way as to prevent interchange of material between the sample cell and the steel bomb. Liquid and solid phases were allowed to attain equilibrium in the teflon cell at constant

Table 2.26.

Solubility of $\mathrm{NaCl}$ in water as a function of temperature

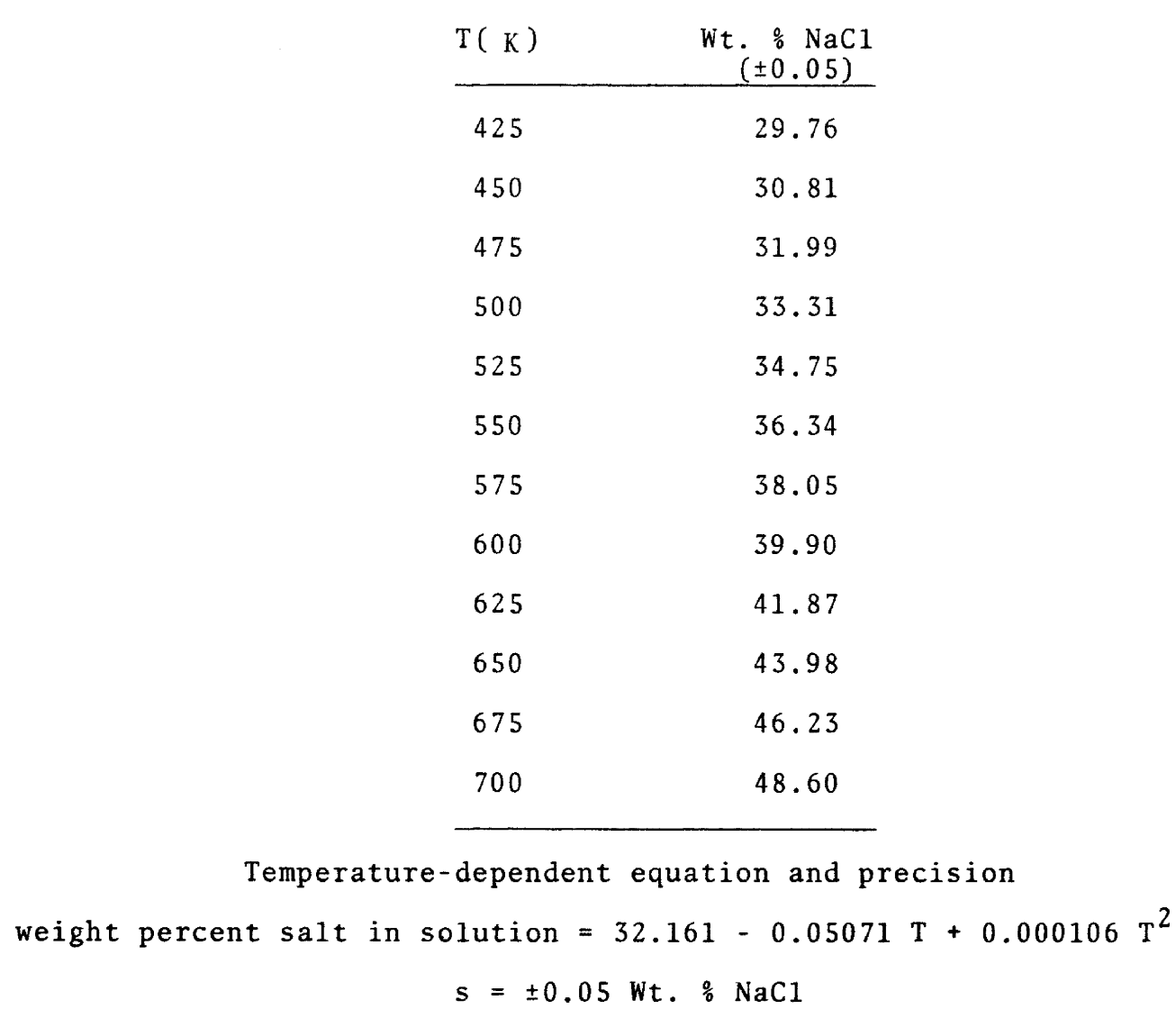




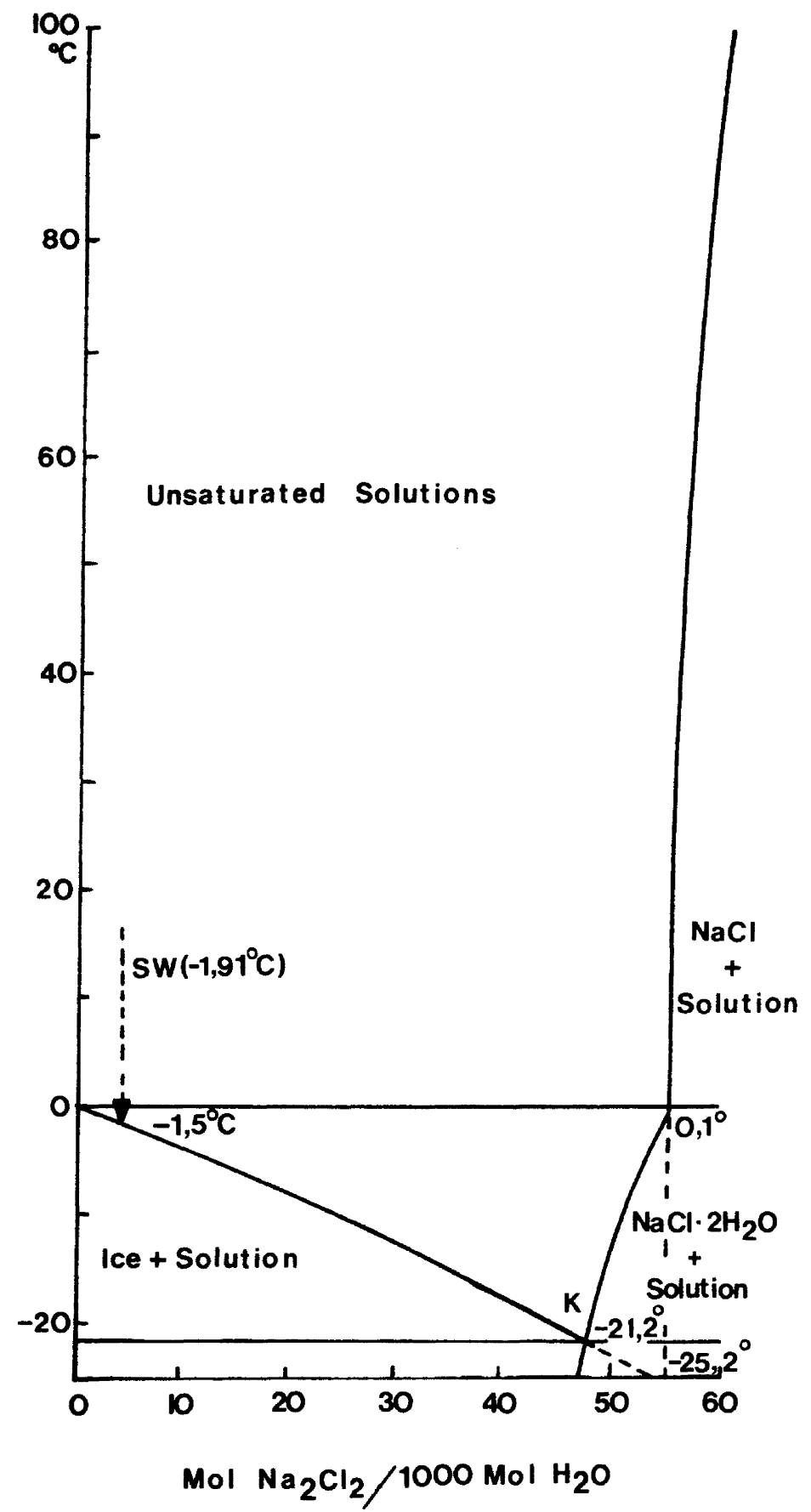

FIGURE 2.2. Ref. [44]. A temperature-composition phase diagram for the $\mathrm{NaCl}-\mathrm{H}_{2} \mathrm{O}$ system. The metastable areas are indicated by broken lines. Below K (=cryohydric point) 'all phases are solid with stable paragenesis (ice + hydrohalite), left of $K$ with ice inclusions, right of $K$ with hydrohalite inclusions. SW refers to seawater. 


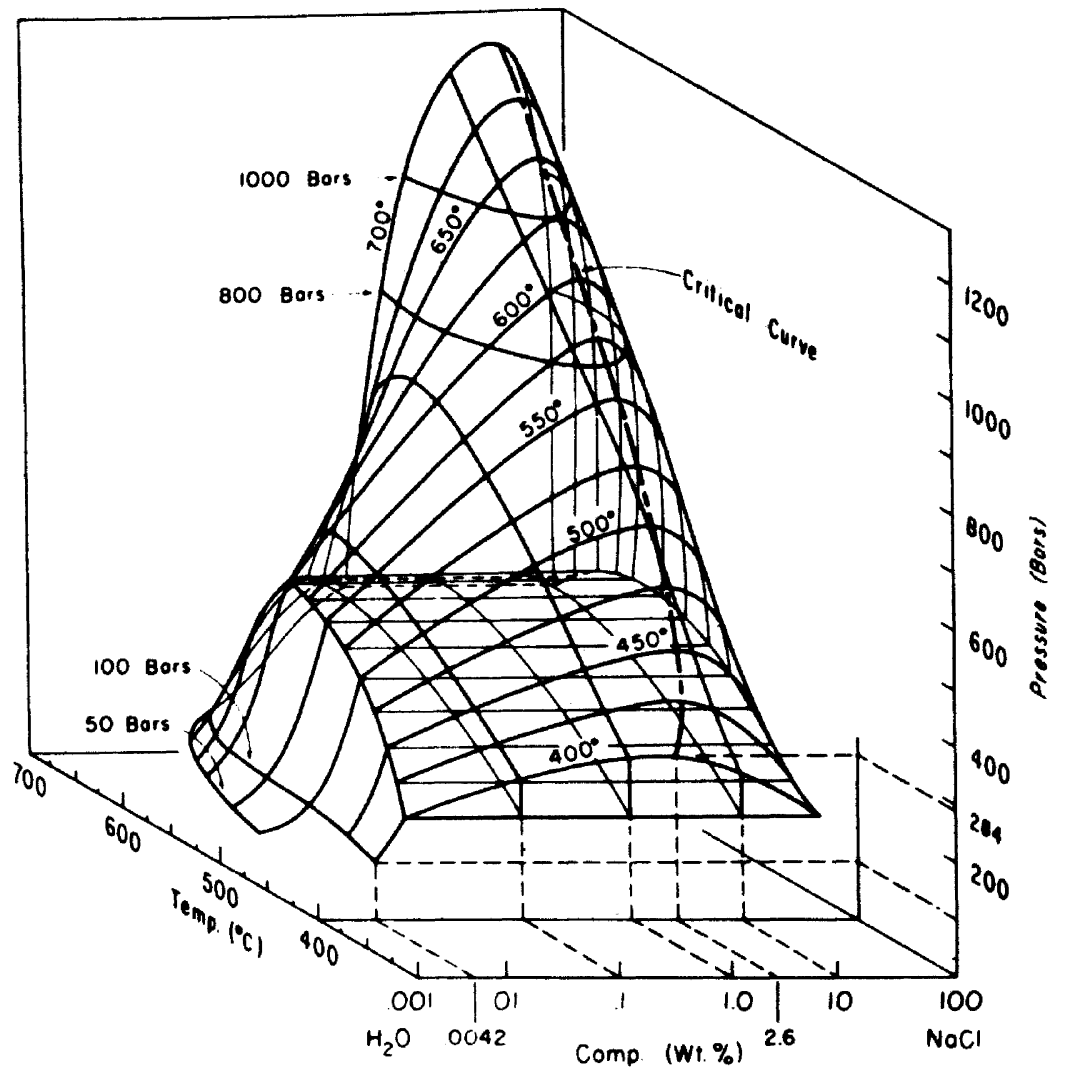

FIGURE 2.3. Ref. [81] Pressure-temperature composition model for the system $\mathrm{NaCl}-\mathrm{H}_{2} \mathrm{O}$. 


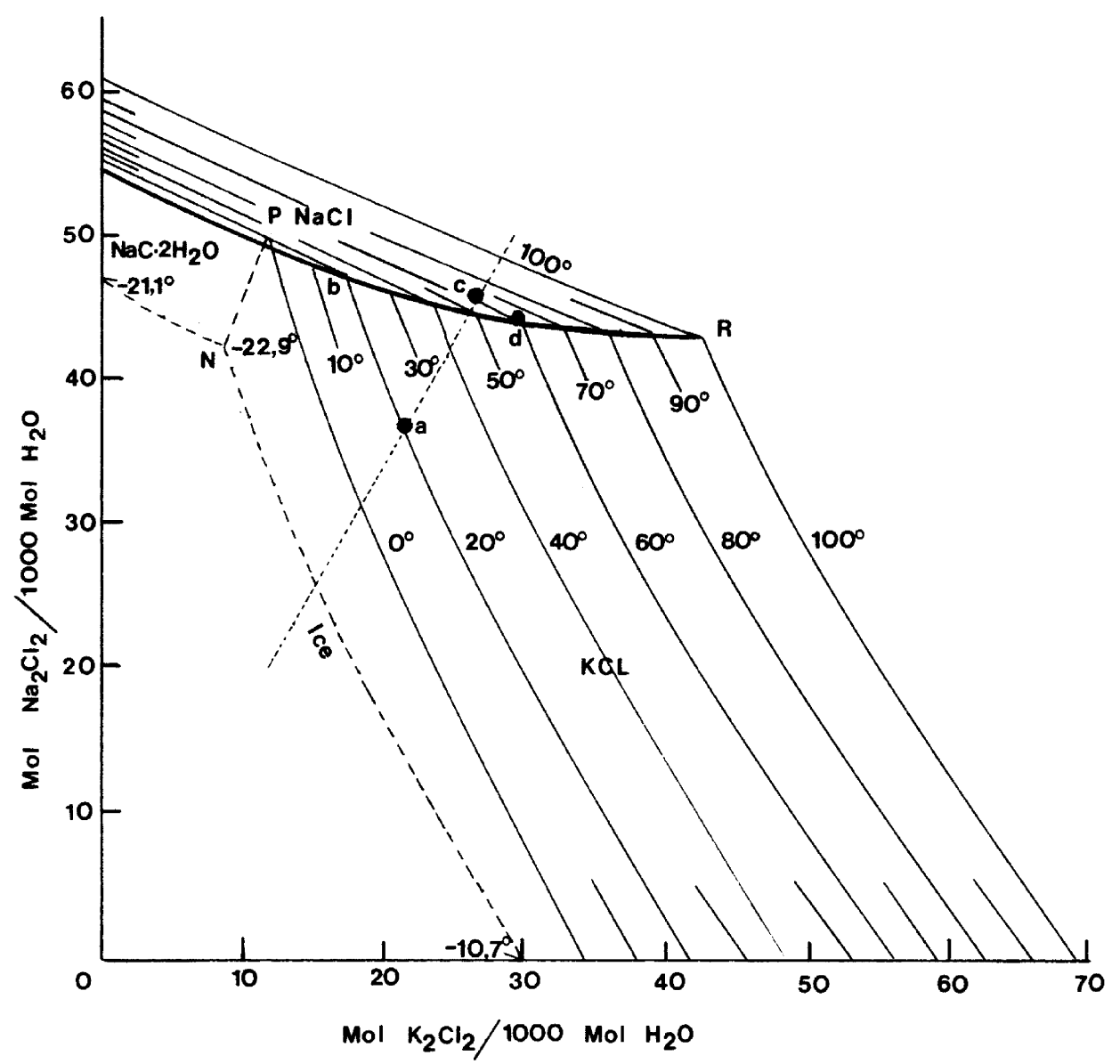

FigurE 2.4. Ref. [44]. Solubility isotherms in the system $\mathrm{NaCl}-\mathrm{KCl}-\mathrm{H}_{2} \mathrm{O}$ for the temperature range $0-100^{\circ} \mathrm{C}$. 


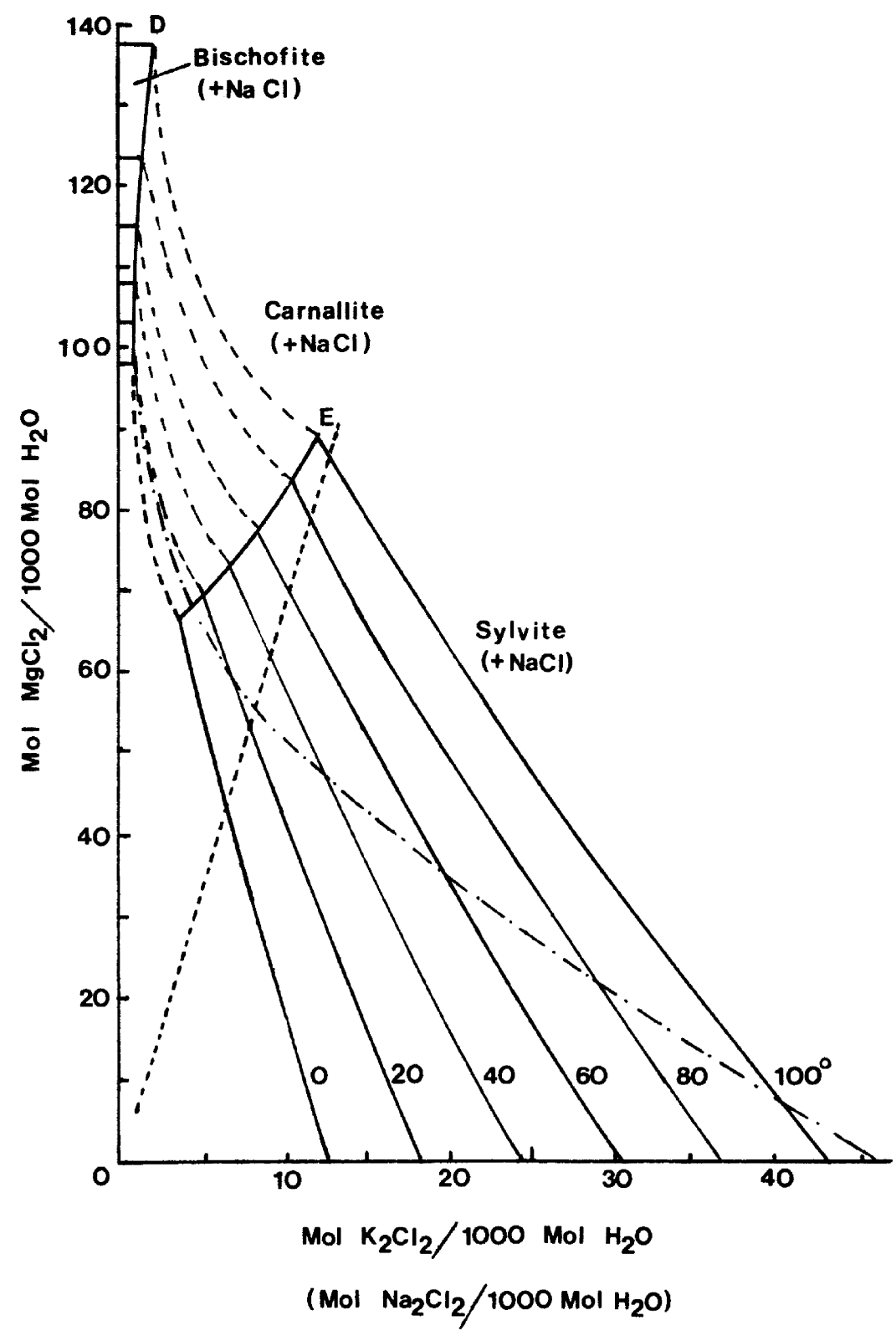

FIGURE 2.5. Ref [44]. Solubility isotherms in the system $\mathrm{NaCl}-\mathrm{KCl}-\mathrm{MgCl}_{2}-\mathrm{H}_{2} \mathrm{O}$, saturated with respect to $\mathrm{NaCl}$, for the temperature range $0-100^{\circ} \mathrm{C}$.

$\mathrm{E}$ : at this point there is no joint precipitation of carnallite and sylvite. D: upon final evaporation at this point the residual solution can yield bischofite, carnallite and halite. 


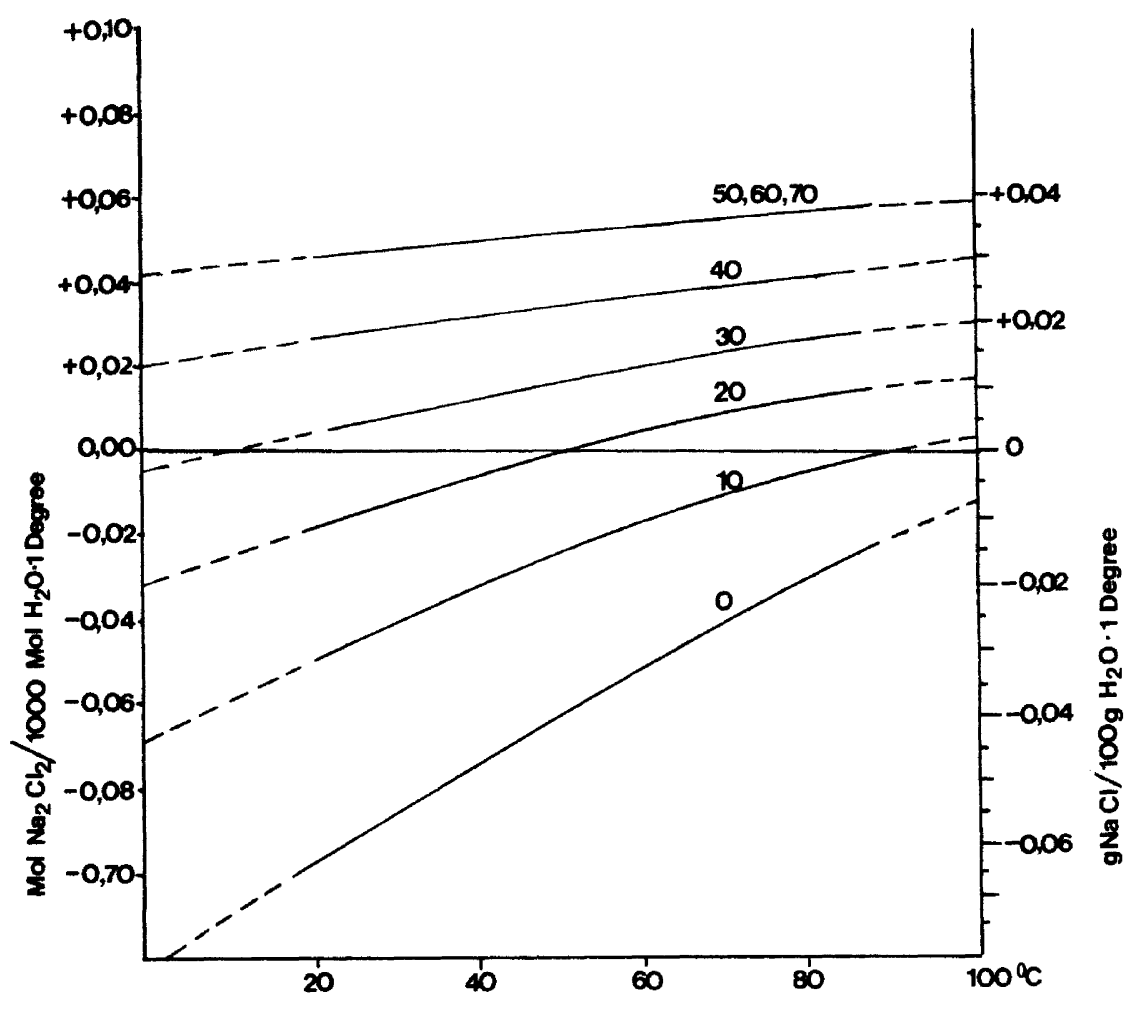

FigurE 2.6. Ref. [44]. Solubility isotherms in the system $\mathrm{KCl}-\mathrm{NaCl}-\mathrm{MgCl}_{2} \cdot \mathrm{H}_{2} \mathrm{O}$ at $\mathrm{KCl}+\mathrm{NaCl}$ saturation for the temperature range $0-70^{\circ} \mathrm{C}$. The $\mathrm{MgCl}_{2}$ content in $\mathrm{mol} / 1000 \mathrm{~mol} \mathrm{H}_{2} \mathrm{O}$ serves as a parameter. 


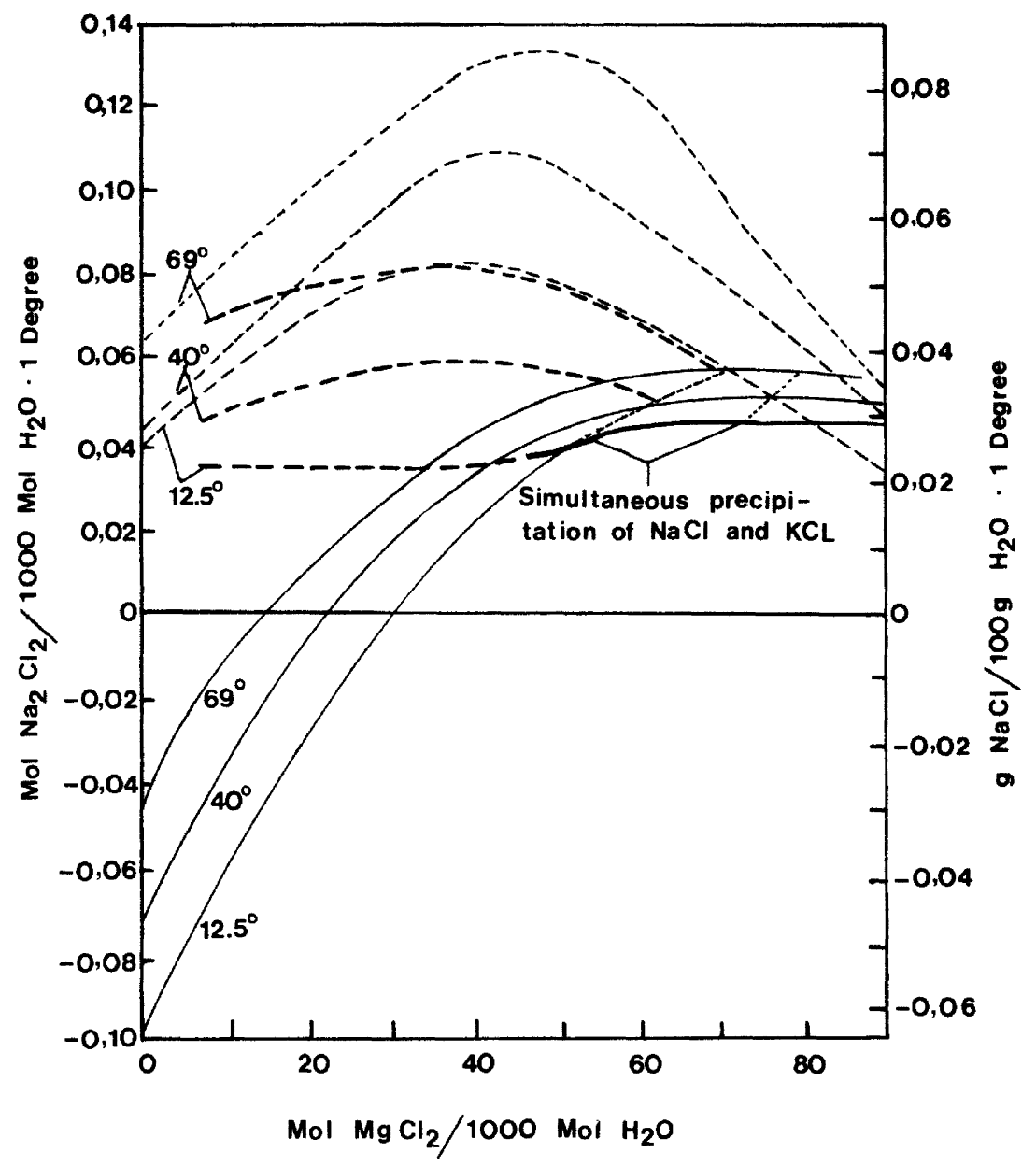

Figure 2.7. Ref. [44]. Temperature coefficient of $\mathrm{NaCl}$ solubility at temperatures from $0-70^{\circ} \mathrm{C}$ and $\mathrm{MgCl}_{2}$ concentrations - - - system $\mathrm{NaCl}-\mathrm{MgCl}_{2} \cdot \mathrm{H}_{2} \mathrm{O}$ saturated in $\mathrm{NaCl}$; - - system $\mathrm{NaCl}-\mathrm{KCl}-\mathrm{MgCl}_{2} \cdot \mathrm{H}_{2} \mathrm{O}$ saturated in $\mathrm{NaCl}$ and $\mathrm{KCl}$; - $\mathrm{MgSO}_{4}^{-}$free seawater, $\mathrm{NaCl}$-saturated, $\mathrm{KCl}$-unsaturated;- simultaneous precipitation of $\mathrm{NaCl}+\mathrm{KCl}$; following by simultaneous precipitation of $\mathrm{NaCl}+$ carnallite. 
temperature and pressure. This procedure minimized the contamination of the solutions.

The solubility data obtained with the use of the hydrothermal solution equipment at pressure slightly above the vapor pressure of the system are in good agreement with previous data as shown in figure 2.8 . The data reported by Dickson et al. [82] have been reanalyzed and values of the solubility of anhydrite in water at various pressures and at rounded temperatures are advanced as recommended values in tables $2.27-2.30$. Temperature-dependent equations, together with standard errors of estimate are also given.

It is seen that the solubility of anhydrite decreases with rising temperature.

Templeton and Rodgers [89] have determined the solubility of anhydrite in a number of salt solutions at elevated temperatures and at pressures just above the vapor pressure. The $\mathrm{CaSO}_{4}-\mathrm{NaCl} \cdot \mathrm{H}_{2} \mathrm{O}$ system was investigated at $523,548,573$ and $598 \mathrm{~K}$ from essentially zero to about 6 molal $\mathrm{NaCl}$. A high temperature flow solubility apparatus was used in this study with the temperature controlled to $\pm 1 \mathrm{~K}$. Reagent grade salts were used for all the measurements and distilled water was used to prepare solutions. Spectrophotometric or EDTA methods were employed to measure either calcium or sulfate. The precision of the data was reported to be $\pm 2 \%$ of the value of $c m_{\mathrm{Cas}}$. The data of Templeton and Rodgers [89] have been reanalyzed and values of the solubility of anhydrite at rounded concentrations of $\mathrm{NaCl}$ are advanced in tables 2.31 and 2.32. Equations representing the solubility of anhydrite as a function of sodium chloride concentration are also given. In addition, Templeton and Rodgers [89] measured the solubility of anhydrite in the systems $\mathrm{CaSO}_{4}-\mathrm{CaCl}_{2}-\mathrm{H}_{2} \mathrm{O}$ and $\mathrm{CaSO}_{4}-\mathrm{MgCl}_{2}-\mathrm{H}_{2} \mathrm{O}$. These data have been similarly reanalyzed and values of the solubility of anhydrite at rounded concentrations of either $\mathrm{CaCl}_{2}$ or $\mathrm{MgCl}_{2}$ are given in tables 2.33 and 2.34 , respectively. Finally the quaternary systems $\mathrm{CaSO}_{4}-\mathrm{CaCl}_{2} \mathrm{NaCl}-\mathrm{H}_{2} \mathrm{O}$ and $\mathrm{CaSO}_{4}-\mathrm{MgCl}_{2} \cdot \mathrm{NaCl} \cdot \mathrm{H}_{2} \mathrm{O}$ were also investigated and values are advanced in table 2.35 .

\subsubsection{The System Gypsum-Water-NaCl}

Blount and Dickson [90] used the hydrothermal solution apparatus to measure the solubility of gypsum in water at various pressures and temperatures. Reagent grade material was used and the maximum estimated uncertainty in the values was $\pm 2.5 \%$ for the solubility and \pm 4 bars $\left(4 \times 10^{5} \mathrm{~Pa}\right)$ for the pressure. The data were reanalyzed and values of solubility at rounded pressures are advanced in table 2.36 . The gypsum solubility in water at one atmosphere pressure changes only slowly

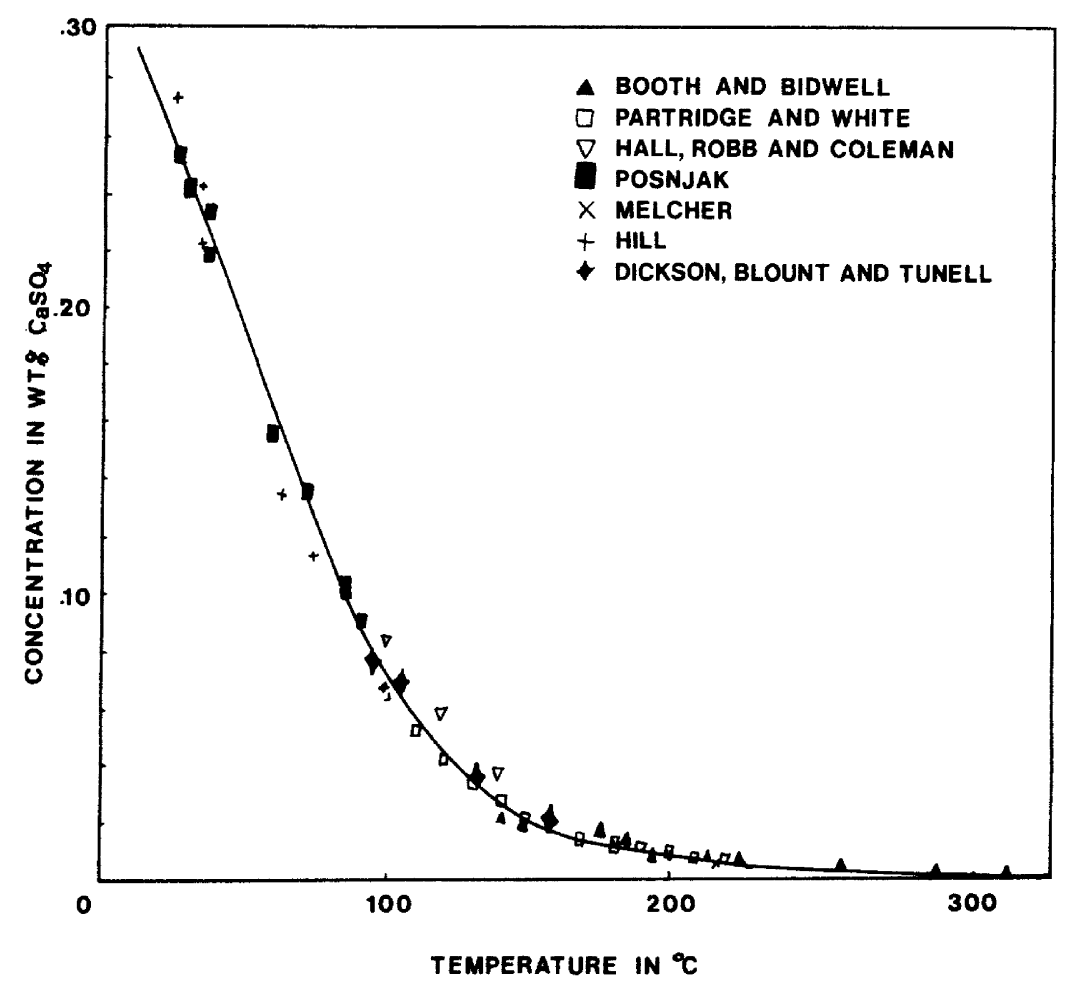

FIGURE 2.8. Comparsion of the hydrothermal method for solubilities of anhydrite at 1 atmosphere below $100^{\circ} \mathrm{C}$ and at the vapor pressure of the system above $100^{\circ} \mathrm{C}$. (The curve represents a fit to all of the data.) 
Table 2.27.

Solubility of anhydrite in water as a function of temperature at a pressure of $100 \times 10^{5}$ pascals

\begin{tabular}{llcl}
\hline $\mathrm{T}(\mathrm{K})$ & Wt. $\&$ anhydrite & $\mathrm{T}(\mathrm{K})$ & Wt. 8 anhydrite \\
\hline 380 & 0.073 & 440 & 0.017 \\
390 & 0.058 & 450 & 0.014 \\
400 & 0.046 & 460 & 0.011 \\
410 & 0.036 & 470 & 0.009 \\
420 & 0.028 & 480 & 0.007 \\
430 & 0.022 & 490 & 0.007 \\
\hline
\end{tabular}

Temperature-dependent equation and precision

$W t \%=5.2255961-3.21053 .10^{-2} \mathrm{~T}+6.6167237 .10^{-5} \mathrm{~T}^{2}-0.4568792 .10^{-7} \mathrm{~T}^{3}$

precision $\mathrm{s}=2.123 \%$

Table 2.28.

Solubility of anhydrite in water as a function of

\begin{tabular}{|c|c|c|c|}
\hline$I(K)$ & Wt. $q$ anhydrite & $T(K)$ & Wt. $:$ anhydrite \\
\hline 375 & 0.119 & 465 & 0.016 \\
\hline 385 & 0.097 & 475 & 0.013 \\
\hline 395 & 0.079 & 485 & 0.011 \\
\hline 405 & 0.063 & 495 & 0.010 \\
\hline 415 & 0.050 & 505 & 0.008 \\
\hline 425 & 0.039 & 515 & 0.007 \\
\hline 435 & 0.031 & 525 & 0.005 \\
\hline 445 & 0.024 & 535 & 0.003 \\
\hline 455 & 0.019 & & \\
\hline
\end{tabular}

Temperature-dependent equation and precision Wt $:=5.978863-3.5464 .10^{-2} \mathrm{~T}+7.04671 .10^{-5} \mathrm{~T}^{2}$

$$
-0.4683758 .10^{-7} \mathrm{~T}^{3}
$$

precision $s=3.550 \%$
Table 2.29 .

Solubility of anhydrite in water as a function of temperature at a pressure of $1000 \times 10^{5}$ pascals

\begin{tabular}{|c|c|c|c|}
\hline$\underline{T}(K)$ & Wt. $\&$ anhydrite & $T(K)$ & Wt. $\&$ anhydrite \\
\hline 380 & 0.176 & 470 & 0.023 \\
\hline 390 & 0.145 & 480 & 0.018 \\
\hline 400 & 0.118 & 490 & 0.015 \\
\hline 410 & 0.095 & 500 & 0.013 \\
\hline 420 & 0.076 & 510 & 0.011 \\
\hline 430 & 0.060 & 520 & 0.009 \\
\hline 440 & 0.047 & 530 & 0.007 \\
\hline 450 & 0.037 & 535 & 0.006 \\
\hline 460 & 0.029 & & \\
\hline
\end{tabular}

Temperature-dependent equation and precision $W_{t}:=7.4676808-0.4118806 .10^{-1} \mathrm{~T}+7.1843308 .10^{-5} \mathrm{~T}^{2}$ $-3.0831114 .10^{-8} \mathrm{~T}^{3}-1.5485214 .10^{-11} \mathrm{~T}^{4}$ precision $s=5.7678$

Table 2.30 .

Solubility of anhydrite in water as a function of temperature at pressures slightly greater than the vapor pressure of the system.

\begin{tabular}{ccc}
$\mathrm{I}(\mathrm{K})$ & $\mathrm{P}\left(\times 10^{-5}\right) \mathrm{Pa}$ & $W_{t}:$ anhydrite \\
\hline 369 & 2 & 0.0781 \\
378 & 6 & 0.0682 \\
404 & 5 & 0.0357 \\
430 & 15 & 0.0198 \\
583 & 100 &
\end{tabular}


Table 2.31

Solubility of anhydrite in $\mathrm{NaCl}-\mathrm{H}_{2} \mathrm{O}$ solutions at constant $\mathrm{NaCl}$ concentrations.

\begin{tabular}{|c|c|c|c|}
\hline $\mathrm{T}(\mathrm{K})$ & & & \\
\hline & $\mathrm{c}_{\mathrm{maCl}}=2.0$ & $\mathrm{~m}_{\mathrm{NaCl}}=4.0$ & $\mathrm{c}_{\mathrm{NaCl}}=6.0$ \\
\hline 375 & 0.0261 & 0.0280 & 0.0255 \\
\hline 395 & 0.0207 & 0.0240 & 0.0235 \\
\hline 415 & 0.0168 & 0.0210 & 0.0220 \\
\hline 435 & 0.0139 & 0.0187 & 0.0209 \\
\hline 455 & 0.0116 & 0.0168 & 0.0201 \\
\hline 475 & 0.0098 & 0.0154 & 0.0196 \\
\hline 495 & 0.0083 & 0.0142 & 0.0193 \\
\hline 515 & 0.0070 & 0.0133 & 0.0191 \\
\hline 535 & 0.0059 & 0.0125 & 0.0191 \\
\hline 555 & 0.0049 & 0.0118 & 0.0191 \\
\hline 575 & 0.0041 & 0.0112 & 0.0192 \\
\hline 595 & 0.0033 & 0.0107 & 0.0193 \\
\hline 615 & 0.0026 & 0.0102 & 0.0194 \\
\hline 635 & 0.0020 & 0.0097 & 0.0195 \\
\hline 655 & 0.0015 & 0.0092 & 0.0194 \\
\hline 675 & 0.0011 & 0.0087 & 0.0193 \\
\hline 695 & 0.0008 & 0.0082 & 0.0190 \\
\hline 715 & 0.0005 & 0.0076 & 0.0185 \\
\hline
\end{tabular}

Temperature-dependent equations

$\mathrm{c}_{\mathrm{NaCl}}=2.0$

$\ln \mathrm{m}=10.16-0.07407 \mathrm{~T}+1.329 .10^{-4} \mathrm{~T}^{2}-8.95 .10^{-8} \mathrm{~T}^{3}$

$\mathrm{c}_{\mathrm{NaCl}}=4.0$

$\ln \mathrm{m}=4.943-0.04246 \mathrm{~T}+6.640 .10^{-5} \mathrm{~T}^{2}-3.667 .10^{-8} \mathrm{~T}^{3}$

$\mathrm{c}_{\mathrm{NaCl}}=6.0$

$\ln \mathrm{m}=3.2342-3.741 .10^{-2} \mathrm{~T}+6.443 .10^{-5} \mathrm{~T}^{2}-3.670 .10^{-8} \mathrm{~T}^{3}$ 
Table 2.32 .

Solubilities of anhydrite in $\mathrm{NaCl}-\mathrm{H}_{2} \mathrm{O}$ solutions from $523 \mathrm{~K}$ to $598 \mathrm{~K}$

\begin{tabular}{|c|c|c|c|c|}
\hline $\begin{array}{l}\mathrm{NaC1} \\
\left(\mathrm{c}_{\mathrm{m}}\right)\end{array}$ & $523 \mathrm{~K}$ & $548 \mathrm{~K}$ & $573 \mathrm{~K}$ & $598 \mathrm{~K}$ \\
\hline 0.00025 & 0.000176 & 0.000078 & & \\
\hline 0.00050 & 0.000177 & 0.000079 & & \\
\hline 0.00075 & 0.000178 & 0.000079 & & \\
\hline 0.00100 & 0.000179 & 0.000080 & & \\
\hline 0.00250 & 0.000185 & 0.000084 & & \\
\hline 0.00500 & 0.000194 & 0.000091 & & \\
\hline 0.00750 & 0.000203 & 0.000098 & 0.000026 & \\
\hline 0.01000 & 0.000213 & 0.000105 & 0.000032 & \\
\hline 0.02500 & 0.000269 & 0.000146 & 0.000065 & 0.000051 \\
\hline 0.05000 & 0.000362 & 0.000215 & 0.000119 & 0.000072 \\
\hline 0.07500 & 0.000455 & 0.000284 & 0.000173 & 0.000094 \\
\hline 0.10000 & 0.000548 & 0.000353 & 0.000227 & 0.000118 \\
\hline 0.25000 & 0.001104 & 0.000765 & 0.000537 & 0.000297 \\
\hline 0.50000 & 0.002024 & 0.001453 & 0.001042 & 0.000705 \\
\hline 0.75000 & 0.002933 & 0.002143 & 0.001563 & 0.001210 \\
\hline 1.00000 & 0.003832 & 0.002838 & 0.002127 & 0.001775 \\
\hline 2.00000 & 0.007329 & 0.005699 & 0.004968 & 0.004325 \\
\hline 3.00000 & 0.010665 & 0.008796 & 0.008352 & 0.007373 \\
\hline 4.00000 & 0.013841 & 0.012265 & 0.011473 & 0.011444 \\
\hline 5.00000 & 0.016856 & 0.016242 & 0.014734 & 0.016227 \\
\hline 6.00000 & 0.019711 & 0.020862 & 0.021596 & 0.018813 \\
\hline
\end{tabular}


Table 2.32.

Solubilities of anhydrite in $\mathrm{NaCl}-\mathrm{H}_{2} \mathrm{O}$ solutions from $523 \mathrm{~K}$ to $598 \mathrm{~K}$ "--Continued"

Concentration-dependent equations and precision $c_{\text {anhydrite }}=a+b M+c M^{2}+d M^{3}+e M^{4}+f M^{5}$ $M=$ the molal concentration of sodium chloride

\begin{tabular}{|c|c|c|c|}
\hline Temp (K) & a. $10^{4}$ & b. $10^{2}$ & c. $10^{4}$ \\
\hline 523 & 1.7516 & 0.37371 & -0.80182 \\
\hline 548 & 0.772789 & 0.27549 & -0.17102 \\
\hline 573 & 0.098800 & 0.22202 & -6.0258 \\
\hline 598 & 0.32922 & 0.069153 & 16.399 \\
\hline Temp (K) & d. $10^{3}$ & e. $10^{3}$ & f. $10^{4}$ \\
\hline \multicolumn{4}{|l|}{523} \\
\hline 548 & 0.02248 & 0.00109 & \\
\hline 573 & 0.066368 & -0.17952 & 0.15337 \\
\hline \multirow[t]{6}{*}{598} & -0.74941 & 0.17449 & -0.13965 \\
\hline & Temp (K) & $\begin{array}{c}\text { precision } \\
\text { (s) }\end{array}$ & \\
\hline & 523 & $2.37 \%$ & \\
\hline & 548 & $1.08 \%$ & \\
\hline & 573 & $3.12 \%$ & \\
\hline & 598 & $0.53 \%$ & \\
\hline
\end{tabular}


Table 2.33

Solubilities of anhydrite in the $\mathrm{CaSO}_{4}-\mathrm{CaCl}_{2}-\mathrm{H}_{2} \mathrm{O}$ system

\begin{tabular}{|c|c|c|c|c|c|}
\hline $\begin{array}{l}\mathrm{CaCl}{ }_{2} \\
\left(\mathrm{c}_{\mathrm{m}}\right)^{2}\end{array}$ & $523 \mathrm{~K}$ & $573 \mathrm{~K}$ & $\begin{array}{l}\left.\mathrm{CaCl}_{\left(\mathrm{C}_{\mathrm{m}}\right.}\right)^{2} \\
\end{array}$ & $523 \mathrm{~K}$ & $573 \mathrm{~K}$ \\
\hline \multicolumn{3}{|c|}{$\mathrm{c}_{\mathrm{m}_{\mathrm{CaSO}}}\left(\times 10^{3}\right)$} & \multicolumn{3}{|c|}{$\mathrm{cm}_{\mathrm{CaSO}_{4}}\left(\times 10^{3}\right)$} \\
\hline 0.04 & 0.134 & 0.045 & 0.17 & 0.249 & 0.131 \\
\hline 0.05 & 0.142 & 0.052 & 0.18 & 0.258 & 0.138 \\
\hline 0.06 & 0.151 & 0.059 & 0.19 & 0.267 & 0.144 \\
\hline 0.07 & 0.160 & 0.065 & 0.20 & 0.275 & 0.151 \\
\hline 0.08 & 0.169 & 0.072 & 0.21 & 0.284 & 0.157 \\
\hline 0.09 & 0.178 & 0.078 & 0.22 & 0.293 & 0.164 \\
\hline 0.10 & 0.187 & 0.085 & 0.23 & 0.302 & 0.170 \\
\hline 0.11 & 0.196 & 0.092 & 0.24 & 0.311 & 0.177 \\
\hline 0.12 & 0.204 & 0.098 & 0.25 & 0.320 & 0.184 \\
\hline 0.13 & 0.213 & 0.105 & 0.26 & 0.329 & 0.190 \\
\hline 0.14 & 0.222 & 0.111 & 0.27 & 0.337 & 0.197 \\
\hline 0.15 & 0.231 & 0.118 & 0.28 & 0.346 & 0.203 \\
\hline 0.16 & 0.240 & 0.124 & 0.29 & 0.355 & 0.210 \\
\hline
\end{tabular}

Concentration-dependent equations and precision

$c_{m_{\mathrm{CaSO}_{4}}}=0.98183 .10^{-4}+0.88596 .10^{-3} \mathrm{c}_{\mathrm{m}_{\mathrm{CaCl}}}(523 \mathrm{~K}) ; \mathrm{s}=4.01 \%$
$\mathrm{c}_{\mathrm{maSO}_{4}}=0.19131 .10^{-4}+0.60801 .10^{-3} \mathrm{c}_{\mathrm{maCl}_{2}}(573 \mathrm{~K}) ; \mathrm{s}=6.32 \%$ 
Tab1e 2.34.

Solubilities of anhydrite in the $\mathrm{CaSO}_{4}-\mathrm{MgCl}_{2}-\mathrm{H}_{2} \mathrm{O}$ system

\begin{tabular}{llllll}
$\mathrm{MgCl}_{\left(\mathrm{c}_{\mathrm{m}}\right)}$ & $523 \mathrm{~K}$ & $573 \mathrm{~K}$ & $\begin{array}{c}\mathrm{MgCl} 2 \\
\left(\mathrm{c}_{\mathrm{m}}\right)\end{array}$ & $523 \mathrm{~K}$ & $573 \mathrm{~K}$ \\
\hline & $\mathrm{c}_{\mathrm{m}_{\mathrm{CaSO}_{4}}\left(\mathrm{x} 10^{2}\right)}$ & & $\mathrm{c}_{\mathrm{m}_{\mathrm{CaSO}}}\left(\mathrm{x} 10^{2}\right)$ \\
\hline 0.04 & 0.2125 & 0.1454 & 0.17 & 0.5852 & 0.4739 \\
0.05 & 0.2467 & 0.1706 & 0.18 & 0.6100 & 0.4992 \\
0.06 & 0.2797 & 0.1959 & 0.19 & 0.6346 & 0.5245 \\
0.07 & 0.3116 & 0.2212 & 0.20 & 0.6592 & 0.5498 \\
0.08 & 0.3423 & 0.2465 & 0.21 & 0.6839 & 0.5750 \\
0.09 & 0.3721 & 0.2717 & 0.22 & 0.7087 & 0.6003 \\
0.10 & 0.4010 & 0.2970 & 0.23 & 0.7337 & 0.6256 \\
0.11 & 0.4291 & 0.3223 & 0.24 & 0.7589 & 0.6509 \\
0.12 & 0.4564 & 0.3476 & 0.25 & 0.7846 & 0.6762 \\
0.13 & 0.4831 & 0.3728 & 0.26 & 0.8108 & 0.7014 \\
0.14 & 0.5093 & 0.3981 & 0.27 & 0.8375 & 0.7267 \\
0.15 & 0.5349 & 0.4234 & 0.28 & 0.8648 & 0.7520 \\
0.16 & 0.5602 & 0.4487 & 0.29 & 0.8929 & 0.7773 \\
\hline & & & & & \\
\hline
\end{tabular}

Concentration-dependent equations and precision

$$
\begin{aligned}
& \mathrm{Cm}_{\mathrm{CaSO}_{4}}=0.61341 .10^{-3}+0.409 .10^{-1} \mathrm{~m}_{\mathrm{MgCl}_{2}}-0.83632 .10^{-1} \mathrm{c}_{\mathrm{MgCl}_{2}}^{2} \\
& +0.14303 \mathrm{Cm}_{\mathrm{MgCl}_{2}}^{3}(523 \mathrm{~K}) ; \mathrm{s}=0.20 \% \\
& c_{\mathrm{maSO}_{4}}=0.44251 .10^{-3}+0.25276 .10^{-1} \mathrm{c}_{\mathrm{m}_{\mathrm{MgCl}}}(573 \mathrm{~K}) ; \mathrm{s}=0.27 \%
\end{aligned}
$$


Table 2.35

Solubilities of anhydrite in solutions of constant ionic

strength for some quaternary systems

\begin{tabular}{|c|c|c|}
\hline \multicolumn{3}{|c|}{$\mathrm{CaSO}_{4}-\mathrm{CaCl}_{2}-\mathrm{NaCl}-\mathrm{H}_{2} \mathrm{O}$ System } \\
\hline $\mathrm{c}_{\mathrm{m}_{\mathrm{CaCl}}}$ & $\mathrm{c}_{\mathrm{maCl}}$ & $\mathrm{c}_{\mathrm{m}} \mathrm{CaSO}_{4}$ \\
\hline \multicolumn{3}{|c|}{$523 \mathrm{~K}, I=0.50$} \\
\hline & 0.492 & 0.00199 \\
\hline 0.0080 & 0.4747 & 0.000496 \\
\hline 0.0080 & 0.4747 & 0.000517 \\
\hline 0.0250 & 0.4246 & 0.000263 \\
\hline 0.0250 & 0.4246 & 0.000262 \\
\hline 0.0700 & 0.2898 & 0.000236 \\
\hline 0.0700 & 0.2898 & 0.000244 \\
\hline 0.1666 & & 0.000237 \\
\hline \multicolumn{3}{|c|}{$523 \mathrm{~K}, \mathrm{I}=0.90$} \\
\hline & 0.8868 & 0.00330 \\
\hline 0.0040 & 0.8763 & 0.00186 \\
\hline 0.0100 & 0.8653 & 0.00109 \\
\hline 0.0180 & 0.8434 & 0.000746 \\
\hline 0.0250 & 0.8231 & 0.000532 \\
\hline 0.0400 & 0.7788 & 0.000420 \\
\hline 0.0800 & 0.6594 & 0.000372 \\
\hline 0.0800 & 0.6594 & 0.000370 \\
\hline 0.0800 & 0.6594 & 0.000364 \\
\hline 0.100 & 0.5995 & 0.000360 \\
\hline 0.200 & 0.2996 & 0.000366 \\
\hline 0.200 & 0.2996 & 0.000385 \\
\hline 0.300 & & 0.000364 \\
\hline \multicolumn{3}{|c|}{$573 \mathrm{~K}, \mathrm{I}=0.50$} \\
\hline & 0.496 & 0.00100 \\
\hline 0.0080 & 0.4747 & 0.000184 \\
\hline 0.0250 & 0.4246 & 0.0000939 \\
\hline 0.0250 & 0.4246 & 0.0000970 \\
\hline 0.0700 & 0.2898 & 0.0000889 \\
\hline 0.0700 & 0.2898 & 0.0000913 \\
\hline 0.1666 & & 0.000110 \\
\hline \multicolumn{3}{|c|}{$573 \mathrm{~K}, I=0.90$} \\
\hline & 0.892 & 0.00189 \\
\hline 0.0040 & 0.8763 & 0.000802 \\
\hline 0.0180 & 0.8434 & 0.000315 \\
\hline 0.0400 & 0.7788 & 0.000210 \\
\hline 0.0400 & 0.7788 & 0.000217 \\
\hline 0.0800 & 0.6594 & 0.000166 \\
\hline 0.200 & 0.2996 & 0.000208 \\
\hline 0.200 & 0.2996 & 0.000195 \\
\hline 0.300 & & 0.000223 \\
\hline
\end{tabular}

Table 2.35 .

Solubilities of anhydrite in solutions of constant ionic strength for some quaternary systems "--Continued"

\begin{tabular}{|c|c|c|}
\hline \multicolumn{3}{|c|}{$\mathrm{CaSO}_{4}-\mathrm{MgCl}_{2}-\mathrm{NaCl}-\mathrm{H}_{2} \mathrm{O}$ System } \\
\hline $\mathrm{c}_{\mathrm{m}_{\mathrm{MgCl}}}$ & $\mathrm{m}_{\mathrm{NaCl}}$ & $\mathrm{c}_{\mathrm{m} \mathrm{CaSO}_{4}}$ \\
\hline \multicolumn{3}{|c|}{$523 \mathrm{~K}, I=0.50$} \\
\hline & 0.492 & 0.00199 \\
\hline 0.00295 & 0.4853 & 0.00204 \\
\hline 0.00811 & 0.4694 & 0.00218 \\
\hline 0.00811 & 0.4694 & 0.00214 \\
\hline 0.0204 & 0.4320 & 0.00262 \\
\hline 0.0240 & 0.4320 & 0.00260 \\
\hline 0.0608 & 0.3070 & 0.00358 \\
\hline 0.0608 & 0.3070 & 0.00360 \\
\hline 0.1219 & 0.1240 & 0.00490 \\
\hline 0.1219 & 0.1240 & 0.00492 \\
\hline 0.1631 & & 0.00568 \\
\hline \multicolumn{3}{|c|}{$573 \mathrm{~K}, I=0.50$} \\
\hline & 0.496 & 0.00100 \\
\hline 0.00295 & 0.4853 & 0.00107 \\
\hline 0.00295 & 0.4853 & 0.00107 \\
\hline 0.00811 & 0.4694 & 0.00131 \\
\hline 0.0204 & 0.4320 & 0.00166 \\
\hline 0.0608 & 0.3070 & 0.00251 \\
\hline 0.0608 & 0.3070 & 0.00265 \\
\hline 0.1219 & 0.1240 & 0.00378 \\
\hline 0.1631 & & 0.00456 \\
\hline 0.1631 & & 0.00455 \\
\hline
\end{tabular}


Table 2.36 .

The solubility of gypsum in water as a function

of temperature and pressure

\begin{tabular}{|c|c|c|c|c|c|c|}
\hline $\begin{array}{l}\mathrm{P} \times 10^{-5} \mathrm{~Pa} \\
( \pm 4)\end{array}$ & $313 \mathrm{~K}$ & $323 \mathrm{~K}$ & $333 \mathrm{~K}$ & $340 \mathrm{~K}$ & $352 \mathrm{~K}$ & $356 \mathrm{~K}$ \\
\hline \multicolumn{7}{|c|}{$\mathrm{CaSO}_{4}\left(\mathrm{c}_{\mathrm{m}}\right)$} \\
\hline 3 & & & & & 0.0138 & \\
\hline 5 & & & & & 0.0139 & \\
\hline 25 & & 0.0155 & 0.0147 & & 0.0140 & \\
\hline 50 & & 0.0159 & 0.0151 & & 0.0143 & \\
\hline 75 & & 0.0162 & 0.0155 & & 0.0146 & \\
\hline 100 & & 0.0166 & 0.0159 & & 0.0149 & \\
\hline 125 & & 0.0170 & 0.0163 & & 0.0152 & \\
\hline 150 & & 0.0173 & 0.0167 & & 0.0155 & \\
\hline 175 & & 0.0177 & 0.0171 & & 0.0158 & \\
\hline 200 & & 0.0181 & 0.0174 & & 0.0162 & \\
\hline 225 & & 0.0185 & 0.0178 & & 0.0165 & \\
\hline 250 & & 0.0189 & 0.0182 & & 0.0168 & \\
\hline 275 & & 0.0193 & 0.0186 & & 0.0172 & \\
\hline 300 & & 0.0198 & 0.0190 & & 0.0175 & \\
\hline 325 & & 0.0202 & 0.0195 & & 0.0179 & \\
\hline 350 & & 0.0206 & 0.0199 & & 0.0182 & \\
\hline 375 & & 0.0211 & 0.0203 & & 0.0186 & \\
\hline 400 & & 0.0215 & 0.0207 & & 0.0190 & \\
\hline 425 & & 0.0219 & 0.0211 & & 0.0194 & \\
\hline 450 & & 0.0224 & 0.0215 & & 0.0198 & \\
\hline 475 & & 0.0229 & 0.0219 & & 0.0202 & \\
\hline 500 & & 0.0233 & 0.0223 & 0.0226 & 0.0206 & \\
\hline 525 & & 0.0238 & & 0.0229 & 0.0210 & \\
\hline 545 & 0.0259 & & & & & \\
\hline 550 & 0.0260 & 0.0243 & & 0.0232 & 0.0214 & \\
\hline 555 & 0.0262 & & & & & \\
\hline 560 & 0.0263 & & & & & \\
\hline 565 & 0.0264 & & & & & \\
\hline \multicolumn{7}{|l|}{570} \\
\hline 575 & & 0.0248 & & 0.0235 & 0.0218 & \\
\hline 600 & & 0.0253 & & 0.0219 & 0.0222 & \\
\hline 625 & & 0.0258 & & 0.0242 & 0.0227 & \\
\hline 650 & & 0.0263 & & 0.0247 & 0.0231 & \\
\hline 675 & & 0.0268 & & 0.0251 & 0.0236 & \\
\hline 700 & & 0.0273 & & 0.0256 & 0.0240 & \\
\hline 725 & & 0.0278 & & 0.0261 & 0.0245 & \\
\hline 750 & & 0.0284 & & 0.0266 & 0.0250 & \\
\hline 775 & & 0.0289 & & 0.0272 & 0.0255 & \\
\hline 800 & & 0.0294 & & 0.0278 & 0.0259 & \\
\hline 825 & & 0.0300 & & 0.0284 & 0.0264 & \\
\hline 850 & & 0.0305 & & 0.0290 & 0.0269 & \\
\hline 875 & & 0.0311 & & 0.0297 & 0.0274 & \\
\hline 900 & & 0.0317 & & 0.0304 & 0.0279 & \\
\hline 925 & & 0.0323 & & 0.0312 & 0.0285 & \\
\hline 950 & & 0.0328 & & 0.0319 & 0.0290 & \\
\hline 975 & & 0.0334 & & 0.0327 & 0.0295 & \\
\hline 998 & & & & & & 0.0311 \\
\hline 999 & & & & & & 0.0311 \\
\hline 1000 & & & & 0.0336 & 0.0301 & 0.0311 \\
\hline 1001 & & & & & & 0.0311 \\
\hline 1002 & & & & & & 0.0311 \\
\hline 1003 & & & & & & 0.0310 \\
\hline 1004 & & & & & & 0.0310 \\
\hline
\end{tabular}


Table 2.36 .

The solubility of gypsum in water as a function of temperature and pressure "--Continued"

Pressure-dependent equations and precision $\mathrm{c}_{\mathrm{CaSO}_{4}}=\mathrm{a}+\mathrm{b} \mathrm{p}+\mathrm{c} \mathrm{p}^{2}$

\begin{tabular}{lcccc}
\hline T ( K ) & a.10 & b.10 & c. $10^{18}$ & $\begin{array}{c}\text { precision } \\
(\mathrm{s})\end{array}$ \\
\hline 313 & 0.13106 & 0.23528 & & $0.00 \%$ \\
323 & 0.15165 & 0.13797 & 0.50605 & $0.72 \%$ \\
333 & 0.14332 & 0.15290 & 0.14252 & $0.00 \%$ \\
340 & 0.23529 & -0.13725 & 2.3769 & $1.50 \%$ \\
352 & 0.13747 & 0.10966 & 0.53396 & $0.94 \%$ \\
356 & 0.51140 & -0.20040 & & $1.05 \%$
\end{tabular}

with temperature and passes through a very weak maximum at about $313 \mathrm{~K}$.

A study of the solubility of gypsum in $\mathrm{NaCl}-\mathrm{H}_{2} \mathrm{O}$ solutions from 273-383 K has been performed by Marshall and Slusher [91]. A small high pressure titanium alloy vessel incorporating a Teflon gasket was used for the measurements, with the special feature of the design being the containment of the Teflon above its transition temperature of $600 \mathrm{~K}$. Selected mixtures of solid and solution were sealed in the vessels. The solution phases were sampled by means of flexible capillary tubing and valves. Since the liquid phase was sampled at its equilibration temperature and subsequently analyzed, a correction for loss of water or other constituents to the vapor was unnecessary. The temperature of equilibrium was approached from both lower and higher tem. peratures; agreement of analyses was used to show that equilibrium had been attained. The data of Marshall and Slusher [91] were reanalyzed and values of the solubility of gypsum were generated at rounded concentrations of sodium chloride over the temperature range from 273-383 K. The recommended values, compositiondependent equations and precisions are in tables 2.37-2.39.

\subsubsection{Comparison of the Systems Anhydrite-Water and Gypsum-Water}

A comparison of the solubilities of anhydrite and gypsum in water with added sodium chloride is shown in figure 2.9. The solubility of gypsum and anhydrite is in general influenced by the presence of additional ions, increasing through the addition of foreign ions, and conversely being reduced by the addition of the same ions. These effects for both gypsum and anhydrite are shown in figure 2.10. Because of the different temperature coefficients, the point of intersection of the gypsum and anhydrite solubility curves is displaced towards lower temperatures as the $\mathrm{NaCl}$ content of the solution increases. With an additional $\mathrm{SO}_{4}^{-2}$ content the solubility of gypsum and anhydrite is reduced and the maximum becomes broader.

\subsubsection{The System Calcite-Water $+\left(\mathrm{NaCl}, \mathrm{CaCl}_{2} \ldots\right)$}

The solubility of calcite in water as a function of $\mathrm{CO}_{2}$ pressure and temperature is presented graphically in figures 2.11-2.15. The curves in these figures represent fits to all of the data.

Macdonald and North [97] investigated the effect of pressure on the solubility of calcite in water between 273 and $308 \mathrm{~K}$ and for pressures up to $101325 \mathrm{~Pa}$. The distilled water used in the measurements was de-ionized water which was boiled vigorously prior to use to expel any dissolved $\mathrm{CO}_{2}$. The calcium carbonate was in the form of small natural calcite crystals. An analysis of the calcite showed that it contained less than $0.1 \%$ of magnesium. In the determination of solubility the solutions were saturated by allowing the water to percolate, at a known rate, through the reaction column which was packed with the dissolving solid. The particular method used in this study produces a large surface area to liquid volume ratio and so allows a relatively rapid attainment of equilibrium. The solutions were analyzed for calcium by atomic absorption, and all determinations had an accuracy of at least $\pm 2 \%$. The data of Macdonald and North [97] were reanalyzed and values of both solubility and thermodynamic solubility products were derived at rounded pressures and are

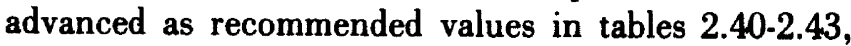
together with pressure dependent equations.

Akin and Lagerwerff [98] studied the effects of added electrolytes on the solubility of calcite in water, using an apparatus designed to minimize $\mathrm{CO}_{2}$ fluctuations. Calcium was determined by EDTA titration, while sodium was monitored with a flame photometer. The values reported by Akin and Lagerwerff [98] were reevaluated using statistical analysis and results are given for the solubility of calcite at rounded concentrations of sodium chloride in tables 2.44-2.48. Concentration-dependent equations and precisions are also reported.

\subsubsection{Dehydration of Gypsum}

The main point of interest in the chemistry of gypsum concerns the products of its dehydration. Four principal phases have been reported [99] in the system calcium 
1 aDLe $<.31$

The solubility of gypsum in $\mathrm{NaCl}-\mathrm{H}_{2} \mathrm{O}$

solutions at 273-293 K

\begin{tabular}{|c|c|c|c|c|c|}
\hline \multirow[t]{2}{*}{$\begin{array}{l}\mathrm{NaCl} \\
\left(\mathrm{c}_{\mathrm{m}}\right)\end{array}$} & \multicolumn{5}{|c|}{$\begin{array}{c}\mathrm{CaSO}_{4} \cdot 2 \mathrm{H}_{2} \mathrm{O} \\
\left(\mathrm{c}_{\mathrm{m}}\right)\end{array}$} \\
\hline & $273.5 \mathrm{~K}$ & $278 \mathrm{~K}$ & $283 \mathrm{~K}$ & $288 \mathrm{k}$ & $293 \mathrm{~K}$ \\
\hline 0.01 & 0.0148 & 0.0154 & 0.0162 & 0.0168 & 0.0165 \\
\hline 0.02 & 0.0152 & 0.0158 & 0.0166 & 0.0173 & 0.0170 \\
\hline 0.03 & 0.0156 & 0.0163 & 0.0171 & 0.0177 & 0.0175 \\
\hline 0.04 & 0.0160 & 0.0167 & 0.0175 & 0.0182 & 0.0179 \\
\hline 0.05 & 0.0165 & 0.0171 & 0.0179 & 0.0186 & 0.0184 \\
\hline 0.06 & 0.0169 & 0.0175 & 0.0184 & 0.0190 & 0.0188 \\
\hline 0.07 & 0.0173 & 0.0180 & 0.0188 & 0.0195 & 0.0193 \\
\hline 0.08 & 0.0177 & 0.0184 & 0.0192 & 0.0199 & 0.0197 \\
\hline 0.09 & 0.0181 & 0.0188 & 0.0196 & 0.0203 & 0.0202 \\
\hline 0.10 & 0.0185 & 0.0192 & 0.0200 & 0.0207 & 0.0206 \\
\hline 0.20 & 0.0230 & 0.0231 & 0.0239 & 0.0247 & 0.0248 \\
\hline 0.30 & 0.0258 & 0.0266 & 0.0275 & 0.0283 & 0.0286 \\
\hline 0.40 & 0.0291 & 0.0298 & 0.0308 & 0.0316 & 0.0320 \\
\hline 0.50 & 0.0320 & 0.0328 & 0.0338 & 0.0347 & 0.0352 \\
\hline 0.60 & 0.0348 & 0.0355 & 0.0366 & 0.0374 & 0.0380 \\
\hline 0.70 & 0.0373 & 0.0379 & 0.0390 & 0.0399 & 0.0405 \\
\hline 0.80 & 0.0395 & 0.0401 & 0.0413 & 0.0421 & 0.0428 \\
\hline 0.90 & 0.0416 & 0.0421 & 0.0433 & 0.0442 & 0.0448 \\
\hline 1.00 & 0.0435 & 0.0439 & 0.0451 & 0.0460 & 0.0465 \\
\hline 2.0 & 0.0542 & 0.0535 & 0.0547 & 0.0553 & 0.0553 \\
\hline 3.0 & 0.0564 & 0.0553 & 0.0560 & 0.0566 & 0.0562 \\
\hline 4.0 & 0.0556 & 0.0554 & 0.0554 & 0.0563 & 0.0563 \\
\hline 5.0 & 0.0530 & 0.0537 & 0.0534 & 0.0553 & 0.0556 \\
\hline 6.0 & 0.0451 & 0.0447 & 0.0455 & 0.0489 & 0.0473 \\
\hline
\end{tabular}

Concentration-dependent equations and precisions

$$
\begin{aligned}
& c_{m_{\text {gypsum }}}=a+b M+c M^{2}+d M^{3}+e M^{4} \\
& M=\text { molal concentration of sodium chloride }
\end{aligned}
$$

\begin{tabular}{ccccccc}
$\begin{array}{c}\text { Temp } \\
(\mathrm{K})\end{array}$ & $\mathrm{a} .10$ & $\mathrm{~b} .10$ & $\mathrm{c} .10$ & $\mathrm{~d} .10^{2}$ & $\mathrm{e} .10^{3}$ & $\begin{array}{c}\text { precision } \\
(\mathrm{s})\end{array}$ \\
\hline 273.5 & 0.1436225 & 0.4279379 & -0.1623401 & 0.2766863 & -0.1845770 & $1.67 \%$ \\
278 & 0.1496224 & 0.4394013 & -0.1815735 & 0.3388285 & -0.2408431 & $1.96 \%$ \\
283 & 0.1574711 & 0.4445050 & -0.1814384 & 3.276261 & -2.248609 & $1.97 \%$ \\
288 & 0.163198 & 0.4512401 & -0.1873406 & 3.423325 & -2.339645 & $2.25 \%$ \\
293 & 0.1605044 & 0.4775160 & -0.2102661 & 0.4057587 & -0.2891751 & $2.73 \%$
\end{tabular}


Table 2.38 .

The solubility of gypsum in $\mathrm{NaCl}-\mathrm{H}_{2} \mathrm{O}$ solutions at $298-343 \mathrm{~K}$

\begin{tabular}{|c|c|c|c|c|}
\hline \multirow[t]{2}{*}{$\begin{array}{l}\mathrm{NaCl} \\
\left(\mathrm{c}_{\mathrm{m}}\right) \\
\end{array}$} & \multicolumn{4}{|c|}{$\begin{array}{c}\mathrm{CaSO}_{4} \cdot 2 \mathrm{C}_{2} \mathrm{O} \\
\end{array}$} \\
\hline & $298 \mathrm{~K}$ & $303 \mathrm{~K}$ & $313 \mathrm{~K}$ & $343 \mathrm{~K}$ \\
\hline 0.01 & 0.0174 & 0.0164 & 0.0169 & 0.0170 \\
\hline 0.02 & 0.0178 & 0.0171 & 0.0175 & 0.0174 \\
\hline 0.03 & 0.0182 & 0.0178 & 0.0181 & 0.0178 \\
\hline 0.04 & 0.0187 & 0.0184 & 0.0187 & 0.0182 \\
\hline 0.05 & 0.0191 & 0.0191 & 0.0193 & 0.0186 \\
\hline 0.06 & 0.0196 & 0.0197 & 0.0198 & 0.0190 \\
\hline 0.07 & 0.0200 & 0.0203 & 0.0204 & 0.0194 \\
\hline 0.08 & 0.0204 & 0.0209 & 0.0210 & 0.0198 \\
\hline 0.09 & 0.0208 & 0.0215 & 0.0215 & 0.0202 \\
\hline 0.10 & 0.0213 & 0.0221 & 0.0220 & 0.0205 \\
\hline 0.20 & 0.0252 & 0.0271 & 0.0268 & 0.0242 \\
\hline 0.30 & 0.0288 & 0.0311 & 0.0307 & 0.0277 \\
\hline 0.40 & 0.0321 & 0.0342 & 0.0339 & 0.0308 \\
\hline 0.50 & 0.0351 & 0.0366 & 0.0366 & 0.0338 \\
\hline 0.60 & 0.0377 & 0.0385 & 0.0388 & 0.0365 \\
\hline 0.70 & 0.0401 & 0.0402 & 0.0407 & 0.0390 \\
\hline 0.80 & 0.0423 & 0.0418 & 0.0424 & 0.0413 \\
\hline 0.90 & 0.0442 & 0.0436 & 0.0441 & 0.0434 \\
\hline 1.00 & 0.0459 & 0.0458 & 0.0458 & 0.0453 \\
\hline 2.00 & 0.0541 & & & 0.0558 \\
\hline 3.00 & 0.0553 & & & 0.0567 \\
\hline 4.00 & 0.0561 & & & 0.0566 \\
\hline 5.00 & 0.0569 & & & 0.0643 \\
\hline 6.00 & 0.0511 & & & 0.0883 \\
\hline
\end{tabular}

Concentration-dependent equations and precisions

$c_{m_{\text {gypsum }}}=a+b M+c M^{2}+d M^{3}+e M^{4}$

$M=$ molal concentration of sodium chloride

\begin{tabular}{ccccccc}
\hline $\begin{array}{c}\text { Temp } \\
(\mathrm{K})\end{array}$ & $\mathrm{a} .10$ & $\mathrm{~b} .10$ & $\mathrm{c} .10$ & $\mathrm{~d} .10^{2}$ & $\mathrm{e} .10^{3} \begin{array}{c}\text { precision } \\
(\mathrm{s})\end{array}$ \\
\hline 298 & 0.1690221 & 0.4549512 & -0.2017596 & 0.3924890 & -0.2891751 & $2.16 \%$ \\
303 & 0.1573776 & 0.7053267 & -0.7498029 & 3.449260 & -0.2779556 & $1.34 \%$ \\
313 & 0.1624119 & 0.6350437 & -0.5876340 & 2.798339 & & $1.40 \%$ \\
343 & 0.1660804 & 0.4073127 & -0.1344950 & 1.446642 & & $5.51 \%$
\end{tabular}


Table 2.39 .

The solubility of gypsum in $\mathrm{NaCl}-\mathrm{H}_{2} \mathrm{O}$ solutions at $353-383 \mathrm{~K}$

\begin{tabular}{|c|c|c|c|}
\hline \multirow[t]{2}{*}{$\begin{array}{l}\mathrm{NaCl} \\
\left(\mathrm{c}_{\mathrm{m}}\right) \\
\end{array}$} & \multicolumn{3}{|c|}{$\begin{array}{c}\mathrm{CaSO}_{4} \cdot 2 \mathrm{H}_{2} \mathrm{O} \\
\left(\mathrm{c}_{\mathrm{m}}\right)\end{array}$} \\
\hline & $353 \mathrm{~K}$ & $368 \mathrm{~K}$ & $383 \mathrm{~K}$ \\
\hline 0.01 & 0.0176 & 0.0158 & 0.0119 \\
\hline 0.02 & 0.0178 & 0.0161 & 0.0124 \\
\hline 0.03 & 0.0180 & 0.0164 & 0.0129 \\
\hline 0.04 & 0.0182 & 0.0166 & 0.0135 \\
\hline 0.05 & 0.0184 & 0.0169 & 0.0140 \\
\hline 0.06 & 0.0186 & 0.0172 & 0.0145 \\
\hline 0.07 & 0.0188 & 0.0174 & 0.0150 \\
\hline 0.08 & 0.0190 & 0.0177 & 0.0155 \\
\hline 0.09 & 0.0192 & 0.0180 & 0.0160 \\
\hline 0.10 & 0.0194 & 0.0183 & 0.0165 \\
\hline 0.20 & 0.0214 & 0.0209 & 0.0213 \\
\hline 0.30 & 0.0234 & 0.0236 & 0.0257 \\
\hline 0.40 & 0.0254 & 0.0261 & 0.0299 \\
\hline 0.50 & 0.0273 & 0.0287 & 0.0338 \\
\hline 0.60 & 0.0292 & 0.0312 & 0.0374 \\
\hline 0.70 & 0.0311 & 0.0336 & 0.0408 \\
\hline 0.80 & 0.0330 & 0.0360 & 0.0439 \\
\hline 0.90 & 0.0349 & 0.0384 & 0.0468 \\
\hline 1.00 & 0.0367 & 0.0407 & 0.0494 \\
\hline 2.00 & 0.0538 & 0.0612 & 0.0647 \\
\hline 3.00 & 0.0688 & 0.0771 & 0.0670 \\
\hline 4.00 & 0.0814 & 0.0883 & 0.0661 \\
\hline 5.00 & 0.0919 & 0.0950 & 0.0717 \\
\hline 6.00 & 0.1001 & 0.0970 & 0.0934 \\
\hline
\end{tabular}

Concentration-dependent equations and precisions

$c_{\text {gypsum }}=a+b M+c M^{2}+d M^{3}$

$M=$ molal concentration of sodium chloride

\begin{tabular}{ll}
\hline Temp & precision (s) \\
$(K)$ &
\end{tabular}

\begin{tabular}{|c|c|c|c|c|c|}
\hline 353 & 0.1735577 & 0.2046287 & -0.1109989 & & $6.3 \%$ \\
\hline 368 & 0.1552855 & 0.2745152 & -0.2312935 & & $6.7 \%$ \\
\hline 383 & 0.1137741 & 0.525739 & -1.619548 & 0.1618607 & $5.8 \%$ \\
\hline
\end{tabular}




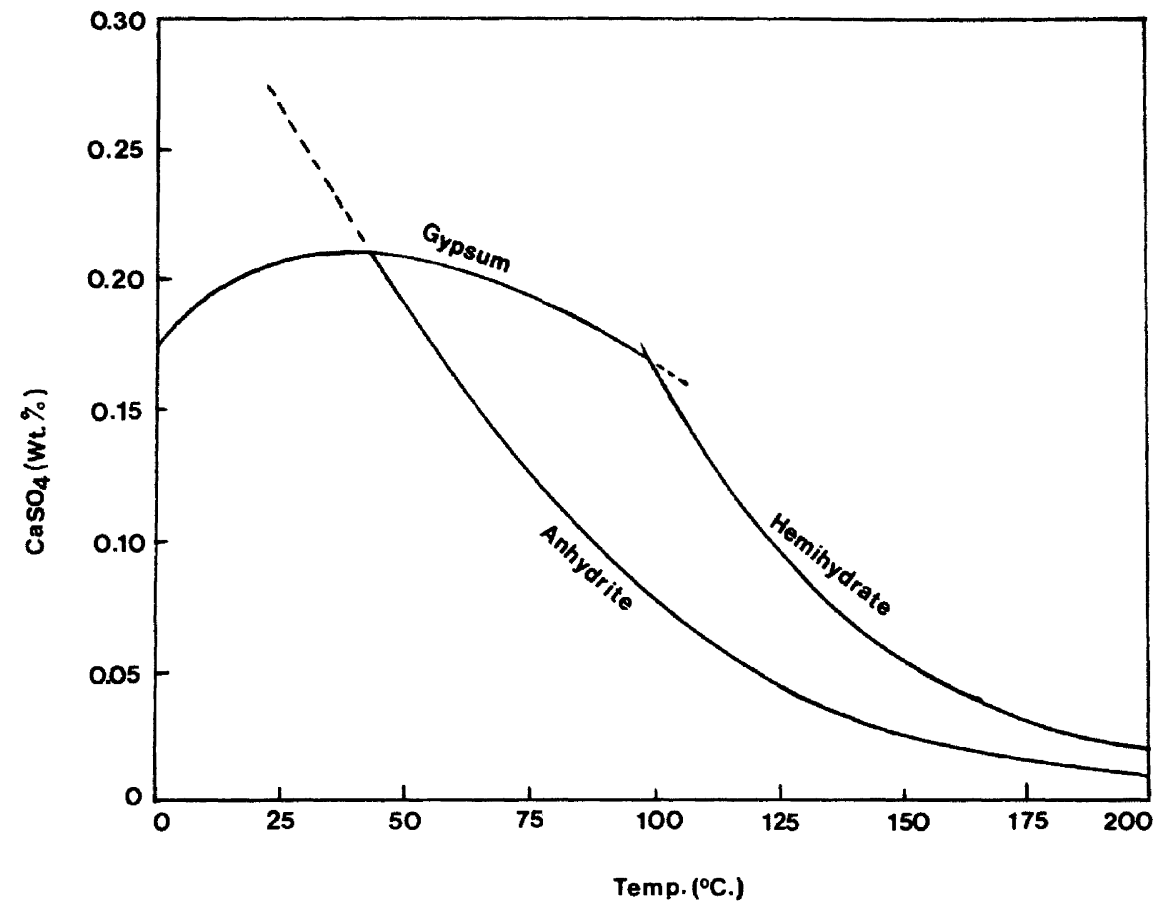

FIGURE 2.9. Ref. [86]. Solubility of gypsum, hemihydrate, and anhydrite in water.

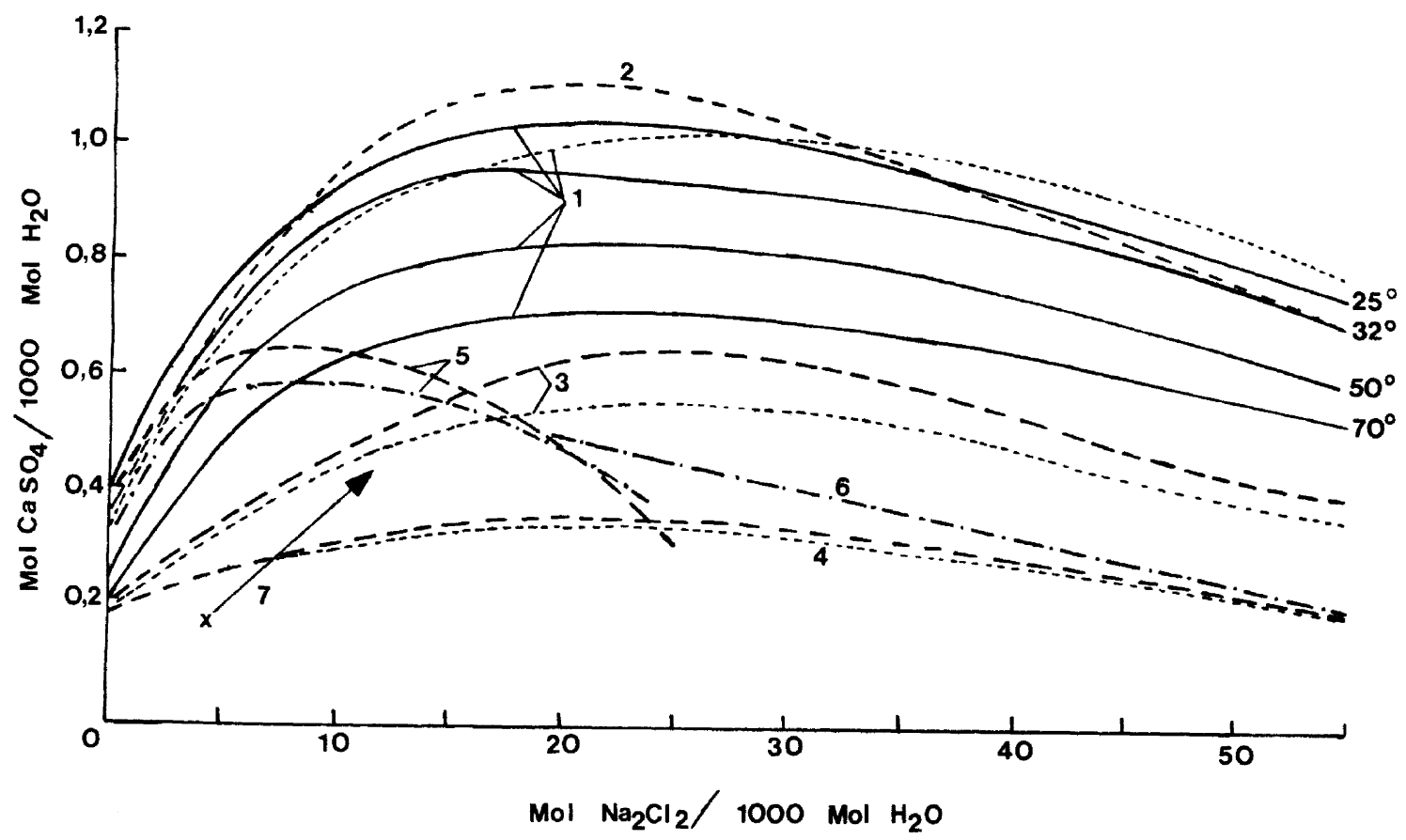

FIGURE 2.10. Solubility of gypsum and anhydrite in saline solutions from $25-70^{\circ} \mathrm{C}$. Solid phases; anhydrite $=$ solid and broken lines; gypsum-dotted lines (heavy and light). 1 [93]; 2-4 [94]; 5 [95] 6, extrapolated from 3 and 4; 7 , seawater and its alterations in concentration. 


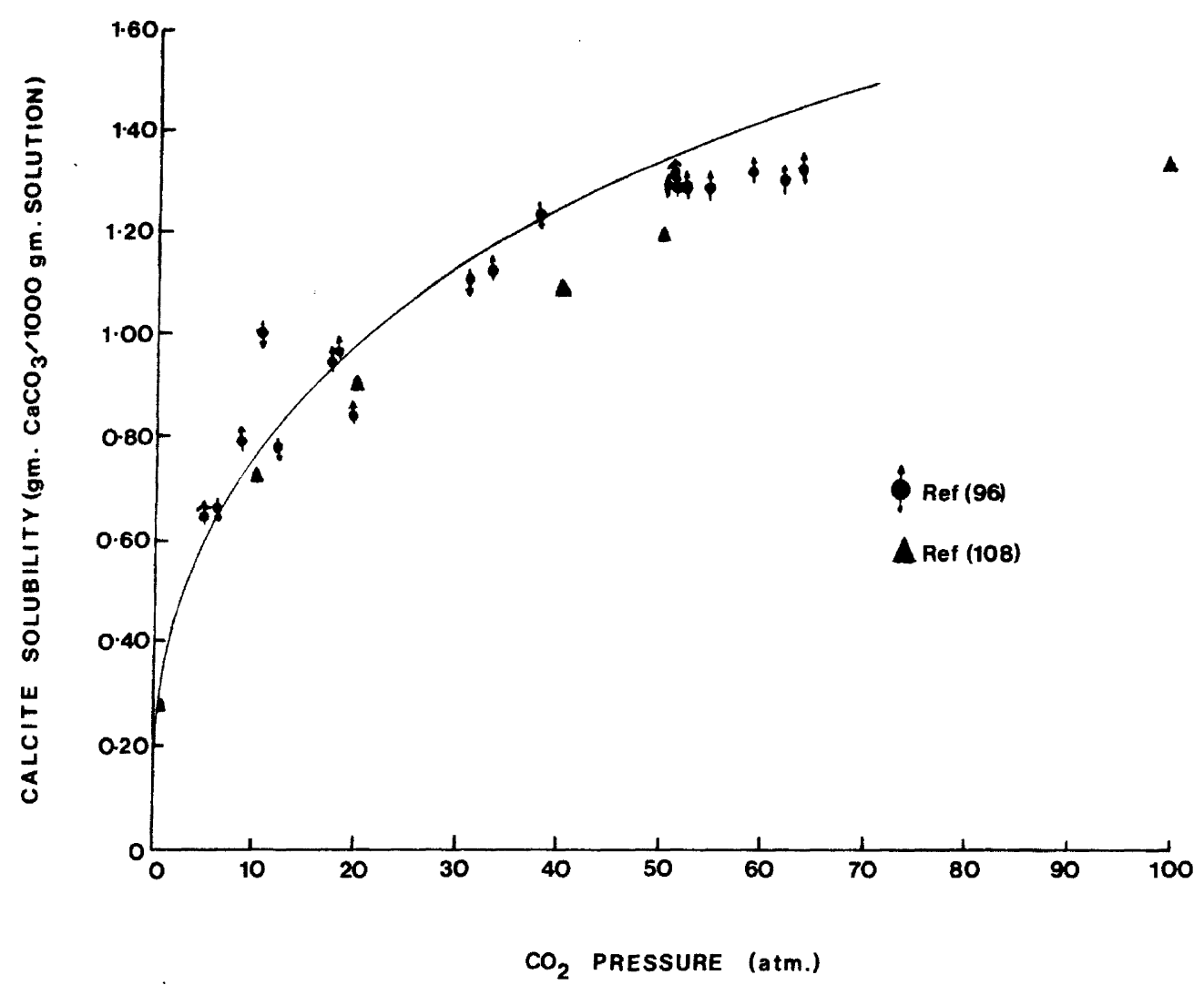

FigURE 2.11. The solubility of calcite in water at $75^{\circ} \mathrm{C}$ as a function of $\mathrm{CO}_{2}$ pressure.

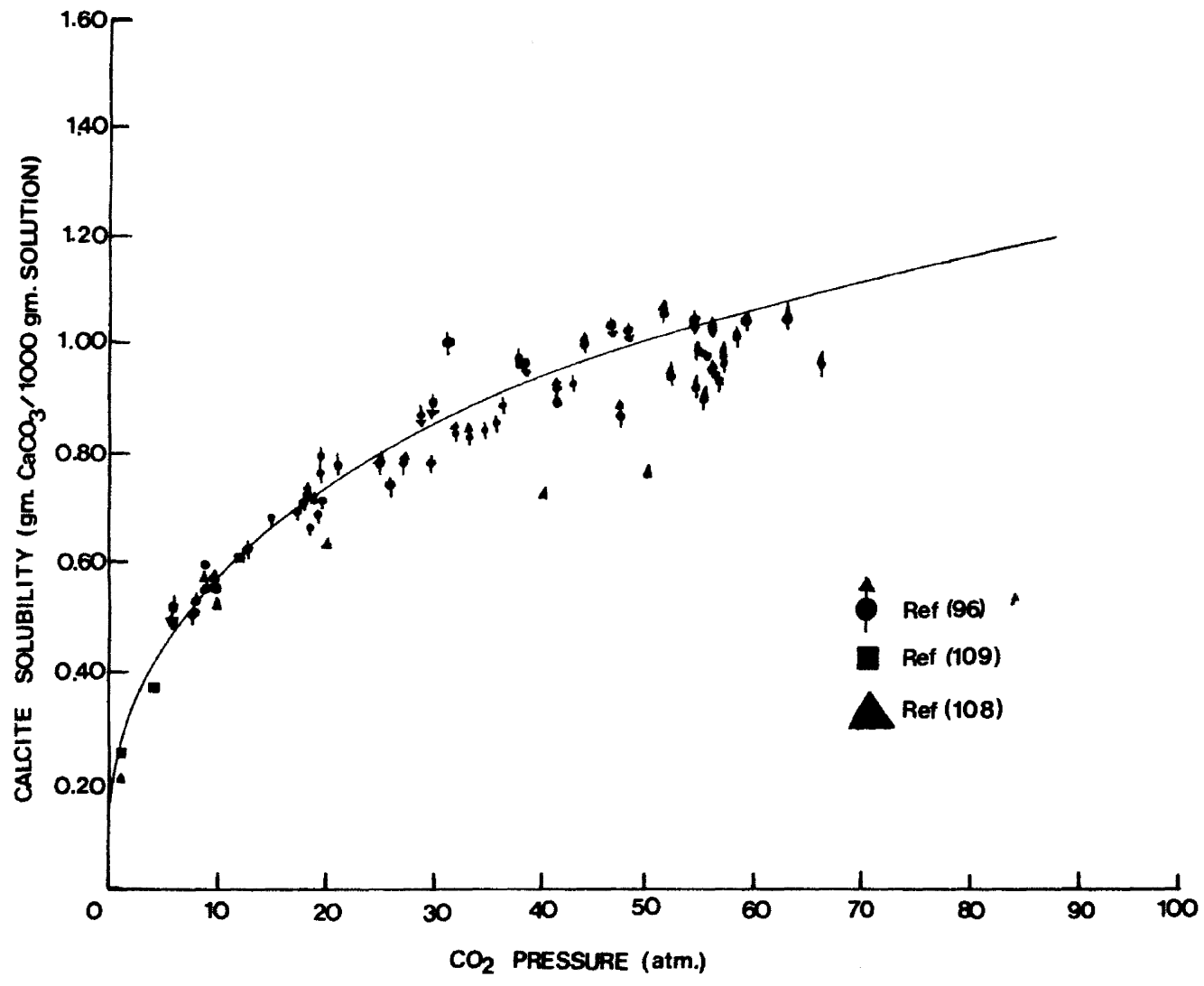

Figure 2.12. The solubility of calcite in water at $100^{\circ} \mathrm{C}$ as a function of $\mathrm{CO}_{2}$ pressure. 


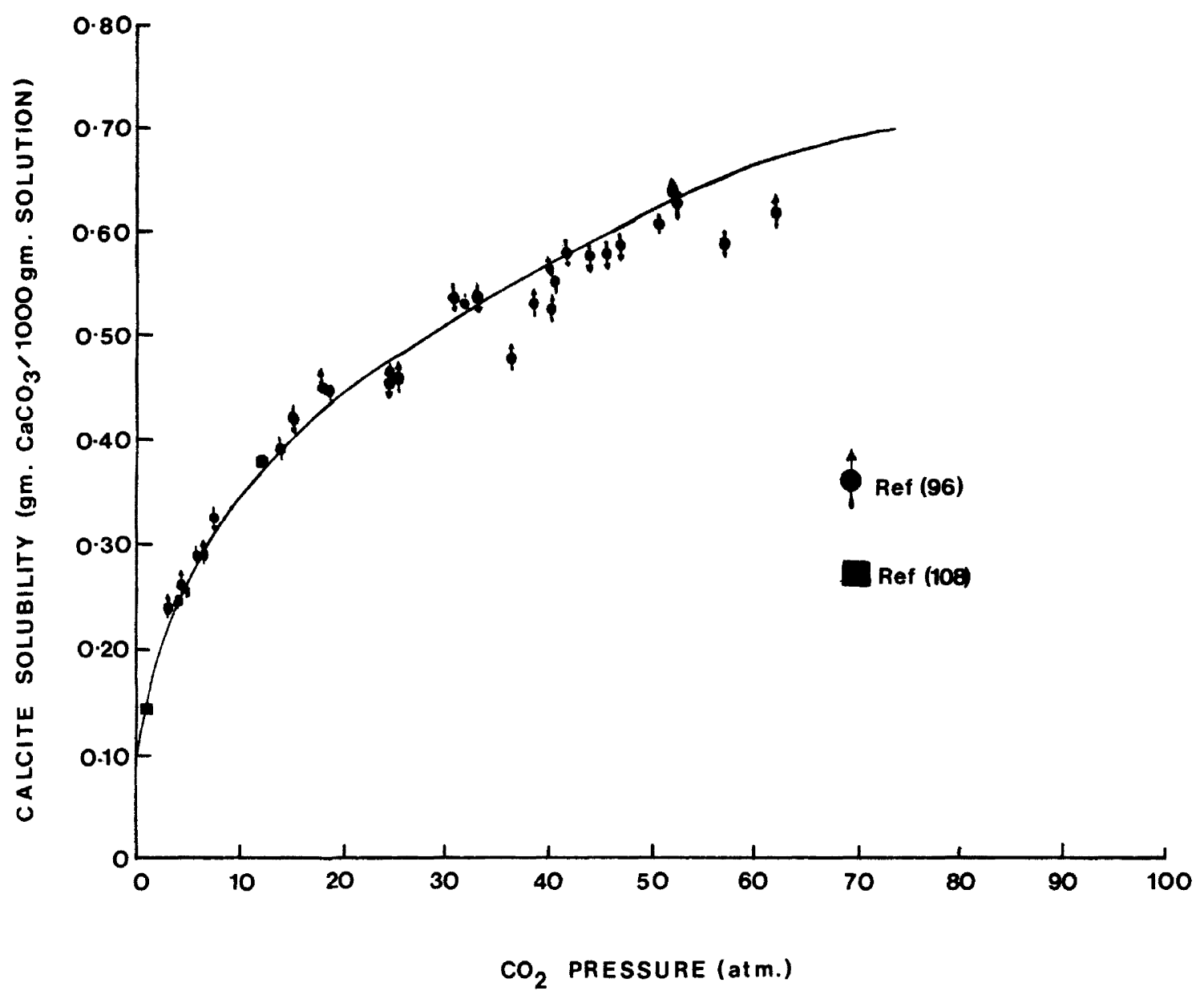

FigURE 2.13. The solubility of calcite in water at $125^{\circ} \mathrm{C}$ as a function of $\mathrm{CO}_{2}$ pressure. 


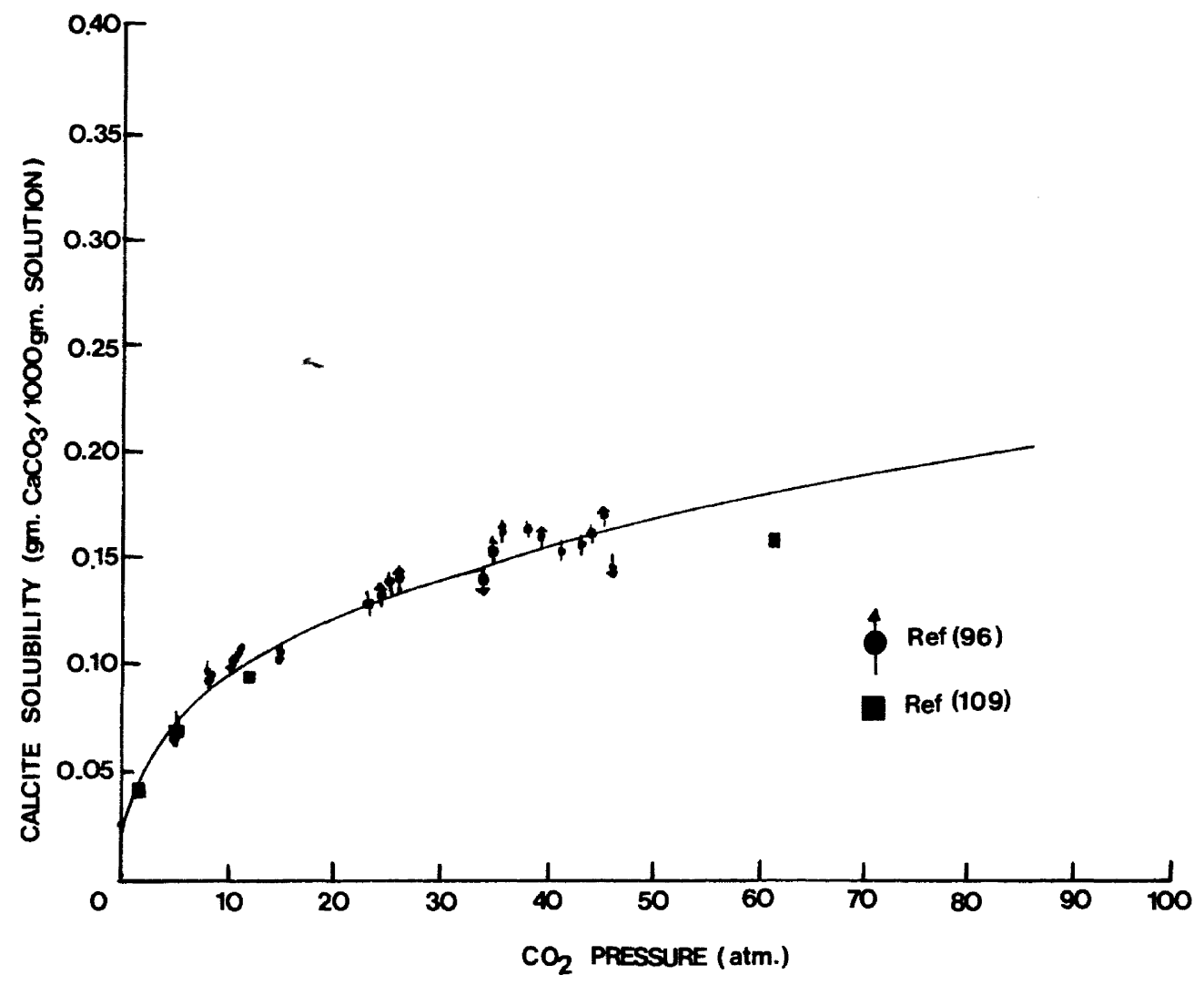

Figure 2.14. The solubility of calcite in water at $150^{\circ} \mathrm{C}$ as a function of $\mathrm{CO}_{2}$ pressure.

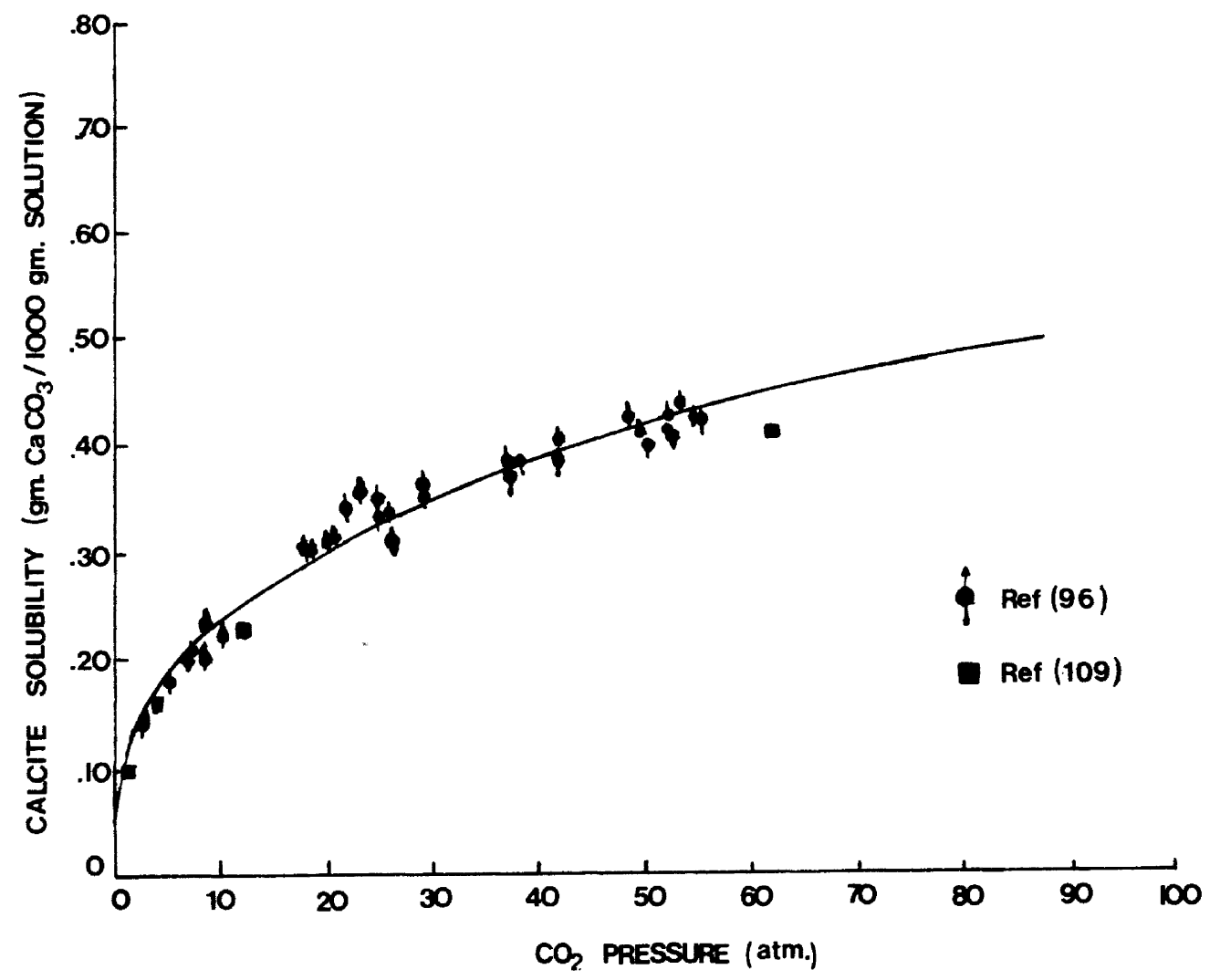

FIGURE 2.15. The solubility of calcite in water at $200^{\circ} \mathrm{C}$ as a function of $\mathrm{CO}_{2}$ pressure. 
Table 2.40 .

Effect of pressure on the solubility of calcite in water at $274 \mathrm{~K}$ and thermodynamic solubility products $\left[\mathrm{CaCO}_{3}(\mathrm{~s})=\mathrm{Ca}^{2+}+\mathrm{CO}_{3}{ }^{2-}\right]$

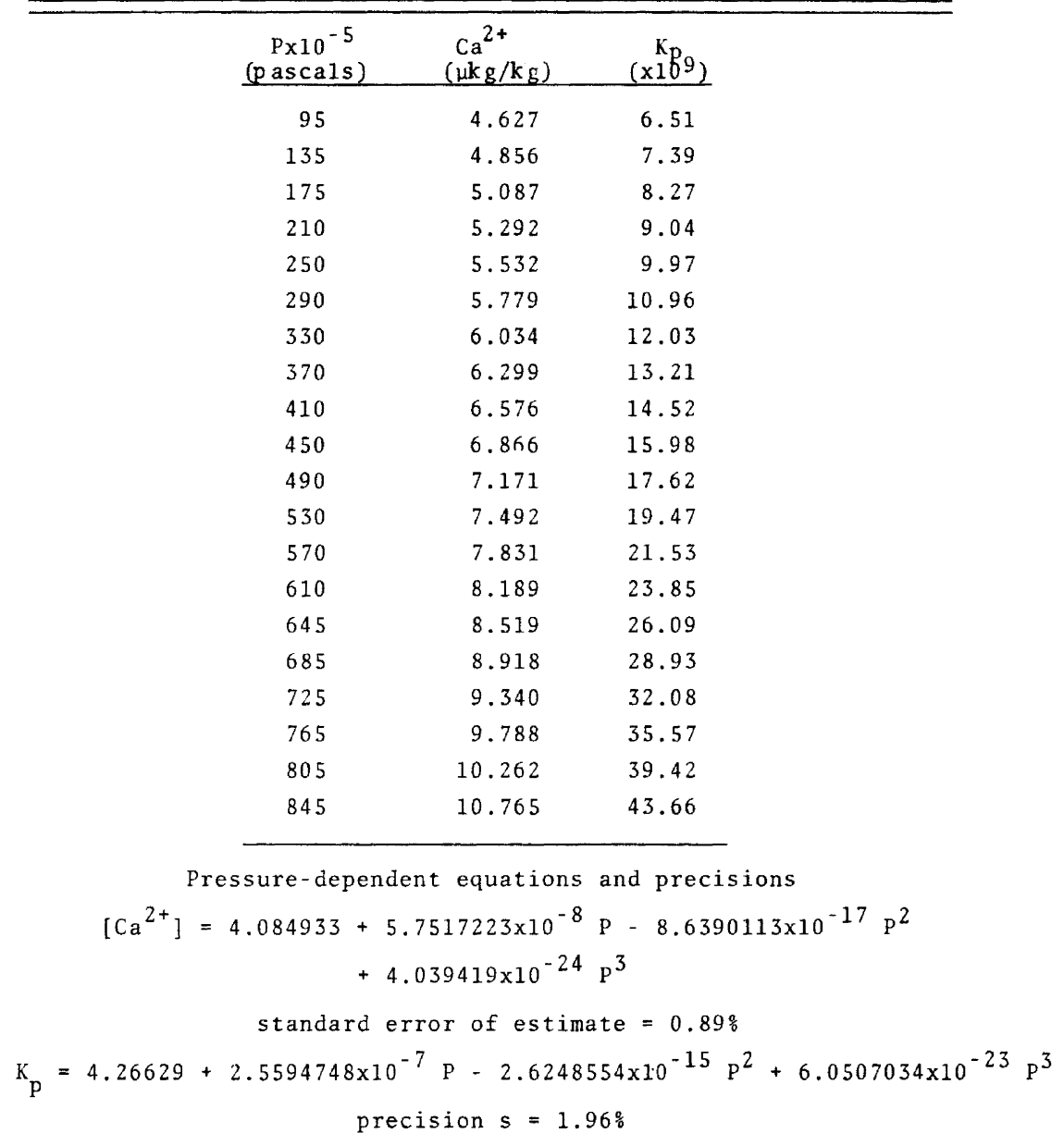


Table 2.41 .

Effect of pressure on the solubility of calcite in water

at $281 \mathrm{~K}$ and thermodynamic solubility products

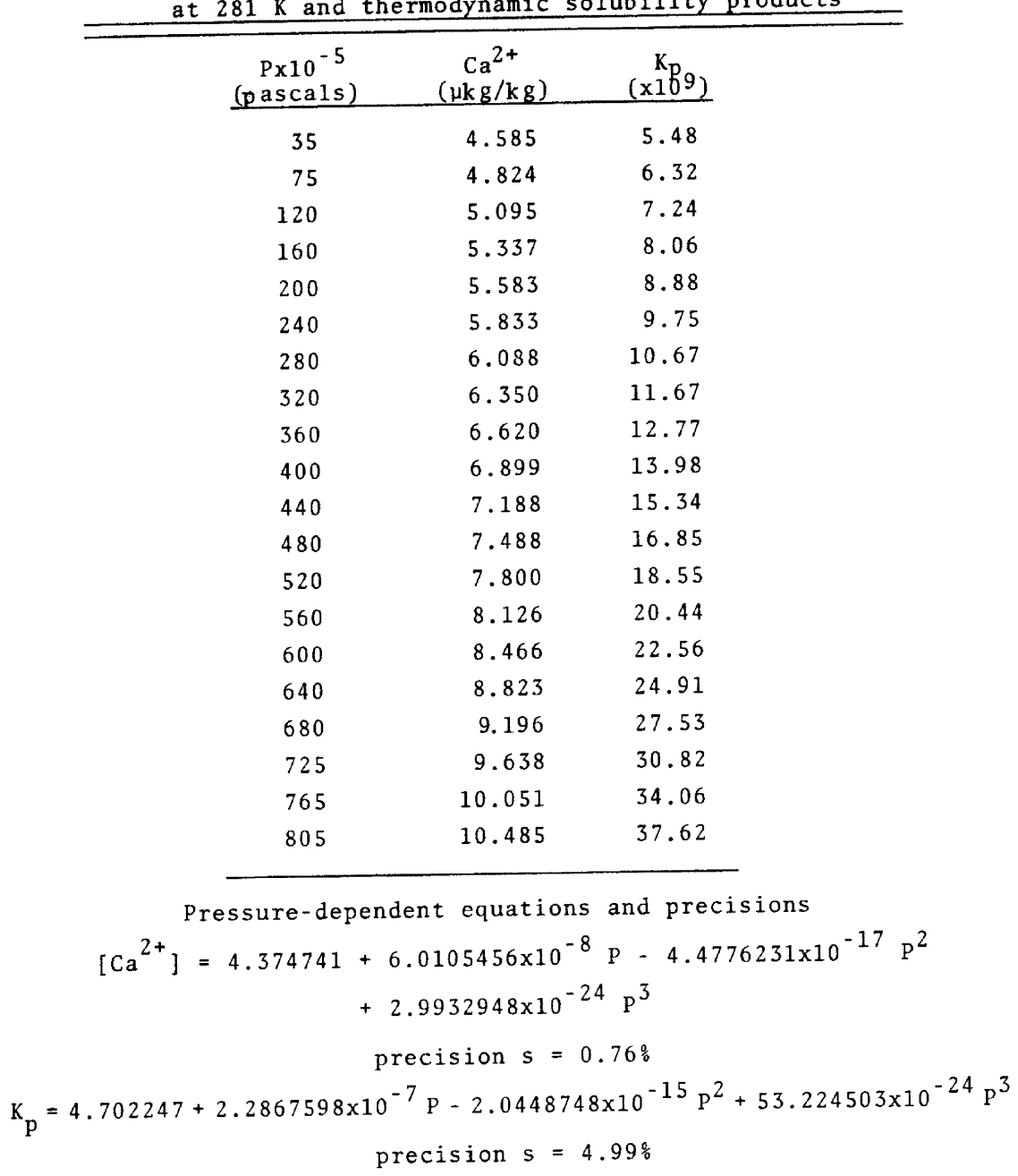


Table 2.42 .

Effect of pressure on the solubility of calcite in water at $300 \mathrm{~K}$ and thermodynamic solubility products

\begin{tabular}{|c|c|c|}
\hline $\begin{array}{r}\mathrm{P} \times 10^{-5} \\
(\mathrm{p} \text { ascals }) \\
\end{array}$ & $\begin{array}{c}\mathrm{Ca}^{2+} \\
(\mu \mathrm{kg} / \mathrm{kg})\end{array}$ & $\begin{array}{r}\mathrm{K}_{1} \\
\left(\times 1{ }^{2}\right.\end{array}$ \\
\hline 45 & 5.296 & 4.91 \\
\hline 85 & 5.415 & 5.17 \\
\hline 130 & 5.576 & 5.57 \\
\hline 170 & 5.743 & 6.03 \\
\hline 210 & 5.929 & 6.57 \\
\hline 250 & 6.133 & 7.21 \\
\hline 290 & 6.355 & 7.95 \\
\hline 330 & 6.593 & 8.77 \\
\hline 370 & 6.845 & 9.69 \\
\hline 410 & 7.110 & 10.71 \\
\hline 450 & 7.386 & 11.81 \\
\hline 490 & 7.673 & 13.01 \\
\hline 530 & 7.969 & 14.30 \\
\hline 570 & 8.272 & 15.68 \\
\hline 615 & 8.620 & 17.35 \\
\hline 655 & 8.934 & 18.93 \\
\hline 695 & 9.252 & 20.60 \\
\hline 735 & 9.571 & 22.37 \\
\hline 775 & 9.891 & 24.23 \\
\hline 815 & 10.210 & 26.18 \\
\hline 855 & 10.526 & 28.22 \\
\hline
\end{tabular}

$$
\begin{aligned}
& \text { Pressure-dependent equations and precisions } \\
& {\left[\mathrm{Ca}^{2+}\right]=5.190895+1.9778396 \times 10^{-8} \mathrm{P}+8.0679045 \times 10^{-16} \mathrm{p}^{2}} \\
& -3.6058291 .10^{-24} p^{3} \\
& \text { precision } \mathrm{s}=1.05 \% \\
& K_{p}=4.731204+2.6838933 \times 10^{-8} \mathrm{p}+2.8998339 \times 10^{-15} \mathrm{p}^{2} \\
& \text { precision } \mathrm{s}=2.96 \%
\end{aligned}
$$


Tab1e 2.43

Effect of pressure on the solubility of calcite in water at $298 \mathrm{~K}$ and thermodynamic solubility products

\begin{tabular}{|c|c|c|}
\hline $\begin{array}{r}\operatorname{Px} 10^{-5} \\
\text { (pasca1s) } \\
\end{array}$ & $\begin{array}{c}\mathrm{Ca}^{2+} \\
(\mu \mathrm{kg} / \mathrm{kg}) \\
\end{array}$ & $\begin{array}{r}K_{\mathrm{p}} \\
\left(\times 10^{2}\right) \\
\end{array}$ \\
\hline 25 & 4.898 & 5.04 \\
\hline 75 & 5.151 & 4.68 \\
\hline 130 & 5.431 & 4.71 \\
\hline 180 & 5.687 & 5.10 \\
\hline 230 & 5.945 & 5.80 \\
\hline 280 & 6.205 & 6.76 \\
\hline 330 & 6.468 & 7.95 \\
\hline 380 & 6.734 & 9.34 \\
\hline 430 & 7.003 & 10.88 \\
\hline 480 & 7.276 & 12.55 \\
\hline 530 & 7.553 & 14.31 \\
\hline 580 & 7.834 & 16.11 \\
\hline 630 & 8.121 & 17.93 \\
\hline 685 & 8.442 & 19.91 \\
\hline 735 & 8.739 & 21.64 \\
\hline 785 & 9.043 & 23.28 \\
\hline 835 & 9.353 & 24.78 \\
\hline 890 & 9.702 & 26.23 \\
\hline 940 & 10.027 & 27.33 \\
\hline
\end{tabular}

Pressure-dependent equations and precisions

$$
\begin{gathered}
{\left[\mathrm{Ca}^{2+}\right]=4.7712206+5.0521587 \times 10^{-8} \mathrm{P}+1.0647239 \times 10^{-17} \mathrm{p}^{2}} \\
+4.9697389 \times 10^{-25} \mathrm{p}^{3} \\
\text { precision } \mathrm{s}=3.4 \% \\
\mathrm{~K}_{\mathrm{p}}=5.3800985-1.5579606 \times 10^{-7} \mathrm{P}+8.6712745 \times 10^{-15} \mathrm{P}^{2}-4.818458 \times 10^{-23} \mathrm{P}^{3} \\
\text { precision } \mathrm{s}=3.78 \%
\end{gathered}
$$


Table 2.44 .

The solubility of calcite in solutions containing $\mathrm{NaCl}$ and $\mathrm{NaHCO}_{3}$ [concentration of $\mathrm{NaHCO}_{3}=0.04 \mathrm{~mol} / \mathrm{m}^{3}$ ); $\mathrm{P}=26000$ pascals,

$\mathrm{T}=300 \mathrm{~K}]$

\begin{tabular}{|c|c|c|c|}
\hline $\begin{array}{r}\mathrm{NaCl} 1 \\
\mathrm{~mol} / \mathrm{m}^{3} \\
\end{array}$ & $\begin{array}{l}\mathrm{CaCO}_{3} \\
\mathrm{~mol} 1 / \mathrm{m}^{3}\end{array}$ & $\begin{array}{c}\mathrm{NaCl} \\
\mathrm{mol} / \mathrm{m}^{3}\end{array}$ & $\begin{array}{l}\mathrm{CaCO}_{3} \\
\mathrm{~mol} / \mathrm{m}^{3}\end{array}$ \\
\hline 4 & .5175 & 32 & .465 \\
\hline 6 & .5280 & 34 & .436 \\
\hline 8 & .5400 & 36 & .408 \\
\hline 10 & .5530 & 38 & .582 \\
\hline 12 & .5640 & 40 & .359 \\
\hline 14 & .5730 & 42 & .343 \\
\hline 16 & .5790 & 44 & .335 \\
\hline 18 & .5805 & 46 & .338 \\
\hline 20 & .5775 & 48 & .356 \\
\hline 22 & .5695 & 50 & .391 \\
\hline 24 & .5565 & 52 & .447 \\
\hline 26 & .5390 & 54 & .527 \\
\hline 28 & .5175 & 56 & .639 \\
\hline 30 & .4930 & & \\
\hline
\end{tabular}

\footnotetext{
Concentration-dependent equation and precision

$\mathrm{c}_{\mathrm{m}_{\mathrm{CaCO}}}=0.511263-1.91324 \times 10^{-3} \mathrm{M}+1.07952 \times 10^{-3} \mathrm{M}^{2}$

$-5.3719 \times 10^{-5} \mathrm{M}^{3}+6.38586 \times 10^{-7} \mathrm{M}^{4}$

$M=$ molal concentration of sodium chloride

precision, $\mathrm{s}=1.70 \%$
} 
Table 2.45.

The solubility of calcite in solutions containing $\mathrm{NaCl}$

\begin{tabular}{cccc}
\multicolumn{4}{c}{$[\mathrm{P}=35700 \mathrm{pascals} ; \mathrm{T}=301 \mathrm{~K}]$} \\
\hline $\begin{array}{c}\mathrm{NaC1} \\
\mathrm{mol} / \mathrm{m}^{3}\end{array}$ & $\begin{array}{l}\mathrm{CaCO} 3 \\
\mathrm{~mol} / \mathrm{m} 3\end{array}$ & $\begin{array}{c}\mathrm{NaC1} \\
\mathrm{mol} / \mathrm{m}^{3}\end{array}$ & $\begin{array}{c}\mathrm{CaCO} 3 \\
\mathrm{~mol} / \mathrm{m}^{3}\end{array}$ \\
\hline 8 & .6050 & 36 & .7065 \\
10 & .6085 & 38 & .7090 \\
12 & .6140 & 40 & .7105 \\
14 & .6220 & 42 & .7115 \\
16 & .6305 & 44 & .7115 \\
18 & .6400 & 46 & .7115 \\
20 & .6500 & 48 & .7120 \\
22 & .6600 & 50 & .7130 \\
24 & .6695 & 52 & .7150 \\
26 & .6780 & 54 & .7185 \\
28 & .6860 & 56 & .7240 \\
30 & .6930 & 58 & .7330 \\
32 & .6985 & 60 & .7450 \\
34 & .7030 & & \\
\hline
\end{tabular}

Concentration-dependent equation and precision

$$
\begin{gathered}
\mathrm{c}_{\mathrm{m}_{\mathrm{CaCO}_{3}}}=0.629765-0.0824625 \mathrm{M}+7.882835 \times 10^{-4} \mathrm{M}^{2} \\
-9.92469 \times 10^{-5} \mathrm{M}^{3}+1.488825 \times 10^{-8} \mathrm{M}^{4} \\
\mathrm{M}=\text { molal concentration of sodium chloride } \\
\text { precision, } \mathrm{s}=0.00 \%
\end{gathered}
$$


Table 2.46 .

The solubility of calcite in solutions containing $\mathrm{CaCl}_{2}$ and $\mathrm{NaCl}$ [concentration of $\mathrm{CaCl}_{2}=1.00 \mathrm{~mol} / \mathrm{m}^{3}$;

$\mathrm{P}=35000$ pascals; $\mathrm{T}=302 \mathrm{~K}]$

\begin{tabular}{cccc}
\hline \multicolumn{1}{c}{$\mathrm{NaC1} 3$} \\
\hline $\begin{array}{c}\mathrm{CaCO}_{3} \\
\mathrm{~mol} / \mathrm{m}^{3}\end{array}$ & $\begin{array}{c}\mathrm{NaCl} \\
\mathrm{mol} / \mathrm{m}^{3}\end{array}$ & $\begin{array}{l}\mathrm{CaCO}_{3} \\
\mathrm{~mol}^{3} 3\end{array}$ \\
\hline 0 & .353 & 55 & .502 \\
5 & .374 & 60 & .520 \\
10 & .390 & 65 & .539 \\
15 & .402 & 70 & .557 \\
20 & .412 & 75 & .572 \\
25 & .422 & 80 & .584 \\
30 & .431 & 85 & .591 \\
35 & .442 & 90 & .590 \\
40 & .454 & 95 & .579 \\
45 & .468 & 100 & .555 \\
50 & .484 & & \\
\hline
\end{tabular}

Concentration-dependent equation and precision

$$
\begin{gathered}
\mathrm{c}_{\mathrm{m}_{\mathrm{CaCO}_{3}}}=0.3530265+4.8765 \times 10^{-3} \mathrm{M}-1.4755 \times 10^{-4} \mathrm{M}^{2} \\
+2.907575 \times 10^{-6} \mathrm{M}^{3}-1.717735 \times 10^{-8} \mathrm{M}^{4} \\
\mathrm{M}=\text { molal concentration of sodium chloride } \\
\text { precision, } \mathrm{s}=0.89 \%
\end{gathered}
$$

Tab1e 2.47

The solubility of calcite in solutions containing $\mathrm{CaCl}_{2}$ and $\mathrm{NaCl}$ [concentration of $\mathrm{CaCl}_{2}=2.47 \mathrm{~mol} / \mathrm{m}^{3}$;

\begin{tabular}{cccc}
\multicolumn{4}{c}{$\mathrm{P}=26000 \mathrm{pasca} 1 \mathrm{~s} ; \mathrm{T}=300 \mathrm{~K}]$} \\
\hline $\begin{array}{c}\mathrm{NaCl}_{\mathrm{mol} / \mathrm{m}^{3}} \\
\mathrm{CaCO}\end{array}$ & $\begin{array}{c}\mathrm{NaCl} \\
\mathrm{mol} / \mathrm{m}^{3}\end{array}$ & $\begin{array}{l}\mathrm{CaCO}_{3} \\
\mathrm{~mol} / \mathrm{m}^{3}\end{array}$ \\
\hline 0 & .250 & 55 & .335 \\
5 & .263 & 60 & .339 \\
10 & .275 & 65 & .343 \\
15 & .285 & 70 & .347 \\
20 & .294 & 75 & .352 \\
25 & .302 & 80 & .357 \\
30 & .309 & 85 & .363 \\
35 & .315 & 90 & .369 \\
40 & .321 & 95 & .377 \\
45 & .326 & 100 & .385 \\
50 & .330 & & \\
\hline
\end{tabular}

$$
\begin{aligned}
& \text { Concentration-dependent equation and precision } \\
& \mathrm{c}_{\mathrm{maCO}_{3}}=0.250000+2.78839 \times 10^{-3} \mathrm{M}-3.31517 \times 10^{-5} \mathrm{M}^{2} \\
& +1.87678 \times 10^{-7} \mathrm{M}^{3} \\
& M=\text { molal concentration of sodium chloride } \\
& \text { precision, } s=0.00 \%
\end{aligned}
$$


Table 2.48 .

\begin{tabular}{|c|c|c|c|c|c|}
\hline $\begin{array}{l}\mathrm{NaHCO}_{3} \\
\mathrm{~mol} / \mathrm{m}^{3} \\
\end{array}$ & $\begin{array}{c}\mathrm{NaCl} \\
\mathrm{mol} / \mathrm{m}^{3}\end{array}$ & $\begin{array}{l}\mathrm{CaCl}_{2} \\
\mathrm{~mol} / \mathrm{m}^{3}\end{array}$ & $\begin{array}{c}\mathrm{P} \\
\left(\mathrm{Pax} 10^{-5}\right) \\
\end{array}$ & $\begin{array}{c}\mathrm{T} \\
(\mathrm{K}) \\
\end{array}$ & $\begin{array}{l}\mathrm{CaCO}_{3} \\
\mathrm{~mol} / \mathrm{m}^{3} \\
\end{array}$ \\
\hline 19.3 & 0.53 & 0 & 0.254 & 300 & 0.015 \\
\hline 2.10 & 19.79 & 0 & 0.254 & 300 & 0.150 \\
\hline 0 & 56.38 & 0 & 0.274 & 299 & 0.700 \\
\hline 0 & 18.65 & 0.84 & 0.254 & 300 & 0.400 \\
\hline
\end{tabular}

sulfate-water: $\mathrm{CaSO}_{4} \cdot 2 \mathrm{H}_{2} \mathrm{O}$ (gypsum), $\mathrm{CaSO}_{4} \cdot 1 / 2 \mathrm{H}_{2} \mathrm{O}$ (bassanite), $\gamma-\mathrm{CaSO}_{4}$ (soluble anhydrite), and $\beta-\mathrm{CaSO}_{4}$ (anhydrite). A good deal of controversy exists as to the actual existence of two distinct compounds other than the dihydrate and anhydrite; however, both thermal dehydration studies [99] and x-ray studies [100] provide substantial evidence for the existence of the hemihydrate. On the dehydration of gypsum, water is removed zeolitically but with slight changes in cell parameter due to lack of collapse of the $\mathrm{Ca}-\mathrm{SO}_{4}$ framework until $n=1 / 2$. Further heating expels the remaining water molecules yielding $\gamma-\mathrm{CaSO}_{4}$, again with a slight deformation of the structure and corresponding change in cell parameters. The hemi-hydrate $\rightarrow \gamma-\mathrm{CaSO}_{4}$ may not be recognized.

Of the four principal phases in the system $\mathrm{CaSO}_{4}$ $\mathrm{H}_{2} \mathrm{O}$, only two, the hemihydrate and $\gamma \cdot \mathrm{CaSO}_{4}$, exist metastably. Thus under equilibrium conditions the reaction

$$
\text { gypsum } \rightleftarrows \text { anhydrite }+ \text { water }
$$

occurs without the formation of intermediate compounds. The temperature of the transition of gypsum to anhydrite in pure water is $315 \mathrm{~K}$. Gypsum persists metastably above this temperature where it inverts to the metastable hemi-hydrate at $370 \mathrm{~K}$ [92]. The solubilities of gypsum and anhydrite in various saline solutions are shown in figure 2.10 . This shows that at $303 \mathrm{~K}$ gypsum is the stable phase up to a concentration of 4.8 times the normal salinity of sea water.

The effects of pressure and of different concentrations of $\mathrm{NaCl}$ on the gypsum-anhydrite equilibrium temperature have been calculated by Macdonald [101] and are illustrated in figures 2.16 and 2.17. At $314 \mathrm{~K} d P / d T=$ $85.4 \times 10^{5} \mathrm{~Pa} / \mathrm{K}$ if the same pressure acts on all phases, but $d P / d T=-39.45 \times 10^{5} \mathrm{~Pa} / \mathrm{K}$ if the rock pressure is assumed to act on the solid and hydrostatic pressure on the liquid phase.

Gypsum in contact with aqueous salt solutions is converted to natural anhydrite at $363.5 \mathrm{~K}$. The mechanism of the reaction is the conversion of gypsum first to the hemi-hydrate and then to natural anhydrite. The investigation shows that gypsum is the stable phase of calcium sulfate precipitated from water solutions at temperatures as high as $370 \mathrm{~K}$. The solid phases occurring during the dehydration of gypsum [102] are summarized in table 2.49 .

\subsubsection{Additional Information}

a. Thermodynamics of brine-salt equilibria.

Wood [103] has developed a thermodynamic model for concentrated brines which is capable of predicting the solubilities of many of the common evaporite minerals in chloro-sulfate brines. Solubility curves and solution compositions were predicted for the systems $\mathrm{NaCl}-\mathrm{KCl}-\mathrm{MgCl}_{2}-\mathrm{CaCl}_{2}-\mathrm{H}_{2} \mathrm{O}$ and $\mathrm{NaCl}-\mathrm{MgSO}_{4}-\mathrm{H}_{2} \mathrm{O}$. The model requires data on the constituent binary and quaternary systems only. Data on the binary systems must include measurements on the unsaturated solutions but solubility data is all that is required for the quaternary systems.

Pitzer et al. [110,111] have discussed several approaches which use equations to provide a convenient analytical representation of the thermodynamic properties of sodium chloride.

b. Models for calculating density and vapor pressure of geothermal brines.

Potter and Haas [104] have developed a model for estimating the density of a brine at a known temperature, pressure and composition using the densities of the component salt solutions in the complex brine. In addition a model for estimating the vapor pressure is also reported. The methods can be used to estimate the partial molal volume and partial molal enthalpy of $\mathrm{H}_{2} \mathrm{O}$ in the natural brine and the partial molal volume change and partial molal heat change for the $\mathrm{H}_{2} \mathrm{O}$ component in the vaporization process. Preliminary steam tables are available $[105,106]$ that give the thermodynamic data for the coexisting liquid and gas phases for the $\mathrm{NaCl}-\mathrm{H}_{2} \mathrm{O}$ system, for liquid concentrations between $0 \mathrm{~mol}$ $\mathrm{NaCl} / \mathrm{kgH}_{2} \mathrm{O}$ and halite saturation at temperatures between 353 and $598 \mathrm{~K}$. The densities of aqueous sodium chloride solutions from 273 to $773 \mathrm{~K}$ at pressures up to 2 $\times 10^{8} \mathrm{~Pa}$ have also been reported using a regression analysis of available data [107].

At a pressure of $10^{5} \mathrm{~Pa}$ and with 93 parts per thousand of chlorine by weight, the transition of anhydrite to gypsum is predicted to occur at $303 \mathrm{~K}$. The depth to which gypsum is found in nature will depend on the temperature gradient, composition of groundwaters and ratio of lithostatic to hydrostatic pressure acting on the calcium sulfate deposit. 




FIGURE 2.16. Pressure-temperature relations for the reaction gypsum $\approx$ anhydrite + water.

A. Pure water; same pressure on all phases.

B. Pure water; rock pressure on solid phases, hydrostatic pressure on water.

C. Saturated $\mathrm{NaCl}$ solution; same pressure on all phases.

D. Saturated $\mathrm{NaCl}$ solution; rock pressure on solid phases; hydrostatic pressure on $\mathrm{NaCl}$ solution.

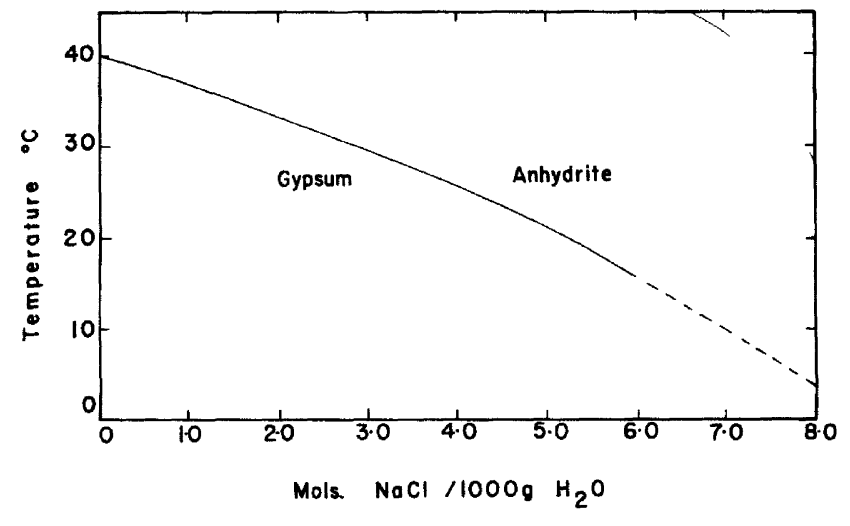

$\begin{array}{lllllll}34 & 64 & 91 & 115 & 137 & 157 & 176\end{array}$

FiguRE 2.17. Ref. [101]. Dependence of the dehydration temperature of gypsum on concentration of $\mathrm{NaCl}$ in solution at $10^{5}$ pascal pressure.

\begin{tabular}{|c|c|c|}
\hline $\begin{array}{r}\text { Time } \\
(\mathrm{sec})\end{array}$ & $\begin{array}{c}\text { Initial water } \\
\text { lost }\left(\frac{8}{8}\right)\end{array}$ & Solid Phase \\
\hline 30 & 0 & $\mathrm{CaSO}_{4} \cdot 2 \mathrm{H}_{2} \mathrm{O}$ \\
\hline 120 & 3.7 & $\mathrm{CaSO}_{4} \cdot 2 \mathrm{H}_{2} \mathrm{O}$ and $\mathrm{CaSO}_{4} \cdot \frac{3}{2} \mathrm{H}_{2} \mathrm{O}$ \\
\hline 240 & 6.2 & $\mathrm{CaSO}_{4} \cdot 2 \mathrm{H}_{2} \mathrm{O}$ and $\mathrm{CaSO}_{4} \cdot \frac{1}{2} \mathrm{H}_{2} \mathrm{O}$ \\
\hline 978 & 3.1 & $\mathrm{CaSO}_{4} \cdot 2 \mathrm{H}_{2} \mathrm{O}$ and $\mathrm{CaSO}_{4} \cdot \frac{1}{2} \mathrm{H}_{2} \mathrm{O}$ \\
\hline 2508 & 14.9 & $\mathrm{CaSO}_{4} \cdot 2 \mathrm{H}_{2} \mathrm{O}$ and $\mathrm{CaSO}_{4} \cdot \frac{1}{2} \mathrm{H}_{2} \mathrm{O}$ \\
\hline 2880 & 11.7 & $\mathrm{CaSO}_{4} \cdot 2 \mathrm{H}_{2} \mathrm{O}$ and $\mathrm{CaSO}_{4} \cdot \frac{1}{2} \mathrm{H}_{2} \mathrm{O}$ \\
\hline 5400 & 26.8 & $\mathrm{CaSO}_{4} \cdot 2 \mathrm{H}_{2} \mathrm{O}$ and $\mathrm{CaSO}_{4} \cdot \frac{1}{2} \mathrm{H}_{2} \mathrm{O}$ \\
\hline 5700 & 31.5 & $\mathrm{CaSO}_{4} \cdot 2 \mathrm{H}_{2} \mathrm{O}$ and $\mathrm{CaSO}_{4} \cdot \frac{1}{2} \mathrm{H}_{2} \mathrm{O}$ \\
\hline 8178 & 68.8 & $\mathrm{CaSO}_{4} \cdot \frac{\mathrm{k}_{2}}{2} \mathrm{O}_{2} \mathrm{O}$ \\
\hline 11442 & 95.2 & Anhydrite \\
\hline 15342 & 95.2 & Anhydrite \\
\hline
\end{tabular}




\section{References}

[1] Bloomberg, A., and Ladenburg, K., J. Electrochem. Soc., 106, 56 (1959).

[2] Bauer, N., and Lewin, S.Z., in "Technique of Organic Chemistry, Vol. 1, Physical Methods, Part 1," 3rd Ed., Weissberger, A., Editor, Interscience Publ., Co., New York (1959).

[3] Grimshaw, R.W., in "The Chemistry and Physics of Clays," 4th Ed. (revised), Wiley-Interscience, New York (1971).

[4] Jamieson, J.C., and Lawson, A.W., J. Appl. Physics, 33, 776 (1962).

[5] Sato, Y., Ida, Y., and Akimoto, S., High Temp. High Pressures, 5, 679 (1973).

[6] Sturtevant, J.M., in "Technique of Organic Chemistry, Vol. 1, Physical Methods, Part 1," 3rd Ed., W eissberger, A., Ed., Interscience Publ. Co., New York (1959).

[7] Staveley, L.A.K., and Linford, R.G., J. Chem. Thermodynam., I, 1 (1969).

[8] Potter, R.W., II, Babcock, R.S., and Brown, D.L., J. Res. U.S. Geol. Survey, 5, 389 (1977).

[9] Kaufman, D.W., Ed., "Sodium Chloride. The Production and Properties of Salt and Brine," ACS Monograph Series, Reinhold Publ. Corp., New York (1960).

[10] "The Sterling Brine Handbook," International Salt Company (1972).

[11] Doelter, C., and Leitmeier, H., Eds. "Handbuch der Mineralchemie, 4, Part 2," Verlag von Theodor Steinkopff, Dresden and Leipzig (1929).

[12] Sterry Hunt, N., Amer. J. Sci., 19, 417 (1855).

[13] Retgers, J., Z. Phys. Chem. 3, 289 (1889).

[14] Moseley, H.G.J., Phil. Mag.. 26, 1024 (1913).

[15] Spencer, L.J., Min. Mag., 21, 337 (1927).

[16] Spannenberg, K., Z. Kryst., 57, 494 (1922).

[17] Kaufman, D.W., Ed. "Sodium Chloride. The Production and Properties of Salt and Brine," p. 592, ACS Monograph Series, Reinhold Publ. Corp., New York (1960).

[18] Madelung. E., and Fuchs, R., Ann. Physik (4), 65, 305 (1921).

[19] Richards, T.W., and Jones, G., J. Amer. Chem. Soc., 31, 176 (1900).

[20] Slater, J.C., Phs. Rev., (2), 23, 492 (1924).

[21] Bridgman, P.W., Proc. Am. Acad. Arts Sci., 74, 21 (1940).

[22] Davey, W.P., Phys. Rev., 21,143 (1923).

[23] Ksanda, C.J., Amer. J. Sci., 22, 131 (1931).

[24] Hanawalt, J.D., Rinn, H.W., and Frevel, L.K., Ind. Eng. Chem., Anal. Ed., 10, 457 (1938).

[25] Olshusen, S.V., Z. Krist., 61, 463 (1925).

[26] Waldo, A.W., Amer. Miner., 20, 575 (1935).

[27] Brill, R., Grimm, H.G., Hermann, C., and Peters, C.L., Ann. der Physik., 426, 393 (1939).

[28] Wasastilerna, J.A., Svenska Vetensk.-Akad. Handlingar., 2 1, No. 5 (1944).

[29] Sidhu, S.S., Am. J. Phys., 16, 199 (1948).

[30] Swanson, H.E., Fuyat, R.K., and Ugrinic, G.M., NBS Circular 539, 2, 41 (1953).

[31] Stull, D.R., and Prophet, H., Eds. "JANAF Thermochemical Tables, Second Edition," NSRDS-NBS 37, June (1971).

[32] Cowley, E.R., J. Phys., C, Solid State Phys., 4 (9), 988 (1971).

[33] Kieffer, S.W., California Institute of Technology, Pasadena, California, (1971); cited by Center for Information and Numerical Data Analysis and Synthesis (CINDAS), Purdue Univ.

[34] Gorbunov, L.V., Russ. J. Phys. Chem., 39 (6), 717 (1965).

[35] Ukshe, E.A., Fiz. Khim. Elektrokhim. Rasplav. Solei Shlakov. Tr. Vses. Soveshch, 29 (1966).
[36] Kovon, T.H. and Henkel, J.H., Can. J. Phys., 49 (1) 20 (1971).

[37] Rossini, F.D., Cowie, P.A., Ellison, F.O., and Browne, C.C., ONR Rpt. ACR17 448 pp. (1956); cited by Center for Information and Numerical Data Analysis and Synthesis (CINDAS), Purdue Univ.

[38] Lu, W.C., Univ. of Utah, Tech. Rept., (1968); cited by Center for Information and Numerical Data Analysis and Synthesis (CINDAS), Purdue Univ.

[39] Sinke, G.C., Thermal Lab.. DOW WADC and ARPA ASTIA. AR-IS-59, AD-214587 (1959).

[40] Bockris, J.O.M. and Richards, N.E., Proc Roy. Soc. (London), A241, 44 (1957).

[41] Kelemen, F. and Neda, A., Studia Univ. Bales-Bolyai, Ser. MathPhys., (2), 81 (1965).

[42] Vilcu, R. and Misdolea, C., Rev. Roum. Chim, 18 (3), 387 (1973).

[43] Deer, W.A., Howie, R.A., and Zussman, J., "Rock-Forming Minerals." Vol. 5. Non-Silicates, Longmans Publ. Co., London (1968):

[44] Braitsch, 0., "Salt Deposits, Their Origin and Composition," Springer-Verlag, New York (1971).

[45] Ludwig, U., and Muller, W., Glas Blaustoffe, 109, 198 (1976).

[46] Dickson, E.C.S., and Binks, W., Phil. Mag., 2, 114 (1926).

[47] Hill, W.L., and Hendricks, S.B., Ind. Eng. Chem., 28, 441 (1936).

[48] Wasastjerna, J.A., "Der Bau Der Sulfatgruppe," Soc. Sci. Fennica, Commentationes Phys.-Math., 2, 26 (1925).

[49] Jung, H., Z. Anorg. U. Allgem. Chem., 142, 73 (1925).

[50] Swanson, H.E., Fuyat, R.K. and Ugrinic, G.M., NBS Circular $539,4,65$ (1953).

[51] Morikawa, H., Minato, L., Tomita, T., and Iwa, S., Acta Cryst., B31, 2164 (1975).

[52] Hawthorne, F.C., and Ferguson, R.B., Can. Miner., 13, 289 (1975).

[53] Barin, I., and Knacke, O., "Thermochemical Properties of Inorganic Substances," Springer-Verlag, New York (1973)

[54] Kubaschewski, O., Evans, E.LL., and Alock, C.B., "Metallurgical Thermochemistry," 4th Ed., Pergamon Press, New York (1967).

[55] Rossini, F.D., Wagman, D.D., Evans, W.H., Levine, S., and Jaffe, I., "Selected Values of Chemical Thermodynamic Properties," NBS Circ. 500; U.S. Govt. Printing Office, Washington, D.C. (1952).

[56] Kelley, K.K., The entropies of inorganic substances; U.S. Bur. Mines Report No. 477 (1950).

[57] Kelley, K.K., Critical evaluation of high temperature heat capacities of inorganic compounds; U.S. Bur. Mines Report No. 476 (1949).

[58] Appleyard, F.C., in "Industrial Minerals and Rocks, 4th Ed., p. 708 (1975).

[59] Wooster, W.A., Z. Kristallog., 94, 375 (1936).

[60] Atoji, M., and Rundle, R.E., J. Chem. Phys., 29, 1306 (1958).

[61] Gillery, F.H., Tech. Rpt., Pennsylvania State Univ., Pa. (1955).

[62] Mcedlow-Petrosjan, O.P., Babuskin, V.I., and Matveev, G.M., "Thermodynamik der Silikate", Berlin: VEB Verlag für Bauwesen (1966).

[63] Humbert, P., and Plicque, F., C.R.Acad. Sci. Paris, 275, 391 (1972).

[64] Harrington, E.A., Am. J. Sci., 13, 467 (1927).

[65] Krieger, P., Am. Min., 15, 23 (1930).

[66] Nagelschmidt, G., Z. Krist., 87, 120 (1934).

[67] Mizgier, S., Z. Krist., 70, 160 (1929).

[68] Swanson, H.E., et al., NBS Circular 539, 2, 51 (1953). 
[69] Armstong, G., Dunham, K.C., Harvey, C.O., Sabine, P.A., and Waters, W.F., Mineral Mag., 29, 667 (1951).

[70] Conley, J.E., and Partridge, E.P., Potash Salts from Texas-New Mexico Polyhalite Deposits; U.S. Bur. Mines Bulletin 459, U.S. Govt. Printing Office, Washington, D.C. (1944).

[71] Braitsch, O., Beitr. Mineral Petr., 8, 84 (1961).

[72] Görgey, R., Tschermak's mineral. petrogr. Mitt., 33, 48 (1915).

[73] Peacock, M.A., Amer. Mineral, 23, 38 (1938).

[74] Gad, G.M., Trans. Brit. Ceram. Soc., 51, 429 (1952).

[75] Sudo, T., and Sato, M., Int. Clay Conference, Jerusalem, Israel, Israel Program for Scientific Translations, (1966).

[76] Berkley, Earl of; Royal Soc. London Philos. Trans., Ser A., 203, 189 (1904).

[77] Schroeder, W.C., Gabriel, A., and Partridge, E.P., J. Amer. Chem. Soc., 57, 1539 (1935).

[78] Benrath, A., Gjedebo, F., Schiffers, B., and Wunderlich, H., Z. Anorg. u. Allg. Chemie., 231,285 (1937).

[79] Keevil, N.B., J., Amer. Chem. Soc., 64, 841 (1942).

[80] Liu, C., and Lindsay, W.T., Jr., Office of Saline W ater, Research and Devel. Prog. Rept. 722, 124 pp. (1972).

[81] Sourirajan, S., and Kennedy, G.C., Am. J. Sci., 260, 137 (1962).

[82] Dickson, F.W., Blount, C.W., and Tunell, G., Amer. J. Sci., 261, 61 (1963).

[83] Booth, H.S., and Bidwell, R.M., J. Amer. Chem. Soc., 72, 2567 (1950).

[84] Partridge, E.P., and White, A.A., J. Amer. Chem. Soc., 5 1, 360 (1929).

[85] Hall, R.E., Robb, J.A . and Coleman, C.E., J. Amer. Chem. Soc., 48, 927 (1926).

[86] Posniak, E., Am. J. Sci., 35A, 268 (1938).

[87] Melcher, A.C., J. Amer. Chem. Soc., 32, 50 (1910).

[88] Hill, A.E., J. Amer. Chem. Soc., 59, 2242 (1937).

[89] Templeton, C.C., and Rodgers, J.C., J. Chem. Eng. Data, 12, 536 (1967).

[90] Blount, C.W., and Dickson, F.W., Amer. Mineralogist, 58, 323 (1973).

[91] Marshall, W.L., and Slusher, R., J. Phys. Chem., 70, 4015 (1966).

[92] Posnjak, E., Amer. J. Sci., 35A, 247 (1938).

[93] D'Ans. J., Bretschneider, D., Eick, H., and Freund, H.E., Kali und Steinsalz; 9, 17 (1955).

[94] Madgian, W.M., and Swales, D.A., J. Appl. Chem. (London), 6, 482 (1956).

[95] Posniak, E., Am. J. Sci., 238, 559 (1940).

[96] Segnit, E.R., Holland, H.D., and Biscardi, C.J., Geochimica et Cosmochimica Acta, 26, 1301 (1962).

[97] Macdonald, R.W., and North, N.A., Can. J. Chem., 52, 3181 (1974).

[98] Akin, G.W. and Lagerwerff, J.V., Geochimica et Cosmochimica Acta, 29, 343 (1965).

[99] Florke, O.W., Neues. Jahrb. Minn., Abh., 84, 189 (1952).

[100] Cano, R., and Chatelain, P., Bull. Soc. Franc. Min. Crist., 81, 10 (1958).

[101] Macdonald, G.J.F., Amer. J. Sci., 25 1, 884 (1953).
[102] Ostroff, A.G., Geochimica et Cosmochimica Acta, 28, 1363 (1964).

[103] Wood, J.R., Geochimica et Cosmochimica Acta. 39, 1147 (1975).

[104] Potter, R.W., II, and Haas, J.L., Jr., J. Res. U.S. Geol. Survey, 6, 247 (1978).

[105] Haas, J.L., Jr., Geological Survey Bulletin, 1421-A; U.S. Govt. Printing Office, Washington, D.C. (1976).

[106] Haas, J.L., Jr., Geological Survey Bulletin, 1421-B; U.S. Govt. Printing Office, Washington, D.C. (1976).

[107] Potter, R.W., II, and Brown, D.L., Geological Survey Bulletin, 1421-C; U.S. Govt. Printing Office, Washington, D.C. (1977).

[108] Miller, J.P., Amer. J. Sci., 250, 161 (1952).

[109] Ellis, A.J., Amer. J. Sci., 257, 354 (1959).

[110] Silvester, L.F., and Pitzer, K.S., J. Phys. Chem., 81, 1822 (1977).

[111] Pitzer, K.S., and Mayorga, G., J.Solution, Chem., 3, 539 (1974).

[112] Heard, H.C., Geophysical Monograph, 16, 191 (1972).

[113] Carter, N.L., and Heard, H.C., Amer. J. Sci., 269, 193 (1970).

[114] Mueller, P., and Siemes, S., Tectonophysics, 23, 105 (1974).

[115] Heard, H.C., and Rubey, W.M., Geol. Soc. Amer. Bull., 77, 761 (1966).

[116] Voidya, S.N., Bailey, S., Pasternack, T., and Kennedy, G.C., J. Geophys. Res. 78, 6893 (1973).

[117] Robie, R.A., Hemingway, B.S., and Fisher, J.R., U.S. Geol. Survey, Bulletin 1452, U.S. Govt. Printing Office, (1978).

\section{Symbols and Units}

\begin{tabular}{lll}
\hline \hline Symbol & Physical Quantity & Unit \\
\hline$\rho$ & density & $\mathrm{kg} \mathrm{m}^{-3}$ \\
$S^{\circ}$ & entropy & $\mathrm{J} \cdot \mathrm{mol}^{-1} \mathrm{~K}^{-1}$ \\
$\Delta H_{\mathrm{f}}^{\circ}$ & standard enthalpy of formation & $\mathrm{kJ} \mathrm{mol}{ }^{-1}$ \\
$\Delta G_{\mathrm{f}}^{\circ}$ & free energy of formation & $\mathrm{kJ} \mathrm{mol}$ \\
$C_{p}^{\circ}$ & heat capacity & $\mathrm{J} \cdot \mathrm{mol}^{-1} \mathrm{~K}^{-1}$ \\
$P$ & pressure & $\mathrm{N} \mathrm{m}^{-2}$ \\
$c_{m}$ & concentration & $\mathrm{mol} \mathrm{dm}^{3}$ \\
$K_{p}$ & solubility product & \\
\hline
\end{tabular}

\section{Conversion Factors from Non-SI Units to SI Units}

$\begin{array}{ll}0^{\circ} \mathrm{C} & =273.15 \mathrm{~K} \\ 1 \AA & =10^{-10} \mathrm{~m} \\ 1 \mathrm{bar} & =10^{5} \mathrm{~Pa} \\ 1 \mathrm{~atm} & =101325 \mathrm{~Pa} \\ 1 \mathrm{cal} & =4.184 \mathrm{~J} \\ 1 \mathrm{~g} \mathrm{~cm} & =1 \times 10^{3} \mathrm{Kg} \mathrm{m}^{-3}\end{array}$





\section{Chapter 3 \\ Mechanical Properties}

H. R. Hume and A. Shakoor*

\section{Contents}

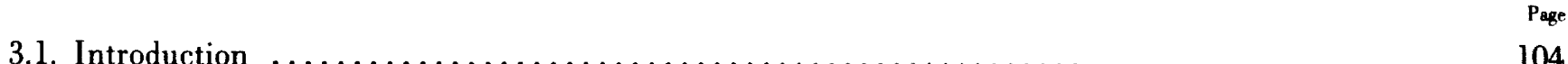

3.2. Review of Measurement Methods $\ldots \ldots \ldots \ldots \ldots \ldots \ldots \ldots \ldots \ldots \ldots \ldots \ldots \ldots \ldots \ldots \ldots \ldots \ldots \ldots$

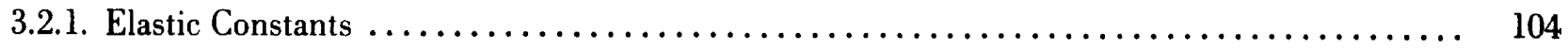

3.2.2. Stress-Strain and Creep-Strain Data $\ldots \ldots \ldots \ldots \ldots \ldots \ldots \ldots \ldots \ldots \ldots \ldots \ldots \ldots \ldots \ldots \ldots$

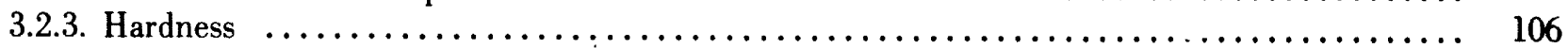

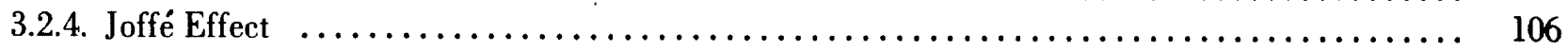

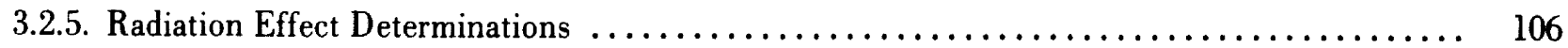

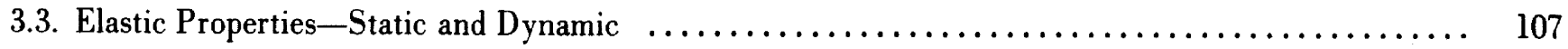

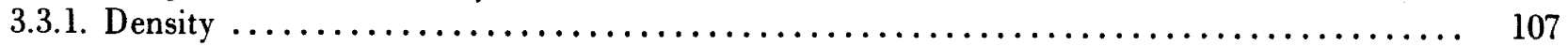

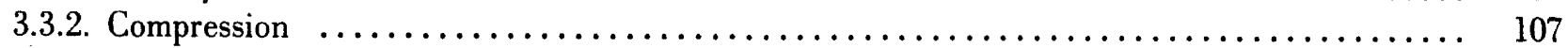

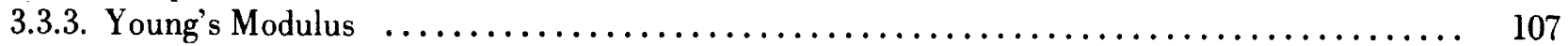

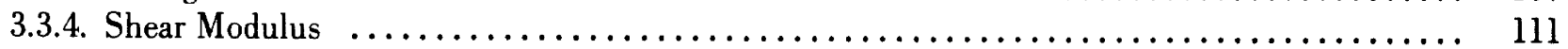

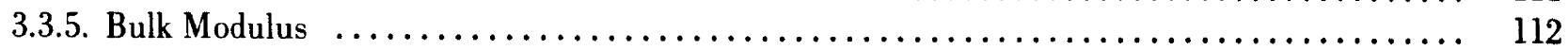

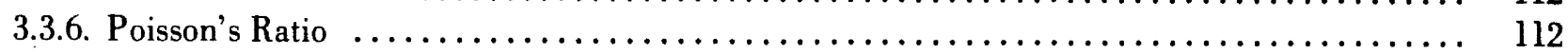

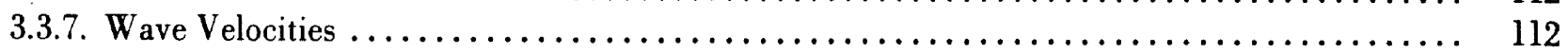

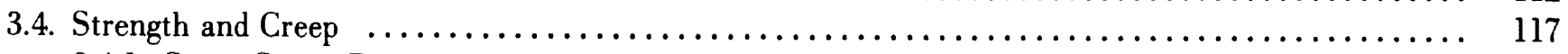

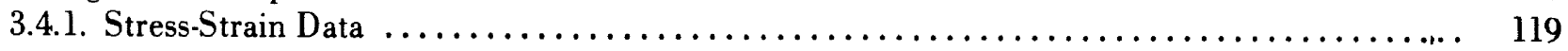

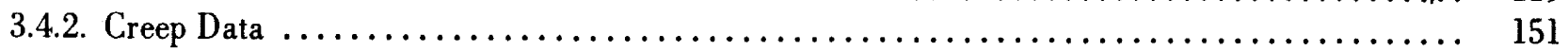

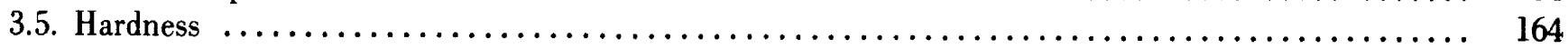



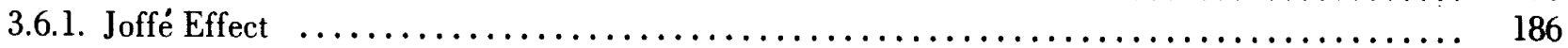

3.7. Effect of Nuclear Irradiation on Mechanical Properties of Rock Salt $\ldots \ldots \ldots \ldots \ldots \ldots \ldots \ldots \ldots . .189$

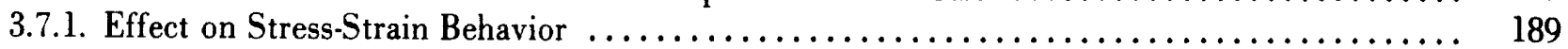

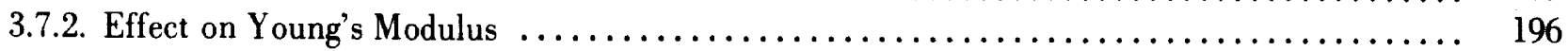

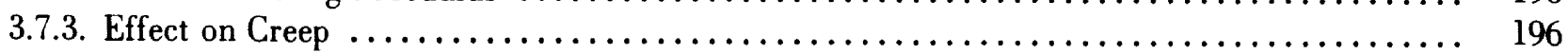

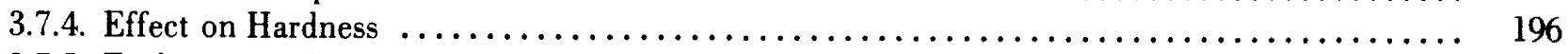

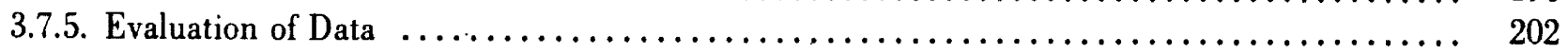

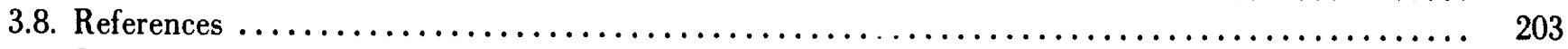

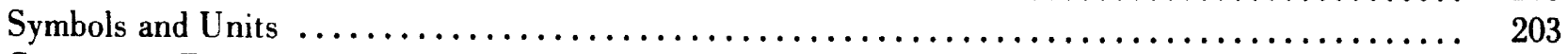

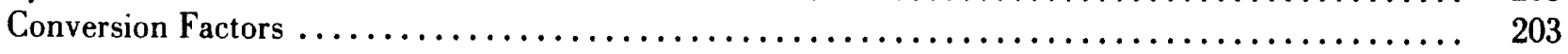

*Center for Information and Numerical Data Analysis and Synthesis, Purdue University, 2595 Yeager Road, West Lafayette, Indiana 47906 


\section{1. Introduction}

As a general introduction, some typical in situ values of the elastic constants of rock salt are presented as well as a brief introduction to the geological environment and some of the factors affecting the mechanical behavior of rock salt. ${ }^{1}$

\subsection{Review of Measurement Methods}

\subsubsection{Elastic Constants}

Compression: Data shown in figure 3.2 on compression were obtained by Voronov and Grigor'ev [2] and by Heard et al. [7]. Voronov and Grigor'ev applied

Physical constants of rock salt obtained in situ

These results (salt dome) were obtained in the Winnfield salt dome, Louisiana, using surface geophysical techniques; the bedded salt results are from the GNOME drift, New Mexico.

\begin{tabular}{llccc}
\hline \hline & Salt Dome & Deviation, \% & Bedded Salt & Deviation, \% \\
\hline & & & & \\
Longitudinal velocity & $4370 \mathrm{~m} \mathrm{~s}^{-1}$ & \pm 0.7 & $4085 \mathrm{~m} \mathrm{~s}^{-1}$ & \pm 2.3 \\
Shear velocity & $2550 \mathrm{~m} \mathrm{~s}^{-1}$ & \pm 1.2 & $2150 \mathrm{~m} \mathrm{~s}^{-1}$ & \pm 2.6 \\
Poisson's ratio & 0.241 & \pm 6.1 & 0.31 & $24.5 \mathrm{GPa}$ \\
Modulus of elasticity & $35.6 \mathrm{GPa}$ & \pm 4.5 & $9.8 \mathrm{GPa}$ \\
Modulus of rigidity & $14.4 \mathrm{GPa}$ & \pm 3.3 & $16.1 \mathrm{GPa}$ \\
Lame's constant & $13.4 \mathrm{GPa}$ & & $21.7 \mathrm{GPa}$ \\
Bulk modulus & $23.0 \mathrm{GPa}$ & & $2020 \mathrm{~kg} \mathrm{~m}^{-3}$ \\
Density & $2160 \mathrm{~kg} \mathrm{~m}^{-3}$ & &
\end{tabular}

Mechanical properties of salt are strongly temperature dependent since deformation and work hardening, due to a specific load, increase and decrease, respectively, with a rise in temperature. Confining pressure (fig. 3.1) also exerts an influence on the mechanical behavior of salt; however, it is less significant than that exerted by temperature. In addition there are several other factors which influence the mechanical properties of in situ rock salt: stress rate application, magnitude of stress difference, grain size, thickness of salt body or formation, and the amount and nature of the impurities present.

Since the pertinent data available at present are inconclusive, and the composition of rock salt and the location of defects strongly influence the mechanical behavior, it has been decided not to present recommended values. It should be noted that there is some doubt (Baar [17]) about the extrapolation of laboratory obtained parameters for use as in situ parameters.

The data are presented as a series of figures and corresponding combined specification and data tables. The curve numbers in circles shown in the figures correspond to the data set numbers in the tables.

\footnotetext{
${ }^{1}$ A comprehensive report [28] was released as this manuscript was completed, treating a number of physical aspects of in-situ rock salt masses. This work should be of value in engineering studies.
}

ultrasonic methods under hydrostatic conditions $\sigma_{1}=$ $\sigma_{2}$ using two high pressure chambers at $298 \mathrm{~K}$. Heard et al. tested four samples $(50 \times .32 \mathrm{~mm})$ under hydrostatic conditions to $0.8 \mathrm{GPa}$, two samples $(25 \times 22 \mathrm{~mm})$ under quasihydrostatic $\left(\sigma_{1}=\sigma_{3}\right)$ conditions from 0.8 to $3.2 \mathrm{GPa}$ and applied uniaxial strain loading $\left(\epsilon_{2}=\epsilon_{3}\right)$ on single sample with single strain gauge.

Elastic Moduli: Dynamic moduli of $\mathrm{NaCl}$ give more consistent values than static moduli and, therefore, all modern investigators prefer to use ultrasonic techniques for their measurement, i.e., to calculate them from a measurement of longitudinal and shear wave velocities. Voronov and Grigor'ev measured acoustic velocities of $\mathrm{NaCl}$ samples, 6-10 $\mathrm{mm}$ long and $15 \mathrm{~mm}$ in diameter, using two high pressure chambers of $2.7 \mathrm{~cm}^{3}$. The time taken by the ultrasonic wave to travel through the investigated samples was measured with a two channel ultrasonic system to an accuracy of $\pm 0.01 \mu \mathrm{s}$. The experimentally determined pressure dependence of the length of a sample and the change in the travel time of the ultrasonic signal were used to calculate the velocities which were then used to determine Young's modulus, shear modulus, bulk modulus, and Poisson ratio. The measurements were made up to a pressure range of $0-10$ $\mathrm{GPa}$ and at a temperature of $300 \mathrm{~K}$. It is noteworthy that at pressures less than 0.1 MPa dynamic methods probably give extrinsic values of constants due to open cracks in the samples. The results of these investigations are shown in figures $3.3,3.4,3.5,3.6,3.7$, and 3.8. 
Heard et al. [7] measured loading and unloading moduli in uniaxial stress and strain at pressures to 0.7 $\mathrm{GPa}$. They also measured ultrasonic velocities at pressures to $0.4 \mathrm{GPa}$ to find the dynamic values of shear modulus, bulk modulus, and Poisson's ratio. The samples used for static tests were $19 \mathrm{~mm}$ in diameter and $38 \mathrm{~mm}$ in length, while those for dynamic tests measured $19 \mathrm{~mm}$ in diameter and $25 \mathrm{~mm}$ in length. The temperature for all tests was $298 \mathrm{~K}$. The range of pressures used by Heard et al. was small-up to $3.2 \mathrm{GPa}$, but the data obtained is useful in studying the variation of static and dynamic moduli at low confining pressures. The data from these studies are shown in figures 3.5 , 3.6, 3.7, 3.8, and 3.9.

In order to study the effect of very high confining pressures on the elastic moduli, Frankel, Rich, and Homan used a pressure range of 2.5-27.0GPa to measure the velocities. The highest range to which the acoustic velocities had previously been measured was $10 \mathrm{GPa}$ by Voronov and Grigor'ev. To measure the acoustic velocities at these very high pressures it was necessary to use a solid pressure device with a large specimen. Details of the apparatus can be found in Reference [16] and the data have been plotted in figure 3.7.

Morris, Jamieson, and Yarger [4] used the ratio of longitudinal to shear wave velocity, measured up to a pressure of $9 \mathrm{GPa}$, to determine directly the Poisson's ratio and used shock wave data to determine other moduli. The Poisson ratio was derived from the equation below:

$$
\sigma=0.5\left(R^{2}-2\right) /\left(R^{2}-1\right)
$$

$R$ being the ratio of the velocities. Before determining the velocities, Morris, Jamieson, and Yarger used third order elasticity theory to correct for a probable uniaxial superimposed stress component. This was an improvement upon the previous methods. They also modified the ultrasonic interferometer so that thicker samples with higher and more uniform pressure distribution could be used. The details of the apparatus can be found in reference [4] and the data have been plotted in figure 3.7.

\subsubsection{Stress-Strain and Creep-Strain Data}

Data related to figures 3.10 and 3.11 were obtained on samples of halitic rock with a mean grain diameter of 2 $\mathrm{mm}$. Samples were cubical with an $0.106 \mathrm{~m}$ edge length. Stresses up to $44.471 \mathrm{GPa}$ were applied using a 444.8 MN triaxial testing machine with an $0.1 \mathrm{~m} \times 0.1 \mathrm{~m} \times 0.1$ m loading platen.

Three experiments were conducted under triaxial conditions and one test under multiaxial loading conditions at $293 \mathrm{~K}$. Sample No. 1 was loaded uniaxially, 3 and 4 were triaxially loaded at $4.447 \mathrm{GPa}$ and 13.341 $\mathrm{GPa}$, respectively. Sample No. 2 was multiaxially loaded with lateral stresses of $2.223 \mathrm{GPa}$ and $4.447 \mathrm{GPa}$.

The differential stress versus confining pressure data shown in figure 3.13 were obtained using uniaxial strain loading. A single sample utilizing a single strain gauge was used. Maximum confining pressure was $700 \mathrm{MPa}$ because of limitations in strain gauge accuracy.

Heard et al. [7] used a single cylinder of fine grained $\mathrm{NaCl}$ with $1 \%$ porosity for the determination of data shown in figure 3.14 (confining pressure $\sigma_{3}^{\prime}=100 \mathrm{MPa}$ ). The cylinder dimensions were $19 \mathrm{~mm}$ diameter, $38 \mathrm{~mm}$ length. Axial and circumferential strain gauges were fitted to the sample which was subjected to uniaxial stress loading and unloading. Several other similar tests were run using different confining pressures. Their results followed the same trend as indicated by the data given in figure 3.14.

Artificial rock salt samples were used by Dreyer [12], to obtain the data in figure 3.36. Mean grain size diameter was 0.1 to $0.6 \mathrm{~mm}$. Time-strain tests were run on samples at temperatures of $302 \mathrm{~K}, 377 \mathrm{~K}$ and $471 \mathrm{~K}$ and at pressures of $45.36 \mathrm{GPa}, 9.07 \mathrm{GPa}$, and $0 \mathrm{GPa}$.

The creep behavior illustrated in figure 3.37 was determined on square rock salt prisms $(0.04 \mathrm{~m} \times 0.04 \mathrm{~m}$ $\times 0.1 \mathrm{~m}$ ) using a $44.48 \mathrm{MN}$ constant load lever testing apparatus. Deformation was accurate to $10^{-2} \%$ and temperature could be controlled to within $0.5 \mathrm{~K}$ (Dreyer, [12] 1972). The untempered specimen was banded white rock salt with a mean rock salt content of $98.64 \%, 1.05 \%$ anhydrite, $0.29 \%$ Keserite, and $0.02 \%$ clay. The tempered sample had a different composition, having $7.56 \%$ anhydrite, $1.03 \%$ keserite and $0.23 \%$ clay.

For details concerning test methods for data shown in figure 3.12, the reader is referred to reference [5].

Nair and Deere [23], Burke [19], Thompson [25], Odé [24], and Baar [17] all presented various forms of straintime data for rock salt. These data are displayed in figures 3.23 to 3.35 .

Burke [19] used a dead load compression creep unit fitted with fine grained aluminum oxide platens. Sample deflections were measured using a colinearly mounted dial gauge. Commercially obtained high purity artificial salt samples were used in all cases. Extruded single crystals of $0.64 \times 10^{-2} \mathrm{~m}$ diameter and $0.305 \mathrm{~m}$ long were used. These crystals were extruded at 573 to $623 \mathrm{~K}$ an hour at extrusion rates of $0.254 \mathrm{~m}$ to $0.381 \mathrm{~m}$ per hour. Certain samples were annealed and then slow cooled. Test temperatures were kept constant at approximately $275 \mathrm{~K}$.

The values produced by Thompson [25] were achieved using a triaxial creep testing machine. The confining pressure provided by oil was measured by a Bourdon gage 
and kept constant by use of a hydraulic accumulator filled with nitrogen. The axial load was read using a dynamometer between the hydraulic ram and the line leading to the test chamber. The entire test chamber was temperature controlled thermostatically by means of a heating tape wrapped around the chamber. The specimens themselves were of various lengths between $0.203 \mathrm{~m}-0.305 \mathrm{~m}$ with a diameter of $0.102 \mathrm{~m}$ having been drilled from blocks taken in situ from Grand Saline, Texas and Hockley, Texas.

Heard [21] used artificial samples of reagent grade $\mathrm{NaCl}$ compacted hydrostatically at $170 \mathrm{MPa}$ for $2 \mathrm{~h}$ at 403 $K$. The apparatus used consisted of an externally heated pressure vessel fitted with an internal force transducer to measure axial strain. Differential stress-strain behavior of annealed jacketed samples of the above $\mathrm{NaCl}$ was then determined in tension at a confining pressure of $2 \mathrm{kbar}$ and temperatures of $296 \mathrm{~K}$ to $673 \mathrm{~K}$ and strain rates ranging from $10^{-1}$ to $10^{-5} \mathrm{~s}^{-1}$

Creep data obtained by Le Comte [22] were achieved using creep apparatus capable of achieving greater than $573 \mathrm{~K}$, and a confining pressure of $100 \mathrm{MPa}$ at a stress difference of 13.8 MPa. Le Comte's results were obtained in compression on artificially made specimens consisting of chemically pure $\mathrm{NaCl}$. Prior to testing these samples were annealed at $573 \mathrm{~K}$ and then slowly cooled. For details of the apparatus used refer to reference [22].

Odé [24] and Baar [17] present a synthesis of data collected by other researchers and for identification of the original data the user is referred to each of these documents.

\subsubsection{Hardness}

The data shown in figure 3.38 were obtained by Strelkov, Shpunt, and Nabutovskaya [15] by using methods developed by them earlier and referred to in Reference [15]. The vibration on the automatic indentor was only $0.3-0.4 \mu \mathrm{m}$ causing the error due to this factor to be negligible.

Ksishsh and Sharkezi [14] used $\mathrm{NaCl}$ crystals $(2 \times 2 \times$ $6 \mathrm{~mm}$ ) grown by the Kiropolous method and with cation impurities introduced in them. High purity $\mathrm{NaCl}$ crystals were developed by the Bridgeman method. All samples were primarily annealed at $923 \mathrm{~K}$ and then cooled at $2^{\circ} / \mathrm{h}$. The microhardness was then determined on Model 32 of the Zeiss type instrument with an indentor load of $4 \mathrm{~g}$. The microhardness of each sample was estimated from $30-40$ impressions. The results are plotted in figures 3.39 and 3.40 .

\subsubsection{Joffé Effect}

The method described below was used to obtain the data shown in figure 3.41. Polishing of crystals was achieved by submersing the crystal and agitating in water for 30 seconds. Thereafter a 5-10 second methyl alcohol bath and then a 5 second ether bath was given again using agitation. The crystal was then dried in a hot air stream. If the time in the methyl alcohol and ether was shortened not all the water from the initial bath was removed. This resulted in a small amount of sodium chloride being precipitated on the surface of the crystal as a "stain" or tarnish.

"Painting" of polished crystals was achieved using a drop of saturated sodium chloride solution or distilled water. This drop was "painted" on a specific area of a crystal and then the crystal was air dried. This "painting" produced a precipitate on the surface of the crystal which seems to introduce microflaws in its immediate vicinity.

The crystals had a $1.27 \mathrm{~cm}$ gauge length and were water polished, rinsed, and dried so that the cross section was $0.254 \mathrm{~cm}$ square. Each crystal was sealed in aluminum grips with Duco cement and heated to $323 \mathrm{~K}$ for 24 hours in order to dry the cement. The tests themselves were done on a conventional hard tensile machine at a strain rate of $5 \times 10^{-5} \mathrm{~s}^{-1}$.

\subsubsection{Radiation Effect Determinations}

Bradshaw et al. [13] used two inch cubes prepared from large blocks of bedded and dome salt to study the effects of ionizing radiation on stress-strain and creep behavior as shown in figures $3.42,3.43$ and 3.47 . The test cubes were accurately machined to assure uniform application of pressure and were subjected to irradiation in a gamma field of $3.2 \times 10^{6} \mathrm{R}$ per hour with a temperature of $343 \mathrm{~K}$ inside the chamber. Radiation doses of $0,10^{6}, 10^{7}, 10^{8}$, and $5 \times 10^{8} \mathrm{R}$ were used first at room temperature and then at $473 \mathrm{~K}$.

Most of the investigations done in connection with radiation effects on $\mathrm{NaCl}$ were on macrocrystals. Demidova and Gol'denberg [8] used $\mathrm{NaCl}$ whisker crystals measuring $10-100 \mu \mathrm{m}$ in diameter and irradiated them at room temperature with unfiltered $x$-radiation for 2-16 hours. This makes it possible to study the difference between macro and whisker crystal behavior on irradiation. The data from these experiments are shown in figures 3.44 and 3.45 .

In order to investigate the dislocation density and the correlation existing between interstitials and dislocations which might explain why small irradiation doses produce very little hardening compared to coloration, Inabe and Takeuchi [9] used $\mathrm{NaCl}$ crystals grown by the Kiropolous technique. Speciments measuring $7 \times 7 \times 3$ $\mathrm{mm}^{3}$ were annealed in air at $923 \mathrm{~K}$ for 80 hours and cooled at $20^{\circ} / \mathrm{h}$ to room temperature. Some of these 
crystals were heated again and then quenched. The dislocation density of a specimen was determined by counting etch pits on a unit area. Each specimen was irradiated with an exposure rate of $500 \mathrm{R} / \mathrm{min}$ using $\mathrm{x}$ rays from a tungsten target. Their results are presented in figure 3.4.7.

\subsection{Elastic Properties-Static and Dynamic}

Considerable interest has been shown in the investigations of elastic properties of rock salt in recent years. Some of the researchers in this field are Voronov, Grigor'ev, Morris, Yarger, Frankel, Burke and Heard. Although their work provides important information, the data are not sufficient to generate recommended values except in a few cases.

A word of caution is sounded since some authors, notably Baar [17] and Handin [20] are critical of the significance of elastic properties in the case of rock salt. Baar, in particular, regards elastic parameters as insignificant when regarded from a design viewpoint, given the extremely low limits of elastic behavior of rock salt.

In general, dynamic elastic constants are less sensitive to pore crush-up (closing of pore spaces within the salt) that occurs somewhere between $0.05 \mathrm{GPa}$ and $0.2 \mathrm{GPa}$ during the loading of salt specimens than are the static constants. For example, Poisson's ratio, $\sigma$, for the static case shows a marked variation at low confining pressures because of pore crush. The dynamically obtained values on the other hand do not show such a pronounced variation. This applies also to both the shear modulus and bulk modulus.

Voronov and Grigor'ev [2] measured the velocities of longitudinal and transverse elastic waves on polycrystalline $\mathrm{NaCl}$ samples under quasi-hydrostatic conditions using ultrasonic methods at pressures from $0-10 \mathrm{GPa}$ at $298 \mathrm{~K}$. These velocities were then used to calculate compression, Poisson ratio, bulk modulus, shear modulus, and Young's modulus. Heard et al. [7] investigated in detail the variation of these properties at a low range of pressure under different conditions. They tested $\mathrm{NaCl}$ samples with $1.0 \%$ porosity to determine loading and unloading moduli in uniaxial stress and uniaxial strain at pressures up to $0.7 \mathrm{GPa}$, in hydrostatic compression up to $0.8 \mathrm{GPa}$, and in quasi-hydrostatic compression up to $3.2 \mathrm{GPa}$. They also determined ultrasonic velocities at pressures up to $0.4 \mathrm{GPa}$. Morris, Jamieson, and Yarger [4] measured transit times of longitudinal and transverse ultrasonic waves in $\mathrm{NaCl}$ as a function of quasi-hydrostatic pressure up to $9.0 \mathrm{GPa}$. They utilized the ratio of the longitudinal to shear wave velocity to determine Poisson's ratio and shock wave data to obtain other elastic moduli. They also corrected their values for a probable superimposed uniaxial stress component. Frankel et al. [16] used ultrasonic interferometry to measure room temperature longitudinal and shear acoustic velocities in polycrystalline $\mathrm{NaCl}$ at static pressures from 2.5 to $27.0 \mathrm{GPa}$.

\subsubsection{Density}

The average density of rock salt measured in situ using surface geophysical methods is $2160 \mathrm{~kg} \mathrm{~m}^{-3}$. The relationship of density with confining pressure has been studied by Voronov and Grigor'ev [2] up to $8.0 \mathrm{GPa}$ and by Heard et al. [7] up to $0.4 \mathrm{GPa}$. The data from these investigations are given in table 3.1 and plotted in figure 3.1. Density variation with confining pressure is nonlinear but as a rough approximation linearity can be assumed, at least up to $10.0 \mathrm{GPa}$. Hydrostatic, quasihydrostatic, and uniaxial loading all yield fairly consistent values.

\subsubsection{Compression}

For a plastic solid-like $\mathrm{NaCl}$, the pressure-volume relationship is of interest. Values of compression at various confining pressures, and/or hydrostatic conditions, as calculated by Voronov and Grigor'ev [2] and Heard et al. [7] are tabulated in table 3.2 and shown in figure 3.2. Voronov and Grigor'ev's values are represented by curve 1 and are quoted by them to match closely with the values found by Bridgeman, Albuerne and Drickamer, and Decker, Sekoyan, and Kabalkina. Curves 2 and 3 represent Heard et al. [7] values for hydrostatic and uniaxial strain loading conditions respectively. Their values for hydrostatic and quasi-hydrostatic conditions fall on the same composite curve. For a pressure of $3.0 \mathrm{GPa}$ the variation in compression between curves 1 and 2 as compared with the total compression is $1.5 \%$. The reasons for this discrepancy are not apparent.

Voronov and Grigor'ev's values of compression, being the average of many investigations, are recommended as the more dependable values.

\subsubsection{Young's Modulus}

The average static and dynamic values of Young's modulus can be taken as 35.6 and $36.9 \mathrm{GPa}$, respectively. Voronov and Grigor'ev [2] used pressure dependencies of the velocities of sound up to $10.0 \mathrm{GPa}$ to calculate Young's modulus. Their relationship of Young's modulus vs confining pressure is shown in figure 3.3 and the corresponding values are given in table 3.3. Burke [19] presents data showing the variation of Young's 
TABLE 3.1. PRESSURE DEPENDENCE OF DENSITY OF ROCK SALT

[Confining Pressure, P, GPa; Density, $\rho, \mathrm{kg} \mathrm{m}^{-3}$ ]

\begin{tabular}{|c|c|c|c|c|}
\hline $\begin{array}{l}\text { Data } \\
\text { Set }\end{array}$ & Author (s), Year [Ref.] & $\mathrm{P}$ & $\rho$ & Remarks \\
\hline 1 & $\begin{array}{l}\text { Voronov, F.F. and } \\
\text { Grigor'ev, S.B., } 1976 \\
\text { [2] }\end{array}$ & $\begin{array}{l}0 \\
1 \\
2 \\
3 \\
4 \\
5 \\
6 \\
7 \\
8\end{array}$ & $\begin{array}{l}2614 \\
2248 \\
2322 \\
2388 \\
2449 \\
2506 \\
2559 \\
2610 \\
2658\end{array}$ & $\begin{array}{l}\text { Densities calculated from wave velocities at } \\
298 \mathrm{~K} \text {. }\end{array}$ \\
\hline 2 & $\begin{array}{l}\text { Heard, H.C., Abey, } \\
\text { A.E., Bonner, B.P., } \\
\text { and Duba, A., } 1975 \text { [7] }\end{array}$ & $\begin{array}{l}0 \\
0.1 \\
0.2 \\
0.3 \\
0.4\end{array}$ & $\begin{array}{l}2140 \\
2151 \\
2164 \\
2181 \\
2192\end{array}$ & $\begin{array}{l}\text { Results obtained dynamically from tests on } \\
\text { polycrystalline halite at } 298 \mathrm{~K} \text {. }\end{array}$ \\
\hline
\end{tabular}

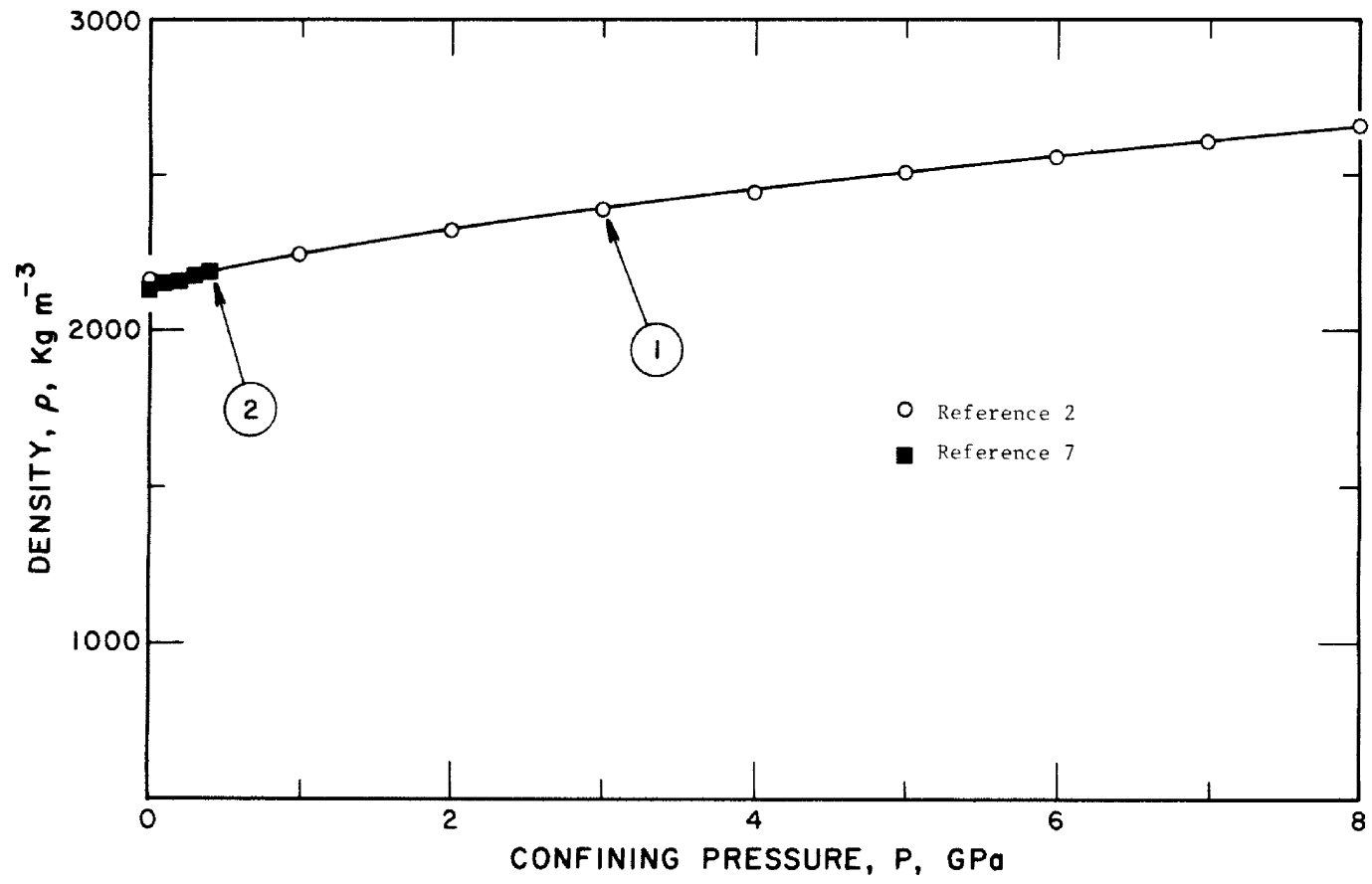

FIGURE 3.1. Variation of density with confining pressure (curve numbers correspond to data set numbers in matching table). 
TABLE 3.2. PRESSURE DEPENDENCE OF COMPRESSION OF ROCK SALT

[Confining Pressure, P, GPa; Compression, $\rho_{0} / \rho$ ]

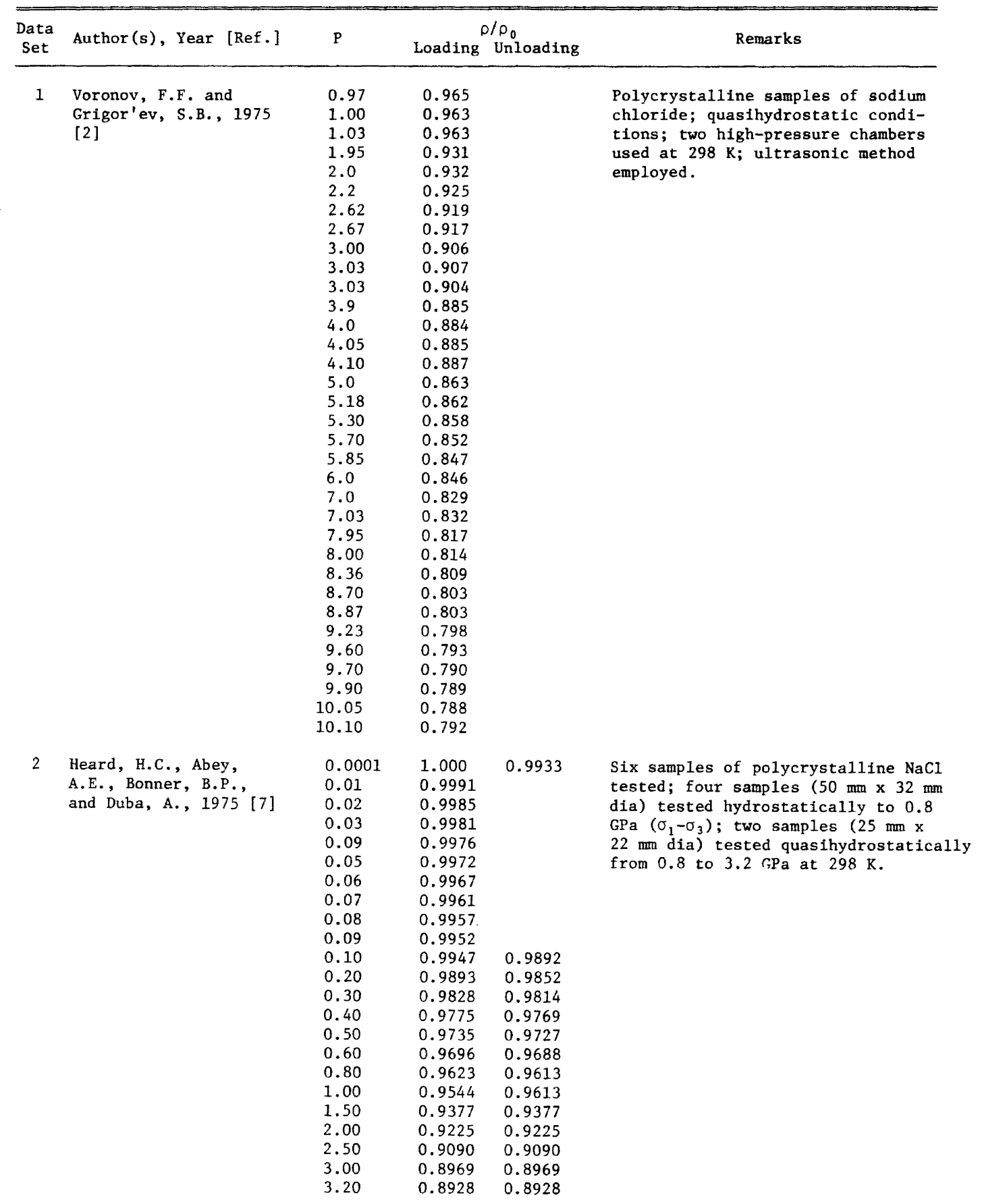


TABLE 3.2. PRESSURE DEPENDENCE OF COMPRESSIOX OF ROCK SALT (continued)

\begin{tabular}{|c|c|c|c|c|}
\hline $\begin{array}{l}\text { Data } \\
\text { Set }\end{array}$ & Author (s), Year [Ref.] & $\mathbf{P}$ & $p_{0} / p$ & Remarks \\
\hline 3 & $\begin{array}{l}\text { Heard, H.C., Abey, } \\
\text { A.E., Bonner, B.P., } \\
\text { and Duba, A., } 1975 \\
{[7]}\end{array}$ & $\begin{array}{l}0.76 \\
0.74 \\
0.73 \\
0.48 \\
0.45 \\
0.43 \\
0.39 \\
0.37 \\
0.32 \\
0.27 \\
0.22 \\
0.20 \\
0.18 \\
0.15 \\
0.12 \\
0.10 \\
0.09 \\
0.08 \\
0.07 \\
0.06 \\
0.05 \\
0.04 \\
0.03 \\
0.02 \\
0.01\end{array}$ & $\begin{array}{l}0.9656 \\
0.9659 \\
0.9662 \\
0.9749 \\
0.9758 \\
0.9768 \\
0.9782 \\
0.9792 \\
0.9816 \\
0.9847 \\
0.9881 \\
0.9892 \\
0.9908 \\
0.9925 \\
0.9946 \\
0.9953 \\
0.9959 \\
0.9966 \\
0.9972 \\
0.9975 \\
0.9981 \\
0.9984 \\
0.9988 \\
0.9992 \\
0.9997\end{array}$ & $\begin{array}{l}\text { Uniaxial strain loading, } \varepsilon_{2}= \\
\varepsilon_{3}=0 ; \text { single sample with } \\
\text { single strain gauge; maximum } \\
\text { confining pressure } 689 \mathrm{KPa} \text {. }\end{array}$ \\
\hline
\end{tabular}

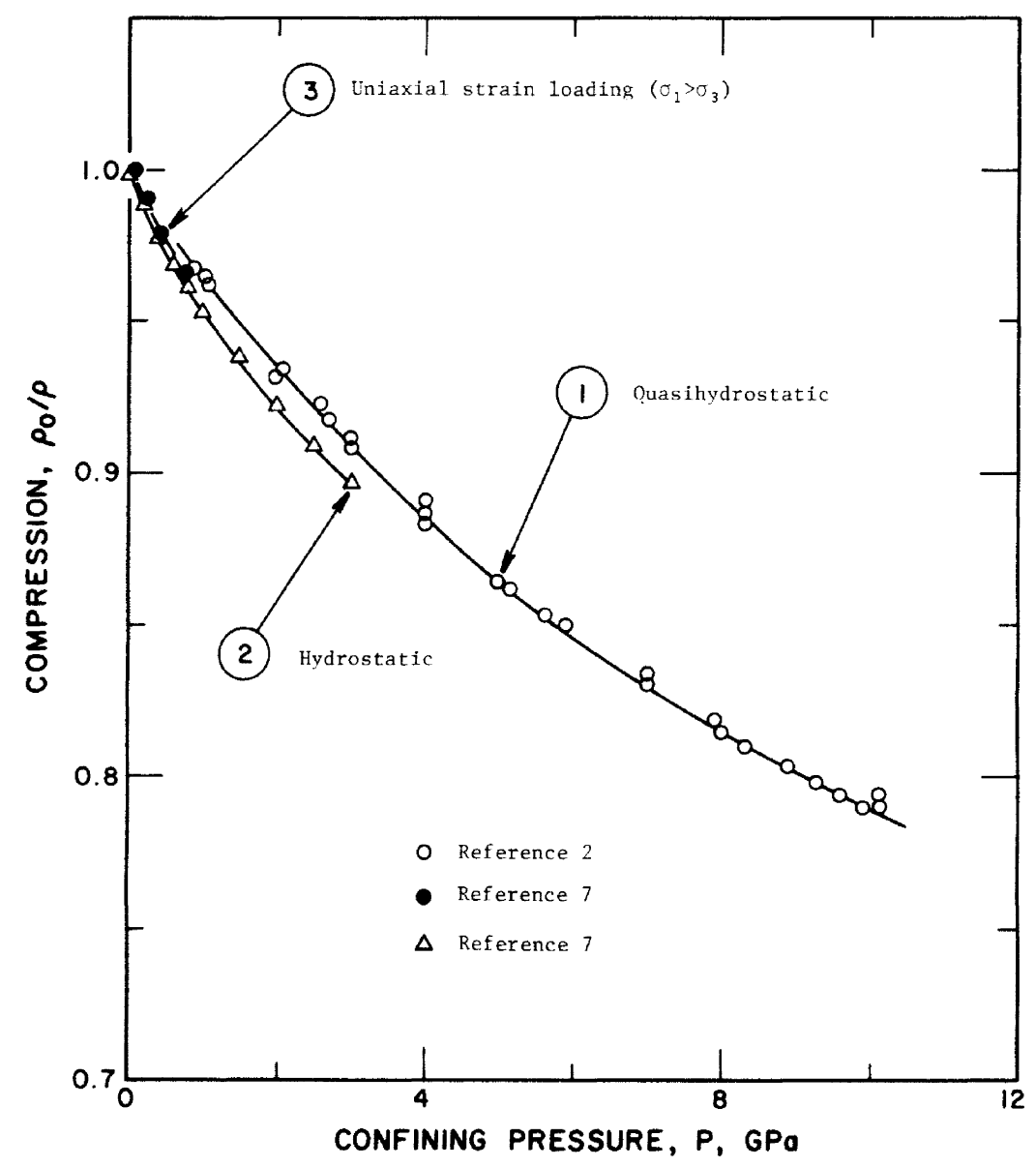

FiGURE 3.2. Pressure dependence of the compression of rock salt (curve numbers correspond to data set numbers in matching table). 
modulus with temperature in figure 3.4 and the corresponding table.

The dynamic values of Young's modulus are more consistent as compared with static values. This is a fortunate situation as the data on longitudinal and shear wave velocities in $\mathrm{NaCl}$ by various investigators agree closely. Therefore, the corresponding values of Young's modulus could be calculated with a reasonable degree of accuracy using the data on velocities.

\subsubsection{Shear Modulus}

Table 3.5 shows the values of shear modulus (dynamic) for various values of confining pressure as calculated by Voronov and Grigor'ev [2] while curve 3 in figure 3.5 is a plot of the same values. Static and dynamic values of shear modulus calculated by Heard et al. [7] are also given. As can be seen from the figure, the dynamic shear modulus increases continuously with pressure in both cases, but the static modulus shows a marked variation at low confining pressures $(<0.1 \mathrm{GPa})$. Heard et al. related this variation to pore crush-up that occurs somewhere between $0.05 \mathrm{GPa}$ to $0.2 \mathrm{GPa}$. According to them, static moduli at low pressures are sensitive to closing of pores while dynamic moduli are not.

As the sonic velocities are generally consistent, they can be used to find the values of shear modulus. On this basis, Voronov and Grigor'ev's values may be used as the provisional values.

TABLE 3.3. PRESSURE DEPENDENCE OF YOUNG'S MODULUS OF ROCK SALT

[Confining Pressure, P, GPa; Young's Modulus, $\mathrm{E}_{\mathrm{S}}, \mathrm{GPa}$ ]

\begin{tabular}{|c|c|c|c|c|}
\hline $\begin{array}{c}\text { Data } \\
\text { Set }\end{array}$ & Author (s), Year [Ref.] & P & $\mathrm{E}_{\mathrm{S}}$ & Remarks \\
\hline 1 & $\begin{array}{l}\text { Voronov, F.F. and } \\
\text { Grigor'ev, S.B., } 1976 \\
{[2]}\end{array}$ & $\begin{array}{l}0 \\
1.0 \\
2.0 \\
3.0 \\
4.0 \\
5.0 \\
6.0 \\
7.0 \\
8.0\end{array}$ & $\begin{array}{l}36.91 \\
40.72 \\
44.02 \\
46.85 \\
49.30 \\
51.44 \\
53.39 \\
55.25 \\
57.16\end{array}$ & $\begin{array}{l}\text { Values calculated from pressure-velocity-density } \\
\text { relationship - sonic method; samples were com- } \\
\text { posed of compacted, fine, chemically pure } \mathrm{NaCl} \\
\text { powder. }\end{array}$ \\
\hline
\end{tabular}

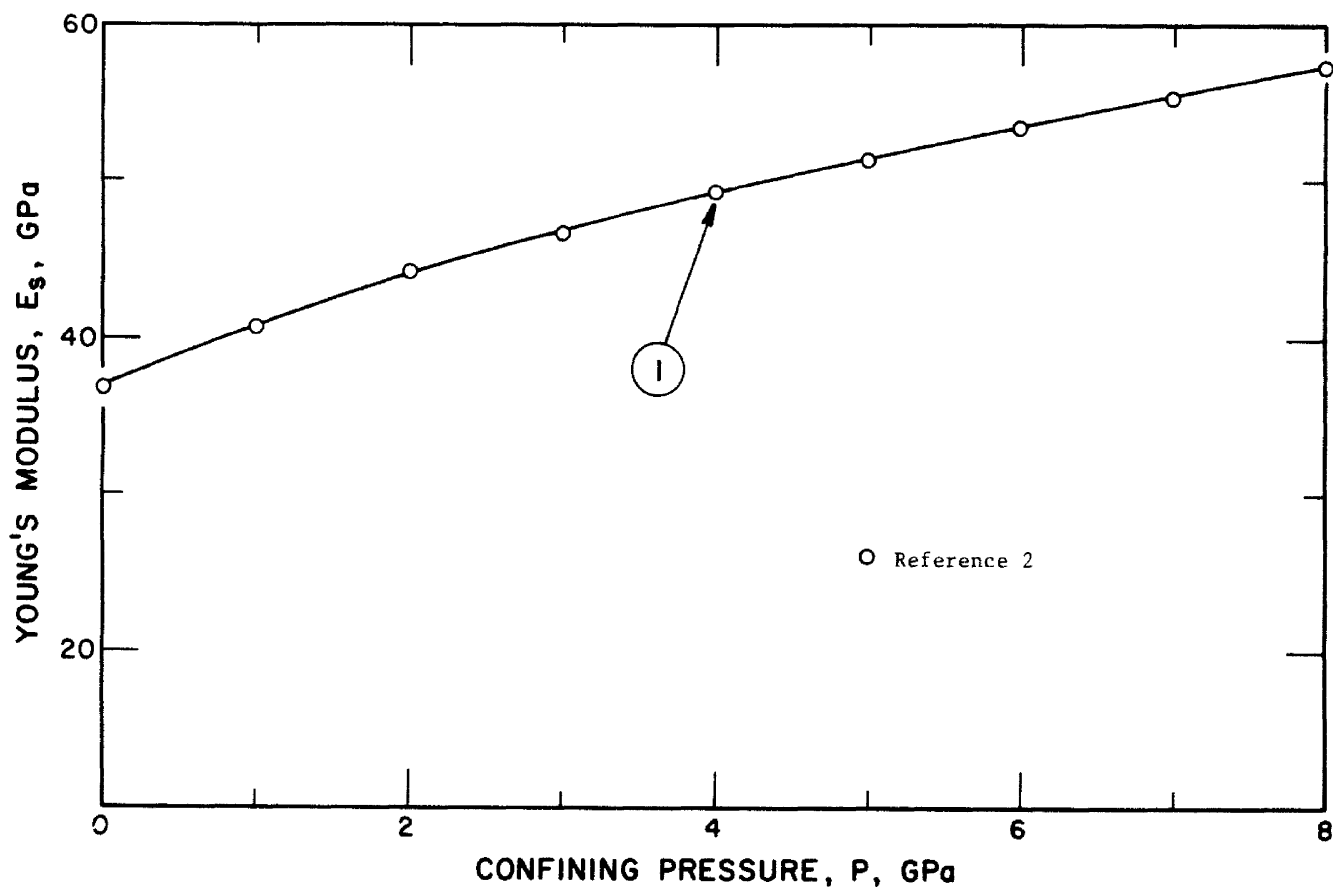

FiguRE 3.3. Relationship between Young's Modulus and confining pressure (curve numbers correspond to data set numbers in matching table). 
TABLE 3.4. EFFECT OF TEMPERATURE ON DYNAMIC YOUNG'S MODULUS OF NaC1

[Temperature, T, K; Young's Modulus, E, MPa]

\begin{tabular}{|c|c|c|c|c|c|}
\hline $\begin{array}{l}\text { Data } \\
\text { Set }\end{array}$ & $\begin{array}{l}\text { Author (s), } \\
{[\operatorname{Ref} .]}\end{array}$ & Year & $\mathrm{T}$ & E & Remarks \\
\hline 1 & $\begin{array}{l}\text { Burke, P.M., } \\
{[19]}\end{array}$ & 1968 & $\begin{array}{l}290.262 \\
337.036 \\
411.993 \\
456.947 \\
484.788 \\
506.179 \\
544.738 \\
594.027 \\
666.880 \\
711.874 \\
797.520 \\
881.091\end{array}$ & $\begin{array}{l}36.830 \\
36.100 \\
34.750 \\
34.240 \\
33.740 \\
33.740 \\
32.900 \\
31.540 \\
29.680 \\
28.580 \\
27.320 \\
25.120\end{array}$ & $\mathrm{~d}=2 \mathrm{~mm}$. \\
\hline 2 & $\begin{array}{l}\text { Burke, P.M., } \\
{[19]}\end{array}$ & 1968 & $\begin{array}{l}296.400 \\
349.950 \\
401.332 \\
433.440 \\
491.257 \\
531.938 \\
613.313 \\
643.305\end{array}$ & $\begin{array}{l}36.010 \\
34.910 \\
34.240 \\
33.900 \\
32.970 \\
32.380 \\
31.030 \\
30.360\end{array}$ & $\mathrm{~d}=2 \mathrm{~mm}$ \\
\hline 3 & $\begin{array}{l}\text { Burke, P.M., } \\
{[19]}\end{array}$ & 1968 & $\begin{array}{l}287.804 \\
309.211 \\
317.796 \\
330.613 \\
433.412 \\
587.639 \\
654.074 \\
951.895 \\
984.015\end{array}$ & $\begin{array}{l}36.600 \\
36.350 \\
35.930 \\
36.180 \\
34.330 \\
31.120 \\
29.250 \\
21.900 \\
21.390\end{array}$ & $\mathrm{~d}=2 \mathrm{~mm}$ \\
\hline 4 & $\begin{array}{l}\text { Burke, P.M., } \\
\text { [19] }\end{array}$ & 1968 & $\begin{array}{l}296.303 \\
379.856 \\
489.135 \\
581.273 \\
630.556 \\
684.175 \\
754.911 \\
844.978 \\
907.136 \\
941.400 \\
990.609\end{array}$ & $\begin{array}{l}37.450 \\
35.510 \\
32.720 \\
30.350 \\
29.080 \\
26.970 \\
24.760 \\
21.380 \\
19.520 \\
18.920 \\
18.760\end{array}$ & $\mathrm{~d}=50 \mu \mathrm{m}$. \\
\hline
\end{tabular}

\subsubsection{Bulk Modulus}

Voronov and Grigor'ev's [2] values of bulk modulus have been plotted as curve 2 of figure 3.6 while curves 1,3 , and 4 represent bulk modulus data from Heard et al. [7] under various conditions of testing. These data are also tabulated in table 3.6. The minimum difference between dynamic bulk modulus measured by Voronov and Heard, respectively, is $2.4 \mathrm{GPa}$. The values for other conditions also differ considerably. As a general trend, both static and dynamic values of bulk modulus increase with confining pressure at pressure values $>$ $0.2 \mathrm{GPa}$. Recommended values cannot be generated at this stage.

\subsubsection{Poisson's Ratio}

The relationship between Poisson's ratio and confining pressure is shown in figure 3.7 for dynamic and static cases and the corresponding values are tabulated in table 3.7. The dynamic values of Poisson's ratio calculated by
Voronov and Grigor'ev [2] agree closely with those calculated by Morris et al. [4]. However, the corresponding values as determined by Heard et al. [7] differ from other data by approximately $8.0 \%$. Voronov's values of Poisson's ratio may be used as provisional values because of their close agreement with Morris' data.

\subsubsection{Wave Velocities}

Data on longitudinal and shear wave velocities from Voronov and Grigor'ev [2], Heard et al. [7], Morris, Jamieson, and Yarger [4] , and Frankel, Rich, and Homan [16] have been plotted in figure 3.8 and also given in table 3.8. These values are seen to agree within the uncertainty of measurements. Frankel et al. [16] values represent the largest range of pressure and may be used as the recommended values. These longitudinal and shear acoustic velocities in polycrystalline $\mathrm{NaCl}$ were measured at static pressures in the range of $2.5-27.0 \mathrm{GPa}$ at $300 \mathrm{~K}$. The measurements were made by ultrasonic 


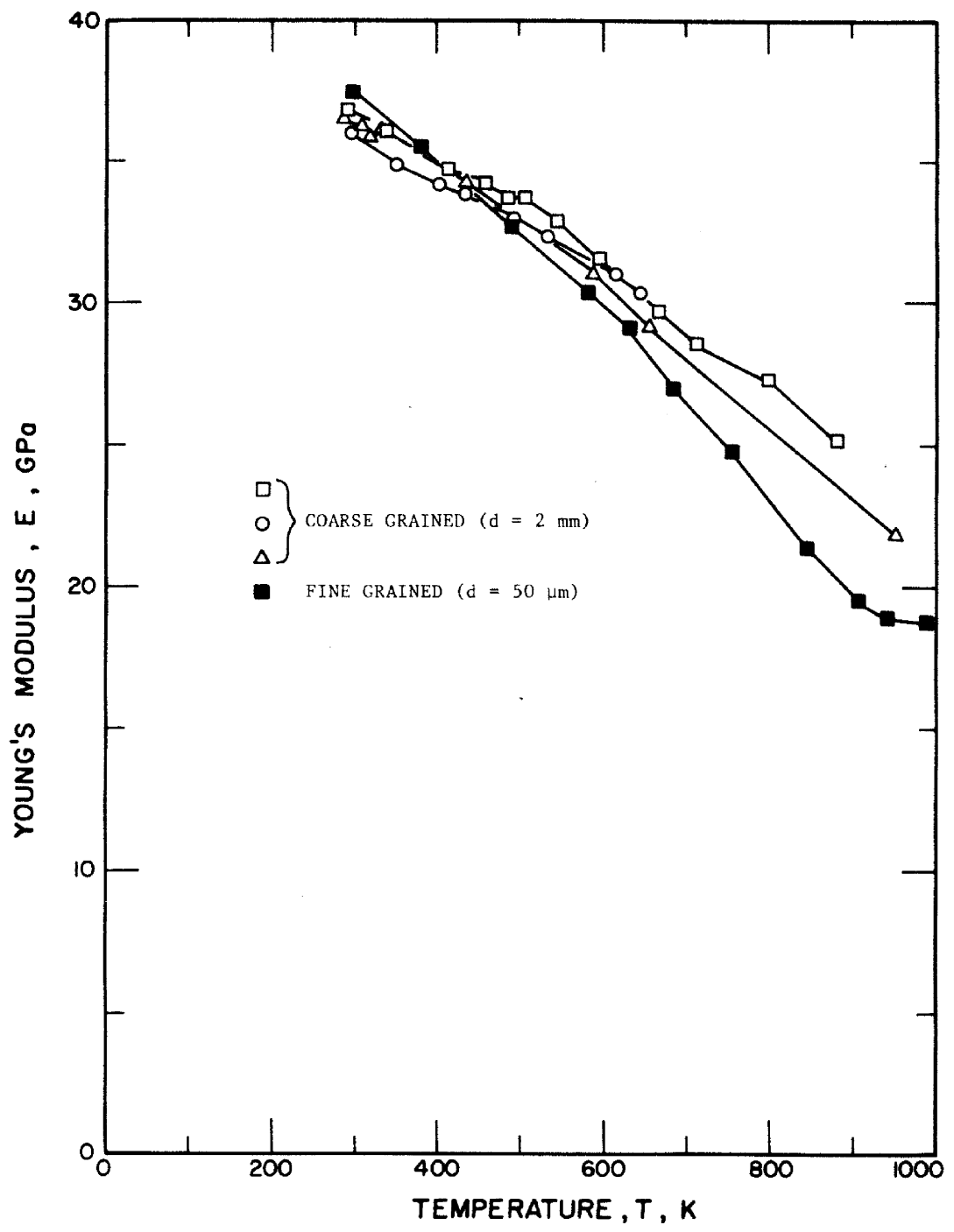

FIGURE 3.4. Temperature dependence of Young's Modulus. 
TABLE 3.5. PRESSURE DEPENDENCE OF SHEAR MODULUS OF ROCK SALT

[Confining Pressure, P, GPa: Shear Modulus, G, GPa]

\begin{tabular}{|c|c|c|c|c|}
\hline $\begin{array}{l}\text { Data } \\
\text { Set }\end{array}$ & Author(s), Year [Ref.] & $P$ & G & Remarks \\
\hline 1 & $\begin{array}{l}\text { Heard, H.C., Abey, } \\
\text { A.E., Bonner, B.P., } \\
\text { and Duba, A., } 1975 \text { [7] }\end{array}$ & $\begin{array}{l}0.000 \\
0.020 \\
0.050 \\
0.075 \\
0.100 \\
0.150 \\
0.200 \\
0.250 \\
0.300 \\
0.350 \\
0.400\end{array}$ & $\begin{array}{l}12.50 \\
13.49 \\
14.41 \\
14.81 \\
15.00 \\
15.23 \\
15.31 \\
15.43 \\
15.55 \\
15.69 \\
15.91\end{array}$ & $\begin{array}{l}\text { Dynamic values; five cylindrical samples } \\
\text { ( } 19 \mathrm{~mm} \text { dia } \times 38 \mathrm{~mm} \text { length); uniaxial load- } \\
\text { ing; strain measured with axial and circum- } \\
\text { ferential strain gauges. }\end{array}$ \\
\hline 2 & $\begin{array}{l}\text { Heard, H.C., et al., } \\
1975 \text { [7] }\end{array}$ & $\begin{array}{l}0.010 \\
0.020 \\
0.100 \\
0.400\end{array}$ & $\begin{array}{l}13.80 \\
11.50 \\
13.70 \\
14.00\end{array}$ & $\begin{array}{l}\text { Static values: uniaxial strain loading } \\
\text { conditions. }\end{array}$ \\
\hline 3 & $\begin{array}{l}\text { Voronov, F.F. and } \\
\text { Grigor'ev, S.B., } 1976 \\
\text { [2] }\end{array}$ & $\begin{array}{l}0 \\
1.0 \\
2.0 \\
3.0 \\
4.0 \\
5.0 \\
6.0 \\
7.0 \\
8.0\end{array}$ & $\begin{array}{l}14.69 \\
15.97 \\
17.05 \\
17.97 \\
18.75 \\
19.44 \\
20.08 \\
20.72 \\
21.39\end{array}$ & $\begin{array}{l}\text { Dynamic values obtained using ultrasonic } \\
\text { method at } 298 \mathrm{~K} \text {. }\end{array}$ \\
\hline
\end{tabular}

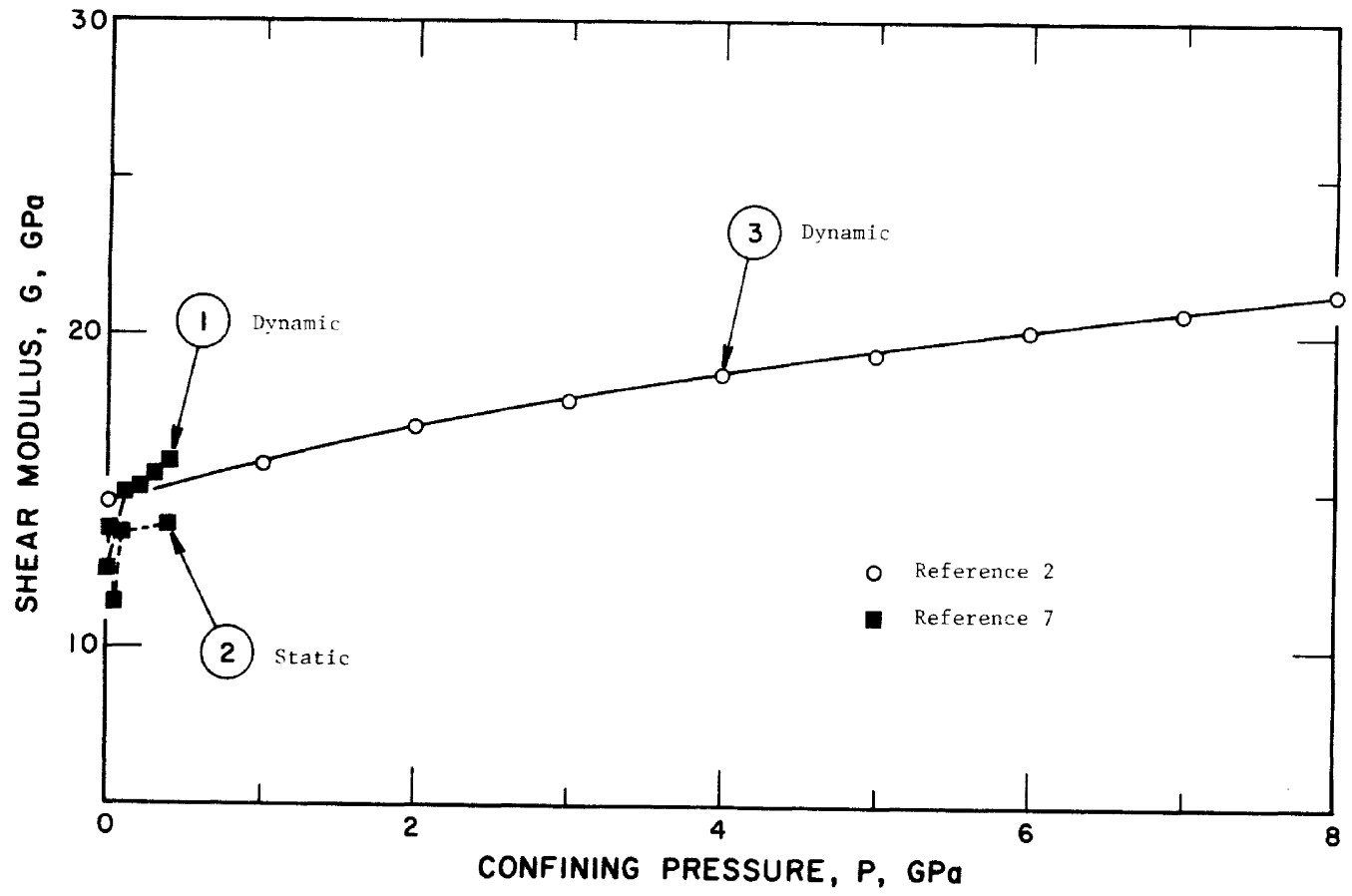

FIGURE 3.5. Variation of shear modulus with confining pressure (curve numbers correspond to data set numbers in matching table). 
TABLE 3.6. PRESSURE DEPENDENCE OF BULK MODULUS OF ROCK SALT

[Confining Pressure, $\mathrm{P}, \mathrm{GPa}$; Bulk Modulus, $\mathrm{K}_{\mathrm{s}} \mathrm{GPa}$ ]

\begin{tabular}{|c|c|c|c|c|}
\hline $\begin{array}{l}\text { Data } \\
\text { Set }\end{array}$ & Author(s), Year [Ref.] & $\mathrm{P}$ & $\mathrm{K}_{\mathrm{s}}$ & Remarks \\
\hline 1 & $\begin{array}{l}\text { Heard, H.C., Abey, } \\
\text { A.E., Bonner, B.P., } \\
\text { and Duba, A., } 1975[7]\end{array}$ & $\begin{array}{l}0.00 \\
0.02 \\
0.02 \\
0.02 \\
0.11 \\
0.12 \\
0.15 \\
0.17 \\
0.21 \\
0.24 \\
0.26 \\
0.29 \\
0.31 \\
0.33 \\
0.38 \\
0.45 \\
0.54 \\
0.70 \\
0.90 \\
1.15 \\
1.51 \\
1.86 \\
2.33 \\
2.85 \\
3.09 \\
3.22\end{array}$ & $\begin{array}{l}11.15 \\
12.30 \\
15.08 \\
17.71 \\
20.00 \\
20.66 \\
20.66 \\
20.34 \\
19.03 \\
17.55 \\
16.22 \\
16.08 \\
16.08 \\
17.07 \\
18.71 \\
21.01 \\
22.82 \\
25.12 \\
27.26 \\
29.73 \\
32.38 \\
35.35 \\
38.32 \\
41.63 \\
43.12 \\
41.11\end{array}$ & $\begin{array}{l}\text { Hydrostatic and quasi-hydrostatic loading; } \\
\text { samples were dry, polycrystalline, fine grained } \\
\mathrm{NaCl}(99.4-99.9 \% \text { pure); porosity } 1.1 \% \text {; samples } \\
\text { were partially work hardened; measurements } \\
\text { made at } 296 \mathrm{~K} \text {. }\end{array}$ \\
\hline 2 & $\begin{array}{l}\text { Voronov, F.F. and } \\
\text { Grigor'ev, S.B., } 1976 \\
{[2]}\end{array}$ & $\begin{array}{l}0.0 \\
1.0 \\
2.0 \\
3.0 \\
4.0 \\
5.0 \\
6.0 \\
7.0 \\
8.0\end{array}$ & $\begin{array}{l}25.23 \\
30.18 \\
35.07 \\
39.79 \\
44.24 \\
48.36 \\
52.08 \\
55.34 \\
58.10\end{array}$ & $\begin{array}{l}\text { Dynamic test results; longitudinal and trans- } \\
\text { verse wave velocities are ultrasonic at pres- } \\
\text { sures 0-10 } \mathrm{GPa} \text {; sample material pure, fine } \\
\text { polycrystalline } \mathrm{NaCl} \text {; measurements made at } \\
298 \mathrm{~K} \text {. }\end{array}$ \\
\hline 3 & $\begin{array}{l}\text { Heard, H.C., Abey, } \\
\text { A.E., Bonner, B.P., } \\
\text { and Duba, A., } 1975[7]\end{array}$ & $\begin{array}{l}0.0 \\
0.1 \\
0.2 \\
0.3 \\
0.4\end{array}$ & $\begin{array}{l}18.98 \\
22.63 \\
23.20 \\
24.27 \\
24.19\end{array}$ & $\begin{array}{l}\text { Two different dynamic test techniques were } \\
\text { used to obtain shear wave velocity and long1- } \\
\text { tudinal wave velocity; variability between two } \\
\text { methods greatest at ambient temperature - } 11 \% \\
\text { in } v_{10} \text { and } 8 \% \text { in } V_{\text {shear }} \text {; sample composition } \\
\text { as for Data Set } 1 .\end{array}$ \\
\hline 4 & $\begin{array}{l}\text { Heard, H.C., et al., } \\
1975 \text { [7] }\end{array}$ & $\begin{array}{l}0.01 \\
0.02 \\
0.1 \\
0.4\end{array}$ & $\begin{array}{l}21.3 \\
17.3 \\
23.8 \\
22.0\end{array}$ & $\begin{array}{l}\text { Static uniaxial loading was used; sample compo- } \\
\text { sition as for Data Set } 1 \text {; measurements made at } \\
296 \mathrm{~K} \text {. }\end{array}$ \\
\hline
\end{tabular}




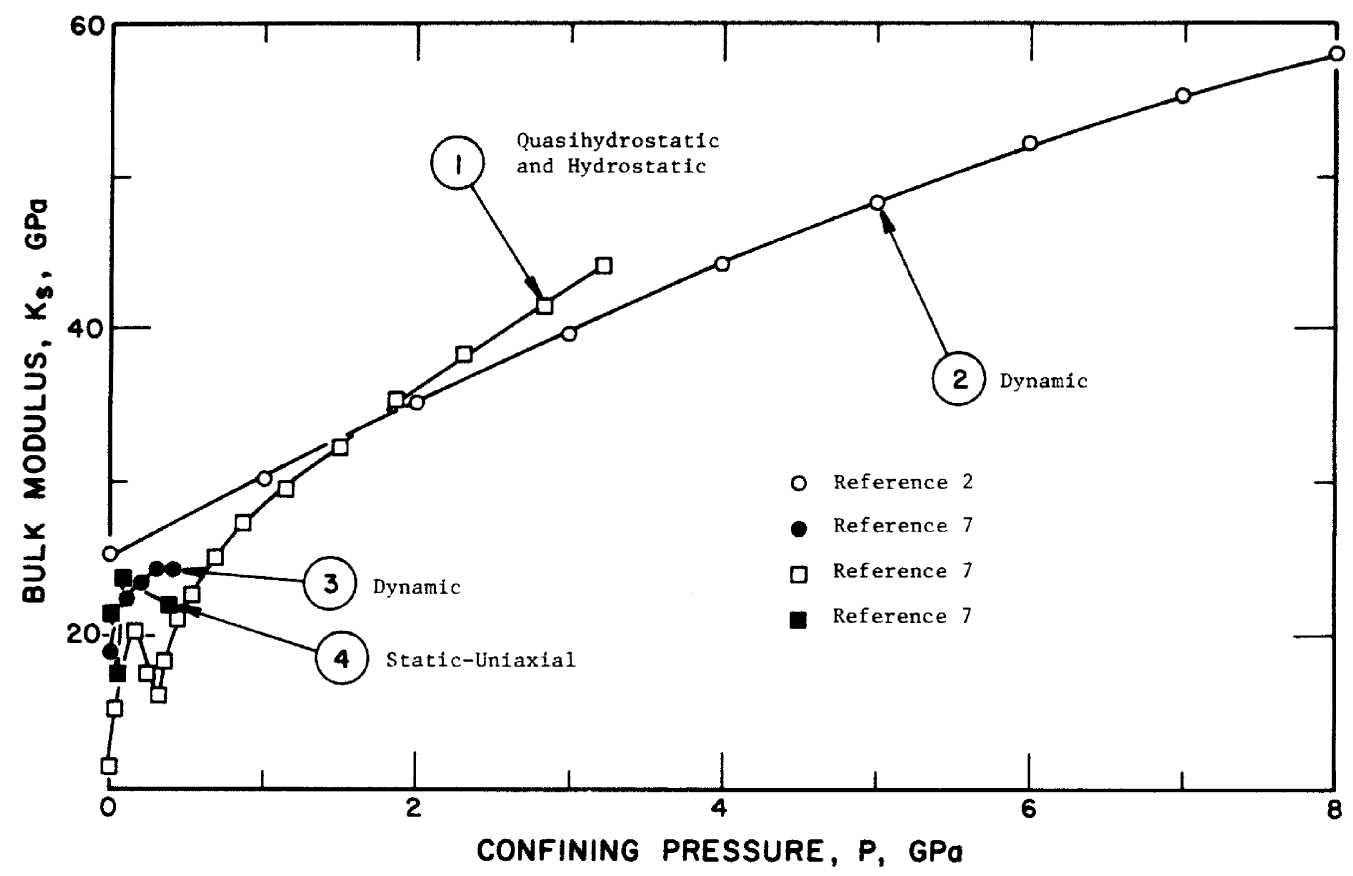

FigURE 3.6. Variation of bulk modulus with confining pressure (curve numbers correspond to data set numbers in matching table).

TABLE 3.7. PRESSURE DEPENDENCE OF POISSON'S RATIO OF ROCK SALT

[Confining Pressure, P, GPa; Poisson's Ratio, $\sigma$ ]

\begin{tabular}{|c|c|c|c|c|}
\hline $\begin{array}{l}\text { Data } \\
\text { Set }\end{array}$ & Author(s), Year [Ref.] & $P$ & $\mu$ & Remarks \\
\hline 1 & $\begin{array}{l}\text { Heard, H.C., Abey, } \\
\text { A.E., Bonner, B.P., } \\
\text { and Duba, A., } 1975[7]\end{array}$ & $\begin{array}{l}0.01 \\
0.02 \\
0.1 \\
0.2\end{array}$ & $\begin{array}{l}0.26 \\
0.32 \\
0.24 \\
0.29\end{array}$ & $\begin{array}{l}\text { Static uniaxial loading test; ratio obtained } \\
\text { by using transverse and axial strain gauges; } \\
\text { measurements made at } 298 \mathrm{~K} \text {. }\end{array}$ \\
\hline 2 & $\begin{array}{l}\text { Voronov, F.F. and } \\
\text { Grigor'ev, S.B., } 1976 \\
{[2]}\end{array}$ & $\begin{array}{l}0.0 \\
1.0 \\
2.0 \\
3.0 \\
4.0 \\
5.0 \\
6.0 \\
7.0 \\
8.0\end{array}$ & $\begin{array}{l}0.256 \\
0.275 \\
0.291 \\
0.304 \\
0.314 \\
0.323 \\
0.329 \\
0.334 \\
0.336\end{array}$ & $\begin{array}{l}\text { Dynamic results calculated from sound veloci- } \\
\text { ties; measurements made at } 298 \mathrm{~K} \text {. }\end{array}$ \\
\hline 3 & $\begin{array}{l}\text { Morris, C.E., Jamieson, } \\
\text { J.C., and Yarger, F.L., } \\
1976 \text { [4] }\end{array}$ & $\begin{array}{l}0.00 \\
1.50 \\
3.06 \\
4.50\end{array}$ & $\begin{array}{l}0.250 \\
0.280 \\
0.300 \\
0.315\end{array}$ & $\begin{array}{l}\text { Dynamic results calculated from measurements } \\
\text { obtained using a specially modified pressure } \\
\text { cel1; samples composed of reagent grade NaC1 } \\
(99.5 \% \text { pure). }\end{array}$ \\
\hline 4 & $\begin{array}{l}\text { Heard, H.C., Abey, } \\
\text { A.E., Bonner, B.P., } \\
\text { and Duba, A., } 1975 \text { [7] }\end{array}$ & $\begin{array}{l}0.0 \\
0.1 \\
0.2 \\
0.3 \\
0.4\end{array}$ & $\begin{array}{l}0.230 \\
0.229 \\
0.230 \\
0.236 \\
0.230\end{array}$ & $\begin{array}{l}\text { Dynamic results calculated from ultrasonic } \\
\text { velocities for pressures between } 0 \text { and } 0.4 \\
\text { GPa and at a temperature of } 298 \mathrm{~K} \text {. }\end{array}$ \\
\hline
\end{tabular}




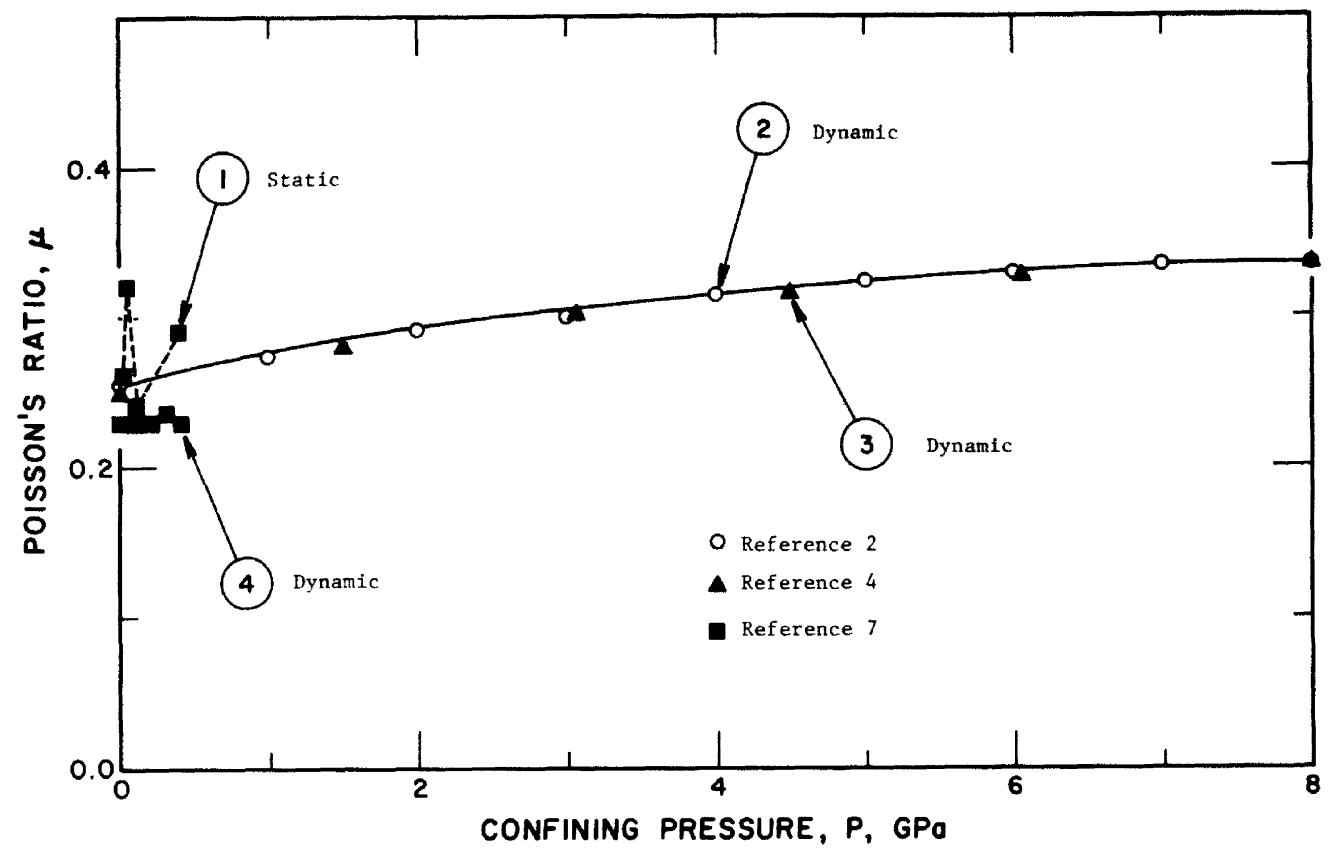

Figure 3.7. Variation of Poisson's Ratio with confining pressure (curve numbers correspond to data set numbers in matching table).

interferometry in a variable lateral support Bridgeman anvil device. The previous measurements of velocities in the range of $0-10 \mathrm{GPa}$ agree with these values. As can be seen from the figure, at higher pressures the shear wave velocity is almost constant or increases very gradually with increasing pressure. Figure 3.9 (after Heard) also indicates that at lower values of confining pressure the velocity increases rapidly with increasing pressure, but at higher values of confining pressure, the increase in velocity is gradual and small.

\subsection{Strength and Creep}

Due to the low limit of elasticity of rock salt, it is hard to divorce strength and creep. To quote Handin [20], "Strength is a meaningless term unless all environmental conditions are specified". In tests of short duration, the terms yield strength or ultimate strength or stress at a given strain are appropriate provided pressure, temperature, and chemical environment are specified. To quote Handin [20] further, with reference to the term strength, "It is better to avoid the term altogether for tests of long duration since there is no obvious connection between rigidity and creep". Odé [24] makes the following statement: "It is not known yet whether rock salt has a true yield limit, but, if it does the limit is low". From these quotes by both Handin and Ode, it is apparent that difficulties exist in the definition of strength for an elasto-plastic material like rock salt.
Bearing such comments in mind, it is difficult to reconcile the claims and statements of various researchers. It is suggested that possibly the elastic-ductile transition is perhaps a distinction criterion between strength and creep provided all conditions are specified.

Baar [17] claims much of the technical and scientific literature on salt rocks is misleading. The reason given is that laboratory testing gives different behavior than that found in-situ. Laboratory strength testing causes "work hardening" which does not occur in-situ. From an engineering viewpoint it appears that laboratory obtained parameters are possibly not valid. An example occurs in underground excavations where most rocks behave elastically; however, this does not occur in salt rocks because they display stress relief creep.

Generally, salt rocks are elasto-plastic and behavior will be elastic unless the $\left(\sigma_{1}-\sigma_{3}\right)$ stress difference exceeds the limit of elasticity. Such rocks reassume elastic behavior once the stress difference has dropped below a certain critical value. It should be noted that stress difference initiates creep and not stress magnitude.

In particular, Baar [17] disagrees with the ideal creep curves obtained by many researchers. It is his contention that the decreasing creep rates displayed by such curves are a manifestation of work hardening, something not often found in situ.

Assuming a viscous analogue, salt may be assigned an equivalent viscosity. This viscosity behavior is a 
TABLE 3.8. PRESSURE DEPENDENCE OF LONGITUDINAL AND SHEAR WAVE VELOCITIES OF ROCK SALT [Confining Pressure, P, GPa; Velocity, $\mathrm{v}, \mathrm{m} \mathrm{s}^{-1}$ ]

\begin{tabular}{|c|c|c|c|c|}
\hline $\begin{array}{l}\text { Data } \\
\text { Set }\end{array}$ & Author(s), Year [Ref.] & $\mathrm{P}$ & $\mathbf{v}$ & Remarks \\
\hline 1 & $\begin{array}{l}\text { Frankel, J., Rich, F.J., } \\
\text { and Homan, C.G., } 1976 \\
{[16]}\end{array}$ & $\begin{array}{r}2.5 \\
3.0 \\
3.5 \\
4.0 \\
4.5 \\
5.0 \\
5.5 \\
6.0 \\
6.5 \\
7.0 \\
7.5 \\
8.0 \\
9.0 \\
10.0 \\
11.0 \\
12.0 \\
13.0 \\
15.0 \\
17.0 \\
19.0 \\
21.0 \\
23.0 \\
25.0 \\
27.0\end{array}$ & $\begin{array}{l}5007 \\
5088 \\
5165 \\
5238 \\
5307 \\
5380 \\
5450 \\
5518 \\
5585 \\
5648 \\
5710 \\
5769 \\
5877 \\
5986 \\
6092 \\
6193 \\
6290 \\
6478 \\
6647 \\
6785 \\
6915 \\
7056 \\
7188 \\
7304\end{array}$ & $\begin{array}{l}\text { Longitudinal wave velocity; polycrystalline } \\
\mathrm{NaCl} \text {; long1tudina1 wave velocity measured at } \\
\text { static pressures from } 2.5-27.0 \mathrm{GPa} \text { at } 300 \mathrm{~K} \text {; } \\
\text { Bridgeman Anvil device used for velocity } \\
\text { measurements. }\end{array}$ \\
\hline 2 & $\begin{array}{l}\text { Frankel, J., et al., } \\
1976[16]\end{array}$ & $\begin{array}{r}2.5 \\
3.0 \\
3.5 \\
4.0 \\
4.5 \\
5.0 \\
5.5 \\
6.0 \\
6.5 \\
7.0 \\
7.5 \\
8.0 \\
9.0 \\
10.0 \\
11.0 \\
12.0 \\
13.0 \\
15.0 \\
17.0 \\
19.0 \\
21.0 \\
23.0 \\
25.0 \\
27.0\end{array}$ & $\begin{array}{l}2679 \\
2696 \\
2710 \\
2722 \\
2732 \\
2750 \\
2768 \\
2785 \\
2804 \\
2820 \\
2835 \\
2849 \\
2867 \\
2894 \\
2923 \\
2950 \\
2976 \\
3033 \\
3076 \\
3083 \\
3088 \\
3123 \\
3154 \\
3169\end{array}$ & $\begin{array}{l}\text { Shear wave velocity; sample specifications and } \\
\text { testing conditions are the same as above. }\end{array}$ \\
\hline 3 & $\begin{array}{l}\text { Voronov, F.F. and } \\
\text { Grigor'ev, S.B., } 1975 \\
\text { [2] }\end{array}$ & $\begin{array}{l}0 \\
1 \\
2 \\
3 \\
4 \\
5\end{array}$ & $\begin{array}{l}4551 \\
4785 \\
4989 \\
5166 \\
5317 \\
5445\end{array}$ & $\begin{array}{l}\text { Longitudinal wave velocity; ultrasonic method } \\
\text { used on polycrystalline } \mathrm{NaC} 1 \text { samples under } \\
\text { quasi-hydrostatic conditions; measurements } \\
\text { made at } 298 \mathrm{~K} \text {. }\end{array}$ \\
\hline
\end{tabular}


TABLE 3.8. PRESSURE DEPENDENCE OF LONGITUDINAL AND SHEAR WAVE VELOCITIES OF ROCK SALT (continued)

\begin{tabular}{|c|c|c|c|c|}
\hline $\begin{array}{c}\text { Data } \\
\text { Set }\end{array}$ & Author (s), Year [Ref.] & $\mathrm{P}$ & $\mathbf{v}$ & Remarks \\
\hline $\begin{array}{c}3 \\
(\operatorname{cont} .)\end{array}$ & $\begin{array}{l}\text { Voronov, F.F. and } \\
\text { Grigor'ev, S.B., } 1975 \\
\text { [2] }\end{array}$ & $\begin{array}{l}6 \\
7 \\
8\end{array}$ & $\begin{array}{l}5551 \\
5638 \\
5708\end{array}$ & \\
\hline 4 & $\begin{array}{l}\text { Voronov, F.F. and } \\
\text { Grigor'ev, S.B., } 1975 \\
\text { [2] }\end{array}$ & $\begin{array}{l}0 \\
1 \\
2 \\
3 \\
4 \\
5 \\
6 \\
7 \\
8\end{array}$ & $\begin{array}{l}2606 \\
2665 \\
2709 \\
2743 \\
2767 \\
2786 \\
2802 \\
2818 \\
2837\end{array}$ & Shear wave velocity; conditions same as above. \\
\hline 5 & $\begin{array}{l}\text { Heard, H.C., Abey, } \\
\text { A.E., Bonner, B.P., } \\
\text { and Duba, A., } 1975 \text { [7] }\end{array}$ & $\begin{array}{l}0.000 \\
0.010 \\
0.020 \\
0.050 \\
0.075 \\
0.100 \\
0.150 \\
0.200 \\
0.250 \\
0.300 \\
0.350 \\
0.400\end{array}$ & $\begin{array}{l}4078 \\
4310 \\
4371 \\
4419 \\
4430 \\
4453 \\
4463 \\
4493 \\
4509 \\
4538 \\
4530 \\
4549\end{array}$ & $\begin{array}{l}\text { Longitudinal wave velocity; ultrasonic veloci- } \\
\text { ties calculated on } 4 \text { small samples (19 mm } \\
\text { diameter } \times 25 \mathrm{~mm} \text { length) and } 2 \text { slightly larger } \\
\text { samples; transducers were polycrystalline } \\
\text { ceramic } \mathrm{Pb}(\mathrm{Zn}, \mathrm{T} 1) \mathrm{O}_{3} \text { polarized for transverse } \\
\text { shear with dominant frequency of } 1 \mathrm{MHz} \text {. }\end{array}$ \\
\hline 6 & $\begin{array}{l}\text { Heard, H.C., et al., } \\
1975[7]\end{array}$ & $\begin{array}{l}0.000 \\
0.020 \\
0.050 \\
0.070 \\
0.100 \\
0.150 \\
0.200 \\
0.250 \\
0.300 \\
0.350 \\
0.400\end{array}$ & $\begin{array}{l}2419 \\
2509 \\
2591 \\
2629 \\
2636 \\
2659 \\
2657 \\
2666 \\
2668 \\
2676 \\
2685\end{array}$ & $\begin{array}{l}\text { Shear wave velocity; test conditions similar } \\
\text { to above. }\end{array}$ \\
\hline
\end{tabular}

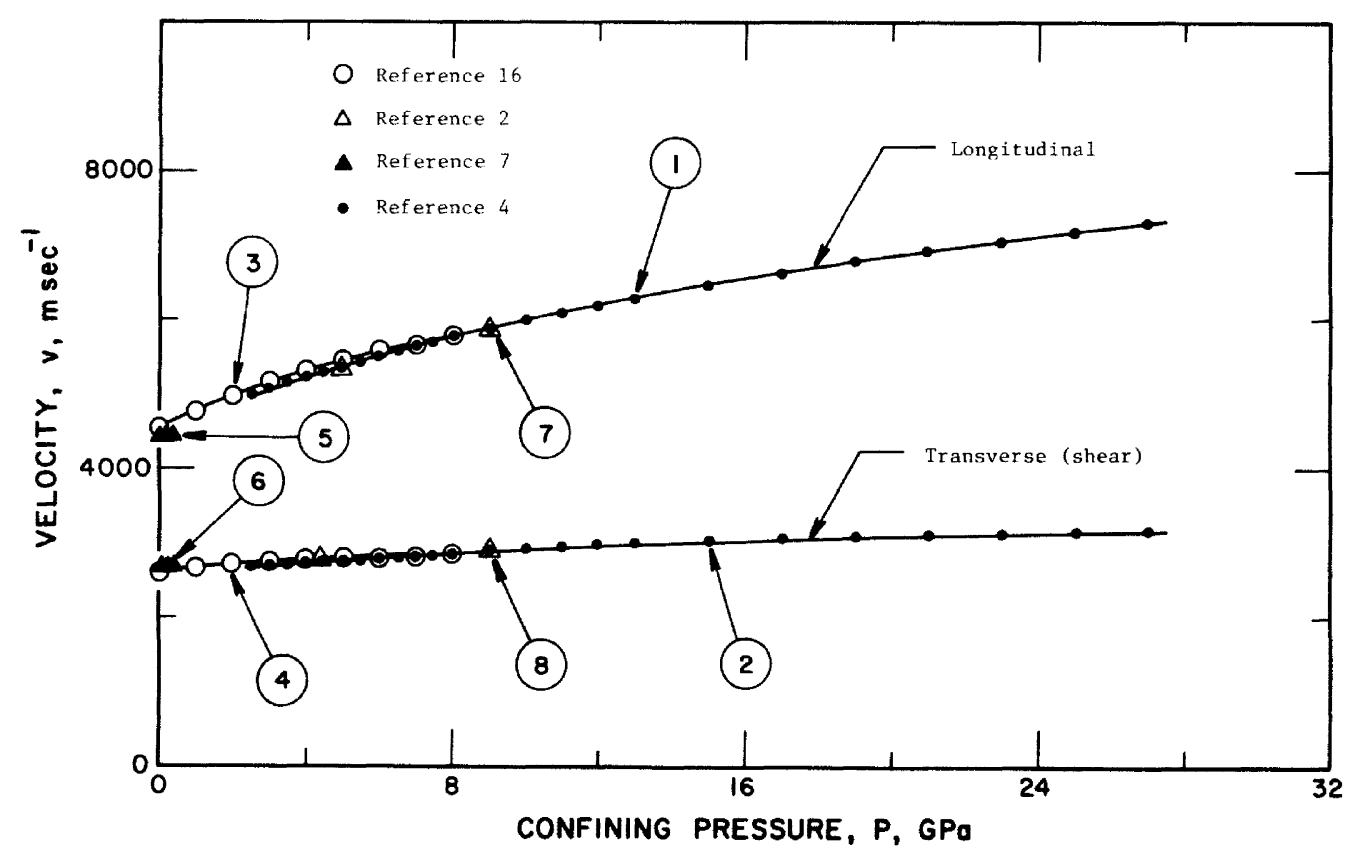

FIGURE 3.8. Variation of longitudinal wave velocity and shear wave velocity with high confining pressures (curve numbers correspond to data set numbers in matching table). 


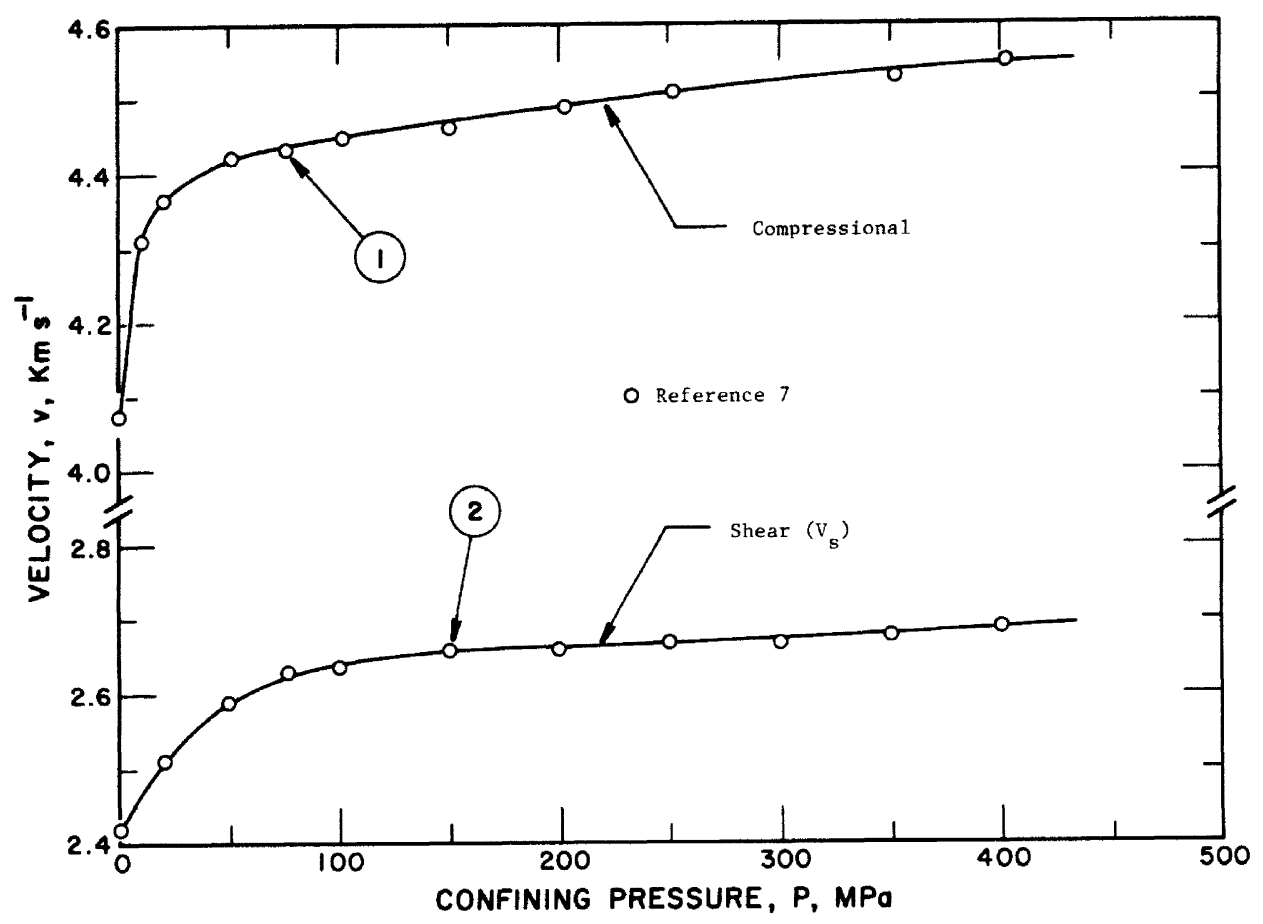

FiguRE 3.9. Variation of longitudinal wave velocity and shear wave velocity with lower confining pressures (curve numbers correspond to data set numbers in matching table).

function of temperature, confining pressure, differential stress and time. Assuming that creep of salt takes place by a steady state mode there are factors such as axial stress, grain size, temperature and confining pressure which affect its behavior.

Le Comte [22] investigated the above four factors and drew the following conclusions. In the case of the axial stress an increase in the stress produces an increase in creep rate. An increase in grain size on the other hand decreases that creep rate. Confining pressure tends to decrease the creep rate, whereas, an increase in pressure increases the creep rate several fold. Of these factors the temperature effect is by far the most significant and exerts the greatest influence.

Due to the controversy surrounding the term "strength" when applied to rock salt, it has been decided to drop this term and rather to designate data in a general way as "stress-strain" or as "creep" data. It is then left to the user as to which of the two groups best satisfies his needs.

\subsubsection{Stress-Strain Data}

In the case of stress, the primary quantities are the principal stresses $\sigma_{1}, \sigma_{3}$, the differential stress $\left(\sigma_{1}-\sigma_{3}\right)$, and the shear stress, $\tau$. On occasions a relationship between differential stress and the minor principal stress $\left(\sigma_{3}\right)$ is also used.
Initially, in almost every case, the relationship at either low confining stress or strain displays behavior with an elastic component. Beyond a certain stress $\left(\sigma_{3}\right)$ or strain, however, the salt shows more of a plastic character. The former behavior may be regarded as elastic, whereas the latter is plastic in nature.

In the case of some relationships between shear stress and strain, the elastic-plastic transition is not pronounced and has arbitrarily been taken to occur at about $0.2 \%$ axial strain. The above transition is observed at 298 $\mathrm{K}$; however, this transition changes and may even almost disappear depending on the prevailing temperature.

Dreyer's [12] data on shear and normal stress and their variation with test conditions are tabulated in tables 3.9 and 3.10 and are shown in figures 3.10 and 3.11 , respectively. In general, the relationship suggests that the influence of strain hardening is small and, as expected, the shear stress bearing capacity is a minimum under uniaxial loading and increases as the confining pressure increases.

The effect of temperature and confining pressure on the deformation of halite single crystals has been studied by Gera [5] and can be seen in Figure 3.12 with the corresponding values in Table 3.11. From the figure it is observed that as temperature increases, creep also increases, and that the effect of confining pressure is secondary. This latter observation is clear from the small difference between the $100 \mathrm{MPa}$ and $200 \mathrm{MPa}$ curves. 
TABLE 3.9. RELATIONSHIP BETWEEN SHEAR STRESS AND STRAIN FOR

ROCK SALT UNDER VARYING TEST CONDITIONS

[Shear Stress, $\tau$, GPa; Strain, $\varepsilon, \%$ ]

\begin{tabular}{|c|c|c|c|c|}
\hline $\begin{array}{l}\text { Data } \\
\text { Set }\end{array}$ & Author (s), Year [Ref.] & $\tau$ & $\varepsilon$ & Remarks \\
\hline 1 & Dreyer, W., 1972 [12] & $\begin{array}{l}2.206 \\
3.625 \\
4.650 \\
5.243 \\
5.639 \\
5.887 \\
6.037 \\
6.119 \\
6.239 \\
6.320 \\
6.362\end{array}$ & $\begin{array}{l}0.15 \\
0.33 \\
0.52 \\
0.74 \\
0.95 \\
1.13 \\
1.35 \\
1.57 \\
1.74 \\
1.95 \\
2.16\end{array}$ & $\begin{array}{l}\text { Cubical samples of halite with } 10.6 \mathrm{~cm} \text { edge } \\
\text { length; grain size distribution homogeneous; } \\
\text { uniaxially loaded }-\sigma_{2}=\sigma_{3}, \sigma_{3}=0 \text {; room tem- } \\
\text { perature. }\end{array}$ \\
\hline 2 & Dreyer, W., 1972 [12] & $\begin{array}{l}3.309 \\
4.649 \\
5.399 \\
5.795 \\
6.034 \\
6.312 \\
6.472 \\
6.671 \\
6.791 \\
6.872 \\
6.953\end{array}$ & $\begin{array}{l}0.22 \\
0.45 \\
0.64 \\
0.85 \\
1.06 \\
1.25 \\
1.46 \\
1.67 \\
1.84 \\
2.05 \\
2.25\end{array}$ & $\begin{array}{l}\text { Sample similar to above; multiaxially loaded; } \\
\sigma_{2} \neq \sigma_{3}, \sigma_{2}=4.447 \mathrm{GPa}, \sigma_{3}=2.223 \mathrm{GPa} \text {; room tem- } \\
\text { perature. }\end{array}$ \\
\hline 3 & Dreyer, W., 1972 [12] & $\begin{array}{l}2.678 \\
5.081 \\
5.989 \\
6.384 \\
6.583 \\
6.744 \\
6.903 \\
7.024 \\
7.144 \\
7.186 \\
7.306 \\
7.309\end{array}$ & $\begin{array}{l}0.13 \\
0.34 \\
0.55 \\
0.74 \\
0.93 \\
1.18 \\
1.37 \\
1.56 \\
1.76 \\
1.98 \\
2.16 \\
2.39\end{array}$ & $\begin{array}{l}\text { Sample similar to above; } \sigma_{2}=\sigma_{3}, \sigma_{3}=4.447 \mathrm{GPa} ; \\
\text { room temperature. }\end{array}$ \\
\hline 4 & Dreyer, W., 1972 [12] & $\begin{array}{l}2.204 \\
3.228 \\
5.611 \\
6.500 \\
6.974 \\
7.252 \\
7.412 \\
7.572 \\
7.653 \\
7.734 \\
7.855 \\
7.975 \\
8.057 \\
8.177\end{array}$ & $\begin{array}{l}0.07 \\
0.10 \\
0.34 \\
0.51 \\
0.72 \\
0.95 \\
1.14 \\
1.35 \\
1.56 \\
1.75 \\
1.98 \\
2.17 \\
2.39 \\
2.58\end{array}$ & $\begin{array}{l}\text { Sample similar to above; } \sigma_{2}=\sigma_{3}, \sigma_{3}=13.341 \mathrm{GPa} \text {; } \\
\text { room temperature. }\end{array}$ \\
\hline
\end{tabular}




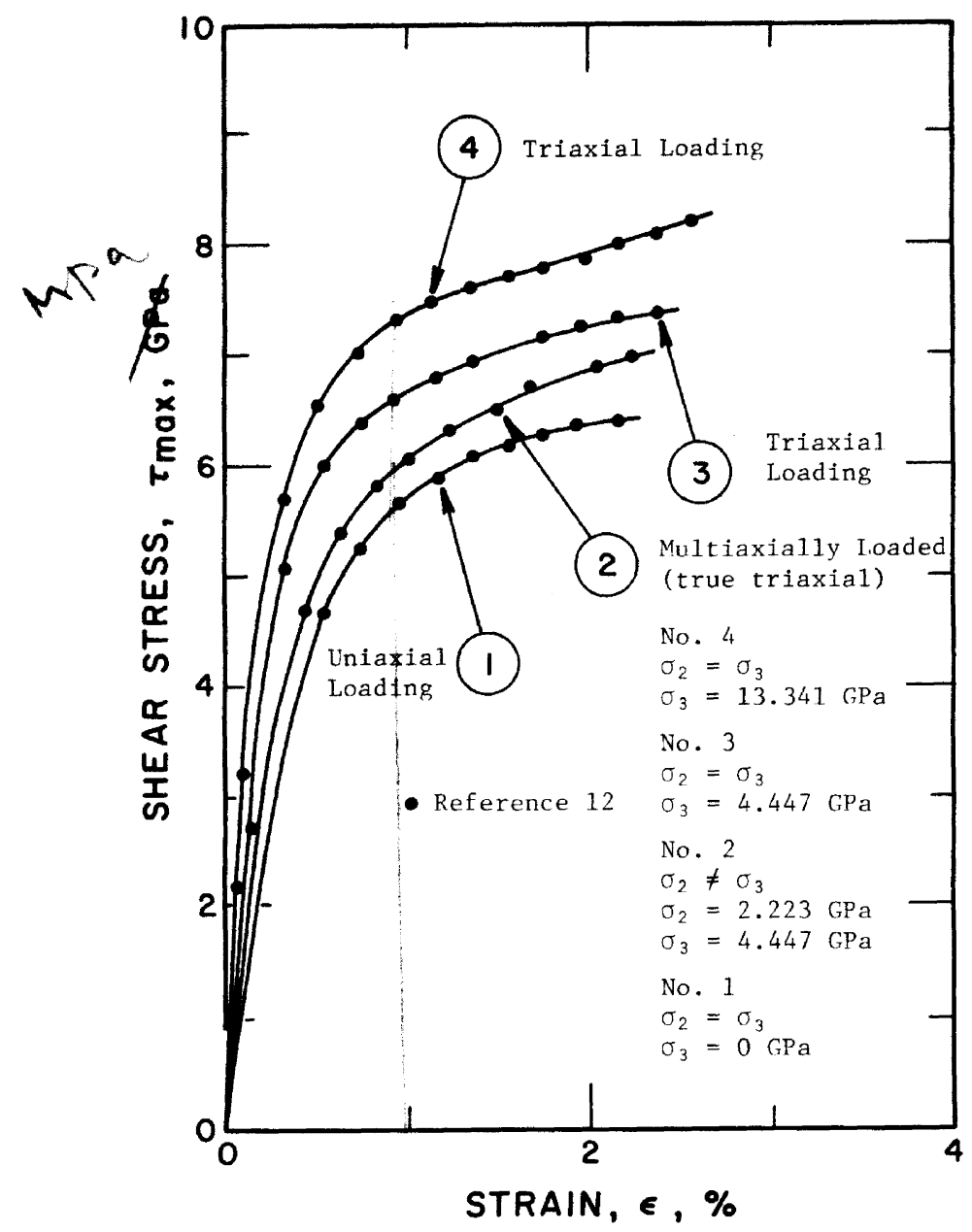

FIGURE 3.10. Shear stress-strain behavior of rock salt for different test conditions (curve numbers correspond to data set numbers in matching table). 
TABLE 3.10. STRESS-STRAIN RELATIONSHIP FOR ROCK SALT UNDER VARYING TEST CONDITIONS

[Stress, $\sigma_{1}$, GPa; Strain, $\varepsilon$, \%]

\begin{tabular}{|c|c|c|c|c|}
\hline $\begin{array}{l}\text { Data } \\
\text { Set }\end{array}$ & Author (s), Year [Ref.] & $\sigma_{1}$ & $\varepsilon$ & Remarks \\
\hline 1 & Dreyer, W., 1972 [12] & $\begin{array}{r}3.234 \\
7.142 \\
9.164 \\
10.511 \\
11.185 \\
11.724 \\
11.994 \\
12.129 \\
12.263 \\
12.533 \\
12.802\end{array}$ & $\begin{array}{l}0.06 \\
0.28 \\
0.49 \\
0.68 \\
0.90 \\
1.10 \\
1.32 \\
1.51 \\
1.73 \\
1.92 \\
2.11\end{array}$ & $\begin{array}{l}\text { Cubical sample of halite with } 10.6 \mathrm{~cm} \text { edge } \\
\text { length; uniaxially loaded, } \sigma_{2}=\sigma_{3}, \sigma_{3}=0 \text {; room } \\
\text { temperature. }\end{array}$ \\
\hline 2 & Dreyer, W., 1972 [12] & $\begin{array}{r}3.234 \\
8.760 \\
11.455 \\
13.072 \\
13.341 \\
14.015 \\
14.419 \\
14.959 \\
15.363 \\
15.632 \\
15.767 \\
16.037 \\
16.037\end{array}$ & $\begin{array}{l}0.03 \\
0.19 \\
0.39 \\
0.58 \\
0.71 \\
0.90 \\
1.10 \\
1.32 \\
1.52 \\
1.73 \\
1.95 \\
2.14 \\
2.33\end{array}$ & $\begin{array}{l}\text { Sample similar to above; } \sigma_{2} \neq \sigma_{3}, \sigma_{2}=4.447 \mathrm{GPa} \text {, } \\
\sigma_{3}=2.223 \mathrm{GPa} \text {; room temperature. }\end{array}$ \\
\hline 3 & Dreyer, W., 1972 [12] & $\begin{array}{r}9.703 \\
14.419 \\
16.576 \\
17.115 \\
17.249 \\
17.657 \\
17.923 \\
18.193 \\
18.597 \\
18.732 \\
18.866 \\
19.136\end{array}$ & $\begin{array}{l}0.08 \\
0.28 \\
0.49 \\
0.69 \\
0.88 \\
1.08 \\
1.32 \\
1.51 \\
1.71 \\
1.92 \\
2.12 \\
2.33\end{array}$ & $\begin{array}{l}\text { Sample similar to above; } \sigma_{2}=\sigma_{3}, \sigma_{3}=4.447 \mathrm{GPa} \text {; } \\
\text { room temperature. }\end{array}$ \\
\hline 4 & Dreyer, W., 1972 [12] & $\begin{array}{l}19.54 \\
24.39 \\
26.144 \\
27.087 \\
27.626 \\
28.030 \\
28.300 \\
28.569 \\
28.839 \\
29.108 \\
29.243 \\
29.648 \\
29.917\end{array}$ & $\begin{array}{l}0.08 \\
0.27 \\
0.47 \\
0.68 \\
0.88 \\
1.08 \\
1.29 \\
1.49 \\
1.71 \\
1.90 \\
2.11 \\
2.29 \\
2.51\end{array}$ & $\begin{array}{l}\text { Sample similar to above; } \sigma_{2}=\sigma_{3}, \sigma_{3}=13.341 \mathrm{GPa} \text {; } \\
\text { room temperature. }\end{array}$ \\
\hline
\end{tabular}




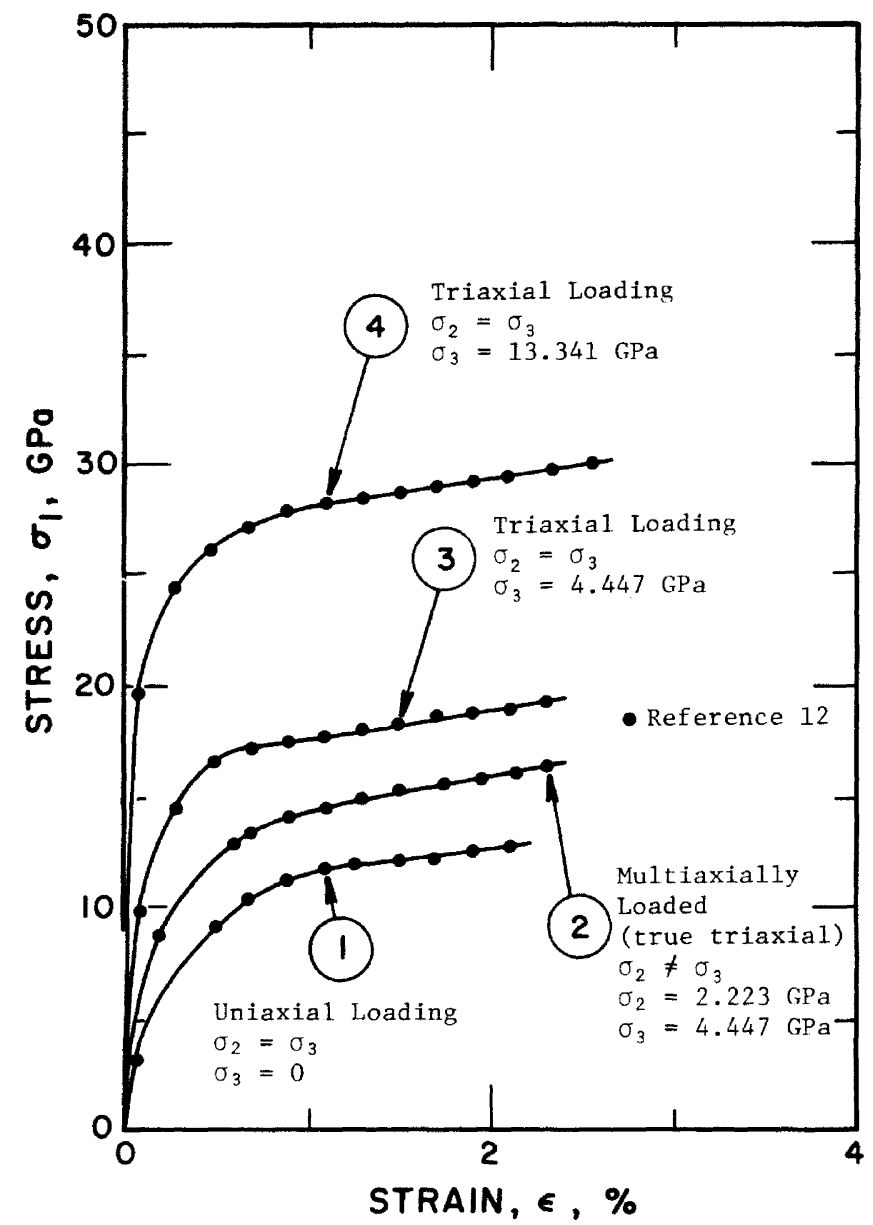

FiguRE 3.11. Normal stress-strain behavior of rock salt for different test conditions (curve numbers correspond to data set numbers in matching table). 
TABLE 3.11 . RELATIONSHIP BETWEEN DIFFERENTIAL STRESS AND STRAIN FOR SINGLE HALITE CRYSTALS AT VARYING CONFINING PRESSURE AND TEMPERATURE

[Differential Stress $\left(\sigma_{1}-\sigma_{3}\right), \mathrm{MPa}$; Strain, $\varepsilon, \%$ ]

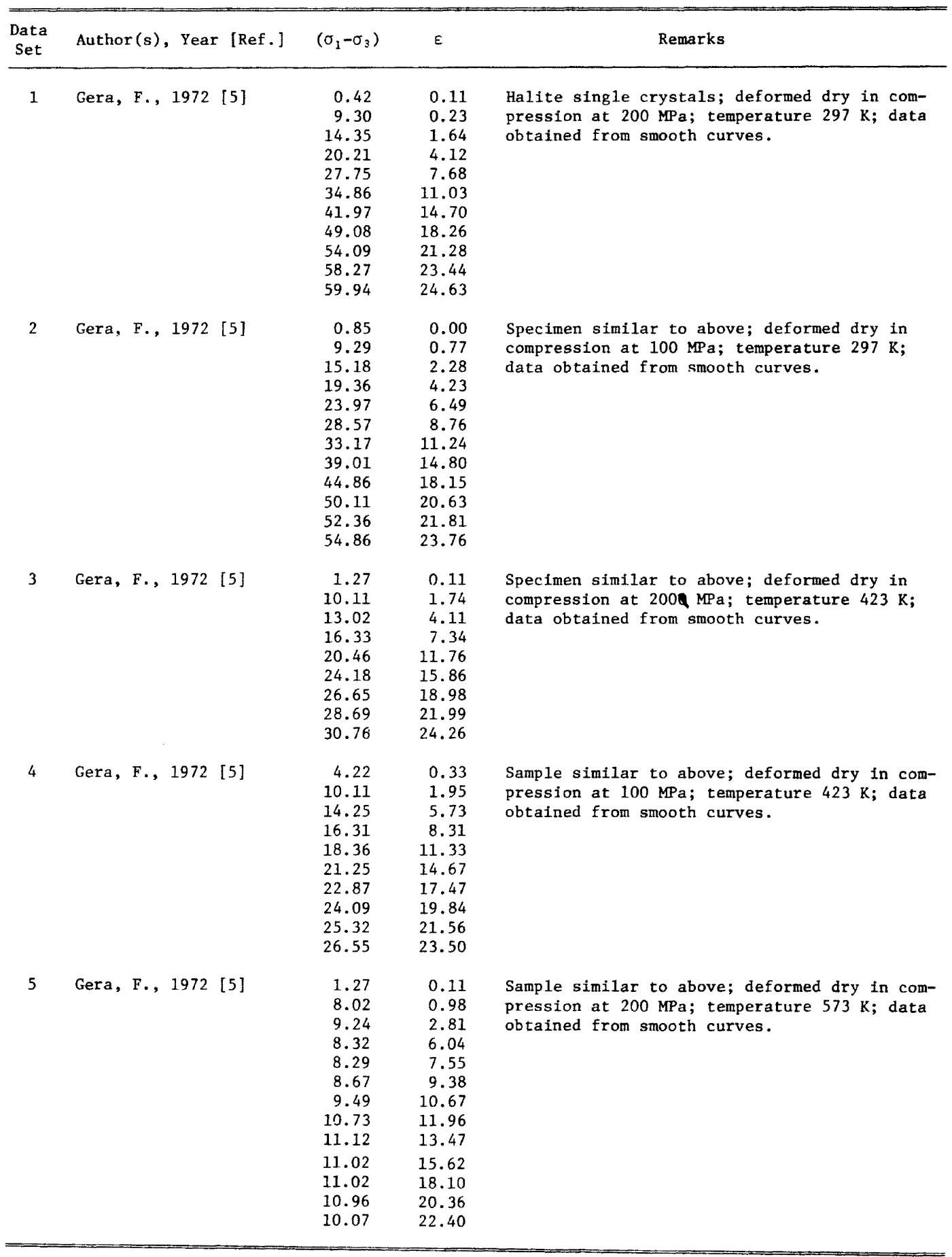




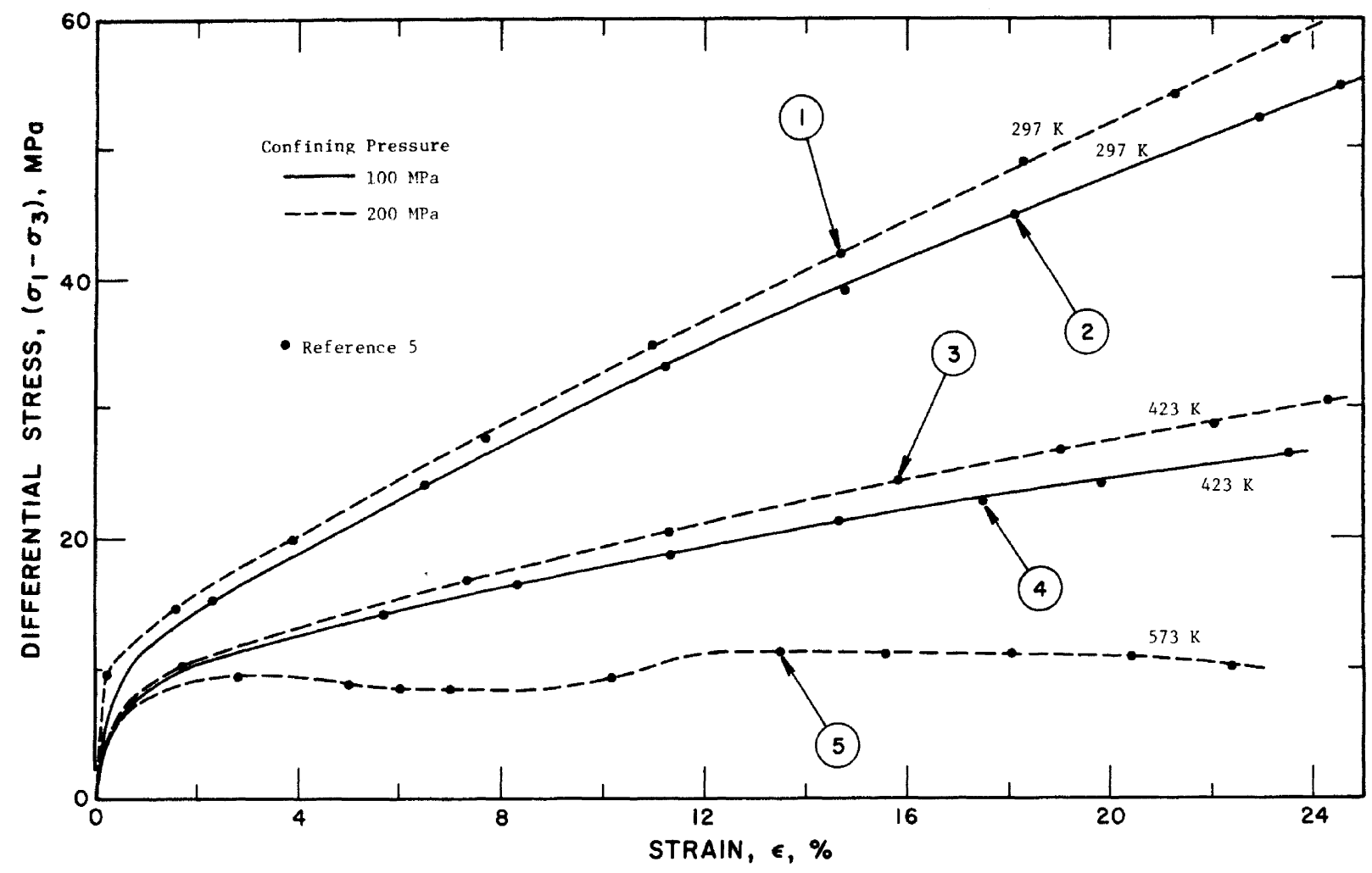

FigurE 3.12. Differential stress-strain relationship at several temperatures and different confining pressures (curve numbers correspond to data set numbers in matching table).

Another relationship of interest is that of differential stress versus confining pressure which is shown in figure 3.13. The corresponding data are taken from ref. [7] and reported in table 3.12. It can be observed that after a maximum differential stress of about $50 \mathrm{MPa}$ has been achieved, there is a decrease in differential stress $\left(\sigma_{1}-\right.$ $\left.\sigma_{3}\right)$ as $\sigma_{3}$ increases. This behavior has been attributed by Heard et al. [7] to pore collapse in the rock salt and continues until confining pressure has reached a value of about $230 \mathrm{MPa}$ after which differential stress increases with confining pressure.

Axial and circumferential strain of rock salt samples as a function of stress difference during triaxial loading and unloading are presented in figure 3.14 with the corresponding values in table 3.13 . The data have been taken from ref. [7] and indicate that for cylindrical samples with an $\mathrm{L} / \mathrm{D}$ ratio $=2$, and loads $>50 \mathrm{MPa}$, there is a marked change in the slope of both stress-strain curves. This implies two different modes of behavior beyond this $50 \mathrm{MPa}$ demarcation, i.e., elastic-plastic transition.

Typical differential stress-strain curves for annealed halite aggregates are illustrated in figures 3.15 to 3.19 and tables 3.14-3.18 for a broad range of strain rates at
$273 \mathrm{~K}$ to $400 \mathrm{~K}$ (Heard [21]). It is noteworthy that strain hardening is decreased by decreasing strain rate or increasing temperature. Steady-state flow is closely approximated during most of the deformation at $10^{-8} \mathrm{~s}^{-1}$ and $373 \mathrm{~K}$. The onset of steady-state flow occurs at somewhat higher rates at intermediate temperature, and at $673 \mathrm{~K}$, strain hardening appears dominant only at the highest rates investigated.

Figures 3.20 and 3.21 and tables $3.19-3.20$ show stress-strain results as a function of temperature at two strain rates, $10^{-5}$ and $10^{-7} \mathrm{~s}^{-1}$ at a confining pressure of $200 \mathrm{MPa}$. In both of these cases, strain hardening disappears as the intermediate temperatures are reached.

A comparison of the behavior of annealed and unannealed rock salt samples which are work hardened to some degree can be observed in figure 3.22 and table 3.21 which represent data from Gera [5]. The annealed sample shows lower shear stress resistance as evidenced by the greater amount of strain it undergoes for the same load compared to the unannealed sample. This lower resistance of the annealed sample is thought to be caused by recrystallization that occurs during annealing allowing the rock salt to revert to its former state (i.e., work hardening effect is destroyed). 
TABLE 3.12. VARIATION OF DIFFERENTIAL STRESS WITH CONFINING PRESSURE FOR UNIAXIAL STRAIN LOADING OF ROCK SALT

[Confining Pressure, $\sigma_{3}, \mathrm{MPa}$; Differential Stress, $\left(\sigma_{1}-\sigma_{3}\right), \mathrm{MPa}$ ]

\begin{tabular}{|c|c|c|c|c|}
\hline $\begin{array}{c}\text { Data } \\
\text { Set }\end{array}$ & Author (s), Year [Ref.] & $\sigma_{3}$ & $\left(\sigma_{1}-\sigma_{3}\right)$ & Remarks \\
\hline 1 & $\begin{array}{l}\text { Heard, H.C., Abey, } \\
\text { A.E., Bonner, B.P., } \\
\text { and Duba, A., 1975 [7] }\end{array}$ & $\begin{array}{r}4.90 \\
6.12 \\
11.23 \\
11.17 \\
12.41 \\
16.22 \\
26.44 \\
46.99 \\
59.83 \\
71.39 \\
80.37 \\
111.26 \\
126.70 \\
135.72 \\
155.03 \\
160.21 \\
175.65 \\
197.52 \\
227.16 \\
243.87 \\
274.74 \\
296.57 \\
322.31 \\
378.85 \\
425.15 \\
663.06 \\
681.06 \\
697.77 \\
699.12 \\
641.62 \\
600.92\end{array}$ & $\begin{array}{l}18.39 \\
23.23 \\
26.14 \\
30.65 \\
34.20 \\
38.08 \\
42.93 \\
45.52 \\
48.12 \\
50.10 \\
51.68 \\
51.06 \\
51.07 \\
50.12 \\
49.49 \\
47.23 \\
47.25 \\
47.91 \\
44.39 \\
45.69 \\
46.69 \\
49.93 \\
49.95 \\
55.48 \\
57.11 \\
67.98 \\
68.96 \\
70.27 \\
65.43 \\
35.38 \\
-0.136\end{array}$ & $\begin{array}{l}\text { Dry, fine grained, polycrystalline } \mathrm{NaCl} \text { with } \\
1 \% \text { porosity; uniaxial strain loading }\left(\sigma_{2}=\sigma_{3}=\right. \\
0) \text {; maximum confining pressyre } 100 \mathrm{MPa} \text {; tem- } \\
\text { perature } 296 \mathrm{~K} \text {. }\end{array}$ \\
\hline
\end{tabular}

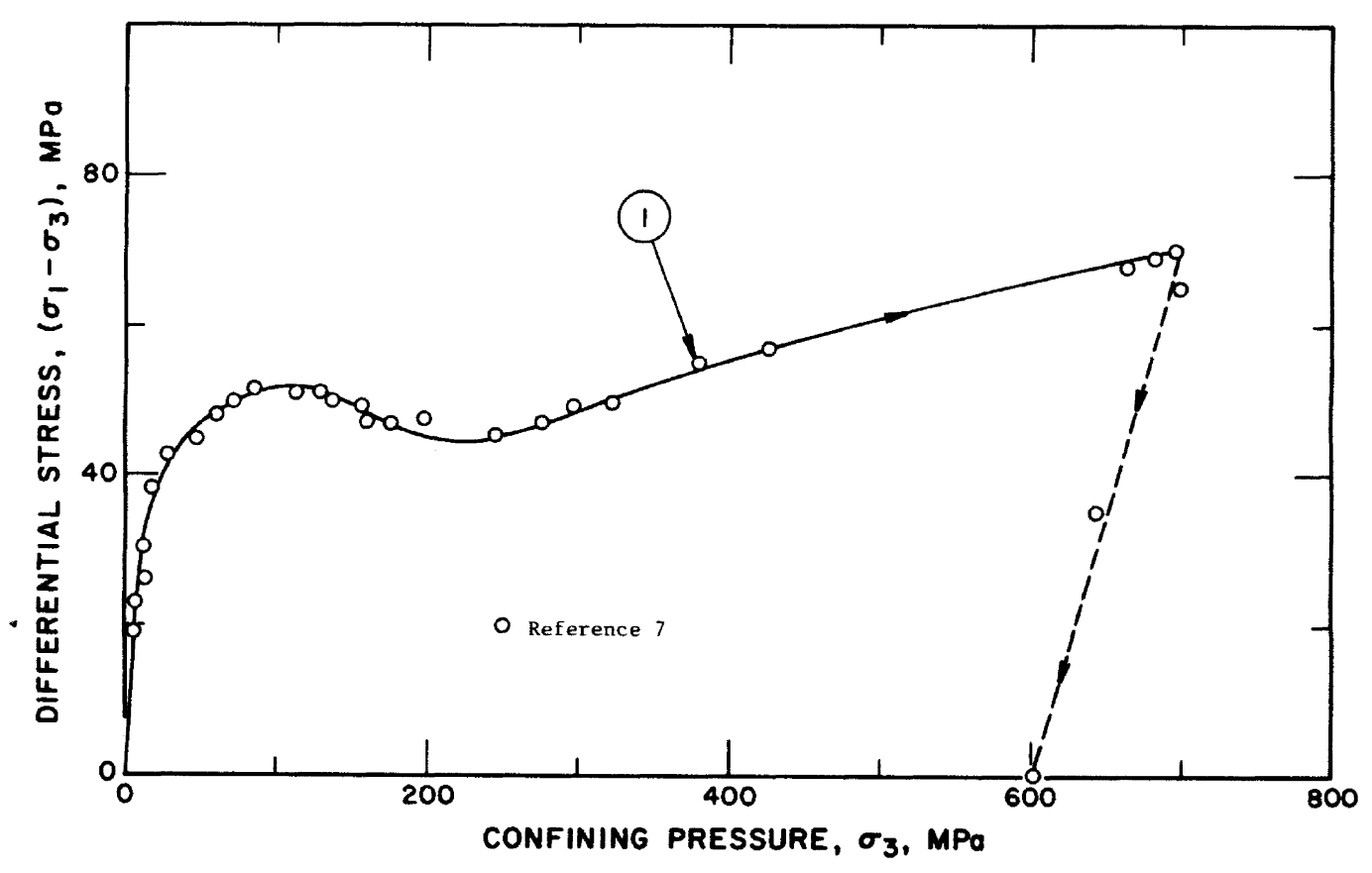

FIGURE 3.13. Relationship of differential stress to confining pressure of rock salt under uniaxial strain loading (curve numbers correspond to data set numbers in matching table). 
TABLE 3.13. AXIAL $\left(\varepsilon_{1}\right)$ AND CIRCUMFERENTIAL $\left(\varepsilon_{3}\right)$ STRAINS AS A FUNCTION OF STRESS DIFFERENCE ON UNIAXIAL STRESS LOADING AND UNLOADING

[Differential Stress, $\left(\sigma_{1}-\sigma_{3}\right)$, MPa; Strain, $\varepsilon$ ]

\begin{tabular}{|c|c|c|c|c|}
\hline $\begin{array}{l}\text { Data } \\
\text { Set }\end{array}$ & Author (s), Year [Ref.] & $\left(\sigma_{1}-\sigma_{3}\right)$ & $\varepsilon$ & Remarks \\
\hline 1 & $\begin{array}{l}\text { Heard, H.C., Abey, } \\
\text { A.E., Bonner, B.P., } \\
\text { and Duba, A., } 1975[7]\end{array}$ & $\begin{array}{r}3.89 \\
9.93 \\
26.70 \\
43.73 \\
55.51 \\
59.33 \\
66.41 \\
74.43 \\
80.75 \\
66.29 \\
41.05 \\
13.01\end{array}$ & $\begin{array}{r}0.000 \\
0.000 \\
-0.001 \\
-0.002 \\
-0.004 \\
-0.006 \\
-0.010 \\
-0.023 \\
-0.039 \\
-0.048 \\
-0.045 \\
-0.045\end{array}$ & $\begin{array}{l}\text { Axial strain }\left(\varepsilon_{1}\right) \text {; dry, fine grained, poly- } \\
\text { crystalline } \mathrm{NaCl} \text { with } 1 \% \text { porosity; uniaxial } \\
\text { stress loading and unloading; } \sigma_{3}=100 \mathrm{MPa} \text {. }\end{array}$ \\
\hline 2 & $\begin{array}{l}\text { Heard, H.C., et a1., } \\
1975 \text { [7] }\end{array}$ & $\begin{array}{r}3.89 \\
9.67 \\
26.44 \\
55.32 \\
66.37 \\
71.08 \\
78.06 \\
82.02 \\
65.82 \\
12.48\end{array}$ & $\begin{array}{l}0.000 \\
0.000 \\
0.000 \\
0.001 \\
0.004 \\
0.007 \\
0.012 \\
0.019 \\
0.020 \\
0.020\end{array}$ & $\begin{array}{l}\text { Circumferential strain }\left(\varepsilon_{3}\right) \text {; sample and test } \\
\text { conditions same as above. }\end{array}$ \\
\hline
\end{tabular}

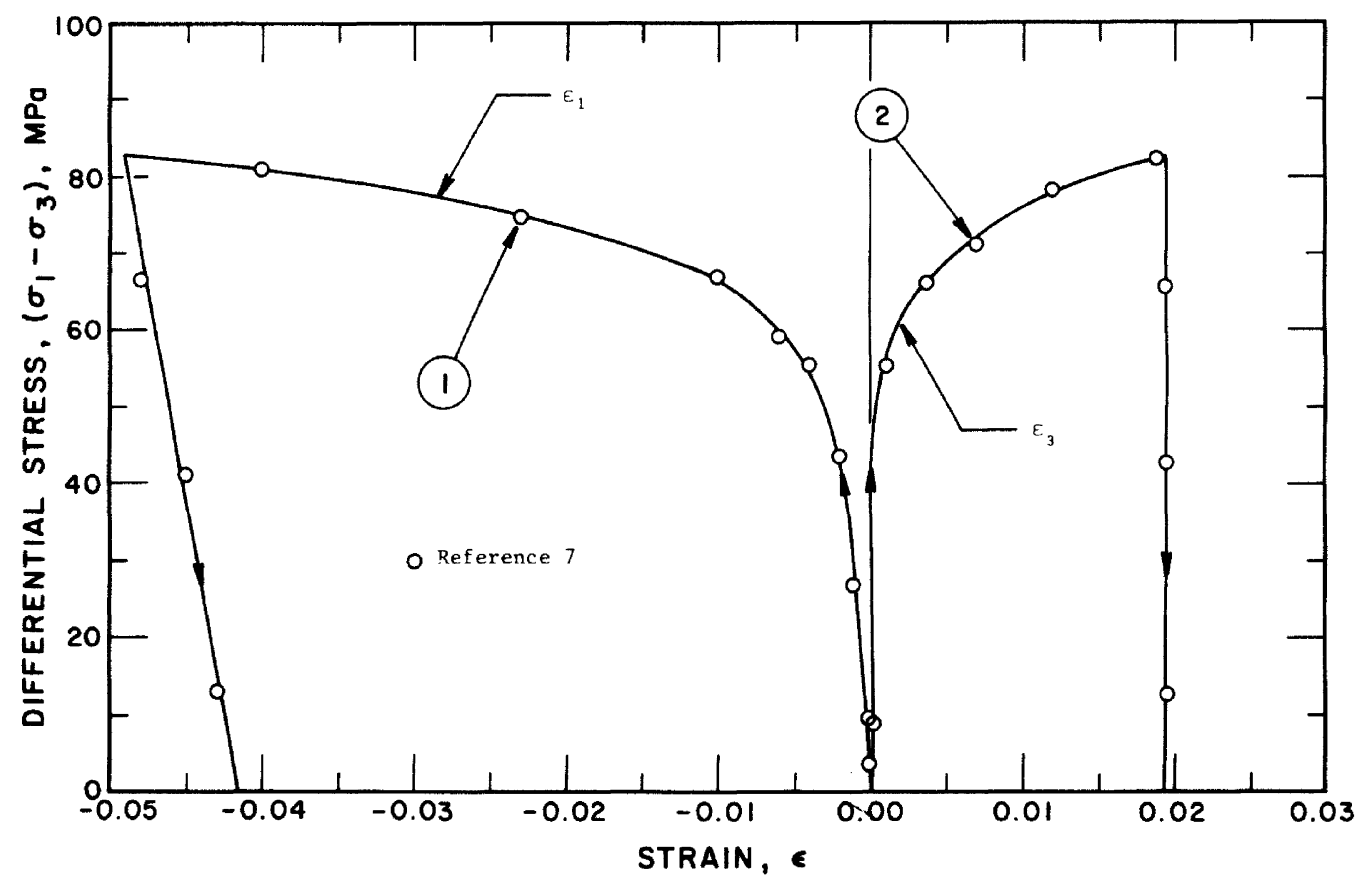

FIGURE 3.14. Axial $\left(\epsilon_{1}\right)$ and circumferential $\left(\epsilon_{3}\right)$ strain as a function of differential stress (curve numbers correspond to data set numbers in matching table). 
TABLE 3.14. DIFFERENTIAL STRESS-STRAIN CURVE FOR POLYCRYSTALLINE HALITE EXTENDED AT $200 \mathrm{MPa}, 373 \mathrm{~K}$, AND $\dot{\varepsilon}=1.5 \times 10^{-3} \mathrm{TO}$ $1.5 \times 10^{-8} \mathrm{~s}^{-1}$

[Strain, $E$, \%; Differential Stress, $\left(\sigma_{1}-\sigma_{3}\right) \mathrm{MPa}$ ]

\begin{tabular}{|c|c|c|c|c|c|}
\hline $\begin{array}{l}\text { Data } \\
\text { Set }\end{array}$ & $\begin{array}{r}\text { Author (s), } \\
\text { [Ref.] }\end{array}$ & Year & $\varepsilon$ & $\sigma_{1}-\sigma_{3}$ & Remarks \\
\hline 1 & $\begin{array}{l}\text { Heard, H.C., } \\
{[21]}\end{array}$ & 1972 & $\begin{array}{r}0.000 \\
0.087 \\
0.218 \\
0.480 \\
0.655 \\
1.004 \\
1.441 \\
1.878 \\
2.576 \\
3.712 \\
4.978 \\
6.943 \\
8.603 \\
9.869 \\
11.354\end{array}$ & $\begin{array}{r}4.988 \\
9.977 \\
14.966 \\
17.728 \\
19.955 \\
22.449 \\
25.033 \\
27.171 \\
29.309 \\
31.804 \\
33.674 \\
35.902 \\
37.327 \\
38.307 \\
39.287\end{array}$ & $\dot{\varepsilon}=1.5 \times 10^{-3} \mathrm{~s}^{-1}$ \\
\hline 2 & $\begin{array}{l}\text { Heard, H.C., } \\
{[21]}\end{array}$ & 1972 & $\begin{array}{r}0.655 \\
1.004 \\
1.616 \\
2.358 \\
3.537 \\
5.371 \\
7.031 \\
8.777 \\
10.131 \\
11.616\end{array}$ & $\begin{array}{l}12.294 \\
14.877 \\
18.262 \\
20.935 \\
23.875 \\
26.726 \\
28.418 \\
30.111 \\
31.180 \\
32.249\end{array}$ & $\dot{\varepsilon}=1.5 \times 10^{-4} \mathrm{~s}^{-1}$ \\
\hline 3 & $\begin{array}{l}\text { Heard, H.C., } \\
{[21]}\end{array}$ & 1972 & $\begin{array}{r}0.262 \\
0.742 \\
1.354 \\
2.052 \\
2.314 \\
3.362 \\
5.066 \\
6.376 \\
7.904 \\
9.127 \\
10.611 \\
11.528\end{array}$ & $\begin{array}{l}10.155 \\
15.055 \\
18.351 \\
20.222 \\
20.935 \\
22.539 \\
24.409 \\
25.389 \\
26.369 \\
26.993 \\
27.616 \\
27.884\end{array}$ & $\dot{\varepsilon}=1.5 \times 10^{-5} \mathrm{~s}^{-1}$ \\
\hline
\end{tabular}


TABLE 3.14. DIFFERENTIAL STRESS-STRAIN CURVE FOR POLYCRYSTALLINE HALITE EXTENDED AT $200 \mathrm{MPa}, 373 \mathrm{~K}$, AND $\dot{\varepsilon}=1.5 \times 10^{-3} \mathrm{TO}$ $1.5 \times 10^{-8} \mathrm{~s}^{-1}$ (Continued)

\begin{tabular}{|c|c|c|c|c|c|}
\hline $\begin{array}{l}\text { Data } \\
\text { Set }\end{array}$ & $\begin{array}{l}\text { Author(s), Year } \\
\text { [Ref.] }\end{array}$ & $\varepsilon$ & $\sigma_{1}-\sigma_{3}$ & Remarks & \\
\hline 4 & $\begin{array}{l}\text { Heard, H.C., } 1972 \\
{[21]}\end{array}$ & $\begin{array}{r}0.087 \\
0.175 \\
0.262 \\
0.437 \\
0.611 \\
1.004 \\
1.703 \\
2.402 \\
3.712 \\
5.066 \\
6.201 \\
7.991 \\
9.389 \\
10.699 \\
11.310\end{array}$ & $\begin{array}{r}2.405 \\
4.988 \\
6.770 \\
9.977 \\
11.492 \\
13.363 \\
15.055 \\
16.302 \\
17.995 \\
19.420 \\
20.311 \\
21.469 \\
22.093 \\
22.717 \\
22.806\end{array}$ & $\dot{\varepsilon}=1.5 \times 10^{-6}$ & $s^{-1}$ \\
\hline 5 & $\begin{array}{l}\text { Heard, H.C., } 1972 \\
{[21]}\end{array}$ & $\begin{array}{r}0.568 \\
1.310 \\
2.271 \\
3.450 \\
4.585 \\
6.201 \\
7.467 \\
8.908 \\
10.000 \\
10.699\end{array}$ & $\begin{array}{l}10.957 \\
12.472 \\
13.897 \\
15.233 \\
16.124 \\
17.104 \\
17.728 \\
18.262 \\
18.619 \\
18.708\end{array}$ & $\dot{\varepsilon}=1.5 \times 10^{-7}$ & $s^{-1}$ \\
\hline 6 & $\begin{array}{l}\text { Heard, H.C., } 1972 \\
{[21]}\end{array}$ & $\begin{array}{r}0.437 \\
0.568 \\
0.742 \\
1.354 \\
2.183 \\
3.362 \\
4.803 \\
6.594 \\
7.904 \\
9.127 \\
10.262\end{array}$ & $\begin{array}{r}9.175 \\
9.621 \\
9.977 \\
10.423 \\
10.779 \\
11.135 \\
11.403 \\
11.581 \\
11.670 \\
11.581 \\
11.581\end{array}$ & $\dot{\varepsilon}=1.5 \times 10^{-8}$ & $s^{-1}$ \\
\hline
\end{tabular}




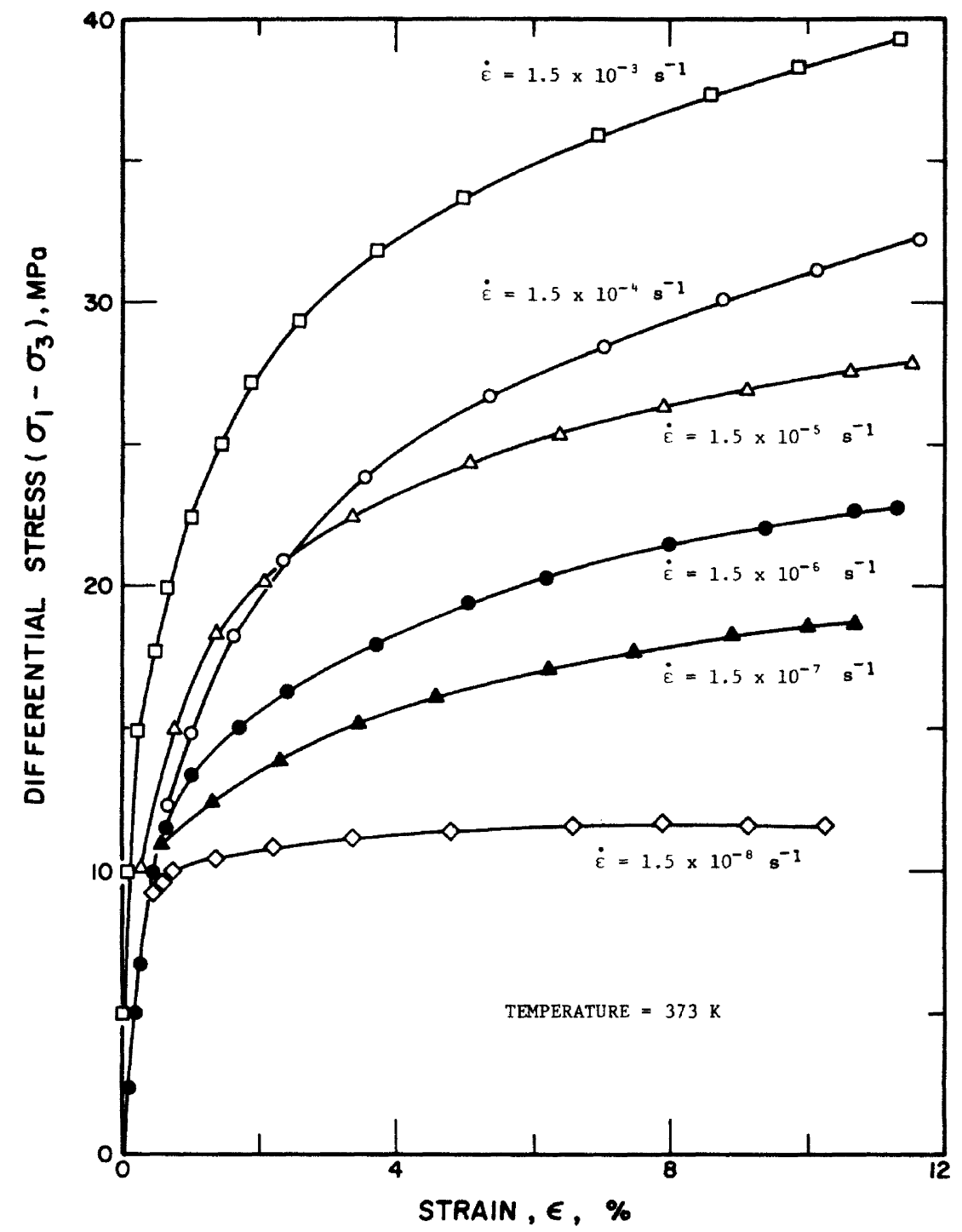

FIGURE 3.15. Differential stress-strain curves for polycrystalline halite at $373 \mathrm{~K}$. 
TABLE 3.15. DIFFERENTIAL STRESS-STRAIN RELATIONSHIP FOR POLYCRYSTALLINE HALITE AT $200 \mathrm{MPa}, 473 \mathrm{~K}$, AND $\dot{\varepsilon}=1.8 \times 10^{-2} \mathrm{TO}$

$1.2 \times 10^{-8} \mathrm{~s}^{-1}$

[Strain, $\varepsilon, \%$; Differential Stress, $\left(\sigma_{1}-\sigma_{3}\right)$ MPa]

\begin{tabular}{|c|c|c|c|c|c|c|}
\hline $\begin{array}{l}\text { Data } \\
\text { Set }\end{array}$ & $\begin{array}{r}\text { Author }(\mathbf{s}), \\
{[\text { Ref.] }}\end{array}$ & Year & $\varepsilon$ & $\sigma_{1}-\sigma_{3}$ & Remarks & \\
\hline 1 & $\begin{array}{l}\text { Heard, H.C., } \\
{\left[\begin{array}{llll}2 & 1\end{array}\right]}\end{array}$ & 1972 & $\begin{array}{r}0.050 \\
0.145 \\
0.280 \\
0.547 \\
1.034 \\
1.785 \\
2.842 \\
3.811 \\
4.823 \\
5.880 \\
7.904 \\
9.883 \\
11.686\end{array}$ & $\begin{array}{r}4.955 \\
9.999 \\
12.299 \\
15.041 \\
17.516 \\
19.990 \\
22.020 \\
23.254 \\
24.310 \\
25.366 \\
26.949 \\
28.000 \\
28.610\end{array}$ & $\dot{\varepsilon}=1.8 \times 10^{-2}$ & $s^{-1}$ \\
\hline 2 & $\begin{array}{l}\text { Heard, H.C., } \\
{[21]}\end{array}$ & 1972 & $\begin{array}{r}0.635 \\
1.032 \\
1.385 \\
1.869 \\
3.849 \\
5.917 \\
7.984 \\
9.919 \\
11.107\end{array}$ & $\begin{array}{l}14.598 \\
16.100 \\
16.806 \\
17.335 \\
19.006 \\
20.145 \\
21.196 \\
22.070 \\
22.507\end{array}$ & $\dot{\varepsilon}=1.5 \times 10^{-3}$ & $s^{-1}$ \\
\hline 3 & $\begin{array}{l}\text { Heard, H.C., } \\
{[21]}\end{array}$ & 1972 & $\begin{array}{r}0.323 \\
0.764 \\
1.161 \\
1.821 \\
3.889 \\
5.913 \\
7.892 \\
9.914 \\
11.233\end{array}$ & $\begin{array}{l}11.591 \\
12.916 \\
13.533 \\
14.149 \\
15.731 \\
16.959 \\
17.745 \\
18.265 \\
18.524\end{array}$ & $\dot{\varepsilon}=1.5 \times 10^{-4}$ & $s^{-1}$ \\
\hline 4 & $\begin{array}{l}\text { Heard, H.C., } \\
{[21]}\end{array}$ & 1972 & $\begin{array}{r}0.051 \\
0.141 \\
0.495 \\
0.760 \\
1.290 \\
1.906 \\
2.787 \\
3.887 \\
4.987 \\
5.911 \\
7.934 \\
9.913 \\
11.232\end{array}$ & $\begin{array}{r}5.044 \\
6.901 \\
9.023 \\
9.907 \\
11.232 \\
12.290 \\
13.525 \\
14.492 \\
15.283 \\
15.720 \\
16.594 \\
17.292 \\
17.727\end{array}$ & $\dot{\varepsilon}=1.2 \times 10^{-4}$ & $s^{-1}$ \\
\hline
\end{tabular}


TABLE 3.15. DIFFERENTIAL STRESS-STRAIN RELATIONSHIP FOR POLYCRYSTALLINE HALITE AT $200 \mathrm{MPa}, 473 \mathrm{~K}$, AND $\dot{\varepsilon}=1.8 \times 10^{-2} \mathrm{TO}$ $1.2 \times 10^{-8} \mathrm{~s}^{-1} \quad$ (Continued)

\begin{tabular}{|c|c|c|c|c|c|}
\hline $\begin{array}{l}\text { Data } \\
\text { Set }\end{array}$ & $\begin{array}{r}\text { Author(s), } \\
\text { [Ref.] }\end{array}$ & Year & $\varepsilon$ & $\sigma_{1}-\sigma_{3}$ & Remarks \\
\hline 5 & $\begin{array}{l}\text { Heard, H.C., } \\
{[21]}\end{array}$ & 1972 & $\begin{array}{r}0.405 \\
1.374 \\
1.859 \\
3.047 \\
3.883 \\
5.951 \\
7.929 \\
9.908 \\
10.919\end{array}$ & $\begin{array}{r}7.254 \\
8.842 \\
9.547 \\
10.691 \\
11.395 \\
12.534 \\
13.143 \\
13.663 \\
13.747\end{array}$ & $\dot{\varepsilon}=1.2 \times 10^{-5} \mathrm{~s}^{-1}$ \\
\hline 6 & $\begin{array}{l}\text { Heard, H.C., } \\
\text { [21] }\end{array}$ & 1972 & $\begin{array}{r}0.140 \\
0.624 \\
1.900 \\
3.923 \\
5.945 \\
7.924 \\
9.946 \\
11.397\end{array}$ & $\begin{array}{l}6.194 \\
6.722 \\
7.335 \\
7.943 \\
8.375 \\
8.895 \\
9.150 \\
9.142\end{array}$ & $\dot{\varepsilon}=1.2 \times 10^{-6} \mathrm{~s}^{-1}$ \\
\hline 7 & $\begin{array}{l}\text { Heard, H.C., } \\
{[21]}\end{array}$ & 1972 & $\begin{array}{r}0.093 \\
0.357 \\
1.281 \\
1.897 \\
2.952 \\
3.875 \\
5.985 \\
7.963 \\
9.985 \\
11.348\end{array}$ & $\begin{array}{l}3.893 \\
4.245 \\
4.683 \\
4.945 \\
5.117 \\
5.289 \\
5.543 \\
5.532 \\
5.521 \\
5.514\end{array}$ & $\dot{\varepsilon}=1.2 \times 10^{-7} \mathrm{~s}^{-1}$ \\
\hline 8 & $\begin{array}{l}\text { Heard, H.C., } \\
{[21]}\end{array}$ & 1972 & $\begin{array}{l}0.138 \\
1.106 \\
1.897 \\
3.084 \\
3.920 \\
5.414 \\
5.414 \\
5.500 \\
5.543 \\
5.587 \\
5.939 \\
6.554\end{array}$ & $\begin{array}{l}4.424 \\
5.038 \\
5.388 \\
5.647 \\
5.642 \\
5.723 \\
5.546 \\
3.864 \\
3.687 \\
3.510 \\
3.508 \\
3.416\end{array}$ & $\dot{\varepsilon}=1.2 \times 10^{-7} \mathrm{~s}^{-1}$ \\
\hline 9 & $\begin{array}{l}\text { Heard, H.C., } \\
{[21]}\end{array}$ & 1972 & $\begin{array}{l}0.048 \\
0.136 \\
1.191\end{array}$ & $\begin{array}{l}3.008 \\
3.273 \\
3.268\end{array}$ & $\dot{\varepsilon}=1.2 \times 10^{-8} \mathrm{~s}^{-1}$ \\
\hline
\end{tabular}




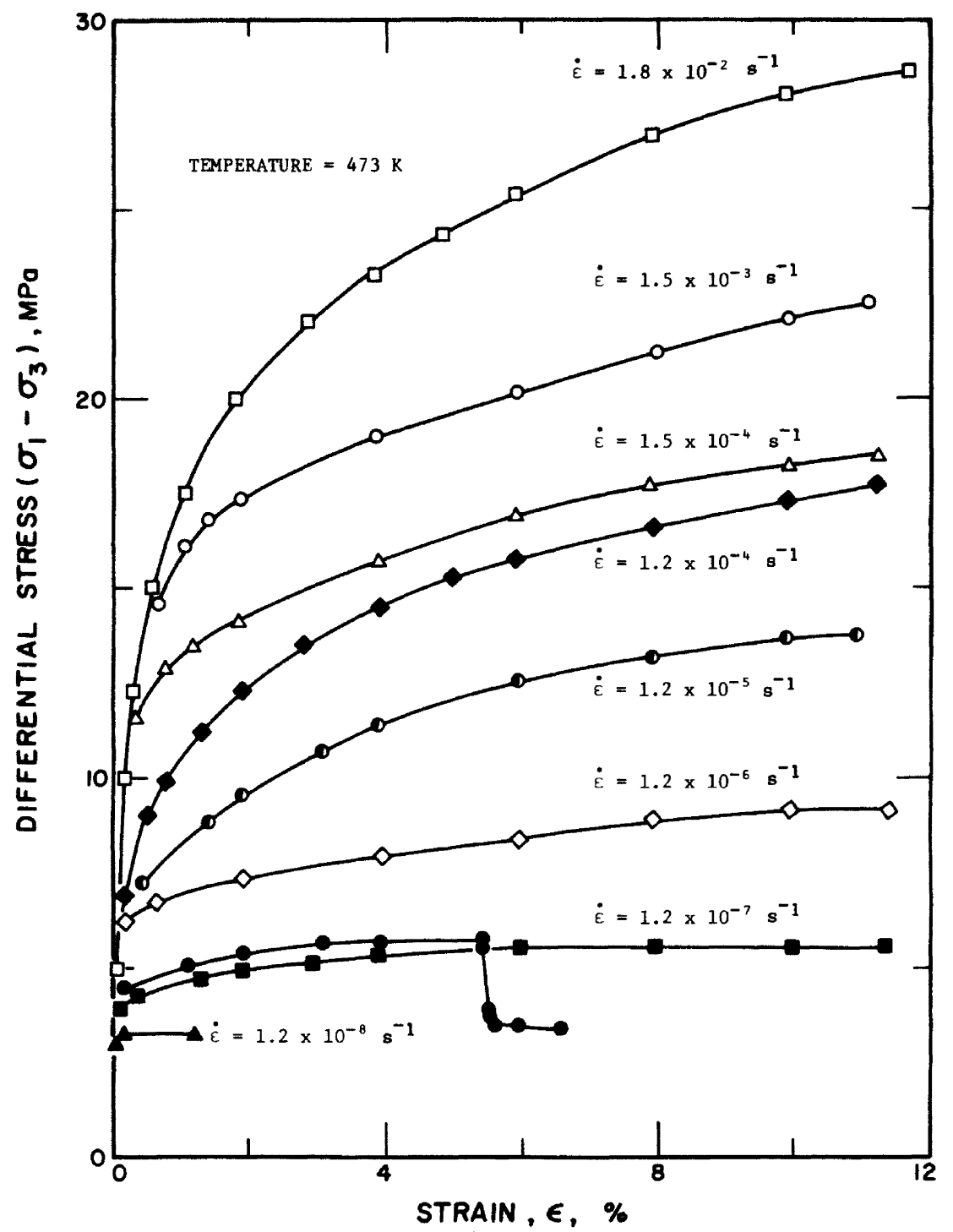

FigURE 3.16. Differential stress-strain curves for polycrystalline halite at $473 \mathrm{~K}$. 
TABLE 3.16. DIFFERENTIAL STRESS-STRAIN CURVES FOR POLYCRYSTALLINE HALITE EXTENDED AT $200 \mathrm{MPa}, 521 \mathrm{~K}$, AND $\dot{\varepsilon}=1.8 \times 10^{-1} \mathrm{TO}$

$$
\begin{aligned}
& 1.2 \times 10^{-7} \mathrm{~s}^{-1} \\
& \text { [Strain, } \varepsilon, \% \text {; Differential Stress, }\left(\sigma_{1}-\sigma_{3}\right) \mathrm{MPa} \text { ] }
\end{aligned}
$$

\begin{tabular}{|c|c|c|c|c|c|c|}
\hline $\begin{array}{l}\text { Data } \\
\text { Set }\end{array}$ & $\begin{array}{l}\text { Author (s), } \\
\text { [Ref.] }\end{array}$ & Year & $\varepsilon$ & $\sigma_{1}-\sigma_{3}$ & Remarks & \\
\hline 1 & $\begin{array}{l}\text { Heard, H.C., } \\
{[21]}\end{array}$ & 1972 & $\begin{array}{r}1.631 \\
1.733 \\
2.643 \\
3.702 \\
5.714 \\
7.623 \\
9.630 \\
10.282\end{array}$ & $\begin{array}{l}15.457 \\
15.761 \\
17.633 \\
19.300 \\
21.571 \\
23.285 \\
24.745 \\
25.147\end{array}$ & $\dot{\varepsilon}=1.8 \times 10^{-1}$ & $s^{-1}$ \\
\hline 2 & $\begin{array}{l}\text { Heard, H.C., } \\
{[21]}\end{array}$ & 1972 & $\begin{array}{r}0.063 \\
0.126 \\
0.239 \\
0.353 \\
0.716 \\
1.025 \\
1.329 \\
1.785 \\
2.693 \\
3.748 \\
5.705 \\
7.661 \\
9.716 \\
11.470\end{array}$ & $\begin{array}{r}2.433 \\
4.969 \\
7.503 \\
9.988 \\
12.572 \\
14.244 \\
15.053 \\
16.116 \\
17.632 \\
18.539 \\
19.949 \\
21.104 \\
22.057 \\
22.859\end{array}$ & $\dot{\varepsilon}=1.9 \times 10^{-2}$ & $s^{-1}$ \\
\hline 3 & $\begin{array}{l}\text { Heard, H.C., } \\
{[21]}\end{array}$ & 1972 & $\begin{array}{r}0.063 \\
0.076 \\
0.189 \\
0.303 \\
0.563 \\
0.766 \\
1.220 \\
1.824 \\
3.783 \\
5.788 \\
7.743 \\
9.747 \\
11.149\end{array}$ & $\begin{array}{r}2.438 \\
4.979 \\
7.468 \\
10.008 \\
12.039 \\
12.546 \\
13.306 \\
14.116 \\
15.731 \\
16.838 \\
17.641 \\
18.443 \\
18.893\end{array}$ & $\dot{\varepsilon}=1.5 \times 10^{-3}$ & $s^{-1}$ \\
\hline 4 & $\begin{array}{l}\text { Heard, H.C., } \\
{[21]}\end{array}$ & 1972 & $\begin{array}{l}0.063 \\
0.126 \\
0.489 \\
0.947 \\
1.804 \\
2.909\end{array}$ & $\begin{array}{r}2.433 \\
4.969 \\
7.502 \\
8.920 \\
10.284 \\
11.191\end{array}$ & $\dot{\varepsilon}=1.2 \times 10^{-4}$ & $s^{-1}$ \\
\hline
\end{tabular}


TABLE 3.16. DIFFERENTIAL STRESS-STRAIN CURVES FOR POLYCRYSTALLINE HALITE EXTENDED AT $200 \mathrm{MPa}, 521 \mathrm{~K}$, AND $\dot{\varepsilon}=1.8 \times 10^{-1} \mathrm{TO}$ $1.2 \times 10^{-7} \mathrm{~s}^{-1} \quad$ (Continued)

\begin{tabular}{|c|c|c|c|c|c|}
\hline $\begin{array}{l}\text { Data } \\
\text { Set }\end{array}$ & $\begin{array}{r}\text { Author(s), } \\
\text { [Ref.] }\end{array}$ & Year & $\varepsilon$ & $\sigma_{2}-\sigma_{3}$ & Remarks \\
\hline $\begin{array}{c}4 \\
(\text { cont. })\end{array}$ & $\begin{array}{l}\text { Heard, H.C., } \\
{[21]}\end{array}$ & 1972 & $\begin{array}{r}3.812 \\
5.816 \\
7.819 \\
9.822 \\
10.672\end{array}$ & $\begin{array}{l}11.795 \\
12.595 \\
13.193 \\
13.588 \\
13.735\end{array}$ & \\
\hline 5 & $\begin{array}{l}\text { Heard, H.C., } \\
{[21]}\end{array}$ & 1972 & $\begin{array}{r}0.283 \\
1.887 \\
3.941 \\
5.844 \\
7.846 \\
9.848 \\
10.998\end{array}$ & $\begin{array}{l}6.235 \\
7.089 \\
7.838 \\
8.386 \\
8.730 \\
9.023 \\
9.169\end{array}$ & $\dot{\varepsilon}=1.2 \times 10^{-5} \mathrm{~s}^{-1}$ \\
\hline 6 & $\begin{array}{l}\text { Heard, H.C., } \\
{[21]}\end{array}$ & 1972 & $\begin{array}{r}0.321 \\
1.876 \\
3.929 \\
5.930 \\
7.931 \\
9.931 \\
10.431\end{array}$ & $\begin{array}{l}4.004 \\
4.858 \\
5.506 \\
5.748 \\
5.890 \\
5.930 \\
5.927\end{array}$ & $\dot{\varepsilon}=1.2 \times 10^{-6} \mathrm{~s}^{-1}$ \\
\hline 7 & $\begin{array}{l}\text { Heard, H.C., } \\
{[21]}\end{array}$ & 1972 & $\begin{array}{r}0.167 \\
0.718 \\
1.870 \\
4.021 \\
5.972 \\
7.923 \\
9.973 \\
11.023\end{array}$ & $\begin{array}{r}3.295 \\
3.495 \\
3.742 \\
4.035 \\
4.126 \\
4.267 \\
4.307 \\
4.250\end{array}$ & $\dot{\varepsilon}=1.2 \times 10^{-7} \mathrm{~s}^{-1}$ \\
\hline
\end{tabular}




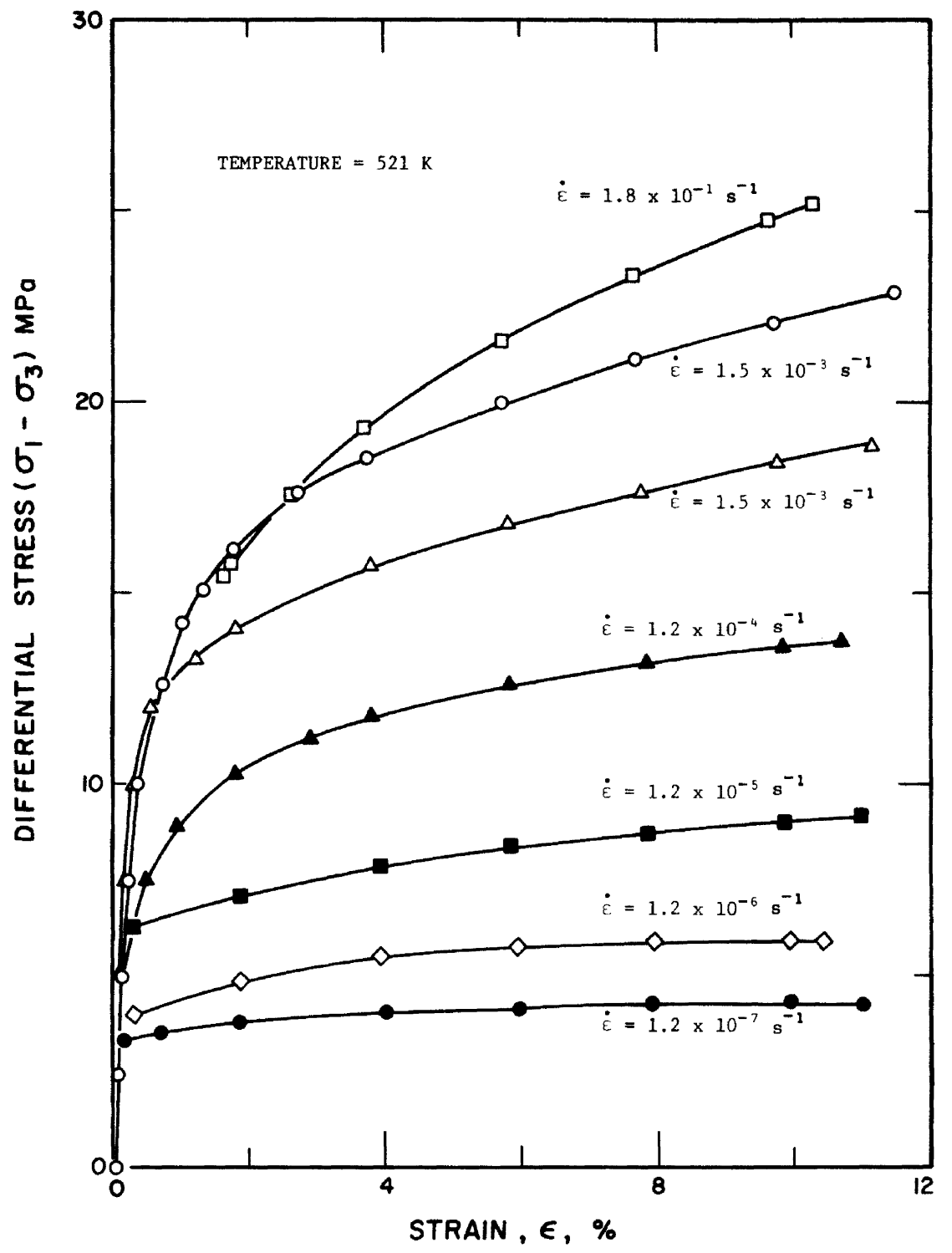

FIGURE 3.17. Differential stress-strain curves for polycrystalline halite at $521 \mathrm{~K}$. 
TABLE 3.17. DIFFERENTIAL STRESS-STRAIN CURVES FOR POLYCRYSTALLINE HALITE AT $200 \mathrm{MPa}, 573 \mathrm{~K}$ AND $\dot{\varepsilon}=1.8 \times 10^{-1} \mathrm{TO} 1.2 \times 10^{-8} \mathrm{~s}^{-1}$

[Strain, $\varepsilon, \%$; Differential Stress, $\left.\left(\sigma_{1}-\sigma_{3}\right) \mathrm{MPa}\right]$

\begin{tabular}{|c|c|c|c|c|c|c|}
\hline $\begin{array}{l}\text { Data } \\
\text { Set }\end{array}$ & $\begin{array}{l}\text { Author(s), } \\
\text { [Ref.] }\end{array}$ & Year & $\varepsilon$ & $\sigma_{1}-\sigma_{3}$ & Remarks & \\
\hline 1 & $\begin{array}{l}\text { Heard, H.C., } \\
\lceil 21\rceil\end{array}$ & 1972 & $\begin{array}{r}0.957 \\
1.304 \\
2.043 \\
2.870 \\
4.043 \\
5.174 \\
6.087 \\
8.043 \\
9.957 \\
11.913\end{array}$ & $\begin{array}{r}7.556 \\
8.933 \\
10.933 \\
12.533 \\
14.044 \\
15.066 \\
15.600 \\
16.711 \\
17.466 \\
18.044\end{array}$ & $\dot{\varepsilon}=1.6 \times 10^{-1}$ & $s^{-1}$ \\
\hline 2 & $\begin{array}{l}\text { Heard, H.C., } \\
{[21]}\end{array}$ & 1972 & $\begin{array}{r}0.043 \\
0.217 \\
0.391 \\
0.435 \\
0.696 \\
1.304 \\
2.043 \\
4.000 \\
6.043 \\
8.043 \\
9.957 \\
12.043\end{array}$ & $\begin{array}{r}0.044 \\
2.533 \\
5.066 \\
5.866 \\
6.533 \\
7.422 \\
8.266 \\
10.133 \\
11.733 \\
13.066 \\
14.133 \\
14.933\end{array}$ & $\dot{\varepsilon}=1.8 \times 10^{-2}$ & $s^{-1}$ \\
\hline 3 & $\begin{array}{l}\text { Heard, H.C., } \\
{[21]}\end{array}$ & 1972 & $\begin{array}{r}0.087 \\
0.217 \\
0.304 \\
0.565 \\
1.043 \\
2.043 \\
3.609 \\
4.000 \\
6.000 \\
8.043 \\
9.957 \\
11.304\end{array}$ & $\begin{array}{r}0.044 \\
2.488 \\
3.466 \\
4.533 \\
5.777 \\
7.022 \\
8.088 \\
8.444 \\
9.644 \\
10.533 \\
11.066 \\
11.155\end{array}$ & $\dot{\varepsilon}=1.2 \times 10^{-3}$ & $s^{-1}$ \\
\hline 4 & $\begin{array}{l}\text { Heard, H.C., } \\
{[21]}\end{array}$ & 1972 & $\begin{array}{r}0.348 \\
2.043 \\
4.000 \\
6.000 \\
8.000 \\
9.957 \\
11.043\end{array}$ & $\begin{array}{l}2.311 \\
4.266 \\
5.644 \\
6.444 \\
6.577 \\
7.288 \\
7.377\end{array}$ & $\dot{\varepsilon}=1.5 \times 10^{-4}$ & $s^{-1}$ \\
\hline
\end{tabular}


TABLE 3.17. DIFFERENTIAL STRESS-STRAIN CURVES FOR POLYCRYSTALLINE HALITE AT $200 \mathrm{MPa}, 573 \mathrm{~K}$ AND $\dot{\varepsilon}=1.8 \times 10^{-1} \mathrm{TO} 1.2 \times 10^{-8} \mathrm{~s}^{-1}$ Continued)

\begin{tabular}{|c|c|c|c|c|c|}
\hline $\begin{array}{l}\text { Data } \\
\text { Set }\end{array}$ & $\begin{array}{r}\text { Author (s), } \\
\text { [Ref.] } \\
\end{array}$ & Year & $\varepsilon$ & $\sigma_{1}-\sigma_{3}$ & Remarks \\
\hline 5 & $\begin{array}{l}\text { Heard, H.C., } \\
{[21]}\end{array}$ & 1972 & $\begin{array}{r}0.304 \\
0.739 \\
1.000 \\
2.043 \\
4.000 \\
6.000 \\
8.000 \\
9.957 \\
11.087\end{array}$ & $\begin{array}{l}2.044 \\
2.577 \\
2.711 \\
3.155 \\
3.866 \\
4.355 \\
4.755 \\
4.888 \\
4.844\end{array}$ & $\dot{\varepsilon}=1.2 \times 10^{-5} \mathrm{~s}^{-1}$ \\
\hline 6 & $\begin{array}{l}\text { Heard, H.C., } \\
{[21]}\end{array}$ & 1972 & $\begin{array}{r}0.391 \\
0.652 \\
0.826 \\
2.043 \\
4.000 \\
6.000 \\
8.043 \\
10.000 \\
11.435\end{array}$ & $\begin{array}{l}1.911 \\
2.177 \\
2.222 \\
2.444 \\
2.666 \\
2.844 \\
2.800 \\
2.844 \\
2.844\end{array}$ & $\dot{\varepsilon}=1.2 \times 10^{-6} \mathrm{~s}^{-1}$ \\
\hline 7 & $\begin{array}{l}\text { Heard, H.C., } \\
{[21]}\end{array}$ & 1972 & $\begin{array}{r}0.304 \\
0.652 \\
0.913 \\
1.217 \\
2.043 \\
4.000 \\
6.000 \\
8.043 \\
10.000 \\
11.435\end{array}$ & $\begin{array}{l}1.600 \\
1.955 \\
2.044 \\
2.044 \\
2.088 \\
2.133 \\
2.844 \\
2.800 \\
2.844 \\
2.844\end{array}$ & $\dot{\varepsilon}=1.2 \times 10^{-7} \mathrm{~s}^{-1}$ \\
\hline 8 & $\begin{array}{l}\text { Heard, H.C., } \\
\lceil 21\rceil\end{array}$ & 1972 & $\begin{array}{l}0.261 \\
1.174 \\
2.000 \\
3.913\end{array}$ & $\begin{array}{l}1.422 \\
1.555 \\
1.600 \\
1.600\end{array}$ & $\dot{\varepsilon}=1.2 \times 10^{-8} \mathrm{~s}^{-1}$ \\
\hline
\end{tabular}




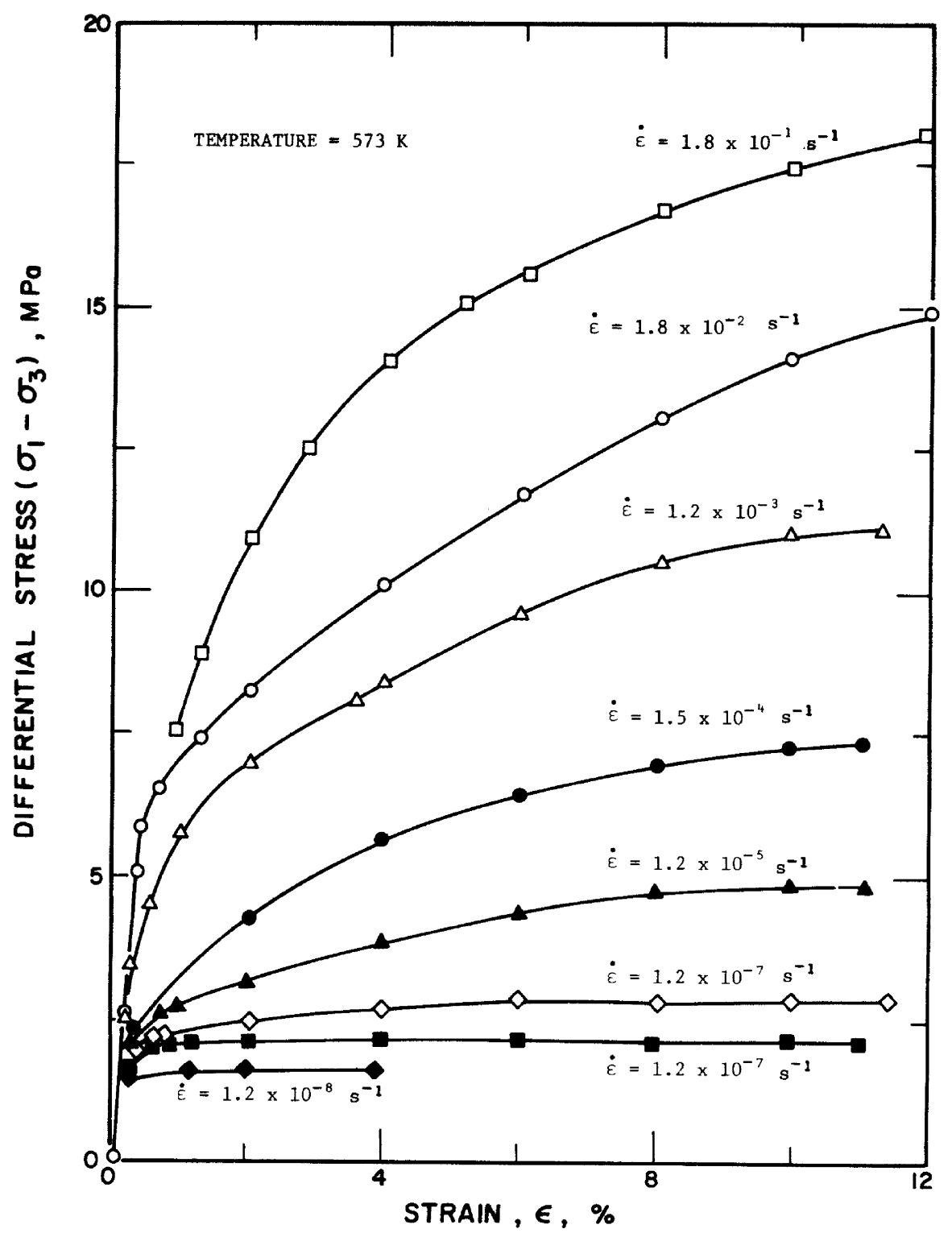

FIGURE 3.18. Differential stress-strain curves for polycrystalline halite at $573 \mathrm{~K}$. 
TABLE 3.18. DIFFERENTIAL STRESS-STRAIN CURVES FOR POLYCRYSTALLINE HALITE EXTENDED AT $200 \mathrm{MPa}, 673 \mathrm{~K}$, AND $\dot{\varepsilon}=1.9 \times 10^{-1}$ TO $1.2 \times 10^{-7} \mathrm{~s}^{-1}$

[Strain, $\varepsilon, \%$; Differential Stress, $\left(\sigma_{1}-\sigma_{3}\right)$ MPa]

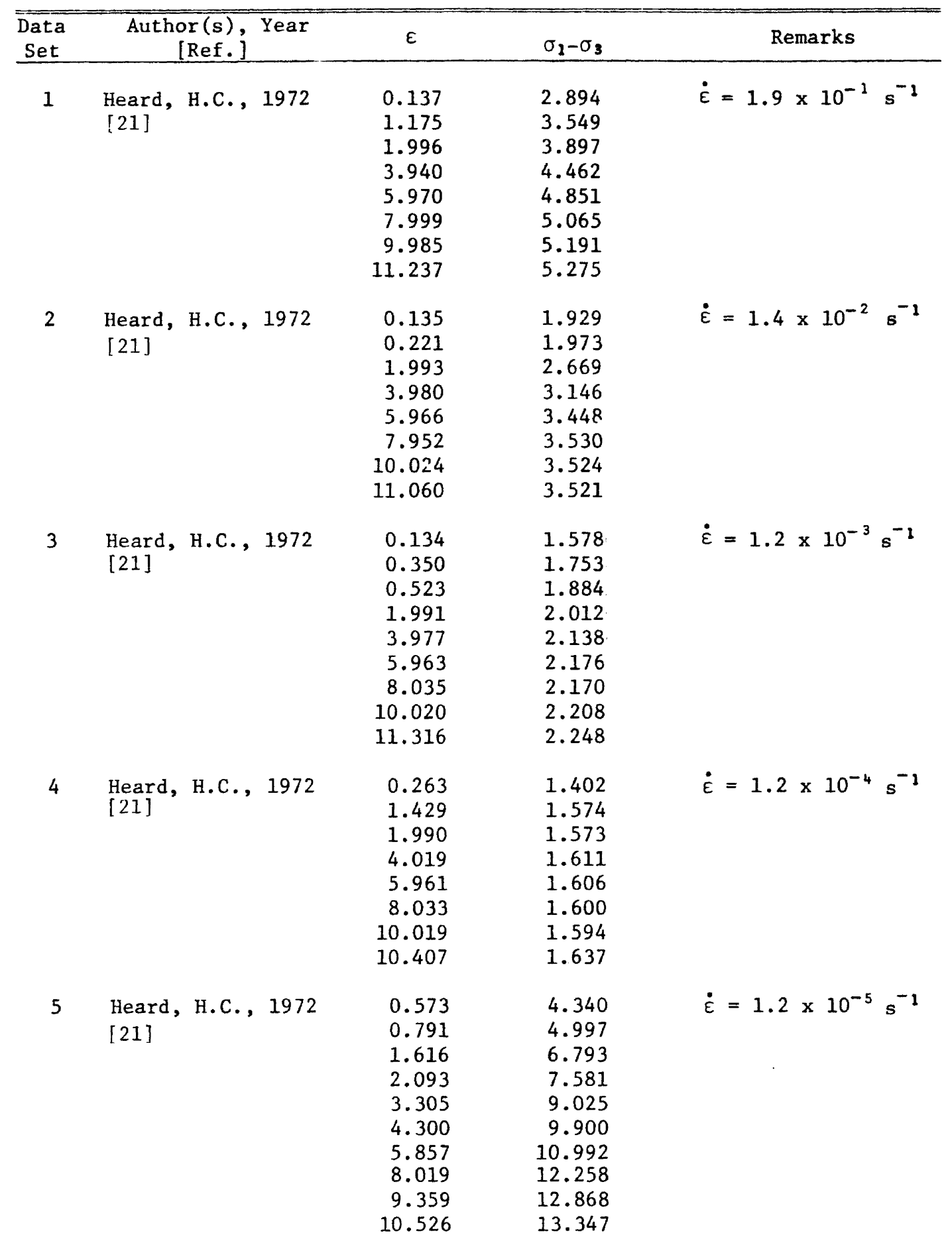


TABLE 3.18. DIFFERENTIAL STRESS-STRAIN CURVES FOR POLYCRYSTALLINE HALITE EXTENDED AT $200 \mathrm{MPa}, 673 \mathrm{~K}$, AND $\dot{\varepsilon}=1.9 \times 10^{-1} \mathrm{TO}$

$1.2 \times 10^{-7} \mathrm{~s}^{-1}$ (Continued)

\begin{tabular}{|c|c|c|c|c|c|c|}
\hline $\begin{array}{l}\text { Data } \\
\text { Set }\end{array}$ & $\begin{array}{r}\text { Author (s), } \\
\text { [Ref.] }\end{array}$ & Year & $\varepsilon$ & $\sigma_{1}-\sigma_{3}$ & Remarks & \\
\hline 6 & $\begin{array}{l}\text { Heard, H.C., } \\
{[21]}\end{array}$ & 1972 & $\begin{array}{r}0.093 \\
0.182 \\
0.270 \\
0.618 \\
1.052 \\
1.615 \\
1.962 \\
3.000 \\
3.952 \\
5.940 \\
7.971 \\
9.958 \\
11.253\end{array}$ & $\begin{array}{r}2.499 \\
3.376 \\
4.078 \\
5.042 \\
5.918 \\
6.706 \\
7.143 \\
7.974 \\
8.629 \\
9.764 \\
10.547 \\
10.980 \\
11.021\end{array}$ & $\dot{\varepsilon}=1.2 \times 10^{-6}$ & $s^{-1}$ \\
\hline 7 & $\begin{array}{l}\text { Heard, H.C., } \\
{[21]}\end{array}$ & 1972 & $\begin{array}{r}0.049 \\
0.095 \\
0.572 \\
1.957 \\
3.989 \\
5.933 \\
8.006 \\
10.035 \\
11.633\end{array}$ & $\begin{array}{l}1.973 \\
3.069 \\
4.165 \\
5.433 \\
6.392 \\
6.957 \\
7.433 \\
7.647 \\
7.774\end{array}$ & $\dot{\varepsilon}=1.2 \times 10^{-7}$ & $s^{-1}$ \\
\hline
\end{tabular}




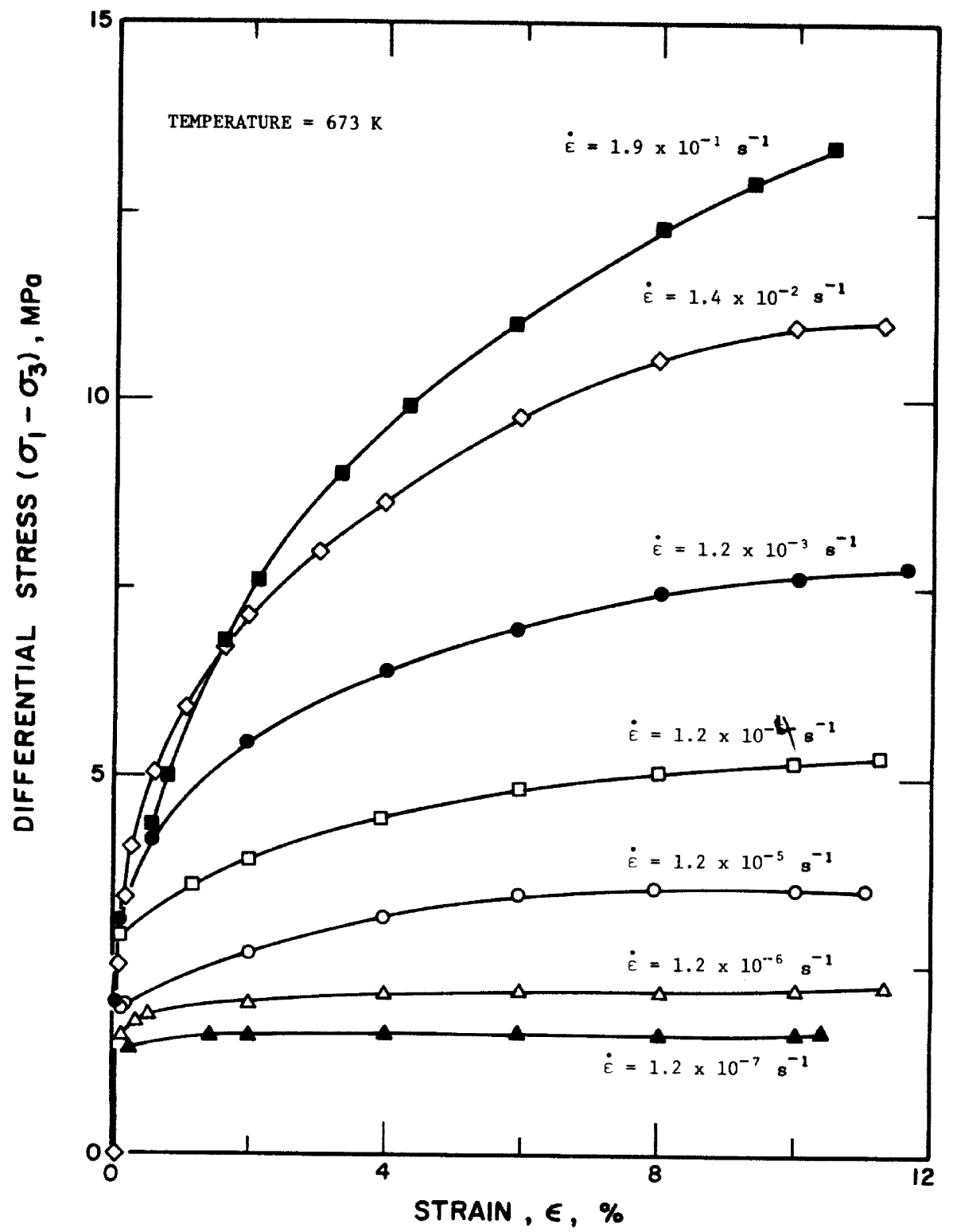

FIGURE 3.19. Differential stress-strain curves for polycrystalline halite at $673 \mathrm{~K}$. 
TABLE 3.19. DIFFERENTIAL STRESS-STRAIN CURVES FOR POLYCRYSTALLINE HALITE EXTENDED AT $200 \mathrm{MPa}$. TEMPERATURE FROM 300 TO $673 \mathrm{~K}$ AND $\dot{\varepsilon}=1.2-1.5 \times 10^{-5} \mathrm{~s}^{-1}$

[Strain, $\varepsilon, \%$; Differential Stress, $\left(\sigma_{1}-\sigma_{3}\right) \mathrm{MPa}$ ]

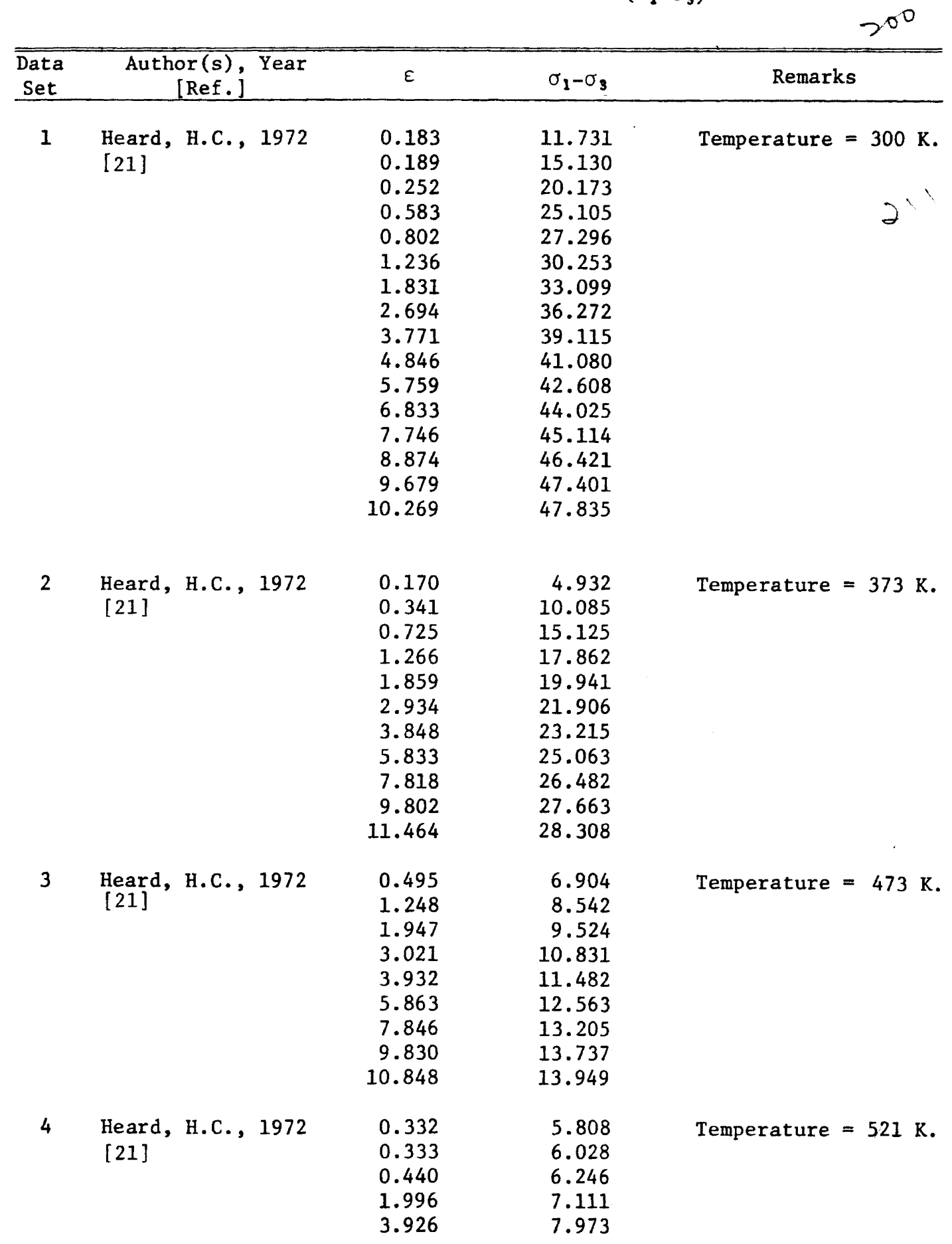


TABLE 3.19. DIFFERENTIAL STRESS-STRAIN CURVES FOR POLYCRYSTALLINE HALITE EXTENDED AT $200 \mathrm{MPa}$. TEMPERATURE FROM 300 TO $673 \mathrm{~K}$ AND $\dot{\varepsilon}=1.2-1.5 \times 10^{-5} \mathrm{~s}^{-1} \quad$ (Continued)

\begin{tabular}{|c|c|c|c|c|c|}
\hline $\begin{array}{l}\text { Data } \\
\text { Set }\end{array}$ & $\begin{array}{r}\text { Author (s), } \\
{[\operatorname{Ref} .]}\end{array}$ & Year & $\varepsilon$ & $\sigma_{1}-\sigma_{3}$ & Remarks \\
\hline $\begin{array}{c}4 \\
(\operatorname{con} t .)\end{array}$ & $\begin{array}{l}\text { Heard, H.C., } \\
{[21]}\end{array}$ & 1972 & $\begin{array}{r}5.909 \\
7.892 \\
9.875 \\
11.160\end{array}$ & $\begin{array}{l}8.505 \\
8.928 \\
9.132 \\
9.231\end{array}$ & \\
\hline 5 & $\begin{array}{l}\text { Heard, H.C., } \\
{[21\rceil}\end{array}$ & 1972 & $\begin{array}{r}0.326 \\
1.988 \\
3.972 \\
5.901 \\
7.938 \\
9.867 \\
10.671\end{array}$ & $\begin{array}{l}2.190 \\
3.273 \\
3.915 \\
4.448 \\
4.871 \\
5.075 \\
5.178\end{array}$ & Temperature $=573 \mathrm{~K}$ \\
\hline 6 & $\begin{array}{l}\text { Heard, H.C., } \\
{[21]}\end{array}$ & 1972 & $\begin{array}{r}0.325 \\
1.934 \\
3.970 \\
5.899 \\
7.989 \\
9.918 \\
11.471\end{array}$ & $\begin{array}{l}2.080 \\
2.616 \\
3.148 \\
3.462 \\
3.664 \\
3.759 \\
3.637\end{array}$ & Temperature $=673 \mathrm{~K}$. \\
\hline
\end{tabular}

was +2 


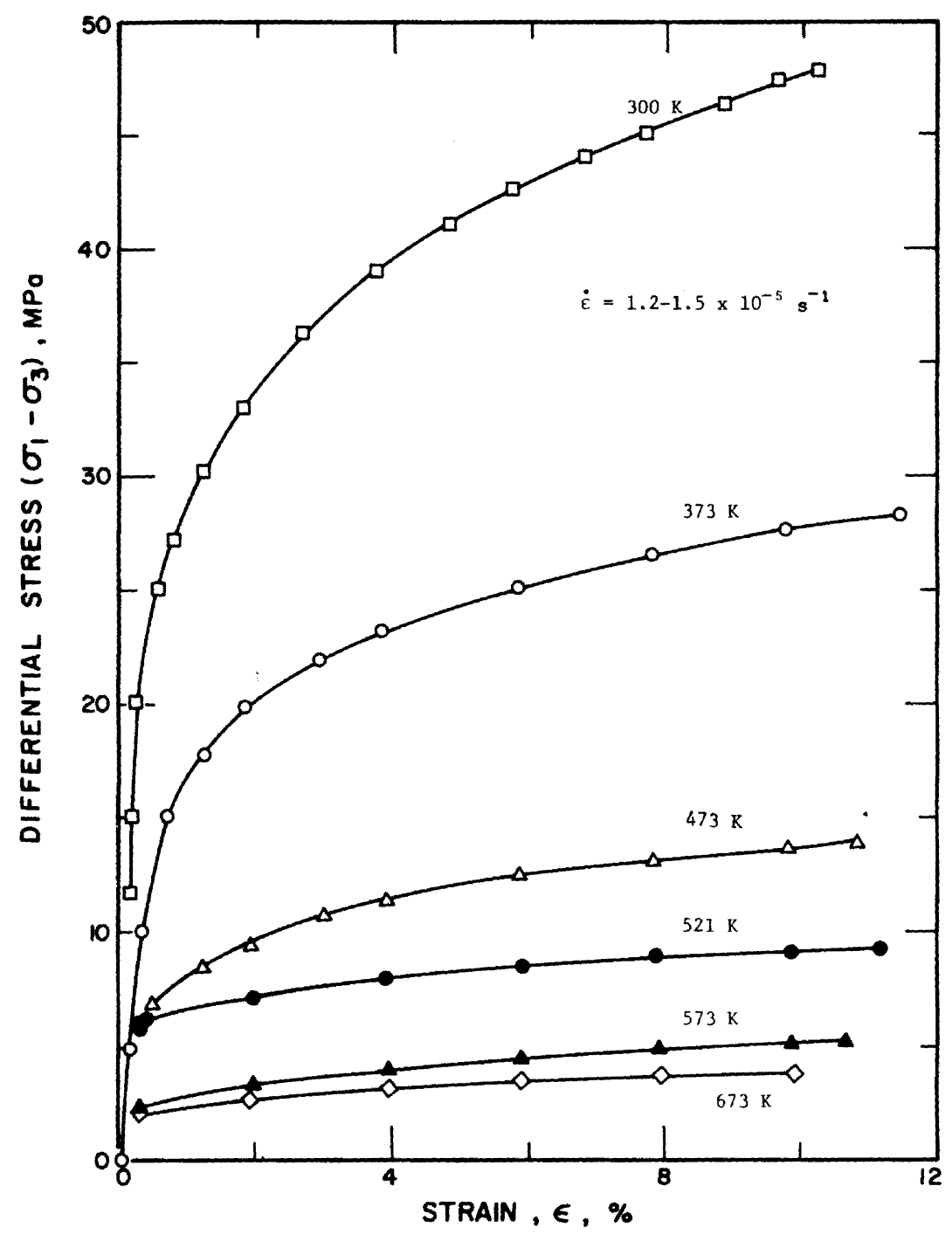

FICURE 3.20. Differential stress-strain curves for polycrystalline halite at temperatures from 300 to $673 \mathrm{~K}$. 
TABLE 3.20. DIFFERENTIAL STRESS-STRAIN CURVES FOR POLYCRYSTALLINE HALITE EXTENDED AT $200 \mathrm{MPa}, 300$ TO $673 \mathrm{~K}$, AND $\dot{\varepsilon}=1.2-1.5 \times 10^{-7} \mathrm{~s}^{-1}$

[Strain, $\varepsilon, \%$; Differential Stress, $\left(\sigma_{1}-\sigma_{3}\right) \mathrm{MPa}$ ]

\begin{tabular}{|c|c|c|c|c|c|}
\hline $\begin{array}{l}\text { Data } \\
\text { Set }\end{array}$ & $\begin{array}{r}\text { Author (s), } \\
\text { [Ref.] }\end{array}$ & Year & $\varepsilon$ & $\sigma_{1}-\sigma_{3}$ & Remarks \\
\hline 1 & $\begin{array}{l}\text { Heard, H.C., } \\
{[21]}\end{array}$ & 1972 & $\begin{array}{r}0.225 \\
0.493 \\
0.674 \\
0.986 \\
1.516 \\
1.955 \\
2.438 \\
3.181 \\
3.924 \\
5.933 \\
7.898 \\
9.862 \\
11.040\end{array}$ & $\begin{array}{r}4.987 \\
10.064 \\
15.141 \\
20.128 \\
25.203 \\
27.695 \\
29.385 \\
30.540 \\
31.337 \\
32.841 \\
33.811 \\
34.246 \\
34.418\end{array}$ & $\frac{0.28}{2.9}$ \\
\hline 2 & $\begin{array}{l}\text { Heard, H.C., } \\
[2]]\end{array}$ & 1972 & $\begin{array}{r}0.581 \\
0.756 \\
1.456 \\
1.981 \\
3.947 \\
5.956 \\
7.965 \\
9.929 \\
11.195\end{array}$ & $\begin{array}{l}10.509 \\
11.399 \\
12.909 \\
13.530 \\
15.658 \\
17.073 \\
18.131 \\
18.744 \\
18.826\end{array}$ & $\begin{aligned} \text { Temperature } & =373 \mathrm{k} . \\
6 & =3.25\end{aligned}$ \\
\hline 3 & $\begin{array}{l}\text { Heard, H.C., } \\
{[21]}\end{array}$ & 1972 & $\begin{array}{r}0.311 \\
0.748 \\
1.184 \\
1.970 \\
4.021 \\
5.985 \\
7.993 \\
10.000 \\
11.178\end{array}$ & $\begin{array}{l}4.007 \\
4.450 \\
4.715 \\
4.978 \\
5.412 \\
5.669 \\
5.659 \\
5.648 \\
5.642\end{array}$ & Temperature $=473 \mathrm{~K}$. \\
\hline 4 & $\begin{array}{l}\text { Heard, H.C., } \\
{[21]}\end{array}$ & 1972 & $\begin{array}{r}0.310 \\
0.397 \\
1.969 \\
4.020 \\
6.027 \\
7.991 \\
9.998 \\
10.958\end{array}$ & $\begin{array}{l}3.294 \\
3.472 \\
3.820 \\
4.076 \\
4.333 \\
4.233 \\
4.312 \\
4.306\end{array}$ & Temperature $=521 \mathrm{k}$. \\
\hline
\end{tabular}


TABLE 3.20. DIFFERENTIAL STRESS-STRAIN CURVES FOR POLYCRYSTALLINE HAIITE EXTENDED AT $200 \mathrm{MPa}, 300$ TO $673 \mathrm{~K}$, AND $\dot{\varepsilon}=1.2-1.5 \times 10^{-7} \mathrm{~s}$ (Continued)

\begin{tabular}{|c|c|c|c|c|c|}
\hline $\begin{array}{l}\text { Data } \\
\text { Set }\end{array}$ & $\begin{array}{r}\text { Author(s), } \\
\text { [Ref.] }\end{array}$ & Year & $\varepsilon$ & $\sigma_{1}-\sigma_{3}$ & Remarks \\
\hline 5 & $\begin{array}{l}\text { Heard, H.C., } \\
{[21]}\end{array}$ & 1972 & $\begin{array}{r}0.220 \\
0.483 \\
1.966 \\
4.017 \\
6.025 \\
7.989 \\
9.996 \\
11.130\end{array}$ & $\begin{array}{l}1.780 \\
1.957 \\
2.127 \\
2.205 \\
2.195 \\
2.362 \\
2.352 \\
2.435\end{array}$ & Temperature $=573 \mathrm{~K}$ \\
\hline 6 & $\begin{array}{l}\text { Heard, H.C., } \\
{[21]}\end{array}$ & 1972 & $\begin{array}{r}0.307 \\
2.009 \\
4.017 \\
6.024 \\
7.988 \\
9.951 \\
10.693\end{array}$ & $\begin{array}{l}1.423 \\
1.682 \\
1.671 \\
1.749 \\
1.739 \\
1.817 \\
1.813\end{array}$ & Temperature $=673 \mathrm{~K}$. \\
\hline
\end{tabular}




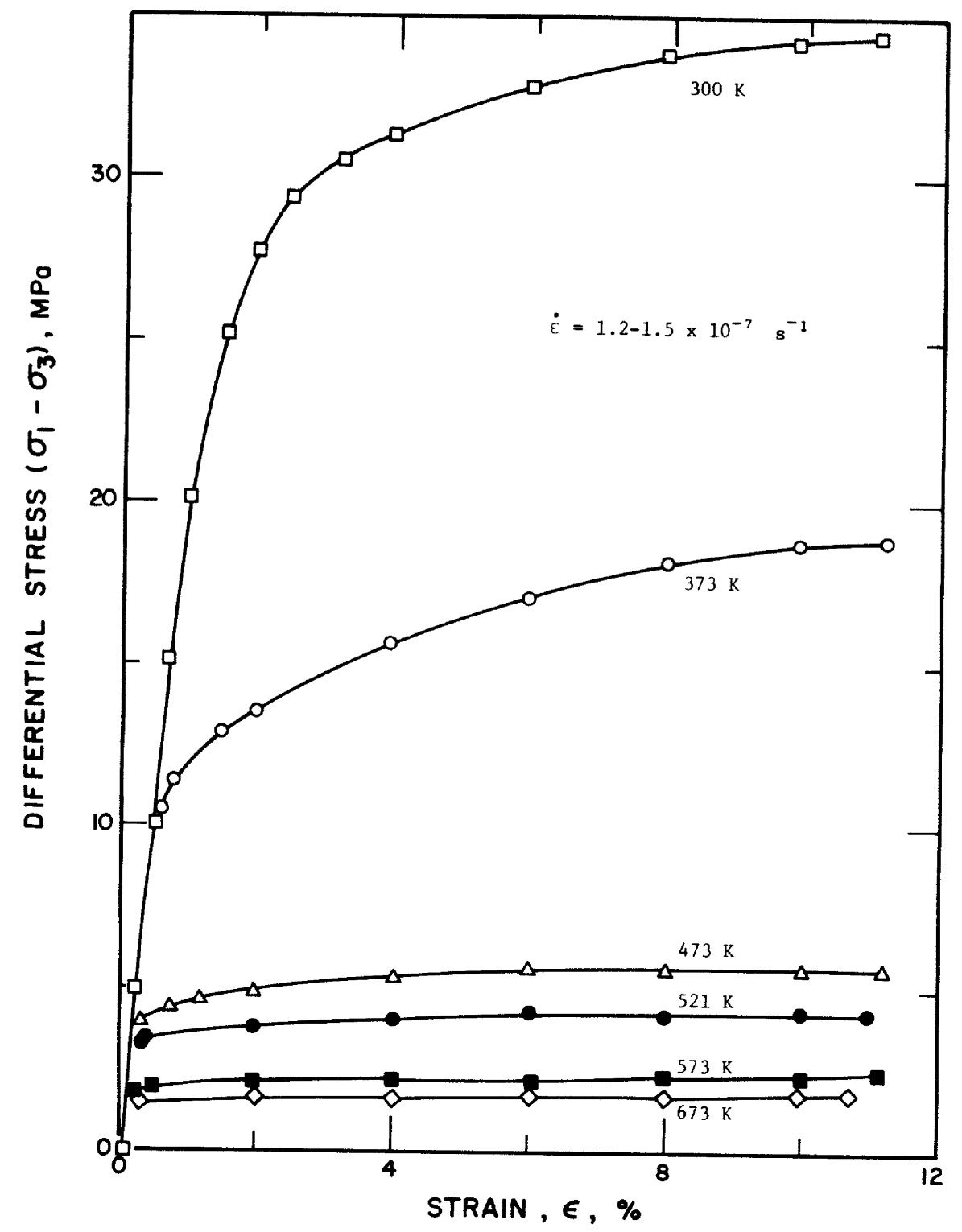

FIGURE 3.21. Differential stress-strain curves for polycrystalline halite at temperatures from 300 to $673 \mathrm{~K}$. 
TABLE 3.21. EFFECT OF ANNEALING AT $873 \mathrm{~K}$ ON STRESS-STRAIN RELATIONSHIP OF ROCK SALT

[Stress, $\sigma_{1}$, MPa; Strain, $\varepsilon, \%$ ]

\begin{tabular}{|c|c|c|c|c|}
\hline $\begin{array}{l}\text { Data } \\
\text { Set }\end{array}$ & Author(s), Year [Ref.] & $\sigma_{1}$ & $\varepsilon$ & Remarks \\
\hline 1 & Gera, F., 1972 [5] & $\begin{array}{c}0.15 \\
1.29 \\
1.9 \\
2.66 \\
3.42 \\
3.80 \\
4.48 \\
5.32 \\
5.93 \\
6.92 \\
7.60 \\
8.36 \\
8.97 \\
9.65 \\
10.57 \\
11.63 \\
12.85 \\
13.45 \\
14.14 \\
14.75 \\
15.28 \\
15.97 \\
16.42 \\
16.88 \\
17.26 \\
17.57 \\
17.95 \\
18.26 \\
18.71 \\
19.02 \\
19.32 \\
19.71 \\
19.78\end{array}$ & $\begin{array}{l}0.00 \\
0.02 \\
0.02 \\
0.03 \\
0.04 \\
0.04 \\
0.04 \\
0.05 \\
0.06 \\
0.07 \\
0.08 \\
0.09 \\
0.10 \\
0.10 \\
0.11 \\
0.13 \\
0.14 \\
0.16 \\
0.17 \\
0.19 \\
0.22 \\
0.26 \\
0.29 \\
0.33 \\
0.36 \\
0.39 \\
0.41 \\
0.45 \\
0.48 \\
0.52 \\
0.552 \\
0.581 \\
0.596\end{array}$ & $\begin{array}{l}\text { Lower Stassfurt halite; unannealed; sample } \\
\text { taken from a mine. }\end{array}$ \\
\hline 2 & Gera, F., 1972 [5] & $\begin{array}{r}0.00 \\
0.61 \\
1.45 \\
2.21 \\
2.74 \\
3.35 \\
3.88 \\
4.57 \\
5.18 \\
5.71 \\
6.32 \\
6.70 \\
7.16 \\
7.47 \\
7.85 \\
8.15 \\
8.46 \\
8.69 \\
8.99 \\
9.22 \\
9.38 \\
9.68 \\
9.91 \\
10.22 \\
10.37 \\
10.60 \\
10.75\end{array}$ & $\begin{array}{l}0.00 \\
0.02 \\
0.05 \\
0.08 \\
0.10 \\
0.13 \\
0.15 \\
0.19 \\
0.21 \\
0.25 \\
0.29 \\
0.32 \\
0.36 \\
0.39 \\
0.43 \\
0.47 \\
0.49 \\
0.52 \\
0.55 \\
0.58 \\
0.61 \\
0.63 \\
0.67 \\
0.69 \\
0.72 \\
0.75 \\
0.76\end{array}$ & After annealing; sample similar to above. \\
\hline
\end{tabular}




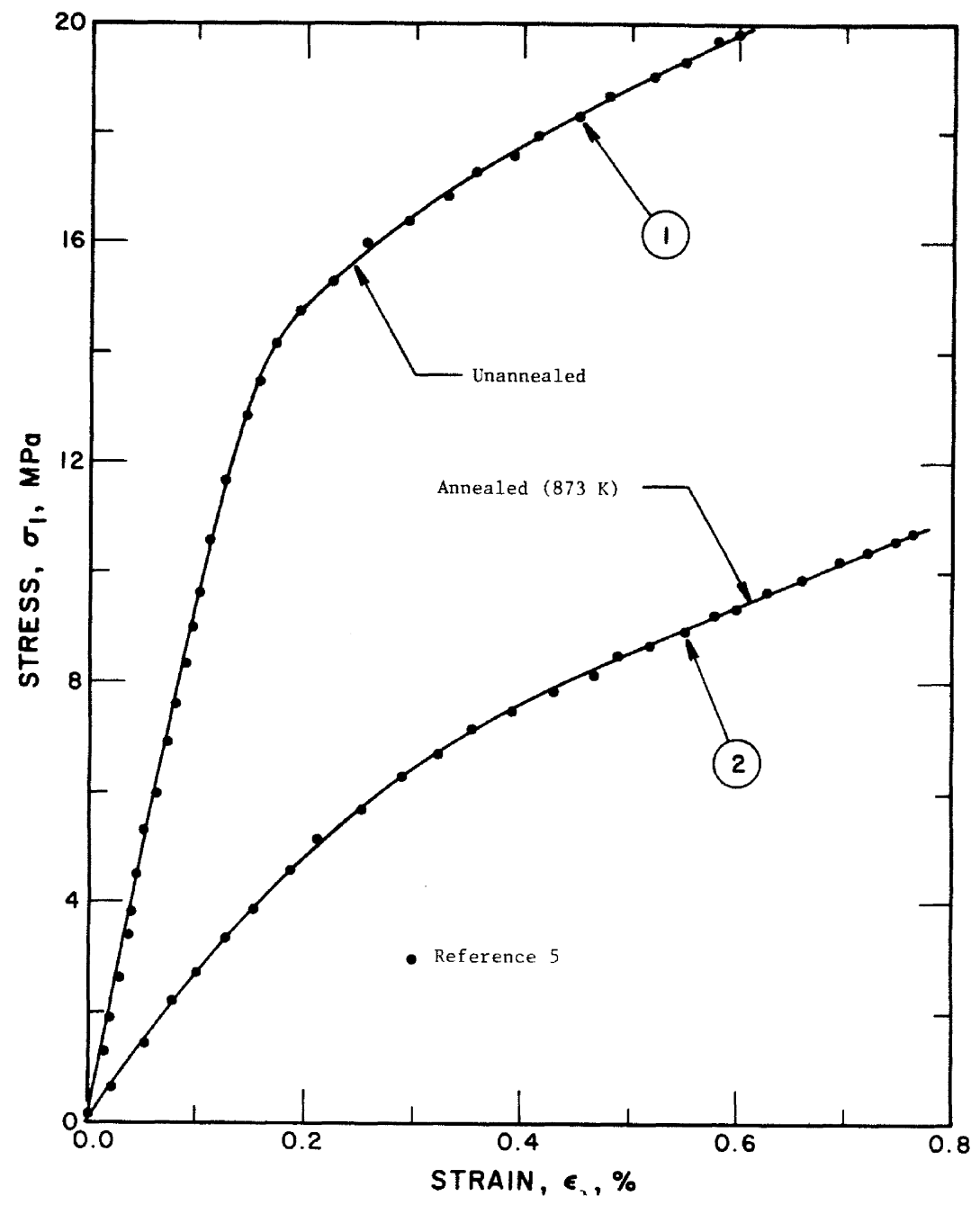

FIGURE 3.22. Effect of annealing on a stress-strain relationship (curve numbers correspond to data set numbers in matching table).

\subsubsection{Creep Data}

Creep can be defined as slow deformation over a long period of time at essentially constant load. At room temperature and low stresses, rock salt will exhibit considerably less creep deformation than at high temperatures and pressures. In general, salt shows marked plastic character, and even at relatively low temperatures it will display a recognizable component of creep. Creep data are generally presented as some type of time relationship.

Thompson [25] investigated creep as a function of differential stress on four rock salt specimens from Hockly, Texas. The tests were conducted at $306 \mathrm{~K}$ and a confining pressure of $11.37 \mathrm{MPa}$. Various load stresses and strain rates were adopted. These data are tabulated in table 3.22 and displayed in figure 3.23. Typical curves showing primary and steady-state creep were presented by Burke [19]. This information was obtained using a dead load compression unit and artificial salt samples and is illustrated in figure 3.24 and table 3.23. Tensile tests using various $\sigma_{1}$ and $\sigma_{3}$ values were carried out by Nair and Deere [23]. Data obtained from these triaxial extension tests are displayed in table 3.24 and figure 3.25.

Two variations on basic creep relationships are given by Odé [34] in which he shows nonuniform creep of $\mathrm{NaCl}$ at different load stresses and the behavior of halite single crystals compressed at different constant loads. Data related to these two aspects are given in table 3.25 and figure 3.26 and table 3.26 and figure 3.27 , respectively.

The effect of confining pressure and temperature on the creep of rock salt has been investigated by several researchers. LeComte [22] investigated the effects of temperature to $573 \mathrm{~K}$ and confining pressure to 100 $\mathrm{MPa}$. The results of this work are presented in table 3.27 
TABLE 3.22. CREEP CURVES FOR HALITE

[Time, $t$, min; Strain, $\varepsilon, \%$ ]

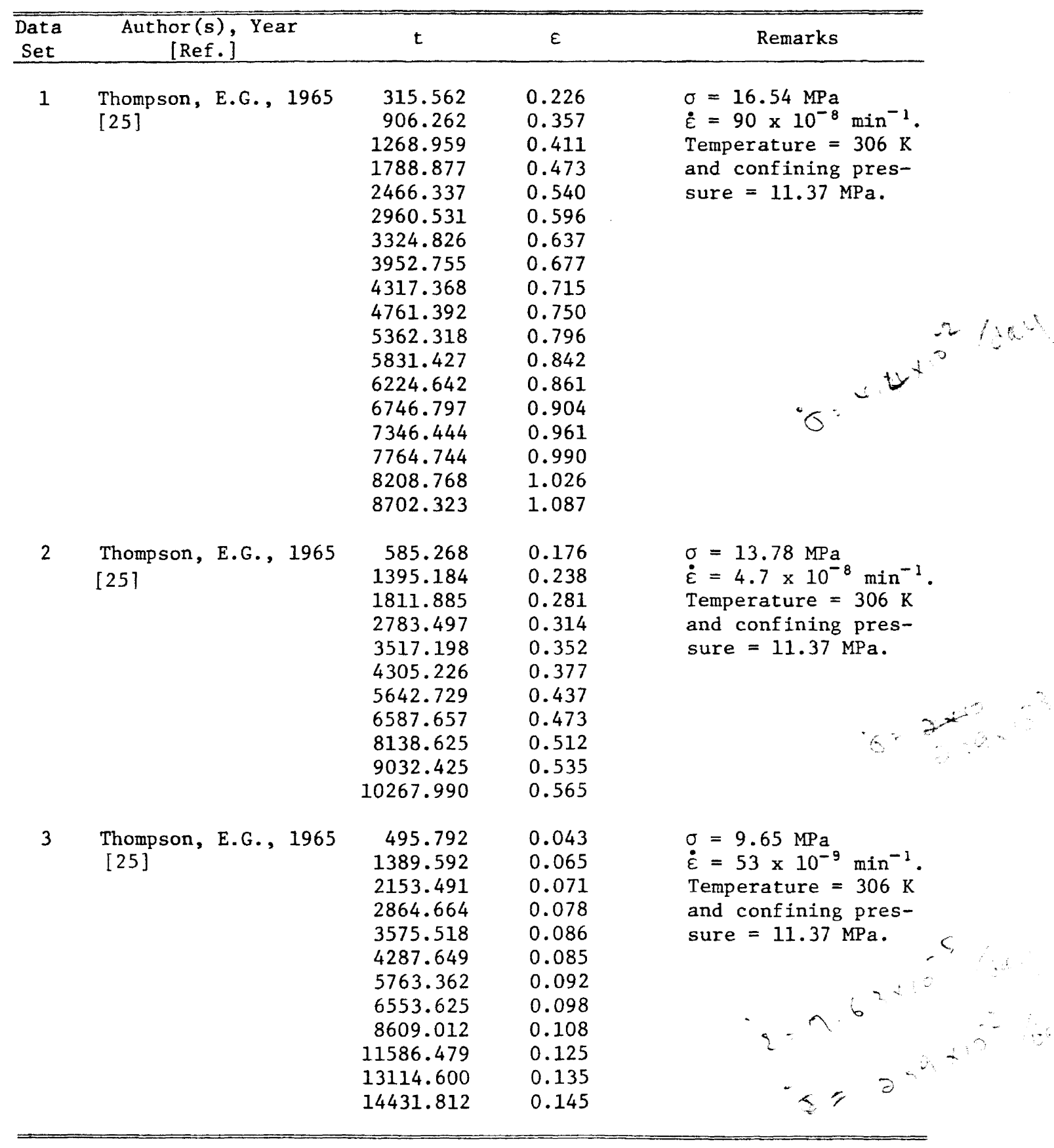




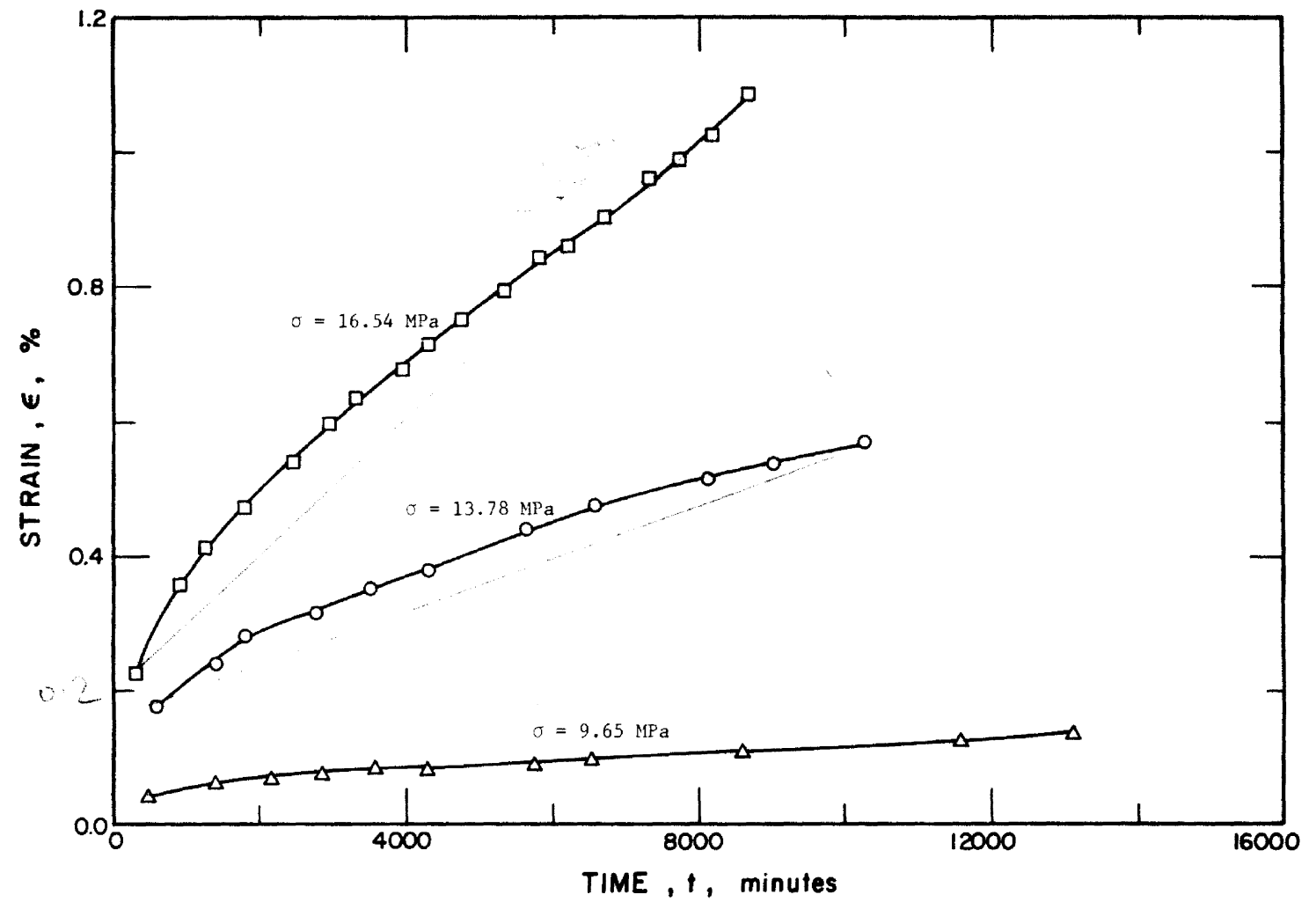

FIGURE 3.23. Creep curves for halite at various load stresses and strain rates. 
TABLE 3.23. TYPICAL CREEP CURVES FOR POLYCRYSTALLINE NaC1 SHOWING PRIMARY AND STEADY STATE CREEP AT TEMPERATURE $=721 \mathrm{~K}$ AND GRAINIZE $\sim 370 \mu \mathrm{m}$

$$
\text { [Time, } t \text {, min; Strain, } E, \% \text { ] }
$$

\begin{tabular}{|c|c|c|c|c|c|}
\hline $\begin{array}{l}\text { Data } \\
\text { Set }\end{array}$ & $\begin{array}{r}\text { Author(s), } \\
\text { [Ref.] }\end{array}$ & Year & $t$ & $\varepsilon$ & Remarks \\
\hline 1 & $\begin{array}{l}\text { Burke, P.M., } \\
{[19]}\end{array}$ & 1968 & $\begin{array}{r}3.120 \\
7.430 \\
11.653 \\
15.875 \\
17.319 \\
21.476 \\
24.276 \\
27.077 \\
29.885 \\
32.670 \\
35.456 \\
38.957\end{array}$ & $\begin{array}{r}5.137 \\
6.272 \\
6.994 \\
7.716 \\
8.129 \\
8.540 \\
8.953 \\
9.365 \\
9.812 \\
10.155 \\
10.498 \\
11.014\end{array}$ & $\begin{array}{l}\sigma=4.34 \mathrm{MPa} \\
\dot{\varepsilon}=2.3 \times 10^{-5} \mathrm{~s}^{-1}\end{array}$ \\
\hline 2 & $\begin{array}{l}\text { Burke, P.M., } \\
{[19]}\end{array}$ & 1968 & $\begin{array}{r}1.582 \\
3.070 \\
7.227 \\
12.084 \\
17.612 \\
26.560 \\
35.465 \\
45.726 \\
69.618 \\
96.201 \\
113.923 \\
144.569 \\
184.702 \\
224.858 \\
248.706 \\
319.470 \\
328.310\end{array}$ & $\begin{array}{l}1.068 \\
1.688 \\
2.100 \\
2.614 \\
3.094 \\
3.710 \\
4.119 \\
4.527 \\
5.238 \\
5.844 \\
6.249 \\
6.818 \\
7.348 \\
7.981 \\
8.485 \\
9.516 \\
9.614\end{array}$ & $\begin{array}{l}\sigma=3.03 \mathrm{MPa} \\
\dot{\varepsilon}=2.6 \times 10^{-6} \mathrm{~s}^{-1}\end{array}$ \\
\hline 3 & $\begin{array}{l}\text { Burke, P.M., } \\
\text { [19] }\end{array}$ & 1968 & $\begin{array}{r}5.455 \\
19.706 \\
41.476 \\
76.125 \\
109.396 \\
129.094 \\
165.078 \\
179.329 \\
210.572 \\
249.269 \\
306.308 \\
351.124\end{array}$ & $\begin{array}{l}0.135 \\
0.162 \\
0.460 \\
0.717 \\
0.871 \\
0.999 \\
1.151 \\
1.178 \\
1.368 \\
1.519 \\
1.798 \\
2.015\end{array}$ & $\begin{array}{l}\sigma=2.17 \mathrm{MPa} \\
\dot{\varepsilon}=6.8 \times 10^{-7} \mathrm{~s}^{-1}\end{array}$ \\
\hline
\end{tabular}




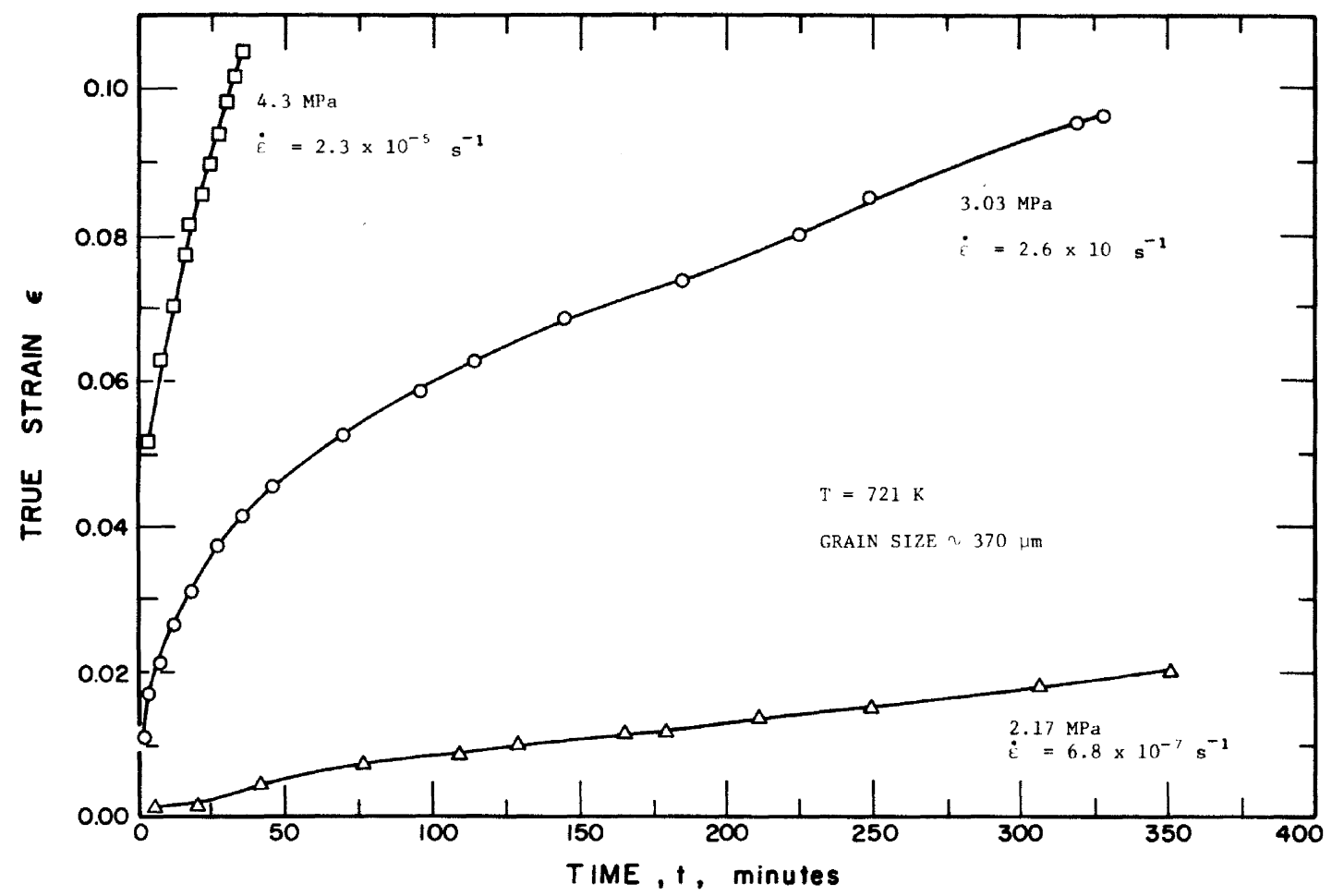

FIGURE 3.24. Typical creep curves for polycrystalline $\mathrm{NaCl}$. 
TABLE 3.24. CREEP STRAIN-TIME CURVES FOR SALT (TENSILE TEST)

$$
\text { [Time, } t \text {, hr; Strain, } \varepsilon, \% \text { ] }
$$

\begin{tabular}{|c|c|c|c|c|}
\hline $\begin{array}{l}\text { Data } \\
\text { Set }\end{array}$ & $\begin{array}{l}\text { Author (s), Year } \\
{[\operatorname{Ref} .]}\end{array}$ & $t$ & $\varepsilon$ & Remarks \\
\hline 1 & $\begin{array}{l}\text { Nair, K. and Deere, } \\
\text { D.U., } 1970[23]\end{array}$ & $\begin{array}{l}0.250 E+00 \\
0.502 E+00 \\
0.125 E+01 \\
0.275 E+01 \\
0.464 E+01 \\
0.220 E+02 \\
0.482 E+02 \\
0.114 E+03 \\
0.369 E+03 \\
0.479 E+03 \\
0.991 E+03\end{array}$ & $\begin{array}{l}0.180 E+00 \\
0.215 E+00 \\
0.272 E+00 \\
0.344 E+00 \\
0.455 E+00 \\
0.698 E+00 \\
0.845 E+00 \\
0.113 E+01 \\
0.171 E+01 \\
0.199 E+01 \\
0.278 E+01\end{array}$ & $\begin{array}{l}\sigma_{3}=20.7 \mathrm{MPa} \\
\sigma_{1}=3.4 \mathrm{MPa} .\end{array}$ \\
\hline 2 & $\begin{array}{l}\text { Nair, K. and Deere, } \\
\text { D.U., } 1970 \text { [23] }\end{array}$ & $\begin{array}{l}0.509 E+00 \\
0.994 E+00 \\
0.212 E+01 \\
0.204 E+02 \\
0.489 E+02 \\
0.982 E+02 \\
0.292 E+03 \\
0.719 E+03\end{array}$ & $\begin{array}{l}0.256 E+00 \\
0.297 E+00 \\
0.393 E+00 \\
0.845 E+00 \\
0.115 E+01 \\
0.154 E+01 \\
0.244 E+01 \\
0.362 E+01\end{array}$ & $\begin{array}{l}\sigma_{3}=17.9 \mathrm{MPa} \\
\sigma_{1}=0.7 \mathrm{MPa} .\end{array}$ \\
\hline 3 & $\begin{array}{l}\text { Nair, K. and Deere, } \\
\text { D.U., } 1970 \text { [23] }\end{array}$ & $\begin{array}{l}0.192 E+00 \\
0.334 E+00 \\
0.447 E+00 \\
0.135 E+01 \\
0.275 E+01 \\
0.620 E+01 \\
0.126 E+02 \\
0.448 E+02 \\
0.996 E+02 \\
0.189 E+03\end{array}$ & $\begin{array}{l}0.248 E+00 \\
0.292 E+00 \\
0.310 E+00 \\
0.422 E+00 \\
0.559 E+00 \\
0.697 E+00 \\
0.908 E+00 \\
0.143 E+01 \\
0.223 E+01 \\
0.357 E+01\end{array}$ & $\begin{array}{l}\sigma_{3}=23.6 \mathrm{MPa} \\
\sigma_{1}=2.1 \mathrm{MPa}\end{array}$ \\
\hline 4 & $\begin{array}{l}\text { Nair, K. and Deere, } \\
\text { D.U., } 1970 \text { [23] }\end{array}$ & $\begin{array}{l}0.985 E-01 \\
0.993 E+00 \\
0.183 E+01 \\
0.931 E+01 \\
0.198 E+02 \\
0.122 E+03\end{array}$ & $\begin{array}{l}0.224 E+00 \\
0.558 E+00 \\
0.676 E+00 \\
0.133 E+01 \\
0.195 E+01 \\
0.478 E+01\end{array}$ & $\begin{array}{l}\sigma_{3}=24.8 \mathrm{MPa} \\
\sigma_{1}=3.4 \mathrm{MPa} .\end{array}$ \\
\hline 5 & $\begin{array}{l}\text { Nair, K. and Deere, } \\
\text { D.U., } 1970[23]\end{array}$ & $\begin{array}{l}0.999 E-01 \\
0.509 E+00 \\
0.101 E+01 \\
0.197 E+01 \\
0.620 E+01 \\
0.207 E+02\end{array}$ & $\begin{array}{l}0.238 E+00 \\
0.461 E+00 \\
0.685 E+00 \\
0.893 E+00 \\
0.145 E+01 \\
0.254 E+01\end{array}$ & $\begin{array}{l}\sigma_{3}=22 \mathrm{MPa} \\
\sigma_{1}=0.7 \mathrm{MPa}\end{array}$ \\
\hline
\end{tabular}


TABLE 3.24. CREEP STRAIN-TIME CURVES FOR SALT (TENSILE TEST) (Continued)

\begin{tabular}{|c|c|c|c|c|}
\hline $\begin{array}{l}\text { Data } \\
\text { Set }\end{array}$ & $\begin{array}{l}\text { Author(s), Year } \\
\text { [Ref.] }\end{array}$ & $t$ & $\varepsilon$ & Remarks \\
\hline 6 & $\begin{array}{l}\text { Nair, K. and Deere, } \\
\text { D.U., } 1970 \text { [23] }\end{array}$ & $\begin{array}{l}0.164 E+00 \\
0.198 E+00 \\
0.253 E+00 \\
0.107 E+01 \\
0.205 E+01 \\
0.498 E+01 \\
0.144 E+02 \\
0.219 E+02 \\
0.269 E+02 \\
0.495 E+02\end{array}$ & $\begin{array}{l}0.397 \mathrm{E}+00 \\
0.434 \mathrm{E}+00 \\
0.488 \mathrm{E}+00 \\
0.892 \mathrm{E}+00 \\
0.111 \mathrm{E}+01 \\
0.161 \mathrm{E}+01 \\
0.250 \mathrm{E}+01 \\
0.294 \mathrm{E}+01 \\
0.312 \mathrm{E}+01 \\
0.470 \mathrm{E}+01\end{array}$ & $\begin{array}{l}\sigma_{3}=25.5 \mathrm{MPa} \\
\sigma_{1}=2.1 \mathrm{MPa}\end{array}$ \\
\hline 7 & $\begin{array}{l}\text { Nair, K. and Deere, } \\
\text { D.U., } 1970 \text { [23] }\end{array}$ & $\begin{array}{l}0.301 E+00 \\
0.680 E+00 \\
0.165 E+01 \\
0.498 E+01 \\
0.865 E+01 \\
0.198 E+02\end{array}$ & $\begin{array}{l}0.541 E+00 \\
0.748 E+00 \\
0.113 E+01 \\
0.186 E+01 \\
0.243 E+01 \\
0.340 E+01\end{array}$ & $\begin{array}{l}\sigma_{3}=26.5 \mathrm{MPa} \\
\sigma_{1}=0.7 \mathrm{MPa} .\end{array}$ \\
\hline 8 & $\begin{array}{l}\text { Nair, K. and Deere, } \\
\text { D.U., } 1970 \quad \text { [23] }\end{array}$ & $\begin{array}{l}0.131 E+00 \\
0.200 E+00 \\
0.513 E+00 \\
0.100 E+01 \\
0.818 E+01 \\
0.670 E+02 \\
0.387 E+03\end{array}$ & $\begin{array}{l}0.394 \mathrm{E}+00 \\
0.437 \mathrm{E}+00 \\
0.612 \mathrm{E}+00 \\
0.730 \mathrm{E}+00 \\
0.144 \mathrm{E}+01 \\
0.295 \mathrm{E}+01 \\
0.720 \mathrm{E}+01\end{array}$ & $\begin{array}{l}\sigma_{3}=22 \mathrm{MPa} \\
\sigma_{1}=1.4 \mathrm{MPa}\end{array}$ \\
\hline 9 & $\begin{array}{l}\text { Nair, K. and Deere, } \\
\text { D.U., } 1970 \text { [23] }\end{array}$ & $\begin{array}{l}0.121 \mathrm{E}+01 \\
0.200 \mathrm{E}+01 \\
0.499 \mathrm{E}+01 \\
0.494 \mathrm{E}+02 \\
0.196 \mathrm{E}+03 \\
0.376 \mathrm{E}+03\end{array}$ & $\begin{array}{l}0.129 \mathrm{E}+01 \\
0.145 \mathrm{E}+01 \\
0.186 \mathrm{E}+01 \\
0.346 \mathrm{E}+01 \\
0.492 \mathrm{E}+01 \\
0.596 \mathrm{E}+01\end{array}$ & $\begin{array}{l}\sigma_{3}=24.1 \mathrm{MPa} \\
\sigma_{1}=3.4 \mathrm{MPa}\end{array}$ \\
\hline 10 & $\begin{array}{l}\text { Nair, K. and Deere, } \\
\text { D.U., } 1970 \quad[23]\end{array}$ & $\begin{array}{l}0.101 E+01 \\
0.308 E+00 \\
0.512 E+00 \\
0.103 E+01 \\
0.191 E+01 \\
0.309 E+01 \\
0.505 E+01\end{array}$ & $\begin{array}{l}0.726 \mathrm{E}+00 \\
0.121 \mathrm{E}+01 \\
0.156 \mathrm{E}+01 \\
0.203 \mathrm{E}+01 \\
0.268 \mathrm{E}+01 \\
0.333 \mathrm{E}+01 \\
0.440 \mathrm{E}+01\end{array}$ & $\begin{array}{l}\sigma_{3}=31.7 \mathrm{MPa} \\
\sigma_{1}=3.4 \mathrm{MPa} .\end{array}$ \\
\hline 11 & $\begin{array}{l}\text { Nair, K. and Deere. } \\
\text { D.U., } 1970 \text { [23] }\end{array}$ & $\begin{array}{l}0.101 \mathrm{E}+00 \\
0.148 \mathrm{E}+01 \\
0.136 \mathrm{E}+02 \\
0.193 \mathrm{E}+02\end{array}$ & $\begin{array}{l}0.399 E+00 \\
0.587 E+00 \\
0.115 E+01 \\
0.134 E+01\end{array}$ & $\begin{array}{l}\sigma_{3}=17.2 \mathrm{MPa} \\
\sigma_{1}=3.4 \mathrm{MPa}\end{array}$ \\
\hline 12 & $\begin{array}{l}\text { Nair, K. and Deere, } \\
\text { D.U., } 1970 \text { [23] }\end{array}$ & $\begin{array}{l}0.625 E+01 \\
0.980 E+01 \\
0.218 E+02 \\
0.520 E+02 \\
0.141 E+03 \\
0.545 E+03\end{array}$ & $\begin{array}{l}0.120 E+00 \\
0.135 E+00 \\
0.155 E+00 \\
0.187 E+00 \\
0.221 E+00 \\
0.319 E+00\end{array}$ & $\begin{array}{l}\sigma_{1}=17.2 \mathrm{MPa} \\
\sigma_{3}=6.9 \mathrm{MPa} .\end{array}$ \\
\hline
\end{tabular}




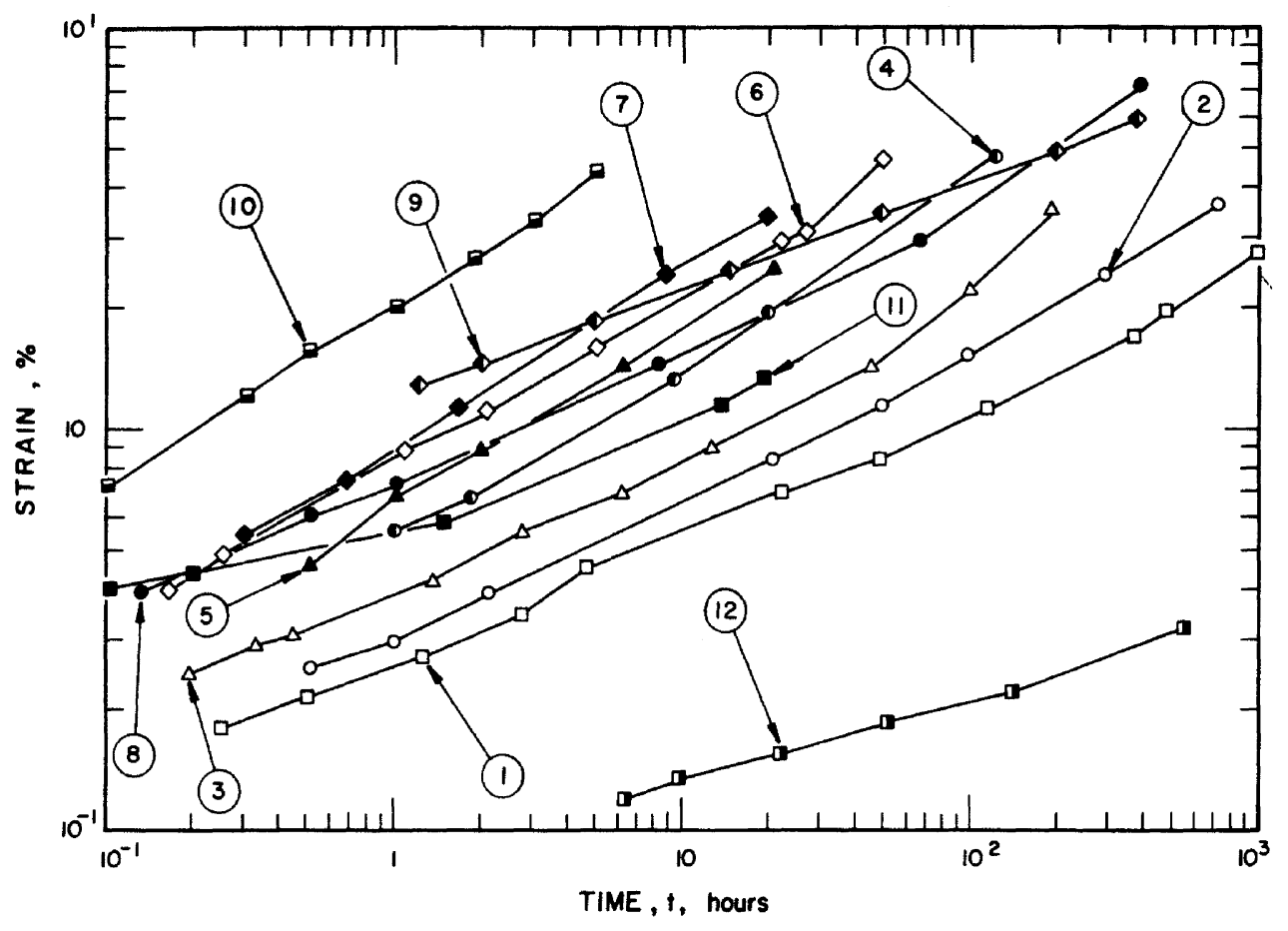

FIGURE 3.25. Tensile creep-strain curves for salt (curve numbers correspond to data set numbers in matching table). 
TABLE 3.25. NONUNIFORM CREEP OF NaCl WITH VARYING LOADS

[Time, $t$, min; Strain, $\varepsilon, \%$ ]

\begin{tabular}{|c|c|c|c|c|c|}
\hline $\begin{array}{l}\text { Data } \\
\text { Set }\end{array}$ & $\begin{array}{c}\text { Author(s), Y } \\
\text { [Ref.] }\end{array}$ & lear & $t$ & $\varepsilon$ & Remarks \\
\hline 1 & Ode, H., 1968 & {$[24]$} & $\begin{array}{l}0.244 E+00 \\
0.490 E+00 \\
0.943 E+00 \\
0.140 E+01 \\
0.199 E+01 \\
0.252 E+01 \\
0.290 E+01 \\
0.342 E+01 \\
0.393 E+01 \\
0.432 E+01 \\
0.474 E+01 \\
0.545 E+01 \\
0.583 E+01 \\
0.625 E+01 \\
0.702 E+01 \\
0.736 E+01 \\
0.808 E+01 \\
0.908 E+01 \\
0.997 E+01 \\
0.197 E+02 \\
0.249 E+02 \\
0.408 E+02 \\
0.503 E+02 \\
0.622 E+02 \\
0.120 E+03 \\
0.232 E+03\end{array}$ & $\begin{array}{l}0.735 E-02 \\
0.323 E-01 \\
0.495 E-01 \\
0.578 E-01 \\
0.661 E-01 \\
0.687 E-01 \\
0.698 E-01 \\
0.708 E-01 \\
0.724 E-01 \\
0.745 E-01 \\
0.766 E-01 \\
0.864 E-01 \\
0.958 E-01 \\
0.101 E+00 \\
0.104 E+00 \\
0.107 E+00 \\
0.109 E+00 \\
0.111 E+00 \\
0.112 E+00 \\
0.116 E+00 \\
0.117 E+00 \\
0.120 E+00 \\
0.121 E+00 \\
0.123 E+00 \\
0.125 E+00 \\
0.126 E+00\end{array}$ & $\begin{array}{l}\sigma=44.5 \mathrm{MPa} \text { load } \\
\text { stress. }\end{array}$ \\
\hline 2 & Ode, H., 1968 & [24] & $\begin{array}{l}0.244 E+00 \\
0.331 E+00 \\
0.492 E+00 \\
0.651 E+00 \\
0.786 E+00 \\
0.993 E+00 \\
0.144 E+01 \\
0.191 E+01 \\
0.285 E+01 \\
0.395 E+01 \\
0.575 E+01 \\
0.964 E+01 \\
0.158 E+02 \\
0.247 E+02 \\
0.454 E+02 \\
0.601 E+02 \\
0.891 E+02 \\
0.890 E+02 \\
0.976 E+02 \\
0.112 E+03 \\
0.118 E+03\end{array}$ & $\begin{array}{l}0.166 \mathrm{E}-02 \\
0.946 \mathrm{E}-02 \\
0.178 \mathrm{E}-01 \\
0.240 \mathrm{E}-01 \\
0.267 \mathrm{E}-01 \\
0.303 \mathrm{E}-01 \\
0.381 \mathrm{E}-01 \\
0.438 \mathrm{E}-01 \\
0.465 \mathrm{E}-01 \\
0.491 \mathrm{E}-01 \\
0.517 \mathrm{E}-01 \\
0.539 \mathrm{E}-01 \\
0.570 \mathrm{E}-01 \\
0.597 \mathrm{E}-01 \\
0.629 \mathrm{E}-01 \\
0.650 \mathrm{E}-01 \\
0.930 \mathrm{E}-01 \\
0.966 \mathrm{E}-01 \\
0.101 \mathrm{E}+00 \\
0.106 \mathrm{E}+00 \\
0.108 \mathrm{E}+00\end{array}$ & $\begin{array}{l}\sigma=2.45 \mathrm{MPa} \text { load } \\
\text { stress. }\end{array}$ \\
\hline
\end{tabular}


TABLE 3.25. NONUNIFORM CREEP OF NaCl WITH VARYING LOADS (Cont inued)

\begin{tabular}{|c|c|c|c|c|c|}
\hline $\begin{array}{c}\text { Data } \\
\text { Set } \\
\end{array}$ & $\begin{array}{c}\text { Author(s), Y } \\
\text { [Ref.] }\end{array}$ & ear & $t$ & $\varepsilon$ & Remarks \\
\hline $\begin{array}{c}2 \\
(\operatorname{con} t .)\end{array}$ & Ode, н., 1968 & [24] & $\begin{array}{l}0.145 E+03 \\
0.175 E+03 \\
0.216 E+03 \\
0.293 E+03 \\
0.407 E+03\end{array}$ & $\begin{array}{l}0.112 E+00 \\
0.115 E+00 \\
0.117 E+00 \\
0.121 E+00 \\
0.124 E+00\end{array}$ & \\
\hline 3 & Ode, H., 1968 & [24] & $\begin{array}{l}0.493 E+00 \\
0.653 E+00 \\
0.826 E+00 \\
0.996 E+00 \\
0.132 E+01 \\
0.148 E+01 \\
0.167 E+01 \\
0.201 E+01 \\
0.232 E+01 \\
0.266 E+01 \\
0.293 E+01 \\
0.329 E+01 \\
0.361 E+01 \\
0.397 E+01 \\
0.490 E+01 \\
0.605 E+01 \\
0.696 E+01 \\
0.801 E+01 \\
0.880 E+01 \\
0.101 E+02 \\
0.117 E+02 \\
0.141 E+02 \\
0.209 E+02 \\
0.241 E+02 \\
0.327 E+02 \\
0.499 E+02 \\
0.709 E+02 \\
0.103 E+03 \\
0.134 E+03 \\
0.181 E+03 \\
0.246 E+03 \\
0.509 E+03\end{array}$ & $\begin{array}{l}0.795 \mathrm{E}-02 \\
0.121 \mathrm{E}-01 \\
0.142 \mathrm{E}-01 \\
0.163 \mathrm{E}-01 \\
0.200 \mathrm{E}-01 \\
0.221 \mathrm{E}-01 \\
0.236 \mathrm{E}-01 \\
0.252 \mathrm{E}-01 \\
0.273 \mathrm{E}-01 \\
0.289 \mathrm{E}-01 \\
0.304 \mathrm{E}-01 \\
0.315 \mathrm{E}-01 \\
0.325 \mathrm{E}-01 \\
0.341 \mathrm{E}-01 \\
0.367 \mathrm{E}-01 \\
0.388 \mathrm{E}-01 \\
0.398 \mathrm{E}-01 \\
0.430 \mathrm{E}-01 \\
0.445 \mathrm{E}-01 \\
0.466 \mathrm{E}-01 \\
0.482 \mathrm{E}-01 \\
0.508 \mathrm{E}-01 \\
0.555 \mathrm{E}-01 \\
0.571 \mathrm{E}-01 \\
0.592 \mathrm{E}-01 \\
0.618 \mathrm{E}-01 \\
0.655 \mathrm{E}-01 \\
0.686 \mathrm{E}-01 \\
0.702 \mathrm{E}-01 \\
0.718 \mathrm{E}-01 \\
0.719 \mathrm{E}-01 \\
0.719 \mathrm{E}-01\end{array}$ & $\begin{array}{l}\sigma=2.94 \mathrm{MPa} \text { load } \\
\text { stress. }\end{array}$ \\
\hline 4 & Ode, H., 1968 & [24] & $\begin{array}{l}0.999 \mathrm{E}+00 \\
0.123 \mathrm{E}+01 \\
0.142 \mathrm{E}+01 \\
0.171 \mathrm{E}+01 \\
0.197 \mathrm{E}+01 \\
0.243 \mathrm{E}+01 \\
0.308 \mathrm{E}+01 \\
0.389 \mathrm{E}+01 \\
0.480 \mathrm{E}+01 \\
0.593 \mathrm{E}+01\end{array}$ & $\begin{array}{l}0.389 E-02 \\
0.702 E-02 \\
0.911 E-02 \\
0.112 E-01 \\
0.123 E-01 \\
0.138 E-01 \\
0.170 E-01 \\
0.185 E-01 \\
0.201 E-01 \\
0.217 E-01\end{array}$ & $\begin{array}{l}\sigma=3.43 \mathrm{MPa} \text { load } \\
\text { stress. }\end{array}$ \\
\hline
\end{tabular}


TABLE 3.25. NONUNIFORM CREEP OF NaCl WITH VARYING LOADS (Continued)

\begin{tabular}{cccccc}
\hline $\begin{array}{c}\text { Data } \\
\text { Set }\end{array}$ & $\begin{array}{c}\text { Author(s), Year } \\
\text { [Ref.] }\end{array}$ & $t$ & $\varepsilon$ & Remarks \\
\hline & Ode, H., 1968 & {$[24]$} & $0.805 \mathrm{E}+01$ & $0.228 \mathrm{E}-01$ \\
(cont.) & & $0.994 \mathrm{E}+01$ & $0.254 \mathrm{E}-01$ \\
& $0.138 \mathrm{E}+02$ & $0.301 \mathrm{E}-01$ \\
& & $0.159 \mathrm{E}+02$ & $0.322 \mathrm{E}-01$ \\
& $0.201 \mathrm{E}+02$ & $0.363 \mathrm{E}-01$ \\
& $0.242 \mathrm{E}+02$ & $0.390 \mathrm{E}-01$ \\
& $0.344 \mathrm{E}+02$ & $0.447 \mathrm{E}-01$ \\
& $0.524 \mathrm{E}+02$ & $0.484 \mathrm{E}-01$ \\
& $0.711 \mathrm{E}+02$ & $0.510 \mathrm{E}-01$ \\
& $0.899 \mathrm{E}+02$ & $0.552 \mathrm{E}-01$ \\
& $0.101 \mathrm{E}+03$ & $0.572 \mathrm{E}-01$ \\
& $0.186 \mathrm{E}+03$ & $0.625 \mathrm{E}-01$ \\
& $0.246 \mathrm{E}+03$ & $0.636 \mathrm{E}-01$ \\
& $0.297 \mathrm{E}+03$ & $0.636 \mathrm{E}-01$ \\
& $0.487 \mathrm{E}+03$ & $0.642 \mathrm{E}-01$ \\
\hline
\end{tabular}

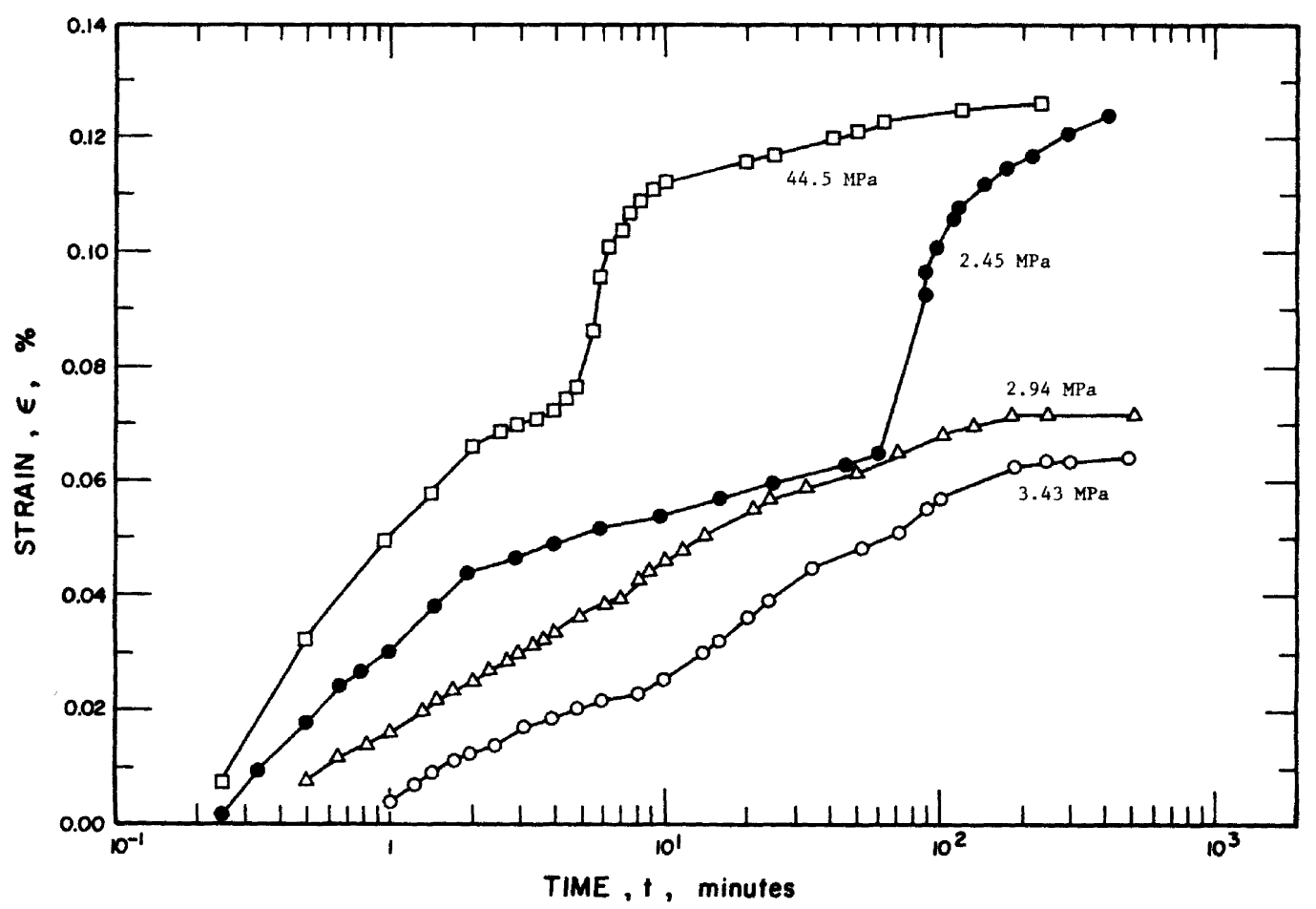

Figure 3.26. Nonuniform creep of $\mathrm{NaCl}$. 
TABLE 3.26. CREEP CURVES FOR HALITE SINGLE CRYSTALS AT DIFFERENT CONSTANT LOADS

[Time, $t$, min; Strain, $\varepsilon, \%$ ]

\begin{tabular}{|c|c|c|c|c|}
\hline $\begin{array}{l}\text { Data } \\
\text { Set }\end{array}$ & $\begin{array}{l}\text { Author }(s), \text { Year } \\
\text { [Ref.] }\end{array}$ & $t$ & $\varepsilon$ & Remarks \\
\hline 1 & Ode, H., 1968 [24] & $\begin{array}{r}83.952 \\
146.852 \\
204.529 \\
403.971 \\
603.509 \\
808.323 \\
1002.679\end{array}$ & $\begin{array}{l}0.498 \\
0.997 \\
1.416 \\
2.492 \\
3.385 \\
4.251 \\
4.987\end{array}$ & $\sigma=25 \mathrm{MPa}$. \\
\hline 2 & Ode, H., 1968 [24] & $\begin{array}{r}120.767 \\
204.787 \\
404.433 \\
604.161 \\
803.929 \\
1003.725 \\
1203.561 \\
1403.384 \\
1597.971 \\
1797.834 \\
2002.947\end{array}$ & $\begin{array}{l}0.551 \\
0.919 \\
1.602 \\
2.128 \\
2.576 \\
2.971 \\
3.288 \\
3.631 \\
3.921 \\
4.185 \\
4.476\end{array}$ & $\sigma=23 \mathrm{MPa}$. \\
\hline 3 & Ode, H., 1968 [24] & $\begin{array}{r}36.788 \\
73.385 \\
110.105 \\
204.678 \\
404.433 \\
604.242 \\
804.092 \\
998.693 \\
1203.847 \\
1398.474 \\
1598.378 \\
1793.020 \\
1998.200\end{array}$ & $\begin{array}{l}0.105 \\
0.577 \\
0.813 \\
1.128 \\
1.602 \\
1.971 \\
2.262 \\
2.526 \\
2.738 \\
2.950 \\
3.136 \\
3.321 \\
3.481\end{array}$ & $\sigma=17 \mathrm{MPa}$. \\
\hline 4 & Ode, H., 1968 [24] & $\begin{array}{r}78.838 \\
199.796 \\
399.686 \\
604.854 \\
804.758 \\
1004.703 \\
1199.371 \\
1399.316 \\
1604.524 \\
1799.206 \\
1599.151\end{array}$ & $\begin{array}{l}0.210 \\
0.395 \\
0.607 \\
0.793 \\
0.979 \\
1.086 \\
1.220 \\
1.327 \\
1.434 \\
1.541 \\
1.649\end{array}$ & $\sigma=22 \mathrm{MPa}$ \\
\hline
\end{tabular}


TABLE 3.26. CREEP CURVES FOR HALITE SINGLE CRYSTALS

AT DIFFERENT CONSTANT LOADS (Continued)

\begin{tabular}{|c|c|c|c|c|c|}
\hline $\begin{array}{l}\text { Data } \\
\text { Set }\end{array}$ & $\begin{array}{c}\text { Author (s), Y } \\
\text { [Ref.] }\end{array}$ & ear & $t$ & $\varepsilon$ & Remarks \\
\hline 5 & Ode, H., 1968 & {$[24]$} & $\begin{array}{r}10.445 \\
89.297 \\
126.098 \\
205.032 \\
404.963 \\
604.935 \\
810.143 \\
1004.866 \\
1204.824 \\
1399.547 \\
1599.533 \\
1799.519 \\
1999.518\end{array}$ & $\begin{array}{l}0.157 \\
0.341 \\
0.420 \\
0.448 \\
0.581 \\
0.636 \\
0.743 \\
0.772 \\
0.853 \\
0.882 \\
0.911 \\
0.939 \\
0.942\end{array}$ & $\sigma=70 \mathrm{MPa}$. \\
\hline 6 & Ode, H., 1968 & [24] & $\begin{array}{r}10.526 \\
205.235 \\
405.207 \\
605.180 \\
805.179 \\
1005.138 \\
1205.110 \\
1405.082 \\
1599.791 \\
1794.514 \\
1999.749\end{array}$ & $\begin{array}{l}0.000 \\
0.055 \\
0.110 \\
0.165 \\
0.167 \\
0.249 \\
0.303 \\
0.358 \\
0.413 \\
0.442 \\
0.497\end{array}$ & $\sigma=10.5 \mathrm{MPa}$. \\
\hline
\end{tabular}

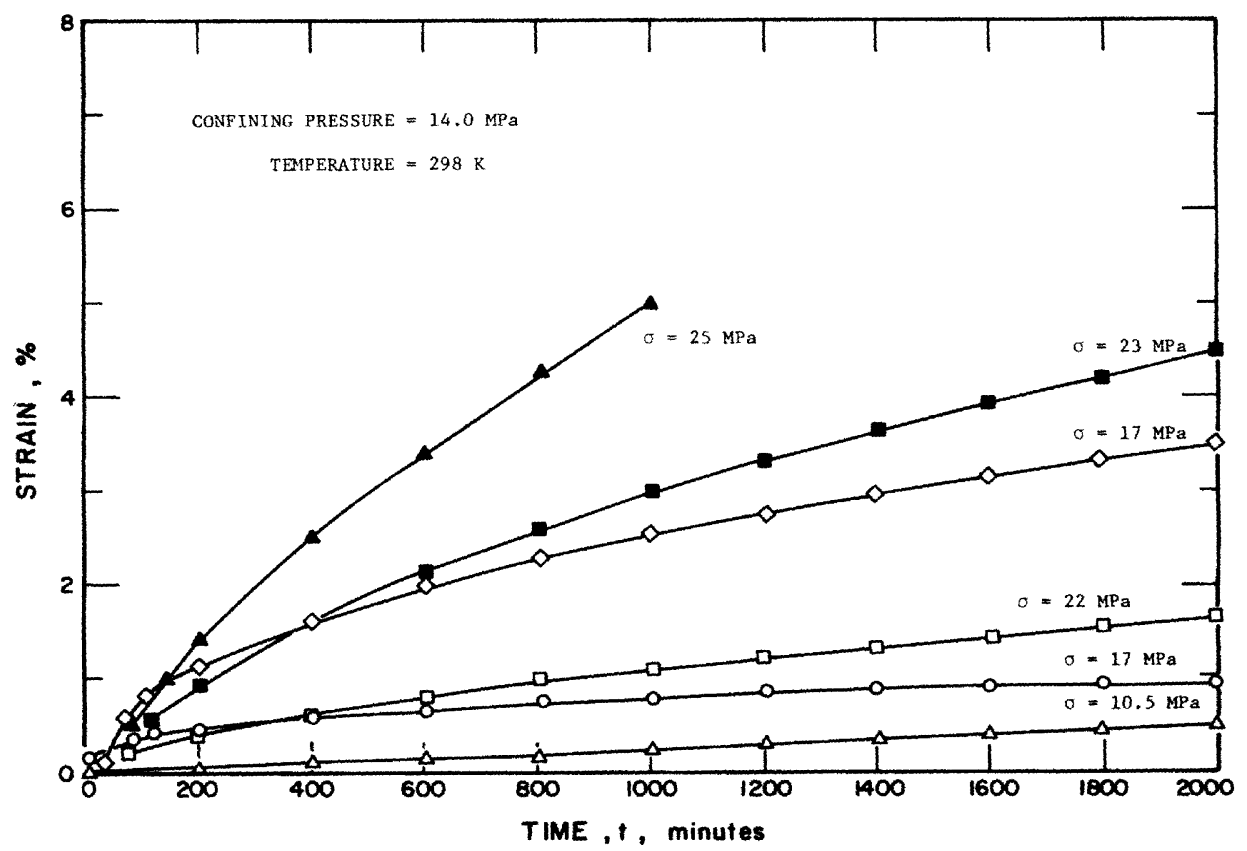

FiGURE 3.27. Creep curves for halite single crystals. 
and figure 3.28. Similar work on the effects of confining pressure only was conducted by Thompson [25]. Differential stress was kept constant and a range of confining pressures was used. The evidence is that the effect of confining pressure is minimal. Data related to Thompson's work are supplied in table 3.28 and figure 3.29. Baar [17] gives field data indicating the acceleration of creep caused by heating of a salt mine pillar to peak temperatures of about $423 \mathrm{~K}$. The data presented in table 3.29 and figure 3.30 yield four data sets, each set related to connected rooms in the salt mine in which the experiment was performed. From the information presented, it can be seen that creep is a thermally activated process since if it were not, the creep rate at any temperature would depend on stress difference only. LeComte also investigated the effect of axial stress on creep and the combined effects of grain size and axial stress on creep of rock salt. These results can be found in table 3.30 and figure 3.31 , and table 3.31 and figure 3.32 , respectively.

Steady-state creep rate as some function of stress has been studied by Burke and is also reported by Odé. Burke [29] presents a relationship between steady-state creep rate and stress for coarse-grained salt $(1000-3000 \mu \mathrm{m})$. These values are given in table 3.32 and figure 3.33. The same relationship for polycrystalline $\mathrm{NaCl}$ and single crystal $\mathrm{NaCl}$ was also investigated by Burke at $1013 \mathrm{~K}$ (see table 3.33 and figure 3.34 ). Steady-state creep rate of $\mathrm{NaCl}$ at several stresses as a function of temperature are reported by Odé [34] and is illustrated in figure 3.35 and table 3.34.

Figure 3.36 shows the time-strain data at various confining pressures and temperatures and table 3.35 tabulates the corresponding values. These values were obtained by Dreyer [12] in 1972 from creep tests on artificial rock salt samples. The lower three curves indicate that confining pressure has only a small influence on time dependent strain at room temperature. The upper curves show that the effect of confining pressure is greater at higher temperatures. In general, temperature has a marked effect on the deformational behavior of rock salt.

Dreyer [12] has also studied the creep behavior of untempered and tempered rock salt as a function of time and the relevant data are presented in figure 3.37 and table 3.36. Although these two rock salt samples have a slightly different composition (see measurement methods), it is considered that they are representative of the trend in creep behavior of tempered and untempered rock salt.

Generally, tempered samples show a much more prolonged "creep life" than do untempered samples. This is because untempered samples reach this maximum creep strain in a short time whereas tempered samples take longer to reach their maximum. In addition, tempered rock salt exhibits a much higher maximum creep strain (5 to 6 times greater). It is believed that the behavior of the tempered salt is due to recrystallization during tempering.

\subsection{Hardness}

The hardness of rock salt depends on atmospheric humidity, previous plastic deformation, impurities in the crystals, and quench temperatures. Large discrepancies in hardness values of $\mathrm{NaCl}$ are found at small loads. The various factors which influence the hardness number at small loads include microrelief of surface, roughness of indentor, elastic recovery in indent, vibration, loading rate, etc.

Strelkov and Shpunt [15] have shown that the published data on hardness may be represented by curves 1-3 of figure 3.38 which may be obtained on a single specimen of $\mathrm{NaCl}$ by varying the atmospheric humidity $\mathrm{B}$ and the previous plastic deformation $\epsilon$. Curve $l$ is for an unstressed $(\epsilon \sim 0)$ specimen in dry air $\left(B \mid \leqslant^{\mid} 30 \%\right)$ while curve 3 is for the same specimen in moist air. Curve 3 is for a deformed specimen $(\epsilon \geqslant 0.3-0.4 \%)$ in dry atmosphere.

The values of hardness at low loads indicated by these curves and tabulated in table 3.37 have not been corrected for the factors mentioned above. The absolute values of hardness can be obtained only if all factors have been considered, which is difficult to accomplish. However, as the above curves represent an average of a large data set, they can be considered to represent the recommended values of microhardness.

According to Strelkov and Shpunt [15] $1=3$ transition involves a delay (relative to the change in $B$ ) of 15-20 minutes. Curve 2 differs from 1 for $\epsilon \geqslant 0.3-0.4 \%$. The $2=3$ transition is analogous to $l=3$. A. $2 \rightarrow 1$ transition occurs on annealing even highly deformed materials $(\epsilon \geqslant 2-3 \%)$. The maximum humidity at which $\mathrm{NaCl}$ can be tested for microhardness is $75 \%$; for values higher than this water is deposited on the crystals.

For values of load $\mathrm{p}>20 \mathrm{~g}$ and indentation depth $h>6-7 \mu$, the microhardness is steady and independent of load, humidity, and previous plastic deformation. The values of steady microhardness have been found to fall in the range of $19-23 \mathrm{~kg} / \mathrm{mm}^{2}$ due to differences in impurity content.

Kishsh and Sharkezi [14] have studied the microhardness of $\mathrm{NaCl}$ crystals containing cation and anion impurities in relation to temperature and rate of quenching. Their data are presented in figure 3.39 with the corresponding values in table 3.38 . The figure shows 
TABLE 3.27. EFFECT OF TEMPERATURE AND CONFINING PRESSURE ON THE CREEP OF ROCK SALT

[Time, $t$, hr; Strain, $E, \%$ ]

\begin{tabular}{|c|c|c|c|c|c|c|}
\hline $\begin{array}{c}\text { Data } \\
\text { Set } \\
\end{array}$ & $\begin{array}{r}\text { Author(s), } \\
\text { [Ref.] }\end{array}$ & Year & & $t$ & $\varepsilon$ & Remarks \\
\hline 1 & LeComte, P., & 1965 & {$[22]$} & $\begin{array}{r}2.328 \\
6.003 \\
9.693 \\
19.558 \\
24.520 \\
33.191 \\
43.116 \\
52.426 \\
67.948 \\
79.749 \\
90.924 \\
94.650\end{array}$ & $\begin{array}{l}1.199 \\
1.719 \\
2.141 \\
3.085 \\
3.346 \\
3.900 \\
4.422 \\
4.879 \\
5.597 \\
6.120 \\
6.643 \\
6.806\end{array}$ & $\begin{array}{l}\text { Confining pressure }= \\
100 \mathrm{MPa} ; \\
\text { Temperature }=471 \mathrm{~K} \text {; } \\
\text { Axial stress }=6.9 \\
\mathrm{MPa} \text {. }\end{array}$ \\
\hline 2 & LeComte, P., & 1965 & [22] & $\begin{array}{r}1.759 \\
5.416 \\
11.540 \\
21.428 \\
32.589 \\
36.311 \\
49.352 \\
59.296 \\
68.629 \\
83.564 \\
96.637\end{array}$ & $\begin{array}{l}0.810 \\
1.460 \\
2.336 \\
3.118 \\
3.737 \\
3.933 \\
4.521 \\
4.914 \\
5.209 \\
5.668 \\
6.029\end{array}$ & $\begin{array}{l}\text { Confining pressure }= \\
0.1 \mathrm{MPa} ; \\
\text { Temperature }=377 \mathrm{~K} \text {; } \\
\text { Axial stress }=6.9 \\
\mathrm{MPa} \text {. }\end{array}$ \\
\hline 3 & LeComte, P., & 1965 & [22] & $\begin{array}{r}0.485 \\
4.856 \\
14.846 \\
27.318 \\
36.679 \\
54.775 \\
72.256 \\
84.733 \\
98.459 \\
120.944 \\
134.060\end{array}$ & $\begin{array}{l}0.972 \\
1.006 \\
1.075 \\
1.274 \\
1.375 \\
1.576 \\
1.712 \\
1.879 \\
2.046 \\
2.152 \\
2.222\end{array}$ & $\begin{array}{l}\text { Confining pressure }= \\
100 \mathrm{MPa} ; \\
\text { Temperature }=377 \mathrm{~K} \text {; } \\
\text { Axial stress }=6.9 \\
\mathrm{MPa} .\end{array}$ \\
\hline 4 & LeComte, P., & 1965 & $\lceil 22\rceil$ & $\begin{array}{r}10.592 \\
35.578 \\
55.568 \\
72.433 \\
86.178 \\
96.803 \\
108.677 \\
131.167 \\
153.042 \\
173.037\end{array}$ & $\begin{array}{l}0.231 \\
0.338 \\
0.410 \\
0.481 \\
0.519 \\
0.523 \\
0.528 \\
0.601 \\
0.610 \\
0.650\end{array}$ & $\begin{array}{l}\text { Confining pressure }= \\
0.1 \mathrm{MPa} \text {; } \\
\text { Temperature }=302 \mathrm{~K} \text {; } \\
\text { Axial stress }=6.9 \\
\mathrm{MPa} \text {. }\end{array}$ \\
\hline
\end{tabular}


TABLE 3.27. EFFECT OF TEMPERATURE AND CONFINING PRESSURE ON THE CREEP OF ROCK SALT (Continued)

\begin{tabular}{|c|c|c|c|c|c|}
\hline $\begin{array}{l}\text { Data } \\
\text { Set }\end{array}$ & $\begin{array}{l}\text { Author (s), Year } \\
\text { [Ref.] }\end{array}$ & & $t$ & $\varepsilon$ & Remarks \\
\hline 5 & LeComte, P., 1965 & [22] & $\begin{array}{r}8.097 \\
15.592 \\
23.712 \\
49.327 \\
69.327 \\
99.321 \\
142.440 \\
169.314\end{array}$ & $\begin{array}{l}0.197 \\
0.233 \\
0.268 \\
0.343 \\
0.351 \\
0.395 \\
0.444 \\
0.454\end{array}$ & $\begin{array}{l}\text { Confining pressure = } \\
100 \mathrm{MPa} ; \\
\text { Temperature }=302 \mathrm{~K} \text {; } \\
\text { Axial stress }=6.9 \\
\mathrm{MPa} \text {. }\end{array}$ \\
\hline 6 & LeComte, P., 1965 & [22] & $\begin{array}{r}4.338 \\
30.578 \\
58.697 \\
78.692 \\
94.321 \\
119.316 \\
126.811 \\
151.185 \\
179.935\end{array}$ & $\begin{array}{l}0.261 \\
0.336 \\
0.379 \\
0.419 \\
0.393 \\
0.435 \\
0.470 \\
0.479 \\
0.490\end{array}$ & $\begin{array}{l}\text { Confining pressure }= \\
20 \mathrm{MPa} ; \\
\text { Temperature }=302 \mathrm{~K} \text {; } \\
\text { Axial stress }=6.9 \\
\text { MPa. }\end{array}$ \\
\hline
\end{tabular}

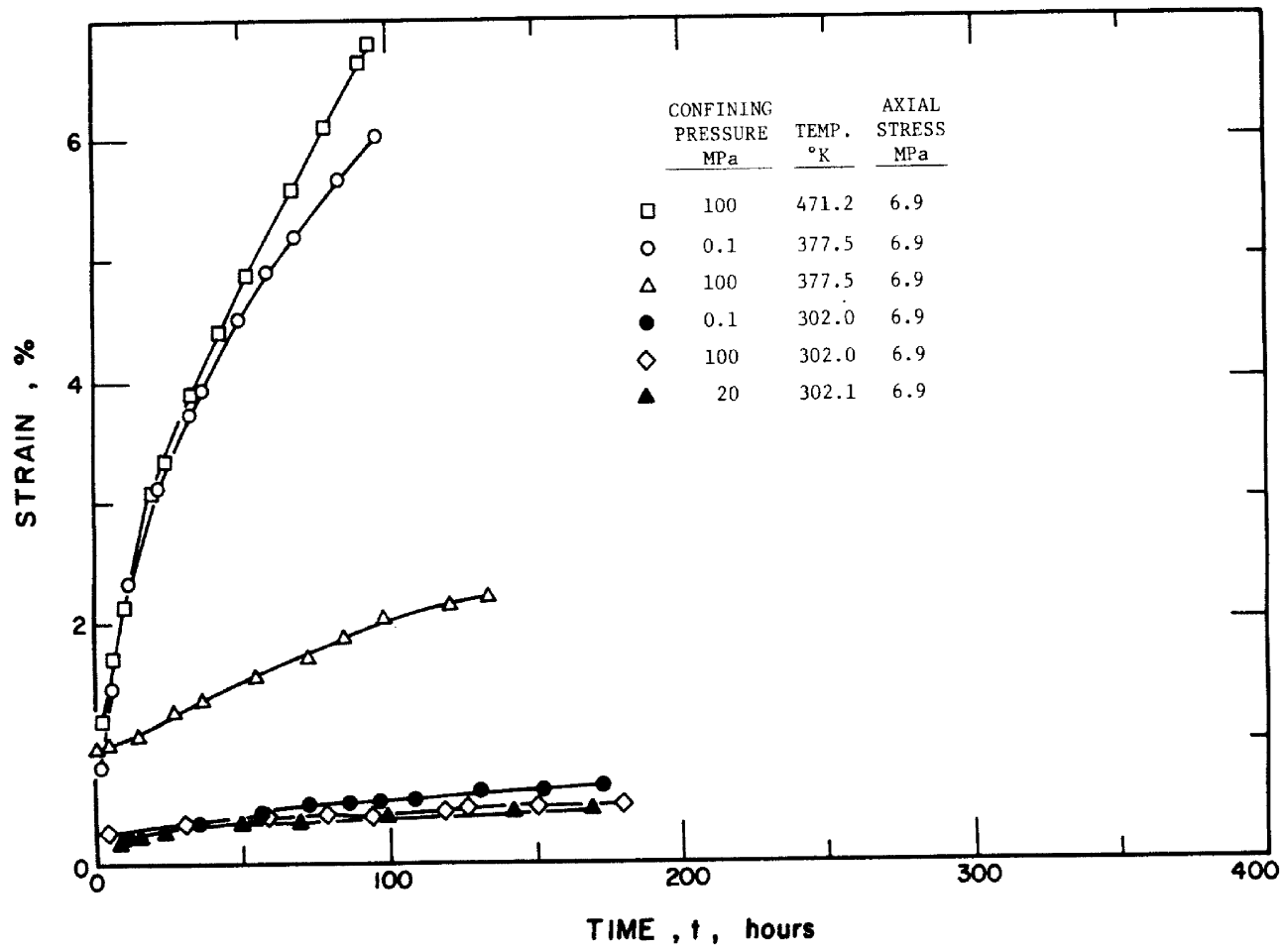

FIGURE 3.28. Effect of temperature and confining pressure on creep of rock salt. 
TABLE 3.28. EFFECT OF CONFINING PRESSURE ON THE STEADY STATE CREEP RATE OF HALITE

$$
\text { [Time, } t \text {, min; Strain, } \varepsilon, \% \text { ] }
$$

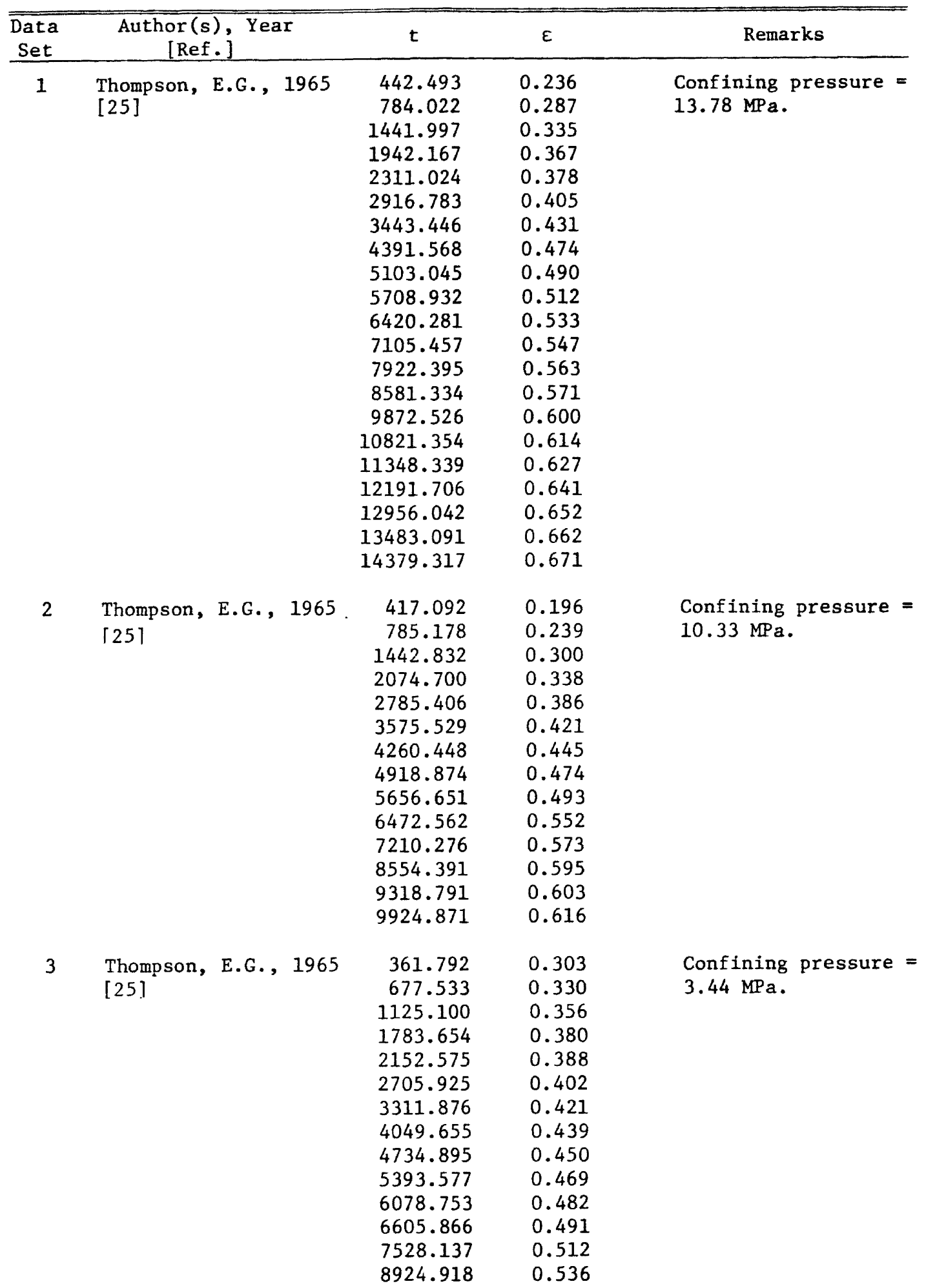


TABLE 3.28. EFFECT OF CONFINING PRESSURE ON THE STEADY STATE CREEP RATE OF HALITE (Continued)

\begin{tabular}{|c|c|c|c|c|}
\hline $\begin{array}{c}\text { Data } \\
\text { Set }\end{array}$ & $\begin{array}{l}\text { Author(s), Year } \\
\text { [Ref.] }\end{array}$ & $t$ & $\varepsilon$ & Remarks \\
\hline 4 & $\begin{array}{l}\text { Thompson, E.G., } 1965 \\
{[25]}\end{array}$ & $\begin{array}{r}466.868 \\
1124.008 \\
1544.889 \\
1965.834 \\
2465.619 \\
3361.010 \\
3887.481 \\
4941.192 \\
5441.554 \\
6126.602 \\
7074.916 \\
8287.013 \\
8945.695 \\
9683.666 \\
10395.079 \\
11106.619 \\
12529.509 \\
13056.494 \\
13978.958\end{array}$ & $\begin{array}{l}0.319 \\
0.401 \\
0.441 \\
0.479 \\
0.527 \\
0.570 \\
0.604 \\
0.642 \\
0.666 \\
0.685 \\
0.719 \\
0.749 \\
0.768 \\
0.779 \\
0.797 \\
0.811 \\
0.846 \\
0.859 \\
0.873\end{array}$ & $\begin{array}{l}\text { Confining pressure = } \\
0 \mathrm{MPa} \text {. }\end{array}$ \\
\hline
\end{tabular}

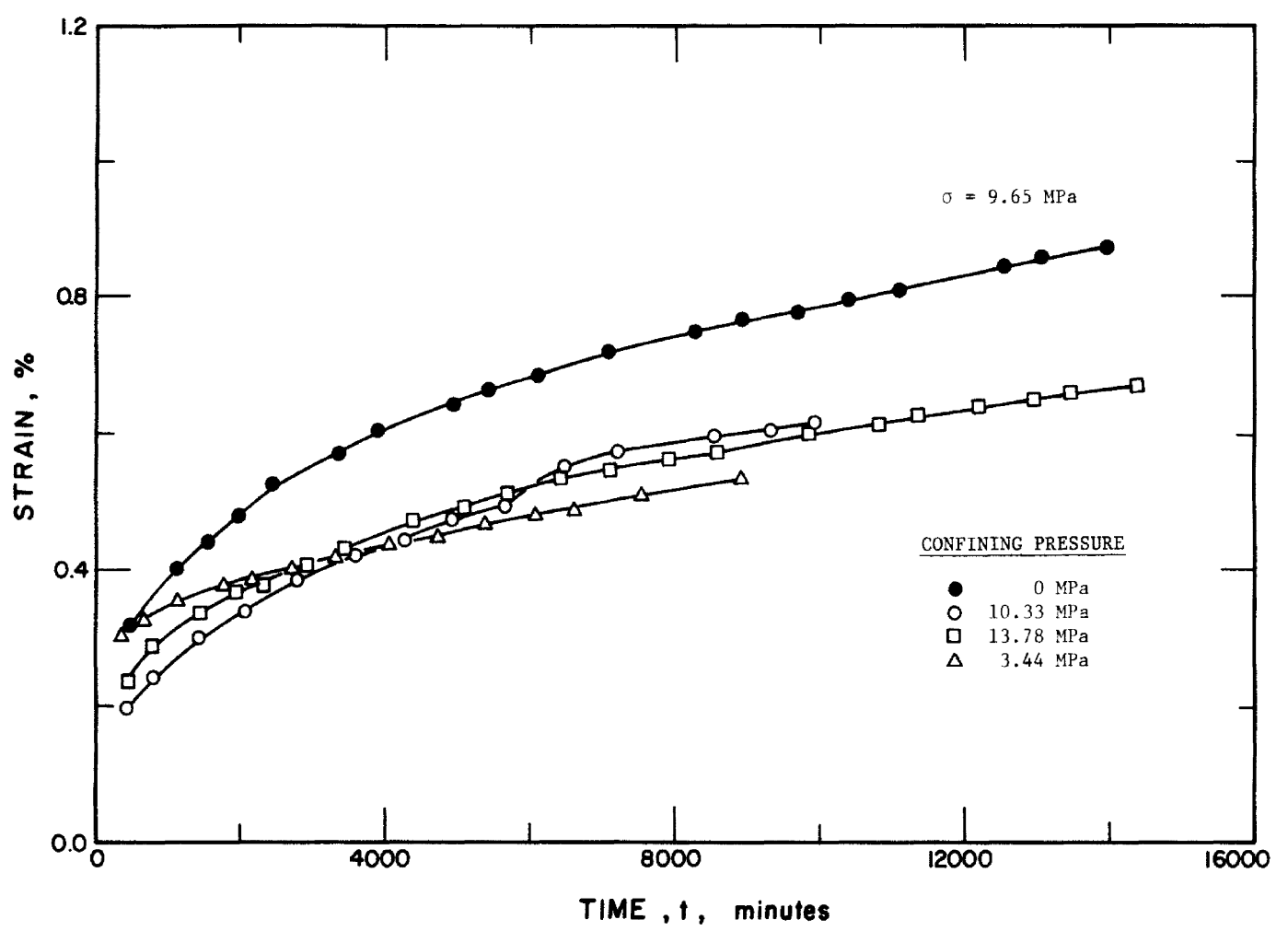

FIGURE 3.29. Effect of confining pressure on steady state flow of halite. 
TABLE 3.29. ACCELERATED CREEP CAUSED BY HEATING A SALT MINE PILLAR TO PEAK TEMPERATURE OF $\pm 423 \mathrm{~K}$

[Time, $t$, days; Vertical Deformation, $\Delta L, c m s$ ]

\begin{tabular}{|c|c|c|c|}
\hline $\begin{array}{l}\text { Data } \\
\text { Set }\end{array}$ & $\begin{array}{l}\text { Author(s), Year } \\
\text { [Ref.] }\end{array}$ & $t$ & $\Delta \mathrm{L}$ \\
\hline 1 & Baar, C.A., 1977 [17] & $\begin{array}{l}472.185 \\
487.272 \\
498.591 \\
506.150 \\
511.190 \\
517.493 \\
523.789 \\
531.351 \\
537.654 \\
545.216 \\
554.044 \\
561.613 \\
571.707 \\
583.051 \\
593.141 \\
603.232 \\
614.585 \\
624.680 \\
639.824 \\
652.434 \\
681.464 \\
701.652 \\
718.056 \\
730.668 \\
744.550 \\
759.699 \\
774.847 \\
787.459 \\
798.816 \\
808.903 \\
813.947 \\
823.983 \\
826.481 \\
834.013 \\
844.087 \\
849.110 \\
856.652 \\
864.217 \\
871.769 \\
884.365 \\
891.923 \\
899.485 \\
923.438 \\
930.993 \\
941.087 \\
952.430\end{array}$ & $\begin{array}{l}0.091 \\
0.248 \\
0.358 \\
0.398 \\
0.424 \\
0.449 \\
0.490 \\
0.523 \\
0.548 \\
0.581 \\
0.607 \\
0.624 \\
0.640 \\
0.690 \\
0.716 \\
0.741 \\
0.764 \\
0.782 \\
0.800 \\
0.840 \\
0.866 \\
0.899 \\
0.924 \\
0.957 \\
0.975 \\
0.983 \\
0.993 \\
1.026 \\
1.043 \\
1.077 \\
1.092 \\
1.249 \\
1.318 \\
1.424 \\
1.491 \\
1.559 \\
1.640 \\
1.666 \\
1.724 \\
1.800 \\
1.841 \\
1.874 \\
1.966 \\
2.016 \\
2.032 \\
2.082\end{array}$ \\
\hline
\end{tabular}


TABLE 3.29. ACCELERATED CREEP CAUSED BY HEATING A SALT MINE PILLAR TO PEAK TEMPERATURE OF $\pm 423 \mathrm{~K}$ (Continued)

\begin{tabular}{|c|c|c|c|}
\hline $\begin{array}{l}\text { Data } \\
\text { Set }\end{array}$ & $\begin{array}{c}\text { Author(s), Year } \\
\text { [Ref.] }\end{array}$ & $t$ & $\Delta \mathrm{L}$ \\
\hline $\begin{array}{c}1 \\
(\text { cont. })\end{array}$ & Baar, C.A., 1977 [17] & $\begin{array}{r}968.831 \\
981.447 \\
990.272 \\
997.837 \\
1005.409 \\
1012.982 \\
1023.076 \\
1038.210\end{array}$ & $\begin{array}{l}2.115 \\
2.141 \\
2.174 \\
2.199 \\
2.209 \\
2.217 \\
2.232 \\
2.275\end{array}$ \\
\hline 2 & Baar, C.A., 1977 [17] & $\begin{array}{l}463.384 \\
472.147 \\
485.941 \\
499.758 \\
507.303 \\
511.091 \\
516.108 \\
523.667 \\
529.963 \\
537.518 \\
545.073 \\
553.898 \\
562.723 \\
571.544 \\
582.891 \\
594.244 \\
606.853 \\
640.903 \\
653.519 \\
667.394 \\
680.010 \\
702.717 \\
714.071 \\
731.734 \\
744.350 \\
756.962 \\
773.376 \\
787.255 \\
799.871 \\
808.689 \\
811.187 \\
823.711 \\
827.448 \\
836.232 \\
846.282 \\
848.759 \\
858.854 \\
866.382 \\
875.189\end{array}$ & $\begin{array}{l}0.000 \\
0.182 \\
0.414 \\
0.589 \\
0.662 \\
0.665 \\
0.746 \\
0.789 \\
0.830 \\
0.881 \\
0.929 \\
0.962 \\
0.998 \\
1.038 \\
1.079 \\
1.104 \\
1.148 \\
1.247 \\
1.272 \\
1.305 \\
1.331 \\
1.381 \\
1.407 \\
1.440 \\
1.465 \\
1.498 \\
1.498 \\
1.524 \\
1.549 \\
1.600 \\
1.666 \\
1.915 \\
2.039 \\
2.171 \\
2.296 \\
2.413 \\
2.430 \\
2.547 \\
2.621\end{array}$ \\
\hline
\end{tabular}


TABLE 3.29. ACCELERATED CREEP CAUSED BY HEATING A SALT MINE PILLAR TO PEAK TEMPERATURE OF $\pm 423 \mathrm{~K}$ (Continued)

\begin{tabular}{|c|c|c|c|}
\hline $\begin{array}{l}\text { Data } \\
\text { Set }\end{array}$ & $\begin{array}{l}\text { Author (s), Year } \\
\text { [Ref.] }\end{array}$ & $t$ & $\Delta \mathrm{L}$ \\
\hline 3 & Baar, C.A., 1977 [17] & $\begin{array}{r}604.794 \\
611.097 \\
624.972 \\
642.635 \\
655.241 \\
666.591 \\
681.736 \\
703.183 \\
718.325 \\
732.200 \\
747.341 \\
758.695 \\
776.364 \\
785.196 \\
802.859 \\
809.152 \\
812.916 \\
822.938 \\
829.214 \\
836.749 \\
843.025 \\
850.573 \\
856.859 \\
865.667 \\
873.209 \\
883.289 \\
894.625 \\
902.177 \\
912.255 \\
926.120 \\
942.500 \\
955.105 \\
967.715 \\
981.576 \\
995.448 \\
1004.273 \\
1013.104 \\
1025.717 \\
1040.848\end{array}$ & $\begin{array}{l}0.010 \\
0.035 \\
0.068 \\
0.101 \\
0.152 \\
0.185 \\
0.203 \\
0.243 \\
0.269 \\
0.302 \\
0.327 \\
0.353 \\
0.370 \\
0.386 \\
0.421 \\
0.469 \\
0.528 \\
0.718 \\
0.810 \\
0.911 \\
1.003 \\
1.069 \\
1.135 \\
1.209 \\
1.292 \\
1.343 \\
1.409 \\
1.468 \\
1.526 \\
1.585 \\
1.668 \\
1.717 \\
1.760 \\
1.826 \\
1.866 \\
1.902 \\
1.917 \\
1.950 \\
2.001\end{array}$ \\
\hline 4 & Baar, C.A., 1977 [17] & $\begin{array}{l}613.639 \\
624.989 \\
627.508 \\
642.652 \\
655.265 \\
667.898 \\
680.504 \\
700.692 \\
718.352\end{array}$ & $\begin{array}{l}0.000 \\
0.027 \\
0.043 \\
0.061 \\
0.094 \\
0.078 \\
0.127 \\
0.160 \\
0.203\end{array}$ \\
\hline
\end{tabular}


TABLE 3.29. ACCELERATED CREEP CAUSED BY HEATING A SALT MINE PILLAR TO PEAK TEMPERATURE OF $\pm 423 \mathrm{~K}$ (Continued)

\begin{tabular}{|c|c|c|c|}
\hline $\begin{array}{l}\text { Data } \\
\text { Set }\end{array}$ & $\begin{array}{l}\text { Author(s), Year } \\
\text { [Ref.] }\end{array}$ & $t$ & $\Delta \mathrm{L}$ \\
\hline $\begin{array}{c}4 \\
(\text { Cont. })^{B}\end{array}$ & Baar, C.A., 1977 [17] & $\begin{array}{r}732.234 \\
744.850 \\
759.991 \\
773.877 \\
785.230 \\
801.634 \\
809.196 \\
814.206 \\
822.959 \\
829.231 \\
836.763 \\
843.042 \\
850.590 \\
858.139 \\
865.677 \\
873.229 \\
884.538 \\
893.346 \\
902.157 \\
912.234 \\
926.092 \\
931.129 \\
942.476 \\
953.822 \\
966.418 \\
980.286 \\
994.151 \\
1002.976 \\
1014.329 \\
1024.417 \\
1039.551\end{array}$ & $\begin{array}{l}0.221 \\
0.243 \\
0.269 \\
0.279 \\
0.304 \\
0.330 \\
0.363 \\
0.462 \\
0.670 \\
0.769 \\
0.876 \\
0.960 \\
1.026 \\
1.094 \\
1.186 \\
1.244 \\
1.376 \\
1.450 \\
1.518 \\
1.577 \\
1.651 \\
1.684 \\
1.727 \\
1.767 \\
1.841 \\
1.892 \\
1.950 \\
1.983 \\
2.009 \\
2.042 \\
2.085\end{array}$ \\
\hline
\end{tabular}




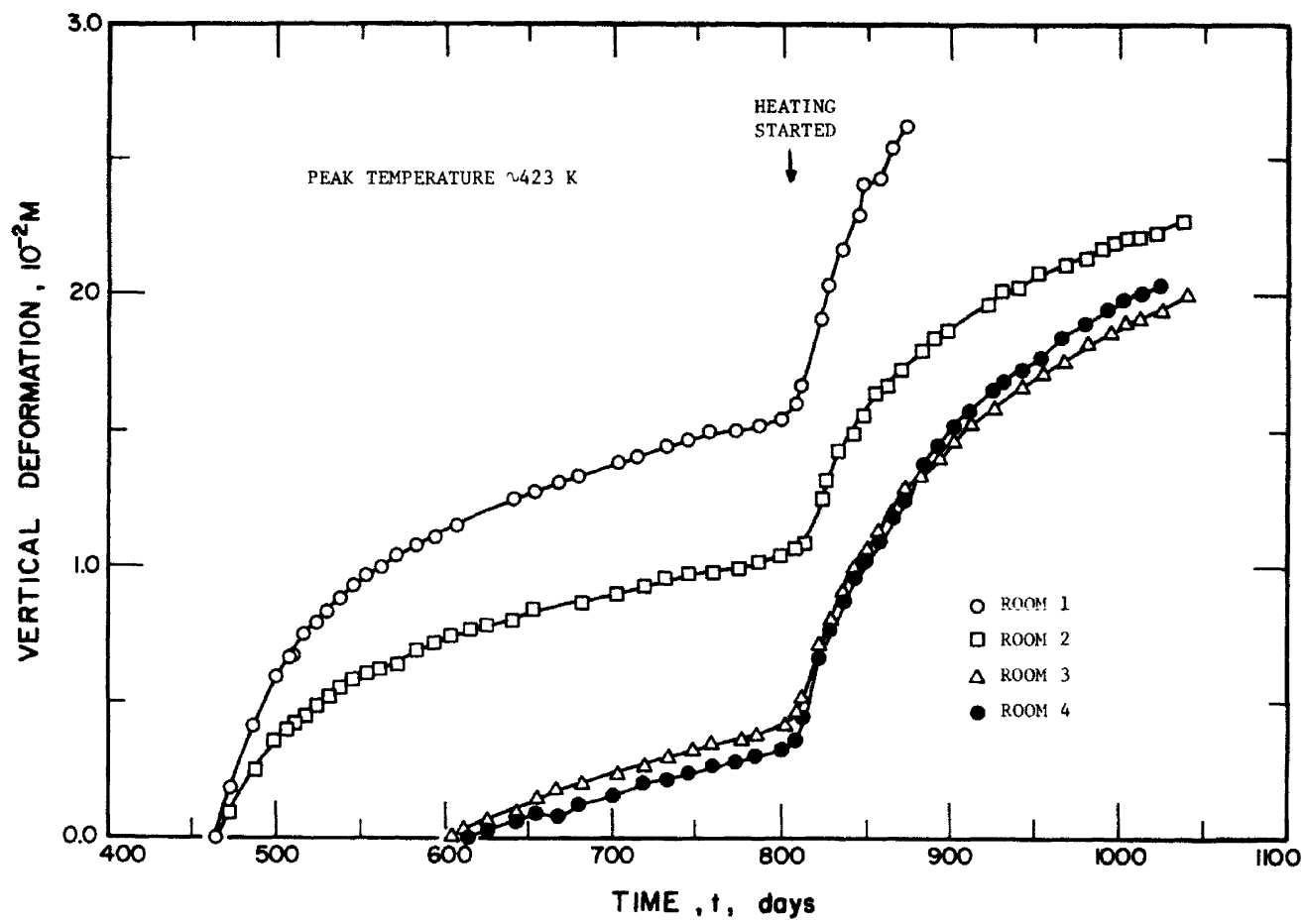

FIGURE 3.30. Accelerated creep caused by heating a salt mine pillar. 
TABLE 3.30. EFFECT OF AXIAL STRESS ON THE CREEP OF ROCK SALT

$$
\text { [Time, } t \text {, hr; Strain, } \varepsilon, \% \text { ] }
$$

\begin{tabular}{|c|c|c|c|c|}
\hline $\begin{array}{l}\text { Data } \\
\text { Set }\end{array}$ & $\begin{array}{c}\text { Author(s), Year } \\
\text { [Ref.] }\end{array}$ & $t$ & $\varepsilon$ & Remarks \\
\hline 1 & LeComte, P., 1965 & $\begin{array}{r}2.548 \\
7.755 \\
15.585 \\
26.033 \\
28.640 \\
35.176 \\
48.247 \\
57.401 \\
73.095 \\
97.949 \\
124.117 \\
143.746 \\
158.139 \\
168.608 \\
194.786 \\
240.595 \\
265.465 \\
292.956 \\
311.282 \\
336.158 \\
362.343 \\
371.506\end{array}$ & $\begin{array}{l}0.643 \\
0.933 \\
1.206 \\
1.496 \\
1.608 \\
1.737 \\
1.994 \\
2.139 \\
2.381 \\
2.703 \\
2.992 \\
3.186 \\
3.347 \\
3.443 \\
3.653 \\
4.023 \\
4.217 \\
4.394 \\
4.523 \\
4.652 \\
4.797 \\
4.862\end{array}$ & $\begin{array}{l}\text { Confining pressure }= \\
100 \mathrm{MPa} ; \\
\text { Temperature }=302 \mathrm{~K} ; \\
\text { Axial stress }=13.8 \\
\mathrm{MPa} .\end{array}$ \\
\hline 2 & LeComte, P., 1965 & [22] $\begin{array}{r}6.438 \\
27.368 \\
37.836 \\
60.077 \\
71.853 \\
83.629 \\
108.496 \\
133.366 \\
141.217 \\
155.618\end{array}$ & $\begin{array}{l}0.997 \\
1.271 \\
1.383 \\
1.641 \\
1.770 \\
1.899 \\
2.108 \\
2.301 \\
2.382 \\
2.462\end{array}$ & $\begin{array}{l}\text { Confining pressure }= \\
100 \mathrm{MPa} ; \\
\text { Temperature }=377.5 \mathrm{~K} \text {; } \\
\text { Axial stress }=6.9 \\
\text { MPa. }\end{array}$ \\
\hline 3 & LeComte, P., 1965 & [22] $\begin{array}{r}5.150 \\
13.008 \\
24.797 \\
32.655 \\
48.376 \\
73.265 \\
96.842 \\
123.043 \\
145.313 \\
171.511 \\
195.090 \\
216.050 \\
238.321 \\
263.208\end{array}$ & $\begin{array}{l}0.804 \\
0.820 \\
0.836 \\
0.853 \\
0.853 \\
0.869 \\
0.902 \\
0.902 \\
0.903 \\
0.935 \\
0.952 \\
0.952 \\
0.953 \\
0.985\end{array}$ & $\begin{array}{l}\text { Confining pressure }= \\
100 \mathrm{MPa} ; \\
\text { Temperature }=377.5 \mathrm{~K} \text {; } \\
\text { Axial stress }=34.5 \\
\text { MPa. }\end{array}$ \\
\hline
\end{tabular}


TABLE 3.30. EFFECT OF AXIAL STRESS ON THE CREEP OF ROCK SALT (Continued)

\begin{tabular}{|c|c|c|c|c|c|}
\hline $\begin{array}{l}\text { Data } \\
\text { Set } \\
\end{array}$ & $\begin{array}{r}\text { Author (s), } \\
\text { [Ref.] }\end{array}$ & Year & $t$ & $\varepsilon$ & Remarks \\
\hline $\begin{array}{c}3 \\
(\text { cont. })\end{array}$ & $\begin{array}{l}\text { LeComte, P., } \\
{[22]}\end{array}$ & 1965 & $\begin{array}{l}293.337 \\
311.676 \\
336.567 \\
364.074 \\
391.583\end{array}$ & $\begin{array}{l}1.002 \\
1.018 \\
1.019 \\
1.051 \\
1.068\end{array}$ & \\
\hline 4 & $\begin{array}{l}\text { LeComte, P., } \\
{[22]}\end{array}$ & 1965 & $\begin{array}{r}6.467 \\
16.944 \\
28.734 \\
49.693 \\
81.132 \\
116.500 \\
150.557 \\
168.898 \\
187.238\end{array}$ & $\begin{array}{l}0.740 \\
0.772 \\
0.772 \\
0.789 \\
0.805 \\
0.838 \\
0.871 \\
0.871 \\
0.871\end{array}$ & $\begin{array}{l}\text { Confining pressure }= \\
100 \mathrm{MPa} ; \\
\text { Temperature }=377 \mathrm{~K} ; \\
\text { Axial stress }=34.5 \\
\text { MPa. }\end{array}$ \\
\hline 5 & $\begin{array}{l}\text { LeComte, P., } \\
\text { [22] }\end{array}$ & 1965 & $\begin{array}{r}10.451 \\
24.855 \\
36.643 \\
49.740 \\
60.219 \\
79.866 \\
104.749 \\
127.014 \\
142.735 \\
151.902 \\
170.242 \\
180.719\end{array}$ & $\begin{array}{l}0.257 \\
0.322 \\
0.338 \\
0.371 \\
0.387 \\
0.419 \\
0.484 \\
0.533 \\
0.533 \\
0.565 \\
0.566 \\
0.598\end{array}$ & $\begin{array}{l}\text { Confining pressure }= \\
100 \mathrm{MPa} ; \\
\text { Temperature }=302 \mathrm{~K} ; \\
\text { Axial stress }=6.9 \\
\mathrm{MPa} \text {. }\end{array}$ \\
\hline
\end{tabular}

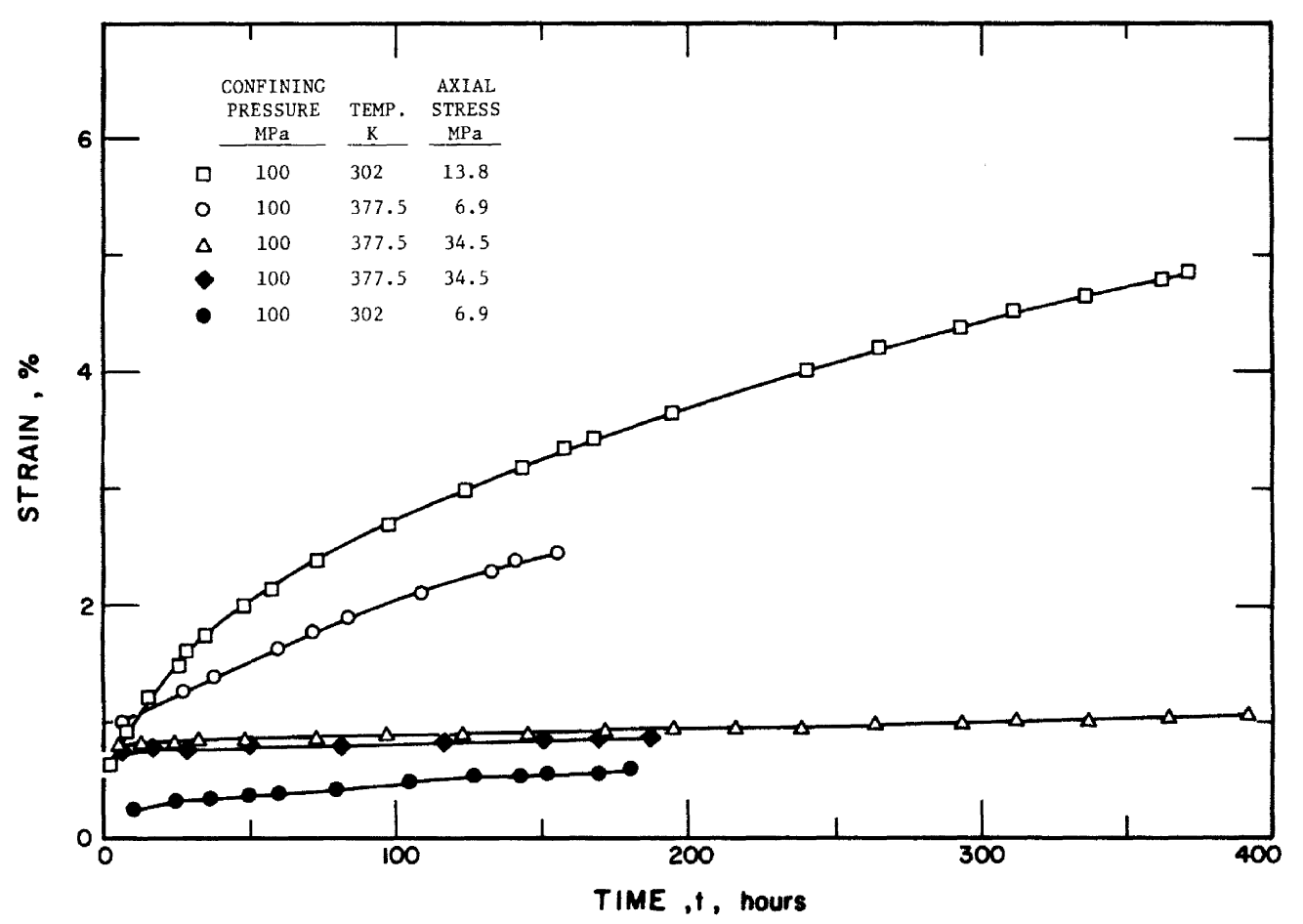

FIGURE 3.31. Effect of axial stress on creep. 
TABLE 3.31. EFFECT OF GRAIN SIZE AND AXIAL STRESS ON THE CREEP OF ROCK SALT

[Time, $t, h r$; Strain, $\varepsilon, \%$ ]

\begin{tabular}{|c|c|c|c|c|}
\hline $\begin{array}{l}\text { Data } \\
\text { Set }\end{array}$ & $\begin{array}{l}\text { Author(s), Year } \\
\text { [Ref.] }\end{array}$ & $t$ & $\varepsilon$ & Remarks \\
\hline 1 & LeComte, P., 1965 & [22] $\begin{array}{r}3.560 \\
8.382 \\
11.603 \\
13.212 \\
26.063 \\
29.263 \\
33.285 \\
36.498 \\
39.715 \\
49.358 \\
51.771 \\
58.209 \\
61.418 \\
73.478 \\
77.504 \\
86.356 \\
110.515 \\
122.597 \\
128.231 \\
135.478 \\
143.526 \\
156.425\end{array}$ & $\begin{array}{l}0.941 \\
1.000 \\
1.026 \\
1.043 \\
1.212 \\
1.279 \\
1.321 \\
1.363 \\
1.397 \\
1.515 \\
1.541 \\
1.600 \\
1.650 \\
1.786 \\
1.819 \\
1.904 \\
2.099 \\
2.192 \\
2.242 \\
2.302 \\
2.378 \\
2.454\end{array}$ & $\begin{array}{l}\text { Confining pressure }= \\
100 \mathrm{MPa} ; \\
\text { Temperature }=377.5 \mathrm{~K} .\end{array}$ \\
\hline 2 & LeComte, P., 1965 & [22] $\begin{array}{r}2.885 \\
3.676 \\
6.081 \\
6.872 \\
10.081 \\
14.089 \\
16.498 \\
26.967 \\
32.605 \\
38.249 \\
51.152 \\
55.178 \\
65.681 \\
74.563 \\
82.645 \\
98.800 \\
106.882 \\
122.232 \\
134.357 \\
146.473 \\
169.102 \\
184.444 \\
195.764\end{array}$ & $\begin{array}{l}0.681 \\
0.714 \\
0.757 \\
0.790 \\
0.841 \\
0.908 \\
0.942 \\
1.027 \\
1.069 \\
1.103 \\
1.171 \\
1.205 \\
1.222 \\
1.248 \\
1.257 \\
1.291 \\
1.300 \\
1.326 \\
1.335 \\
1.361 \\
1.388 \\
1.430 \\
1.431\end{array}$ & $\begin{array}{l}\text { Confining pressure }= \\
100 \mathrm{MPa} ; \\
\text { Temperature }=377.5 \mathrm{~K}\end{array}$ \\
\hline
\end{tabular}


TABLE 3.31. EFFECT OF GRAIN SIZE AND AXIAL STRESS

ON THE CREEP OF ROCK SALT (Continued)

\begin{tabular}{|c|c|c|c|c|}
\hline $\begin{array}{l}\text { Data } \\
\text { Set }\end{array}$ & $\begin{array}{c}\text { Author(s), Year } \\
\text { [Ref.] }\end{array}$ & $t$ & $\varepsilon$ & Remarks \\
\hline $\begin{array}{c}2 \\
(\text { cont. })\end{array}$ & LeComte, P., 1965 [22] & $\begin{array}{l}217.588 \\
246.681 \\
265.279 \\
288.716 \\
311.357 \\
333.986 \\
359.053\end{array}$ & $\begin{array}{l}1.449 \\
1.484 \\
1.485 \\
1.512 \\
1.513 \\
1.540 \\
1.541\end{array}$ & \\
\hline 3 & LeComte, P., 1965 「22〕 & $\begin{array}{r}2.167 \\
3.750 \\
4.537 \\
5.328 \\
7.728 \\
11.750 \\
22.223 \\
26.253 \\
36.735 \\
43.991 \\
51.251 \\
59.303 \\
64.946 \\
76.253 \\
77.862 \\
89.174 \\
98.847 \\
102.077\end{array}$ & $\begin{array}{l}0.504 \\
0.572 \\
0.614 \\
0.647 \\
0.698 \\
0.740 \\
0.816 \\
0.842 \\
0.901 \\
0.944 \\
0.978 \\
1.045 \\
1.079 \\
1.105 \\
1.122 \\
1.139 \\
1.199 \\
1.207\end{array}$ & $\begin{array}{l}\text { Confining pressure }= \\
100 \mathrm{MPa} ; \\
\text { Temperature }=377.5 \mathrm{~K} \\
\text { Axial stress }=6.9 \\
\mathrm{MPa} \text {. }\end{array}$ \\
\hline
\end{tabular}

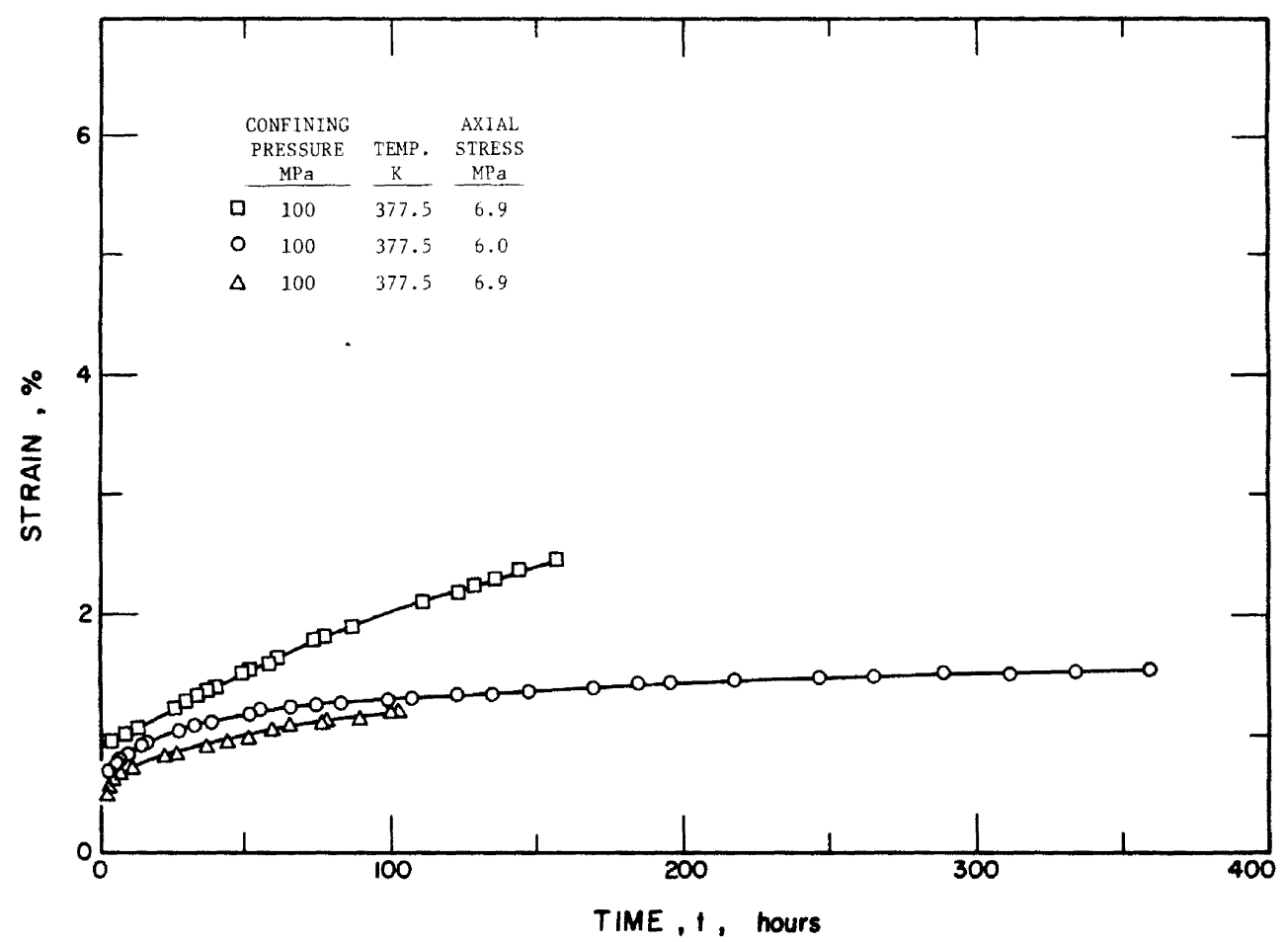

FigurE 3.32. Combined effects of axial stress and grain size on creep rate. 
TABLE 3.32. EFFECT OF STRESS AND TEMPERATURE ON THE STEADY STATE CREEP RATE OF COARSE GRAIN SODIUM CHLORIDE

[Stress, $\sigma, \mathrm{MPa} ;$ Log Steady State Creep Rate, $\log \dot{\varepsilon} s^{-1}$ ]

\begin{tabular}{|c|c|c|c|c|c|}
\hline $\begin{array}{c}\text { Data } \\
\text { Set }\end{array}$ & $\begin{array}{r}\text { Author (s), } \\
{[\operatorname{Ref} .]}\end{array}$ & Year & $\sigma$ & $\log (\dot{\varepsilon}$ & Remarks \\
\hline 1 & $\begin{array}{l}\text { Burke, P.M., } \\
{[19]}\end{array}$ & 1968 & $\begin{array}{l}4.327 \\
8.612\end{array}$ & $\begin{array}{l}-0.611 E+01 \\
-0.475 E+01\end{array}$ & Temperature $=638 \mathrm{~K}$. \\
\hline 2 & $\begin{array}{l}\text { Burke, P.M., } \\
\text { [19] }\end{array}$ & 1968 & $\begin{array}{l}3.066 \\
5.932\end{array}$ & $\begin{array}{l}-0.561 E+01 \\
-0.351 E+01\end{array}$ & Temperature $=722 \mathrm{~K}$ \\
\hline 3 & $\begin{array}{l}\text { Burke, P.M., } \\
\text { [19] }\end{array}$ & 1968 & $\begin{array}{l}2.122 \\
4.237\end{array}$ & $\begin{array}{l}-0.530 E+01 \\
-0.356 E+01\end{array}$ & Temperature $=513 \mathrm{~K}$. \\
\hline 4 & $\begin{array}{l}\text { Burke, P.M., } \\
\text { [19] }\end{array}$ & 1968 & $\begin{array}{l}0.9439 \\
1.860\end{array}$ & $\begin{array}{l}-0.530 E+01 \\
-0.424 E+01\end{array}$ & Temperature $=876 \mathrm{~K}$ \\
\hline 5 & $\begin{array}{l}\text { Burke, P.M., } \\
{[19]}\end{array}$ & 1968 & $\begin{array}{l}0.276 \\
0.406 \\
0.477 \\
0.550 \\
0.806 \\
0.930 \\
0.896\end{array}$ & $\begin{array}{l}-0.539 E+01 \\
-0.494 E+01 \\
-0.519 E+01 \\
-0.457 E+01 \\
-0.411 E+01 \\
-0.356 E+01 \\
-0.336 E+01\end{array}$ & Temperature $=1015 \mathrm{~K}$. \\
\hline
\end{tabular}

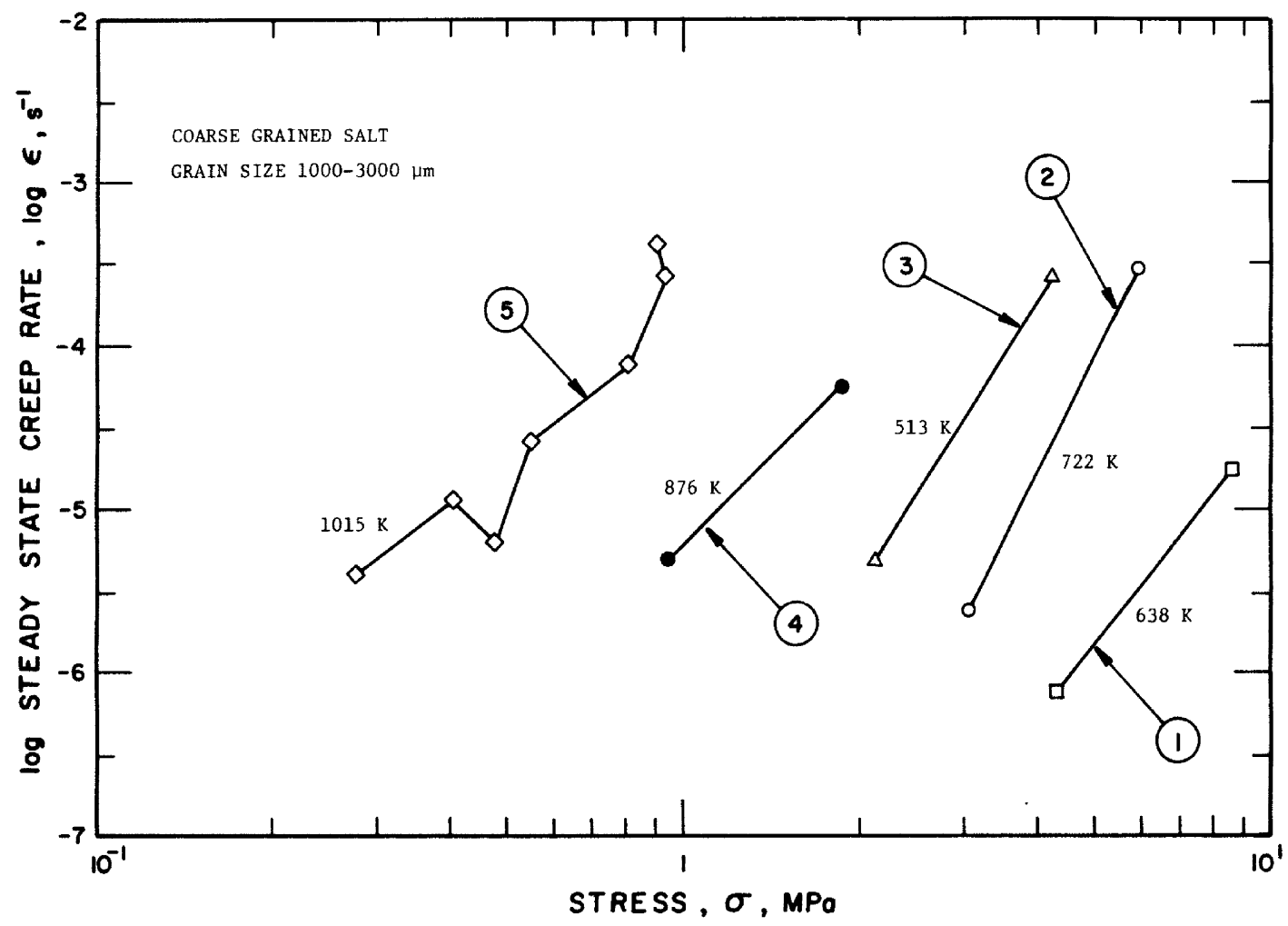

FIGURE 3.33. Effect of stress and temperature on the steady state creep rate of coarse grained $\mathrm{NaCl}$ (curve numbers correspond to data set numbers in matching table). 
TABLE 3.33. STEADY-STATE CREEP RATE OF SINGLE CRYSTAL AND POLYCRYSTALLINE SODIUN CHLORIDE AS A FUNCTION OF STRESS AT $1013 \mathrm{~K}$

$$
\text { [Stress, } \sigma, \mathrm{MPa} \text {; Creep Rate, } \dot{\varepsilon}, \mathrm{s}^{-1}
$$

\begin{tabular}{|c|c|c|c|c|}
\hline $\begin{array}{l}\text { Data } \\
\text { Set. }\end{array}$ & $\begin{array}{r}\text { Author (s), } \\
\text { [Ref.] }\end{array}$ & Year & $\sigma$ & $\dot{\varepsilon}$ \\
\hline 1 & $\begin{array}{l}\text { Burke, P.M., } \\
{[19]}\end{array}$ & 1968 & $\begin{array}{l}0.688 \\
0.999\end{array}$ & $\begin{array}{l}0.662 \mathrm{E}-03 \\
0.209 \mathrm{E}-02\end{array}$ \\
\hline 2 & $\begin{array}{l}\text { Burke, P.M., } \\
{[19]}\end{array}$ & 1968 & $\begin{array}{l}0.499 \\
2.391\end{array}$ & $\begin{array}{l}0.928 \mathrm{E}-05 \\
0.526 \mathrm{E}-02\end{array}$ \\
\hline 3 & $\begin{array}{l}\text { Burke, P.M., } \\
{[19]}\end{array}$ & 1968 & $\begin{array}{l}0.606 \\
1.02\end{array}$ & $\begin{array}{l}0.313 \mathrm{E}-04 \\
0.232 \mathrm{E}-03\end{array}$ \\
\hline 4 & $\begin{array}{l}\text { Burke, P.M., } \\
\text { [19] }\end{array}$ & 1968 & $\begin{array}{l}0.599 \\
0.656 \\
0.717 \\
0.799 \\
0.841\end{array}$ & $\begin{array}{l}0.396 \mathrm{E}-05 \\
0.482 \mathrm{E}-05 \\
0.515 \mathrm{E}-05 \\
0.607 \mathrm{E}-05 \\
0.627 \mathrm{E}-05\end{array}$ \\
\hline 5 & $\begin{array}{l}\text { Burke, P.M., } \\
{[19]}\end{array}$ & 1968 & $\begin{array}{l}0.046 \\
0.104 \\
1.033\end{array}$ & $\begin{array}{l}0.198 \mathrm{E}-07 \\
0.363 \mathrm{E}-03 \\
0.326 \mathrm{E}-03\end{array}$ \\
\hline 6 & $\begin{array}{l}\text { Burke, P.M., } \\
{[19]}\end{array}$ & 1968 & $\begin{array}{l}0.104 \\
0.296\end{array}$ & $\begin{array}{l}0.363 \mathrm{E}-03 \\
0.306 \mathrm{E}-05\end{array}$ \\
\hline
\end{tabular}




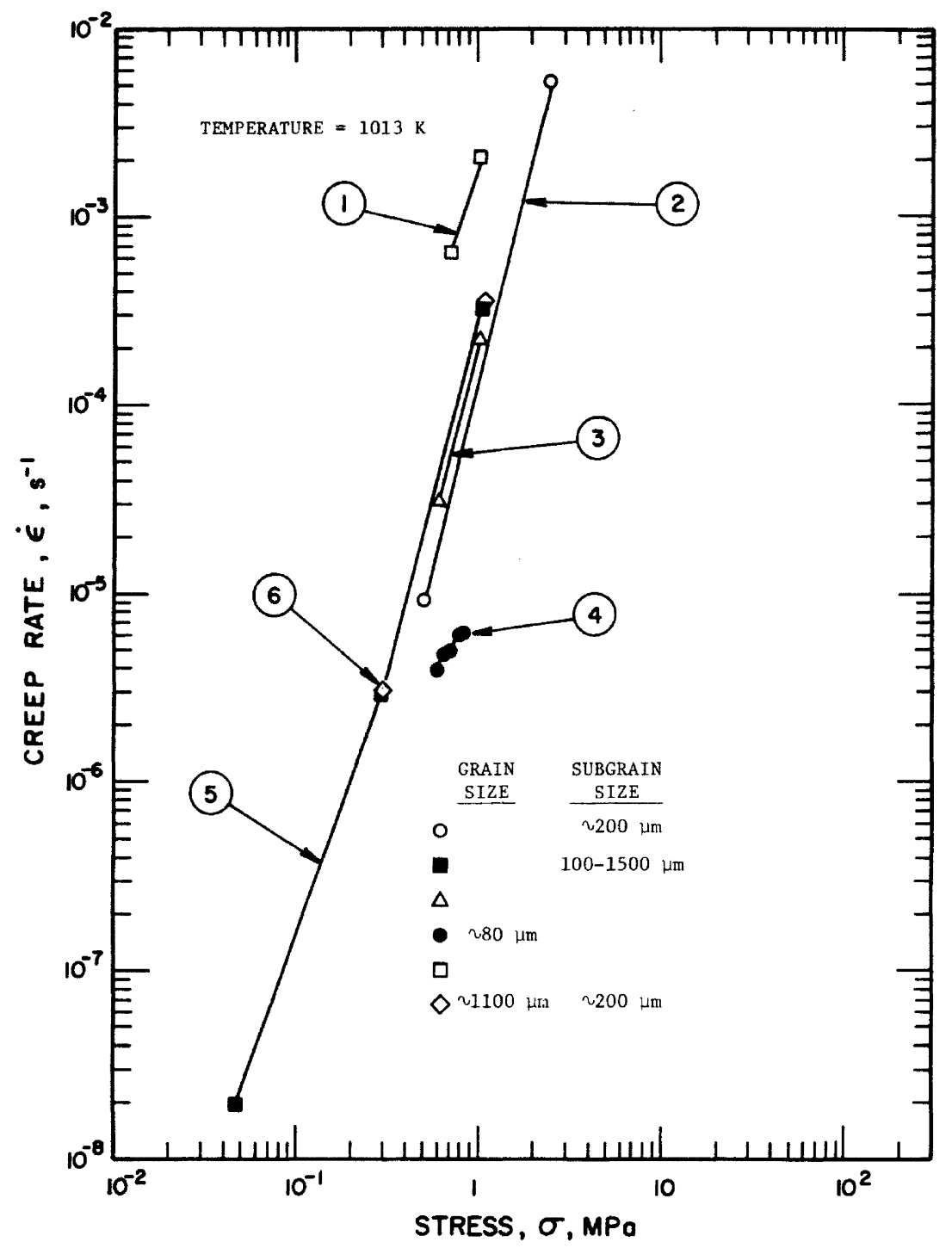

FIGURE 3.34. Steady state creep rate single crystal and polycrystalline $\mathrm{NaCl}$ as a function of stress at $1013 \mathrm{~K}$ (curve numbers correspond to data set numbers in matching table). 
TABLE 3.34. STEADY STATE CREEP RATE OF NaCl VERSUS TEPERATURE AT VARIOUS STRESSES

[Temperature, T, K; Creep Rate, $\dot{\varepsilon}, \mathrm{min}^{-1}$ ]

\begin{tabular}{|c|c|c|c|c|}
\hline $\begin{array}{l}\text { Data } \\
\text { Set } \\
\end{array}$ & $\begin{array}{c}\text { Author(s), Year } \\
\text { [Ref.] }\end{array}$ & $\mathrm{T}$ & $\dot{\varepsilon}$ & Remarks \\
\hline 1 & Ode, H., 1968 [24] & $\begin{array}{r}900 \\
917 \\
999 \\
1004\end{array}$ & $\begin{array}{l}0.163 \mathrm{E}-03 \\
0.754 \mathrm{E}-03 \\
0.142 \mathrm{E}-01 \\
0.183 \mathrm{E}-01\end{array}$ & $\begin{array}{l}\sigma=0.59 \mathrm{MPa} \text { load } \\
\text { stress. }\end{array}$ \\
\hline 2 & Ode, н., 1968 [24] & $\begin{array}{r}907 \\
937 \\
1014 \\
1057\end{array}$ & $\begin{array}{l}0.178 \mathrm{E}-03 \\
0.637 \mathrm{E}-03 \\
0.113 \mathrm{E}-01 \\
0.133 \mathrm{E}-01\end{array}$ & $\begin{array}{l}\sigma=0.78 \mathrm{MPa} \text { load } \\
\text { stress. }\end{array}$ \\
\hline 3 & Ode, H., 1968 [24] & $\begin{array}{r}937 \\
943 \\
984 \\
1024 \\
1032 \\
1029\end{array}$ & $\begin{array}{l}0.194 \mathrm{E}-03 \\
0.344 \mathrm{E}-03 \\
0.113 \mathrm{E}-02 \\
0.608 \mathrm{E}-02 \\
0.873 \mathrm{E}-02 \\
0.970 \mathrm{E}-02\end{array}$ & $\begin{array}{l}\sigma=0.98 \mathrm{MPa} \text { load } \\
\text { stress. }\end{array}$ \\
\hline
\end{tabular}

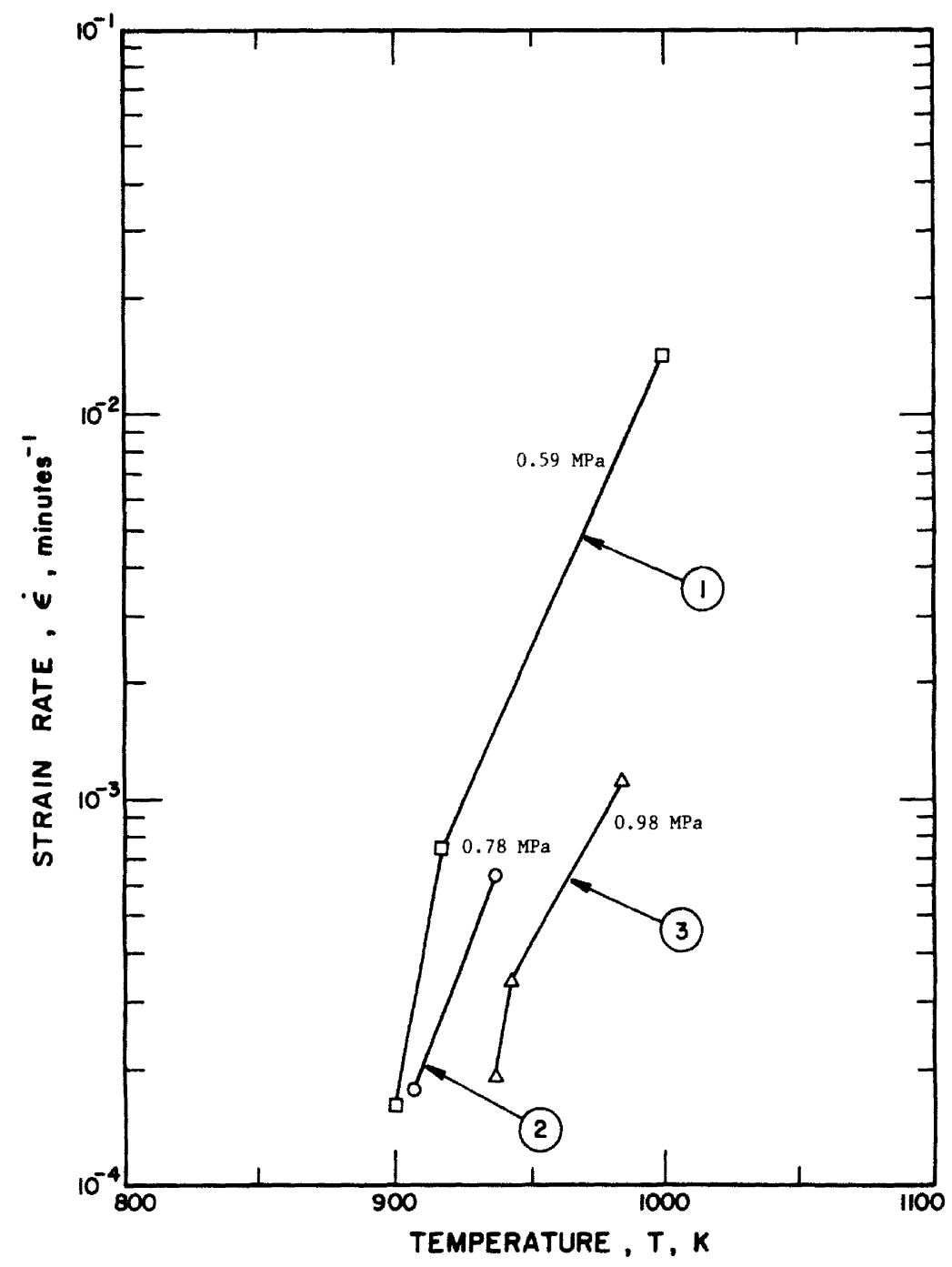

FIGURE 3.35. Relationship of steady state creep rate of $\mathrm{NaCl}$ with temperature at various stresses (curve numbers correspond to data set numbers in matching table). 
TABLE 3.35. TIME-STRAIN DATA OF HALITIC ROCK SALT AT VARIOUS CONFINING PRESSURES AND TEMPERATURES [Time, $t$, hrs; Strain, $\varepsilon, \%$ ]

\begin{tabular}{|c|c|c|c|c|}
\hline $\begin{array}{l}\text { Data } \\
\text { Set }\end{array}$ & Author(s), Year [Ref.] & $t$ & $\varepsilon$ & Remarks \\
\hline 1 & Dreyer, W., 1972 [12] & $\begin{array}{r}1.83 \\
8.84 \\
19.74 \\
29.37 \\
66.67 \\
84.70 \\
96.93\end{array}$ & $\begin{array}{l}13.34 \\
24.93 \\
33.38 \\
38.67 \\
53.84 \\
58.79 \\
62.33\end{array}$ & $\begin{array}{l}\text { Artificial rock sample; confining pressure } \\
0 \mathrm{MPa} \text {; temperature } 377.65 \mathrm{~K} \text {. }\end{array}$ \\
\hline 2 & Dreyer, w., 1972 [12] & $\begin{array}{r}9.48 \\
21.65 \\
40.28 \\
67.93 \\
90.43\end{array}$ & $\begin{array}{l}24.93 \\
36.19 \\
46.06 \\
58.40 \\
68.28\end{array}$ & $\begin{array}{l}\text { Artificial rock sample; confining pressure } \\
1088 \mathrm{MPa} \text {; temperature } 471.35 \mathrm{~K} \text {. }\end{array}$ \\
\hline 3 & Dreyer, W., 1972 [12] & $\begin{array}{r}6.36 \\
25.70 \\
54.06 \\
83.72 \\
121.12\end{array}$ & $\begin{array}{l}11.59 \\
13.74 \\
16.62 \\
19.49 \\
22.39\end{array}$ & $\begin{array}{l}\text { Artificial rock sample; confining pressure } \\
1088 \mathrm{MPa} \text {; temperature } 377.65 \mathrm{~K} \text {. }\end{array}$ \\
\hline 4 & Dreyer, W., 1972 [12] & $\begin{array}{r}27.71 \\
53.51 \\
81.90 \\
105.12 \\
123.82 \\
150.27\end{array}$ & $\begin{array}{l}3.57 \\
4.69 \\
5.45 \\
5.86 \\
6.25 \\
7.00\end{array}$ & $\begin{array}{l}\text { Artificial rock salt sample; confining pres- } \\
\text { sure } 0 \mathrm{MPa} \text {; temperature } 302.15 \mathrm{~K} \text {. }\end{array}$ \\
\hline 5 & Dreyer, W., 1972 [12] & $\begin{array}{r}6.42 \\
23.85 \\
36.10 \\
56.75 \\
78.69 \\
118.68 \\
141.91 \\
166.41 \\
183.19\end{array}$ & $\begin{array}{l}3.52 \\
2.51 \\
2.89 \\
2.59 \\
2.99 \\
4.14 \\
3.84 \\
4.95 \\
4.64\end{array}$ & $\begin{array}{l}\text { Artificial rock salt sample; confining pres- } \\
\text { sure } 212 \mathrm{MPa} \text {; temperature } 302.15 \mathrm{~K} \text {. }\end{array}$ \\
\hline 6 & Dreyer, W., 1972 [12] & $\begin{array}{r}6.42 \\
23.21 \\
36.11 \\
56.75 \\
78.69 \\
100.62 \\
125.13 \\
150.29 \\
167.07 \\
175.46 \\
183.20\end{array}$ & $\begin{array}{l}3.52 \\
2.51 \\
2.89 \\
2.94 \\
2.99 \\
3.74 \\
3.80 \\
4.21 \\
3.20 \\
3.57 \\
3.58\end{array}$ & $\begin{array}{l}\text { Artificial rock salt sample; confining pres- } \\
\text { sure } 1088 \mathrm{MPa} \text {; temperature } 302.15 \mathrm{~K} \text {. }\end{array}$ \\
\hline
\end{tabular}




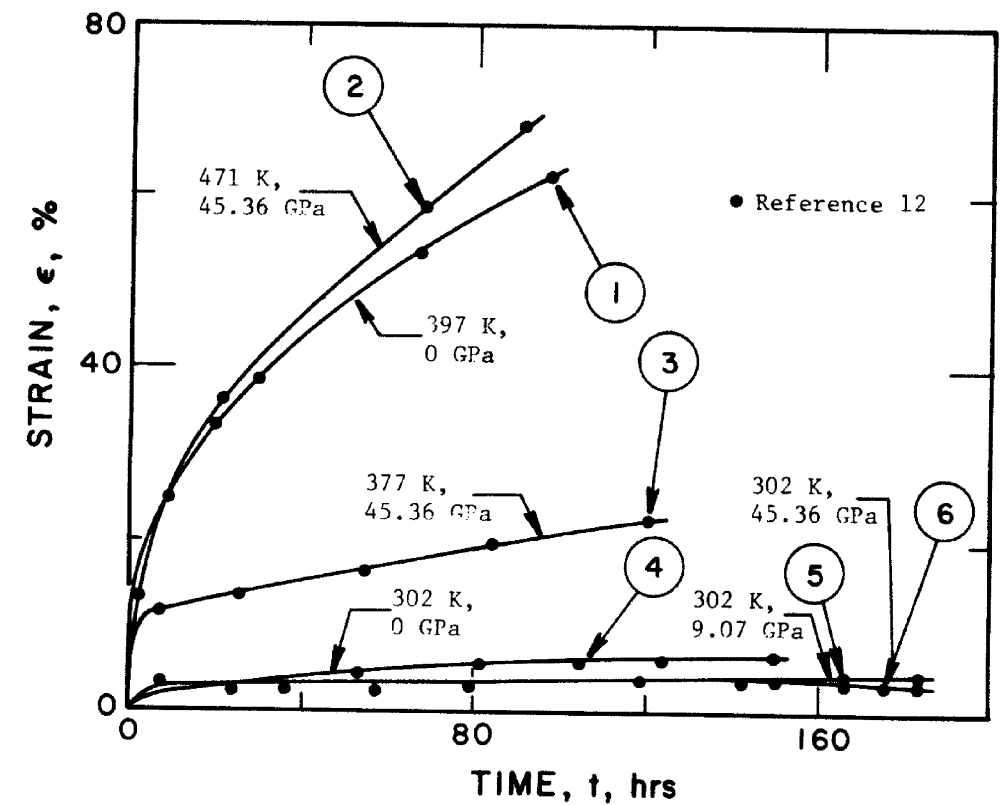

FIGURE 3.36. Time-strain relationship for halitic rock salt (curve numbers correspond to data numbers in matching table). 
TABLE 3.36. TIME-STRAIN RELATIONSHIP OF TEMPERED AND UNTEMPERED ROCK SALT AT 106 MPa AND $298 \mathrm{~K}$

[Time, $t$, days; Strain, $\varepsilon, \%$ ]

\begin{tabular}{|c|c|c|c|c|}
\hline $\begin{array}{l}\text { Data } \\
\text { Set }\end{array}$ & Author(s), Year [Ref.] & $t$ & $\varepsilon$ & Remarks \\
\hline 1 & Dreyer, W., 1972 [12] & $\begin{array}{r}0.25 \\
0.50 \\
0.75 \\
1 \\
2 \\
3 \\
4 \\
5 \\
6 \\
7 \\
8 \\
9 \\
10 \\
11 \\
12 \\
13 \\
14 \\
15 \\
16 \\
17 \\
18 \\
28 \\
56 \\
84 \\
112 \\
140 \\
168\end{array}$ & $\begin{array}{r}86 \\
102 \\
112 \\
119 \\
144 \\
161 \\
173 \\
182 \\
188 \\
193 \\
198 \\
203 \\
208 \\
213 \\
217 \\
221 \\
224 \\
228 \\
232 \\
235 \\
238 \\
264 \\
307 \\
324 \\
335 \\
342 \\
348\end{array}$ & $\begin{array}{l}\text { Square prisms }(4 \times 4 \times 10 \mathrm{~cm}) \text { of white rock } \\
\text { salt containing a1ternating layers of fine } \\
\text { and coarse grained material separated by thin } \\
\text { argillaceous bands of anhydrite; untempered; } \\
\text { constant stress of } 106 \mathrm{MPa} \text {; temperature } 291 \mathrm{~K} \text {. }\end{array}$ \\
\hline 2 & Dreyer, W., 1972 [12] & $\begin{array}{r}1 \\
2 \\
3 \\
4 \\
5 \\
6 \\
7 \\
8 \\
9 \\
10 \\
11 \\
12 \\
13 \\
14 \\
15 \\
16 \\
17 \\
18 \\
19 \\
20 \\
22 \\
24 \\
26 \\
28\end{array}$ & $\begin{array}{l}359 \\
363 \\
366 \\
368 \\
369 \\
369 \\
369 \\
369 \\
370 \\
370 \\
370 \\
370 \\
370 \\
370 \\
370 \\
370 \\
370 \\
371 \\
371 \\
371 \\
371 \\
371 \\
371 \\
371\end{array}$ & $\begin{array}{l}\text { Tempered; sample and testing conditions same } \\
\text { as above. }\end{array}$ \\
\hline
\end{tabular}


TIME, $\uparrow$, days (TEMPERED)

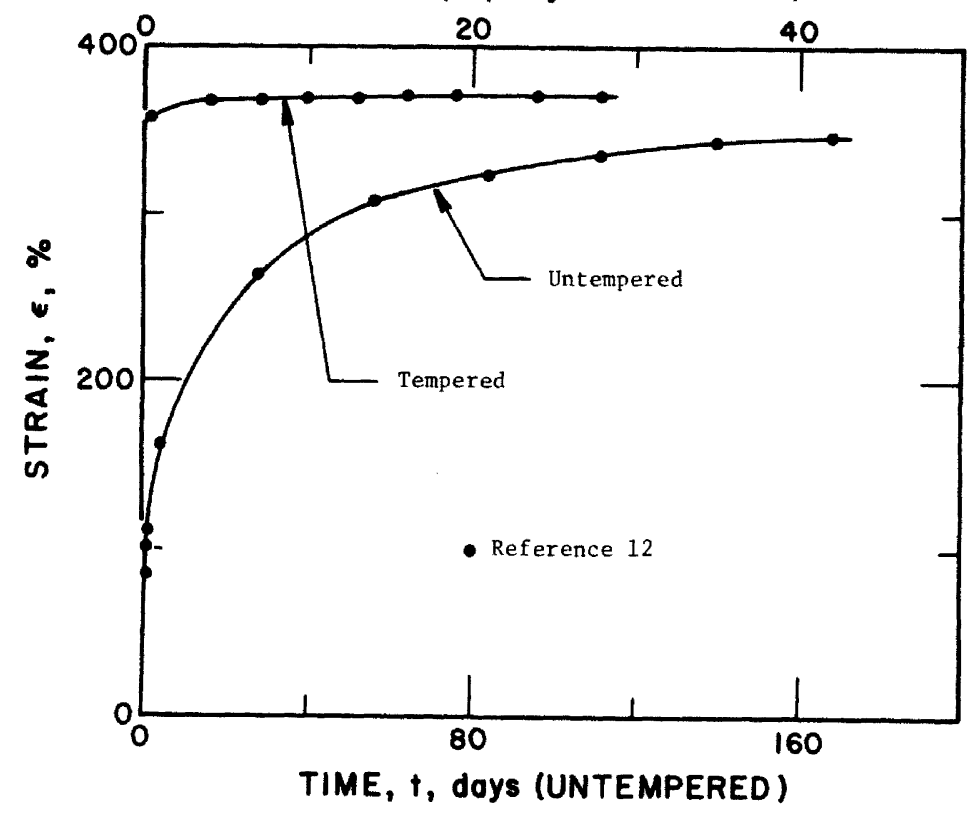

FIGURE 3.37 Time-strain relationship for tempered and untempered rock salt (curve numbers correspond to data set numbers in matching table).

TABLE 3.37. RELATIONSHIP OF MICROHARDNESS TO INDENTATION DEPTH OF ROCK SALT [Indentation Depth, h, $\mu \mathrm{m}$; Microhardness, $\mathrm{H}, \mathrm{kg} \mathrm{mm}^{-2}$; Load, P, $\mathrm{g}$ ]

\begin{tabular}{|c|c|c|c|c|}
\hline $\begin{array}{c}\text { Data } \\
\text { Set }\end{array}$ & Author (s), Year [Ref.] & $\mathrm{h}$ & $\mathrm{H}$ & Remarks \\
\hline 1 & $\begin{array}{l}\text { Strelkov, P.G., Shpunt, } \\
\text { A.A., and Nabutovskaya, } \\
\text { O.A., } 1967 \text { [15] }\end{array}$ & $\begin{array}{r}1.31 \\
1.65 \\
2.06 \\
3.16 \\
4.54 \\
6.26 \\
9.70 \\
13.70 \\
19.70\end{array}$ & $\begin{array}{l}10.25 \\
17.07 \\
18.89 \\
20.50 \\
20.51 \\
20.54 \\
20.33 \\
20.35 \\
20.15\end{array}$ & $\begin{array}{l}\mathrm{NaCl} \text { specimen; plastic deformation }(\varepsilon) \approx 0 \\
\text { dry air with atmospheric humidity }(B) \leq 30 \%\end{array}$ \\
\hline 2 & $\begin{array}{l}\text { Strelkov, P.G., et a1., } \\
1967 \text { [15] }\end{array}$ & $\begin{array}{l}1.44 \\
1.85 \\
2.88 \\
4.54\end{array}$ & $\begin{array}{l}20.02 \\
21.84 \\
22.77 \\
20.51\end{array}$ & $\begin{array}{l}\text { Deformed specimen of } \mathrm{NaCl} \text {; dry atmosphere; } \\
\text { plastic deformation }(\varepsilon) \geq 0.3-0.4 \% \text {. }\end{array}$ \\
\hline 3 & $\begin{array}{l}\text { Strelkov, P.G., et a1., } \\
1967 \text { [15] }\end{array}$ & $\begin{array}{l}0.58 \\
0.73 \\
1.22 \\
1.63 \\
2.05 \\
2.46 \\
2.74 \\
3.57 \\
3.85 \\
4.12 \\
6.26\end{array}$ & $\begin{array}{l}43.42 \\
37.28 \\
30.47 \\
29.11 \\
27.75 \\
26.85 \\
26.17 \\
23.91 \\
23.23 \\
22.78 \\
20.54\end{array}$ & $\mathrm{NaCl}$; plastic deformation $(\varepsilon) \approx 0$; molst air. \\
\hline
\end{tabular}




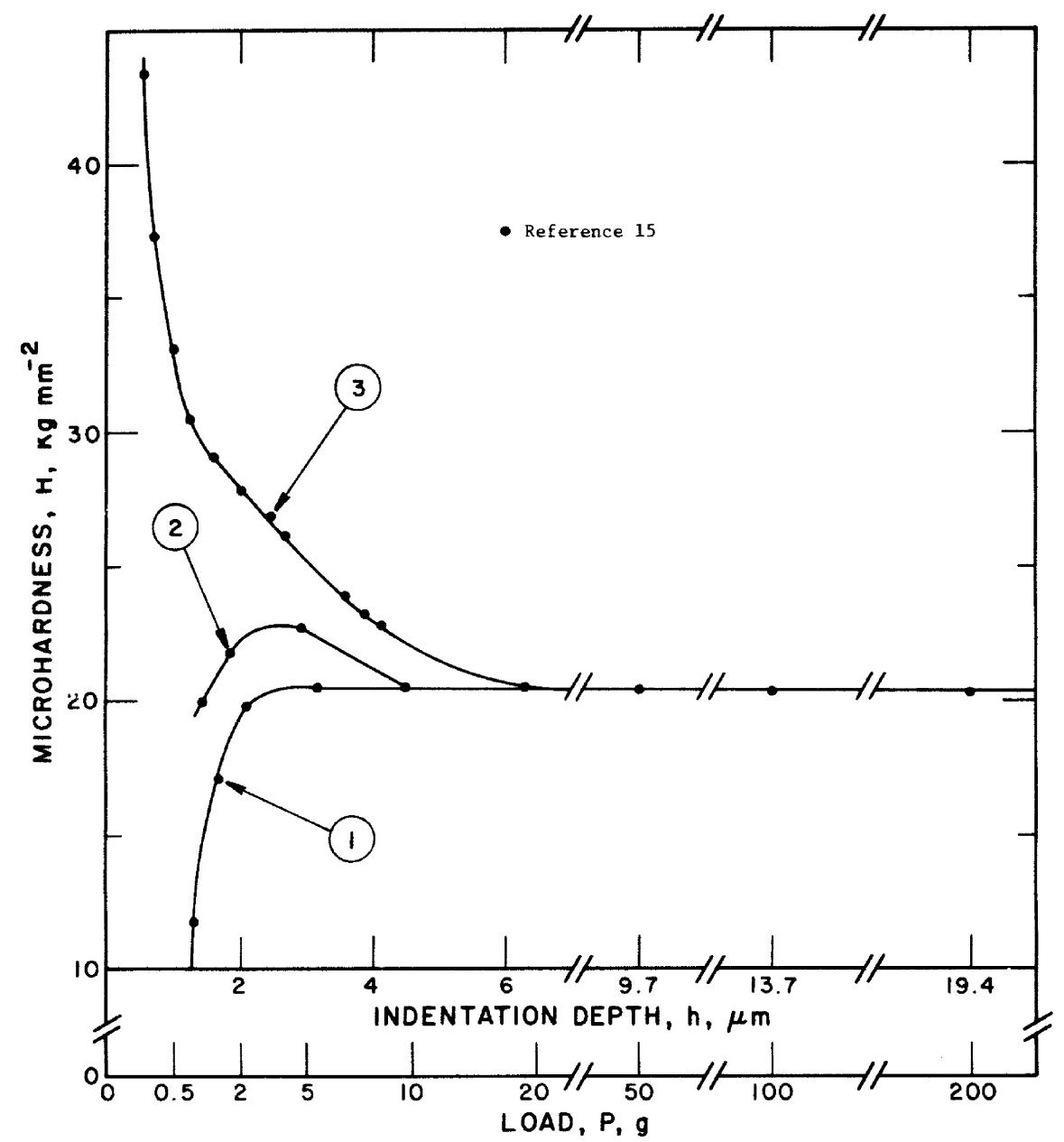

FIGURE 3.38. Relationship of microhardness to indentation depth of rock salt (curve numbers correspond to data set numbers in matching table).

the change in microhardness $\mathrm{H}$ of $\mathrm{NaCl}$ samples of nominal purity $\left(\mathrm{Ca}^{2+} 10^{-3}-10^{-2}\right.$ mole \%) in relation to the quench temperature $T$. The curve exhibits maxima and minima attributable to the presence of impurities in the crystals. At temperatures greater than $873 \mathrm{~K}$ $\left(600^{\circ} \mathrm{C}\right)$ the microhardness increases without any deviations. On reducing the quenching rate, the microhardness of the samples diminishes and so does the difference between maximum and minimum values.

Figure 3.40 shows the quench temperature depend. ence of microhardness of $\mathrm{NaCl}$ crystals containing impurities. These data are also from reference [14] and tabulated in table 3.39. For the purest material no maxima and minima appear, even for very high cooling rates as indicated by curve 1 . It can be seen from this figure that for a quench temperature of over $873 \mathrm{~K}$ $\left(600^{\circ} \mathrm{C}\right)$, the microhardness gradually increases, independently of the impurity content, and approaches a constant value on quenching from about the melting point of the crystal.

\subsection{Surface Effects}

\subsubsection{Joffé Effect}

The Joffé effect is the only surface effect considered here. The Joffé effect is attributed to microfractures in the surface of the crystals. If surface microfractures are removed either by etching or the chemical polishing process, the ductility of a crystal is increased significantly. Cleaved crystals are known to fracture after about $2 \%$ elongation, while the maximum elongation for polished crystals was $20 \%$. Crystals that were tested in solvent show even higher ductility.

The behavior of single halite crystals is strongly influenced by the surface preparation of the crystal itself prior to loading and consequent deformation. It is thought that microfractures on the surface of crystals cause brittleness. If these microfractures are removed by either polishing or etching, the ductility of the crystal increases significantly. 
TABLE 3.38. QUENCH TEMPERATURE DEPENDENCE OF MICROHARDNESS OF ROCK SALT [Quench Temperature, T, K; Microhardness, $\mathrm{H}, \mathrm{kg} \mathrm{m} \mathrm{m}^{-2}$ ]

\begin{tabular}{|c|c|c|c|c|}
\hline $\begin{array}{c}\text { Data } \\
\text { Set }\end{array}$ & Author (s), Year [Ref.] & $\mathrm{T}$ & H & Remarks \\
\hline 1 & $\begin{array}{l}\text { Kishsh, I. and Sharkezi, } \\
\text { I., } 1971 \text { [14] }\end{array}$ & $\begin{array}{r}306.0 \\
379.5 \\
429.7 \\
483.9 \\
530.1 \\
584.2 \\
630.9 \\
681.4 \\
735.5 \\
785.6 \\
839.8 \\
890.2 \\
940.3 \\
990.4 \\
1040.6\end{array}$ & $\begin{array}{l}21.58 \\
22.02 \\
22.59 \\
22.59 \\
23.52 \\
24.45 \\
22.96 \\
21.97 \\
22.68 \\
23.89 \\
23.76 \\
23.33 \\
24.19 \\
25.68 \\
26.11\end{array}$ & $\begin{array}{l}2 \times 2 \times 6 \mathrm{~mm} \mathrm{NaCl} \text { crystals preliminarily } \\
\text { annealed at } 923 \mathrm{~K} \text { and then cooled at } 2 \mathrm{deg} / \\
\mathrm{h} \text {; both slow and fast quenching used; Zeiss } \\
\text { Model } 32 \text { used for microhardness determina- } \\
\text { tion with an indentor load of } 4 \mathrm{~g} ; 30-40 \\
\text { impressions used for hardness estimation. }\end{array}$ \\
\hline
\end{tabular}

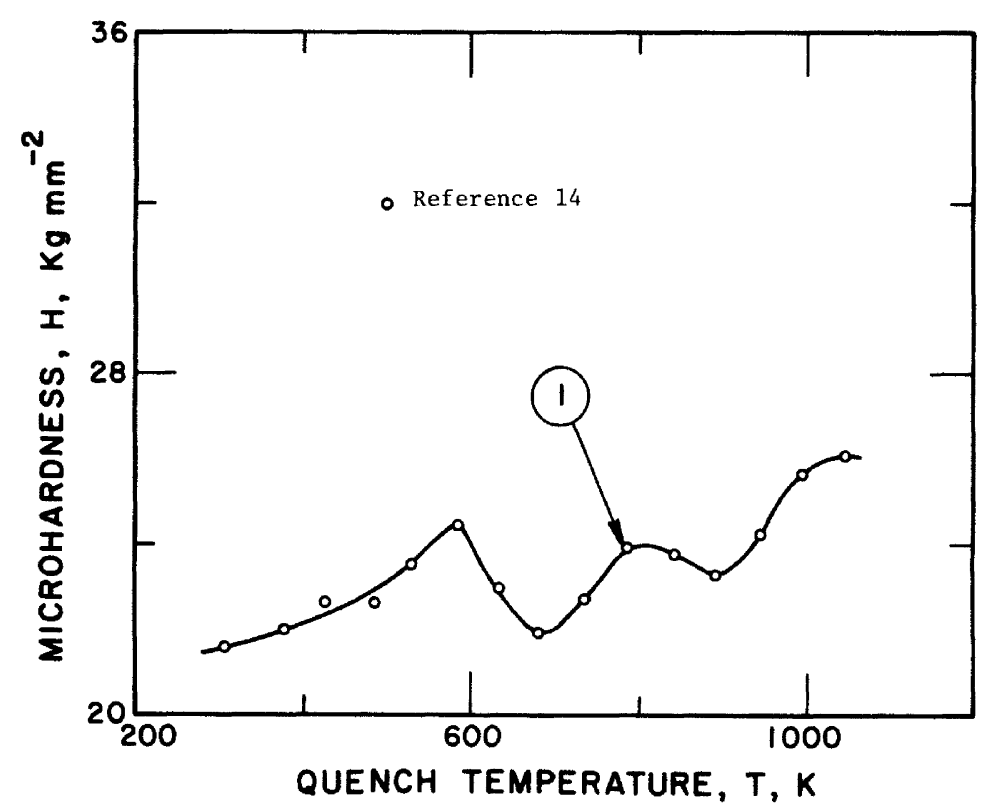

FIGURE 3.39. Dependence of microhardness on quench temperature of rock salt (curve numbers correspond to data set numbers in matching table). 
TABLE 3.39. QUENCH TEMPERATURE DEPENDENCE OF MICROHARDNESS OF ROCK SALT CRYSTALS CONTAINING IMPURITIES

[Quench Temperature, $\mathrm{T}, \mathrm{K}$; Microhardness, $\mathrm{H}, \mathrm{kg} \mathrm{m}^{-2}$ ]

\begin{tabular}{|c|c|c|c|c|}
\hline $\begin{array}{l}\text { Data } \\
\text { Set }\end{array}$ & Author(s), Year [Ref.] & $\mathrm{T}$ & $\mathrm{H}$ & Remarks \\
\hline 1 & $\begin{array}{l}\text { Kishsh, I. and Sharkezi, } \\
\text { I., } 1971 \text { [14] }\end{array}$ & $\begin{array}{r}298.2 \\
374.6 \\
441.6 \\
527.4 \\
578.4 \\
629.3 \\
670.0 \\
731.1 \\
776.9 \\
833.0 \\
934.3 \\
984.9 \\
1035.6\end{array}$ & $\begin{array}{l}21.75 \\
21.80 \\
21.91 \\
21.97 \\
22.02 \\
22.07 \\
22.13 \\
22.23 \\
22.28 \\
22.68 \\
23.28 \\
23.89 \\
24.50\end{array}$ & $\begin{array}{l}\text { Sample and testing conditions same as those } \\
\text { of Table } 3.17 \text {; impurity introduced but total } \\
\text { impurity is under } 10^{-7} \text { mole } \% \text {. }\end{array}$ \\
\hline 2 & $\begin{array}{l}\text { Kishsh, I. and Sharkezi, } \\
\text { I., } 1971 \text { [14] }\end{array}$ & $\begin{array}{r}303.1 \\
374.3 \\
471.0 \\
526.9 \\
577.9 \\
629.0 \\
675.0 \\
725.6 \\
776.1 \\
832.3 \\
883.3 \\
934.0 \\
984.7 \\
1035.5\end{array}$ & $\begin{array}{l}22.20 \\
22.30 \\
22.56 \\
22.76 \\
22.87 \\
22.52 \\
22.27 \\
22.97 \\
23.73 \\
23.53 \\
23.43 \\
23.83 \\
24.24 \\
24.59\end{array}$ & Sample same as above; $\mathrm{Ca}^{2+} 10^{-5}$ mole $\%$. \\
\hline 3 & $\begin{array}{l}\text { Kishsh, I. and Sharkezi, } \\
\text { I., } 1971 \text { [14] }\end{array}$ & $\begin{array}{r}302.8 \\
374.0 \\
480.5 \\
531.0 \\
576.8 \\
628.3 \\
669.8 \\
730.4 \\
781.0 \\
832.1 \\
883.2 \\
933.9 \\
989.8 \\
1035.4\end{array}$ & $\begin{array}{l}22.65 \\
22.96 \\
23.76 \\
24.36 \\
24.82 \\
23.72 \\
22.47 \\
23.37 \\
24.03 \\
23.88 \\
23.63 \\
24.03 \\
24.39\end{array}$ & Sample same as above; $\mathrm{Ca}^{2+} 10^{-3}-10^{-2}$ mole $\%$. \\
\hline 4 & $\begin{array}{l}\text { Kishsh, I. and Sharkezi, } \\
\text { I., } 1971 \text { [14] }\end{array}$ & $\begin{array}{r}302.7 \\
378.9 \\
480.3 \\
530.9 \\
576.5 \\
628.0 \\
679.8 \\
725.0 \\
785.4 \\
831.5 \\
882.9 \\
933.7 \\
989.6 \\
1035.3\end{array}$ & $\begin{array}{l}22.85 \\
23.26 \\
24.16 \\
24.81 \\
25.32 \\
24.37 \\
22.77 \\
23.97 \\
25.33 \\
24.83 \\
24.18 \\
24.44 \\
24.74 \\
24.89\end{array}$ & $\begin{array}{l}\text { Sample same as above; } \mathrm{Ag}^{+} 10^{-1} \text { mole } \%+\mathrm{Ca}^{+2} \\
10^{-3} \text { mole } \% \text {. }\end{array}$ \\
\hline
\end{tabular}




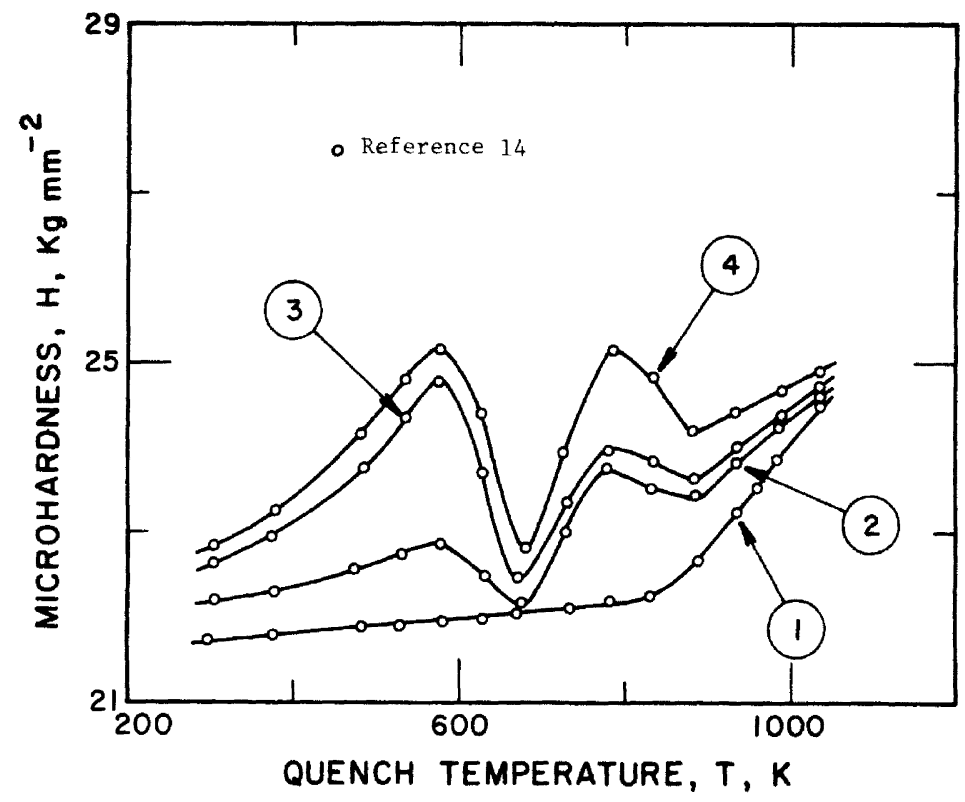

FIGURE 3.40. Dependence of microhardness on quench temperature of impure rock salt crystals (curve numbers correspond to data set numbers in matching table).

Stokes, Johnston, and Li [3] have studied the Joffé effect on $\mathrm{NaCl}$ crystals. Their data are tabulated in table 3.40 and shown in figure 3.41. A plot of the resolved shear stress versus percent strain is given for differently prepared single $\mathrm{NaCl}$ crystals. Curves for the following conditions are presented:

1. Fresh cleaved crystal.

2. Polished crystal deliberately "painted" and showing a stain.

3. Polished crystal showing a stain and exposed to humid atmosphere.

4. Unstained polished crystal after one day in dry air.

5. The same as curve 4.

6. Unstained polished crystal after eight days in dry air.

7. Unstained polished crystals after three months in dry air.

An interesting feature of the data in figure 3.41 is that storage time seems to play no part in the ductility of polished crystals. For details concerning the test, see the section on the measurement methods.

\subsection{Effect of Nuclear Irradiation on Mechanical Properties of Rock Salt}

Ionizing radiation leads to a significant variation of the stress-strain properties of rock salt. The effect of radiation varies with temperature, the time of radiation, the radiation dose, as well as with the type of salt considered and the dimensions of the specimen.

\subsubsection{Effect on Stress-Strain Behavior}

Bradshaw et al. [13] performed uniaxial compression testing on bedded salt and dome salt to evaluate the effects of radiation on stress-strain behavior, maximum compressive stress, and yield stress. The tests were first run at $293 \mathrm{~K}$ and then at $473 \mathrm{~K}$ using radiation doses of 0 , $10^{6}, 10^{7}, 10^{8}$, and $5 \times 10^{8} \mathrm{R}$, respectively. Three samples each of dome salt of two cases: (1) bedded salt with force applied perpendicular to bedding planes, and (2) bedded salt with force applied parallel to bedding planes, were considered. Their values are presented in Tables 3.41 and 3.42 and have been plotted in figures 3.42 and 3.43 , respectively. Figure 3.42 shows the stress-strain curves for different exposure doses and the force applied perpendicular to bedding planes at $293 \mathrm{~K}$. Figure 3.43 shows the relationship between radiation dose and maximum compressive stress and yield stress at $293 \mathrm{~K}$. These investigations indicate the following trends:

1. The maximum compressive stress of rock salt exposed to $5 \times 10^{8} \mathrm{R}$ is less than that of unirradiated salt for both bedded and dome salt.

2. At exposures of $5 \times 10^{8} \mathrm{R}$ and $473 \mathrm{~K}$, there is little difference between the stress capacities of bedded and dome salt.

3 . The yield stress of dome salt is higher than the yield stress of bedded salt for radiation doses $<3 \times 10^{7} \mathrm{R}$.

Studies by Demidova and Gol'denberg [10] have shown that generally the yield limit of $\mathrm{NaCl}$ crystal irradiated at room temperature increases with irradiation 
TABLE 3.40. STRESS-STRAIN RELATIONSHIP OF ROCX SALT CRYSTAL HAVING DIFFERENT SURFACE CONDITIONS [Resolved Shear Stress, $\tau$, MPa; Strain, $\varepsilon, \%$ ]

\begin{tabular}{|c|c|c|c|c|}
\hline $\begin{array}{l}\text { Data } \\
\text { Set }\end{array}$ & Author (s), Year [Ref.] & $\tau$ & $\varepsilon$ & Remarks \\
\hline 1 & $\begin{array}{l}\text { Stokes, R.J., Johnston, } \\
\text { T.L., and Li, C.H., } 1959 \\
{[3]}\end{array}$ & $\begin{array}{l}0.23 \\
0.55 \\
0.75 \\
0.87 \\
0.94 \\
0.98 \\
1.04 \\
1.08 \\
1.18 \\
1.22 \\
1.26\end{array}$ & $\begin{array}{l}0.43 \\
0.47 \\
0.51 \\
0.51 \\
0.66 \\
0.88 \\
1.15 \\
1.48 \\
1.87 \\
2.14 \\
2.47\end{array}$ & $\begin{array}{l}\text { Cleaved NaCl crystals; all tests (Data Sets } \\
1-7 \text { ) done on a conventional hard tensile } \\
\text { machine at what is assumed to be room tem- } \\
\text { perature. }\end{array}$ \\
\hline 2 & $\begin{array}{l}\text { Stokes, R.J., et al., } \\
1959 \text { [3] }\end{array}$ & $\begin{array}{l}0.29 \\
0.65 \\
0.85 \\
1.04 \\
1.14 \\
1.25 \\
1.36\end{array}$ & $\begin{array}{l}3.97 \\
3.89 \\
3.98 \\
3.97 \\
4.13 \\
4.35 \\
4.62\end{array}$ & $\begin{array}{l}\text { Polished } \mathrm{NaCl} \text { crystals deliberately "painted" } \\
\text { and showing a stain. }\end{array}$ \\
\hline 3 & $\begin{array}{l}\text { Stokes, R.J., et al., } \\
1959 \text { [3] }\end{array}$ & $\begin{array}{l}0.22 \\
0.58 \\
0.73 \\
0.83 \\
0.86 \\
0.96 \\
1.04 \\
1.09\end{array}$ & $\begin{array}{l}4.80 \\
4.77 \\
4.99 \\
5.20 \\
5.48 \\
5.86 \\
6.24 \\
6.51\end{array}$ & $\begin{array}{l}\text { Polished } \mathrm{NaCl} \text { crystals showing a stain and } \\
\text { exposed to a humid atmosphere. }\end{array}$ \\
\hline 4 & $\begin{array}{l}\text { Stokes, R.J., et al., } \\
1959 \text { [3] }\end{array}$ & $\begin{array}{l}0.19 \\
0.43 \\
0.77 \\
0.88 \\
0.97 \\
1.03 \\
1.13 \\
1.22 \\
1.34 \\
1.50 \\
1.71 \\
1.92 \\
2.16 \\
2.47 \\
2.70 \\
3.07 \\
3.50 \\
3.97 \\
4.40 \\
4.88 \\
5.30 \\
5.70 \\
6.1 \\
6.42 \\
6.71 \\
7.00 \\
7.29 \\
7.51 \\
7.7\end{array}$ & $\begin{array}{r}7.89 \\
7.82 \\
7.86 \\
7.91 \\
7.90 \\
8.17 \\
8.61 \\
9.05 \\
9.43 \\
10.08 \\
10.68 \\
11.22 \\
11.81 \\
12.34 \\
12.77 \\
13.30 \\
14.00 \\
14.91 \\
15.77 \\
17.01 \\
18.26 \\
19.50 \\
21.08 \\
22.50 \\
23.86 \\
25.28 \\
26.87 \\
28.40 \\
29.78\end{array}$ & $\begin{array}{l}\text { Unstained polished crystals of } \mathrm{NaCl} \text { after } \\
1 \text { day in dry air. }\end{array}$ \\
\hline
\end{tabular}


TABLE 3.40. STRESS-STRAIN RELATIONSHIP OF ROCK SALT CRYSTAL HAVING DIFFERENT SURFACE CONDITIONS (continued)

\begin{tabular}{|c|c|c|c|c|}
\hline $\begin{array}{l}\text { Data } \\
\text { Set }\end{array}$ & Author (s), Year [Ref.] & $\tau$ & $\varepsilon$ & Remarks \\
\hline 5 & $\begin{array}{l}\text { Stokes, R.J., Johnston, } \\
\text { T.L., and Li, C.H., } 1959 \\
\text { [3] }\end{array}$ & $\begin{array}{l}0.2 \\
0.52 \\
0.78 \\
0.91 \\
1.02 \\
1.08 \\
1.12 \\
1.20 \\
1.33 \\
1.55 \\
1.81 \\
2.18 \\
2.50 \\
2.88 \\
3.23 \\
3.52 \\
3.82 \\
4.13 \\
4.5 \\
4.9\end{array}$ & $\begin{array}{r}9.60 \\
9.70 \\
9.68 \\
9.67 \\
9.89 \\
10.16 \\
10.49 \\
10.87 \\
11.36 \\
12.07 \\
12.82 \\
13.80 \\
14.77 \\
15.80 \\
16.89 \\
17.92 \\
18.90 \\
20.01 \\
21.34 \\
22.64\end{array}$ & $\begin{array}{l}\text { Unstained polished NaCl crystals after } 1 \text { day } \\
\text { in dry air. }\end{array}$ \\
\hline 6 & $\begin{array}{l}\text { Stokes, R.J., et al., } \\
1959 \text { [3] }\end{array}$ & $\begin{array}{l}0.18 \\
0.46 \\
0.67 \\
0.77 \\
0.86 \\
1.03 \\
1.30 \\
1.55 \\
1.95 \\
2.33 \\
2.67 \\
3.08 \\
3.42 \\
3.77 \\
4.10 \\
4.35 \\
4.54\end{array}$ & $\begin{array}{l}13.09 \\
13.07 \\
13.22 \\
13.33 \\
13.65 \\
14.03 \\
14.57 \\
15.16 \\
15.97 \\
16.94 \\
17.97 \\
19.16 \\
20.36 \\
21.55 \\
22.75 \\
23.89 \\
24.88\end{array}$ & $\begin{array}{l}\text { Unstained polished } \mathrm{NaCl} \text { crystals after } 8 \\
\text { days in dry a1r. }\end{array}$ \\
\hline 7 & $\begin{array}{l}\text { Stokes, R.J., et al., } \\
1959 \text { [3] }\end{array}$ & $\begin{array}{l}0.10 \\
0.38 \\
0.72 \\
0.98 \\
1.06 \\
1.14 \\
1.23 \\
1.37 \\
1.48 \\
1.67 \\
2.04 \\
2.36 \\
2.72 \\
3.08 \\
3.45 \\
3.75 \\
4.11 \\
4.38\end{array}$ & $\begin{array}{l}17.90 \\
17.88 \\
17.86 \\
17.90 \\
18.06 \\
18.17 \\
18.38 \\
18.71 \\
18.92 \\
19.63 \\
20.60 \\
21.41 \\
22.33 \\
23.14 \\
23.95 \\
24.43 \\
25.33 \\
25.94\end{array}$ & $\begin{array}{l}\text { Unstained polished } \mathrm{NaCl} \text { crystals after } 3 \\
\text { months in dry air. }\end{array}$ \\
\hline
\end{tabular}




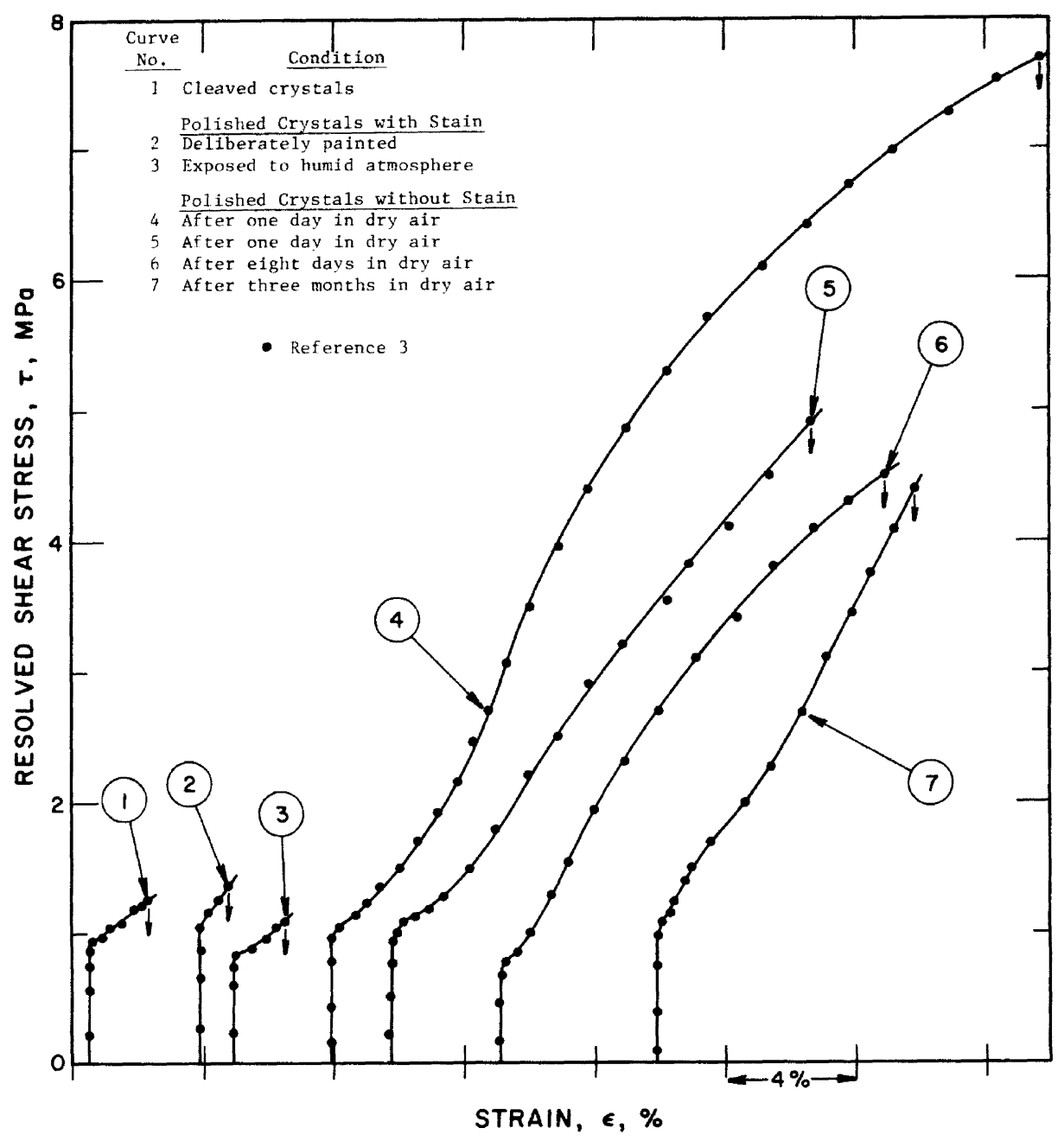

FIGURE 3.41. Stress-strain relationship of salt crystals having different surface conditions. 
TABLE 3.41. RADIATION EFFECTS ON STRESS-STRAIN RELATIONSHIP OF ROCK SALT

[Compressive Stress, $\sigma_{1}, \mathrm{MPa}$; Strain, $\varepsilon$, in/in]

\begin{tabular}{|c|c|c|c|c|}
\hline $\begin{array}{l}\text { Data } \\
\text { Set }\end{array}$ & Author (s), Year [Ref.] & $\sigma_{1}$ & $\varepsilon$ & Remarks \\
\hline 1 & $\begin{array}{l}\text { Bradshaw, R.L., Limpson, } \\
\text { F.M., Boeg1y, W.J., Jr., } \\
\text { Kubobta, H., Parker, F.L., } \\
\text { and Struxness, E.G., } \\
1968 \text { [13] }\end{array}$ & $\begin{array}{l}10.6 \\
13.8 \\
15.7 \\
19.0 \\
21.5 \\
23.6 \\
25.2 \\
26.1 \\
26.7 \\
27.1 \\
27.2 \\
27.3 \\
27.3\end{array}$ & $\begin{array}{l}0.006 \\
0.009 \\
0.011 \\
0.016 \\
0.021 \\
0.026 \\
0.031 \\
0.036 \\
0.041 \\
0.046 \\
0.051 \\
0.056 \\
0.061\end{array}$ & $\begin{array}{l}2 " \times 2 " \text { cubes of bedded salt; force applied } \\
\text { perpendicular to planes of stratification } \\
\text { at room temperature; unirradiated. }\end{array}$ \\
\hline 2 & $\begin{array}{l}\text { Bradshaw, R.L., et a1., } \\
1968 \text { [13] }\end{array}$ & $\begin{array}{r}5.0 \\
9.3 \\
12.4 \\
14.3 \\
17.4 \\
20.0 \\
21.9 \\
23.5 \\
24.7 \\
25.5 \\
25.8 \\
25.9 \\
25.6 \\
25.6\end{array}$ & $\begin{array}{l}0.002 \\
0.006 \\
0.009 \\
0.010 \\
0.016 \\
0.021 \\
0.026 \\
0.031 \\
0.036 \\
0.041 \\
0.046 \\
0.051 \\
0.056 \\
0.061\end{array}$ & $\begin{array}{l}\text { Sample similar to above; irradiated to } \\
10^{6} \mathrm{R} \text {. }\end{array}$ \\
\hline 3 & $\begin{array}{l}\text { Bradshaw, R.L., et al., } \\
1968 \text { [13] }\end{array}$ & $\begin{array}{r}4.9 \\
11.3 \\
15.0 \\
16.9 \\
20.5 \\
23.1 \\
25.0 \\
26.5 \\
27.5 \\
28.0 \\
28.0 \\
28.0 \\
28.0 \\
27.9\end{array}$ & $\begin{array}{l}0.002 \\
0.006 \\
0.009 \\
0.011 \\
0.016 \\
0.021 \\
0.026 \\
0.031 \\
0.036 \\
0.041 \\
0.046 \\
0.051 \\
0.056 \\
0.061\end{array}$ & $\begin{array}{l}\text { Sample similar to above; irradiated to } \\
10^{7} \mathrm{R} \text {. }\end{array}$ \\
\hline 4 & $\begin{array}{l}\text { Bradshaw, R.L., et al., } \\
1968[13]\end{array}$ & $\begin{array}{r}5.3 \\
11.5 \\
15.4 \\
17.3 \\
20.9 \\
23.3 \\
25.3 \\
26.3 \\
27.1 \\
27.3 \\
26.6 \\
25.7 \\
25.1 \\
24.8\end{array}$ & $\begin{array}{l}0.002 \\
0.005 \\
0.009 \\
0.011 \\
0.016 \\
0.021 \\
0.027 \\
0.031 \\
0.036 \\
0.041 \\
0.046 \\
0.051 \\
0.056 \\
0.061\end{array}$ & $\begin{array}{l}\text { Sample similar to above; irradiated to } \\
10^{8} \mathrm{R} \text {. }\end{array}$ \\
\hline 5 & $\begin{array}{l}\text { Bradshaw, R.L., Limpson, } \\
\text { F.M., Boeg1y, W.J., Jr., } \\
\text { Kubota, H., Parker, F.L., } \\
\text { and Struxness, E.G., } \\
1968 \text { [13] }\end{array}$ & $\begin{array}{l}5.27 \\
10.95 \\
15.20 \\
17.57 \\
21.20 \\
22.8 \\
23.8 \\
24.3 \\
23.8 \\
22.7 \\
21.1 \\
19.5 \\
18.5\end{array}$ & $\begin{array}{l}0.002 \\
0.006 \\
0.009 \\
0.011 \\
0.016 \\
0.021 \\
0.026 \\
0.031 \\
0.036 \\
0.041 \\
0.046 \\
0.051 \\
0.055\end{array}$ & $\begin{array}{l}\text { Sample similar to above; irradiated to } \\
5 \times 10^{8} \mathrm{R} \text {. }\end{array}$ \\
\hline
\end{tabular}




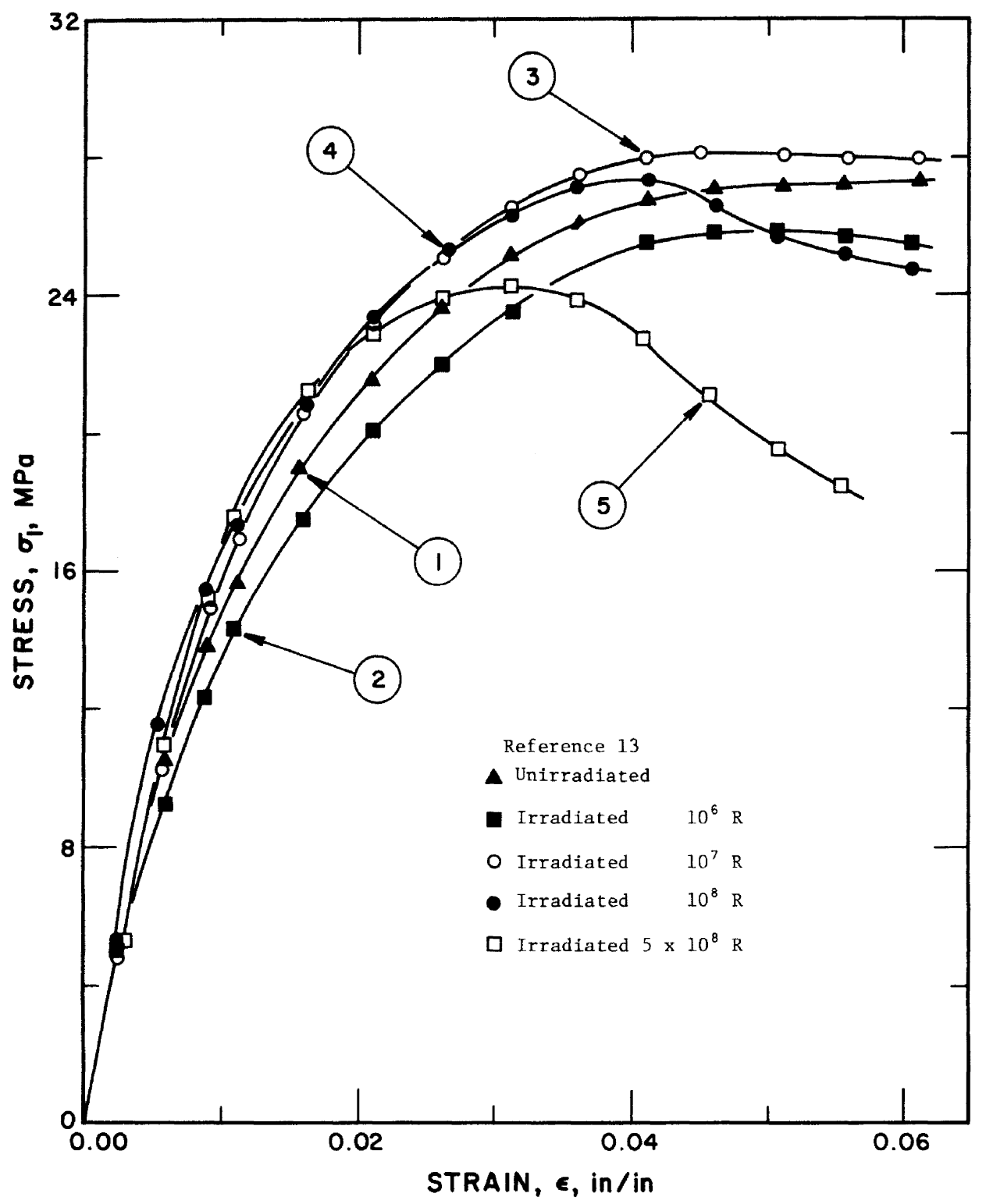

FIGURE 3.42. Effect of radiation on.the stress-strain behavior of rock salt (curve numbers correspond to data set numbers in matching table). 
TABLE 3.42. MAXIMUM COMPRESSIVE AND YIELD STRESS OF ROCK SALT FROM HUTCHINSON, KANSAS, AND GRAND SALINE, TEXAS

All results have been rounded off to the nearest $.69 \mathrm{MPa}$ and standard deviation to the nearest $.34 \mathrm{MPa}$.

(After Bradshaw [13], 1968)

\begin{tabular}{|c|c|c|c|}
\hline Type of Salt & $\begin{array}{l}\text { Exposure } \\
\text { Dose (R) }\end{array}$ & $\begin{array}{c}\text { Maximum } \\
\text { Compressive } \\
\text { Stress } \\
\text { MPa } \\
\end{array}$ & $\begin{array}{l}\text { Yield } \\
\text { Stress } \\
\text { MPa }\end{array}$ \\
\hline \multicolumn{4}{|c|}{ At $293 \mathrm{~K}$} \\
\hline Bedded Paralle1 & $\begin{array}{c}0 \\
10^{6} \\
10^{7} \\
10^{8} \\
5 \times 10^{8}\end{array}$ & $\begin{array}{l}28.95 \pm 3.45 \\
31.03 \pm 3.45 \\
31.72 \pm 2.76 \\
31.72 \pm 1.03 \\
24.13 \pm 0.34\end{array}$ & $\begin{array}{l}17.23 \pm 2.07 \\
17.23 \pm 1.03 \\
18.62 \pm 1.72 \\
23.44 \pm 1.72 \\
18.62 \pm 1.38\end{array}$ \\
\hline Bedded Perpendicular & $\begin{array}{c}0 \\
10^{6} \\
10^{7} \\
10^{8} \\
5 \times 10^{8}\end{array}$ & $\begin{array}{l}27.58 \pm 2.76 \\
26.20 \pm 3.45 \\
28.27 \pm 2.76 \\
27.58 \pm 2.76 \\
24.13 \pm 2.76\end{array}$ & $\begin{array}{l}15.86 \pm 2.07 \\
12.41 \pm 1.72 \\
15.86 \pm 3.45 \\
16.55 \pm 3.45 \\
16.55 \pm 2.07\end{array}$ \\
\hline Dome & $\begin{array}{l}0 \\
10^{6} \\
10^{7} \\
10^{8} \\
5 \times 10^{8}\end{array}$ & $\begin{array}{l}38.61 \pm 0.69 \\
36.54 \pm 0.69 \\
35.16 \pm 1.38 \\
28.27 \pm 1.38 \\
24.13 \pm 3.45\end{array}$ & $\begin{array}{l}19.99 \pm 1.03 \\
19.99 \pm 1.03 \\
20.68 \pm 0.69 \\
18.62 \pm 0.69 \\
17.93 \pm 1.39\end{array}$ \\
\hline \multicolumn{4}{|c|}{ At $473 \mathrm{~K}$} \\
\hline Bedded Para1lel & $5 \times 10^{8}$ & $\begin{array}{l}26.89 \pm 1.38 \\
23.44 \pm 2.76\end{array}$ & $\begin{array}{l}11.03 \pm 1.39 \\
13.10 \pm 1.72\end{array}$ \\
\hline Bedded Perpendicular & $5 \times 10^{8}$ & $\begin{array}{l}24.82 \pm 0.69 \\
22.75 \pm 2.76\end{array}$ & $\begin{array}{l}11.03 \pm 0.69 \\
14.48 \pm 1.03\end{array}$ \\
\hline Dome & $5 \times 10^{8}$ & $\begin{array}{l}24.82 \pm 3.45 \\
21.37 \pm 2.07\end{array}$ & $\begin{array}{l}13.10 \pm 1.03 \\
15.86 \pm 1.03\end{array}$ \\
\hline
\end{tabular}

Bedded Paralle1: bedded salt, force applied parallel to the planes of stratification.

Bedded Perpendicular: bedded salt, force applied perpendicular to the plane of stratification. 


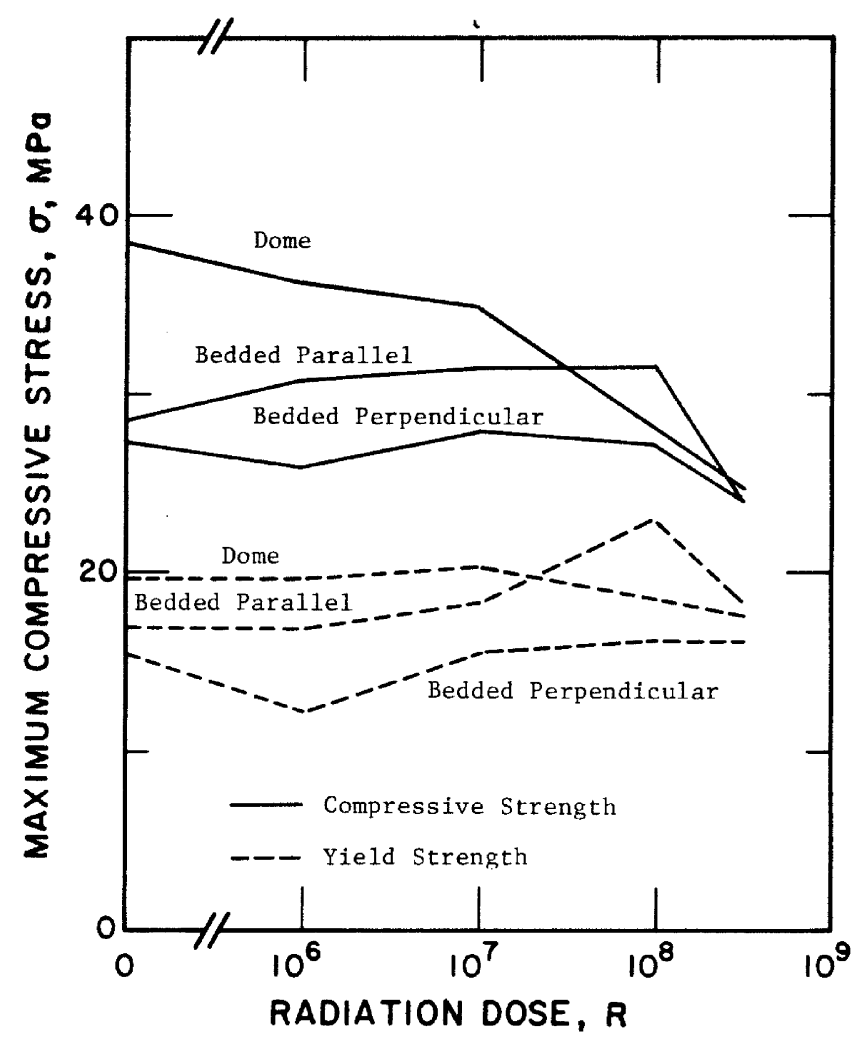

FIGURE 3.43. Relationship between maximum compressive stress and radiation dose.

dose; at low doses the temperature hardening mechanism controls while at higher doses a temperature insensitive mechanism prevails. They also observed that even before two hours of irradiation had occurred, the strain was elastic while the failure was brittle. Only at rupture a small local plastic strain was evident. Whisker crystals irradiated for two or more hours revealed macroscopic plastic flow only if they had first been subject to plastic strain. A substantial difference in the extent of the variation in the ultimate strength of crystals of different diameters was shown as the radiation dose was varied [8]. The ultimate tensile stress capacity of $\mathrm{NaCl}$ whisker crystals, measuring $18 \mu \mathrm{m}$ in diameter, was observed to increase first and then decrease, passing through a maximum at an irradiation time of about eight hours as shown in figure 3.44 with the corresponding values in table 3.43. Specimens measuring $86 \mu \mathrm{m}$ in diameter under the same conditions exhibited a gradual increase in the degree of hardening with dose.

Figure 3.45 is also taken from Demidova and Gol'denberg [10] and shows that another effect of radiation is the change in the nature of crystal whisker fracture. The corresponding values are tabulated in table 3.44. Prior to exposures the specimens fail in a plastic mode whereas the exposed specimens fracture primarily in a brittle mode.

\subsubsection{Effect on Young's Modulus}

The relationship between radiation dose and Young's modulus as investigated by Bradshaw et al. [13] is given in table 3.45 and plotted in figure 3.46 . There is a general increase in modulus of elasticity with increase in radiation dose but this trend is irregular and inconsistent.

\subsubsection{Effect on Creep}

In addition to the static tests, the creep rate resulting from the application of a constant force of $17.237 \mathrm{MPa}$ for 100 minutes was measured by Bradshaw et al. [13]. Figure 3.47 shows the creep curves for bedded salt with the corresponding values given in Table 3.46. The irradiated salt which received $5 \times 10^{8} \mathrm{R}$ was stronger as shown by less creep.

\subsubsection{Effect on Hardness}

The hardness of $\mathrm{NaCl}$ crystals increases on irradiation. Small irradiation doses, however, produce very little hardening compared to coloration. Demidova and Gol'denberg [10] observed that: (1) two hours of exposure to $\mathrm{x}$-rays result in hardening of crystal whiskers, and (2) the degree of hardening increases as the diameter diminishes. 
TABLE 3.43. DEPENDENCE OF ULTTMATE TENSILE STRESS CAPACITY OF NaC1 CRYSTAL WHISKER ON IRRADIATION TIME

[Irradiation Time, $t$, hrs; Tensile Stress, $\sigma_{t}$, MPa]

\begin{tabular}{|c|c|c|c|c|}
\hline $\begin{array}{c}\text { Data } \\
\text { Set }\end{array}$ & Author (s), Year [Ref.] & $t$ & $\sigma_{t}$ & Remarks \\
\hline 1 & $\begin{array}{l}\text { Demidova, N.N. and } \\
\text { Gol'denberg, S.U., } 1975 \\
\text { [8] }\end{array}$ & $\begin{array}{r}-0.08 \\
1.91 \\
3.81 \\
7.78 \\
11.87 \\
15.96\end{array}$ & $\begin{array}{r}2.89 \\
5.61 \\
10.06 \\
16.94 \\
10.84 \\
3.88\end{array}$ & $\begin{array}{l}\mathrm{NaCl} \text { whisker crystals measuring } 10-100 \mu \mathrm{m} \\
\text { in diameter cultivated from solution using } \\
\text { the Amelinck method; specimens irradiated } \\
\text { at room temperature; this data obtained } \\
\text { for a specimen with a diameter of } 18 \mu \mathrm{m} \text {. }\end{array}$ \\
\hline 2 & $\begin{array}{l}\text { Demidova, N.N. and } \\
\text { Go1'denberg, S.U., 1975, } \\
{[8]}\end{array}$ & $\begin{array}{r}0.09 \\
2.07 \\
3.95 \\
8.07 \\
15.96\end{array}$ & $\begin{array}{l}1.20 \\
2.29 \\
2.99 \\
4.24 \\
5.46\end{array}$ & $\begin{array}{l}\text { This data obtained for a specimen with a } \\
\text { diameter of } 86 \mathrm{~m} \text {. }\end{array}$ \\
\hline
\end{tabular}

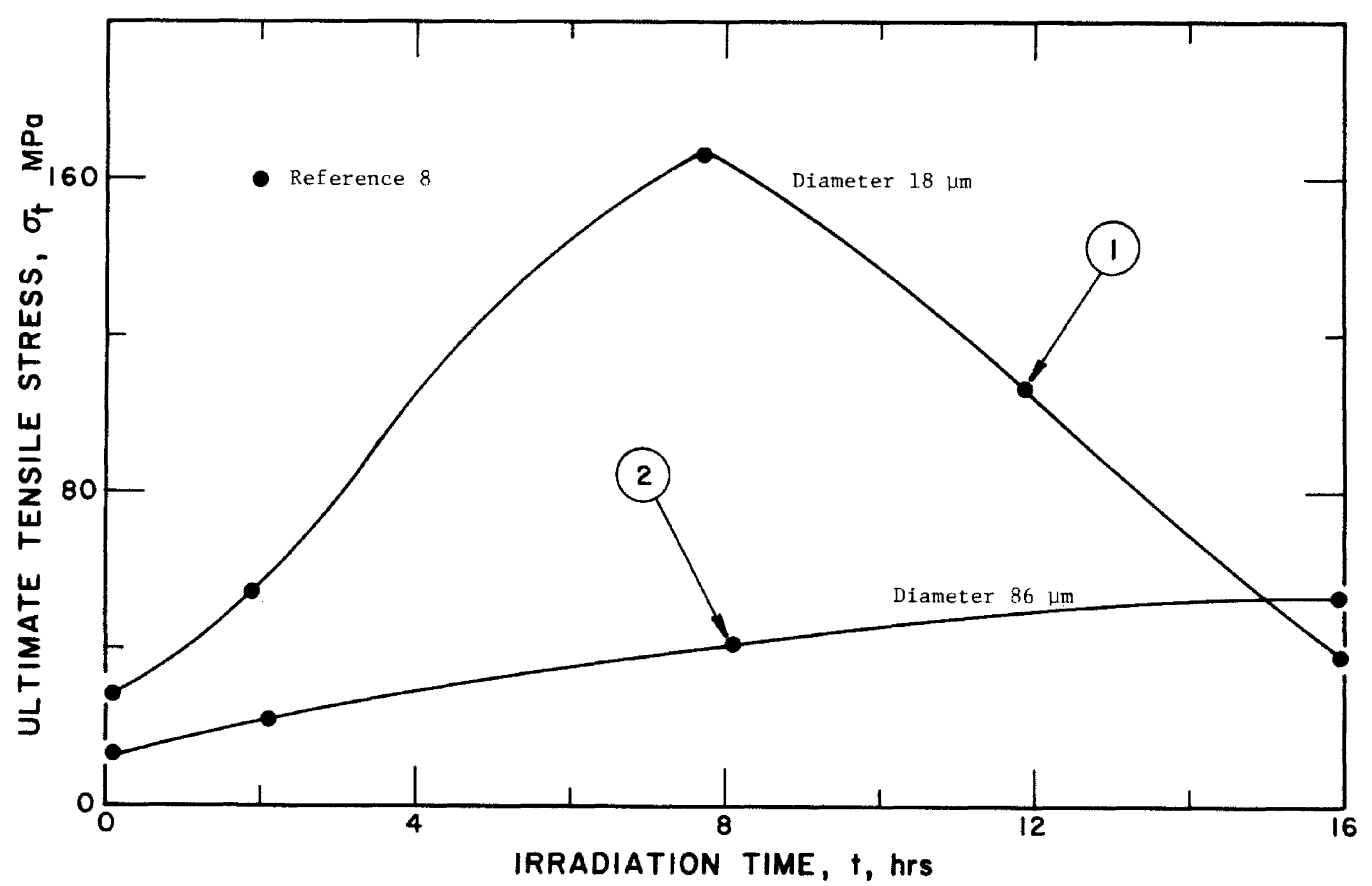

FIGURE 3.44. Dependence of ultimate stress capacity of $\mathrm{NaCl}$ crystal whiskers on irradiation time (curve numbers correspond to data set numbers in matching table). 
TABLE 3.44. EFFECT OF RADIATION ON TENSILE STRESS-STRAIN BEHAVIOR OF NaCl CRYSTAL WHISKER

[Tensile Stress, $\sigma_{t}, \mathrm{MPa}$; Strain, $\varepsilon, \%$ ]

\begin{tabular}{|c|c|c|c|c|}
\hline $\begin{array}{l}\text { Data } \\
\text { Set }\end{array}$ & Author (s), Year [Ref.] & $\sigma_{t}$ & $\varepsilon$ & Remarks \\
\hline 1 & $\begin{array}{l}\text { Demidova, N.N. and } \\
\text { Gol 'denberg, S.U., } \\
1975 \text { [8] }\end{array}$ & $\begin{array}{l}15.11 \\
17.17 \\
16.75 \\
18.80 \\
17.98 \\
16.75 \\
19.20 \\
17.97 \\
16.75 \\
17.96 \\
19.20 \\
20.0 \\
20.8 \\
20.0 \\
21.23 \\
21.22 \\
22.04 \\
23.26 \\
21.22 \\
22.45 \\
20.4 \\
23.75 \\
23.80 \\
24.63 \\
25.48 \\
26.31 \\
26.73 \\
26.73 \\
26.73 \\
27.15 \\
27.99 \\
28.83 \\
29.67 \\
30.09 \\
31.34 \\
31.77 \\
32.60 \\
32.61\end{array}$ & $\begin{array}{l}1.74 \\
1.75 \\
5.08 \\
5.92 \\
6.75 \\
9.24 \\
11.76 \\
13.42 \\
15.08 \\
16.75 \\
19.26 \\
20.93 \\
23.43 \\
25.09 \\
27.60 \\
30.10 \\
30.94 \\
33.44 \\
35.10 \\
36.77 \\
38.43 \\
40.11 \\
42.62 \\
48.07 \\
51.70 \\
53.52 \\
55.36 \\
58.97 \\
60.79 \\
64.42 \\
66.24 \\
68.96 \\
71.69 \\
75.32 \\
77.13 \\
80.77 \\
84.4 \\
87.13\end{array}$ & $\begin{array}{l}\text { Unexposed; } \mathrm{NaCl} \text { crystal whiskers grown } \\
\text { by Amelinck method from solution and } \\
\text { tested on a tensile machine; specimen } \\
\text { diameter } 13.7 \mathrm{\mu} .\end{array}$ \\
\hline 2 & $\begin{array}{l}\text { Demidova, N.N. and } \\
\text { Gol'denberg, S.U., } \\
1974[10]\end{array}$ & $\begin{array}{r}5.24 \\
12.57 \\
19.89 \\
29.30 \\
38.71 \\
44.99 \\
55.45 \\
61.73 \\
72.73 \\
79.51 \\
87.87\end{array}$ & $\begin{array}{l}0.11 \\
0.23 \\
0.33 \\
0.46 \\
0.57 \\
0.69 \\
0.79 \\
0.89 \\
1.01 \\
1.12 \\
1.22\end{array}$ & $\begin{array}{l}\text { Exposed; NaC1 crystal whiskers grown } \\
\text { by Amelinck method from solution and } \\
\text { irradiated directly on a tensile ma- } \\
\text { chine with unfiltered x-radiation for } \\
2 \text { hours; diameter of crystal whisker } \\
\text { used } 26 \mu \text {. }\end{array}$ \\
\hline
\end{tabular}




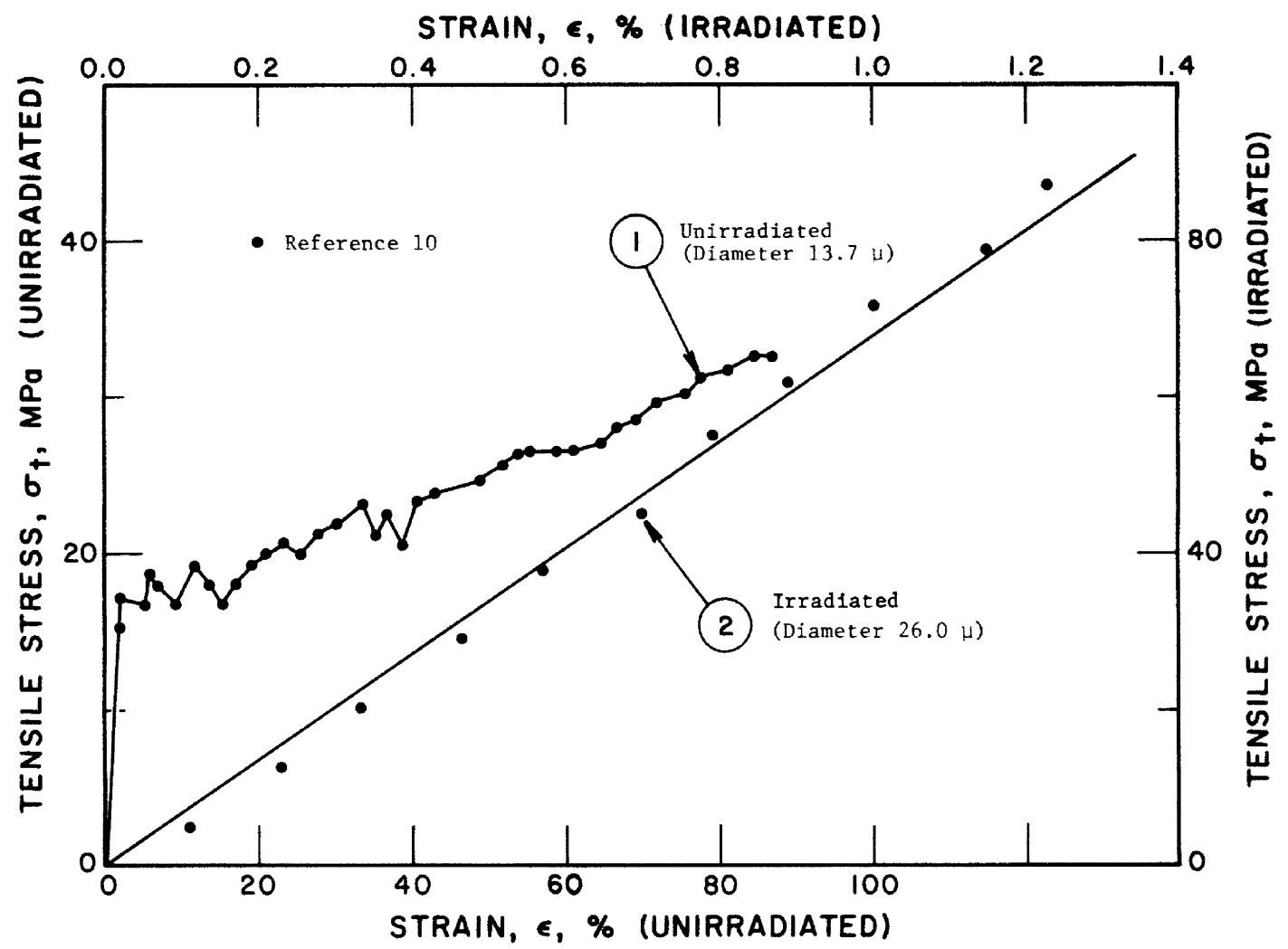

FIGLRE 3.45. Effect of radiation on tensile stress-strain behavior of a $\mathrm{NaCl}$ crystal whisker (curve numbers correspond to data set numbers in matching table). 
TABLE 3.45. YOUNG'S MODULUS OF ROCK SALT FROM HUTCHINSON, KANSAS, AND GRAND SALINE, TEXAS

All results have been rounded off to the nearest $.69 \mathrm{MPa}$ and the standard deviation to the nearest $.34 \mathrm{MPa}$.

(After Bradshaw [13], et al.)

\begin{tabular}{|c|c|c|}
\hline Type of Salt & $\begin{array}{l}\text { Exposure } \\
\text { Dose, D (R) }\end{array}$ & $\begin{array}{c}\text { Modulus of } \\
\text { Elasticity, Es } \\
\text { GPa }\end{array}$ \\
\hline \multicolumn{3}{|c|}{ At $293 \mathrm{~K}$} \\
\hline Bedded Paralle1 & $\begin{array}{c}0 \\
10^{6} \\
10^{7} \\
10^{8} \\
5 \times 10^{8}\end{array}$ & $\begin{array}{l}2.41 \pm 0.41 \\
2.21 \pm 0.41 \\
2.41 \pm 0.14 \\
2.48 \pm 0.62\end{array}$ \\
\hline Bedded Perpendicular & $\begin{array}{c}0 \\
10^{6} \\
10^{7} \\
10^{8} \\
5 \times 10^{8}\end{array}$ & $\begin{array}{l}2.48 \pm 0.80 \\
2.41 \pm 0.69 \\
2.62 \pm 0.26 \\
2.62 \pm 0.41 \\
2.55 \pm 0.76\end{array}$ \\
\hline Dome & $\begin{array}{c}0 \\
10^{6} \\
10^{7} \\
10^{8} \\
5 \times 10^{8}\end{array}$ & $\begin{array}{l}3.45 \pm 0.34 \\
3.52 \pm 0.82 \\
4.27 \pm 0.41 \\
3.81 \pm 0.28 \\
4.06 \pm 0.83\end{array}$ \\
\hline & At $473 \mathrm{~K}$ & \\
\hline Bedded Paralle1 & $5 \times 10^{8}$ & $\begin{array}{l}0.62 \pm 0.07 \\
0.83 \pm 0.14\end{array}$ \\
\hline Bedded Perpendicular & $5 \times 10^{8}$ & $\begin{array}{l}0.90 \pm 0.07 \\
0.90 \pm 0.07\end{array}$ \\
\hline Dome & $5 \times 10^{8}$ & $\begin{array}{l}0.96 \pm 0.07 \\
1.10 \pm 0.07\end{array}$ \\
\hline
\end{tabular}

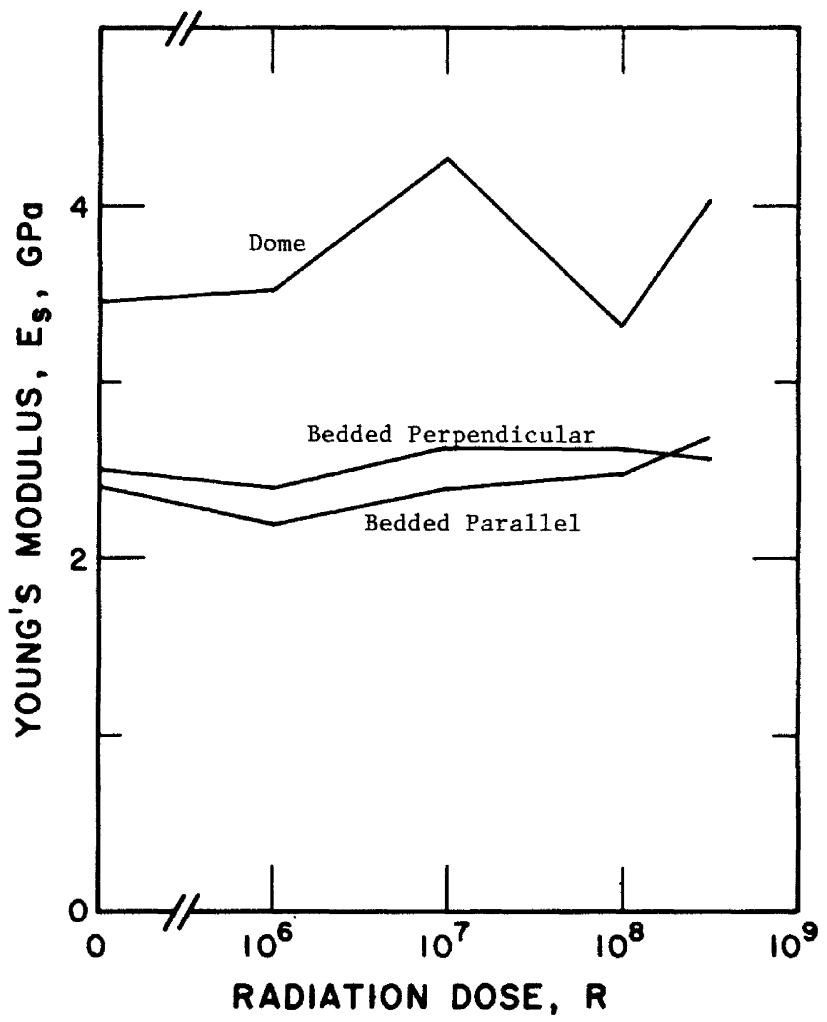

FIGURE 3.46. Variation of Young's Modulus of rock salt with radiation dosage. 
TABLE 3.46. EFFECT OF IRRADIATION ON CREEP PROPERTIES OF ROCK SALT

[Time, $t$, min; Strain, $\epsilon$, (in/in) $\times 10^{3}$ ]

\begin{tabular}{|c|c|c|c|c|}
\hline $\begin{array}{c}\text { Data } \\
\text { Set }\end{array}$ & Author(s), Year [Ref.] & $t$ & $\varepsilon$ & Remarks \\
\hline 1 & $\begin{array}{l}\text { Bradshaw, R.L., Limpson, } \\
\text { F.M., Boegly, W.J., Jr., } \\
\text { Kubobta, H., Parker, F.L., } \\
\text { and Struxness, E.G., } \\
1968[13]\end{array}$ & $\begin{array}{r}0.9 \\
1.4 \\
2.9 \\
6.4 \\
10.3 \\
15.5 \\
26.6 \\
40.8 \\
60.6 \\
80.1 \\
100.2\end{array}$ & $\begin{array}{r}9.00 \\
10.50 \\
10.88 \\
11.26 \\
11.57 \\
11.53 \\
11.92 \\
11.95 \\
11.98 \\
12.29 \\
12.31\end{array}$ & $\begin{array}{l}\text { Bedded salt with force applied perpendicular } \\
\text { to planes of stratification; constant load } \\
\text { of } 17.237 \mathrm{MPa} \text {. }\end{array}$ \\
\hline 2 & $\begin{array}{l}\text { Bradshaw, R.L., et al., } \\
1968 \text { [13] }\end{array}$ & $\begin{array}{r}0.9 \\
1.4 \\
1.9 \\
4.6 \\
8.3 \\
12.5 \\
21.7 \\
30.8 \\
50.6 \\
70.4 \\
90.2\end{array}$ & $\begin{array}{r}6.25 \\
10.25 \\
11.38 \\
14.63 \\
15.14 \\
15.65 \\
15.91 \\
16.31 \\
16.47 \\
16.75 \\
17.04\end{array}$ & $\begin{array}{l}\text { Similar conditions as Data Set } 1 \text {; irradi- } \\
\text { ated to } 5 \times 10^{8} \mathrm{R} \text {. }\end{array}$ \\
\hline
\end{tabular}

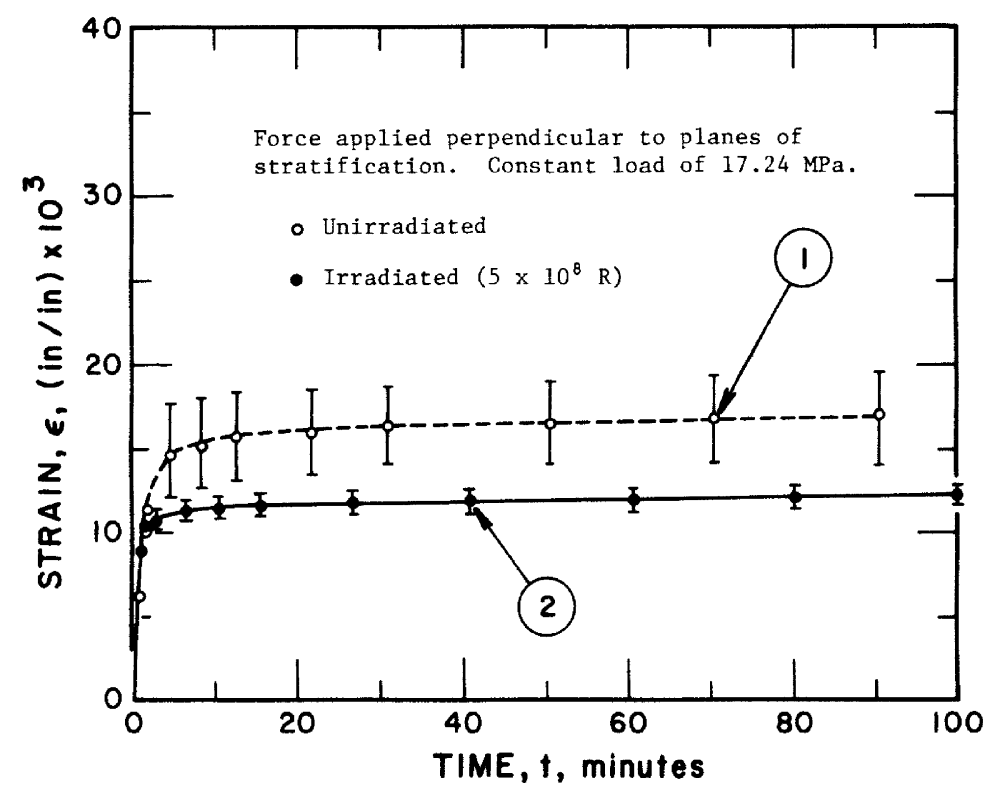

FIGURE 3.47. Effect of radiation on the creep of rock salt (curve numbers correspond to data set numbers in matching table). 
Figure 3.48 from Inabe and Takeuchi [9] shows the relationship between Vickers hardness and $x$-ray dosage for specimens annealed and reheated up to $600^{\circ} \mathrm{C}$ and then cooled. The corresponding values are tabulated in table 3.47.

\subsubsection{Evaluation of Data}

At this stage the published data do not permit the generation of recommended values of the mechanical properties of rock salt. The available data are contradictory and even though measurements seem to have been carefully conducted, the nature of the material under consideration makes it difficult to characterize it adequately.

TABLE 3.47. VICKER'S MICROHARDNESS OF NaC1 CRYSTALS AS A FUNCTION OF X-RAY DOSE [X-Ray Dose, $10^{5} \mathrm{R}$; Change in Vicker's Microhardness, $\Delta \mathrm{H}_{\mathrm{V}}, \mathrm{kg} \mathrm{mm}^{-2}$ ]

\begin{tabular}{|c|c|c|c|c|}
\hline $\begin{array}{l}\text { Data } \\
\text { Set }\end{array}$ & Author (s), Year [Ref.] & $\begin{array}{l}\text { Dose } \\
10^{5} \mathrm{R}\end{array}$ & $\Delta \mathrm{H}_{\mathrm{v}}$ & Remarks \\
\hline 1 & $\begin{array}{l}\text { Inabe, K. and Takeuchi, } \\
\text { N., } 1973 \text { [9] }\end{array}$ & $\begin{array}{l}0.09 \\
0.30 \\
1.05 \\
2.05 \\
3.06\end{array}$ & $\begin{array}{l}0.21 \\
0.45 \\
0.81 \\
1.08 \\
1.00\end{array}$ & $\begin{array}{l}\text { NaCl crystals grown in air by Kyropoulos } \\
\text { technique from a melt reagent grade material. } \\
\text { Specimens annealed in air at } 923 \mathrm{~K} \text { for } 80 \\
\text { hours and slowly cooled at } 293 \mathrm{~K} / \mathrm{hr} \text {. }\end{array}$ \\
\hline 2 & $\begin{array}{l}\text { Inabe, K. and Takeuchi, } \\
\text { N., } 1973 \text { [9] }\end{array}$ & $\begin{array}{l}0.09 \\
0.31 \\
1.03 \\
2.01 \\
3.00\end{array}$ & $\begin{array}{l}0.10 \\
0.20 \\
0.49 \\
0.55 \\
0.50\end{array}$ & $\begin{array}{l}\text { NaC1 crystals grown as indicated above; how- } \\
\text { ever they were reheated to } 873 \mathrm{~K} \text { and allowed } \\
\text { to cool on an asbestos plate. }\end{array}$ \\
\hline
\end{tabular}

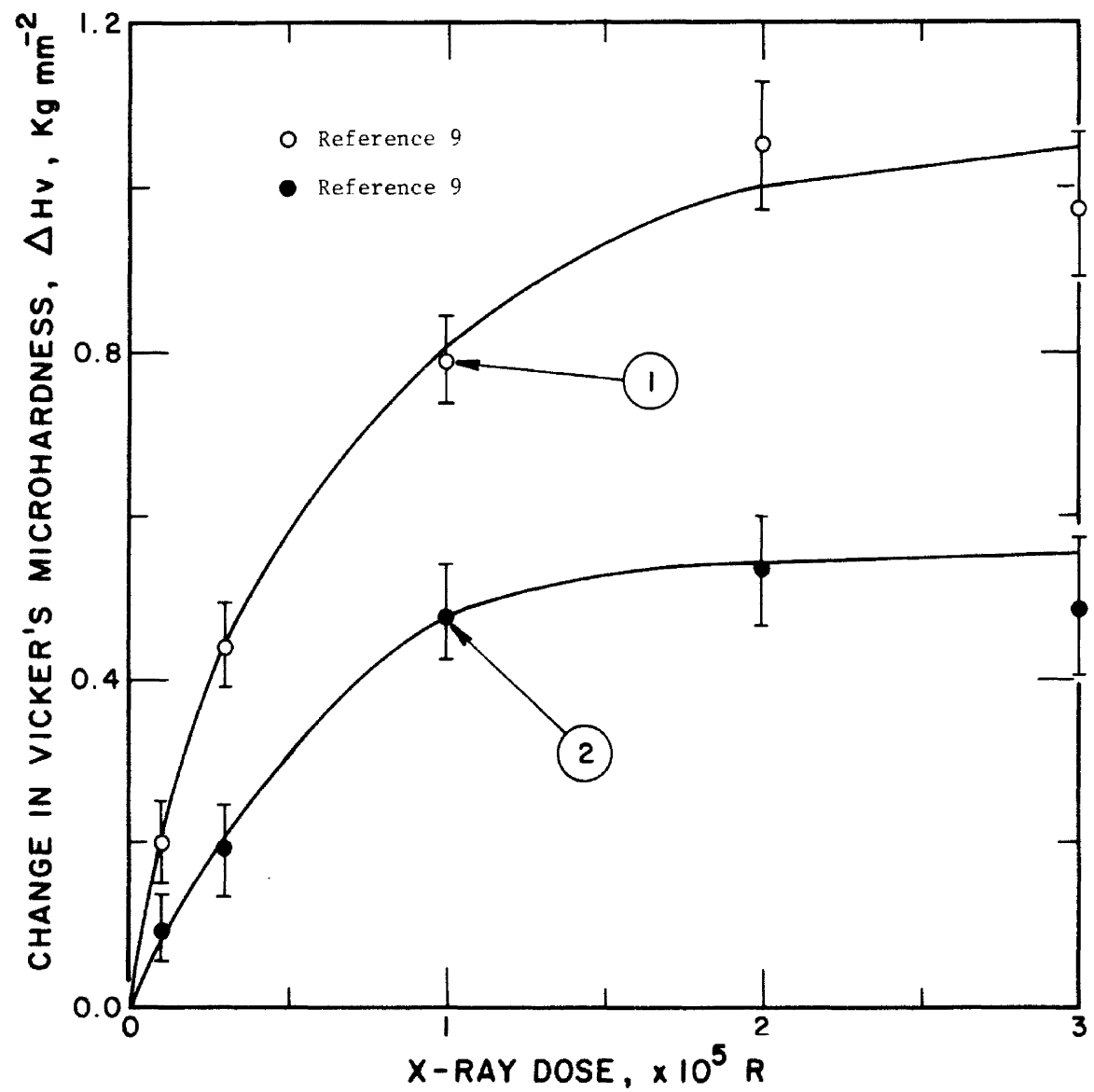

3.48. Effect of radiation on the microhardness of rock salt (curve numbers correspond to data set numbers in matching table.) 


\subsection{References}

[1] Glossary of Geology, American Geological Institute (1974).

[2] Voronov, F.F., and Grigor'ev, S.B., "Influence of Pressures Up to 100 kbar on Elastic Properties of Silver, Sodium and Cesium Chlorides," Sov. Phys. Solid State, 18(2), 325-8 (1976).

[3] Stokes, R.J., Johnston, T.L., and Li, C.H., "Environmental Effects on the Mechanical Properties of Ionic Solids with Particular Reference to the Joffé Effect," Office of Naval Research, Sixth Technical Report, Project NONR-2456(00) NR 032-451 (1959).

[4] Morris, C.E., Jamieson, J.C., and Yarger, F.L., "Ultrasonic Measurements at Elevated Pressures $(9 \mathrm{GPa})$ to Determine Poisson's Ratio and other Elastic Moduli of $\mathrm{NaCl}$ and NaF,'J.Appl. Phys., 47(9), 3979-86 (1976).

[5] Gera, F., "Review of Salt Tectonics in Relation to the Disposal of Radioactive Wastes in Salt Formation," Geological Society of America Bulletin, 83, 3551-74 (1972).

[6] Wu, C. and Phillips, G.C., "Seismic-Wave Propagation from Salt Dome Environments," VESIAC State of the Art Rept. 4410-79-X, 58 pp. (1964).

[7] Heard, H.C., Abey, A.E., Bonner, B.P., and Duba, A., "StressStrain Behavior of Polycrystalline $\mathrm{NaCl}$ to $3.2 \mathrm{GPa}$," Lawrence Livermore Laboratory Rept. UCRL-51743, 16 pp. (1975).

[8] Demidova, N.N. and Gol'denberg, S.U., "Role of the Scaling Factor in Radiation Variation of the Stress-Strain Properties of $\mathrm{NaCl}$ Whisker Crystals," Izv. Vyss. Ucheb. Zaved. Fiz., 12, 123-4, 1975; English Translation: Plenum Pub. Corp. (1975).

[9] Inabe, K. and Takeuchi, N., "Dislocation and Radiation Hardening of $\mathrm{NaCl}$ Single Crystals," Jap. J. Appl. Phys., 12(6) (1973).

[10] Demidova, N.N. and Gol'denberg, S.U., "Radiation Hardening of $\mathrm{NaCl}$ Crystal Whiskers," Izv. Vyss. Ucheb. Zaved. Fitz., 4, 139-41 (1974); English Translation: Plenum Pub. Corp. (1975).

[11] Sanchez, C., Lioma, I.S., Jargiu, F., and Agullo-Lopez, F., "Influence of the Aggregation State of $\mathrm{Ca}^{2+}$ Ions on the Coloring and Hardening Behavior of $\mathrm{NaCl}: \mathrm{Ca}^{2}{ }^{+}$," Crystal Lattice Defects, 6, 227-32 (1976).

[12] Dreyer, W., "The Science of Rock Mechanics, Vol. I," Tran. Tech. Publications, 29-164 (1972).

[13] Bradshaw, R.L., Limpson, F.M., Boegly, W.J., Jr., Kubota, H., Parker, F.L., and Struxness, E.G., "Properties of Salt Important in Radioactive Waste Disposal," Geol. Soc. Am., Special Paper 88 (1968).

[14] Kishsh, I. and Sharkezi, I., "Change in the Microhardness of Alkali Halide Crystals on Quenching," Sov. Phys., 16(5) 827-31 (1972).

[15] Strelkov, P.G., Shpunt, A.A., and Nabutovskaya, O.A., "Use of $\mathrm{NaCl}$ Crystals as Hardness Standards," Zavod. Lab., 34(5) 599-601 (1967).

[16] Frankel, J., Rich, F.J., and Homan, C.G., "Acoustic Velocities in Polycrystalline $\mathrm{NaCl}$ at $300 \mathrm{~K}$ Measured at Static Pressures from 25 to 27 kbar," J. Geophys. Res., 81(35), 6357-63 (1976).

[17] Baar, C.A., "Applied Salt-Rock Mechanics I, The in Situ Behavior of Salt Rocks," Developments in Geotechnical Engineering, 16A, 34 (1977).

[18] Dames \& Moore, White Plains, NY, Consultants Rept. Y/OWI/TM-36, Vol. 4, "Baseline Rock Properties-Salt," of work entitled "Technical Support for GEIS: Radioactive Waste Isolation in Geologic Formations," prepared for Union Carbide, April 1978.
[19] Burke, P.M., "High Temperature Creep of Polycrystalline Sodium Chloride," Stanford Univ., PhD. Thesis (1968).

[20] Handin, J., "An Application of High Pressure in Geophysics: Experimental Rock Deformation," Trans. ASME, 75, 315-24 (1953).

[21] Heard, H.C., "Steady-State Flow in Polycrystalline Halite at 2 Kilobars," (Heard et al., Editors), American Geophysical Union Monograph 16, 191-209 (1972).

[22] LeComte, P., "Creep in Rock Salt," J. Geol., 73, 469-84 (1965).

[23] Nair, K. and Deere, D.V., "Creep Behavior of Salt in Triaxial Extension," in Third Symposium on Salt (Rau and Dellwig, Editors), Vol. 2, N. Ohio Geological Society, Inc. (1970).

[24] Odé, H., "Review of Mechanical Behavior of Salt Relating to Salt Dome Genesis," (Braunstein, J.D. and O'Brien, G.D., Editors), Diapirism and Diapirs. Mem. 8, Am. Assoc. Petroleum Geologists (1968).

[25] Thompson, E.G., "An Experimental Technique for the Investigation of the Flow of Halite and Sylvinite," Univ. of Texas-Austin, Ph.D. Thesis (1965)

\section{Symbols and Units}

\begin{tabular}{lll}
\hline \hline Symbol & Name & Unit \\
\hline$P$ & Pressure & $\mathrm{MPa}_{2} \mathrm{GPa}$ \\
$\rho$ & Density & $\mathrm{kg} \mathrm{m}^{-3}$ \\
$\rho_{0} \rho$ & Compression & dimensionless \\
$E$ & Young's modulus & $\mathrm{GPa}$ \\
$G$ & Shear modulus & $\mathrm{GPa}$ \\
$K_{\mathrm{S}}$ & Bulk modulus & $\mathrm{GPa}$ \\
$\mu$ & Poisson's ratio & $\mathrm{dimensionless}$ \\
$\nu$ & Velocity & $\mathrm{m} \mathrm{s}$ \\
$\tau$ & Shear stress & $\mathrm{GPa}$ \\
$\epsilon$ & Strain, also true strain & $\%$, in $/$ in \\
$\epsilon$ & Creep, also strain rate & $t^{-1}$ \\
$\sigma$ & Compressive stress & $\mathrm{MPa}, \mathrm{GPa}$ \\
$\left(\sigma_{1}-\sigma_{3}\right)$ & Differential stress & $\mathrm{MPa}, \mathrm{GPa}$ \\
$t$ & Time & $\mathrm{min}, \mathrm{h}, \mathrm{s}$ \\
$H$ & Hardness & $\mathrm{kg} \mathrm{mm}$ \\
$T$ & Temperature & $\mathrm{K}$ \\
$\sigma_{1}$ & Tensile stress & $\mathrm{MPa}$ \\
$\Delta L$ & Change in length & $\mathrm{cm}$ \\
\hline
\end{tabular}

\section{Conversion Factors}

\begin{tabular}{|c|c|c|}
\hline \multicolumn{3}{|l|}{ Pressure } \\
\hline To convert from & to & Multiply by \\
\hline $\begin{array}{l}\mathrm{MPa} \\
\mathrm{MPa} \\
\mathrm{GPa} \\
\mathrm{GPa}\end{array}$ & $\begin{array}{l}\text { lb in }{ }^{-2}(p, s i) \\
\text { kbar } \\
\mathrm{lb} \mathrm{in}^{-2}(\mathrm{psi}) \\
\mathrm{kbar} \\
\text { bar }\end{array}$ & $\begin{array}{l}1.45138 \times 10^{2} \\
1 \times 10^{-2} \\
1.45138 \times 10^{5} \\
10 \\
10 \times 10^{3}\end{array}$ \\
\hline \multicolumn{3}{|l|}{ Density } \\
\hline $\begin{array}{c}\text { To convert from } \\
\mathrm{kg} \cdot \mathrm{m}^{-3} \\
\mathrm{~kg} \cdot \mathrm{m}^{-3}\end{array}$ & $\begin{array}{l}\text { to } \\
\mathrm{lb} \cdot \mathrm{ft}^{-3} \\
\mathrm{~g} \cdot \mathrm{cm}^{-3}\end{array}$ & $\begin{array}{l}\text { Multiply by } \\
0.06243 \\
1 \times 10^{-3} \\
\end{array}$ \\
\hline \multicolumn{3}{|l|}{ Temperature } \\
\hline $\begin{array}{c}\text { To convert from } \\
\mathbf{K}\end{array}$ & $\begin{array}{l}\text { to } \\
{ }^{\circ} \mathrm{C}\end{array}$ & $\begin{array}{l}\text { Subtract } \\
273.15\end{array}$ \\
\hline
\end{tabular}





\title{
Chapter 4
}

\section{Thermophysical Properties}

\author{
J. M. Y ang*
}

\section{Contents}

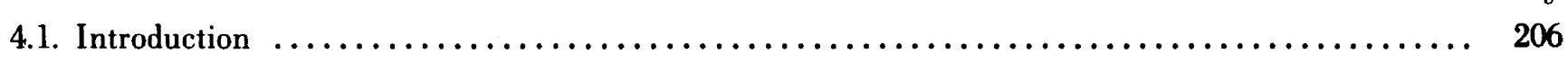

4.2. Review of Measurement Methods for Thermophysical Properties $\ldots \ldots \ldots \ldots \ldots \ldots \ldots \ldots \ldots \ldots \ldots 206$

4.2.1. Measurement Methods for Thermal Conductivity $\ldots \ldots \ldots \ldots \ldots \ldots \ldots \ldots \ldots \ldots \ldots \ldots \ldots$

4.2.1.1. Absolute, Longitudinal Steady-State Heat Flow Method ................. 206

4.2.1.2. Comparative, Longitudinal Steady-State Heat Flow Method $\ldots \ldots \ldots \ldots \ldots \ldots \ldots \ldots$

4.2.1.3. Absolute, Radial Steady-State Heat Flow Method .................... 207

4.2.1.4. Flash Method ..................................... 207

4.2.2. Measurement Methods for Thermal Expansion $\ldots \ldots \ldots \ldots \ldots \ldots \ldots \ldots \ldots \ldots \ldots \ldots \ldots \ldots . \ldots \ldots$

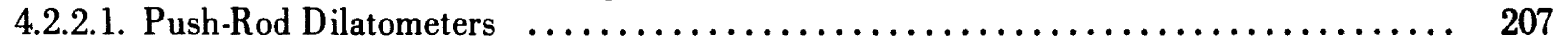

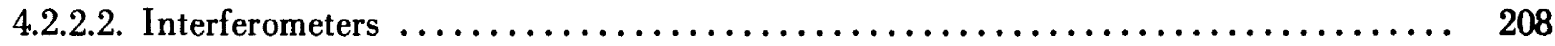

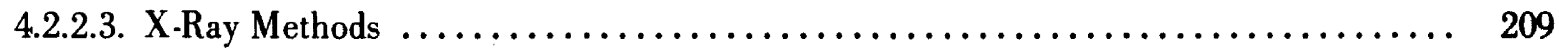

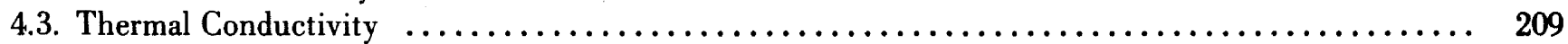

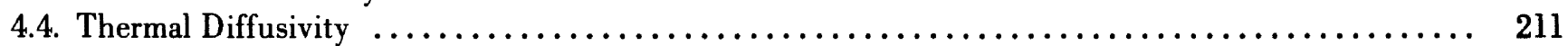

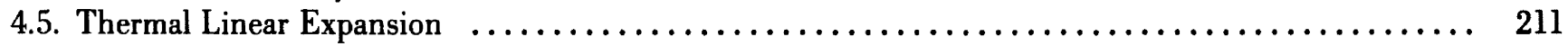

4.6. Effect of Nuclear Irradiation on Thermophysical Properties $\ldots \ldots \ldots \ldots \ldots \ldots \ldots \ldots \ldots \ldots \ldots \ldots .212$

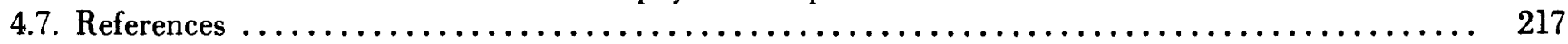

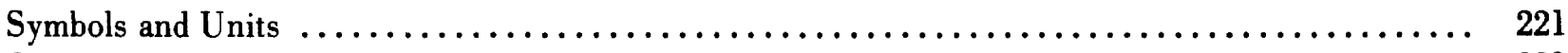

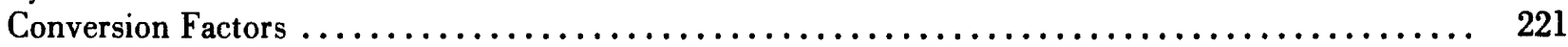

*Center for Information and Numerical Data Analysis and.Synthesis, Purdue University, 2595 Yeager Road, West Lafayette, Indiana 47906 


\subsection{Introduction}

In this chapter the thermophysical properties (thermal conductivity, thermal diffusivity, and thermal linear expansion) of rock salt are discussed. Recommended values which were generated from the analysis and synthesis of the available experimental data are presented. In spite of the fact that the study of molten salts has increased notably in the past thirty years, experimental data on molten rock salt are still very scanty. As a consequence, no recommended values were generated for thermal conductivity above the melting point. Recommended values of the thermal diffusivity were derived by correlating the recommended values of thermal conductivity, specific heat, and thermal expansion. In those cases where the reported values are not adequately substantiated by experimental data or where the material cannot be uniquely characterized, the term "typical" values is used. No attempt was made to estimate the thermal diffusivity beyond the melting point.

The data sets upon which the recommended values are based are shown in the various figures for the respective properties. Additional data sources are given as references.

\subsection{Review of Measurement Methods for Thermophysical Properties}

Many different methods and variations for measuring the thermophysical properties of solids have been developed, especially in the past fifty years. In this section, only the methods that are frequently used for measuring rock salts will be described and discussed.

It is noted that the only commonly used method for measuring thermal diffusivity, the flash method, is often employed (together with independently-obtained specific heat values) to obtain thermal conductivity values. This method will be discussed in section 4.2.1. entitled "Measurement Methods for Thermal Conductivity".

\subsubsection{Measurement Methods for Thermal Conductivity}

\subsubsection{Absolute, Longitudinal Steady-State Heat Flow Method}

In the absolute, longitudinal heat flow method, the experimental arrangement is so designed that the flow of heat is nearly entirely in the axial direction of a rod (or disk) specimen. The radial heat loss or gain of the specimen can either be prevented or minimized and evaluated. Under steady-state condition and assuming no radial heat loss or gain, the thermal conductivity is determined by the following expression which is from the one-dimensional Fourier-Biot heat-conduction equation

$$
k=-\frac{q \Delta x}{A \Delta T}
$$

where $k$ is the average thermal conductivity corresponding to the average temperature $1 / 2 \cdot\left(T_{1}+T_{2}\right), \Delta T=T_{2}-T_{1}$, $q$ is the rate of heat flow, $A$ is the cross-sectional area of the specimen, and $\Delta x$ is the distance between points of temperature measurements for $T_{1}$ and $T_{2}$.

In this method, the specimen used is in the form of a relatively long rod or disk (for poor conductors) so as to produce an appreciable temperature drop along the specimen for precise measurement. A source of heat at a constant temperature is supplied at one end of the rod (or one side of the disk). Heat flows axially through the rod (or disk) to the other end (or side) where a heat sink at a lower constant temperature is located. The radial heat loss or gain of the rod (or disk) should be negligible. In order to calculate the thermal conductivity from equation (4.1), it is necessary to measure the rate of heat flow into and/or out of the rod (or disk), the crosssectional area, the temperature of at least two points along the rod (or of two sides of the disk), and the distance between these points (or the thickness of the disk). This method has been used for most measurements below room temperature. General reviews of the lowtemperature measurements and experimental techniques have been presented by White $[83,84]$. For details of some of the useful low-temperature apparatus the reader may consult references [85-96].

While this method is inherently capable of high precision and accuracy, experience has shown that uncertainties of approximately one percent are attained at room temperature and lower. This figure rises to three percent at high temperatures.

\subsubsection{Comparative, Longitudinal Steady-State Heat Flow Method}

In this method a reference sample (or samples) of known thermal conductivity is placed in series with the unknown specimen with hopefully the same rate of heat flow through both the reference sample and the specimen. Under such ideal conditions, the thermal conductivity of the specimen is given by

$$
k=k_{\mathrm{r}} \frac{A_{\mathrm{r}}(\Delta T / \Delta x)}{A(\Delta T / \Delta x)} \mathrm{r}
$$

where the subscript $\mathbf{r}$ designates the reference sample. 
This method may be divided into two distinct groups: the "long-specimen" type [97-99] for measuring the thermal conductivity of good conductors, and the "short-specimen" type [36,101-104] for measuring poor conductors.

Comparative methods have the advantages of simple apparatus, easier specimen fabrication, and easier operation. Their disadvantages include additional measurement errors due to the required additional measurement of temperatures and thermocouple separations, difficulty in matched guarding against radial heat loss (or gain), and lower accuracy due to the additional uncertainty in the conductivity of the reference sample, the conductivity mismatch between specimen and reference sample, and due to the interfacial thermal contact resistance. These have been carefully analyzed by Laubitz [105] and Flynn [106]. The accuracy of the method is limited by the uncertainties in the reference material used. Normally this may be as high as two or three percent.

\subsubsection{Absolute, Radial Steady-State Heat Flow Method}

This method uses a specimen in the form of a right circular cylinder with a coaxial central hole, which contains either a heater or a heat sink, depending on whether the de red heat flow direction is to be radially outward or inw:. d. In the earlier experiments and also in many later designs [107-110], end guards are not employed. The effect of heat losses from the ends of the specimen is minimized by using a long specimen and monitoring the heater power within only a small section of the specimen away from the ends.

The guarded cylindrical method employing end guards at both ends of the specimen to prevent axial heat losses was developed by Powell [111] and first reported in 1939 for measurements on Armco iron at high temperatures. In this method the specimen is composed of stacked disks with a coaxial central hole containing either a heater or a heat sink. Temperatures are measured either by thermocouples or by an optical pyrometer.

The thermal conductivity is calculated from the expression

$$
k=\frac{q \ln \left(r_{2} / r_{1}\right)}{2 \pi l\left(T_{1}-T_{2}\right)}
$$

where $l$ is the length of the central heater and $T_{1}$ and $T_{2}$ are temperatures measured at radii $r_{1}$ and $r_{2}$, respectively.

For details of some of the useful apparatus employing the guarded cylindrical method, the reader may consult references [111-117]. The uncertainties in this method are normally those encountered in the absolute radial method.

\subsubsection{Flash Method}

The flash method is a variant of the absolute, longitudinal transient heat flow method using a small thin disk specimen. In this method, a flash of thermal energy is supplied to one of the ${ }^{-}$surfaces of the disk specimen within a time interval that is short compared with the time required for the resulting transient flow of heat to propagate through the specimen. This method was developed by Parker, Jenkins, Butler, and Abbott [118] and reported in 1961.

In use, a heat source such as flash tube or laser supplies a flash of energy to the front face of a thin disk specimen and the temperature as a function of time at the rear face is automatically recorded. The thermal diffusivity is obtained from the thickness of the specimen, $l$, and a specific time, $t_{y_{2}}$, at which the back face temperature reaches half its maximum value by the expression

$$
\alpha=1.37 l^{2} / \pi^{2} t_{1 / 2}
$$

The thermal conductivity of the specimen is then calculated by the relation

$$
k=\rho \alpha_{p}
$$

where $k$ is the thermal conductivity, $\rho$ is the density, and $c_{p}$ is the specific heat at constant pressure.

Subsequent improvements on this method have been made $[119,110]$ by the application of corrections for the finite pulse-time effect and the radiation-loss effect. Current capabilities exhibit an uncertainty of the order of five to ten percent depending on sample transparency and temperature level.

\subsubsection{Measurement Methods for Thermal Expansion}

\subsubsection{Push-Rod Dilatometers}

The push-rod dilatometer method for measuring thermal expansion is experimentally simple, reliable, and easy to automate [121]. With this method, the expansion of the specimen is transferred out of the heated zone to an extensometer by means of rods (or tubes) of some stable material. The expansion of the specimen is given by

$$
\frac{\Delta L}{L_{0}}=c_{0} \frac{(\Delta L)_{\mathrm{a}}}{L_{0}}+c_{1}
$$

where $(\Delta L)_{\mathrm{a}}$ is the apparent change in length as calculated from the difference between the extensometer readings at two different temperatures, and $c_{0}$ and $c_{1}$ are calibration constants for the system. If the reference rod 
is made the same length as the push rod and a second specimen placed on the base plate, the dilatometer will measure the difference between the specimens [122]. The difference, or differential expansion is given by

$$
\frac{(\Delta L)_{2}}{L_{0}}-\frac{(\Delta L)_{1}}{L_{0}}=c_{0} \frac{(\Delta L)_{\mathbf{a}}}{L_{0}}+c_{1} \text {. }
$$

When used this way the dilatometer can have a very high sensitivity. This technique is also very useful for quality control measurements and for studying phase transitions.

One of the most common sources of error in using dilatometers is the measurement of temperature. All too often the temperature that is measured is not the temperature of the specimen. If a thermocouple is used, care must be taken to ensure that its junction and specimen are the same temperature; they can be at different temperatures even if in contact with each other. Another common source of error, especially for flexible materials or materials near their softening temperatures, is deformation under the load of the push rod. Special techniques such as increasing sample diameter, reducing push rod pressure, and using horizontal mounts must be used for these soft materials.

The uncertainty of this method depends on the quality of the push rod used and precision of construction. Results of two or three percent uncertainty may be achieved routinely.

\subsubsection{Interferometers}

These methods are based on the interference of monochromic light reflected from two surfaces [123] that are separated by a specimen or by the combination of a specimen and a reference material. The general condition for interference is

$$
2 n L \cos \theta=N \lambda_{\nu}
$$

where $n$ is the index of refraction of the atmosphere between the surfaces, $L$ the distance between the two surfaces, $\theta$ the angle between the direction of the incident rays and the direction normal to the surfaces, $N$ the order of interference, and $\lambda_{\nu}$ the wavelength of the light in vacuum. Monochromatic light sources that may be used include cadmium, helium, mercury, and sodium low-pressure discharge lamp [124] and a stabilized He-Ne laser [125].

If slightly inclined surfaces are illuminated with collimated light and viewed at normal incidence $(\theta=0$ for all rays), fringes of equal inclination are observed. When the surfaces are flat the fringes will be straight; otherwise they are determined by the contour of the surfaces. This type of interference is used in the Fizeau interferometer
[126]. If plane-parallel surfaces are illuminated with an extended source ( $\theta$ will vary), fringes of equal inclination are observed. This type of interference (concentric rings) is used in the Fabry-Perot interferometer [127].

When an interferometer is used to measure thermal expansion, the expansion of the specimen is given by

$$
\frac{\Delta L}{L}=\frac{\lambda_{\nu} \Delta N}{2 n L \cos \theta}-\frac{\Delta n}{n}
$$

where $\Delta N$ is the number of the fringes that pass a fiducial mark and $\Delta n$ is the change of refractive index. A useful approximation for the refractive index is

$$
n=1+\left(n_{r}-1\right) \frac{T_{r} P}{P_{r} T}
$$

where $n_{\mathrm{r}}$ is the index at the reference temperature $T_{\mathrm{r}}$ and the reference pressure $P_{\mathrm{r}}$. In vacuum or in sufficiently low-pressure atmosphere

$$
\frac{\Delta L}{L}=\frac{\lambda_{\nu} \cdot \Delta N}{2 L \cdot \cos \theta}
$$

In a Fizeau interferometer (straight fringes) the fractional part of $\Delta N$ is easily determined from measurements of the position of the fiducial mark between two fringes. In a Fabry-Perot interferometer (circular fringes) the fractional part, $v$ is given by

$$
\nu=1-p+\frac{n L d_{p}^{2}}{\mathrm{f}^{2} \lambda_{\nu}}
$$

where $d_{p}$ is the diameter of the $p$ th fringe (counted from the center of the concentric pattern) and $f$ is the focal length of the lens that forms the pattern. If measurements are made on the second and fourth fringes, the fractional part is

$$
\nu=\frac{3 d_{2}^{2}-d_{4}^{2}}{d_{4}^{2}-d_{2}^{2}}
$$

The number of fringes that move past a reference point during the expansion of a specimen can be counted by eye or automatically by photographic [128] or photoelectric [129] techniques. Another way of determining $\Delta N$ is by finding the value of $N$ at each temperature. This can be done by using at least three different wavelengths [124]. From eq (4.8) it can be seen that

$$
\left(N_{1}+\nu_{1}\right) \lambda_{1}=\left(N_{2}+\nu_{2}\right) \lambda_{2}=\left(N_{3}+\nu_{3}\right) \lambda_{3}
$$

where $N_{1}, N_{2}$, and $N_{3}$ are the fringe integers and $\nu_{1}, \nu_{2}$, and $\nu_{3}$ are the fringe fractions for each of the three wavelengths. In the method of exact fractions a value is 
guessed for $N_{1}\left(\sim 2 n L / \lambda_{1}\right)$ and using the measured value of $\nu_{1}$ the values of $\left(N_{2}+\nu_{2}\right)$ and $\left(N_{3}+\nu_{3}\right)$ are calculated. This procedure is repeated with different values of $N_{1}$ until the calculated values of $\nu_{2}$ and $\nu_{3}$ agree with their measured values. If $N$ is known, then

$$
\frac{\Delta L}{L}=\frac{\Delta N}{N}-\frac{\Delta n}{n} \text {. }
$$

The Fizeau interferometer can be used to measure either the absolute or relative expansion of a specimen. In the relative method a pedestal of one material fills most of space within a ring or cylinder of a second material. The pedestal is preferably made of a reference material. While the ring supports the optical flat, the interference is formed by reflections from the optical flat and the top surface of the pedestal. Since the reflecting surfaces are close together this method has three advantages: (1) the fringes are bright and well defined; (2) the change of the refractive index of the gas within the small space does not affect the measurements; and (3) longer specimens can be used with a corresponding increase in sensitivity. The thermal expansion is given by

$$
\left[\frac{\Delta L}{L}\right]_{s}=\frac{\lambda_{\nu} \Delta N}{2 n L_{s}}+\frac{L_{r}}{L_{s}}\left[\frac{\Delta L}{L}\right]_{r}+\frac{L_{s}-L_{r}}{L_{s}} \frac{\Delta n}{n}(4.16)
$$

where the subscripts $s$ and $r$ refer to the specimen and reference materials. When $\mathrm{L}_{\mathrm{r}} \sim \mathrm{L}_{s}$ the last term can be ignored.

\subsubsection{X-Ray Methods}

These methods are based on the diffraction of a collimated beam of monochromatic $x$-rays that is scattered by atoms in a crystal lattice. The Bragg law

$$
\lambda=2 d(h k l) \sin \theta
$$

gives the condition for constructive reflection of the incident radiation. Here $d$ is the separation of the lattice planes, $h, k$, and $l$ are the Miller indices for the planes, and $\theta$ is the angle measured between the direction of the incident or reflected beam and the planes. Except for a small correction due to refraction, the measurement of expansion is independent of wavelength such that

$$
\frac{\Delta d(h k l)}{d(h k l)}=-\cos \theta \Delta \theta=\frac{\sin \theta_{1}-\sin \theta_{2}}{\sin \theta_{2}}(4.18)
$$

where $\theta_{1}$ and $\theta_{2}$ are the angles of incidence of the beam with the crystal plane at temperatures $T_{1}$ and $T_{2}$, respectively.

The thermal expansion of crystalline materials can be accurately measured with $x$-ray cameras and diffractometers under conditions that preclude the use of any other method, as when the specimens are very small, weak, and/or irregular in shape. These methods are also unique in that they can easily be used to determine the principal coefficients of thermal expansion of anisotropic crystals and permit direct observation of phase changes. There is a further advantage in that measurements with $\mathrm{x}$-rays do not include effects that are observed in measurements on bulk specimens. The problems associated with heating the specimen and accurately measuring its temperature in both $x$-ray cameras and diffractometers are discussed in several articles [131-133].

Unique $\mathbf{x}$-ray techniques exist for special situations. In particular, the use of the Bond technique for single crystals [134] has resulted in a sensitivity of $10^{-7}$ in measurements of $\Delta a / a$ [135]. In this technique the specimen is rotated between equivalent diffracting orientations on either side of the incident beam. The value of $\theta$ thus obtained is unaffected by any specimen eccentricity, absorption, and zero errors, and errors due to specimen tilt and beam axial divergence are minimized.

The inherent accuracy of this technique is extremely high for well characterized and stable materials.

\subsection{Thermal Conductivity}

The thermal conductivity of different samples of rock salt can be different by four orders of magnitude, depending on the temperature region. This variation is dependent upon the degree of lattice imperfection, the various treatments before the measurement, and the kind and the amount of impurities present in the sample.

Figure 4.1 shows several types of thermal conductive behavior of rock salts with different treatments. Group 1 represents the thermal conductivity of high-purity rock salt $[1-8,16]$. Based on the data in this group, recommended values for pure rock salt were generated for temperatures above $100 \mathrm{~K}$ and are tabulated in table 4.1. Those tabulated values below $100 \mathrm{~K}$ are merely typical values. The recommended values are considered accurate to within $\pm 5 \%$. Rock salts which were annealed at different temperatures are represented by group 2 $[9,10]$. The thermal conductivity of samples with different amounts of $\mathrm{Na}[2]$ and $\mathrm{NaOH}[7,8]$ are shown in group 3 and group 4, respectively. Data for rock salts which were melted, treated with $\mathrm{Cl}_{2}$, and recrystallized are also shown, group 5 [7]. Finally, data for rock salts with unknown impurities are represented by group 6 $[5,11]$.

It should be noted that at temperatures below $100 \mathrm{~K}$, the thermal conductivity of rock salt is inversely proportional to the quantity of the added impurity. However, at temperatures higher than $100 \mathrm{~K}$, the thermal conductivity seems to be insensitive to the impurity content. 


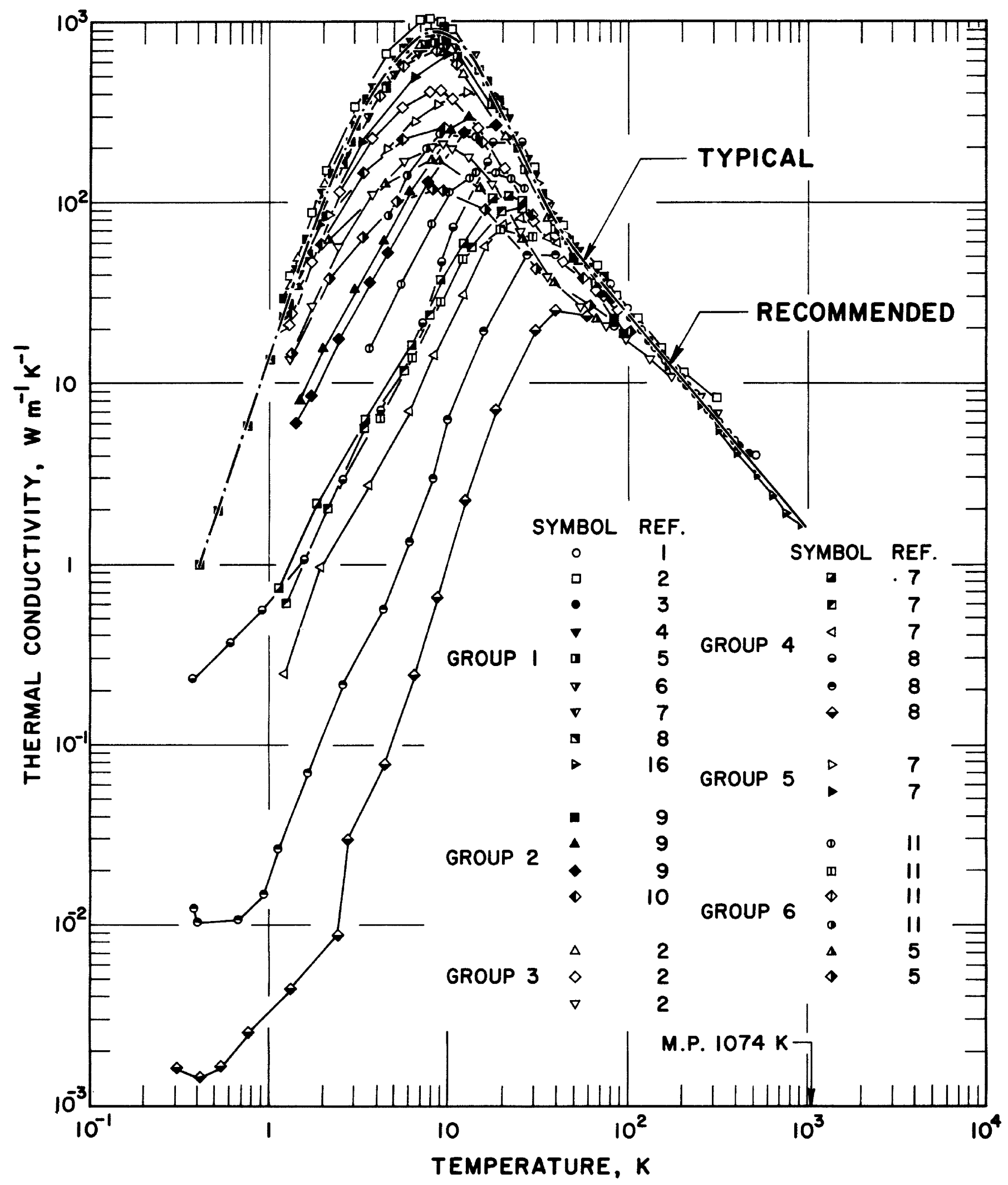

Figure l.1. Therma1 Conductivity of Rock Salt. 
TABLE 4.1. RECOMMENDED VALUES OF THE THERMAL CONDUCTIVITY OF ROCK SALT*

[Temperature, $\mathrm{T}, \mathrm{K}$; Thermal Conductivity, $\mathrm{k}, \mathrm{Wm}^{-1} \mathrm{~K}^{-1}$ ]

$\begin{array}{cccc}T & k & T & k \\ 0.4 & 0.95 & 25 & 191 \\ 0.5 & 1.78 & 30 & 130 \\ 0.6 & 3.13 & 40 & 75.0 \\ 0.7 & 4.97 & 50 & 54.0 \\ 0.8 & 7.40 & 75 & 34.9 \\ 0.9 & 10.0 & 100 & 24.3 \\ 1 & 14.0 & 150 & 15.0 \\ 2 & 99.3 & 200 & 10.9 \\ 3 & 270 & 250 & 8.24 \\ 4 & 443 & 293 & 6.65 \\ 5 & 595 & 300 & 6.57 \\ 6 & 735 & 400 & 4.80 \\ 7 & 820 & 500 & 3.67 \\ 8 & 880 & 600 & 2.98 \\ 9 & 870 & 700 & 2.47 \\ 10 & 836 & 800 & 2.08 \\ 15 & 502 & 900 & 1.85 \\ 20 & 306 & 1000 & 1.67\end{array}$

*Those below $100 \mathrm{~K}$ are typical values.

There are a number of additional references where the thermal conductivity of rock salt, either pure or impure, is reported $[12-15,17-43,45,136-140,148-152]$.

\subsection{Thermal Diffusivity}

There are very few experimental data available for the thermal diffusivity of rock salt. Consequently, the thermal diffusivity values are derived from the recommended values of the thermal conductivity, the specific heat, and the density computed from the recommended thermal expansion values.

The equation used to calculate the thermal diffusivity can be expressed as

$$
\alpha=\frac{k}{c_{p} \rho}
$$

where $\alpha$ is the thermal diffusivity, $k$ is the thermal conductivity, $c_{p}$ is the specific heat at constant pressure, and $\rho$ is the density. The density at temperature $T$ can be calculated from the equation [44]

$$
\rho=\rho_{0}\left(1+3 \frac{\Delta L}{L_{0}}\right)^{-1}
$$

where $\rho_{0}\left(=2.16 \mathrm{~g} / \mathrm{cm}^{3}\right)$ is the density of rock salt at room temperature $(293 \mathrm{~K})$, and $\Delta L=L-L_{0}, L$ and $L_{0}$ being the lengths at temperature $T$ and at room temperature, respectively.

The thermal diffusivity values so calculated are plotted in figure 4.2 and tabulated in table 4.2 . The values in the temperature region above $100 \mathrm{~K}$ can be considered with the uncertainty of $\pm 5 \%$. Some experi- mental data for the thermal diffusivity of high-purity rock salt $[33,43]$ are also exhibited in the figure for comparison. It can be seen that the recommended values agree with the experimental data quite well. Other references on the thermal diffusivity of rock salt are $[46,47]$.

\subsection{Thermal Linear Expansion}

The quantity reported here for the thermal linear expansion of rock salt is the percent expansion, which is defined as $\Delta L / L_{0}(\%)$, where $\Delta L=L-L_{0}$, and $L$ and $L_{0}$ are the lengths at temperature $T$ and at room temperature $(293 \mathrm{~K})$, respectively. In figure 4.3 the recommended values of the thermal linear expansion and the selected experimental data sets which were used to generate the recommended values are shown. These recommended values are considered with the uncertainty of $\pm 5 \%$. The recommended values are also tabulated in table 4.3 , and can be represented approximately by the following equations:

$$
\begin{gathered}
\Delta L / L_{0}=-1.064+3.025 \times 10^{-3} T \\
+1.471 \times 10^{-6} T^{2}-8.559 \times 10^{-11} T^{3} \\
(293 \leqslant T<600 \mathrm{~K}) \\
\Delta L / L_{0}=-1.161+4.030 \times 10^{-3} T \\
-4.554 \times 10^{-7} T^{2}+1.285 \times 10^{-9} T^{3} \\
(600 \leqslant T<1074 \mathrm{~K})
\end{gathered}
$$

and

$\Delta L / L_{0}=-8.5462+0.012169 T \quad(1074 \mathrm{~K}<T)$ 
TABLE 4.2. RECOMMENDED VALUES OF THE THERMAL DIFFUSIVITY OF ROCK SALT*

[Temperature, T,K; Thermal Diffusivity, $10^{-4} \mathrm{~m}^{2} \mathrm{~s}^{-1}$ ]

\begin{tabular}{cccc} 
& \multicolumn{2}{c}{ Solid } & \multicolumn{2}{c}{ Solid } \\
$\mathrm{T}$ & $\alpha$ & 293 & 0.0353 \\
10 & 301 & 300 & 0.0349 \\
15 & 136 & 400 & 0.0249 \\
20 & 36.7 & 500 & 0.0186 \\
25 & 15.9 & 600 & 0.0149 \\
50 & 0.952 & 700 & 0.0123 \\
75 & 0.356 & 800 & 0.0103 \\
100 & 0.192 & 900 & 0.00915 \\
150 & 0.0955 & 1000 & 0.00827 \\
200 & 0.0628 & & \\
250 & 0.0459 & & \\
& &
\end{tabular}

Theoretical calculation of the thermal expansion of rock salt in the temperature range $0-300 \mathrm{~K}$ was conducted by White [69] using the Grüneisen relation; his results agreed with the experimental data.

Strictly speaking, the concept of thermal linear expansion does not apply to liquids and/or materials in the molten state. However, for ease of presentation and ease of comparison with room temperature dimensions, the quantity $\Delta L / L_{0}$, instead of the volumetric expansion, is presented also for the molten state. (For practical purposes, the volumetric expansion, $\Delta V / V_{0}$, can be equated to $\left.3 \Delta L / L_{0}\right)$. These values are calculated from volumetric thermal expansion data which were obtained from density measurements.

The theoretical calculation of the thermal expansion of molten rock salt was carried by Vilcu et al. $[57,58]$ and $\mathrm{Lu}$ [56] using Significant-Structure theory of liquid. Their results agreed well with the experimental data.

Additional experimental data on the thermal linear expansion are given in references $[28,41,48-50$, 6l-82,100,141-147].

\subsection{Effect of Nuclear Irradiation on Thermophysical Properties}

Experimental data on the thermophysical properties of rock salt which has been irradiated are lacking. Only three data sets on the thermal conductivity were reported [10], and no information on the thermal linear expansion and the thermal diffusivity could be found in the literature. Therefore, no recommended values for these thermophysical properties are generated. However, the available thermal conductivity data are plotted in figure 4.4 and tabulated in table 4.4. The recommended and typical curves for high-purity rock salt without nuclear irradiation (from section 4.2) are reproduced in figure 4.4 for comparison. All three sets are for specimens (Optovac sodium chloride) with approximate $\mathrm{OH}^{-1}$ concentration of $3 \mathrm{ppm}$ and $\gamma_{\text {rir- }}$ radiated, with $3.8 \times 10^{16} \mathrm{~F}$ centers $/ \mathrm{cm}^{3}$ (curve 1), 5.6 $\times 10^{17} \mathrm{~F}$ centers $/ \mathrm{cm}^{3}$ (curve 2 ), and $7.6 \times 10^{17} \mathrm{~F}$ centers $/ \mathrm{cm}^{3}$ (curve 3 ). It is seen from figure 4.4 that irradiation drastically reduced the thermal conductivity of rock salt at cryogenic temperatures. No data are available at or above room temperature. 


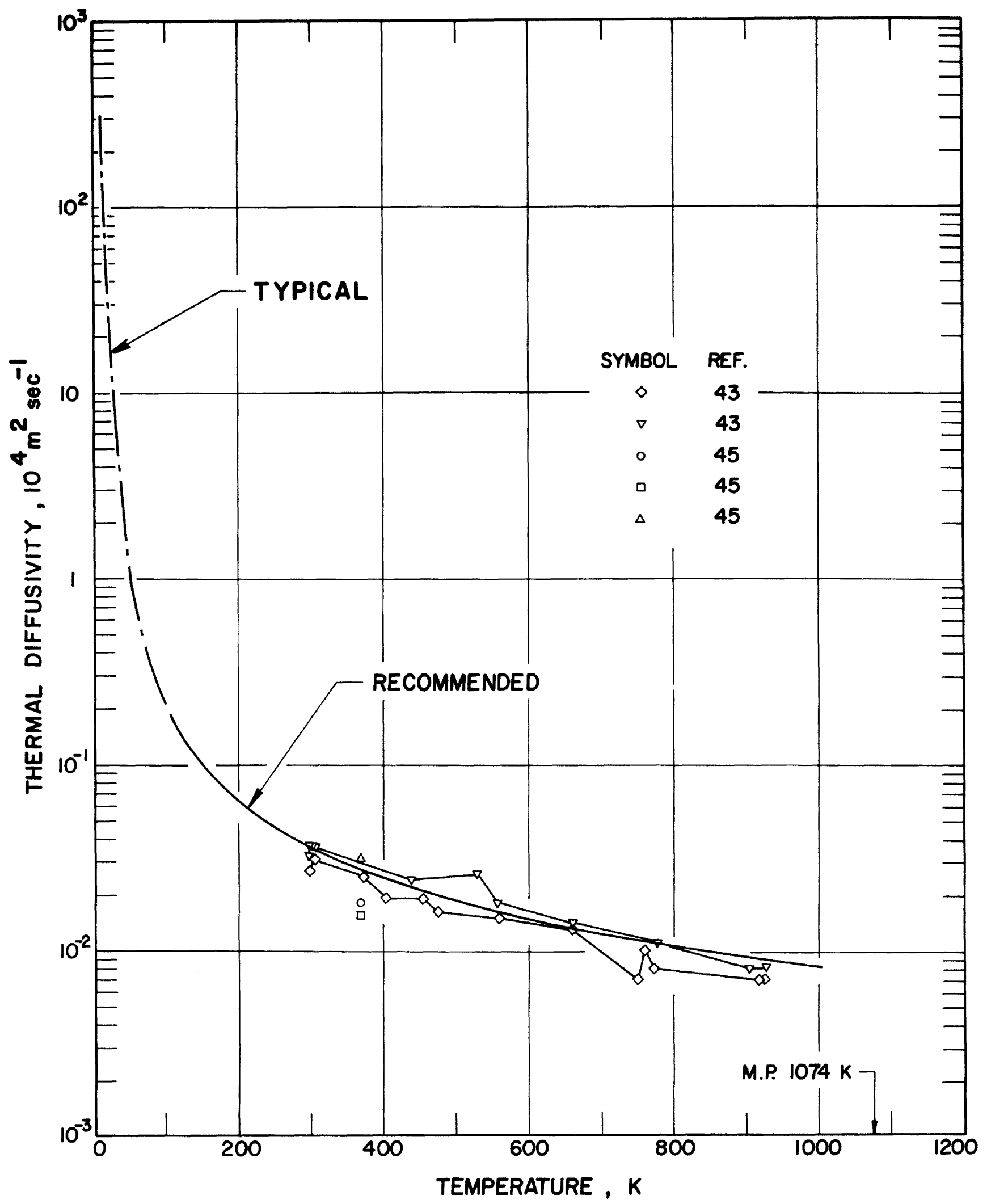

Figure 4.2. Therma1 Diffusivity of Rock Salt. 
TABLE 4.3. RECOMMENDED VALUES OF THE THERMAL LINEAR EXPANSION OF ROCR SALT

[Temperature, T,K; Thermal Linear Expansion, $\Delta L / L_{0}, \%$ ]

\begin{tabular}{rccr}
\multicolumn{1}{c}{$T$} & $\Delta \mathrm{L} / \mathrm{L}_{0}$ & $\mathrm{~T}$ & $\Delta \mathrm{L} / \mathrm{L}_{0}$ \\
5 & -0.772 & 600 & 1.371 \\
10 & -0.772 & 700 & 1.878 \\
15 & -0.772 & 800 & 2.430 \\
20 & -0.771 & 900 & 3.034 \\
25 & -0.771 & 1000 & 3.699 \\
50 & -0.759 & 1074 & 4.528 \\
75 & -0.722 & 1100 & 4.840 \\
100 & -0.666 & 1200 & 6.057 \\
150 & -0.521 & 1300 & 7.274 \\
200 & -0.352 & 1400 & 8.490 \\
250 & -0.168 & 1500 & 9.707 \\
293 & 0.000 & 1600 & 10.924 \\
400 & 0.448 & 1700 & 12.141 \\
500 & 0.896 & 1750 & 12.750
\end{tabular}

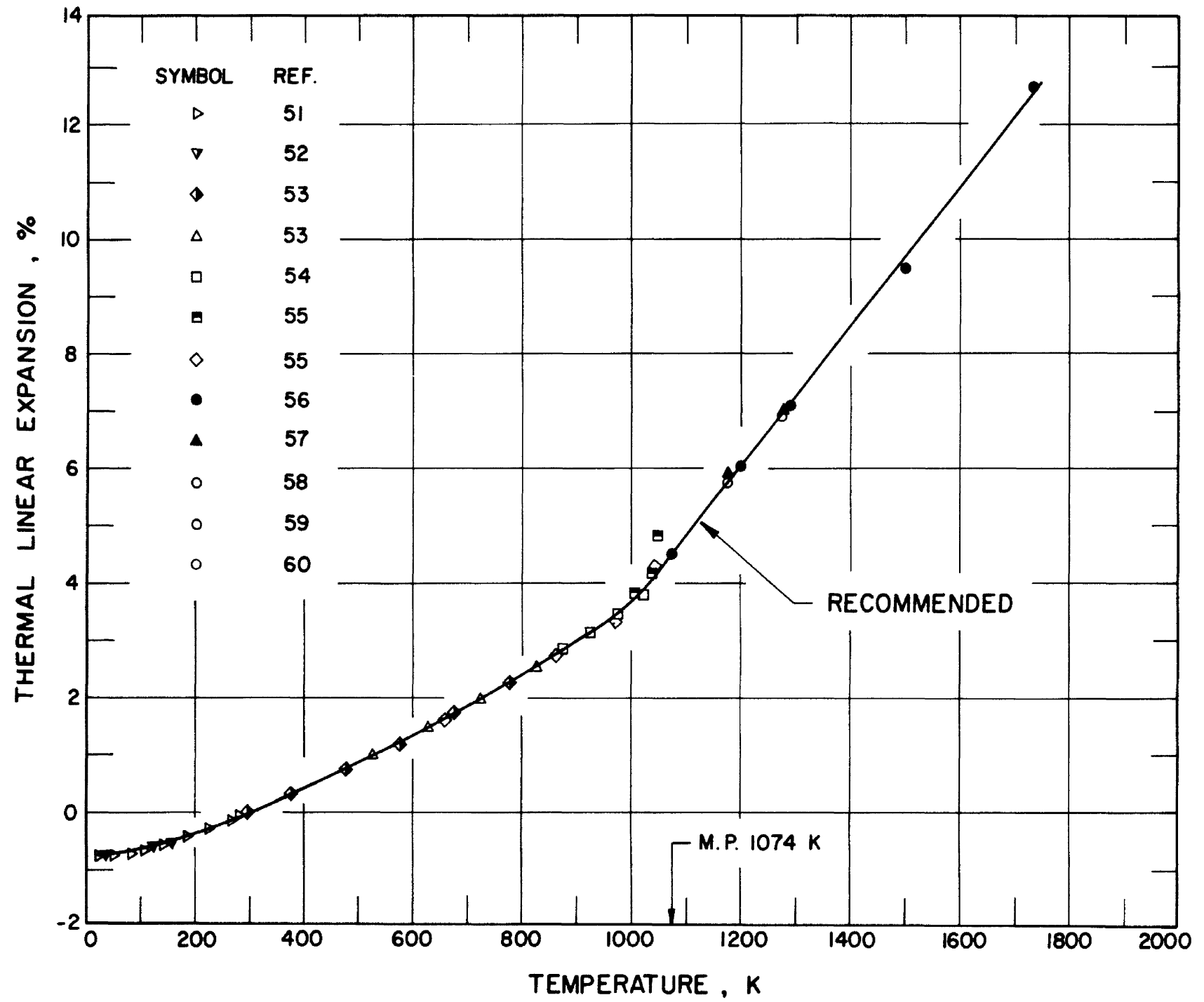

Figure 4.3. Thermal Linear Expansion of Rock Salt. 


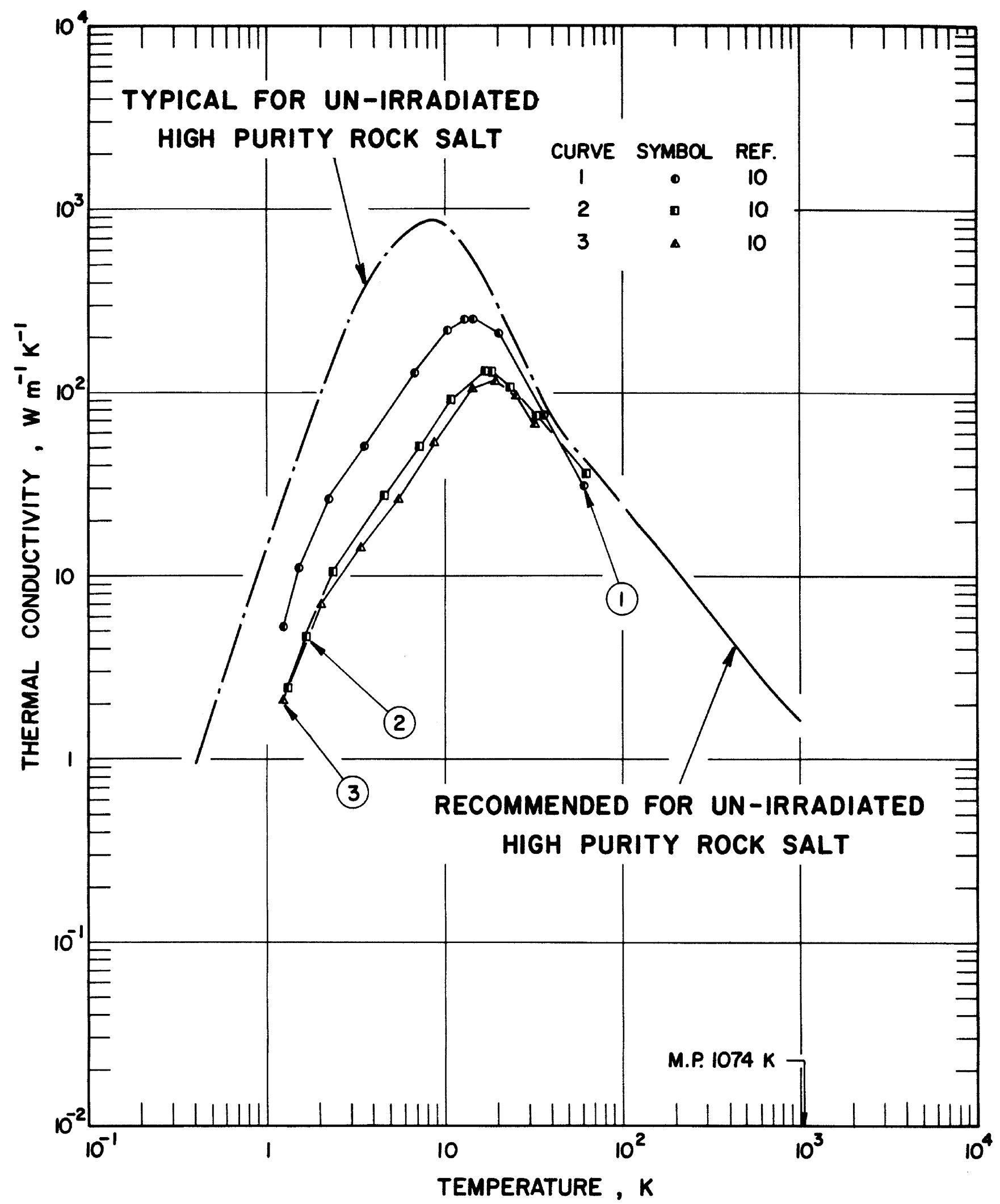

Figure 4.4. Thermal Conductivity of Irradiated Rock Salt. 
TABLE 4.4. EXPERTMENTAL DATA ON THE THERMAL CONDUCTIVITY OF ROCK SALT AFTER NUCLEAR IRRADIATION

[Temperature, T, K; Thermal Conductivity, $\mathrm{k}, \mathrm{Wm}^{-1} \mathrm{~K}^{-1}$ ]

\begin{tabular}{|c|c|c|c|c|c|}
\hline$\left(3.8 \times 10^{\frac{\mathrm{Cu}}{16}}\right.$ & $\frac{1}{\text { enters } / \mathrm{cm}^{3} \text { ) }}$ & $\left(5.6 \times 10^{\frac{\mathrm{Cu}}{17}}\right.$ & 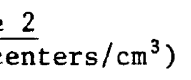 & $\left(7.6 \times 10^{\frac{C_{2}}{\Gamma}}\right.$ & 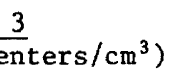 \\
\hline $\mathrm{T}$ & k & $\mathrm{T}$ & k & $T$ & $\mathrm{k}$ \\
\hline 1.26 & 5.19 & 1.33 & 2.43 & 1.26 & 2.10 \\
\hline $1.26 *$ & 5.89 & $1.47 *$ & 2.81 & $1.35 *$ & 2.70 \\
\hline $1.35 *$ & 6.33 & $1.53 *$ & 3.13 & $1.44 *$ & 3.17 \\
\hline $1.35 *$ & 7.18 & $1.58 *$ & 3.88 & $1.63 *$ & 4.24 \\
\hline $1.55 *$ & 9.95 & 1.70 & 4.74 & $1.84 *$ & 5.65 \\
\hline 1.55 & 11.30 & $1.95 *$ & 6.33 & 2.05 & 7.02 \\
\hline $1.75 *$ & 14.00 & $2.13 *$ & 7.87 & $2.40 *$ & 10.40 \\
\hline $1.82 *$ & 15.90 & 2.41 & 10.70 & $2.57 *$ & 11.00 \\
\hline $1.92 \star$ & 18.40 & $2.68 *$ & 13.10 & $2.91 *$ & 11.60 \\
\hline $2.02 *$ & 20.50 & $3.04 *$ & 15.70 & 3.41 & 14.70 \\
\hline $2.09 *$ & 23.70 & $3.38 *$ & 18.40 & $3.41 *$ & 18.00 \\
\hline 2.29 & 26.40 & $3.69 *$ & 20.90 & $3.79 *$ & 16.70 \\
\hline $2.41 *$ & 30.00 & $4.18 *$ & 24.60 & $4.13 *$ & 16.40 \\
\hline $2.73 *$ & 33.40 & 4.64 & 27.40 & $3.72 *$ & 20.70 \\
\hline $2.73 *$ & 38.00 & $5.16 *$ & 31.70 & $4.28 *$ & 18.30 \\
\hline $3.03 *$ & 44.70 & $5.44 *$ & 35.40 & $4.51 *$ & 20.00 \\
\hline 3.37 * & 48.90 & $6.05 *$ & 40.90 & $5.01 *$ & 23.10 \\
\hline 3.56 & 55.50 & $6.73 *$ & 46.40 & 5.57 & 26.20 \\
\hline $3.95 *$ & 64.20 & 7.35 & 51.70 & $6.08 *$ & 30.90 \\
\hline $4.24 *$ & 72.80 & $7.75 *$ & 57.60 & $6.87 *$ & 37.00 \\
\hline $4.55 *$ & 78.30 & $8.47 *$ & 62.00 & $7.77 *$ & 45.10 \\
\hline $5.06 *$ & 90.50 & $8.77 *$ & 66.60 & 8.94 & 54.00 \\
\hline $5.53 *$ & 103.00 & $9.09 *$ & 71.60 & $9.76 *$ & 63.60 \\
\hline $6.15 *$ & 115.00 & $9.75 *$ & 77.00 & $11.60 *$ & 81.90 \\
\hline 6.84 & 130.00 & 11.00 & 92.30 & $12.90 *$ & 92.90 \\
\hline $7.74 *$ & 148.00 & $12.50 *$ & 103.00 & 14.40 & 105.00 \\
\hline $8.02 *$ & 165.00 & $13.90 *$ & 115.00 & $15.90 *$ & 113.00 \\
\hline 9.07 * & 180.00 & $15.40 *$ & 128.00 & $17.70 *$ & 115.00 \\
\hline $9.57 *$ & 204.00 & 17.20 & 133.00 & 19.30 & 118.00 \\
\hline 10.40 & 220.00 & 18.40 & 133.00 & $21.50 *$ & 111.00 \\
\hline $11.60 *$ & 241.00 & $20.10 *$ & 130.00 & 25.60 & 96.40 \\
\hline 12.90 & 254.00 & $21.60 *$ & 128.00 & $27.50 *$ & 91.40 \\
\hline 14.60 & 254.00 & 23.20 & 119.00 & 32.80 & 68.50 \\
\hline 20.10 & 212.00 & $31.40 *$ & 87.60 & & \\
\hline $26.30 *$ & 151.00 & 33.10 & 77.20 & & \\
\hline 36.80 & 77.20 & $48.90 *$ & 46.50 & & \\
\hline $43.20 *$ & 56.80 & 63.80 & 36.80 & & \\
\hline $56.40 \star$ & 37.50 & & & & \\
\hline 61.60 & 31.90 & & & & \\
\hline
\end{tabular}

*Not plotted in the figure. 


\subsection{References}

[1] Devyatkova, E.D. and Smirnov, I.A., "Single Crystals of $\mathrm{NaCl}$ and $\mathrm{KCl}$ as Standard Materials in the Measurement of Thermal Conductivity in the Temperature Range 80-460 ${ }^{\circ}$ K," Sov. Phys-Solid State, 4(7), 1445-6 (1963). [AD 270 841]

[2] Klein, M.V. and Caldwell, R.F., "Low Temperature System for Thermal Conductivity Measurements," Rev. Sci. Instrum., 37(10), 1291-7 (1966).

[3] Lemanov, V.V. and Smirnov, I.A., "Thermal Conductivity of $\mathrm{NaCl}$ Single Crystals Containing Ca Impurities," Fiz. Tverd. Tela, 4(9), 2611-3 (1962).

[4] Singh, D.P. and Verma, G.S., "Variational Calculation of the Three-Phonon Umklapp Resistivity," Phys. Status Solidi, B59(1), 291-6 (1973).

[5] Schwartz, J.W., "Phonon Resonances in Some Alkali Halides Doped with Divalent Ions," Northwestern University, Ph.D. Thesis, 110 pp. (1967).

[6] Worlock, J.M., "Thermal Conductivity and Phonon Scattering in Alkali Halide Crystals Containing Colloidal Particles," Cornell University, Ph.D. Thesis, 163 pp. (1963). [Univ. Microfilms Order No. 63-2813].

[7] Klein, M.V., "Phonon Scattering in Sodium Chloride Containing Oxygen," Phys. Rev., 122(5), 1393-402 (1961).

[8] Rosenbaum, R.L., Chau, C.K., and Klein, M.V., "Thermal Conductivity of Alkali Halide Crystals Containing the Hydroxide Ion," Phys. Rev., 186(3), 852-64 (1969).

[9] Taylor, A., Albers, H.R., and Pohl, R.O., "Effect of Plastic Deformation on the Thermal Conductivity of Various Ionic Crystals," J. Appl. Phys., 36(7) 2270-8 (1965).

[10] Aldrich, R.E., Burke, W.J., and McCarthy, K.A., "Resonant Phonon Scattering in Colored Sodium Chloride Crystals," Solid State Commun., 5(11), 899-903 (1967).

[1]) Shvidkovskii, E.G. andZakharov, V.M., "Thermal Conductivity of Sodium Chloride at Helium Temperatures," Sov. Phys.Dokl., 12(4), 335-6 (1967).

[12] Eucken, A., "Über die Temperaturabhängigkeit der Warmeleitfahigkeit fester Nichtmetalle," Ann. Physik, 34(2), 185-22l (1911).

[13] McCarthy, K.A. and Ballard, S.S., "Thermal Conductivity of Eight Halide Crystals in the Temperature Range 220 to 390 ${ }^{\circ}$ K," J. Appl. Phys., 31(8), 1410-2 (1960).

[14] Birch, F. and Clark, H., "The Thermal Conductivity of Rocks and Its Dependence Upon Temperature and Composition," Am. J. Sci., 238, 529-58 (1940).

[15] Barclay, J.A., Rosemblum, S.S., and Steyert, W.A., "Low Temperature Thermal Conductivity of Some Composite Materials," Cryogenics, 16(9), 539-43 (1976).

[16] Petrov., A.V., Tsypkina, N.S., and Logachav, Yu.A., "Temperature Dependence of Thermal Conductivity in Alkali Halide Salts at Elevated Temperatures," Sov. Phys.-Solid State, 16(1), 39-42 (1974).

[17] Stephens, D.R., "High Temperature Thermal Conductivity of Six Rocks," USAEC Rept. UCRL-7605, 19 pp. (1963). [N64-15399]

[18] Fedorov, V.I. and Machuev, V.I., "Thermal Conductivity of Fused Salts," High Temp., 8(4), 858-60 (1970).

[19] Singh, D.P. and Verma, G.S., "Role of Longitudinal and Transverse Phonons in the Thermal Conductivity of Alkali Halides," Phys. Rev., B6(10), 4013-6 (1972).

[20] Fox, B.L., Soloman, S., and Goldschmidt, M., "Molecular Structures Studies and Other Related Research," U.S. Air Force Rept. AFML-TR-72-6, 38 pp. (1972).
[21] Ishioka, S. and Suzuki, H., "Phonon Scattering by Dislocations," J. Phys. Soc. Japan, 18, 93-8 (1963).

[22] Rosenbaum, R.L., "Tunneling Levels of the Hydroxide Ion in Some Alkali Halide Crystals," Phys. Lett. A, 43(2), 141-3 (1973)

[23] Petrov, A.V., Tsypkina, N.S., and Seleznev, V.E., "The Behavior of Lattice Thermal Conductivity of Crystals at High Temperatures," High Temp.-High Pressures, 8(5), 537-43 (1976).

[24] Chernen'kaya, E.I. and Vernigora, G.A., "Experimental Determination and Calculation of Thermal Conductivity of Liquors of the Ammonia-Soda Process," J. Appl. Chem. USSR 46(6), 1306-9 (1973).

[25] Brailey, R.H.E., "A Rapid Approximate Method for Computing the Thermal Conductivity of Crystals from Their Atomic Structure," in Proceedings of the 3rd Conference on Thermal Conductivity, Oak Ridge National Lab., 57-75 (1963).

[26] Herpin, A., "The Kinetic Theory of Solids," Ann. Phys., 7. 91-139 (1952).

[27] Dugdale, J.S. and MacDonald, D.K.C., "Lattice Thermal Conductivity," Phys. Rev., 98, 1751-2 (1955).

[28] Pretzel, E.E., Vier, S.T., Szklarz, F.G., and Lewis, W.B., "Radiation Effects on Lithium Hydride," USAEC Rept. LA-2463, 123 pp. (1961).

[29] Turnbull, A.G., "The Thermal Conductivity of Molten Salts. II. Theory and Results for Pure Salts," Austr. J. Appl. Sci., 12, 324-9 (1961).

[30] Wilson, H.W., Beahm, K.W., and Cooper, W.J., "Determination and Analysis of the Potentialties of Thermal Energy Storage Materials," U.S. Air Force Rept. ASD-TR-61-187, 113 pp., 1961. [AD 260 523]

[31] Acton, R.U., "Thermal Conductivity of S.E. New Mexico Rocksalt and Anhydrite," Sandia Labs. Rept. SAND-77-0962C, 24 pp. (1977).

[32] Mossahebi, M,. "Thermal Conductivity of Rocks by a Ring Source Device," University of California-Berkeley, M.S. Thesis, 77 pp. (1966).

[33] Somerton, W.H. and Boozer, G.D., "Thermal Characteristics of Porous Rocks at Elevated Temperatures," J. Petrol. Technol., 12. 77-81 (1960)

[34] Stephens, D.R. and Maimoni, A., "Thermal Conductivity of Rock Salt," USAEC Rept. UCRL-6894 (Rev. II), 15 pp. (1964).

[35] Benfield, A.E., "Terrestrial Heat Flow in Great Britain," Proc. Roc. Soc. (London), A 172, 428-50 (1939).

[36] Lees, C.H., "On the Thermal Conductivity of Crystals and Other Bad Conductors," Phil. Trans. Roy. Soc. London, 183, 481-509 (1892).

[37] Zierfuss, H., "Apparatus for the Rapid Determination of the Heat Conductivity of Poor Conductors," J. Sci. Instrum., 40, 69-71 (1963).

[38] Tiwari, M.D., "Optical-Acoustical Phonon Scatterings in the Lattice Thermal Conductivity or Kock Salt Crystals," in Proceedings of 2nd International Conference on Phonon Scattering in Solid. 373-6 (1976).

[39] Giesel, V.W., "Elastic Wave Velocities and Thermal Conductiv. ity in Rock Salt," Z. Geophys., 33, 9-32 (1967).

[40] Barker, R.E., Jr. and Chen, R.Y., "Grũneisen Parameter from Thermal Conductivity Measurements Under Pressure," J. Chem. Phys., 53(7), 2616-20 (1970).

[41] Ballard, S.S., McCarthy, K.A., and Wolfe, W.L., "Optical Materials for Infrared Instrumentation," IRIA Rept. No. 2389-11-S, 115 pp. (1959). 
[42] Smith, N.O., "The Difference Between $\mathrm{C}_{p}$ and $\mathrm{C}_{v}$ for Liquids and Solids," J. Chem. Educ., 42(12), 654-5 (1965).

[43] Smith, D.D., "Thermal Conductivity of Halite Using a Pulsed Laser," Oak Ridge Y =12 Plant Rept. Y/DA-7013, 39 pp. (1976).

[44] Kirby, R.K., "Thermal Expansion," Section 4f in American Institute of Physics Handbook, 2nd Edition, McGraw-Hill, New York, pp. 4-64 to 4-76 (1963).

[45] Fedoroz, V.I. and Machuev, V.I., "Thermal Conductivity of rused Salts," High Temp., 8(4), 858-60 (1970).

[46] Fujisawa, H., Fujii, N., Nizutani, H., and Akimoto, S., "Thermal Diffusivity of $\mathrm{Mg}_{2} \mathrm{SiO}_{4}, \mathrm{Fe}_{2} \mathrm{SiO}_{4}$, and Sodium Chloride at High Pressures and Temperatures," J. Geophys. Res., 73(14), 4727-33 (1968).

[47] Dickerson, R.W., "An Apparatus for the Measurement of Thermal Diffusivity of Foods," J. Food Technol., 19(5), 198-204 (880-6) (1965).

[48] White, G.K., "The Thermal Expansıon of Alkali Halides at Low Temperatures," Proc. Roy. Soc. 286A, 204-17 (1965).

[49] Buffington, R.M. and Latimer, W.M., "The Measurement of Coefficients of Expansion at Low Temperatures. Some Thermodynamic Applications of Expansion Data,"J. Amer. Chem. Soc., 48, 2305-19 (1926).

[50] Rubin, T., Johnston, H.L., and Altman, H.W., "Thermal Expansion of Rock Salt," J. Phys. Chem 65, 65-8 (1961).

[51] Yates, B. and Panter, C.H., "Thermal Expansion of Alkali Halides at Low Temperature," Proc. Phys. Soc., 80, 373-82 (1962).

[52] Meincke, P.P.M. and Graham, G.M., "Thermal Expansion of Sodium Chloride at Low Temperature," Proc. Int. Conf. Low Temperature Phys., 8th, 401-2 (1963).

[53] McKinstry, H.A., "Thermal Expansion of Alkali Halides and Their Solid Solutions," Pennsylvania State University, Ph.D. Thesis. 213 po. (1960).

[54] Patnak, P.D. and Vasavada, N.G., "Thermal Expansion of Sodium Chloride, Potassium Chloride, and Cesium Bromide by X-Ray Diffraction and the Law of Corresponding States," Acta Crystallogr., 26A(6), 655-8 (1970).

[55] Smirnov, M.V., Vasilevskaya, M.M., and Burov, G.V., "Properties of Potassium Chloride Crystals Near the Melting Point," Tr. Inst. Elektrokhim. Akad. Nauk. SSSR, Ural, Filial, 14, 88-90 (1970).

[56] Lu, W.C., "Significant Structure Theory Applied to Surface Tension. Significant Structure Theory Applied to Molten Salts," University of Utah, Ph.D. Thesis, 147 pp. (1968).

[57] Vilcu, R. and Misdolea, C., "Significant-Structure of Liquid, Heat Capacities, Compressibilities, and Thermal Expansion Coefficients of Some Molten Alkali Halides," J. Chem. Phys., 46(3), 906-9 (1967).

[58] Vilcu, R. and Misdolea, C., Significant Structure Theory of Ionic Binary Liquid Mixture, Heat Capacities, Compressibility Coefficients and Thermal Expansion Coefficients," Rev. Roum. Chim., 18(3), 387-98 (1973).

[59] Zuca, S. and Ionescu-Vasu, L., "Electric Conductance of Binary Mixtures of Molten Salts with Common Cation," Rev. Roum. Chim., 12, 1285 (1967).

[60] Van Artsdalen, E.R. and Y'affe, I.S., "Electric Conductance and Density of Molten Systems:KCl-LiCl, KCl-NaCl and KCl-KI," J. Phys. Chem, 59, 118 (1955).

[61] Meincke, P.P.M. and Graham, G.M., "The Thermal Expansion of Alkali Halides," Can J.Phys., 43(10) 1853-66 (1965).

[62] Combes, L.S., Ballard, S.S., and McCarthy, K.A.," "Mechanical and Thermal Properties of Certain Optical Crystalline Materials," J. Opt. Soc. Amer., 41(4), 215-22 (1951).
[63] Enck, F.D. and Dommel, J.G., "Behavior of the Thermal Expansion of $\mathrm{NaCl}$ at Elevated Temperatures," J. Appl. Phys., 36(3), 839-44 (1965).

[64] Antoniou, A.A. and Litvan, G.G., "Calorimeter for Simultanious Measurement of Thermal Properties and Dimensional Changes," Rev. Sci. Instr., 38(11), 1641-4 (1967).

[65] Hsu, Y.T., "Discontinuous Thermal Expansions and Phase Transformations in Crystals at Higher Temperatures," North Texas State University, Ph.D. Thesis, 118 pp. (1967).

[66] Laredo, E., "X-Ray Study of the Expansion of Sodium Chloride at High Temperature," J. Phys. Chem. Solids, 30(5), 1037-42 (1969).

[67] Srinivasan, R., "Thermal Expansion of Sodium and Potassium Chloride from Liquid Air Temperatures to $+300^{\circ} \mathrm{C}$," Indian Inst. Sci., 37A, 232-41 (1955).

[68] Fischmeister, H.E., "The Thermal Expansion of Sodium Chloride and Some Other Alkali Halides at High Temperatures," Acta Crystallogr., 9; 416-20 (1956).

[69] White, G.K. and Collins, J.G., "Thermal Expansion of Alkali Halides at Low Temperatures. II. Sodium, Rubidium, and Cesıum Halides," Proc. Roy. Soc. London, 333(1593). 237-59 (1973).

[70] Srivastava, K.K. and Merchant, H.D., "Thermal Expansion of Alkali Halides Above 300 K," J. Phys. Chem. Solids, 34(12), 2069-73 (1973).

[71] Rapp, J.E. and Merchant, H.D., "Thermal Expansion of Alkali Halides from 70 to $570 \mathrm{~K}$," J. Appl. Phys., 44(9), 3919-23 (1973).

[72] Case, C.R., II and Swenson, C.A., "Thermal Expansions of High-Purity and Hydroxide Doped Sodium Chloride at Temperatures Below 30 K," Phys..Rev. B, 9(10), 4506-11 (1974).

[73] Trost, K.F., "Thermal Expansion of Alkali Halides of the $\mathrm{NaCl}$ Type at High and Low Temperatures," Z. Naturforsch, 18B(8), 662-4 (1963).

[74] Case, C.R., McLean, K.O., Swenson, C.A., and White, C.K., "Thermal Expansion Coefficients for Alkali Halides Containing Defects," AIP Conf. Proc., 3, 183-7 (1972).

[75] Whittemore, D.0., "Thermai Expansion of Polycrystalline Alkali Halides," Bull. Amer. Ceram. Soc., 41(8), 5l3-5 (1962).

[76] Novozhilov, F.K., "Properties of Salt Cores," Russ. Castings Prod., 6, 239-40 (1974).

[77] Straumanis, M and Ievins, A., "The Lattice Constants of Sodium Chloride and Rock Salt," Z. Phys., 102, 353-9 (1936).

[78] Saini, H., "Thermal Expansion of Natural and Synthetic NaCl," Helv. Phys. Acta., 7, 494-500 (1934).

[79] Bockris, J.O'M. and Richards, N.E., "The Compressibilities, Free Volumes and Equation of State for Molten Electrolytes: Some Alkali Halides and Nitrates," Proc. Roy. Soc. (London), A241, 44-66 (1957).

[80] Eucken, A. and Dannohl, W., "Thermal Expansion of Some Alkali Halogenides and Metals at High Temperatures," Z. Elek'rochem., 40(11), 814-21 (1934).

[81] Basu, S. and Maitra, A.T., "Thermal Coefficient of Rock Salt by X-Ray Reflection," Indian J. Phys., 12, 305-16 (1938).

[82] Leaullue iter, A.J. and Newsham, D.M.Y., "Anharmonic Effect in the Thermodynamic Properties of Solids. III. A Liquid Gallium Immersion Dilatometer for the Range $50-700^{\circ} \mathrm{C}$. Thermal Expansivities of Mercury, Calcium. Sodium Chloride and Potassium Chloride," J.Phys. C., 2(1), 210-9 (1969). 
[83] White, G.K., Experimental Techniques in Low Temperature Physics, Oxford University Press, 1959; 2nd Ed. (1968).

[84] White, G.K., "Measurement of Solid Conductors at Low Temperatures," in Thermal Conductivity (Tye, R.P., Editor), Vol. 1, Chap. 2, Academic Press, London, 69-109 (1969).

[85] Lees, C.H., "The Effects of Temperature and Pressure on the Thermal Conductivity of Solids. Part II. The Effects of Low Temperature on the Thermal and Electrical Conductivities of Certain Approximately Pure Metals and Alloys," Phil. Trans. Roy. Soc. (London), A208, 381-443 (1908).

[86] Berman, R., "The Thermal Conductivities of Some Dielectrue Solids at Low Temperatures (Experimental)," Proc. Roy. Soc. (London), A208, 90-108 (1951).

[87] White, G.K., "The Thermal Conductivity of Gold at Low Temperatures," Proc. Phys. Soc. (London), A66, 559-64. (1953).

[88] Mendelssohn, K. and Renton, C.A., "The Heat Conductivity of Superconductors below 1 K," Proc. Roy. Soc. (London), A230, 157-69 (1955).

[89] Rosenberg, H.M., "The Thermal Conductivity of Metals at Low Temperatures," Phil. Trans. Roy. Soc. (London) A247, 441-97 (1955).

[90] White, G.K. and Woods, S.B., "Thermal and Electrical Conductivities of Solids at Low Temperatures," Can. J. Phys., 33, 58-73 (1955).

[91] Poweli, R.L., Rogers, W.M., and Coffin, D.O., "An Apparatus for Measurement of Thermal Conductivity of Solids at Low Temperatures," J. Res. Natl. Bur. Stand., 59(5), 349-55 (1957).

[92] Slack, G.A., "Thermal Conductivity of Potassium Chloride Crystals Containing Calcium," Phys. Rev., 105(3), 832-42 (1957).

[93] Williams, W.S., "Phonon Scattering in $\mathrm{KCl} \cdot \mathrm{KBr}$ Solid Solutions at Low Temperatures," Phys. Rev., 119(3), 1021-4 (1960).

[94] Slack, G.A., "Thermal Conductivity of $\mathrm{CaF}_{2}, \mathrm{MnF}_{2}, \mathrm{CoF}_{2}$, and ZnF ${ }_{2}$ Crystals," Phys. Rev., 122(5), 1451-64. (1961).

[95] Berman, R., Bounds, C.L., and Rogers, S.J., "The Effects of Isotopes on Lattice Heat Conduction. II. Solid Helium," Proc. Roy. Soc. (London), A289 (1416), 46-65 (1965).

[96] Jericho, M.H., "The Lattice Thermal Conductivity of Silver Alloys between $4 \mathrm{~K}$ and $0.3 \mathrm{~K}$," Phil. Trans. Roy. Soc. (London), A257, 385-407 (1965).

[97] Berget, A., "Measurement of the Coefficients of Thermal Conductivity of Metals," Compt. Rend., 107, 227-9 (1888).

[98] van Dusen, M.S. and Shelton, S.M., "Apparatus for Measuring Thermal Conductivity of Metals Up to $600^{\circ} \mathrm{C}$," J. Res. Natl. Bur. Stand., 12, 429-40 (1934).

[99] Powell, R.W., "The Thermal and Electrical Conductivity of a Sample of Acheson Graphite from 0 to $800^{\circ} \mathrm{C}$," Proc. Phys. Soc. (London), 49, 419-25 (1937).

[100] Adams, D.J. and McDonald, I.R., "Rigid-Ion Models of the Interionic Potentials in the Alkali Halides,"J. Phys. C, 7(16), 2761-75 (1974).

[101] Francl, J. and Kingery, W.D., "Apparatus for Determining Thermal Conductivity by a Comparative Method. Data for $\mathrm{Pb}, \mathrm{Al}_{2} \mathrm{O}_{3}, \mathrm{BeO}$, and $\mathrm{MgO}$," J. Am. Ceram. Soc., 37, 80-4 (1954).

[102] Stuckes, A.D. and Chasmar, R.P., "Measurement of the Thermal Conductivity of Semiconductors," Rept. Meeting on Semiconductors (Phys. Soc., (London), 119-25 (1956).

[103] ASTM, "Standard Method of Test for Thermal Conductivity of Whiteware Ceramics," ASTM Designation: C408-58, in 1967 Book of ASTM Standards, Part 13, 348-52 (1967).
[104] Mirkovich, V.V., "Comparative Method and Choice of Standards for Thermal Conductivity Determinations," J. Am. Ceram. Soc., 48(8), 387-91 (1965).

[105] Laubitz, M.J., "Measurement of the Thermal Conductivity of Solids at High Temperatures by Using Steady-State Linear and Quasi-Linear Flow," in Thermal Conductivity (Tye, R.P., Editor), Vol. 1, Chap. 3, Academic Press, London, 111-83 (1969).

[106] Flynn, D.R., "Thermal Conductivity of Ceramics," in Mechanical and Thermal Properties of Ceramics (Wachtman, J.B., Jr., Editors), NBS Spec. Publ. 303, 63-123 (1969).

[107] Kingery, W.D., "Thermal Conductivity. VI. Determination of Conductivity of $\mathrm{Al}_{2} \mathrm{O}_{3}$ by Spherical Envelope and Cylinder Methods," J. Am. Ceram. Soc., 37, 88-90 (1954).

[108] Feith, A.D., "A Radial Heat Flow Apparatus for HighTemperature Thermal Conductivity Measurements," USAEC Rept. GEMP-296, 29 pp. (1964).

[109] Glassbrenner, C.J. and Slack, G.A., "Thermal Conductivity of Silicon and Germanium from $3 \mathrm{~K}$ to the Melting Point," Phys. Rev. A, 134(4), 1058-69 (1964).

[110] Banaev, A.M. and Chekhovskoi, V.Ya., "Experimental Determination of the Coefficient of Thermal Conductivity of Solid Materials in the Temperature Range $200-1000^{\circ} \mathrm{C}$," Teplofiz. Vys. Temp., 3(1), 57-63, 1965; English translation: High Temp., 3(1), 47-52 (1965).

[111] Powell, R.W., "Further Measurements of the Thermal Electrical Conductivity of Iron at High Temperatures," Proc. Phys. Soc. (London), 51, 407-18 (1939).

[112] McElroy, D.L., and Moore, J.P., "Radial Heat Flow Methods for the Measurement of the Thermal Conductivity of Solids," in Thermal Conductivity (Tye, R.P., Editor), Vol. 1, Chap. 4, Academic Press, London, 185-239 (1969).

[113] Powell, R.W. and Hickman, M.J., "The Physical Properties of a Series of Steels. Part II. Section IIIc. Thermal Conductivity of a $0.8 \%$ Carbon Steel (Steel 7)," J. Iron Steel Inst. (London), 154, 112-21 (1946).

[114] Rasor, N.S. and McClelland, J.D., "Thermal Properties of Materials. Part I. Properties of Graphite, Molybdenum and Tantalum to Their Destruction Temperatures," U.S. Air Force Rept. WADC-TR-56-400 (Pt. I), 53pp. (1957). [AD 118 144]

[115] Rasor, N.S. and McClelland, J.D., "Thermal Property Measurements at Very High Temperatures," Rev. Sci. Instrum., $31(6)$, 595-604 (1960).

[116] McElroy, D.L., Godfrey, T.G., and Kollie, T.G., "The Thermal Conductivity of INOR-8 Between 100 and $800^{\circ} \mathrm{C}$," Trans. Am. Soc. Metals, 55(3), 749-51 (1962).

[117] Fulkerson, W., Moore, J.P., and McElroy, D.L., "Comparison of the Thermal Conductivity, Electrical Resistivity, and Seebeck Coefficient of a High-Purity Iron and an Armco Iron to $1000^{\circ}$ C," J. Appl. Phys., 37(7), 2639-53 (1966).

[118] Parker, W.J., Jenkens, R.J., Butler, C.P., and Abbott, G.L., "Flash Method of Determining Thermal Diffusivity, Heat Capacity, and Thermal Conductivity," J. Appl. Phys., 32(9), 1679-84 (1961).

[119] Cape, J.A. and Lehman, G.W., "Temperature and Finite PulseTime Effects in the Flash Method for Measuring Thermal Diffusivity," J.Appl. Phys., 34(7), 1909-13 (1963).

[120] Taylor, R.E. and Cape, J.A., "Finite Pulse-Time Effect in the Flash Diffusivity Technique," Appl. Phys. Letters, 5(10), 212-23 (1964).

[121] Clusener, G.R., "Economy Considerations for Pushrod-Type Dilatometers," in AIP Conf. Proc. No. 3-Thermal Expansion, American Institute of Physics, New York, 51-8 (1972). 
[122] Plummer, W.A., "Differential Dilatometry, A Powerful Tool," in AIP Com. Proc. No. 17-Thermal Expansion, American Institute of Physics, New York, 147-8 (1974).

[123] Jenkins, F.A. and White, H.E., Fundamentals of Optics, McGrawHill, New York, 637 pp. (1957).

[124] Candler, C., Modern Interferometers, The University Press, Glasgow, 502 pp. (1951).

[125] Plummer, W.A., "Thermal Expansion Measurements to $130^{\circ} \mathrm{C}$ by Laser Interferometry,)) in AIP Conf. Proc. No. 3 Thermal Expansion, American Institute of Physics, New York, 36-43 (1972).

[126] ASTM. "ASTM Method of Test, E289, for Linear Thermal Expansion of Rigid Solids with Interferometry," ASTM Standards, Part 41 (1974).

[127] Fraser, D.B. and Hollis-Hallet, A.C., "The Coefficient of Thermal Expansion of Various Cubic Metals Below $100 \mathrm{~K}$," Can. J. Phys., 43, 193-219 (1965).

[128] Saunders, J.B., "An Apparatus for Photographing Interference Phenomena," J. Res. Natl. Bur. Stand., 35, 157-86 (1945).

[129] Feder, R. and Charbnau, H.P., "Equilibrium Defect Concentration in Crystalline Sodium," Phys. Rev., 149, 464-71 (1966).

[130] Dyson, J., Interferometry as a Measuring Tool, Hunt Barnard Printing Ltd., Aylesbury, 206 pp. (1970).

[131] Merryman, R.G. and Kempter, C.P., "Precise Temperature Measurement in Debye-Scherrer Specimens at Elevated Temperatures," J. Amer. Ceram. Soc., 48, 202-5 (1965).

[132] Mauer, F.A. and Bolz, L.H., "Problems in the Temperature Calibration of an X-Ray Diffractometer Furnace," in Advances in X-Ray Analysis (Mueller, W.M., Editor), Vol. 5, Plenum Press, New York, 546 pp. (1961).

[133] Brand, J. A. and Goldschmidt, H.J., "Temperature Calibration of a High-Temperature X-Ray Diffraction Camera," J. Sci. Instrum., 33, 41-5 (1956).

[134] Mauer, F.A. and Hahn, T.A., "Thermal Expansion of Some Azides by a Single Crystal X-Ray Method," in AIPConf. Proc. 3-Thermal Expansion, American Institute of Physics, New York, 139-50 (1972).

[135] d'Heurle, F.M., Feder, R., and Nowick, A.S., "Equilibrıum Concentration of Lattice Vacancies in Lead and Lead Alloys," J. Phys. Soc. Japan, 18(Suppl. II), 184-90 (1963).

[136] Kaufman, D.W., Sodium Chloride: The Production and Properties of Salt and Brine, Reinhold Publishing Corp., New York (1960).
[137] Quittner, F., "Conductivity Measurements on Formed and Tempered Rock Salt Crystals," Z. Phys., 68, 796-802 (1931).

[138] Endo, Y., "A Quantum Theory of the Thermal Conductivity in Non-Metallic Crystals," Sci. Repts., Tohoku Imp. Univ., 11 183-93 (1922).

[139] L'udovit Kubica, R., "Thermal Conductivity of NaCl Single Crystals Doped by Ca and $\mathrm{OH}^{-}, "$ Acta Phys., 27 (3) (1977).

[140] Klein, M.V., "Effect of the Precipitation of Dissolved $\mathrm{MnCl}_{2}$ on the Low Temperature Thermal Conductivity of NaCl," Phys. Rev., 123, 1977-85 (1961).

[141] Tu, Y., "A Precision Comparison of Calculated and Observed Grating Constants of Crystals," Phys. Rev., 40, 662-75 (1932).

[142] Baker, R.E., Jr. and Chen, R.Y., "Grueneisen Parameter from Thermal Conductivity Measurements Under Pressure," J. Chem. Phys., 53(7), 2616-20 (1970).

[144] Dauydov, B.I., "Equation of State for Solid Bodies," Foreign Technology Division, Wright-Patterson AFB, Rept. FTD-TT-63-1113, 14 pp. (1964). [AD 600 614]

[145] Walther, A.K., Haschkowsky, W.Ph., and Strelkov, P.G., "Thermal Constants at High Temperatures. II. The Thermal Expansion of Rock Salt," Phys. Zeit. Sowjetunion, 12 , 35-44 (1937).

[146] Gavshin, V.M. and Volontei, G.M., "Thermal Expansion of Salt as a Possible Tectonic Factor," Geol. Geofiz., 11, 164-8 (1969).

[147] Grüneisen, E., "The State of a Solid Body," in Handbuch der Phys., 10,52 pp. (1926), English translation: NASA Rept. RE 2-18-59W, 76 pp. (1959).

[148] Herrin, E. and Clark, S.P., "Heat Flow in West Texas and Eastern New Mexico," Geophysics, 21(4), 1087-99 (1956).

[149] Cheverton, R.D. and Turner, W.D., "Thermal Analysis of the National Radioactive W aste Repository," Oak Ridge National Lab. Rept. ORNL-4789, 84 pp. (1972).

[150] Zakharov, V.M., "The Effect of Deformation and Geometric Dimensions on $\mathrm{NaCl}$ Heat Conductivity," Fiz. Tverd. Tela, 9(5), 1514-17 (1967).

[151] Walton, D., "Scattering of Phonons by a Square-W ell Potential and the Effect of Colloids on Thermal Conductivity. 1. Experimental," Phys. Rev., 157(3), 720-4 (1967).

[152] Caldwell, R.F. and Klein, M.V., "Experimental and Theoretical Study of Phonon Scattering from Simple Point Defects in Sodium Chloride," Phys. Rev., 158(3), 851-75 (1967). 


\section{Symbols and Units}

\begin{tabular}{|c|c|c|}
\hline Symbol & Name & Unit \\
\hline$A$ & Cross-sectional area of the specimen & $\mathbf{m}^{2}$ \\
\hline$A_{\mathrm{r}}$ & $\begin{array}{l}\text { Cross-sectional area of the reference } \\
\text { sample }\end{array}$ & $\mathbf{m}^{2}$ \\
\hline$c_{0}, c_{1}$ & Calibration constants & dimensionless \\
\hline$c_{p}$ & $\begin{array}{l}\text { Specific heat at constant pressure } \\
\text { Separation of the lattice planes } \\
\text { (eq 4.17) }\end{array}$ & $\mathrm{J} \mathrm{kg} \mathrm{K} \mathrm{K}^{-1}$ \\
\hline$d_{p}$ & Diameter of the $p$ th fringe & $\mathbf{m}$ \\
\hline$f^{P}$ & Focal length of the lens & $\mathrm{m}$ \\
\hline$h, k, l$ & Miller indices & dimensionless \\
\hline$k$ & Thermal conductivity & $\mathbf{W} \mathbf{m}^{-1} \mathrm{~K}^{-1}$ \\
\hline$k_{\mathrm{r}}$ & $\begin{array}{l}\text { Thermal conductivity of the reference } \\
\text { sample }\end{array}$ & $\mathbf{W} \mathbf{m}^{-1} \mathrm{~K}^{-1}$ \\
\hline$L$ & Length at temperature $T$ & $\mathbf{m}$ \\
\hline$L_{\mathbf{s}}$ & Length of the specimen & m \\
\hline$L_{\mathrm{r}}$ & Length of the reference sample & m \\
\hline$L_{0}$ & Length at room temperature ( $293 \mathrm{~K})$ & m \\
\hline$\Delta L$ & $\Delta L=L-L_{0}$ & $\mathbf{m}$ \\
\hline$\Delta L / L_{0}$ & Thermal linear expansion & $\%$ \\
\hline$l$ & Length of the central heater & m \\
\hline$N$ & Order of interference & dimensionless \\
\hline$N_{1}, N_{2}, N_{3}$ & Fringe integers & dimensionless \\
\hline$\Delta N$ & $\begin{array}{l}\text { Number of fringes that pass a fiducial } \\
\text { mark }\end{array}$ & dimensionless \\
\hline$n$ & Refractive index & dimensionless \\
\hline$\Delta n$ & Change of refractive index & dimensionless \\
\hline$P$ & Pressure & atm (use $\mathrm{Pa}$ ) \\
\hline$q$ & Rate of heat flow & watt \\
\hline$r_{1}, r_{2}$ & Radii & $\mathbf{m}$ \\
\hline$T$ & Temperature & $\mathrm{K}$ \\
\hline$T_{1}, T_{2}$ & Temperatures & $\mathrm{K}$ \\
\hline$\Delta T$ & $\Delta T=T_{2}-T_{1}$ & $\mathrm{~K}$ \\
\hline$V$ & Volume at temperature $T$ & $\mathrm{~m}^{3}$ \\
\hline$V_{0}$ & Volume at room temperature $(293 \mathrm{~K})$ & $\mathrm{m}^{3}$ \\
\hline$\Delta V$ & $\Delta V=V-V_{0}$ & $\mathbf{m}^{3}$ \\
\hline$\Delta V / V_{0}$ & Thermal volumetric expansion & $\%$ \\
\hline$\Delta x$ & Distance difference & $\mathrm{m}$ \\
\hline \multicolumn{3}{|l|}{$\begin{array}{l}\text { Greek } \\
\text { symbols }\end{array}$} \\
\hline$\alpha$ & Thermal diffusivity & $m^{2} s^{-1}$ \\
\hline$\theta$ & Angle & degree \\
\hline$\lambda$ & Wavelength & $\mathrm{m}$ \\
\hline$\lambda_{\mathrm{v}}$ & Wavelength of light in vacuum & m \\
\hline$\nu$ & $\begin{array}{l}\text { The fractional part in Fabry-Perot } \\
\text { interferometer }\end{array}$ & dimensionless \\
\hline$\nu_{1}, \nu_{2}, \nu_{3}$ & Fringe integers & dimensionless \\
\hline$\rho$ & Density & $\mathrm{kg} \mathrm{m}^{-3}$ \\
\hline$\rho_{0}$ & Density at room temperature (293 K) & $\mathrm{kg} \mathrm{m}^{-3}$ \\
\hline
\end{tabular}

\section{Conversion Factors}

\begin{tabular}{ccl}
\hline \hline Thermal conductivity & & \\
To convert from & \multicolumn{1}{c}{ to } & Multiply by \\
$\mathrm{W} \mathrm{m} \mathrm{K}^{-1} \mathrm{~K}^{-1}$ & BtuIT h $\mathrm{ft}^{-1} \mathrm{~F}^{-1}$ & 0.5777908 \\
$\mathrm{~W} \mathrm{~m} \mathrm{~K}^{-1}$ & cal IT s $\mathrm{Km}^{-1} \mathrm{C}^{-1}$ & $2.38846 \times 10^{-3}$ \\
\hline Thermal diffusivity & & \\
& & Multiply by \\
To convert from & to & $10^{4}$ \\
$\mathrm{~m}^{2} \mathrm{~s}^{-1}$ & $\mathrm{~cm}^{2} \mathrm{~s}^{-1}$ & 10.7639 \\
$\mathrm{~m}^{2} \mathrm{~s}^{-1}$ & $\mathrm{ft}^{2} \mathrm{~s}^{-1}$ & 3600 \\
$\mathrm{~m}^{2} \mathrm{~s}^{-1}$ & $\mathrm{~m}^{2} \mathrm{~h}^{-1}$ & \\
\hline
\end{tabular}





\section{Chapter 5 \\ Optical Properties}

H. H. Li*

Contents

Page

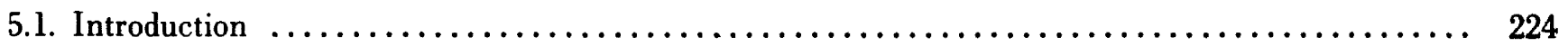

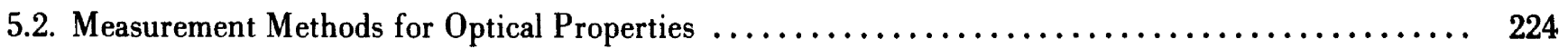

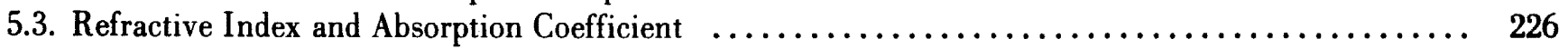

5.4. Effect of Nuclear Irradiation on the Optical Properties $\ldots \ldots \ldots \ldots \ldots \ldots \ldots \ldots \ldots \ldots \ldots \ldots \ldots \ldots 232$

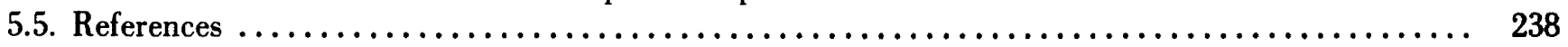

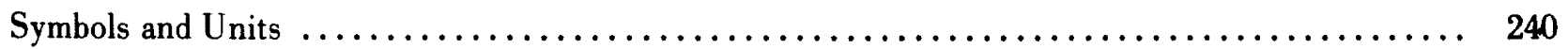

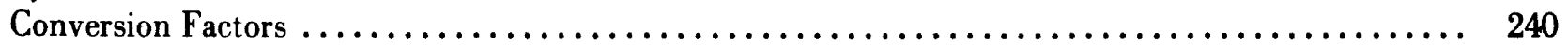

*Center for Information and Numerical Data Analysis and Synthesis, Purdue University, 2595 Yeager Road, West Lafayette, Indiana 47906 


\subsection{Introduction}

Optical properties of a material are of fundamental importance to the description of interactions between electromagnetic radiation and the material. They relate both the absorptive and dispersive characteristics of the material and have a wide range of applications in science and technology. In this chapter, the available information on the refractive index and absorption coefficient of rock salt are reviewed and discussed. For the refractive index, the available data are adequate for data evaluation and the generation of recommended values. In the case of the absorption coefficient, the situation is different in that this property is influenced by a number of factors, notably the thermal history of the crystal, the irradiation history, the impurity contents, the physical environment, etc. As a consequence, no recommended values could be generated. Only qualitative discussions and a few typical graphical presentations are given.

\subsection{Measurement Methods for Optical Properties}

The response of a nonmagnetic solid with isotropic or cubic symmetry to incident electromagnetic radiation can be generally described in terms of two optical constants, which are related to each other through dispersion relations.

These two optical constants can consist of either (l) the refractive index, $n$, and the extinction coefficient, $k$, or (2) $\epsilon_{1}$ and $\epsilon_{2}$ which are, respectively, the real and imaginary part of the complex dielectric constant $\epsilon$. These two pairs of constants are related as follows:

$$
\epsilon(\lambda)=\epsilon_{1}(\lambda) \underset{2 i n(\lambda) k(\lambda)}{+i \epsilon_{2}(\lambda)}=\left[n^{2}(\lambda)-k^{2}(\lambda)\right]+
$$

In the transparent wavelength region where the absorption can be neglected, the refractive index of the material can be directly determined in a number of ways. The basic principle of such measurements is rather simple. It makes use of the dispersive nature of the material and the wavefront reconstruction of the electromagnetic radiation after the radiation has passed through the dispersive medium. Depending on the shape of the dispersive element and the environmental medium surrounding it the reconstructed wavefront is detected through angular displacement, interference order advanced, distant moved or the refractive index of embedding medium changed. The following table

\begin{tabular}{|c|c|c|}
\hline $\begin{array}{c}\text { Shape of } \\
\text { Crystal }\end{array}$ & $\begin{array}{c}\text { Quantity to be } \\
\text { Observed }\end{array}$ & Principle \\
\hline Prism & Deviation angle & Snell's Law \\
\hline $\begin{array}{l}\text { Plane parallel } \\
\text { plate }\end{array}$ & Interference order & $\begin{array}{l}\text { Interference } \\
\text { order depends } \\
\text { on thickness }\end{array}$ \\
\hline $\begin{array}{l}\text { Scratch on } \\
\text { plate }\end{array}$ & Apparent depth & $\begin{array}{l}\text { Optical path } \\
\text { increase in } \\
\text { the plate }\end{array}$ \\
\hline Lens & Focal length & $\begin{array}{l}\text { Lens maker } \\
\text { formula }\end{array}$ \\
\hline Irregular & $\begin{array}{l}\text { Refractive index } \\
\text { of embedding } \\
\text { medium }\end{array}$ & $\begin{array}{l}\text { Contrast } \\
\text { disappears } \\
\text { when crystal } \\
\text { and medium } \\
\text { have same } \\
\text { refractive index }\end{array}$ \\
\hline
\end{tabular}
summarizes these methods.
In general, refractive index obtained by prism method is reported to the fifth or sixth decimal place, interference method gives three to four decimal places, the other methods yield no more than three decimal places. For a comprehensive and concise review of these methods, the reader is referred to the text in refs. [74 and 75].

For a crystal of sufficient thickness so that the reflection from the rear surface can be neglected, the absorption coefficient can be determined by using a simple exponential law:

$$
T_{\infty}=\left(1-R_{\infty}\right)^{2} \mathrm{e}^{-\alpha d}
$$

where $R_{\infty}$ and $T_{\infty}$ are, respectively, the reflectivity and transmission at normal incidence, $\alpha$ the absorption coefficient, and $d$ the thickness of the sample. However, the sample to be measured is not always thick and the reflection from the rear surface is not always negligible. The observed reflectance and transmission of a transparent plate is the resultant of multiple reflections and transmission at the boundary surfaces. In terms of $T_{\infty}$ and $R_{\infty}$, the observed transmission and reflectivity of a plate sample (not a thin film) can be expressed as:

$$
T=\frac{\left[\left(1-R_{\infty}\right)^{2}+4 R_{\infty} \sin ^{2} \psi\right] \mathrm{e}^{-\alpha_{d}}}{1 R_{\infty}^{2} \mathrm{e}^{-2 \alpha_{d}}}
$$

and

$$
R=\frac{R_{\infty}\left(1-\mathrm{e}^{-\alpha d}\right)}{1-R_{\infty}^{2} \mathrm{e}^{-\alpha d}}
$$


where

$$
\begin{aligned}
\psi & =\tan ^{-1} \frac{2 k}{n^{2}+k^{2}-1}, \\
k & =\frac{\lambda \alpha}{4 \pi}, \\
R & =\frac{\left(n-n^{\prime}\right)^{2}+k^{2}}{\left(n+n^{\prime}\right)^{2}+k^{2}}, \\
n^{\prime} & - \text { refractive index of surrounding medium, } \\
n^{\prime} & \simeq 1 \text { for air or vacuum. }
\end{aligned}
$$

It appears that if we know $R_{\infty}$ and either $n$ or $k$, the remaining one can be calculated by this relation. But this is only limited to the transparent region where direct measurement of $\mathrm{n}$ can be made. It is obvious that the key parameters $T$ and $R$ are usually difficult to measure accurately, because of influencing surface conditions, such as flatness, aging, oxide layers, absorbed gas, etc. However, this method is self contained at a given wavelength.

Precise determination for small absorption coefficients, in the order of $10^{-3}$ or lower, was considered impossible until the laser source became available. As the bulk absorption becomes smaller than surface losses measuring the former requires amplification of the absorption effect, which, in turn, requires high-level energy input to the sample. The two commonly used methods are the laser calorimeter [76] and the differential technique [77].

In the laser calorimeter, the absorbed energy is measured in the form of heat. It can be shown that the bulk and surface loss, i.e., the total absorption, is related to the absorbed energy, $E$ a, by

$$
\alpha L+2 \sigma=\frac{E_{\mathrm{a}}}{E_{T}}\left[\frac{2 n}{1+n^{2}}\right]
$$

provided $\alpha L<1$, where $L$ is the sample length through which a laser beam passes, and $\sigma$ the surface loss. $E_{\mathrm{a}}$ can be calculated using the specific heat, the mass of the sample and the measured temperature rise. The transmitted energy can be determined using a black body and the temperature rise. In order to separate the bulk and surface absorptions, the total absorption of a series of samples of different thickness, cut from the same piece of material and polished in the same way must be measured. A plot of total absorption versus sample thickness will give a straight line with slope $\alpha$ and intercept $2 \sigma$. Although this method yields very accurate results and is used to measure absorptions as low as $10^{-5}$ $\mathrm{cm}^{-1}$, it covers only a limited wavelength range. For a wider wavelength range measurement, the differential technique is used.
In the differential technique, a dual-beam spectrometer is used to compare the transmissions of a thick sample $\left(T_{\mathrm{s}}\right.$ and $\left.d_{\mathrm{s}}\right)$ and a reference sample $\left(T_{\mathrm{r}}\right.$ and $\left.d_{\mathrm{r}}\right)$. An optical wedge is added to the reference beam and its transverse position is so adjusted as to balance the transmitted intensity of the sample beam. The transmis. sion of the wedge, $T_{\mathrm{w}}$, is then measured. The relation of the three measured transmissions is therefore

$$
T_{\mathrm{r}} \times T_{\mathrm{w}}=T_{\mathrm{s}}
$$

hence, by using eq (5.3)

$$
T_{\mathrm{w}}=\mathrm{e}^{\alpha \Delta d}\left(\frac{1-R^{2} \mathrm{e}^{-2 \alpha d_{\mathrm{r}}}}{1-R^{2} \mathrm{e}^{-2 \alpha d_{\mathrm{s}}}}\right)
$$

where $\Delta d=d_{\mathrm{s}}-d_{\mathrm{r}}$, and

$$
R=\left(\frac{n-1}{n+1}\right)^{2}
$$

The accuracy of the method depends strongly on the accuracy of the values for refractive index and transmission. While the former can be determined with high accuracy, the accuracy of the latter parameter depends on the instrument utilized. $A \pm 1 \%$ uncertainty is generally expected. This imposes a limit, the order of $1 \times 10^{-3} \mathrm{~cm}^{-1}$, to the lowest value for absorption coefficient to be measured.

Beyond the transparent region in the high absorption region where neither $n$ and $k$ is accessible, one has to rely on the reflection spectrum from which the optical constants can be derived by the Kramers-Kronig analysis [78] or by the multiple-oscillator fit based on the Lorentz theory [79].

The Kramers-Kronig relations are derived from the dispersion relation in that the phase angle $\theta(\omega)$ of the complex reflectivity $\bar{R}(\omega)$ is determined based on the observed reflection spectrum:

$$
\begin{aligned}
& \bar{R}(\omega)=R(\omega) \mathrm{e}^{i \theta(\omega),} \\
& \theta(\omega)=\frac{\omega}{\pi} P \int_{0}^{\infty} \frac{\left\lfloor\ln R\left(\omega^{\prime}\right)-\ln R(\omega)\right\rfloor}{\omega^{2}-\omega^{\prime 2}} d \omega^{\prime}
\end{aligned}
$$

where $\omega$ is the frequency of radiation and $P$ is the principal value of the Cauchy integral. Based on the amplitude, $R(\omega)$, and phase angle of the reflectivity, the refractive index and absorption index can be calculated according to the following

$$
n(\omega)=\frac{1-R(\omega)}{1+R(\omega)-2 \sqrt{R(\omega)} \cos \theta(\omega)}
$$

and 


$$
k(\omega)=\frac{2 \sqrt{R(\omega)} \sin \theta(\omega)}{1+R(\omega)-2 \sqrt{R(\omega)} \cos \theta(\omega)}
$$

In principle, the calculation of $\boldsymbol{\theta}$ requires a complete reflection spectrum with frequency ranging from zero to infinity. In practice, $R$ is measured only for a limited spectral range. In order to use eq (5.10), extrapolation of $R(\omega)$ beyond the measured range must be made based on certain approximations. Consequently, errors are introduced in $\theta$ and hence in $n$ and $k$. It is clear that the accuracies of optical constants derived from the reflection spectra depend strongly on the accurate determination of reflectivity. Unfortunately, measurements on the latter are inherently inaccurate because of experimental difficulties. Typical errors reported for reflectivity observations are one to ten percent. This will reflect an error of about one to ten percent in the calculated optical constants depending on the stability of the light source and the quality of reference mirror used.

In the Lorentz theory, the refractive index and absorption index are related to the oscillator frequencies, $\omega_{i}$, the oscillator strengths, $s_{i}$, and the damping factors, $\gamma_{i}^{i}$, by the expressions:

$$
\begin{aligned}
& \mathrm{n}^{2}-k^{2}=\epsilon_{\infty}+\sum_{i} \frac{S_{i}\left[1-\left(\omega / \omega_{i}\right)^{2}\right]}{\left[1-\left(\omega / \omega_{i}\right)^{2}\right]^{2}+\gamma_{i}{ }^{2}(\omega / \omega i)^{2}} \\
& 2 n k=\sum_{i} \frac{S_{i} \gamma_{i}\left(\omega / \omega_{i}\right)}{\left[1-\left.\left(\omega / \omega_{i}^{1}\right)\right|^{2}\right]^{2}+\gamma_{i}^{2}\left(\omega / \omega_{i}\right)^{2}}
\end{aligned}
$$

where $\epsilon_{\infty}$ is the optical diesectric constant. The resulting $n$ and $k$ have to satisfy the observed reflectivity by the relation

$$
R(\omega)=\left|\frac{n(\omega)-1+i k(\omega)}{n(\underline{\omega})+1+i k(\omega)}\right|^{2}
$$

It is clear that this approach requires knowledge of the oscillator frequencies which in general is not complete. This leaves no choice but to use only the observed predominant ones. Nevertheless, this method, similar to the Kramers-Kronig analysis, yields good approximations to the properties under consideration.

\subsection{Refractive Index and Absorption Coefficient}

Pure rock salt is uniformly transparent from $0.2 \mu \mathrm{m}$ in the ultraviolet to $12 \mu \mathrm{m}$ in the infrared. In the region of $15 \mu \mathrm{m}$ the absorption increases rapidly. Rock salt in moderately thin pieces may be expected to transmit several percent of the light up to wavelengths as long as $26.0 \mu \mathrm{m}$. However, a plate $1 \mathrm{~cm}$ in thickness is completely opaque to radiation of wavelengths greater than $20 \mu \mathrm{m}$.

Rock salt has long been a favorite material for infrared spectroscopy. It polishes easily and, although hygroscopic, can be protected by evaporated plastic coatings. It shows excellent dispersion over its entire transmission range. It has been difficult, however, to obtain natural rock salt crystals of sufficient size and purity for making optical components. As crystal-growing techniques advanced, synthetic sodium chloride crystals have been grown up to $11.3 \mathrm{~kg}$ in weight commercially, making this material readily available for large optical parts and stimulating the design and construction of infrared instruments.

Measurement of the refractive index of sodium chloride dates back to 1871, when Stefan [1] determined the refractive indices of a rock salt prism for solar lines B, $D$, and F. Since then, a large amount of data in the transparent region have been contributed by a number of investigators, among which are Martens [2], Paschen [3], and Langley [4,5]. They used either the deviation method or interferometry in their experiments. It was not until 1929 that measurements were carried out beyond the transparent region in the infrared. Kellner [6] determined refractive indices of $\mathrm{NaCl}$ in the 23-35 $\mu \mathrm{m}$ region, based on information on transmission and reflection of thin specimens. In the vacuum ultraviolet region, Rossler and Walker [7] observed the region from 0.0476 to $0.2480 \mu \mathrm{m}$, and Miyata and Tomiki $[8,9]$ studied from 0.10 to $0.25 \mu \mathrm{m}$. Additional measurements on the refractive index were reported in ref. [10-37]. Data on the refractive index are now available from $0.0476 \mu \mathrm{m}$ up to $300 \mu \mathrm{m}$ and at $2000 \mu \mathrm{m}$.

A collective plot of the available data is shown in figure 5.1., where the reference number for the data source is designated by the number in a circle. In the interest of visual clarity not all the available data are plotted in the figure. Furthermore, most of the UV and IR data were determined from the analysis of the reflection spectra. It was found that refractive index data in the transparent regions for colorless natural rock salt are in close agreement with those for synthetic crystal with discrepancies occurring at the fourth decimal place.

Beyond the transparent regions, in the vacuum ultraviolet and infrared regions, investigations were mainly concerned with the characteristic absorptions. Predominant absorption peaks in the ultraviolet region were measured by Hilsch and Pohl [38], Schneider and O'Bryan [39] and by Ramachandran [40]. Fundamental infrared absorption peaks were reported by Lowndes and Martin [36], and Karheuser [41]. Observation of the 


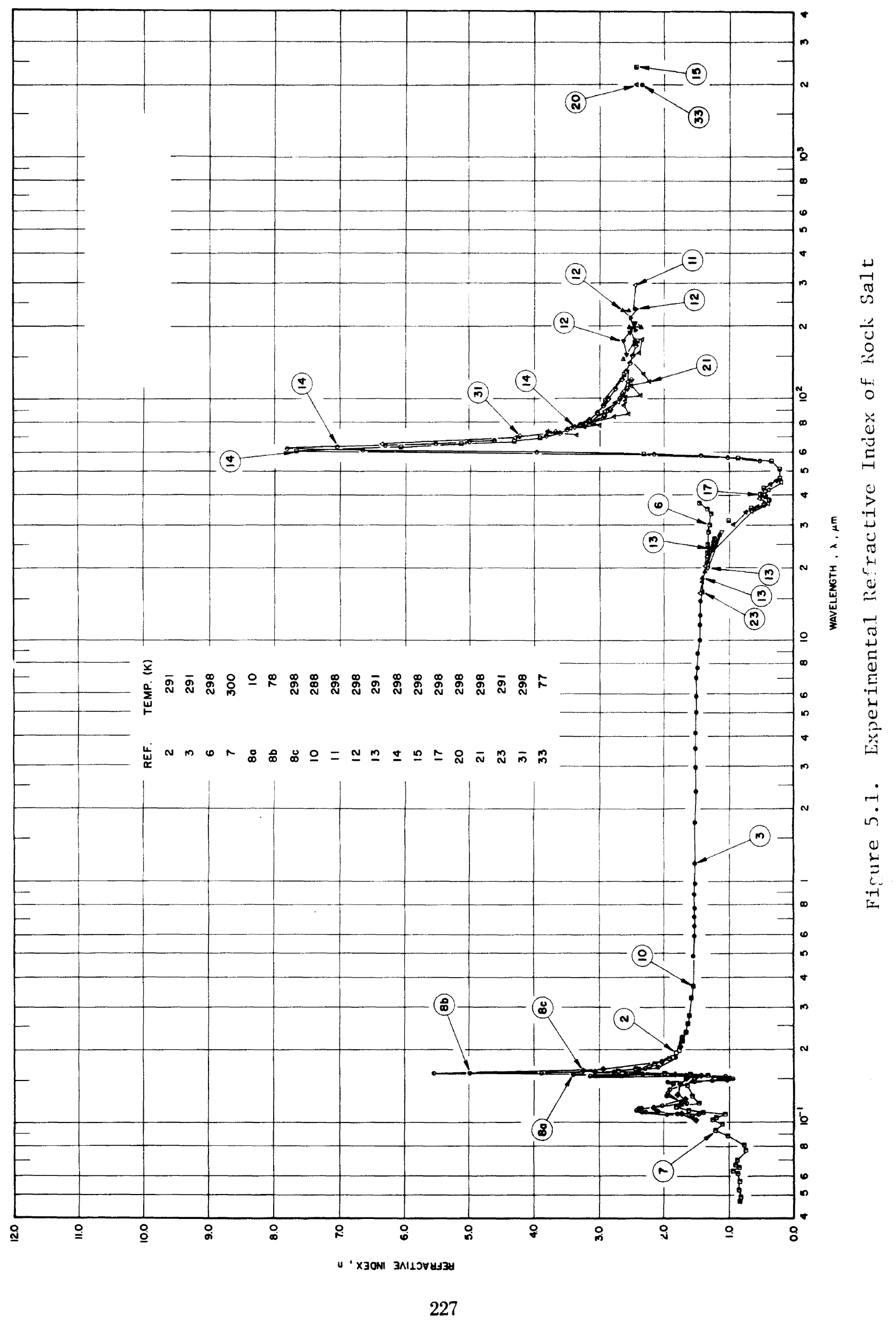


refractive index carried out in the millimeter wavelength region was used to determine the static dielectric constant of the material. Dianov and Irisova [33] determined the refractive index at a wavelength of 2 millimeters. The static dielectric constant, using the relation $\epsilon_{0}=n^{2}$, is in close agreement with that obtained by other methods. The selected absorption peak values taken from these works are given below:

Ultraviolet absorption peaks occur at:

$$
\begin{aligned}
& 0.050 \mu \mathrm{m}, \\
& 0.100 \mu \mathrm{m}, \\
& 0.128 \mu \mathrm{m}, \\
& 0.158 \mu \mathrm{m}
\end{aligned}
$$

Infrared absorption peaks occur at:

$$
\begin{aligned}
40.50 \mu \mathrm{m} & \text { (LO mode), } \\
60.98 \mu \mathrm{m} & \text { (TO mode), } \\
120.34 \mu \mathrm{m}, &
\end{aligned}
$$

And the dielectric constants are:

$$
\begin{array}{ll}
\text { high frequency dielectric constant } & \epsilon_{\infty}=2.33, \\
\text { static dielectric constant } & \check{\epsilon}_{0}=5.99 .
\end{array}
$$

The temperature coefficient $d n / d T$ is available over a large part of the transparent region of $\mathrm{NaCl}$. Notable are those measured by Micheli [42] (from 0.202 to 0.643 $\mu \mathrm{m}$ ), Liebreich [43,44] (from 0.656 to $8.85 \mu \mathrm{m}$ ), and Kolosovskii and Ustimenko [45] (for $10.6 \mu \mathrm{m}$ ). These data are plotted in figure 5.2.

$\mathrm{Li}$ [46], in 1976, reduced the then available experimental data on the refractive index and $d n / d T$ to a common temperature of $293 \mathrm{~K}$ and after careful critical evaluation and analysis adopted a formula, eq (5.16), for the calculation of $d n / d T$ for the temperature range $293 \pm$ $50 \mathrm{~K}$

$$
\begin{aligned}
2 n \frac{d n}{d T}=-11.91 & \left(n^{2}-1\right)-0.50+\frac{6.118 \lambda^{4}}{\left(\lambda^{2}-0.02496\right)^{2}} \\
& +\frac{199.36 \lambda^{4}}{\left(\lambda^{2}-3718.56\right)^{2}},
\end{aligned}
$$

where $d n / d T$ is in units of $10^{-5} \mathrm{~K}^{-1}$ and $\lambda$ is in $\mu \mathrm{m}$.

Similarly a Sellmeier type dispersion equation, (eq 5.17 ), was used to evaluate refractive index at $293 \mathrm{~K}$ in the wavelength region $0.20-30.0 \mu \mathrm{m}$ :

$$
\begin{array}{r}
n^{2}=1.00055+\frac{0.19800 \lambda^{2}}{\lambda^{2}-(0.050)^{2}}+\frac{0.48398 \lambda^{2}}{\lambda^{2}-(0.100)^{2}} \\
+\frac{0.38696 \lambda^{2}}{\lambda^{2}-(0.128)^{2}}+\frac{0.25998 \lambda^{2}}{\lambda^{2}-(0.158)^{2}}+\frac{0.08796 \lambda^{2}}{\lambda^{2}-(40.50)^{2}} \\
\quad+\frac{3.17064 \lambda^{2}}{\lambda^{2}-(60.98)^{2}}+\frac{0.30038 \lambda^{2}}{\lambda^{2}-(120.34)^{2}}, \quad(5.17)
\end{array}
$$

where $\lambda$ is in units of $\mu \mathrm{m}$.
Recommended values calculated from eqs 5.16 and 5.17 are shown in figures 5.2 and 5.3 and are tabulated in table 5.1. It should be noted that values tabulated in table 5.1 are for a pure crystal. Unfortunately, there are no systematic measurements on the refractive index of impure and defective crystal of $\mathrm{NaCl}$ reported. However, the refractive indices of an impure crystal are likely to be higher than the values in table 5.1.

Investigations of the absorption coefficient are generally classified into three broad wavelength regions: the ultraviolet, the infrared, and the transparent region. In the ultraviolet region, the investigations are concerned with the exciton states in the crystal and the determination of the Urbach-rule parameters. Roessler and Walker [7] determined the absorption index of $\mathrm{NaCl}$ in the spectral range from 0.047 to 0.248 $\mu \mathrm{m}$ by a Kramers-Kronig analysis of the reflectance spectrum. The surfaces of the specimen examined were near perfect as evidenced by the strong temperature dependence of reflectance in the exciton region and the appearance of spin-orbit split doublets. Kobayashi and Tomiki [47] studied the effects of impurities on the absorption coefficient and found significant differences between crystals in the spectral range from 0.171 to $0.231 \mu \mathrm{m}$. The main sources of such discrepancies were the presence of hydroxyl ions and dislocations in the crystals. The inclusion of the $\mathrm{OH}^{-}$is also reflected by the presence of an absorption band at $2.8 \mu \mathrm{m}$ in the near infrared region. Miyata and Tomiki $[8,9]$ and Tomiki, Miyata and Tsukamoto [48] studied the absorption of $\mathrm{NaCl}$ in the region of 0.156 to $0.205 \mu \mathrm{m}$ for the purpose of determining the Urbach-rule parameters and finding the features characteristic of the intrinsic tail. Systematic observation and analysis gave the empirical relations of the parameters:

$$
\begin{aligned}
E_{0} & =8.025 \mathrm{eV} \\
A_{0} & =1.2 \times 10^{10} \mathrm{~cm}^{-1} \\
\bar{h} \omega & =0.0095 \mathrm{eV} \\
\sigma_{\mathrm{S}_{0}} & =0.741
\end{aligned}
$$

and led to the expression of the absorption coefficient for the intrinsic tail as:

$$
\begin{aligned}
& \mathrm{A}(\mathrm{E}, \mathrm{T})=\mathrm{A}_{0} \exp \left[-\sigma_{\mathrm{s}}(\mathrm{T})\left(\mathrm{E}_{0}-\mathrm{E}\right) / \mathrm{kT}\right] \\
& \text { where } \sigma_{\mathrm{S}}(T)=\sigma_{\mathrm{s}_{0}} \frac{2 k T}{h \omega} \tan h \frac{h \omega}{2 k T} .
\end{aligned}
$$

Measurements of an absorption coefficient for the infrared region were made for the purpose of studying the optically active lattice vibrations. On the short wavelength side of the reststrahlen band, multiphonon 


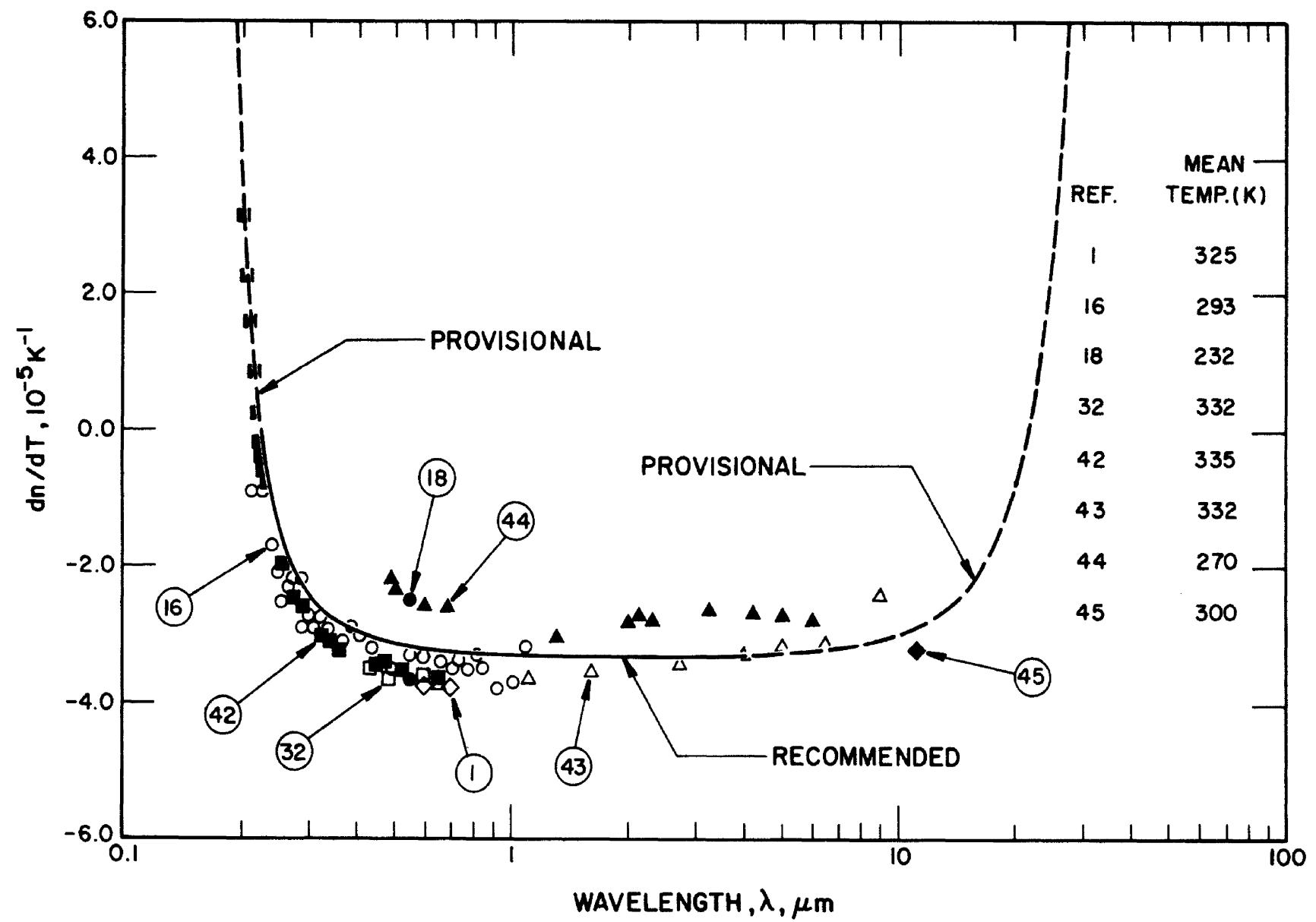

Figure 5.2. Temperature Coefficient of Refractive Index of Rock Salt 


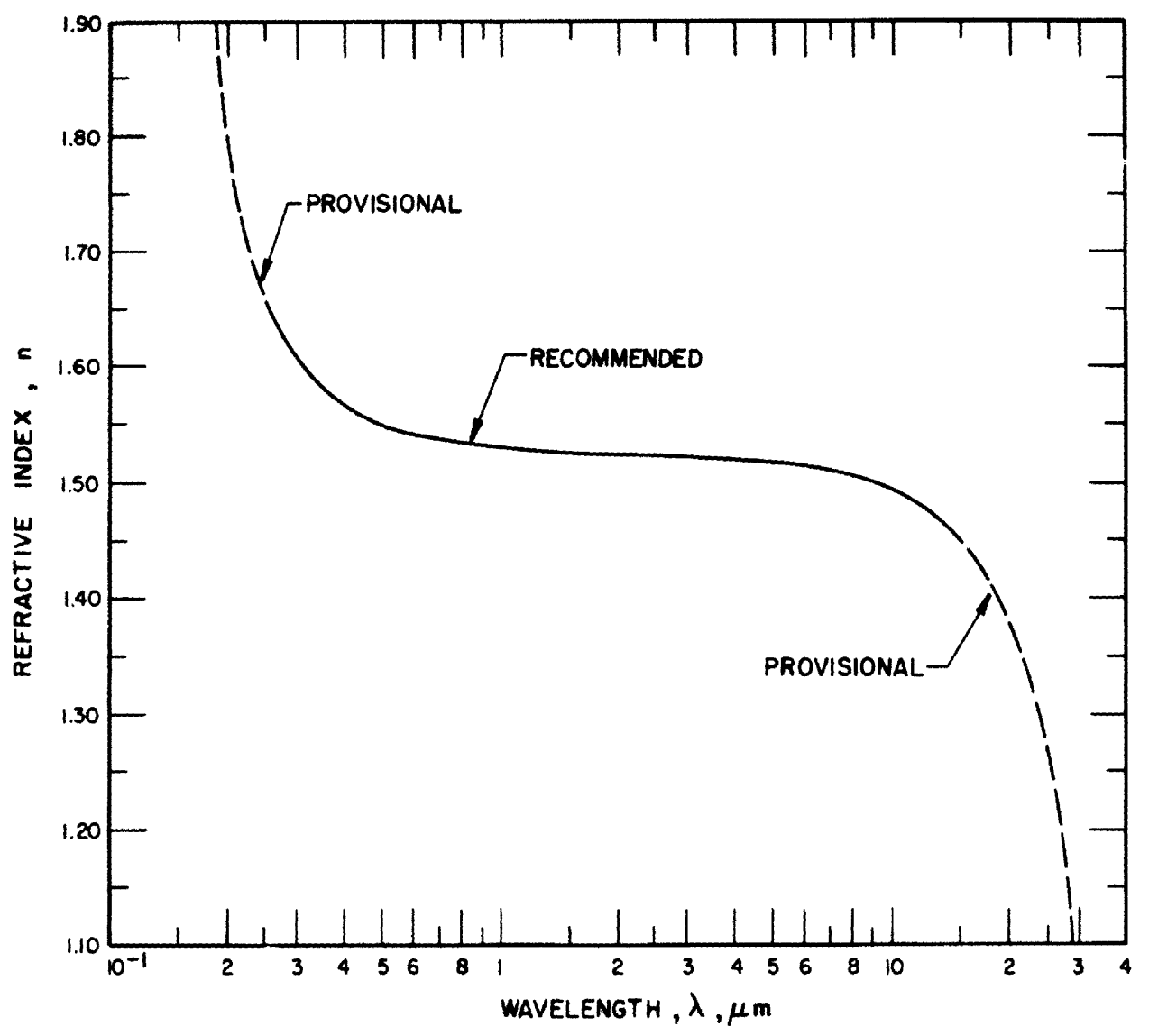

Figure 5.3. Recommended Refractive Index of Rock Salt 
Table 5.1. Recommended Values on the Refractive Index and Its Temperature Derivative for Pure Rock Salt at 293 K*

\begin{tabular}{|c|c|c|c|c|c|}
\hline $\begin{array}{c}\lambda \\
\mu \mathrm{m}\end{array}$ & $\mathrm{n}$ & $\begin{array}{c}\mathrm{dn} / \mathrm{dT} \\
10^{-5} \mathrm{~K}^{-1}\end{array}$ & $\begin{array}{c}\lambda \\
\mu m\end{array}$ & $\mathbf{n}$ & $10^{-5} \mathrm{~K}^{-1}$ \\
\hline $\begin{array}{l}0.200 \\
0.204 \\
0.208 \\
0.212 \\
0.216\end{array}$ & $\begin{array}{l}1.789 \\
1.770 \\
1.754 \\
1.739 \\
1.726\end{array}$ & $\begin{array}{l}4.6 \\
3.4 \\
2.5 \\
1.8 \\
1.2\end{array}$ & $\begin{array}{l}3.500 \\
4.000 \\
4.500 \\
5.000 \\
6.000\end{array}$ & $\begin{array}{l}1.5230 \\
1.5217 \\
1.5203 \\
1.5188 \\
1.5153\end{array}$ & $\begin{array}{l}-3.3 \\
-3.3 \\
-3.2 \\
-3.2 \\
-3.2\end{array}$ \\
\hline $\begin{array}{l}0.220 \\
0.224 \\
0.228 \\
0.232 \\
0.236\end{array}$ & $\begin{array}{l}1.714 \\
1.704 \\
1.694 \\
1.686 \\
1.678\end{array}$ & $\begin{array}{r}0.7 \\
0.3 \\
-0.0 \\
-0.3 \\
-0.6\end{array}$ & $\begin{array}{r}7.000 \\
8.000 \\
9.000 \\
10.000 \\
10.200\end{array}$ & $\begin{array}{l}1.5112 \\
1.5064 \\
1.5009 \\
1.4947 \\
1.4934\end{array}$ & $\begin{array}{l}-3.1 \\
-3.1 \\
-3.0 \\
-2.9 \\
-2.9\end{array}$ \\
\hline $\begin{array}{l}0.240 \\
0.244 \\
0.248 \\
0.252 \\
0.258\end{array}$ & $\begin{array}{l}1.671 \\
1.664 \\
1.658 \\
1.6525 \\
1.6447\end{array}$ & $\begin{array}{l}-0.8 \\
-1.0 \\
-1.2 \\
-1.3 \\
-1.5\end{array}$ & $\begin{array}{l}10.400 \\
10.600 \\
10.800 \\
11.000 \\
11.200\end{array}$ & $\begin{array}{l}1.4920 \\
1.4906 \\
1.4892 \\
1.4877 \\
1.4862\end{array}$ & $\begin{array}{l}-2.9 \\
-2.9 \\
-2.9 \\
-2.8 \\
-2.8\end{array}$ \\
\hline $\begin{array}{l}0.264 \\
0.270 \\
0.276 \\
0.282 \\
0.290\end{array}$ & $\begin{array}{l}1.6376 \\
1.6312 \\
1.6254 \\
1.6201 \\
1.6137\end{array}$ & $\begin{array}{l}-1.7 \\
-1.8 \\
-2.0 \\
-2.1 \\
-2.2\end{array}$ & $\begin{array}{l}12.000 \\
13.000 \\
14.000 \\
15.000 \\
16.000\end{array}$ & $\begin{array}{l}1.4800 \\
1.4713 \\
1.4618 \\
1.451 \\
1.439\end{array}$ & $\begin{array}{l}-2.7 \\
-2.6 \\
-2.5 \\
-2.3 \\
-2.1\end{array}$ \\
\hline $\begin{array}{l}0.300 \\
0.320 \\
0.340 \\
0.360 \\
0.380\end{array}$ & $\begin{array}{l}1.6066 \\
1.5950 \\
1.5859 \\
1.5785 \\
1.5724\end{array}$ & $\begin{array}{l}-2.3 \\
-2.5 \\
-2.7 \\
-2.8 \\
-2.8\end{array}$ & $\begin{array}{l}17.000 \\
18.000 \\
19.000 \\
20.000 \\
22.000\end{array}$ & $\begin{array}{l}1.427 \\
1.413 \\
1.398 \\
1.382 \\
1.344\end{array}$ & $\begin{array}{r}-1.8 \\
-1.5 \\
-1.2 \\
-0.8 \\
0.1\end{array}$ \\
\hline $\begin{array}{l}0.400 \\
0.450 \\
0.500 \\
0.550 \\
0.600\end{array}$ & $\begin{array}{l}1.5674 \\
1.5580 \\
1.5515 \\
1.5469 \\
1.5434\end{array}$ & $\begin{array}{l}-2.9 \\
-3.0 \\
-3.1 \\
-3.1 \\
-3.2\end{array}$ & $\begin{array}{l}23.000 \\
24.000 \\
25.000 \\
26.000 \\
27.000\end{array}$ & $\begin{array}{l}1.323 \\
1.299 \\
1.273 \\
1.24 \\
1.21\end{array}$ & $\begin{array}{l}0.8 \\
1.5 \\
2.5 \\
3.5 \\
4.9\end{array}$ \\
\hline $\begin{array}{l}0.700 \\
0.800 \\
0.900 \\
1.000 \\
1.250\end{array}$ & $\begin{array}{l}1.5386 \\
1.5356 \\
1.5335 \\
1.5320 \\
1.5296\end{array}$ & $\begin{array}{l}-3.2 \\
-3.2 \\
-3.2 \\
-3.3 \\
-3.3\end{array}$ & $\begin{array}{l}28.000 \\
29.000 \\
30.000\end{array}$ & $\begin{array}{l}1.17 \\
1.13 \\
1.09\end{array}$ & $\begin{array}{r}6.4 \\
8.4 \\
10.8\end{array}$ \\
\hline $\begin{array}{l}1.500 \\
1.750 \\
2.000 \\
2.500 \\
3.000\end{array}$ & $\begin{array}{l}1.5282 \\
1.5272 \\
1.5265 \\
1.5253 \\
1.5241\end{array}$ & $\begin{array}{l}-3.3 \\
-3.3 \\
-3.3 \\
-3.3 \\
-3.3\end{array}$ & & & \\
\hline \multicolumn{6}{|c|}{$\begin{array}{l}\text { Estimated uncertainties for } \mathrm{n} ; \pm 0.006 \text { in region } 0.20-0.25 \mu \mathrm{m} ; \pm 0.0005 \text { in } 0.25- \\
0.35 \mu \mathrm{m} ; \pm 0.0001 \text { in } 0.35-10.0 \mu \mathrm{m} ; \pm 0.003 \text { in } 10.0-15.0 \mu \mathrm{m} ; \pm 0.006 \mathrm{in} 15.0-25.0 \mu \mathrm{m} ; \\
\pm 0.02 \text { in } 25.0-30.0 \mu \mathrm{m} \text {. Estimated uncertainties for } \mathrm{dn} / \mathrm{dT} \text { in units of } 10^{-5} \mathrm{~K}^{1}: \\
\pm 0.8 \text { in } 0.20-0.24 \mu \mathrm{m} ; \pm 0.2 \text { in } 0.24-4.0 \mu \mathrm{m} ; \pm 0.4 \text { in } 4.0-15.0 \mu \mathrm{m} ; \pm 0.6 \text { in } 15.0- \\
20.0 \mu \mathrm{m} ; \pm 0.9 \text { in } 20.0-30.0 \mu \mathrm{m} .\end{array}$} \\
\hline
\end{tabular}

absorption, in which a photon is absorbed and two or more phonons are generated, can occur and lead to absorption coefficients that range from $10^{-4} \mathrm{~cm}^{1}$ to 100 $\mathrm{cm}^{-1}$, depending on the number of phonons generated. Recent measurements [49] on $\mathrm{NaCl}$ have shown that the absorption coefficient can be represented in the multiphonon absorption region by the expression:

$$
A=A_{0} \exp \left(-\nu / \nu_{0}\right)
$$

where $\nu_{0}=56.0 \mathrm{~cm}^{-1}$, and $A_{0}=24273 \mathrm{~cm}^{-1}$.

It is not known if the two exponential relations (eqs 5.18 and 5.19) hold for the visible and near infrared regions. If they do, the absorption in the transparent region will be negligible. In a real situation, however, there are always traces of residual impurities and imperfections in the available crystal, consequently the absorption is noticeable though it is negligibly low as a rule.

Absorption data in the transparent region are very scanty. The reason is that absorption in this region is very low and its effects are thus unnoticeable in most applications. However, at high energy levels many unfavorable effects due to absorption take place. Unfortunately, investigations of absorption coefficient at the high energy level were made only at a few wavelengths of interest to laser applications. Harrington and Hass [50] studied the temperature dependence of 
multiphonon absorption at wavelength $10.6 \mu \mathrm{m}$ from room temperature to near the melting point by a calorimetric method. His results are higher than those in the intrinsic tail. Deutsch [49] using a differential technique with a dual beam spectrometer measured an absorption coefficient for the wavelength region from 11.7 to $20 \mu \mathrm{m}$ at room temperature. The predicted value at wavelength $10.6 \mu \mathrm{m}$ obtained by fitting the measured values is $1.1 \times 10^{-3} \mathrm{~cm}^{-1}$ which agrees well with the measured value of $1.3 \times 10^{-3} \mathrm{~cm}^{-1}$ reported by Horrigan and Rudko [51]. This value was believed to conform to the values in the intrinsic tail. No noticeable improvement in the values could be obtained by improvements in purity and growth techniques. Califano and Czerny [52] examined the region, $11-14 \mu \mathrm{m}$, at room temperature. Barker [53] measured the region, 11-20 $\mu \mathrm{m}$, at temperature from $300 \mathrm{~K}$ up to $1105 \mathrm{~K}, 31$ degrees beyond the melting temperature of $\mathrm{NaCl}$. Their room temperature values agreed with those predicted by eq (1.2) $(5,19)$.

Owens [54] measured the room temperature absorption index at three wavelengths, $2.50,8.02$, and 32.3 $\mu \mathrm{m}$. By combining his measurement with others reported in the literature $[11,12,14,55,56]$ in the wavelength range from 10 to $10^{7} \mu \mathrm{m}$, he found a constant background loss corresponding to a residual value in absorption coefficient of $1 \times 10^{4}$. The origin of this loss, which appeared to be independent of temperature is unknown. It is most probably due to imperfections in the crystals. A summary of the knowledge to date on the absorption salt is shown in figure 5.4 .

Based on the above review of available data, the most probable values of intrinsic bulk absorption coefficients of a pure $\mathrm{NaCl}$ crystal at $293 \mathrm{~K}$ are derived as follows:

$$
\begin{array}{ll}
\frac{\text { Wavelength range }}{0.165-0.173 \mu \mathrm{m}} & \frac{\text { Absorption coefficient, } \mathrm{cm}^{-1}}{(5.18)} \\
0.25-9.00 \mu \mathrm{m} & \text { Usually negligibly small } \\
9.0-30 \mu \mathrm{m} & \text { Use eq }(54)(5.19) .
\end{array}
$$

Values derived and recommended in this way are also given in table 5.2. It should be noted that recommended values in table 5.2 are for a pure crystal. Crystals with impurities, other defects, and unfavorable surface conditions yield absorption coefficients in the transparent region which are expected to be noticeable. At the absorption center wavelengths, such absorption coefficients become extraordinarily large and unpredictable, depending upon the amount of foreign substances and the extent of defects.

While rock salt in the form of a pure chemical compound is clear and colorless, rock salts with impurities and defects reveal a variety of colors; gray to black, red, brown, yellow, green, blue, and violet. In table 5.3, a few typical natural colored rock salts are displayed together with the corresponding causes [57]. Most of the colors are caused by impurities, while some of the yellow, blue and violet colors owe their origin to radiation. Effects of radiation on the optical properties of rock salt will be discussed in a later section.

\subsection{Effect of Nuclear Irradiation on the Optical Properties}

Nuclear radiations either corpuscalar or electromagnetic are known to alter the properties of materials. The results of the interaction of energetic radiation with matter are to create microscopically many types of defects which lead to the observable changes of macroscopic properties. These involve such stable primary defects as vacancies, interstitials and dislocations which may be detected optically in a variety of colored absorption bands. These bands are located primarily in the visible region and therefore are easily recognized by the induced color. Generally the effect of nuclear radiation on the optical properties of rock salt is the coloration produced in the crystal. The strongest absorption band occurs at $0.465 \mu \mathrm{m}$ where the crystal turns yellow after being irradiated.

Color centers can be generated in a crystal in a variety of ways. The most important ones are: (1) exposure to ionizing radiation, (2) addition of impurities to produce coloration, and (3) imposition of electrolytic action to produce coloration. All of these processes occur in nature. However, the first process is primarily concerned with the effect of nuclear radiation on the properties. The term, ionizing radiation, includes all sources that can generate free electrons and holes in the crystal. The energies range from photons of a few $\mathrm{eV}$, through $x$-rays and $\gamma$-rays up to high energy protons of $400 \mathrm{MeV}$. However, so far as the effect on the optical properties is concerned, studies showed that radiations of high energies produce similar results as those by lowenergy radiations. They both cause color centers of the same nature. The problem of "the effects of nuclear irradiation on the optical properties of rock salt" is therefore reduced to the studies of the F-center and Faggregate centers of rock salt. Detailed discussion of the subject of color centers is beyond the scope of the present work. For a comprehensive and concise review of the color centers, the interested readers are referred to the excellent articles by Seitz [60], Compton and Robin [61], Schulman and Compton [62], and Crawford and Slifkin [63]. Only a few typical examples pertinent to rock salt will be presented.

Irradiation with any type of ionizing radiation including ultraviolet light will produce an F-center 


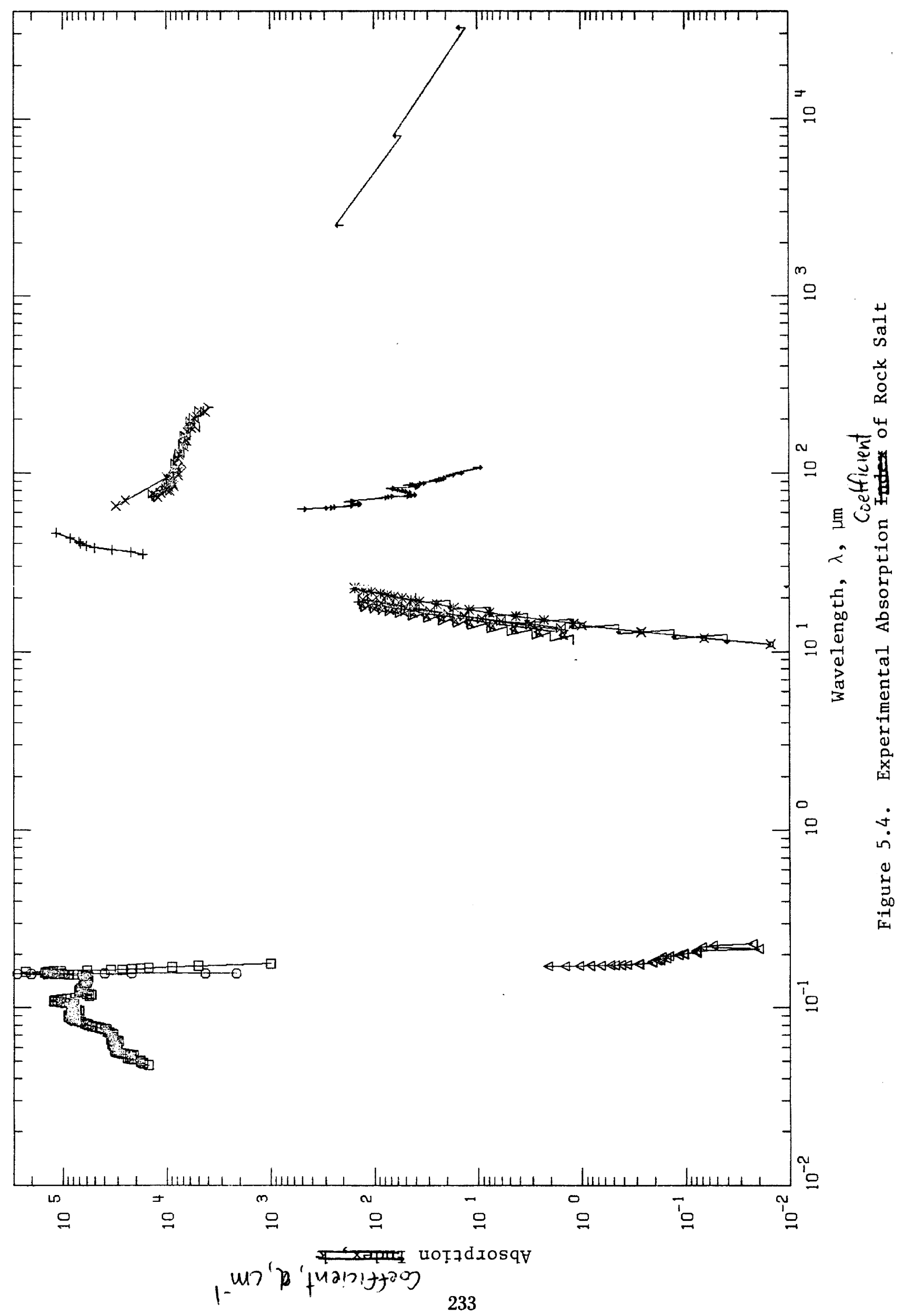


Table 5.2. Calculated Values on the Intrinsic Absorption

Coefficient for Pure Rock Salt at $293 \mathrm{~K}$

$\begin{array}{lc}\lambda, \mu \mathrm{m} & \alpha, \mathrm{cm}^{-1} \\ 0.165 & 4525 \\ 0.166 & 1217 \\ 0.167 & 332 \\ 0.168 & 92 \\ 0.169 & 26 \\ 0.170 & 7.4 \\ 0.171 & 2.2 \\ 0.172 & 0.63 \\ 0.173 & 0.19 \\ 5.3 & 6 \times 10^{-10} \\ 10.6 & 1.1 \times 10^{-3}\end{array}$

TABLE 5.3. COLOR AND CAUSE OF NATURAL ROCK SALT

\begin{tabular}{|c|c|}
\hline Color Family & Cause \\
\hline Black & $38.64 \% \mathrm{NaCl}$ \\
\hline & $55.35 \%$ insoluble matter \\
\hline Grey & $\begin{array}{l}\text { Clay inclusions in either large } \\
\text { aggregates or microscopical particles }\end{array}$ \\
\hline Red & Iron compounds \\
\hline Yellow & Due to radiation or iron compounds \\
\hline Brown & $\begin{array}{l}\text { Bituminous inclusions often arranged } \\
\text { in regular layers }\end{array}$ \\
\hline Green & Copper \\
\hline Blue & Due to radiation \\
\hline Violet & Due to radiation \\
\hline
\end{tabular}

together with a number of other centers, mostly the Faggregate centers. Figure 5.5 shows a typical absorption spectrum of an irradiated $\mathrm{NaCl}$ crystal in the wavelength region from 0.2 to $1.2 \mu \mathrm{m}$ where absorption is otherwise negligibly low. The absorption peaks at 0.210 , $0.465,0.545,0.595,0.720$, and 0.823 are, respectively, identified as $V_{3}, F, R_{1}, R_{2}, M$, and $N$ centers.

The above centers are usually created at a low level of irradiation. At a high level of irradiation, a strong absorption band appears at $0.57 \mu \mathrm{m}$ corresponding to the absorption of colloidal sodium particles. The appearance of this adsorption band is generally accompanied by the diminution of $\mathrm{F}$-absorption. The radiation-induced formation of colloidal sodium particles can amount to 0.001 to 0.1 atomic weight percent range. In one case of study [69], it was noted that the hydroxyl ions in the crystal may play some role in the formation of colloidal particles.

$F$-center production is the result of the capture of an electron by a negative ion vacancy. The $\mathrm{F}$-absorption at $0.465 \mu \mathrm{m}$ corresponds to an electron transition from the ground state to a $p$ excited state. The half-width of the $F$ absorption is temperature dependent, it is smallest at low temperatures and the peak of the band shifts toward shorter wavelengths with decreasing temperature. The $\mathrm{M}$-center is the simplest among the $\mathrm{F}$-aggregate centers. It consists of two adjacent $\mathrm{F}$-centers with its main axis oriented in the $\langle 110\rangle$ plane. Because of anisotropic distribution of the axis of the center, the M-absorption shows dichroism. An R-center consists of three adjacent $\mathrm{F}$-centers occupying an equilateral triangular array in a $<111>$ plane of the $\mathrm{NaCl}$ structure. The $\mathrm{N}$-center consists of four neighboring $\mathrm{F}$-centers occupying a parallelogram array or a tetrahedral array. The $\mathrm{V}$-center is due to the halogen molecular ion occupying two adjacent negative ion vacancies.

Kobayashi $[64,65]$ studied the relationship between the behavior of the color centers and the density change during thermal annealing for sodium chloride crystals irradiated with $350 \mathrm{MeV}$ protons with a total flux of $1 \times$ $10^{16}$ protons $/ \mathrm{cm}^{2}$. Figure 5.6 shows the changes of concentration of color centers and the change of density, $\Delta \mathrm{n}$, of the crystal as a function of annealing temperature. It can be noted that, while below $475 \mathrm{~K}$ the density of the irradiated crystal remains constant, significant changes in the intensity of respective 


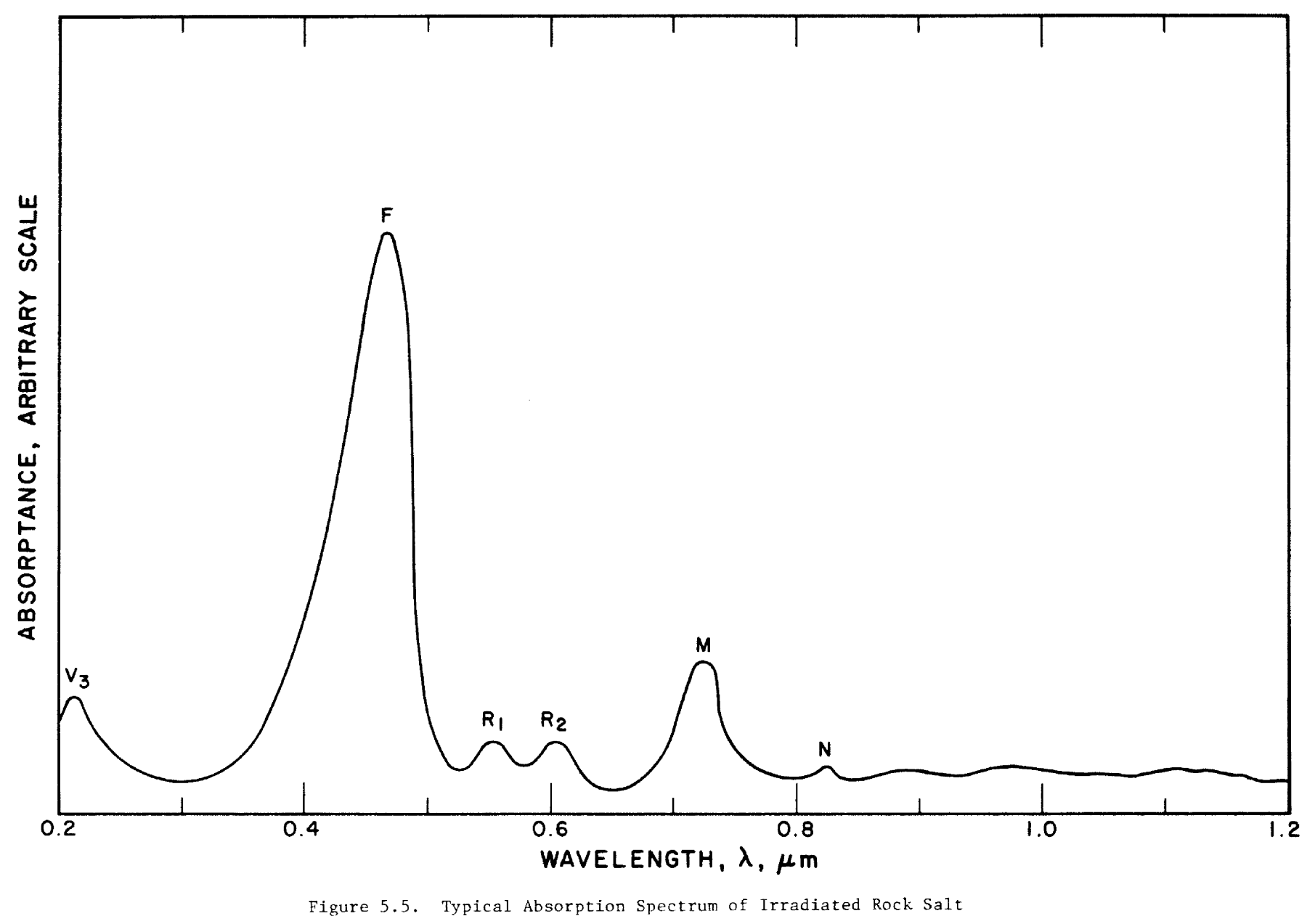

absorption bands are observed. It implies that in this region no noticeable annealing of vacancies takes place, while the continuous decreases of $F$ and $V_{3}$ bands and the growths of the $\mathrm{F}$-aggregate absorption bands are the results of thermal agitation which leads to the redistribution of the vacancies to form more clusters. It appears that the final products of such redistribution of vacancies are the $R$ centers and other stable clusters.

When all of the color centers are converted to $R$ centers and clusters, a further increase of temperature will anneal the vacancies out as indicated by the simultaneous drop of $\Delta p$ and intensity of R-absorption band. At a temperature of $515 \mathrm{~K}$, where all color centers have disappeared, the remaining $\Delta p$ is due to the existence of other types of stable vacancy clusters. Beyond this point, $\Delta p$ decreases almost linearly with increasing temperature and the crystal is completely recovered at $673 \mathrm{~K}$.

It can be said that the nuclear radiation effect on the optical properties is to increase the absorption coefficient particularly at the color centers. A well known method to study the formation of defects induced by radiation in rock salt is to obtain the so-called $F$-coloring curve, which shows the variation of the F-center concentration with irradiation dose. Hodgson, Delgado and Rivas [66] investigated the gamma-ray produced F. coloring curve for $\mathrm{NaCl}$ at and above room temperatures. The dose rate was approximately $350 \mathrm{R} / \mathrm{min}$, produced by bombarding $1.8 \mathrm{MeV}$ electrons on a gold target. The results are shown in figure 5.7 . The curves corresponding to temperatures 293,323 , and $373 \mathrm{~K}$ show the increasing $\mathrm{F}$-center concentrations and the approaching saturations at the respective temperatures. At temperatures above $373 \mathrm{~K}$, the respective curves rave a broad maximum which decreases as the temperature increases. This change is due to the formation of $F$-aggregate centers in accordance with the data shown in figure 5.6. Jain and Lidiard [67], in the study of the growth of colloidal centers in irradiated alkali halides, calculated the growth of F-center concentration as a function of dose as given in figure 5.8. It can be seen that the $\mathrm{F}$-center concentration reaches its saturation at quite a low dose and is very temperature dependent. It should be noted that in all cases the saturated F-center concentration decreases with increased temperature. There are two contributing factors, the thermal 


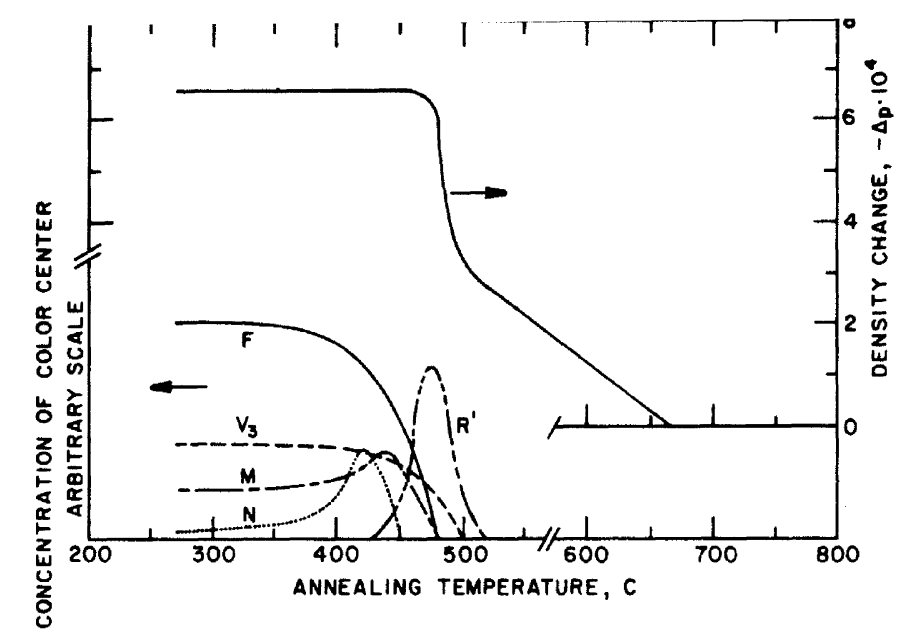

Figure 5.6. Annealing out of absorption bands and of density change in proton irradiated $\mathrm{NaCl}$ as a function of increasing temperature [64].

bleaching and the optical bleaching. The thermal bleaching is actually the thermal annealing caused by energy absorption. The optical bleaching can be obtained either from radiation of appropriate frequency or from luminescence caused by the excitation of the electrons. Both of the bleaching effects are present at any operational condition.

Nowick [68] investigated the growth of the $F$ band in $\mathrm{NaCl}$ crystals with $1.2 \mathrm{MeV}$ gamma-ray irradiation using a $\mathrm{CO}^{60}$ source. Crystals of different origins, heat treatments, and states of deformation were measured. While deformation has a small effect on the concentration of $F$-centers in the early stage of $F$ band growth, the effect on the later stage is large. The growth of $F$ band in the undeformed and annealed crystals appears to saturate rapidly at about $10^{17} \mathrm{~F}$-center $/ \mathrm{cm}^{3}$ and continue to grow slowly and linearly with time. The deformed crystals, however, continue to grow at a considerably higher rate in the later stage of irradiation time as shown in figures 5.9 and 5.10. Furthermore, the deformed crystals cannot be completely bleached; the $R$ band remains. Based on the available information on the F-center investigation, it was concluded that $F$-center coloration at room temperature proceeds in two distinct stages:

(1) The first stage consists of a rapid filling of the vacancies and vacancy clusters present in the crystal prior to irradiation.

(2) The second stage consists of the creation of new vacancies at a slow rate and their transformation into $F$. centers.

The effect of deformations is to create new dislocations and possibly to help disperse the precipitated impurities with the consequence of more F-centers creation.

Compton [69] observed the coloration of synthetic and natural $\mathrm{NaCl}$ crystals with $\mathrm{CO}^{60}$ gamma-ray and 1.3 $\mathrm{MeV}$ electron irradiations. It was found that these

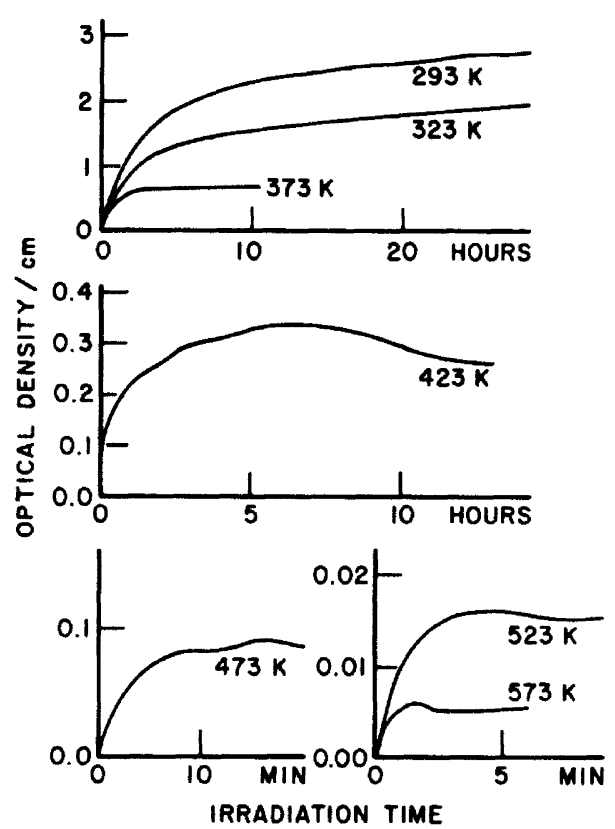

Figure 5.7. F-center color curves obtained for $\mathrm{NaCl}$ sample temperatures between 20 and $300{ }^{\circ} \mathrm{C}$ at a dose rate of approximately $350 \mathrm{R} / \mathrm{min}$ [66].

irradiations produced the colloid band, at $0.565 \mu \mathrm{m}$, in the synthetic crystals but not in natural crystal. This colloid band became much stronger than F-center absorption at high doses. Through various thermal treatments given the natural crystal prior to their coloration, it was found that the hydroxyl ions played an important role in the conversion of F-centers into colloids.

Observations of Nowick [68] and Compton [69] may provide clues regarding the nature of blue rock salt. In the deformed rock salt, the optically unbleachable $R$ - 


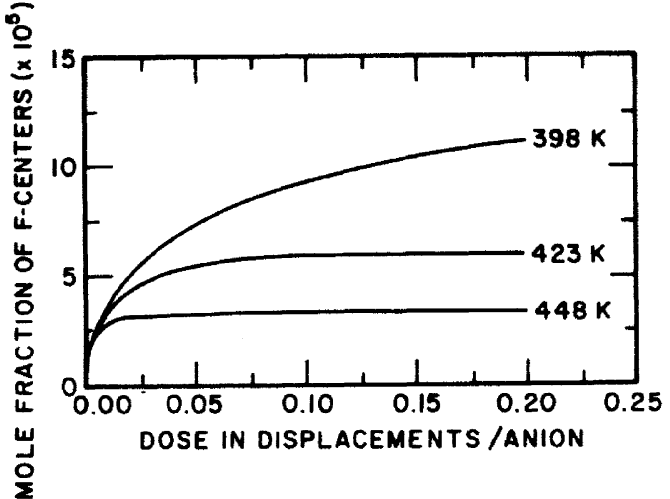

Figure 5.8. The predicted dose dependence of $\mathrm{F}$-center concentration in $\mathrm{NaCl}$ at temperatures of 398,423 and $448 \mathrm{~K}$ $[67]$.

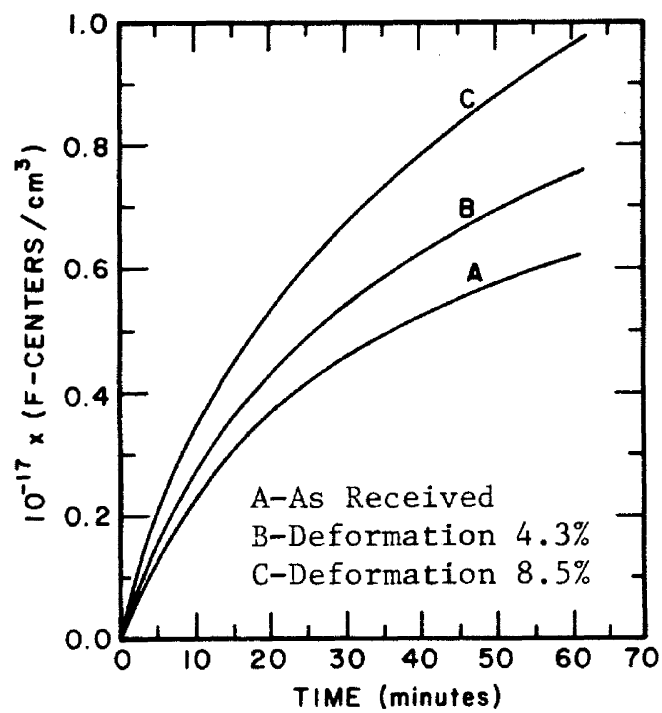

Figure 5.9. Early stage of F-band growth for irradiated $\mathrm{NaCl}$ crystals [68].

band covers a broad spectral range centered at about 0.6 $\mu \mathrm{m}$. The presence of hydroxyl ions in the crystal seem to be essential in the formation of the colloid band, at 0.565 $\mu \mathrm{m}$, by irradiation. As both absorption bands contribute to the blue appearance of the crystal, it may be possible to conclude that the blue rock salt is the consequence of nuclear irradiation on a rock salt crystal which contains hydroxyl ion substituted lattice defects which was plastically deformed in the geological past.

Not only does the F-center concentration depend on temperature and radiation dose, but it also varies with the incident energy of radiation. Figure 5.11 is a plot of the number of $F$-centers produced per proton versus the energy of the protons [70]. It was also observed in the case of intense irradiation that the peak of $\mathbf{F}$-center absorption was slightly shifted toward shorter wavelength. This may be due to the high concentration of lattice defects and an associated interaction between them [71]. Data on the effect of neutron exposure on the optical properties on rock salt is rather scanty. Available information [72] indicates that neutron bombardment is more effective in producing defects.

From the available information on the color center investigations, it is noted that neither F-center nor Faggregate center absorption bands have been found to extend into the $10.6 \mu \mathrm{m}$ region when observed by the usual spectrometric methods. However, Lipson, Ligor, and Martin [73], measured the absorption coefficient at $10.6 \mu \mathrm{m}$ by $\mathrm{CO}_{2}$ laser calorimetry for $\mathrm{NaCl}$ crystals irradiated with $\mathrm{CO}^{60}$ gamma-rays. It was found that the absorption at $10.6 \mu \mathrm{m}$ increased upon irradiation.

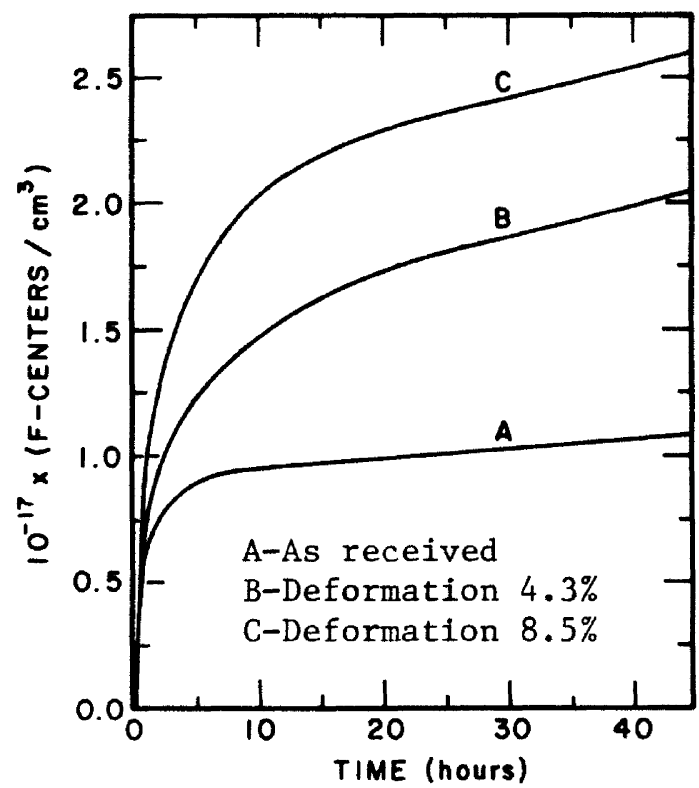

Figure 5.10. The same F-band growth curves as in Figure 5.9 carried out to a much longer irradiation time [68].

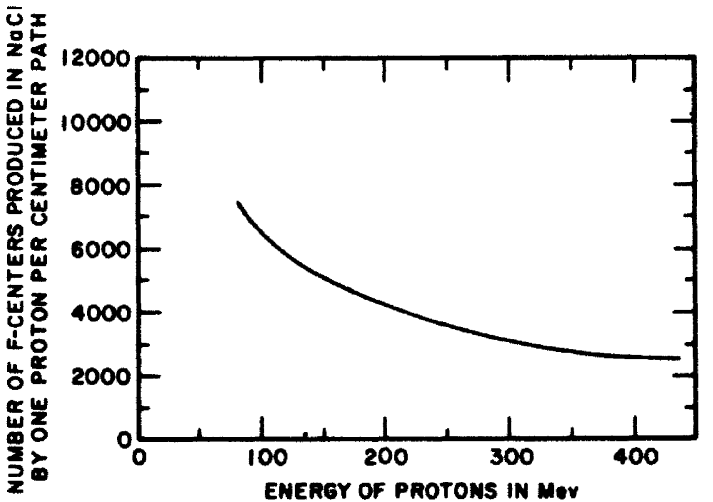

Figure 5.11. Number of F-centers produced by one proton per $\mathrm{cm}$ path in NaCl irradiated with $10^{16}$ protons $/ \mathrm{cm}^{2}[70]$. 
Through a careful analysis, they concluded that the increase in absorption at $10.6 \mu \mathrm{m}$ after irradiation is associated with the $\mathrm{F}$-aggregate centers.

In general, it can be safely said that the effect of nuclear radiation on the optical property of rock salt is to increase the absorption coefficient across the spectrum, with much greater absorption at the color centers. The effects resulting from crystal irradiation are, however, influenced by many factors:

a. The thermal history of the crystal,

b. The irradiation history of the crystal,

c. I'he origin of the crystal,

d. The energy of the radiation,

e. The dose rate of the radiation,

f. The length of exposure (the total dose),

g. The physical environment (temperature, pressure, radiation), and

h. The impurity contents of the crystal.

Whatever the factors are, the result is the coloration of the crystal. Although the colored crystal may be bleached optically or thermally, some of the defects will remain as permanent damage to the crystal. The most important of such defects is the creation of additional impurities which result from the primary bombardment of particles and/or when their products are stopped by the crystal.

\subsection{References}

[1] Stefan, J.M., "The Influence of Heat on the Light Refraction of Solids," Sitzungsber. Akad. Wiss. Wien, 2, 63, 223-45 (1871).

[2] Martens, F.F., "The Dispersion of Ultraviolet Radiation," Ann. Phys., 6, 603-40 (1901).

[3] Paschen, F., "The Dispersion of Rock Salt and Sylvite in Infrared," Ann. Phys., 26, 120-38 (1908).

[4] Langley, S.P., "The Dispersion of Rock Salt and Fluorite," Ann. Astrophys. Obs. Smithsonian Inst., 1, 219-37 (1900).

[5] Langley, S.P., "The Invisible Spectra," Ann. Chem. Phys., 6, 9, 443-506 (1886).

[6] Kellner, L., "Investigations in the Spectral Region Between 20 and 40 Microns," Z Phys., 56, 215-34 (1929).

[7] Roessler, D.M. and Walker, W.C., "Optical Constants of Sodium Chloride and Potassium Chloride in the Far Ultraviolet," J. Opt. Soc. Amer., 58, 279-81 (1968).

[8] Miyata, T. and Tomiki, T., "Optical Studies of $\mathrm{NaCl}$ Single Crystals in $10 \mathrm{eV}$ Region. II., The Spectra of Conductivity at Low Temperatures, Absorption Constant, and Energy Loss," J. Phys. Soc. Jap., 24(6), 1286-302 (1968).

[9] Miyata, T. and Tomiki, T., "The Urbach Tails and Reflection Spectra of $\mathrm{NaCl}$ Single Crystals," J. Phys. Soc. Jap., 22(1), 209-18 (1967).

[10] Borel, G.A., "The Refraction and Dispersion of Ultraviolet Radiation in Some Crystallized Substances," Compt. Rend., 120, 1404-6 (1895).

[11] Genzel, H.H. and Weber, R., "Dispersion Measurement on $\mathrm{NaCl}, \mathrm{KCl}$, and $\mathrm{KBr}$ Between 0.3 and $3 \mathrm{~mm} \mathrm{~W}$ avelength," $\mathrm{Z}$. Phys., 154, 13-8 (1959).
[12] Cartright, C.H. and Czerny, M., "Dispersion Measurements on $\mathrm{NaCl}$ and $\mathrm{KCl}$ in the Infrared Region. II.," Z. Phys., 90, 457-67 (1934).

[13] Hohls, H.W., "Dispersion and Absorption of Lithium Fluoride and Sodium Fluoride in the Infrared," Ann. Phys., 29, 433-48 (1937).

[14] Geick, R., "Dispersion of $\mathrm{NaCl}$ in the Region of Infrared Characteristic Frequencies," Z. Phys., 166; 122-47 (1962).

[15] Vinogradov, E.A., Dianov, E.M., and Irisova, N.A., "Michelson Interferometer Used in Measuring the Refractive Index of Dielectrical Materials in the Region of $2 \mathrm{~mm}$ Wavelength," Radiotekh. Electron., 10, 804-8 (1965).

[16] Harting, H., "The Optical Aspect of Some Crystals and Their Representation by the Hartmann Equation," Z. Instrum., 63, 125-31 (1943).

[17] Czerny, M., "Measurements on the Refractive Index of $\mathrm{NaCl}$ in the Infrared to Prove the Dispersion Theory," Z. Phys., 65, 600-31 (1930).

[18] Barbaron, M., "Refraction of Solids Measured at Low Temperature," Ann. Phys., 6, 899-959 (1951).

[19] Marcoux, J., "Measurement of the Index of Refraction of Some Molten Ionic Salts," Rev. Sci. Instrum., 42(5), 600-2 (1971).

[20] Dianov, E.M., and Irisova, N.A., "Determination of the Absorption Coefficient of Solids in the Short-Wave Region of the Millimeter Band," J. Appl. Spectros. (USSR), 5(2), 187-9 (1966).

[21] Mitskevich, V.V., "Dynamical Theory of NaCl-Type Ionic Crystals. II., Dielectric and Optical Properties," Sov. Phys. Solid State, 3(10), 2211-7 (1962).

[22] Rubens, H. and Nichols, E.F., "Experiments With Heat Radiations of Long Wavelengths," Ann. Phys. Chem., 60, 418-62 (1897).

[23] Rubens, H. and Trowbridge, A., "Contribution to the Knowledge on the Refractive Index and Absorption of Infrared Radiation for Rocksalt and Sylvite," Ann. Phys. Chem., 60, 724-39 (1897).

[24] Rubens, H., "The Dispersion of Infrared Radiation," Wied. Ann., 45, 238-61 (1892).

[25] Rubens, H. and Snow, B.W., "Refraction of Long Wavelength Radiation in Rocksalt, Sylvite, and Fluorite," Wied. Ann., 46, 529-4l (1892).

[26] Rubens, H., "The Ketteler-Helmholtz Dispersion Formula," Wied. Ann 54, 476-85 (1895).

[27] Rubens, H., "The Dispersion of Infrared Radiation in Fluorite," Wied. Ann., 51, 381-95 (1894).

[28] Ramaseshan, S., "Faraday Effect in Some Cubic Crystals," Ind. Acad. Sci., Proc., A25, 459-66 (1947).

[29] Zarzyski, J. and Naudin, F., "Index of Refraction and Refractivity of Molten Salts," Compt. Rend., 256, 1282-5 (1963).

[30] Martens, F.F., "The Dispersion of Fluorite, Sylvite, Rocksalt, Quartz, and Calcite, as Well as the Dispersion of Diamond," Ann. Phys., 8, 459-65 (1902).

[31] Cartright, C.H. and Czerny, M., "Dispersion Measurements on $\mathrm{NaCl}$ in the Far Infrared," Z. Phys., 85, 269-77 (1933).

[32] Pulfrich, C., "The Influence of the Temperature on the Refraction of Glasses," Ann. Phys. Chem., 45(4), 609-65 (1892).

[33] Dianov, E.M. and Irisova, N.A., "Measurement of the Refractive Index of Crystals Having $\mathrm{NaCl}$ - and $\mathrm{CsCl}-\mathrm{T} y p e$ Structures," Sov. Phys. Solid State, 8(7), 1807-8 (1967).

[34] Joubin, P., "The Rotary Magnetic Dispersion," Ann. Phys. Chem., 6, 16, 78-144 (1889). 
[35] Dufet, M.H., "Comparative Measurements of the Refractive Indices Measured by the Prism and the Total Reflection," Soc. Francaise Min. Cristallo. Bull., 14, 130-48 (1891).

[36] Lowndes, R.P. and Martin, D.H., "Dielectric Dispersion and the Structures of Ionic Lattices," Proc. Roy. Soc., A308, 473-96 (1969).

[37] Fedyukina, G.N. and Zlenko, V.Ya., "Determination of the Refractive Index of Transparent Bodies using a Scratch and Immersion Liquids," Zap. Vses. Mineral. Obshchest., 101(3), 374-5 (1972).

[38] Hilsch, R. and Pohl, R.W., "Dispersion Frequencies of Alkali Halides in the Schumann Region," Z. Phys., 59, 812-9 (1930).

[39] Schneider, E.G. and O'Bryan, H.M., "The Absorption of lonic Crystals in the Ultraviolet," Phys. Rev., 51(5), 293-8 (1937).

[40] Ramachandran, G.N., "Thermo-Optic Behavior of Solids v. Alkali Halides," Proc. Indian Acad. Sci., 25A, 481-97 (1947).

[41] Kartheuser, E., "Polarons in Ionic Crystals and Polar Semiconductors," (Devreese, J.T., Editor), NorthHolland/American Elsevier, 717-33 (1972).

[42] Micheli, F.J., "The Influence of the Temperature on the Ultraviolet Radiation Dispersion in Fluorite, Rocksalt, Quartz, and Calcite," Ann. Phys., 4, 7, 772-89 (1902).

[43] Liebreich, E., "The Change of the Refractive Index With the Temperature in the Infrared Region for Rocksalt, Sylvite, and Fluorite," Verh. Deut. Phys. Ges., 13(1), 1-18 (1911).

[44] Liebreich, E., "The Optical Temperature Coefficient for Rocksalt, Sylvite, and Fluorite in the Region of Lower Temperatur es," Verh. Deut. Phys. Ges., 13(18-190, 700-12 (1911).

[45] Kolosovskii, $€$ A. and Ustimenko, L.N., "Measurement of the Temperature Coefficient of the Refractive Index of Infrared Materials Using a $\mathrm{CO}_{2}$ Laser," Opt. Spectros. USSR, 33 (4), 430-1 (1972).

[46] Li, H.H., "Refractive Index of Alkali Halides and Its Wavelength and Temperature Derivatives," J. Phys. Chem. Ref. Data, 5(2), 329-528 (1976).

[47] Kobayashi, K. and Tomiki, T., "Studies on the Preparation of Pure Alkali Chlorides," J. Phys. Soc. Japan, 15(11), 1982-90 (1960).

[48] Tomiki, T., Miyata, T., and Tsukamoto, H., "The Urbach Rule for the Sodium- and Potassium-Halides," Z. Naturforsch., A29(1), 145-57 (1974).

[49] Deutsch, T.F., "Absorption Coefficient of Infrared Laser Window Materials," J. Phys. Chem. Solids, 34, 2091-4. (1973).

[50] Harrington, J.A. and Hass, M., "Temperature Dependence on Multiphonon Absoroption," Phys. Rev. Letters, 31(11), 710-4 (1973).

[51] Horrigan, F.A. and Rudko, R., "Materials for High-Power $\mathrm{CO}_{2}$ Lasers," Final Technical Report, Contract No. DAAH01-69-0038, Raytheon Research Division, Waltham, Mass. (Internal Number S-1170) (1969).

[52] Califano, S. and Czerny, M., "Absorpuon of $\mathrm{NaCl}$ and $\mathrm{KBr}$ in Short Infrared Wavelength Region," Z. Phys., 150, 1-3 (1958).

[53] Barker, A.J., "The Effect of Melting on the Multiphonon Infrared Absorption Spectra of $\mathrm{KBr}, \mathrm{NaCl}$ and $\mathrm{LiF}$," J. Phys. C: Solid State Phys., 5, 2276-82 (1972).

[54] Owens, J.C., "Anharmonicity and Millimeter-Wave Absorption in Alkali-Halide Crystals," Phys. Rev., 181(3), 1228-36 (1969).
[55] Dötsch, H. and Happ, H., "Temperature Dependence of Absorption of $\mathrm{NaCl}$ Between 1 and $3 \mathrm{~mm}$ Wavelength Range," Z. Phys., 177, 360-8 (1964).

[56] McCubbin, Jr. and Sinton, W.M., "Recent Investigations in the Far Infrared," J. Opt. Soc. Am., 40, 537 (1950).

[57] Przibram, K., "Irradiation Colours and Luminescence, Pergamon Press, London, (1956).

[58] Kennard, T.G., Howell, D.H., and Yaeckel, M.P., "Spectrographic Examination of Colorless and Blue Halite," Am. Mineral., 22, 65-7 (1937).

[59] Phipps, T.E. and Brode, W.R., "A Comparative Study of Two Kinds of Colored Rock Salt," J. Phys. Chem., 30, 507-20 (1926).

[60] Seitz, F., "Color Centers in Alkali Halide Crystals II," Rev. of Mod. Phys., 26(1), 7-94 (1954).

[61] Compton, W.D. and Rabin, H., "F-Aggregate Centers in Alkali Halide Crystals," Solid State Phys., 16, 121-226 (1964).

[62] Schulman, J.H. and Compton, W.D., "Color Centers in Solids," The MacMillan Company, New York (1962).

[63] Crawford, J.H. and Slifkin, L.M., "Point Defects in Solids, Volume 1. General and Ionic Crystals," Plenum Press, New York (1972).

[64] Kobayashi, K., "Density Change of Sodium Chloride Produced by Proton Irradiation and Its Thermal Annealing," 107, 41-3 (1957).

[65] Kobayashi, K., "Annealing of Irradiation Effects in Sodium Chloride Irradiated with High-Energy Protons," 102, 348-55 (1955).

[66] Hodgson, E.R., Delgado, A., and Rivas, A., "In-Beam Measurements of the $\mathrm{F}$ Colouring Curves for $\mathrm{NaCl} \mathrm{At}$ and Above Room Temperature," Solid State Commun., 16, 785-8 (1975).

[67] Jain, U. and Lidiard, A.B., "The Growth of Colloidal Centers in Irradiated Alkali Halides," Phil. Mag., 35(1), 245-59 (1977).

[68] Nowick, A.S., "Effect of Plastic Deformation on the $\boldsymbol{\gamma}$-Ray Coloration of $\mathrm{NaCl}$ Crystals," Phys. Rev., 11(1), 16-25 (1958).

[69] Compton, W.D., "Production of Colloidal Sodium in $\mathrm{NaCl}$ by Ionization Radiation," Phys. Rev. 107(5), 1271-5 (1957).

[70] Smoluchowski, R., "Radiation Effects in Dielectric Solids," in The Effects of Radiation on Materials, Reinhold, 1958.

[71] Smoluchowski, R., "Effect of Nuclear Irradiation on Ionic Crystals," Proc. International Conf. on Peaceful Uses of Atomic Energy (United Nations), 7, 676-81 (1956).

[72] Amelinckx, S., "Radiation Effects in Ionic Crystals," Proc. International School of Physics, $422-517$ (1962).

[73] Lipson, H.G., Ligor, P., and Martin, J.J., "The Effect of Ionizing Radiation on the $10.6 \mu \mathrm{m}$ Absorption of $\mathrm{KCl}$ and $\mathrm{NaCl}$," Phys. Status Solidi A, 37(2), 547-52 (1976).

[74] Wood, R.W., "Physical Optics," 3rd Ed., The MacMillan Company, New York (1934).

[75] Jenkins, F.A. and White, H.E., "Fundamentals of Optics," 3rd Ed., McGraw-Hill Company, New York (1957).

[76] Klein, C.A. and Rudko, R.L., " ${ }^{\circ} \mathrm{CO}_{2}$ Laser Radiation Absorption in Semi-Insulating Gallium Arsenide," Appl. Phys. Lett., 13, 129 (1968)

[77] Deutsch, T.F., "Absorption Coefficient of Infrared Laser Window Materials," J. Phys. Chem. Solids., 34, 2091-104 (1973). 
Symbols and Units

\begin{tabular}{lll}
\hline \hline Symbol & Name & Units \\
\hline$A$ & Absorption coefficient & $\mathrm{cm}^{-1}$ \\
$d$ & Sample thickness & $\mathrm{cm}$ \\
$E$ & Energy & $\mathrm{eV}$ \\
$E_{\mathrm{a}}$ & Absorbed energy & $\mathrm{eV}$ \\
$\overline{\mathrm{h} w}$ & Energy of light quantum & $\mathrm{eV}$ \\
$\mathrm{k}$ & Absorption index or extinction & \\
& coefficient & dimensionless \\
LO, TO & Longitudinal and transverse & \\
& optical phonon modes & \\
$n$ & Refractive index & dimensionless \\
$R$ & Reflectivity & dimensionless \\
$T$ & Temperature & $\mathrm{K}$ \\
$T$ & Transmission & dimensionless \\
$\alpha$ & Intrinsic absorption coefficient & $\mathrm{cm}^{-1}$ \\
$\Delta \rho$ & Density change & $\mathrm{cm}^{-3}$ \\
$\epsilon_{0}$ & Static dielectric constant & dimensionless \\
$\epsilon$ & Dielectric constant & dimensionless \\
$\lambda$ & Wavelength & $\mu \mathrm{m}$ \\
$\theta$ & Phase angle & radius \\
$\lambda$ & Light frequency & $\mathrm{s}^{-1}$ \\
\hline
\end{tabular}

Conversion Factors

W avelength

\begin{tabular}{ccc}
$\begin{array}{c}\text { To convert jrom } \\
\mu \mathrm{m}\end{array}$ & to & Multiply by \\
\hline
\end{tabular}




\title{
Chapter 6 \\ Electrical and Magnetic Properties
}

\author{
R. A. Matula*
}

Contents

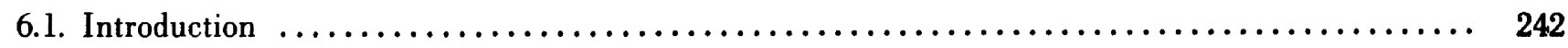

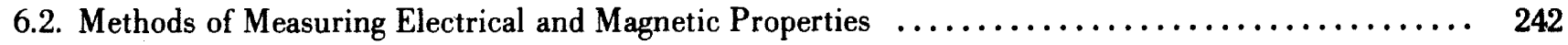

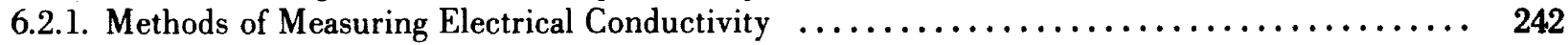

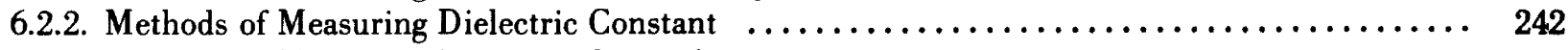

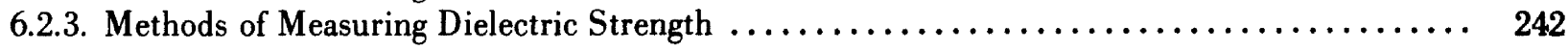

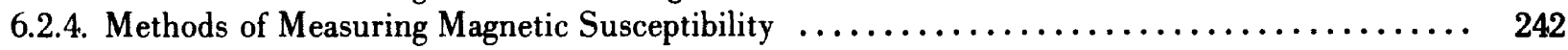

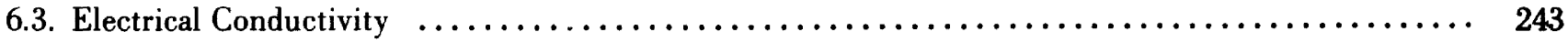

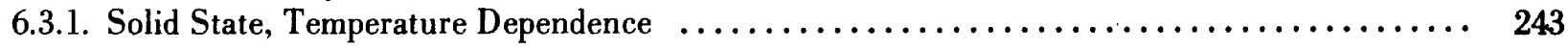

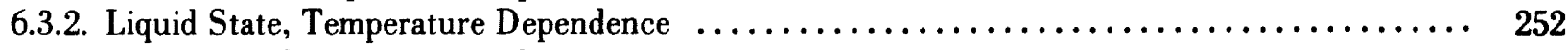

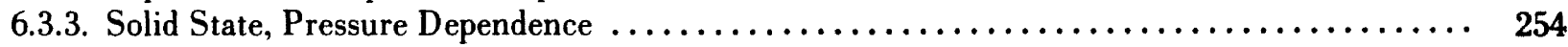

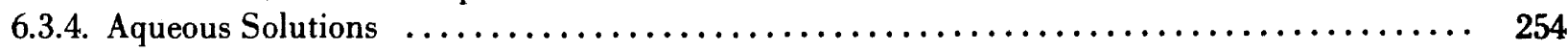

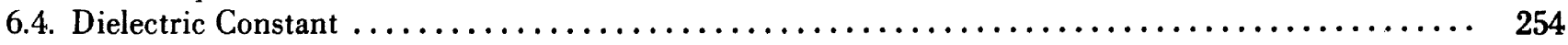

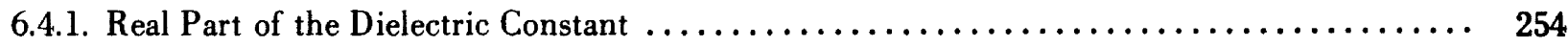

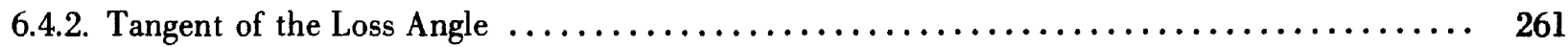

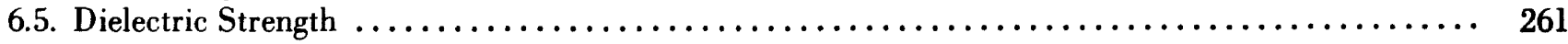

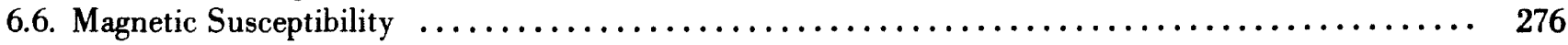

6.7. Effect of Nuclear Irradiation on Electrical and Magnetic Properties $\ldots \ldots \ldots \ldots \ldots \ldots \ldots \ldots \ldots \ldots .276$



6.7.2. Effect of Nuclear Irradiation on Dielectric Constant and Strength $\ldots \ldots \ldots \ldots \ldots \ldots \ldots \ldots \ldots 277$

6.8. References ................................................ 278

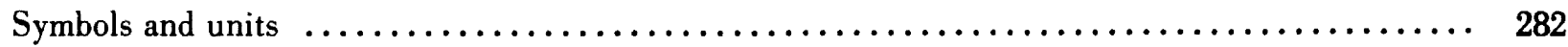

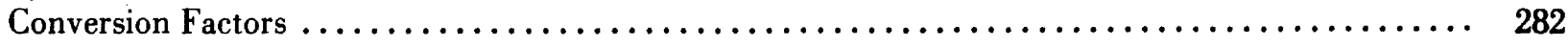

* Center for Information and Numerical Data Analysis and Synthesis, Purdue University, 2595 Yeager Road, West Lafayette, Indiana 47906 


\subsection{Introduction}

There have been extensive measurements made on the electrical properties. In most cases an effort was made to critically evaluate the available data and come forth with recommended reference values. When this was not possible, selected sets of data are presented as typical cases with the data presented in both tabular and graphical form for ease of use. The difficulty in developing recommended values arises from the uncharacterized nature of the samples reported and the large changes in the properties due to impurities. Because of these difficulties, data for pure and doped sodium chloride have been included.

The very meaning of "rock salt" gives an indication of the variation in composition to be expected. The percentage of $\mathrm{NaCl}$ in "rock salt" ranges from $17 \%$ to $99+\%$ with a range around $96 \%$ being a typical value; typical values of impurities are water $0.17-0.5 \%$, anhydrite $0.1-80 \%$, other salts $0.08-0.5 \%$, carbonates $0.01-0.2 \%$, and sulfate $0.1-10 \%$ [128]. In addition, numerous liquid and gaseous inclusions are known to be in rock salt.

Preceding the presentation and discussion of the data, a brief discussion is given of methods of measurement for the purpose of pointing out the basic idea of the methods and giving references for additional information for the interested reader.

\subsection{Methods of Measuring Electrical and Magnetic Properties}

\subsubsection{Methods of Measuring Electrical Conductivity}

The electrical conductivity in the solid state is determined by measuring the resistance of a slab of material of known dimensions. The resistance is found by placing the material between metallic electrodes and finding the current flowing for a given known electric potential. To aid in obtaining good contacts Aquadag, a colloidal dispersion of graphite, is sometimes put on the faces of the material on which the metallic contacts are to be placed. Details of measuring the conductivity in the solid state can be found in references [112, pp. 26-35; 5 , p. 1005; and 2, p. 1497]. A discussion of electrode behavior in the determination of ionic conductivity is given in reference [113]. The error inherent in the measurement of the electrical conductivities with the 4probe method can be of the order of $\pm 0.1 \%$.

In the liquid state there are three main types of cells used to measure the electrical conductivity. With the U. shaped capillary type the liquid material is contained entirely within the cell. With the dip-type cell the capillaries are immersed in the liquid material. The third type uses electrodes immersed in the liquid material. Additional details are in references [46, pp. 875-6; 114, p. 3; and 115, pp. 583-6]. The errors inherent in the measurement of the electrical conductivities in the liquid state can be as high as several percent for the diptype cell because of the problem of parasitic conduction, but for the U-type cell, where this problem is not present, it can be of the order of $0.1 \%$.

\subsubsection{Methods of Measuring Dielectric Constant}

The general idea behind the determination of the real and imaginary parts of the dielectric constant is the measurement and comparison of a capacitor containing the dielectric material and the same capacitor without the dielectric. In different frequency regions, different experimental methods are used. At lower frequencies, typically $10^{2}$ to $10^{7} \mathrm{~Hz}$, bridge methods are applicable. At higher frequencies resonant circuit methods can be used while at frequencies greater than the order of $100 \mathrm{MHz}$ transmission line methods are used while at higher frequencies, waveguide and cavity resonator methods can be used. Details can be found in references [69, pp. $315-6$; 116, chapter 3 , pp. 109-68; 117, chapter 2 , pp. $21-38 ; 118$, p. 1; 119, pp. 47-122; 72; and 120, pp. 364-390]. The inherent inaccuracy in the measurement of the dielectric constant can be of the order of $0.1 \%$ or better.

\subsubsection{Methods of Measuring Dielectric Strength}

The dielectric strength is the maximum electric field strength a material can withstand before the onset of a rapid increase in electrical conduction. The dielectric strength is measured by increasing the voltage applied to a specimen and noting when conducting paths form. Additional details can be found in references [121, pp. 6-7; and 81, pp. 2, 3, 6, and 7]. One writer [98, p. 103] points out that the variation in the breakdown voltage can be held to within $\pm 5 \%$ as well as for the sample thickness thus giving an uncertainty in these quantities alone that should not exceed $\pm 10 \%$.

\subsubsection{Methods of Measuring Magnetic Susceptibility}

The magnetic susceptibility of sodium chloride has been measured using the Faraday method which is also known as the non-uniform field method. The principle behind this method is the measurement of a force, using a sensitive balance, on a small specimen suspended between pole pieces in which the magnetic field and its spatial derivative do not vary very much. The sensitivity using this method is high with an accuracy that can be 
attained of $\pm 0.1 \%$. Additional details can be found in references [122, pp. 428-30; 123, pp. 11-8; and 124, pp. 458-9].

In the Gouy method or uniform field method, a long sample is suspended between pole pieces such that one end of the sample is in the region of maximum field strength and the other end in a region where the field is minimal. The force is measured by a balance and the force is proportioned to the square of the maximum field strength. Generally the accuracy using this method can be $\pm 1 \%$ which can be improved to an accuracy of $\pm 0.1 \%$ [124, p. 454]. Additional details can be found in references [122, pp. 429-30; 123, pp. 3-10; and 124, pp. 456-7].

\subsection{Electrical Conductivity}

\subsubsection{Solid State, Temperature Dependence}

Evaluated data are given for the intrinsic electrical conductivity of pure sodium chloride in the solid state. The evaluated data are given in table 6.1 and shown on figure 6.1. Table 6.2 gives the experimental data for data sets used specifically to develop the evaluated data as well as other selected data in order to illustrate the behavior for pure sodium chloride, sodium chloride with known amounts of dopants, and naturally occurring rock salt. A discussion of some features of the data follows before describing how the evaluated data were arrived at.

There are several characteristics of the conductivity data as a function of temperature that bear mentioning. The conductivity increases as the temperature increases and, moreover, does so by orders of magnitude from room temperature of $293 \mathrm{~K}$ (or $10^{3} / T=3.41$ ) to the melting point of $1074 \mathrm{~K}$ (or $10^{3} / T=0.931$ ). This large change suggests plotting the conductivity on a logarithmic scale.

Another feature of the data is that there are distinct regions where $\log (\sigma T)$ is linear when plotted as a function of $T^{-1}$ (curve 15). This is further illustrated in the literature both for pure and doped sodium chloride [7, fig. $1 ; 15$, fig. 1 ; and 16, fig. 1$]$. In addition, theoretical considerations lead to the conclusion that in three conductivity regions, one of which is the intrinsic, $\log$ $(\sigma T)$ versus $T^{-1}$ is linear [4]. Based on the consideration that much of the data in the literature are presented as $\log (\sigma T)$ as a function of $10^{3} / T$, it was decided to plot figure 6.1 similarly.

On figure 6.1 , it is observed that below the melting point to perhaps $10^{3} / T \sim 1.3$, there is a limiting line below which data do not extend. This is the intrinsic region applicable to the pure material (parts of data sets $4,5,7,8,9$, and 15). Several of these data sets are for pure sodium chloride. Jain and Dahake [4] (curve 7) presented data on spectroscopically pure material, Etzel and Maurer [5] (curve 9) presented results from measurements on pure sodium chloride, and Trnovcova et al. [8] (curve 15) also gave measurements on pure material. It should be noted that very close to the melting point, a behavior different from the extension of linearity of the intrinsic-region behavior is evident (curve 5 for $10^{3} / T<1.0$ ).

Other features are also evident in figure 6.1. Specimens doped with impurities exhibit differences in the value of the conductivity (curves $3,6,10,11,12$, and 14). Specimens that come from natural crystals show a wide variation (curves 4 and 16). Other conditions are for a single crystal (curve 1), pellet (curve 2), disk specimen made under pressure (curve 5), a single crystal with low background impurity (curve 8 ), and a specimen called "rock salt" by the author (curve 13). For the same impurity, the conductivity increases as the impurity content increases (curves 11 and 12).

Recent measurements of the $\mathrm{DC}$ resistivity by Olhoeft [127] (curves 17-20), made at $295 \mathrm{~K}$ on halite cored from a Carlsbad, New Mexico corehole, show a variation between subsamples. In addition, data for the real part of the complex resistivity as a function of frequency are also presented and range from $5.16 \times 10^{6} \Omega \mathrm{m}$ to $1.86 \times$ $10^{6} \Omega \mathrm{m}$ at a frequency of $10^{2} \mathrm{~Hz}$. This can be compared to the estimate based on dielectric measurements of the Laboratory for Insulation Research [60] at $298 \mathrm{~K}$. Using a frequency of $10^{2} \mathrm{~Hz}$, a value for the real part of the dielectric constant of 5.90 (see data set 1 in table 6.7), a value of $\tan \delta$ of $<1 \times 10^{-4}[60$, p. 302], and the relation between this resistivity and the dielectric properties (and

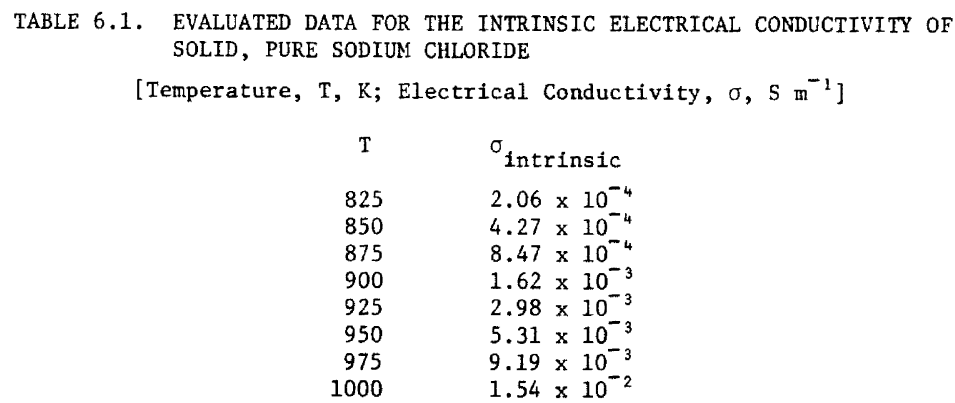




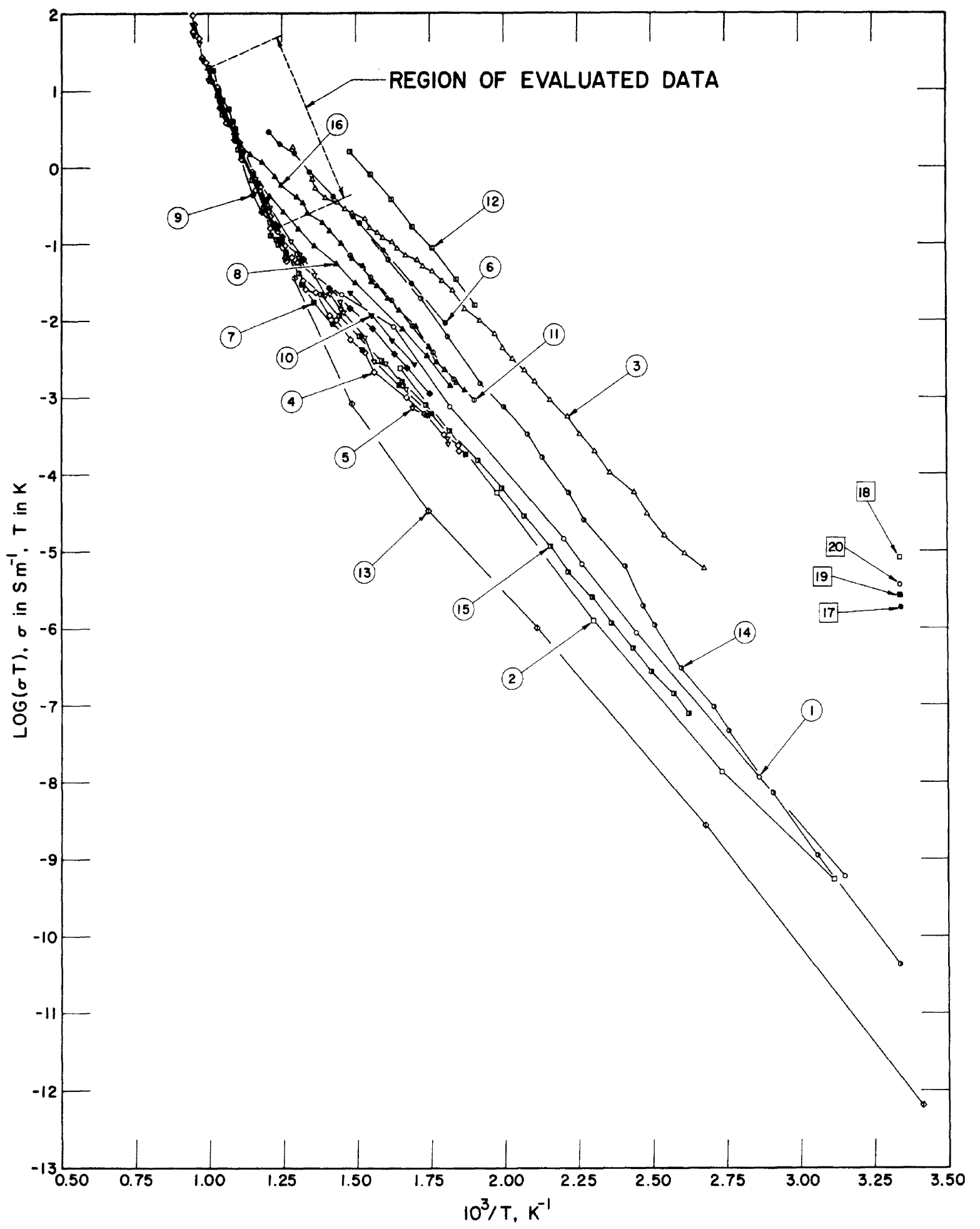

FGGURE 6.1. Electrical conductivity of solid sodium chloride (temperature dependence). 
TABLE 6.2. EXPERIMENTAL DATA ON THE ELECTRICAL CONDUCTIVITY OF SOLID SODIUM CHLORIDE (Temperature Dependence)

[Temperature, T, $\mathrm{K}$; Electrical Conductivity, $\sigma, \mathrm{S} \mathrm{m}^{-1}$ ]

\begin{tabular}{|c|c|c|c|c|}
\hline $\begin{array}{l}\text { Data } \\
\text { Set }\end{array}$ & Author(s), Year [Ref.] & $10^{3} / \mathrm{T}$ & $\log (\sigma T)$ & Remarks \\
\hline 1 & Torkar, K., 1965 [1] & $\begin{array}{l}1.250 \\
1.301 \\
1.304 \\
1.451 \\
1.626 \\
1.818 \\
2.202 \\
2.265 \\
2.448 \\
2.862 \\
3.153\end{array}$ & $\begin{array}{l}-0.952 \\
-1.137 \\
-1.242 \\
-1.668 \\
-2.082 \\
-3.124 \\
-4.849 \\
-5.177 \\
-6.069 \\
-7.944 \\
-9.221\end{array}$ & $\begin{array}{l}\text { NaCl single crystal; measured in air using } \\
\text { isothermal method; data points extracted } \\
\text { from figure; analytically, temperature de- } \\
\text { pendence, } \sigma=2.5 \exp (-20,700 / \mathrm{RT})\end{array}$ \\
\hline 2 & Torkar, K., 1965 [1] & $\begin{array}{l}1.650 \\
1.979 \\
2.302 \\
2.739 \\
3.116\end{array}$ & $\begin{array}{l}-2.625 \\
-4.248 \\
-5.902 \\
-7.872 \\
-9.264\end{array}$ & $\begin{array}{l}\text { NaCl pellet; measured in air using isothermal } \\
\text { method; data points extracted from figure; } \\
\text { analytically, temperature dependence } \sigma= \\
1.0 \exp (-20,700 / \mathrm{RT}) \text {. }\end{array}$ \\
\hline 3 & $\begin{array}{l}\text { Radhakrishna, S. and } \\
\text { Karguppikar, A.M., } \\
1973 \text { [2] }\end{array}$ & $\begin{array}{l}1.287 \\
1.354 \\
1.363 \\
1.397 \\
1.439 \\
1.464 \\
1.489 \\
1.532 \\
1.549 \\
1.574 \\
1.591 \\
1.624 \\
1.641 \\
1.667 \\
1.709 \\
1.726 \\
1.759 \\
1.793 \\
1.827 \\
1.869 \\
1.920 \\
1.970 \\
1.996 \\
2.030 \\
2.072 \\
2.105 \\
2.156 \\
2.215 \\
2.257 \\
2.308 \\
2.359 \\
2.426 \\
2.485 \\
2.544 \\
2.612 \\
2.679\end{array}$ & $\begin{array}{r}0.267 \\
-0.150 \\
-0.283 \\
-0.400 \\
-0.467 \\
-0.567 \\
-0.600 \\
-0.683 \\
-0.800 \\
-0.867 \\
-0.933 \\
-0.983 \\
-1.067 \\
-1.150 \\
-1.217 \\
-1.300 \\
-1.367 \\
-1.483 \\
-1.617 \\
-1.850 \\
-2.017 \\
-2.183 \\
-2.367 \\
-2.500 \\
-2.650 \\
-2.800 \\
-3.033 \\
-3.250 \\
-3.483 \\
-3.700 \\
-3.983 \\
-4.233 \\
-4.517 \\
-4.800 \\
-5.033 \\
-5.233\end{array}$ & $\begin{array}{l}\mathrm{NaCl} \text { crystals Sb-doped to } 0.0080 \text { ( } 80 \mathrm{ppm}) \text {; } \\
\text { crystals grown from melt by Kyropoulos tech- } \\
\text { nique starting with BDH-AR grade salt, Sb } \\
\text { then diffused by heating the crystal in Sb } \\
\text { vapor at } 973 \pm 5 \text { K for about } 6 \text { days, the } \\
\text { NaC1 and Sb metal sealed together in quartz } \\
\text { tube after evacuating to approx } 10^{-3} \text { torr; } \\
\text { impurity content estimated by mass spectro- } \\
\text { scopic analysis; data points of } 10 \mathrm{~g}(\sigma \mathrm{T}) \\
\text { versus } 10^{3} / \mathrm{T} \text { extracted from figure; conduc- } \\
\text { tivity measurements incorporated a GR 1644-A } \\
\text { M bridge; specimens prepared for measure- } \\
\text { ments by coating two opposite faces of } \\
\text { crystal with thin coating of aquadag and } \\
\text { crystal placed between two platinum plates. }\end{array}$ \\
\hline
\end{tabular}


TABLE 6.2. EXPERIMENTAL DATA ON THE ELECTRICAL CONDUCTIVITY OF SOLID SODIUM CHLORIDE (Temperature Dependence) (continued)

\begin{tabular}{|c|c|c|c|c|}
\hline $\begin{array}{l}\text { Data } \\
\text { Set }\end{array}$ & Author (s), Year [Ref.] & $10^{3} / \mathrm{T}$ & $\log (\sigma \mathrm{T})$ & Remarks \\
\hline 4 & $\begin{array}{l}\text { Phipps, T.E., Lansing, } \\
\text { W.D., and Cooke, T.G., } \\
1926 \text { [3] }\end{array}$ & $\begin{array}{l}0.947 \\
0.953 \\
0.950 \\
0.970 \\
0.980 \\
0.993 \\
1.010 \\
1.031 \\
1.060 \\
1.093 \\
1.107 \\
1.110 \\
1.148 \\
1.160 \\
1.175 \\
1.209 \\
1.210 \\
1.210 \\
1.226 \\
1.235 \\
1.237 \\
1.260 \\
1.265 \\
1.260 \\
1.282 \\
1.321 \\
1.330 \\
1.363 \\
1.410 \\
1.431 \\
1.481 \\
1.530 \\
1.561 \\
1.670 \\
1.682 \\
1.747 \\
1.795 \\
1.796\end{array}$ & $\begin{array}{r}1.984 \\
1.871 \\
1.774 \\
1.686 \\
1.430 \\
1.373 \\
1.121 \\
1.057 \\
0.589 \\
0.448 \\
0.336 \\
0.115 \\
-0.068 \\
-0.304 \\
-0.255 \\
-0.589 \\
-0.645 \\
-0.808 \\
-0.759 \\
-0.780 \\
-0.848 \\
-1.022 \\
-1.225 \\
-1.192 \\
-1.184 \\
-1.484 \\
-1.597 \\
-1.631 \\
-1.934 \\
-2.008 \\
-2.250 \\
-2.425 \\
-2.676 \\
-3.008 \\
-3.228 \\
-3.496 \\
-3.635 \\
-3.706\end{array}$ & $\begin{array}{l}\text { NaC1 natural crystal (Navarre), rock salt; } \\
\text { resistances from } 0 \text { to } 0.5 \mathrm{M} \Omega \text { measured using } \\
\text { telephone and drum-wound conductivity bridge } \\
\text { with a Leeds and Northrup } 1000 \mathrm{~Hz} \text { microphone } \\
\text { humer as source of ac, from } 0.5 \text { to } 100 \mathrm{M} \Omega \\
\text { Wheatstone bridge method used with } 8 \mathrm{~V} \mathrm{dc} \\
\text { used in range of lower resistances and } 110 \\
\mathrm{~V} \text { dc used for the highest resistances; un- } \\
\text { certainty in temperature } 1 \text { or } 2 \mathrm{~K} \text {; composite } \\
\text { data of } 3 \text { experiments with different crystals } \\
\text { extracted from table; at } 10^{3} / \mathrm{T}=1.28(\mathrm{~T}= \\
781 \mathrm{~K} \text { ) slope changes in } 10 \mathrm{~g} \sigma \text { versus } 10^{3} / \mathrm{T} \\
\text { plot. }\end{array}$ \\
\hline 5 & $\begin{array}{l}\text { Phipps., T.E., et al. } \\
1926 \text { [3] }\end{array}$ & $\begin{array}{l}0.948 \\
0.950 \\
0.950 \\
0.970 \\
0.980 \\
0.980 \\
1.000 \\
1.010 \\
1.000 \\
1.030 \\
1.060 \\
1.110 \\
1.110 \\
1.116 \\
1.160 \\
1.160\end{array}$ & $\begin{array}{l}1.866 \\
1.724 \\
1.729 \\
1.623 \\
1.405 \\
1.415^{\star} \\
1.306 \\
1.128^{\star} \\
1.130 \\
1.009 \\
0.638 \\
0.209 \\
0.193 \\
0.192 \\
-0.166 \\
-0.200\end{array}$ & $\begin{array}{l}\mathrm{NaCl} \text {; material obtained from S.A. Braley of } \\
\text { the Analytical Division of Chemical Lab. of } \\
\text { the University of Illinois and had been } \\
\text { twice crystallized, twice centrifuged, and } \\
\text { dried at temperatures near the melting point; } \\
\text { specimen prepared by pressing the powdered } \\
\text { salt into disks using } 8000 \text { atmospheres and } \\
\text { disks were quite transparent; disk specimen } \\
1.5 \mathrm{~mm} \text { thick; resistances from } 0 \text { to } 0.5 \mathrm{M} \Omega \\
\text { measured using telephone and drum-wound con- } \\
\text { ductivity bridge with a Leeds and Northrup } \\
1000 \mathrm{~Hz} \text { microphone hummer as source of ac, } \\
\text { from } 0.5 \text { to } 100 \mathrm{M} \Omega \text { Wheatstone bridge method } \\
\text { used with } 8 \mathrm{~V} \text { dc used in range of lower re- } \\
\text { sistances and } 110 \mathrm{~V} \text { dc used for the highest } \\
\text { resistances; uncertainty in temperature } 1 \text { or }\end{array}$ \\
\hline
\end{tabular}


TABLE 6.2. EXPERIMENTAL DATA ON THE ELECTRICAL CONDUCTIVITY OF SOLID SODIUM CHLORIDE (Temperature Dependence) (continued)

\begin{tabular}{|c|c|c|c|c|}
\hline $\begin{array}{l}\text { Data } \\
\text { Set }\end{array}$ & Author(s), Year [Ref.] & $10^{3} / \mathrm{T}$ & $\log (\sigma \mathrm{T})$ & Remarks \\
\hline $\begin{array}{c}5 \\
\text { (cont.) }\end{array}$ & $\begin{array}{l}\text { Phipps, T.E., Lansing, } \\
\text { W.D., and Cooke, T.G., } \\
1926 \text { [3] }\end{array}$ & $\begin{array}{l}1.200 \\
1.210 \\
1.289 \\
1.310 \\
1.310 \\
1.360 \\
1.399 \\
1.410 \\
1.447 \\
1.447 \\
1.460 \\
1.530 \\
1.561 \\
1.600 \\
1.670 \\
1.691 \\
1.740 \\
1.810 \\
1.810\end{array}$ & $\begin{array}{l}-0.447 \\
-0.546 \\
-0.975 \\
-1.141 \\
-1.238 \\
-1.410 \\
-1.686 \\
-1.655 \\
-1.860 \\
-1.764 \\
-1.902 \\
-2.235 \\
-2.540 \\
-2.561 \\
-2.897 \\
-3.140 \\
-3.240 \\
-3.542 \\
-3.624\end{array}$ & $\begin{array}{l}2 \mathrm{~K} \text {; composite data of three runs with } \\
\text { different high-pressure disks extracted } \\
\text { from table; at } 916 \mathrm{~K} \text { slope changes in } 10 \mathrm{~g} \\
\sigma \text { versus } 10^{3} / \mathrm{T} \text { plot; first value of } 10^{3} / \mathrm{T}= \\
1.310 \text { taken with ac, second value taken } \\
\text { with dc. }\end{array}$ \\
\hline 6 & $\begin{array}{l}\text { Jain, S.C. and } \\
\text { Dahake, S.L., } 1964 \text { [4] }\end{array}$ & $\begin{array}{l}1.205 \\
1.243 \\
1.292 \\
1.343 \\
1.421 \\
1.514 \\
1.592 \\
1.690 \\
1.802\end{array}$ & $\begin{array}{r}0.458 \\
0.309 \\
0.128 \\
-0.076 \\
-0.382 \\
-0.745 \\
-1.097 \\
-1.528 \\
-2.049\end{array}$ & $\begin{array}{l}\text { NaC1 single crystal; Ba-doped to concentra- } \\
\text { tion } 0.0045 \text { at.\%; grown from melts of BDH } \\
\text { analar NaC1 using Kyropoulos method; barium } \\
\text { impurity added in form of chloride to melt; } \\
\text { concentration of barium estimated approx by } \\
\text { comparing ionic conductivity (in impurity } \\
\text { range) of Ba-doped NaCl with corresponding } \\
\text { conductivity of NaCl containing known con- } \\
\text { centration of nickel; rapidly quenched; thin } \\
\text { coating of aquadog applied to two opposite } \\
\text { faces and crystal put between two plates } \\
\text { made of a platinum-rhodium alloy; measure- } \\
\text { ments performed in an atmosphere of pure } \\
\text { nitrogen to avoid oxidation of graphite } \\
\text { electrodes; measurements performed using dc } \\
\text { pulse and ballistic galvanometer; data } \\
\text { points of log ( } \sigma \mathrm{T} \text { ) versus } 10^{3} / \mathrm{T} \text { extracted } \\
\text { from a figure; accuracy of conductivity } 5 \% \\
\text { at lowest temperature used and } 1 \% \text { at higher } \\
\text { temperatures. }\end{array}$ \\
\hline 7 & $\begin{array}{l}\text { Jain, S.C. and } \\
\text { Dahake, S.L., } 1964 \text { [4] }\end{array}$ & $\begin{array}{l}1.018 \\
1.034 \\
1.050 \\
1.070 \\
1.081 \\
1.091 \\
1.154 \\
1.160 \\
1.191 \\
1.222 \\
1.233 \\
1.248 \\
1.264 \\
1.316\end{array}$ & $\begin{array}{l}1.262 \\
1.000 \\
0.870 \\
0.765 \\
0.608 \\
0.504 \\
-0.097 \\
-0.202 * \\
-0.437 \\
-0.751 \\
-0.803 \\
-0.986 \\
-1.117 \\
-1.535\end{array}$ & $\begin{array}{l}\text { Spectroscopically pure NaCl; impurity con- } \\
\text { centration } 0.00015 \text { at. } \% \text {; grown from melt at } \\
\text { Johnson Matthey spectroscopically pure } \mathrm{NaCl} \\
\text { using Kyropoulos method; rapidly quenched } \\
\text { from } 973 \mathrm{~K} \text { at about } 200 \mathrm{~K} \text { min }^{-1} \text {; thin coat- } \\
\text { ing of aquadog applied to opposite faces } \\
\text { and then specimen put between two plates } \\
\text { made of a platinum-rhodium alloy; measure- } \\
\text { ments performed in an atmosphere of pure } \\
\text { nitrogen to avoid oxidation of graphite } \\
\text { electrodes; measurements performed using dc } \\
\text { pulse and ballistic galvanometer; data points } \\
\text { of log }(\sigma \mathrm{T}) \text { versus } 10^{3} / \mathrm{T} \text { extracted from a } \\
\text { figure; accuracy of conductivity } 5 \% \text { at }\end{array}$ \\
\hline
\end{tabular}

* Not shown in figure. 
TABLE 6.2. EXPERIMENTAL DATA ON THE ELECTRICAL CONDUCTIVITY OF SOLID SODIUM CHLORIDE (Temperature Dependence) (continued)

\begin{tabular}{|c|c|c|c|c|}
\hline $\begin{array}{l}\text { Data } \\
\text { Set }\end{array}$ & Author(s), Year [Ref.] & $10^{3} / \mathrm{T}$ & $\log (\sigma \mathrm{T})$ & Remarks \\
\hline $\begin{array}{c}7 \\
\text { (cont.) }\end{array}$ & $\begin{array}{l}\text { Jain, S.C. and } \\
\text { Dahake, S.L., } 1964 \text { [4] }\end{array}$ & $\begin{array}{l}1.358 \\
1.421 \\
1.520 \\
1.645 \\
1.755 \\
1.870\end{array}$ & $\begin{array}{l}-1.770 \\
-2.057 \\
-2.396 \\
-2.840 \\
-3.257 \\
-3.753\end{array}$ & $\begin{array}{l}\text { lowest temperature used and } 1 \% \text { at higher } \\
\text { temperatures. }\end{array}$ \\
\hline 8 & $\begin{array}{l}\text { Jain, S.C. and } \\
\text { Dahake, S.L., } 1964 \text { [4] }\end{array}$ & $\begin{array}{l}1.175 \\
1.207 \\
1.255 \\
1.307 \\
1.360 \\
1.434 \\
1.498 \\
1.656 \\
1.741 \\
1.820\end{array}$ & $\begin{array}{l}-0.226 \\
-0.382 \\
-0.591 \\
-0.825 \\
-1.033 \\
-1.267 \\
-1.527 \\
-2.125 \\
-2.464 \\
-2.854\end{array}$ & $\begin{array}{l}\text { NaCl single crystal; background impurity } \\
\text { content } 0.0010 \text { at.\%; grown from me1t of } \mathrm{BDH} \\
\text { analar NaCl using Kyropoulos method; rapidly } \\
\text { quenched from } 973 \mathrm{~K} \text { at about } 200 \mathrm{~K} \text { min } \\
\text { thin coating of aquadag applied to opposite } \\
\text { faces and then specimen put between two } \\
\text { plates made of a platinum-rhodium alloy; } \\
\text { measurements performed in an atmosphere of } \\
\text { pure nitrogen to avoid oxidation of graphite } \\
\text { electrodes; measurements performed using dc } \\
\text { pulse and ballistic galvanometer; data } \\
\text { points of log }(\sigma \mathrm{T}) \text { versus } 10^{3} / \mathrm{T} \text { extracted } \\
\text { from a figure; accuracy of conductivity } 5 \% \\
\text { at lowest temperature used and } 1 \% \text { at higher } \\
\text { temperatures. }\end{array}$ \\
\hline 9 & $\begin{array}{l}\text { Etzel, H.W. and } \\
\text { Maurer, R.J., } 1950 \text { [5] }\end{array}$ & $\begin{array}{l}1.01 \\
1.04 \\
1.09 \\
1.15 \\
1.18 \\
1.22 \\
1.25 \\
1.32 \\
1.41 \\
1.48 \\
1.55 \\
1.63 \\
1.67 \\
1.75\end{array}$ & $\begin{array}{l}1.120 * \\
0.783 \\
0.362 \\
-0.136 \\
-0.519 \\
-0.736 * \\
-0.921 \\
-1.208 \\
-1.587 \\
-1.846 \\
-2.115 \\
-2.437 \\
-2.623 \\
-2.955\end{array}$ & 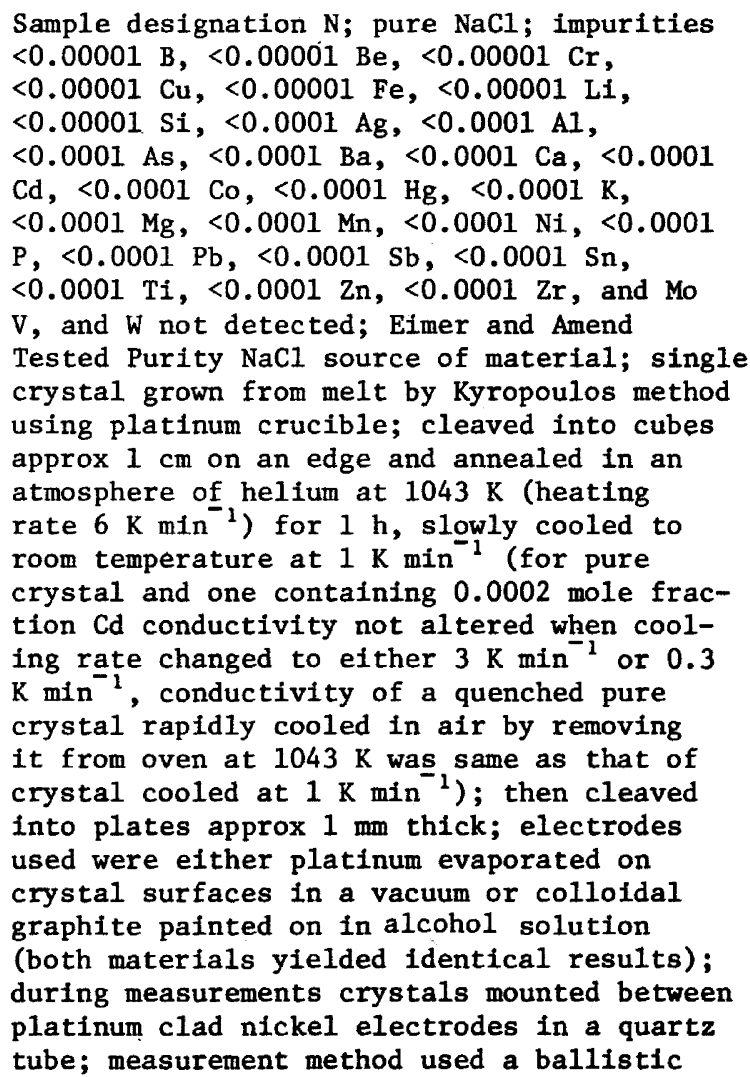 \\
\hline
\end{tabular}

* Not shown in figure. 
TABLE 6.2. EXPERIMENTAL DATA ON THE ELECTRICAL CONDUCTIVITY OF SOLID SODIUM CHLORIDE (Temperature Dependence) (continued)

\begin{tabular}{clll}
\hline $\begin{array}{c}\text { Data } \\
\text { Set }\end{array}$ & Author(s), Year [Ref.] & $10^{3} / \mathrm{T}$ & $\log (\sigma \mathrm{T})$ \\
\hline $\begin{array}{c}\text { 9 } \\
\text { (cont.) }\end{array}$ & $\begin{array}{l}\text { Etze1, H.W. and } \\
\text { Maurer, R.J., 1950 [5] }\end{array}$ & & \\
& & & \\
& & & \\
& & & \\
10 & Etze1, H.W. and & 1.48 & -1.658 \\
& Maurer, R.J., 1950 [5] & 1.55 & -1.940 \\
& & 1.62 & -2.260 \\
& & 1.70 & -2.580 \\
11 & & & \\
& Etze1, H.W. and & 1.48 & -1.157 \\
& & 1.55 & -1.445 \\
& & 1.62 & -1.743 \\
& & 1.69 & -2.079 \\
& & 1.76 & -2.426 \\
& & 1.83 & -2.771 \\
& & 1.90 & -3.046
\end{tabular}

12 Etzel, H.W. and Maurer, R.J., 1950 [5]

Dreyfus, R.W. and Nowick, A.S., 1962 [7]

$\begin{array}{lr}1.48 & 0.208 \\ 1.55 & -0.100 \\ 1.62 & -0.428 \\ 1.69 & -0.785 \\ 1.76 & -1.064 \\ 1.84 & -1.471 \\ 1.90 & -1.803 \\ 1.293 & -1.456 \\ 1.486 & -3.088 \\ 1.745 & -4.479 \\ 2.113 & -6.001 \\ 2.680 & -8.568 \\ 3.413 & -12.197 \\ 1.49 & -0.64 \\ 1.61 & -1.20 \\ 1.72 & -1.71 \\ 1.81 & -2.21 \\ 1.92 & -2.82 \\ 2.00 & -3.12 \\ 2.08 & -3.48 \\ 2.13 & -3.78\end{array}$

Remarks

galvanometer which measured charge passing through crystal on application of square pulse of voltage of known magnitude and duration; accuracy of conductivity estimated as $\pm 5 \%$.

Sample designation $K$; crystal grown from melt containing 0.01 at. $\% \mathrm{KC} 1$, expected concentration of $\mathrm{KCl}$ in crystal was about 0.1 of its concentration in melt.

Sample designation $\mathrm{H}$; mole ratio $\mathrm{Cd} / \mathrm{Na} 1 \mathrm{x}$ $10^{-5}$; single crystal grown from melt by Kyropoulos method using platinum crucible; source materials were Eimer and Amend Tested Purity $\mathrm{NaCl}$ and Baker and Adamson $\mathrm{CdCl}$; cleaved into cube approx $1 \mathrm{~cm}$ on an edge and annealed in an atmosphere of helium at $1043 \mathrm{~K}$ (heating rate $6 \mathrm{k} \mathrm{min}^{-1}$ ) for $1 \mathrm{~h}$, slowly cooled to room temperature at $1 \mathrm{~K} \mathrm{~min}^{-1}$, then cleaved into plates approx $1 \mathrm{~mm}$ thick; electrodes used were either platinum evaporated on crystal surfaces in a vacuum or colloidal graphite painted on in alcohol solution (both materials yielded identical results); during measurements crystals mounted between platinum clad nickel electrodes in a quartz tube; measurement method used a ballistic galvanometer which measured charge passing through crystal on application of square pulse of voltage of known magnitude and duration; accuracy of conductivity estimated as $\pm 5 \%$.

Similar to the above specimen and conditions except sample designated as $A$ and mole ratio $\mathrm{Cd} / \mathrm{Na} 68.6 \times 10^{-5}$ with duplicate analysis giving $64.0 \times 10^{-5}$.

Rock salt; compilation of results reported by this author in this paper; data extracted from table.

Sample number $L 20 \mathrm{~A}$; specimen with $\mathrm{CaCl}_{2}$ added; metallic impurity concentration $0.0100 \pm 0.0030$ and determined by semiquantitative spectroscopic analysis; specimen size $1 \mathrm{~cm}$ by $1 \mathrm{~cm}$ by $0.04 \mathrm{~cm}$; specimen prepared by adding $\mathrm{CaCl}_{2}$ to reagent grade $\mathrm{NaCl}$ and grown by Bridgman technique; cooled from range of 343 to $573 \mathrm{~K}$ down to $203 \mathrm{~K}$ at 
TABLE 6.2. EXPERIMENTAL DATA ON THE ELECTRICAL CONDUCTIVITY OF SOLID SODIUM CHLORIDE (Temperature Dependence) (continued)

\begin{tabular}{|c|c|c|c|c|}
\hline $\begin{array}{c}\text { Data } \\
\text { Set }\end{array}$ & Author(s), Year [Ref.] & $10^{3} / \mathrm{T}$ & $\log (\sigma \mathrm{T})$ & Remarks \\
\hline $\begin{array}{c}14 \\
(\operatorname{cont} .)\end{array}$ & $\begin{array}{l}\text { Dreyfus, R.W. and } \\
\text { Nowick, A.S., } 1962 \text { [7] }\end{array}$ & $\begin{array}{l}2.22 \\
2.27 \\
2.41 \\
2.47 \\
2.51 \\
2.60 \\
2.71 \\
2.76 \\
2.91 \\
3.06 \\
3.34\end{array}$ & $\begin{array}{l}-4.24 \\
-4.59 \\
-5.20 \\
-5.71 \\
-5.96 \\
-6.52 \\
-7.02 \\
-7.33 \\
-8.14 \\
-8.95 \\
-10.37 *\end{array}$ & $\begin{array}{l}\text { cooling rate of } 0.3 \mathrm{~K} \mathrm{~min}^{-1} \text {; data taken with } \\
\text { increasing temperature; data points extracted } \\
\text { from figure; accuracy of temperature } \pm 0.1 \\
\pm 0.005 \mathrm{~T} \text { with } \mathrm{T} \text { in }{ }^{\circ} \mathrm{C} \text {. }\end{array}$ \\
\hline & & \multicolumn{3}{|c|}{ * Not shown in figure. } \\
\hline 15 & $\begin{array}{l}\text { Trnovcova, V., Mariani, } \\
\text { E., and Polak, K., } \\
1974 \text { [8] }\end{array}$ & $\begin{array}{l}1.030 \\
1.049 \\
1.074 \\
1.099 \\
1.112 \\
1.149 \\
1.187 \\
1.212 \\
1.231 \\
1.237 \\
1.262 \\
1.306 \\
1.381 \\
1.443 \\
1.512 \\
1.587 \\
1.656 \\
1.737 \\
1.818 \\
1.912 \\
1.994 \\
2.069 \\
2.156 \\
2.219 \\
2.300 \\
2.362 \\
2.438 \\
2.500 \\
2.575 \\
2.625\end{array}$ & $\begin{array}{r}0.930 \\
0.692 \\
0.560 \\
0.242 \\
0.151 \\
-0.179 \\
-0.537 \\
-0.892 \\
-0.955 \\
-1.014 \\
-1.167 \\
-1.382 \\
-1.664 \\
-1.940 \\
-2.219 \\
-2.526 \\
-2.802 \\
-3.109 \\
-3.444 \\
-3.838 \\
-4.199 \\
-4.559 \\
-4.949 \\
-5.277 \\
-5.607 \\
-5.934 \\
-6.263 \\
-6.560 \\
-6.859 \\
-7.125\end{array}$ & $\begin{array}{l}\text { Pure; contains } 2 \times 10^{-5} \text { molar percent biva- } \\
\text { lent metals; thermal treatment of annealing } \\
\text { for } 2 \mathrm{~h} \text { at } 1023 \mathrm{~K} \text { and quenching employed in } \\
\text { most measurements; sample equipped with } \\
\text { graphite contacts and a dc voltage of } 10 \mathrm{~V} \\
\text { applied for measurements; measured in an } \\
\text { inert atmosphere of dry argon; data extracted } \\
\text { from smooth curve. }\end{array}$ \\
\hline 16 & Lehfeldt, W., 1933 [9] & $\begin{array}{l}1.088 \\
1.107 \\
1.144 \\
1.181 \\
1.228 \\
1.246 \\
1.302 \\
1.321 \\
1.339 \\
1.386\end{array}$ & $\begin{array}{l}0.454 \\
0.301 * \\
0.189 * \\
0.077 \\
-0.136 * \\
-0.240 * \\
-0.406 \\
-0.461 * \\
-0.613 * \\
-0.728 *\end{array}$ & $\begin{array}{l}\text { Naturally occurring rock salt; estimated } \\
\text { inaccuracy } \pm 10 \% \text {; data points extracted from } \\
\text { flgure. }\end{array}$ \\
\hline
\end{tabular}


TABLE 6.2. EXPERIMENTAL DATA ON THE ELECTRICAL CONDUCTIVITY OF SOLID SODIUM CHLORIDE (Temperature Dependence) (continued)

\begin{tabular}{|c|c|c|c|c|}
\hline $\begin{array}{l}\text { Data } \\
\text { Set }\end{array}$ & Author (s), Year [Ref.] & $10^{3} / \mathrm{T}$ & $\log (\sigma \mathrm{T})$ & Remarks \\
\hline $\begin{array}{c}16 \\
(\text { cont.) }\end{array}$ & Lehfe1dt, W., 1933 [9] & $\begin{array}{l}1.414 \\
1.451 \\
1.488 \\
1.525 \\
1.553 \\
1.572 \\
1.609 \\
1.646 \\
1.702 \\
1.748 \\
1.776 \\
1.804 \\
1.841 \\
1.869\end{array}$ & $\begin{array}{l}-0.832 \star \\
-0.990 \\
-1.196 \star \\
-1.304 \\
-1.507 \star \\
-1.561 \star \\
-1.718 \star \\
-1.875 \\
-2.073 \star \\
-2.340 \star \\
-2.541 \\
-2.645 \star \\
-2.801 * \\
-2.905\end{array}$ & \\
\hline & & *Not $s$ & wn in figure. & \\
\hline 17 & $\begin{array}{l}\text { Olhoeft, G.R., } 1978 \\
\text { [127] }\end{array}$ & 3.39 & -5.73 & $\begin{array}{l}\text { Subsample } 1 \text {; halite salt cored from } 786 \mathrm{~m} \\
\text { deep in ERDA } \$ \text { 浱 corehole at Carlsbad, New } \\
\text { Mexico; core cut into } 4 \text { subsamples; salt } \\
\text { crystals in core had undetectable impurity } \\
\text { levels but cracks and grain boundaries con- } \\
\text { tained large amounts of impurities; disc } \\
\text { geometry } 1.7 \mathrm{~cm} \text { thick and } 10.6 \mathrm{~cm} \text { diam; } \\
\text { sample holder was } 3-\text { terminal brass configura- } \\
\text { tion with } 3.8 \mathrm{~cm} \text { diam guarded electrode under } \\
8.5 \mathrm{kPa} \text { uniaxial load; measured in } 3 \% \text { rela- } \\
\text { tive humidity; accuracy } \pm 5 \% \text { in resistivity; } \\
\text { accuracy in dielectric permittivity } \pm 0.65 \% \text {; } \\
\rho=1.57 \times 10^{8} \Omega \mathrm{m} \text { for DC conditions. }\end{array}$ \\
\hline 18 & $\begin{array}{l}\text { Olhoeft, G.R., } 1978 \\
\text { [127] }\end{array}$ & 3.39 & -5.08 & $\begin{array}{l}\text { Similar to the above specimen and conditions } \\
\text { except subsample } 2 \text { and } \rho=3.58 \times 10^{7} \Omega \mathrm{m} \text {. }\end{array}$ \\
\hline 19 & $\begin{array}{l}\text { Olhoeft, G.R., } 1978 \\
\text { [127] }\end{array}$ & 3.39 & -5.57 & $\begin{array}{l}\text { Similar to the above specimen and conditions } \\
\text { except subsample } 3 \text { and } \rho=1.09 \times 10^{8} \Omega \mathrm{m} \text {. }\end{array}$ \\
\hline 20 & $\begin{array}{l}\text { Olhoeft, G.R., } 1978 \\
\text { [127] }\end{array}$ & 3.39 & -5.43 & $\begin{array}{l}\text { Similar to the above specimen and conditions } \\
\text { except subsample } 4 \text { and } \rho=7.92 \times 10^{7} \Omega \mathrm{m} \text {. }\end{array}$ \\
\hline
\end{tabular}

frequency) [60, p. 294], a value of $3.05 \times 10^{11} \Omega \mathrm{m}$ is obtained for fresh sodium chloride crystals from Harshaw.

The evaluated data for the intrinsic conductivity of pure sodium chloride were based on the data from data set 15 . The result of a least-squares fit gave

$$
\sigma_{\text {intrinsic }}=\frac{2.637 \times 10^{10}}{T} \mathrm{e}^{-\frac{21,258}{T}}
$$

( $T$ in $\mathrm{K}, \sigma$ intrinsic in $\mathrm{S} \mathrm{m}^{-1}$ ) which is applicable over the temperature range of $825 \mathrm{~K}$ to $1000 \mathrm{~K}$. The values given in table 6.1 were calculated from equation (6.1). The Least Square Polynomial Equation Curve Fit (LSPE) program at the Purdue University Computing Center was utilized to obtain equation (6.1). This program utilizes the F-statistic to optimize the order of a polynomial fit to data. The order of the polynomial is successively increased until a maximum is found in the F-statistic. LSPE was applied to the intrinsic conductivity data for the data applying to pure sodium chloride (data sets $7,9,15)$; the best fit to $\log (\sigma T)$ versus $10^{3} / T$ data resulted in a linear relation for each of these data sets. Of these three, data set 15 was selected as the one on which to base the evaluated data; the standard deviation of the data about the regression line is $3.27 \times 10^{-2}$ for the fit to the linear form $\log (\sigma T)$ versus $10^{3} / T$. Data set 7 was not used since it is higher than the other two sets and has more scatter. Of the remaining two sets, data set 15 has slightly less scatter and was, therefore, selected. The difference between the evaluated data and the conductivity data for curve 15 can be as high as $10 \%$. Furthermore, even though the data in table 6.1 can be regarded as 
evaluated data, it should be recognized that systematic variations from sample to sample can be large for pure sodium chloride. The difference between the evaluated data for conductivity and curve 9 can be as high as $15 \%$ while for curve 7 it is typically $45 \%$.

Additional data for the electrical conductivity of solid sodium chloride appear in references [15-30]. A review article of ionic conductivity in solids [31] reports both general references as well as references pertaining to sodium chloride.

\subsubsection{Liquid State, Temperature Dependence}

Evaluated data are given for the electrical conductivity of liquid sodium chloride. The evaluated data are given in table 6.3 and are shown in figure 6.2 which shows the general trend of the data. Data from references [32 and 33 ] formed the general base on which the evaluated data were developed and table 6.4 gives the experimental data from these references. A discussion of how the evaluation was arrived at follows.

The evaluated data for the electrical conductivity of liquid sodium chloride were specifically based on the data of Ketelaar and Maenaut [33] (curve 2) because their use of the capillary U-type cell in air did not involve parasitic conduction. On figure 6.2 , it is noted that the data of Van Artsdalen and Yaffe [32] (curve 1) is higher than the data of Ketelaar and Maenaut [33] (curve 2) in the higher temperature region. Also shown are data of Ketelaar and Maenaut [33] (curves 3 and 4) taken with a dip cell with these data higher than their data taken with the U-type cell in air. These higher data have been demonstrated to be due to parasitic conduction, i.e., the cell walls conduct when using the dip-type design for the measurements, which leads to a higher conductivity [33 and 46, pp. 875-6]. The result of a least-squares fit to the data of Ketelaar and Maenaut (data set 2) was

$$
\begin{gathered}
\sigma=-3.9323 \times 10^{2}+11.269 \times 10^{-1} T \\
-3.9452 \times 10^{-4} T^{2}
\end{gathered}
$$

( $T$ in $\mathrm{K}$ and $\sigma$ in $\mathrm{S} \mathrm{m} \mathrm{m}^{-1}$ ) which is valid over the temperature range of $1090 \mathrm{~K}$ to $1300 \mathrm{~K}$. The computer program LSPE, which was previously described in the discussion of the temperature dependence of the electrical conductivity of solid sodium chloride, was used for the least-squares fit. The standard deviation of the



Figure 6.2. Electrical conductivity of liquid sodium chloride. 
TABLE 6.3. EVALUATED DATA FOR THE ELECTRICAL CONDUCTIVITY OF LIQUID SODIUM CHLORIDE

[Temperature, T, K; Electrical Conductivity, $\sigma, \mathrm{S} \mathrm{m}^{-1}$ ]

$\begin{array}{cc}T & \sigma \\ 1090 & 366.4 \\ 1100 & 369.0 \\ 1200 & 390.9 \\ 1300 & 405.0\end{array}$

TABLE 6.4. EXPERIMENTAL DATA ON THE ELECTRICAL CONDUCTIVITY OF LIQUID SODIUM CHLORIDE

[Temperature, T,K; Electrical Conductivity, $\sigma, \mathrm{S} \mathrm{m}^{-1}$ ]

\begin{tabular}{|c|c|c|c|c|}
\hline $\begin{array}{c}\text { Data } \\
\text { Set }\end{array}$ & Author (s), Year [Ref.] & $T$ & $\sigma$ & Remarks \\
\hline 1 & $\begin{array}{l}\text { Van Artsdalen, E.R. and } \\
\text { Yaffe, I.S., 1955 [32] }\end{array}$ & $\begin{array}{l}1075.4 \\
1077.8 \\
1079.6 \\
1079.6 \\
1081.2 \\
1081.4 \\
1091.0 \\
1091.0 \\
1100.6 \\
1113.0 \\
1131.0 \\
1144.6 \\
1165.8 \\
1172.6 \\
1184.6 \\
1186.4 \\
1195.6 \\
1206.4 \\
1207.0 \\
1220.4 \\
1244.6 \\
1245.2 \\
1245.4 \\
1280.0 \\
1283.2 \\
1294.6\end{array}$ & $\begin{array}{l}308.87 \\
344.97 \\
358.04 \\
358.21 \\
360.57 \\
360.60 \\
364.31 \\
364.41 \\
366.01 \\
371.45 \\
376.62 \\
380.41 \\
385.02 \\
386.37 \\
391.54 \\
391.29 \\
394.16 \\
396.80 \\
397.01 \\
401.51 \\
406.53 \\
406.16 \\
407.19 \\
415.95 \\
417.01 \\
418.01\end{array}$ & 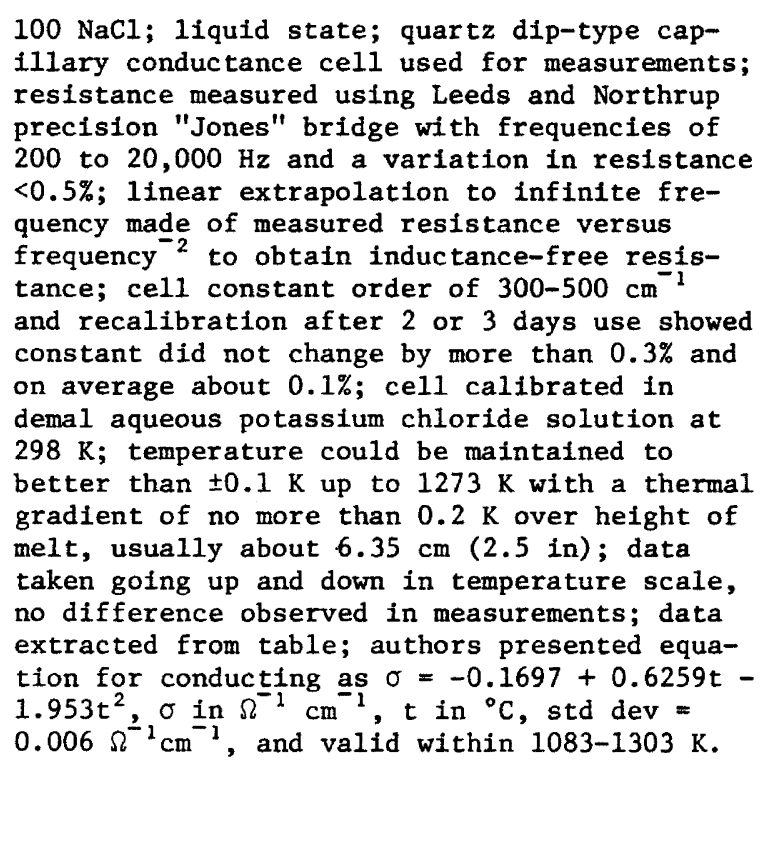 \\
\hline 2 & $\begin{array}{l}\text { Ketelaar, J.A.A. and } \\
\text { Maenaut, P.P.E., } 1972 \\
\text { [33] }\end{array}$ & $\begin{array}{l}1093 \\
1093 \\
1103 \\
1103 \\
1103 \\
1113 \\
1123 \\
1123 \\
1123 \\
1123 \\
1125.6 \\
1133 \\
1143 \\
1148 \\
1148 \\
1173 \\
1173.6 \\
1198 \\
1223 \\
1223 \\
1223 \\
1248 \\
1273 \\
1273 \\
1273 \\
1298\end{array}$ & $\begin{array}{l}367.2 \\
367.65 \\
371.1 \\
369.4 \\
370.25 \\
373.7 \\
372.9 \\
373.77 \\
372.9 \\
374.0 \\
376.5 \\
376.2 \\
378.4 \\
382.5 \\
379.6 \\
385.3 \\
387.1 \\
391.4 \\
394.1 \\
395.1 \\
395.6 \\
398.5 \\
402.2 \\
401.1 \\
402.6 \\
404.5\end{array}$ & $\begin{array}{l}\text { Each impurity does not exceed } 0.003 \% \text {; Baker } \\
\text { analyzed reagent; 1iquid state; capillary } \mathrm{U}- \\
\text { type cell in air used; cell constant } 2500 \mathrm{~cm}^{-1} \\
\text { and determined using a normal solution of po- } \\
\text { tassium chloride at } 298 \mathrm{~K} \text {; cell constant } \\
\text { checked after every series of measurements, } \\
\text { variation never exceeded } 3 \% \text {; resistances mea- } \\
\text { sured at a frequency of } 10 \mathrm{hHz} \text {; higher values } \\
\text { of measurements using dip-cell explained as } \\
\text { due to parasitic conduction; data extracted } \\
\text { from table. }\end{array}$ \\
\hline
\end{tabular}


TABLE 6.4. EXPERTMENTAL DATA ON THE ELECTRICAL CONDUCTIVITY OF LIQUID SODIUM CHLORIDE (contInUed)

\begin{tabular}{clccl}
\hline $\begin{array}{c}\text { Data } \\
\text { Set }\end{array}$ & Author(s), Year [Ref.] & $T$ & $\sigma$ & Remarks \\
\hline 3 & $\begin{array}{l}\text { Ketelaar, J.A.A. and } \\
\text { Maenaut, P.P.E., 1972 } \\
\text { [33] }\end{array}$ & $\begin{array}{l}1223.3 \\
1272.9\end{array}$ & $\begin{array}{l}469.5 \\
469.8\end{array}$ & $\begin{array}{l}\text { Similar to the above specimen and conditions } \\
\text { except dip-cell used, cel1 constant 2520 cm } \\
\text { and data extracted from figure. }\end{array}$ \\
4 & $\begin{array}{l}\text { Ketelaar, J.A.A. and } \\
\text { Maenaut, P.P.E., 1972 } \\
\text { [33] }\end{array}$ & 1113.3 & 376.9 & $\begin{array}{l}\text { Similar to the above specimen and conditions } \\
\text { except cell constant 1520 } \mathrm{cm}^{-1} .\end{array}$ \\
\hline
\end{tabular}

data about the regression line is $1.01 \times 10^{-2}$. The uncertainty assigned to the evaluated data is $\pm 3 \%$ because Ketelaar and Maenaut found a variation of the cell constants within that value.

Additional data for the electrical conductivity of liquid sodium chloride appears in references [34-44]. Two documents which give a compilation of information and an assessment of the data are references [ 45 and 46].

\subsubsection{Solid State, Pressure Dependence}

Selected experimental data are given for the pressure dependence of the electrical conductivity of solid sodium chloride. These selected data are given in table 6.5 and are shown in figure 6.3 .

Pierce [47] (curves 1-6) reported extensive data for doped sodium chloride. Shimizu [13] (curves 7-10) reported data over a lesser range of pressure for a single crystal. Observation of these data on figure 6.3 which are plotted as $\log \sigma$ as a function of pressure shows that above $550 \mathrm{~K}$ there is a single straight line that would be applicable to the data at each temperature.

Other investigators have contributed information to the pressure dependence of the electrical conductivity. Beyeler and Lazarus [14] presented data for single crystal sodium chloride at $923 \mathrm{~K}$ and at $953 \mathrm{~K}$ for $\log$ $(\sigma T)$ as a function of pressure. Cleaver et al. [48] reported data at $1093 \mathrm{~K}$ but the data were presented on the $\log \sigma$ axis such that absolute values cannot be determined. Biermann [21] presented data for the resistance ratio as a function of pressure and, in addition, data for the pressure coefficient of electrical conductivity as a function of temperature. Another data source for the pressure dependence of the electrical conductivity is reference [49]. Murri and Doran [59] studied the effects of shock waves on the electrical conductivity of sodium chloride. Homan et al. [125] reported the conductivity ratio as a function of pressure.

Evaluated data are not given for the pressure dependence of the electrical conductivity because of the lack of confirmatory data on well-characterized materials.

\subsubsection{Aqueous Solutions}

Data for the electrical conductivity of aqueous solutions of sodium chloride for various concentrations and temperatures appear in references [50-56]. Two early compilations appear in references [ 57 and 58].

\subsection{Dielectric Constant}

\subsection{Real Part of the Dielectric Constant}

Evaluated data are given for the real part of the dielectric constant of pure sodium chloride in table 6.6 and are shown on figure 6.5. Figure 6.4 shows the frequency dependence over a range of $1 \times 10^{2} \mathrm{~Hz}$ to $2.5 \times$ $10^{10} \mathrm{~Hz}$ and figure 6.5 shows the temperature dependence. The curves shown on these two figures come from references [60-67] and have been selected to show various characteristics including the variation at room temperature for pure sodium chloride and for naturally occurring samples. The numerical data, together with information on sample characterization, for the curves shown on the two figures are given in table 6.7.

The data in figure 6.4 show interesting features. The measurements of the Laboratory for Insulation Research [60] (curve 1) made at room temperature on a commercial crystal from Harshaw show that the data are constant. The data of the Laboratory for Insulation Research [60] (curve 2) and of Breckenridge [61] (curve 3 ) are also for Harshaw crystals with the measurement temperature $358 \mathrm{~K}$. The data for both curves are close to each other and show an upturn as the frequency is decreased below $10^{4} \mathrm{~Hz}$. Above that frequency the data are constant to $10^{10} \mathrm{~Hz}$. This rise at low frequencies is due to interfacial polarizability which is not included in the real part of the dielectric constant [69, pp. 316-7]. Data for halite cored from a Carlsbad, New Mexico corehole are given in ref. [127] for four subsamples and show a variation of $10^{6} \mathrm{~Hz}$ from 7.012 to 8.705 . 


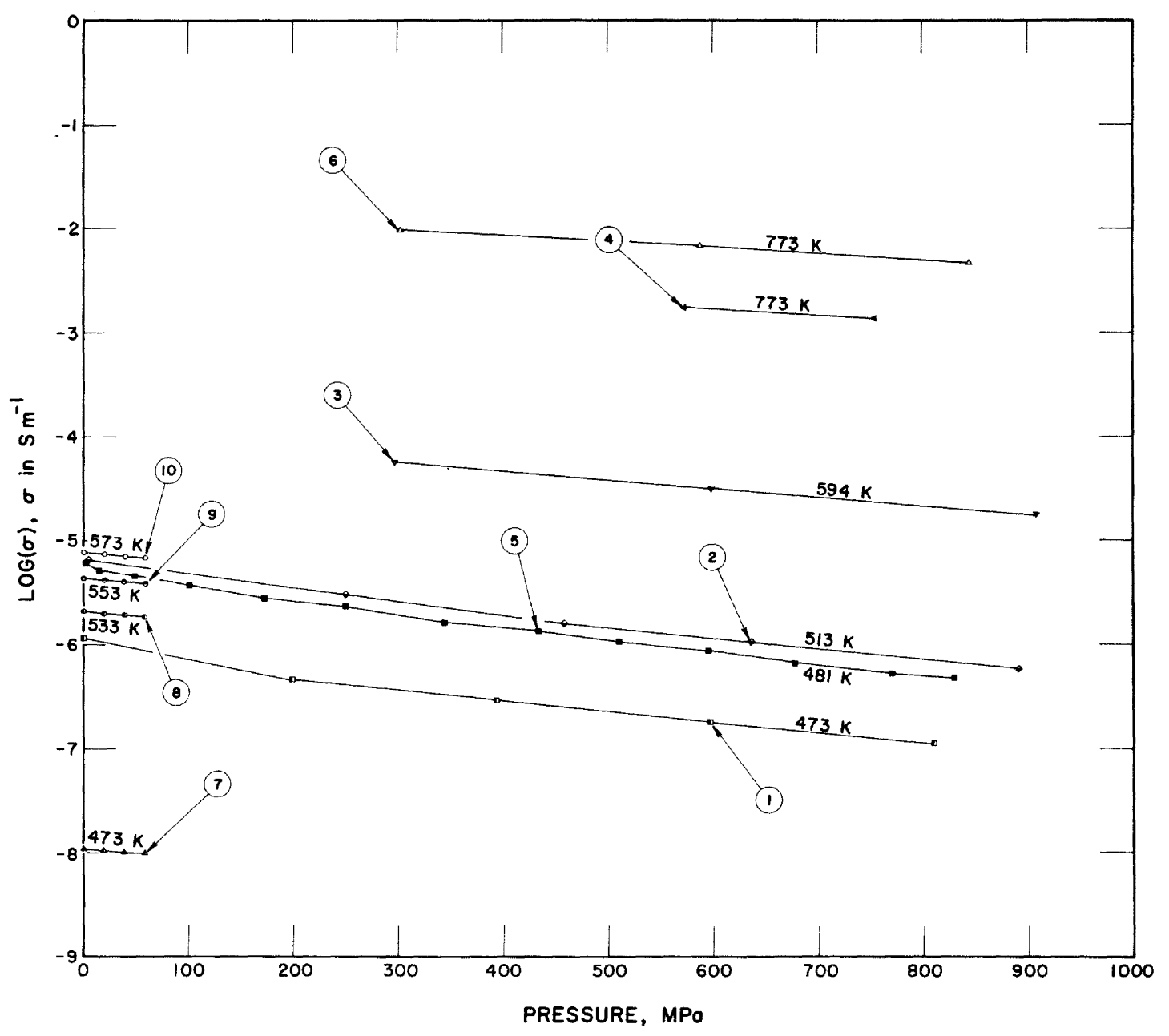

FIGURE 6.3. Electrical conductivity of solid sodium chloride (pressure dependence). 
TABLE 6.5. EXPERIMENTAL DATA ON THE ELECTRICAL CONDUCTIVITY OF SOLID SODIUM CHLORIDE (Pressure Dependence)

[Pressure, $\mathrm{P}, \mathrm{MPa}$; Electrical Conductivity, $\sigma, \mathrm{S} \mathrm{m}^{-1}$ ]

\begin{tabular}{|c|c|c|c|}
\hline $\begin{array}{l}\text { Data } \\
\text { Set }\end{array}$ & Author(s), Year [Ref.] & $\mathbf{P}$ & Remarks \\
\hline 1 & Pierce, C.B., 1961 [47] & $\begin{array}{cc}(\mathrm{T}=473 \mathrm{~K}) \\
0.0 & -5.949 \\
199.6 & -6.347 \\
394.8 & -6.545 \\
598.6 & -6.759 \\
810.8 & -6.957\end{array}$ & $\begin{array}{l}0.02 \text { mole percent } \mathrm{CaCl}_{2} \text {; crystal grown by } \\
\text { Kyropoulos method; measurements made using ac } \\
\text { bridge technique with } 1 \mathrm{hHz} \text { input to a General } \\
\text { Radio } 706 \text { capacitance bridge; measurement tem- } \\
\text { perature } 473 \mathrm{~K} \text {. }\end{array}$ \\
\hline 2 & Pierce, C.B., 1961 [47] & $\begin{array}{rr}(\mathrm{T}=513 \mathrm{~K}) \\
4.2 & -5.196 \\
250.5 & -5.523 \\
458.5 & -5.793 \\
636.8 & -5.977 \\
891.5 & -6.233\end{array}$ & $\begin{array}{l}\text { The above specimen and conditions except mea- } \\
\text { surement temperature } 513 \mathrm{~K} \text {. }\end{array}$ \\
\hline 3 & Pierce, C.B., 1961 [47] & $\begin{array}{cc}(\mathrm{T}=594 \mathrm{~K}) \\
297.1 & -4.259 \\
598.6 & -4.500 \\
908.5 & -4.756\end{array}$ & $\begin{array}{l}\text { The above specimen and conditions except mea- } \\
\text { surement temperature } 594 \mathrm{~K} \text {. }\end{array}$ \\
\hline 4 & Pierce, C.B., 1961 [47] & 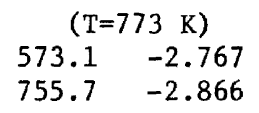 & $\begin{array}{l}\text { The above specimen and conditions except mea- } \\
\text { surement temperature } 773 \mathrm{~K} \text {. }\end{array}$ \\
\hline 5 & Pierce, C.B., 1961 [47] & \begin{tabular}{rr}
\multicolumn{2}{c}{$(\mathrm{T}=481 \mathrm{~K})$} \\
2.7 & -5.204 \\
2.7 & -5.204 \\
15.6 & -5.290 \\
49.7 & -5.347 \\
101.1 & -5.433 \\
173.6 & -5.562 \\
250.4 & -5.633 \\
344.3 & -5.790 \\
433.9 & -5.861 \\
510.7 & -5.975 \\
596.1 & -6.075 \\
677.2 & -6.174 \\
771.1 & -6.288 \\
830.8 & -6.317
\end{tabular} & $\begin{array}{l}0.09 \text { mole percent } \mathrm{CaCl}_{2} \text {; crystal grown by } \\
\text { Kyropoulos method; measurements made using ac } \\
\text { bridge technique with } 1 \mathrm{hHz} \text { input to a General } \\
\text { Radio } 706 \text { capacitance bridge; measurement tem- } \\
\text { perature } 481 \mathrm{~K} \text {. }\end{array}$ \\
\hline 6 & Pierce, C.B., 1961 [47] & \begin{tabular}{cc}
\multicolumn{2}{c}{$(\mathrm{T}=773 \mathrm{~K})$} \\
302.7 & -2.011 \\
588.5 & -2.167 \\
844.5 & -2.337
\end{tabular} & $\begin{array}{l}\text { The above specimen and conditions except mea- } \\
\text { surement temperature } 773 \mathrm{~K} \text {. }\end{array}$ \\
\hline 7 & Shimizu, K., 1962 [13] & 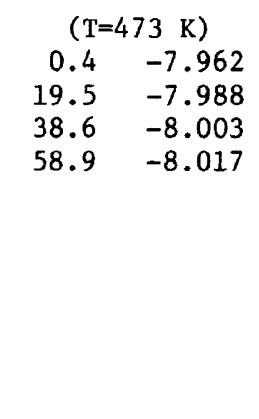 & $\begin{array}{l}\text { Single crystal prepared by Kyropoulos method; } \\
\text { specimen } 1 \mathrm{~mm} \text { by } 5 \mathrm{~mm} \text { by } 8 \mathrm{~mm} \text {; annealed in } \\
\text { NaCl powder at } 873 \mathrm{~K} \text { for } 6 \mathrm{~h} \text { and slowly coded } \\
\text { to room temperature; electrodes applied with } \\
\text { silver paint; conductivity measurements made } \\
\text { for increasing and decreasing pressures by } \\
\text { means of a capacitance bridge at } 1 \mathrm{hKz} \text { at con- } \\
\text { stant temperature; specimen compressed in a } \\
\text { sillcone oil by an oil injector and pressure } \\
\text { measured with a calibrated Bourdon-type gauge; } \\
\text { data points extracted from figure; measurement } \\
\text { temperature } 473 \mathrm{~K} \text {. }\end{array}$ \\
\hline
\end{tabular}


TABLE 6.5. EXPERIMENTAL DATA ON THE ELECTRICAL CONDUCTIVITY OF SOLID SODIUM CHLORIDE (Pressure Dependence) (continued)

\begin{tabular}{|c|c|c|c|c|}
\hline $\begin{array}{l}\text { Data } \\
\text { Set }\end{array}$ & Author(s), Year [Ref.] & $P$ & $\sigma$ & Remarks \\
\hline 8 & Shimizu, K., 1962 [13] & $\begin{array}{r}(\mathrm{T}= \\
0.9 \\
19.9 \\
39.5 \\
59.2\end{array}$ & $\begin{array}{l}33 \mathrm{~K}) \\
-5.680 \\
-5.702 \\
-5.720 \\
-5.738\end{array}$ & $\begin{array}{l}\text { The above specimen and conditions except } \\
\text { measurement temperature } 533 \mathrm{~K} \text {. }\end{array}$ \\
\hline 9 & Shimizu, K., 1962 [13] & $\begin{array}{r}\quad(T= \\
0.9 \\
20.2 \\
39.5 \\
59.5\end{array}$ & $\begin{array}{l}53 \mathrm{~K}) \\
-5.371 \\
-5.388 \\
-5.406 \\
-5.425\end{array}$ & $\begin{array}{l}\text { The above specimen and conditions except } \\
\text { measurement temperature } 553 \mathrm{~K} \text {. }\end{array}$ \\
\hline 10 & Shimizu, K., 1962 [13] & $\begin{array}{c}\quad(\mathrm{T}= \\
0.6 \\
20.4 \\
40.1 \\
59.5\end{array}$ & $\begin{array}{l}73 \mathrm{~K}) \\
-5.120 \\
-5.136 \\
-5.158 \\
-5.172\end{array}$ & $\begin{array}{l}\text { The above specimen and conditions except } \\
\text { measurement temperature } 573 \mathrm{~K} \text {. }\end{array}$ \\
\hline
\end{tabular}



FIGURE 6.4 Real part of the dielectric constant of sodium chloride (frequency dependence). 


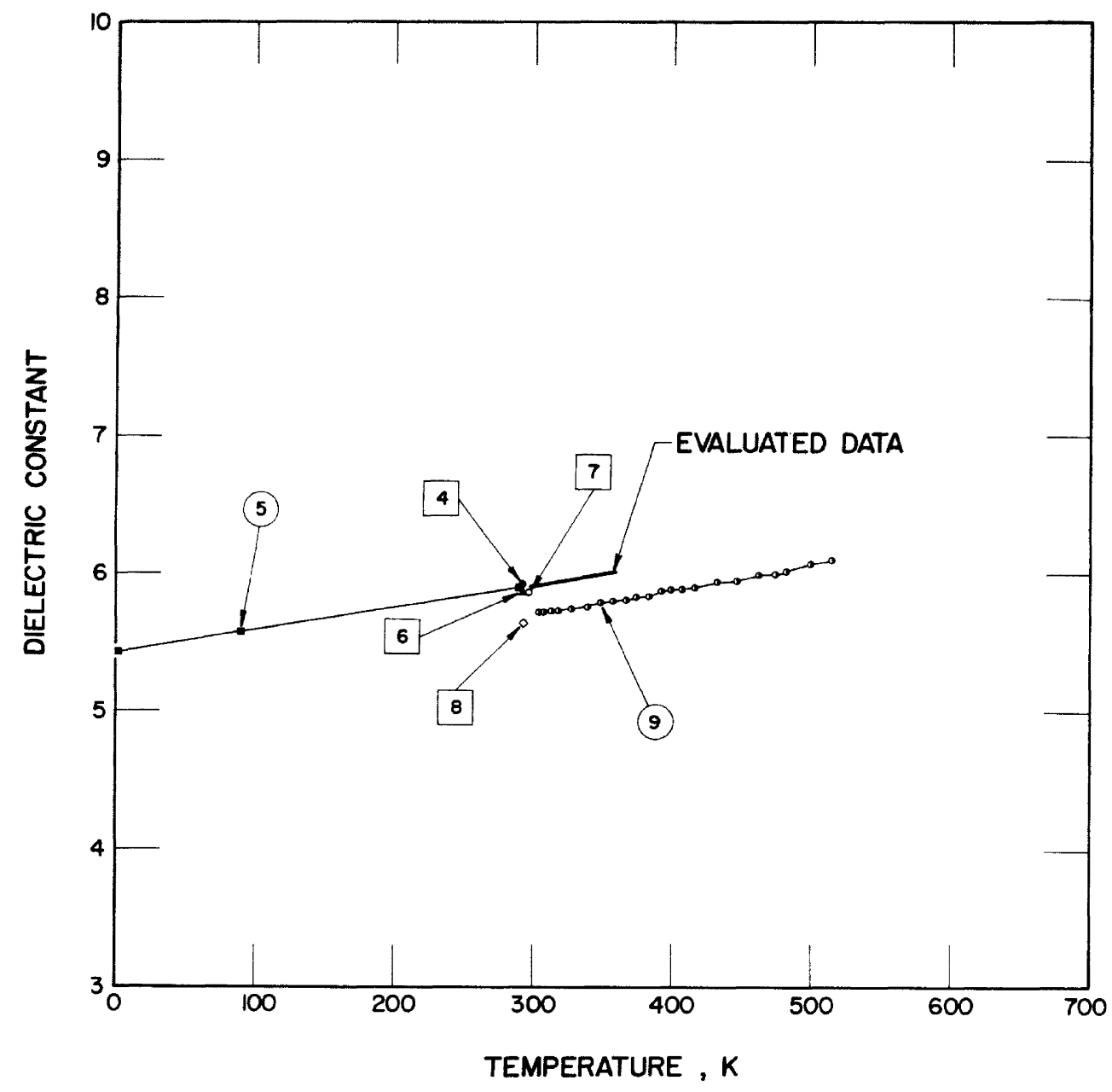

FigurE 6.5. Real part of the dielectric constant of sodium chloride (temperature dependence).

TABLE 6.6. EVALUATED DATA FOR THE REAL PART OF THE DIELECTRIC CONSTANT OF PUKE SODIUM CHLORIDE

[Frequency, $\nu, \mathrm{Hz}$; Temperature, T, K; Real Part of the Dielectric Constant, $\varepsilon^{\prime}$ ]

$\nu$
$\times 10^{2}$
$\times 10^{3}$
$\times 10^{4}$
$\times 10^{5}$
$\times 10^{6}$
$\times 10^{7}$
$\times 10^{8}$
$\times 10^{9}$
$\times 10^{10}$

\begin{tabular}{cc}
\multicolumn{2}{c}{$\varepsilon^{\prime}$} \\
\hline$T=298 \mathrm{~K}$ & $\mathrm{~T}=358 \mathrm{~K}$ \\
5.90 & 6.01 \\
5.90 & 6.01 \\
5.90 & 6.01 \\
5.90 & 6.01 \\
5.90 & 6.01 \\
5.90 & 6.01 \\
5.90 & 6.01 \\
5.90 & 6.01 \\
5.90 & 6.01
\end{tabular}


TABLE 6.7. EXPERIMENTAL DATA FOR THE REAL PART OF THE DIELECTRIC CONSTANT OF SODIUM CHLORIDE

. [Frequency, V,Hz; Temperature, T,K; Real Part of the Dielectric Constant, $\left.\varepsilon^{\prime}\right]$




TABLE 6.7. EXPERIMENTAL DATA FOR THE REAL PART OF THE DIELECTRIC CONSTANT OF SODIUM CHLORIDE (continued)

\begin{tabular}{|c|c|c|c|c|}
\hline $\begin{array}{l}\text { Data } \\
\text { Set }\end{array}$ & Author (s), Year [Ref.] & $\mathrm{T}$ & $\varepsilon^{\prime}$ & Remarks \\
\hline $\begin{array}{c}6 \\
\text { (cont.) }\end{array}$ & Haussühl, S., 1957 [64] & & & $\begin{array}{l}\text { to tabular data not explicitly stated, } \\
293 \mathrm{~K} \text { assumed. }\end{array}$ \\
\hline 7 & Jones, B.W., 1967 [65] & $296^{\left(\nu=1 \times 10^{3}\right.}$ & $\begin{array}{l}\mathrm{Hz}) \\
5.86\end{array}$ & $\begin{array}{l}\text { Naturally occurring sample; } 0.7 \mathrm{ppm} \\
\text { divalent ions; single crystal; flat } \\
\text { plate specimen of about } 1.0 \mathrm{~cm} \times 1.0 \mathrm{~cm} \\
\text { x } 0.1 \mathrm{~cm} \text { with metallic electrodes put on; } \\
\text { dielectric constant measured using a geo- } \\
\text { metrical technique in association with a } \\
\text { three terminal transformer bridge system; } \\
\text { pressures up to } 7 \text { kbars used; low fre- } \\
\text { quency dielectric constant at zero } \\
\text { pressure reported; data extracted from } \\
\text { table; uncertainty } 1 \% \text { or less. }\end{array}$ \\
\hline 8 & $\begin{array}{l}\text { Eucken, A. and Buchner, } \\
\text { A., } 1935[66]\end{array}$ & 293 & 5.62 & $\begin{array}{l}\text { Slab specimen; from natural crystal; } \\
\text { data extracted from table; uncertainty } \\
\pm 0.01 \text {. }\end{array}$ \\
\hline 9 & $\begin{array}{l}\text { Matsonashvile, B.N., } \\
1958 \text { [67] }\end{array}$ & $\begin{array}{l}\left(\nu=8.50 \times 10^{5}\right. \\
304 \\
307 \\
313 \\
318 \\
327 \\
339 \\
348 \\
357 \\
367 \\
374 \\
383 \\
392 \\
399 \\
407 \\
416 \\
432 \\
446 \\
462 \\
474 \\
482 \\
500 \\
514\end{array}$ & $\begin{array}{l}\mathrm{Hz}) \\
5.72 \\
5.72 \\
5.73 \\
5.73 \\
5.75 \\
5.76 \\
5.79 \\
5.80 \\
5.81 \\
5.83 \\
5.84 \\
5.87 \\
5.88 \\
5.89 \\
5.90 \\
5.94 \\
5.95 \\
5.99 \\
6.00 \\
6.02 \\
6.08 \\
6.10\end{array}$ & $\begin{array}{l}\text { Single crystal; grown by Kyropoulos tech- } \\
\text { nique; slabs sawed from crystals by using } \\
\text { water-wetted wire saw; ground and polished } \\
\text { using dehydrated alcohol to disk shape; } \\
\text { plane parallel to within } 1-2 \mu \mathrm{m} \text {; trans- } \\
\text { parent and crossed polaroids showed no } \\
\text { perceptible internal stresses; measured } \\
\text { in vacuum; data extracted from smooth } \\
\text { curve. }\end{array}$ \\
\hline
\end{tabular}

The data in figure 6.5 show several features. There is a spread in the data at room temperature for pure material (curves 4, 5, 6, and 9). The data of Lowndes [63] (curve $5)$ show the variation with temperature for temperatures below room temperature. Above room temperature the data of Matsonashvili [67] (curve 9) appear to show a variation that increases faster than linearly at the higher temperatures. Naturally occurring specimens also have a spread (curves 7 and 8).

The evaluated data for the real part of the dielectric constant at room temperature were based on data set $l$ in figure 6.4 and confirmatory evidence given in reference [74, table IV-1] for the room temperature values at 8.9, 35.4 , and $116 \mathrm{GHz}$ which were all 5.90. The values up to
$358 \mathrm{~K}$ were based on data set 2 together with information on the slope from data sets 5 and 9 as well as information on the temperature coefficient quoted in reference [74, table IV-3]. The evaluated data for pure sodium chloride are given in table 6.6 and between $298 \mathrm{~K}$ and $358 \mathrm{~K}$ are represented by

$$
\epsilon^{\prime}=5.354+0.001833 T
$$

with $T$ in $\mathrm{K}$. Considering the difference beween equation (6.3) and the data of curve 9 , an uncertainty of $3.5 \%$ is assigned to $\epsilon^{\prime}$.

Additional data for the real part of the dielectric constant appear in references [68,70-74, 76, and 80], with reference [12] containing data for doped sodium 
chloride, halite, granulated purified salt, and fine flake salt. Data over a frequency range of $2.96 \times 10^{12} \mathrm{~Hz}$ to 1.17 $\times 10^{13} \mathrm{~Hz}$ appear in reference [79] and were calculated from the magnitude and phase angle of the reflectance which was measured at $300 \mathrm{~K}$. Data for a $10 \%$ solution are reported in reference [78]. Data for the temperature coefficient of the real part of the dielectric constant appear in references $[66,74,75$, and 80$]$ and data on the rate of change with temperature appear in reference [76]. Data for pressure coefficient appear in references [77 and 80], on the rate of change with pressure in references [76], and the variation with pressure in reference [65]. In reference [80] measurements of the real part of the dielectric constant, its pressure and temperature coefficients, were performed on the same samples.

\subsubsection{Tangent of the Loss Angle}

Selected experimental data are given for the tangent of the loss angle, $\tan \delta$, of sodium chloride. These selected data are tabulated in table 6.8 with the frequency dependence shown in figure 6.6 and the temperature dependence shown in figure 6.7.

The frequency dependence, figure 6.6 , contains some general features for various conditions. There are several curves for the pure material. The results reported by Haven [82 an 83] (curve 5) were for a very pure single crystal measured at a temperature of $383 \mathrm{~K}$ with the data decreasing from $1.55 \times 10^{-4}$ at $52.3 \mathrm{~Hz}$ to $4.44 \times 10^{-5}$ at $1.04 \times 10^{5} \mathrm{~Hz}$. Nearby at $1 \times 10^{6} \mathrm{~Hz}$ is the data point reported by Vodop'ianov and Galibina [85] (curve 8) which applies to a pure specimen at $293 \mathrm{~K}$. In a higher frequency range, the data also of Vodop'ianov and Galibina [85] (curve 9) show data for pure material generally decreasing and going from $1.36 \times 10^{-4}$ at $1.718 \times 10^{5} \mathrm{~Hz}$ to $2.3 \times 10^{-5}$ at $1 \times 10^{7} \mathrm{~Hz}$. Similarly, a decrease in $\tan \delta$ with an increase in frequency is evident for the data of Bayley [84] (curve 7) which apply to pure rock salt; the values are higher than for the pure material. The data of Nevald [86] (curve 1) and of Breckenridge [61] (curve 6) both show an increase in $\tan \delta$ at the upper end of their respective frequency intervals; the former data apply to an unstrained specimen of sodium chloride with the upturn starting at $1 \times 10^{6} \mathrm{~Hz}$ and the latter data apply to a commercial crystal from Harshaw with the increase applying to the last point at $7.64 \times 10^{9} \mathrm{~Hz}$. The data for the Harshaw crystal are higher than the data for the unstrained crystal.

Specimens with doping or dislocations show some interesting features. The data of Radhakrishna and Karguppikar [2] (curves 3 and 4) apply to Sb-doped sodium chloride crystal with curve 3 for a temperature of $393 \mathrm{~K}$ and curve 4 for a temperature of $493 \mathrm{~K}$. The magnitude of $\tan \delta$ is higher than for previous curves discussed. Nevald [81] (curve 2) reported data for a specimen having a dislocation density of $5 \times 10^{9} \mathrm{~cm}^{-2}$ and the shape of the curve is concave downward. Data for halite cored from a Carlsbad, New Mexico corehole is given in ref. [127] for four subsamples and show a variation in $\tan \delta$ of:

\begin{tabular}{ll}
$\mathrm{Hz}$ & Variation in $\tan \delta$ \\
\hline 10 & 1.1411 to 3.3953 \\
$10^{3}$ & 0.2909 to 0.4997 \\
$10^{4}$ & 0.4239 to 0.6510 \\
$10^{6}$ & 0.2175 to 0.3639
\end{tabular}

The temperature dependence, figure 6.7 , shows the general trend of the data and illustrates the point that data for pure specimens have lower values of $\tan \delta$ compared to specimens with impurities (compare curves $10,15-17$ with curves 11 and 12), and illustrates the effect of frequency (curves 13 and 14) with the higher frequency giving higher values of $\tan \delta$

Evaluated data are not given for $\tan \delta$ because of the large change in $\tan \delta$ caused by impurities and the lack of confirmatory evidence on well-characterized materials.

Documents containing additional data of $\tan \delta$ in addition to the particular data sets discussed above are references $[2,11,12,60,67,74,81-9]$.

\subsection{Dielectric Strength}

Evaluated data for the dielectric strength of bulk, pure, unstrained sodium chloride are given in table 6.9. Figure 6.8 shows the temperature dependence of the dielectric strength and figure 6.9 shows the thickness dependence. Table 6.10 contains the numerical data, together with information on sample characterization, for the curves shown on the two figures. Before stating the basis of the evaluated data, a discussion of some features of the data is given.

There are several noteworthy characteristics of the temperature dependence of the dielectric strength. The dielectric strength increases in value from low temperatures to reach a maximum slightly above room temperature and then decreases (curves $1,4,11$, and 12).

The data at room temperature show quite a variation. Nevald [81] (data set l) reported a value of $139 \mathrm{MV} \mathrm{m}^{-1}$ at $302 \mathrm{~K}$ for a sodium chloride single crystal. von Hippel and Lee [90] (data set 4) gave $164.7 \mathrm{MV} \mathrm{m}^{-1}$ at $295.5 \mathrm{~K}$ for pure sodium chloride. Caspari [91] (data set 8) reported a value of $146 \mathrm{MV} \mathrm{m}^{-1}$ at $296 \mathrm{~K}$ for a single crystal from Harshaw Chemical Co. with the applied field in the [100] direction; in contrast, he reported $142 \mathrm{MV}$ $\mathrm{m}^{-1}$ for the field in the [110] direction (data set 9). The 


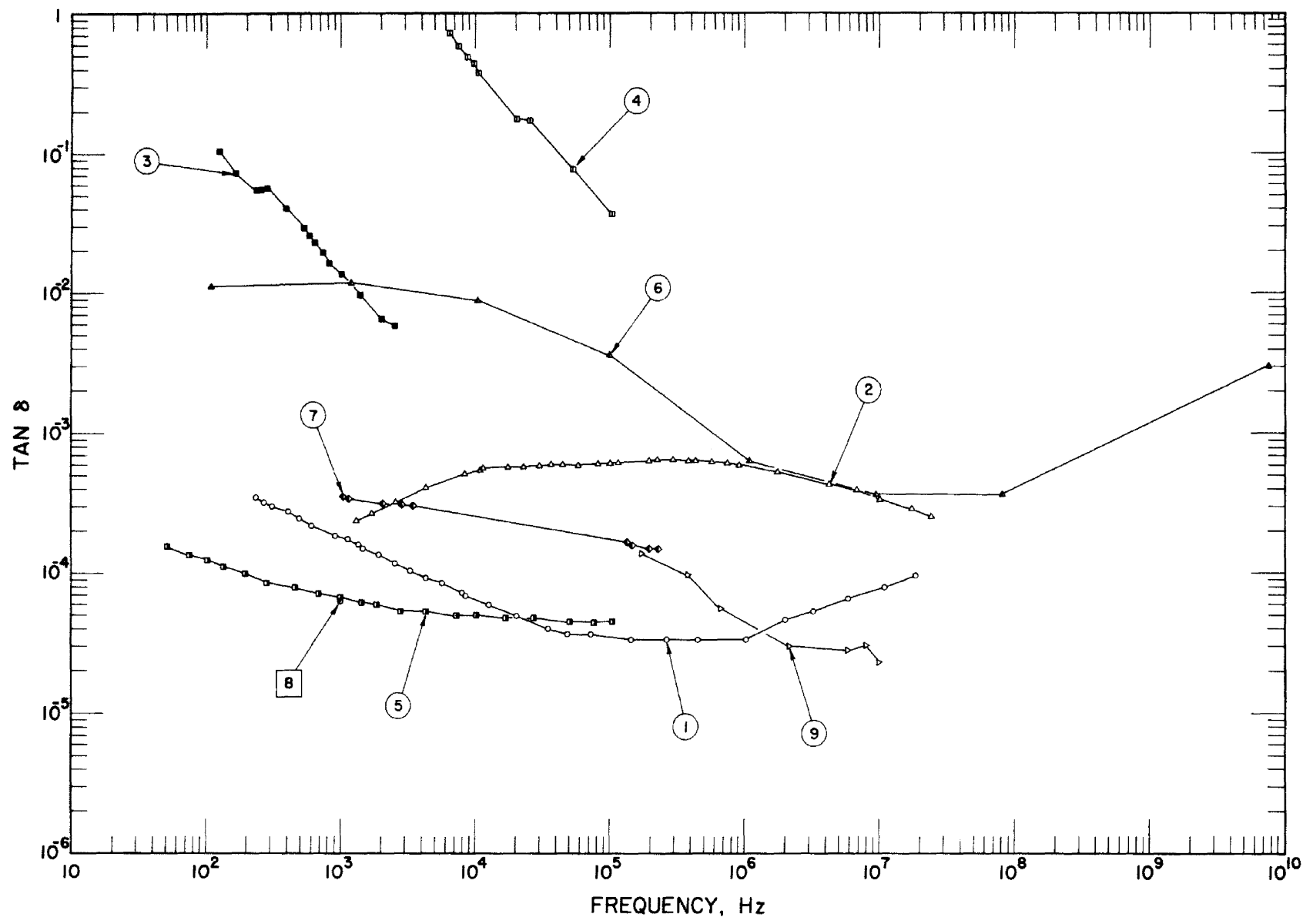

FIGURE 6.6. Tangent of the loss angle of sodium chloride (frequency dependence). 


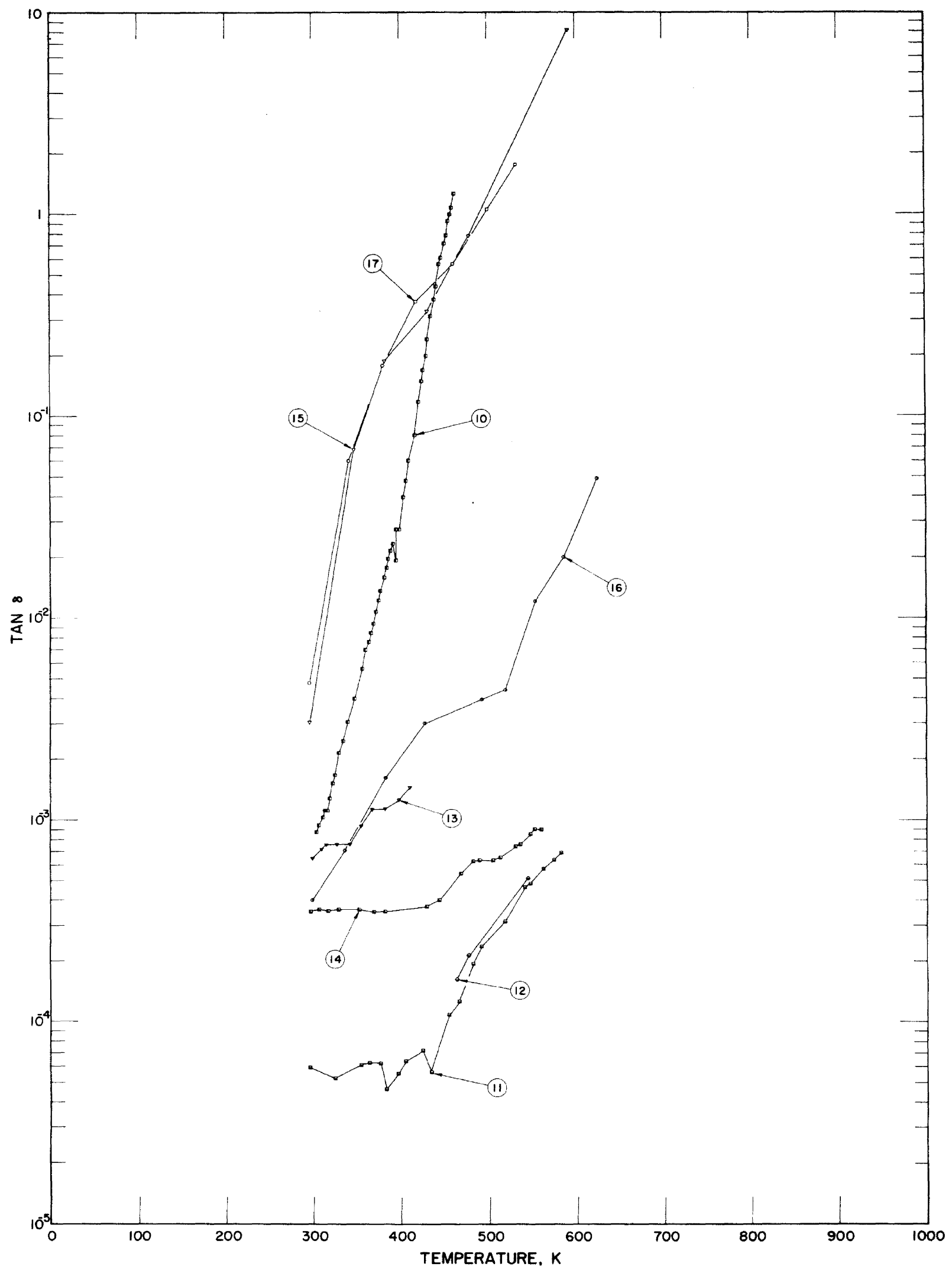

FIGURE 6.7. Tangent of the loss angle of sodium chloride (temperature dependence). 
TABLE 6.8. EXPERIMENTAL DATA FOR THE TANGENT OF THE LOSS ANGLE OF SODIUM CHLORIDE

[Frequency, $U, H z$; Temperature, $T, K$; Tangent of the Loss Angle, tan $\delta$ ]

\begin{tabular}{|c|c|c|c|c|c|}
\hline $\begin{array}{l}\text { Data } \\
\text { Set }\end{array}$ & Author(s), Year [Ref.] & & $v$ & $\tan \delta$ & Remarks \\
\hline 1 & Nevald, R., 1964 [81] & $\begin{array}{l}2.36 \\
2.70 \\
3.31 \\
4.06 \\
4.97 \\
6.09 \\
9.14 \\
1.12 \\
1.37 \\
1.47 \\
1.92 \\
2.52 \\
3.30 \\
4.33 \\
5.67 \\
7.95 \\
8.50 \\
1.27 \\
2.05 \\
3.51 \\
4.92 \\
7.37 \\
1.45 \\
2.66 \\
4.56 \\
1.02 \\
2.01 \\
3.22 \\
5.92 \\
1.09 \\
1.86\end{array}$ & 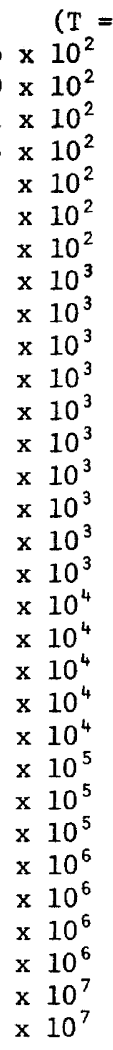 & $\begin{array}{r}293 \mathrm{~K}) \\
3.45 \times 10^{-4} \\
3.19 \times 10^{-4} \\
2.99 \times 10^{-4} \\
2.73 \times 10^{-4} \\
2.44 \times 10^{-4} \\
2.18 \times 10^{-4} \\
1.86 \times 10^{-4} \\
1.73 \times 10^{-4} \\
1.60 \times 10^{-4} \\
1.50 \times 10^{-4} \\
1.34 \times 10^{-4} \\
1.17 \times 10^{-4} \\
1.04 \times 10^{-4} \\
0.915 \times 10^{-4} \\
0.850 \times 10^{-4} \\
0.720 \times 10^{-4} \\
0.687 \times 10^{-4} \\
0.590 \times 10^{-4} \\
0.493 \times 10^{-4} \\
0.396 \times 10^{-4} \\
0.363 \times 10^{-4} \\
0.364 \times 10^{-4} \\
0.332 \times 10^{-4} \\
0.332 \times 10^{-4} \\
0.332 \times 10^{-4} \\
0.333 \times 10^{-4} \\
0.464 \times 10^{-4} \\
0.529 \times 10^{-4} \\
0.659 \times 10^{-4} \\
0.790 \times 10^{-4} \\
0.953 \times 10^{-4}\end{array}$ & $\begin{array}{l}\mathrm{NaCl} \text { unstrained; flat specimen } 2.5 \times \\
1 \times 0.1 \mathrm{~cm}^{3} \text { cleaved from blanks, } \\
\text { gold electrodes evaporated over both } \\
\text { sides, and tin foil pasted to the } \\
\text { gold electrodes with low-loss oil; } \\
\text { smooth data extracted from figure; } \\
\text { measurement temperature specified } \\
\text { as room temperature, } 293 \mathrm{~K} \text { assigned. }\end{array}$ \\
\hline 2 & Nevald, R., 1964 [81] & $\begin{array}{l}1.31 \\
1.71 \\
2.55 \\
4.34 \\
8.45 \\
1.10 \\
1.14 \\
1.76 \\
2.30 \\
3.00 \\
3.67 \\
4.49 \\
5.86 \\
8.18 \\
1.00 \\
1.14 \\
1.95 \\
2.23 \\
2.91 \\
3.81 \\
4.35 \\
5.69\end{array}$ & $\begin{array}{ll} & (\mathrm{T}= \\
\mathrm{x} 10^{3} \\
\mathrm{x} 10^{3} \\
\mathrm{x} 10^{3} \\
\mathrm{x} 10^{3} \\
\mathrm{x} 10^{3} \\
\mathrm{x} 10^{4} \\
\mathrm{x} 10^{4} \\
\mathrm{x} 10^{4} \\
\mathrm{x} 10^{4} \\
\mathrm{x} 10^{4} \\
\mathrm{x} 10^{4} \\
\mathrm{x} 10^{4} \\
\mathrm{x} 10^{4} \\
\mathrm{x} 10^{4} \\
\mathrm{x} 10^{5} \\
\mathrm{x} 10^{5} \\
\mathrm{x} 10^{5} \\
\mathrm{x} 10^{5} \\
\mathrm{x} 10^{5} \\
\mathrm{x} 10^{5} \\
\mathrm{x} 10^{5} \\
\mathrm{x} 10^{5}\end{array}$ & $\begin{array}{r}293 \mathrm{~K}) \\
2.36 \times 10^{-4} \\
2.62 \times 10^{-4} \\
3.21 \times 10^{-4} \\
4.06 \times 10^{-4} \\
5.04 \times 10^{-4} \\
5.43 \times 10^{-4} \\
5.57 \times 10^{-4} \\
5.70 \times 10^{-4} \\
5.76 \times 10^{-4} \\
5.89 \times 10^{-4} \\
5.89 \times 10^{-4} \\
5.89 \times 10^{-4} \\
5.90 \times 10^{-4} \\
6.03 \times 10^{-4} \\
6.03 \times 10^{-4} \\
6.09 \times 10^{-4} \\
6.29 \times 10^{-4} \\
6.42 \times 10^{-4} \\
6.42 \times 10^{-4} \\
6.36 \times 10^{-4} \\
6.36 \times 10^{-4} \\
6.23 \times 10^{-4}\end{array}$ & $\begin{array}{l}\text { Similar to the above specimen and } \\
\text { conditions except dislocation density } \\
5 \times 10^{9} \mathrm{~cm}^{2} \text { and specimen designated } \\
\text { as } 1 \text {. }\end{array}$ \\
\hline
\end{tabular}


TABLE 6.8. EXPERIMFNTAL DATA FOR THE TANGENT OF THE LOSS ANGLE OF SODIUM CHLORIDE (continued)

\begin{tabular}{|c|c|c|c|c|c|}
\hline $\begin{array}{l}\text { Data } \\
\text { Set }\end{array}$ & Author(s), Year [Ref.] & & $v$ & $\tan \delta$ & Remarks \\
\hline $\begin{array}{c}2 \\
(\operatorname{con} t .)\end{array}$ & Nevald, R., 1964 [81] & $\begin{array}{l}7.44 \\
9.09 \\
1.78 \\
4.26 \\
6.81 \\
1.02 \\
1.74 \\
2.44\end{array}$ & $\begin{array}{ll}\times 10^{5} \\
\times 10^{5} \\
\times 10^{6} \\
\times 10^{6} \\
\times 10^{6} \\
\times 10^{7} \\
\times 10^{7} \\
\times 10^{7}\end{array}$ & $\begin{array}{l}6.10 \times 10^{-4} \\
5.97 \times 10^{-4} \\
5.25 \times 10^{-4} \\
4.34 \times 10^{-4} \\
3.89 \times 10^{-4} \\
3.37 \times 10^{-4} \\
2.85 \times 10^{-4} \\
2.52 \times 10^{-4}\end{array}$ & \\
\hline 3 & $\begin{array}{l}\text { Radhakrishna, S. and } \\
\text { Karguppikar, A.M., } \\
1973 \text { [2] }\end{array}$ & $\begin{array}{l}1.25 \\
1.68 \\
2.26 \\
2.52 \\
2.81 \\
3.92 \\
5.36 \\
5.88 \\
6.45 \\
7.47 \\
8.20 \\
1.02 \\
1.40 \\
2.02 \\
2.57\end{array}$ & $\begin{array}{ll} & (\mathrm{T}= \\
\times & 10^{2} \\
\times & 10^{2} \\
\times & 10^{2} \\
\mathrm{x} & 10^{2} \\
\mathrm{x} & 10^{2} \\
\mathrm{x} & 10^{2} \\
\mathrm{x} & 10^{2} \\
\mathrm{x} & 10^{2} \\
\mathrm{x} & 10^{2} \\
\mathrm{x} & 10^{2} \\
\mathrm{x} & 10^{2} \\
\mathrm{x} & 10^{3} \\
\mathrm{x} & 10^{3} \\
\mathrm{x} & 10^{3} \\
\mathrm{x} & 10^{3}\end{array}$ & $\begin{array}{l}393 \mathrm{~K}) \\
1.05 \times 10^{-1} \\
7.30 \times 10^{-2} \\
5.56 \times 10^{-2} \\
5.57 \times 10^{-2} \\
5.78 \times 10^{-2} \\
4.02 \times 10^{-2} \\
2.96 \times 10^{-2} \\
2.56 \times 10^{-2} \\
2.29 \times 10^{-2} \\
1.95 \times 10^{-2} \\
1.63 \times 10^{-2} \\
1.36 \times 10^{-2} \\
9.62 \times 10^{-3} \\
6.58 \times 10^{-3} \\
5.80 \times 10^{-3}\end{array}$ & $\begin{array}{l}\text { NaCl crystals doped with Sb; crystals } \\
\text { grown from melt by Kyropoulos tech- } \\
\text { nique starting with BDH-AR grade salt, } \\
\text { Sb then diffused by heating the } \\
\text { crystal in Sb vapor at } 973 \pm 5 \mathrm{~K} \text { for } \\
\text { about } 6 \text { days, the } \mathrm{NaCl} \text { and } \mathrm{Sb} \text { metal } \\
\text { sealed together in quartz tube after } \\
\text { evacuating to approx } 10^{-3} \text { torr; im- } \\
\text { purity content estimated by mass } \\
\text { spectroscopic analysis; before mea- } \\
\text { surements crystals quenched from } \\
\text { approx } 673 \mathrm{~K} \text {; for measurements thin } \\
\text { coating of aquadog made and crystals } \\
\text { held in vacuum of } 10^{-2} \text { torr; in mea- } \\
\text { surements made by GR } 1615-\mathrm{A} \text { capaci- } \\
\text { tance bridge combined with GR } 1311-\mathrm{A} \\
\text { Audio Oscillator, for higher fre- } \\
\text { quencies a PM 5lo0 Philips Oscillator } \\
\text { used in conjunction with capacitance } \\
\text { bridge; data points of log(tan } \delta \text { ) } \\
\text { versus log(frequency) extracted } \\
\text { from figure. }\end{array}$ \\
\hline 4 & $\begin{array}{l}\text { Radhakrishna, S. and } \\
\text { Karguppikar, A.M., } \\
1973 \text { [2] }\end{array}$ & $\begin{array}{l}6.47 \\
7.50 \\
8.70 \\
9.71 \\
1.05 \\
2.03 \\
2.58 \\
5.30 \\
1.03\end{array}$ & $\begin{array}{ll} & (\mathrm{T}= \\
\times & 10^{3} \\
\times & 10^{3} \\
\times & 10^{3} \\
\times & 10^{3} \\
\times & 10^{4} \\
\times & 10^{4} \\
\times & 10^{4} \\
\times & 10^{4} \\
\times & 10^{4}\end{array}$ & $\begin{array}{l}+93 \mathrm{~K}) \\
7.26 \times 10^{-1} \\
5.84 \times 10^{-1} \\
4.96 \times 10^{-1} \\
4.37 \times 10^{-1} \\
3.78 \times 10^{-1} \\
1.77 \times 10^{-1} \\
1.71 \times 10^{-1} \\
7.69 \times 10^{-2} \\
3.60 \times 10^{-2}\end{array}$ & $\begin{array}{l}\text { Similar to the above specimen and } \\
\text { conditions. }\end{array}$ \\
\hline 5 & $\begin{array}{l}\text { Haven, Y., } 1953 \\
{[82,83]}\end{array}$ & $\begin{array}{l}5.23 \\
7.56 \\
1.02 \\
1.36 \\
1.97 \\
2.85 \\
4.60 \\
6.90 \\
9.98 \\
1.44 \\
1.87 \\
2.80 \\
4.36 \\
7.30\end{array}$ & $\begin{array}{ll} & (\mathrm{T}= \\
\mathrm{x} & 10 \\
\mathrm{x} & 10 \\
\times & 10^{2} \\
\mathrm{x} & 10^{2} \\
\mathrm{x} & 10^{2} \\
\times & 10^{2} \\
\mathrm{x} & 10^{2} \\
\mathrm{x} & 10^{2} \\
\mathrm{x} & 10^{2} \\
\times & 10^{3} \\
\times & 10^{3} \\
\mathrm{x} & 10^{3} \\
\times & 10^{3} \\
\mathrm{x} & 10^{3}\end{array}$ & $\begin{array}{l}383 \mathrm{~K}) \\
1.55 \times 10^{-4} \\
1.34 \times 10^{-4} \\
1.24 \times 10^{-4} \\
1.11 \times 10^{-4} \\
9.95 \times 10^{-5} \\
8.58 \times 10^{-5} \\
7.98 \times 10^{-5} \\
7.14 \times 10^{-5} \\
6.64 \times 10^{-5} \\
6.17 \times 10^{-5} \\
5.94 \times 10^{-5} \\
5.32 \times 10^{-5} \\
5.32 \times 10^{-5} \\
4.95 \times 10^{-5}\end{array}$ & $\begin{array}{l}\text { Very pure; single crystal; smooth } \\
\text { data extracted from figure. }\end{array}$ \\
\hline
\end{tabular}


TABLE 6.8. EXPERIMENTAL DATA FOR THE TANGENT OF THE LOSS ANGLE OF SODIUM CHLORIDE (continued)

\begin{tabular}{|c|c|c|c|c|}
\hline $\begin{array}{l}\text { Data } \\
\text { Set }\end{array}$ & Author (s), Year [Ref.] & $v$ & $\tan \delta$ & Remarks \\
\hline $\begin{array}{c}5 \\
(\operatorname{con} t .)\end{array}$ & $\begin{array}{l}\text { Haven, Y., } 1953 \\
{[82,83]}\end{array}$ & $\begin{array}{l}1.02 \times 10^{4} \\
1.70 \times 10^{4} \\
2.75 \times 10^{4} \\
5.14 \times 10^{4} \\
7.71 \times 10^{4} \\
1.04 \times 10^{5}\end{array}$ & $\begin{array}{l}4.95 \times 10^{-5} \\
4.77 \times 10^{-5} \\
4.78 \times 10^{-5} \\
4.44 \times 10^{-5} \\
4.44 \times 10^{-5} \\
4.44 \times 10^{-5}\end{array}$ & \\
\hline 6 & $\begin{array}{l}\text { Breckenridge, R.G., } \\
1948 \text { [61] }\end{array}$ & $\begin{array}{l}1 \mathrm{~T}= \\
1.09 \times 10^{2} \\
1.20 \times 10^{3} \\
1.03 \times 10^{4} \\
1.00 \times 10^{5} \\
1.09 \times 10^{6} \\
9.42 \times 10^{6} \\
8.11 \times 10^{7} \\
7.64 \times 10^{9}\end{array}$ & $\begin{array}{r}358 \times) \\
1.11 \times 10^{-2} \\
1.19 \times 10^{-2} \\
8.93 \times 10^{-3} \\
3.58 \times 10^{-3} \\
6.35 \times 10^{-4} \\
3.68 \times 10^{-4} \\
3.68 \times 10^{-4} \\
3.04 \times 10^{-3}\end{array}$ & $\begin{array}{l}\text { Commercial crystal from Harshaw } \\
\text { Chemical Co., Cleveland, Ohio; spec- } \\
\text { imen approx } 0.5 \text { in square and about } \\
0.020 \text { in thick; electrodes applied } \\
\text { by painting crystal faces with } \\
\text { duPont Silver Paste No. } 4351 \text {; prob- } \\
\text { able error } \pm 0.0003 \text {; data extracted } \\
\text { from figure except max tan } \delta \text { at } \\
600 \mathrm{~Hz} \text { from text. }\end{array}$ \\
\hline 7 & Bayley, P.L., 1933 [84] & $\begin{array}{l}1.04 \times 10^{3} \\
1.14 \times 10^{3} \\
2.04 \times 10^{3} \\
2.86 \times 10^{3} \\
3.43 \times 10^{3} \\
1.33 \times 10^{5} \\
1.46 \times 10^{5} \\
1.98 \times 10^{5} \\
2.30 \times 10^{5}\end{array}$ & $\begin{array}{r}293 \mathrm{~K}) \\
3.50 \times 10^{-4} \\
3.41 \times 10^{-4} \\
3.18 \times 10^{-4} \\
3.08 \times 10^{-4} \\
3.02 \times 10^{-4} \\
1.65 \times 10^{-4} \\
1.58 \times 10^{-4} \\
1.49 \times 10^{-4} \\
1.49 \times 10^{-4}\end{array}$ & $\begin{array}{l}\text { Pure rock salt; specimen } 0.9 \mathrm{~mm} \text { thick; } \\
\text { sawed from larger block almost par- } \\
\text { allel to natural cleavage planes; } \\
\text { from Ward's Natural Science Estab- } \\
\text { lishment; colored amber by } 40 \mathrm{~min} \\
\text { exposure to x-rays; data points, } \\
\text { before and after exposure to x-rays, } \\
\text { extracted from figure; no difference } \\
\text { in data noted due to x-ray exposure; } \\
\text { temperature assumed to be } 293 \mathrm{~K} \text {. }\end{array}$ \\
\hline 8 & $\begin{array}{l}\text { Vodop'ianov, K.A. and } \\
\text { Galibina, G.I., } 1958 \\
\text { [85] }\end{array}$ & $1 \times 10^{6}=$ & $\begin{array}{l}293 \mathrm{~K}) \\
6.4 \times 10^{-5}\end{array}$ & $\begin{array}{l}\text { Pure; grown by Kyropoulos method from } \\
\text { melt of chemically pure material; } \\
\text { data extracted from table; measure- } \\
\text { ment temperature specified as room } \\
\text { temperature, } 293 \text { K assigned. }\end{array}$ \\
\hline 9 & $\begin{array}{l}\text { Vodop'ianov, K.A. and } \\
\text { Galibina, G.I., } 1958 \\
\text { [85] }\end{array}$ & $\begin{array}{l}\quad(\mathrm{T}= \\
1.718 \times 10^{5} \\
3.784 \times 10^{5} \\
6.714 \times 10^{5} \\
2.158 \times 10^{6} \\
7.998 \times 10^{6} \\
1.00 \times 10^{7} \\
\text { T }\end{array}$ & $\begin{array}{r}293 \mathrm{~K}) \\
1.36 \times 10^{-4} \\
9.6 \times 10^{-5} \\
5.5 \times 10^{-5} \\
3.0 \times 10^{-5} \\
3.1 \times 10^{-5} \\
2.3 \times 10^{-5} \\
\tan \delta\end{array}$ & $\begin{array}{l}\text { Pure; grown by Kyropoulos method } \\
\text { from melt of chemically pure material; } \\
\text { data extracted from figure; measure- } \\
\text { ment temperature presumably room } \\
\text { temperature, } 293 \mathrm{~K} \text { assigned. }\end{array}$ \\
\hline 10 & $\begin{array}{l}\text { Breckenridge, R.G., } \\
1950 \text { [86] }\end{array}$ & $\begin{array}{l}\quad(\nu=1 \\
303.9 \\
305.9 \\
310.6 \\
313.0 \\
315.8 \\
318.1 \\
322.1 \\
324.9 \\
329.2 \\
333.5 \\
338.7 \\
347.0 \\
356.4\end{array}$ & $\begin{array}{r}\left.10^{3} \mathrm{~Hz}\right) \\
8.6 \times 10^{-4} \\
9.4 \times 10^{-4} \\
1.03 \times 10^{-3} \\
1.11 \times 10^{-3} \\
1.11 \times 10^{-3} \\
1.27 \times 10^{-3} \\
1.51 \times 10^{-3} \\
1.67 \times 10^{-3} \\
2.14 \times 10^{-3} \\
2.46 \times 10^{-3} \\
3.01 \times 10^{-3} \\
3.96 \times 10^{-3} \\
5.54 \times 10^{-3}\end{array}$ & $\begin{array}{l}0.18 \text { mole percent } \mathrm{CdCl}_{2} \text {; concentration } \\
\text { of impurity ion determined polaro- } \\
\text { graphically using method of standard } \\
\text { additions; NaCl from Harshaw Chemical } \\
\mathrm{Co.}, \mathrm{Cl} \text { eveland, Ohio; c.p. grade of } \\
\mathrm{CdC1}_{2} \text { used; specimen prepared by } \\
\text { coating pure crystal of approx } 0.02 \\
\text { in by } 0.5 \text { in by } 0.5 \text { in with thin } \\
\text { layer of impurity and heating for } \\
\text { several hours at approx } 25 \mathrm{~K} \text { below } \\
\text { melting point until impurity evenly } \\
\text { distributed; measurements made at } \\
1 \text { kHz; data points extracted from } \\
\text { figure. }\end{array}$ \\
\hline
\end{tabular}


TABLE 6.8. EXPERIMENTAL DATA FOR THE TANGENT OF THE LOSS ANGLE OF SODIUM CHLORIDE (continued)

\begin{tabular}{|c|c|c|c|c|}
\hline $\begin{array}{c}\text { Data } \\
\text { Set }\end{array}$ & Author(s), Year [Ref.] & $\mathrm{T}$ & $\tan \delta$ & Remarks \\
\hline $\begin{array}{c}10 \\
(\text { cont. })\end{array}$ & $\begin{array}{l}\text { Breckenridge, R.G., } \\
1950 \text { [86] }\end{array}$ & $\begin{array}{l}360.3 \\
363.9 \\
366.2 \\
369.0 \\
372.1 \\
374.5 \\
376.8 \\
381.9 \\
385.1 \\
385.8 \\
388.2 \\
391.3 \\
394.8 \\
395.2 \\
399.1 \\
403.9 \\
407.0 \\
410.2 \\
416.5 \\
420.8 \\
424.4 \\
425.9 \\
429.5 \\
431.1 \\
435.4 \\
439.3 \\
440.9 \\
444.8 \\
446.7 \\
450.6 \\
452.6 \\
454.9 \\
456.8 \\
458.8 \\
461.9\end{array}$ & $\begin{array}{r}6.88 \times 10^{-3} \\
7.51 \times 10^{-3} \\
7.51 \times 10^{-3} \\
9.24 \times 10^{-3} \\
1.066 \times 10^{-2} \\
1.200 \times 10^{-2} \\
1.342 \times 10^{-2} \\
1.578 \times 10^{-2} \\
1.759 \times 10^{-2} \\
1.932 \times 10^{-2} \\
2.128 \times 10^{-2} \\
2.302 \times 10^{-2} \\
1.9 \times 10^{-2} \\
2.703 \times 10^{-2} \\
2.7 \times 10^{-2} \\
3.9 \times 10^{-2} \\
4.7 \times 10^{-2} \\
5.9 \times 10^{-2} \\
7.9 \times 10^{-2} \\
1.15 \times 10^{-1} \\
1.46 \times 10^{-1} \\
1.66 \times 10^{-1} \\
1.97 \times 10^{-1} \\
2.37 \times 10^{-1} \\
3.07 \times 10^{-1} \\
3.70 \times 10^{-1} \\
4.29 \times 10^{-1} \\
5.51 \times 10^{-1} \\
5.98 \times 10^{-1} \\
7.00 \times 10^{-1} \\
7.67 \times 10^{-1} \\
9.04 \times 10^{-1} \\
9.79 \times 10^{-1} \\
1.053 \\
1.230\end{array}$ & \\
\hline 11 & $\begin{array}{l}\text { Vodop'ianov, K.A. and } \\
\text { Galibina, G.I., } 1958 \\
\text { [85] }\end{array}$ & $\begin{array}{l}\text { ( } \\
296 \\
325 \\
355 \\
364 \\
377 \\
384 \\
397 \\
406 \\
425 \\
435 \\
455 \\
466 \\
482 \\
492 \\
518 \\
540 \\
547 \\
562 \\
574 \\
581\end{array}$ & $\begin{array}{l}\left.10^{6} \mathrm{~Hz}\right) \\
5.9 \times 10^{-5} \\
5.2 \times 10^{-5} \\
6.1 \times 10^{-5} \\
6.2 \times 10^{-5} \\
6.2 \times 10^{-5} \\
4.6 \times 10^{-5} \\
5.5 \times 10^{-5} \\
6.3 \times 10^{-5} \\
7.2 \times 10^{-5} \\
5.6 \times 10^{-5} \\
1.07 \times 10^{-4} \\
1.25 \times 10^{-4} \\
1.93 \times 10^{-4} \\
2.35 \times 10^{-4} \\
3.12 \times 10^{-4} \\
4.64 \times 10^{-4} \\
4.81 \times 10^{-4} \\
5.75 \times 10^{-4} \\
6.34 \times 10^{-4} \\
6.85 \times 10^{-4}\end{array}$ & $\begin{array}{l}\text { Pure; grown by Kyropoulos method from } \\
\text { melt of chemically pure material; } \\
\text { data extracted from figure; data } \\
\text { reported for two different specimens } \\
\text { with data obtained on increasing } \\
\text { temperature. }\end{array}$ \\
\hline
\end{tabular}


TABLE 6.8. EXPERIMENTAL DATA FOR THE TANGENT OF THE LOSS ANGLE OF SODIUM CHLORIDE (continued)

\begin{tabular}{|c|c|c|c|}
\hline $\begin{array}{l}\text { Data } \\
\text { Set }\end{array}$ & Author(s), Year [Ref.] & $\tan \delta$ & Remarks \\
\hline 12 & $\begin{array}{l}\text { Vodop'ianov, K.A. and } \\
\text { Galibina, G.I., } 1958 \\
{[85]}\end{array}$ & $\begin{array}{l}\quad\left(\nu=1 \times 10^{6} \mathrm{~Hz}\right) \\
464 \\
476\end{array}$ & $\begin{array}{l}\text { The above specimens except data } \\
\text { taken with decreasing temperature. }\end{array}$ \\
\hline 13 & $\begin{array}{l}\text { Matsonashvili, B.N., } \\
1958[67]\end{array}$ & $\begin{array}{lr}\quad\left(V=1 \times 10^{3} \mathrm{~Hz}\right) \\
299 & 6.4 \times 10^{-4} \\
309 & 7.1 \times 10^{-4} \\
315 & 7.5 \times 10^{-4} \\
327 & 7.5 \times 10^{-4} \\
341 & 7.5 \times 10^{-4} \\
354 & 9.3 \times 10^{-4} \\
357 & 1.01 \times 10^{-3} \\
367 & 1.12 \times 10^{-3} \\
372 & 1.12 \times 10^{-3} \\
379 & 1.12 \times 10^{-3} \\
383 & 1.12 \times 10^{-3} \\
398 & 1.25 \times 10^{-3} \\
410 & 1.43 \times 10^{-3}\end{array}$ & $\begin{array}{l}\text { Single crystal; grown by Kyropoulos } \\
\text { technique; slab sawed from crystal } \\
\text { by using water-wetted wire saw; } \\
\text { ground and polished using dehydrated } \\
\text { alcohol to disk shape; plane parallel } \\
\text { to within 1-2 } \mu \mathrm{m} \text {; transparent and } \\
\text { crossed polaroids showed no percep- } \\
\text { tible internal stresses; measured } \\
\text { in vacuum; data taken on heating; } \\
\text { data points extracted from figure. }\end{array}$ \\
\hline 14 & $\begin{array}{l}\text { Matsonashvili, B.N., } \\
1958 \text { [67] }\end{array}$ & $\begin{array}{ll}\quad\left(\nu=8.50 \times 10^{5} \mathrm{~Hz}\right) \\
296 & 3.5 \times 10^{-4} \\
306 & 3.6 \times 10^{-4} \\
317 & 3.5 \times 10^{-4} \\
328 & 3.6 \times 10^{-4} \\
334 & 3.6 \times 10^{-4} \\
341 & 3.6 \times 10^{-4} \\
351 & 3.6 \times 10^{-4} \\
368 & 3.5 \times 10^{-4} \\
382 & 3.5 \times 10^{-4} \\
429 & 3.7 \times 10^{-4} \\
443 & 4.0 \times 10^{-4} \\
468 & 5.4 \times 10^{-4} \\
473 & 5.5 \times 10^{-4} \\
481 & 6.2 \times 10^{-4} \\
488 & 6.3 \times 10^{-4} \\
504 & 6.3 \times 10^{-4} \\
512 & 6.5 \times 10^{-4} \\
530 & 7.4 \times 10^{-4} \\
535 & 7.6 \times 10^{-4} \\
540 & 8.1 \times 10^{-4} \\
546 & 8.5 \times 10^{-4} \\
551 & 9.0 \times 10^{-4} \\
558 & 9.0 \times 10^{-4}\end{array}$ & $\begin{array}{l}\text { Similar to the above specimen and } \\
\text { conditions except different frequency } \\
\text { and data taken on heating. }\end{array}$ \\
\hline 15 & $\begin{array}{l}\text { Westphal, W.B. and } \\
\text { Sils, A., } 1972[12]\end{array}$ & $\begin{array}{cc}\quad\left(\nu=1 \times 10^{2} \mathrm{~Hz}\right) \\
295 & 3 \times 10^{-3} \\
347 & 6.7 \times 10^{-2} \\
383 & 1.84 \times 10^{-1} \\
432 & 3.26 \times 10^{-1} \\
478 & 7.61 \times 10^{-1} \\
591 & 8.020\end{array}$ & $\begin{array}{l}0.075 \text { at. } \% \mathrm{BeCl}_{3} \text {; data points ex- } \\
\text { tracted from figure. }\end{array}$ \\
\hline 16 & $\begin{array}{l}\text { Westphal, W.B. and } \\
\text { Sils, A., } 1972 \text { [12] }\end{array}$ & $\begin{array}{ll} & \left(\nu=1 \times 10^{5} \mathrm{~Hz}\right) \\
298 & 4 \times 10^{-4} \\
335 & 7 \times 10^{-4} \\
382 & 1.6 \times 10^{-3} \\
426 & 2.9 \times 10^{-3}\end{array}$ & $\begin{array}{l}\text { Similar to the above specimen and } \\
\text { conditions. }\end{array}$ \\
\hline
\end{tabular}


TABLE 6.8. EXPERIMENTAL DATA FOR THE TANGEN'T OF THE LOSS ANGLE OF SODIUM CHLORIDE (continued)

\begin{tabular}{|c|c|c|c|c|}
\hline $\begin{array}{l}\text { Data } \\
\text { Set }\end{array}$ & Author(s), Year [Ref.] & $\mathrm{T}$ & $\tan \delta$ & Remarks \\
\hline $\begin{array}{c}16 \\
(\text { cont. })\end{array}$ & $\begin{array}{l}\text { Westphal, W.B. and } \\
\text { Sils, A., } 1972 \text { [12] }\end{array}$ & $\begin{array}{l}492 \\
518 \\
553 \\
586 \\
625\end{array}$ & $\begin{array}{l}3.9 \times 10^{-3} \\
4.4 \times 10^{-3} \\
1.2 \times 10^{-2} \\
2.0 \times 10^{-2} \\
4.9 \times 10^{-2}\end{array}$ & \\
\hline 17 & $\begin{array}{l}\text { Westphal, W.B. and } \\
\text { Sils, A., } 1972 \text { [12] }\end{array}$ & $\begin{array}{l}295 \\
341 \\
380 \\
419 \\
461 \\
500 \\
533\end{array}$ & $\begin{array}{l}\left.10^{2} \mathrm{~Hz}\right) \\
4.7 \times 10^{-3} \\
5.9 \times 10^{-2} \\
1.76 \times 10^{-1} \\
3.63 \times 10^{-1} \\
5.59 \times 10^{-1} \\
1.030 \\
1.730\end{array}$ & $\begin{array}{l}1.23 \text { at. } \% \mathrm{BiC}_{3} \text {; data points ex- } \\
\text { tracted from figure. }\end{array}$ \\
\hline
\end{tabular}




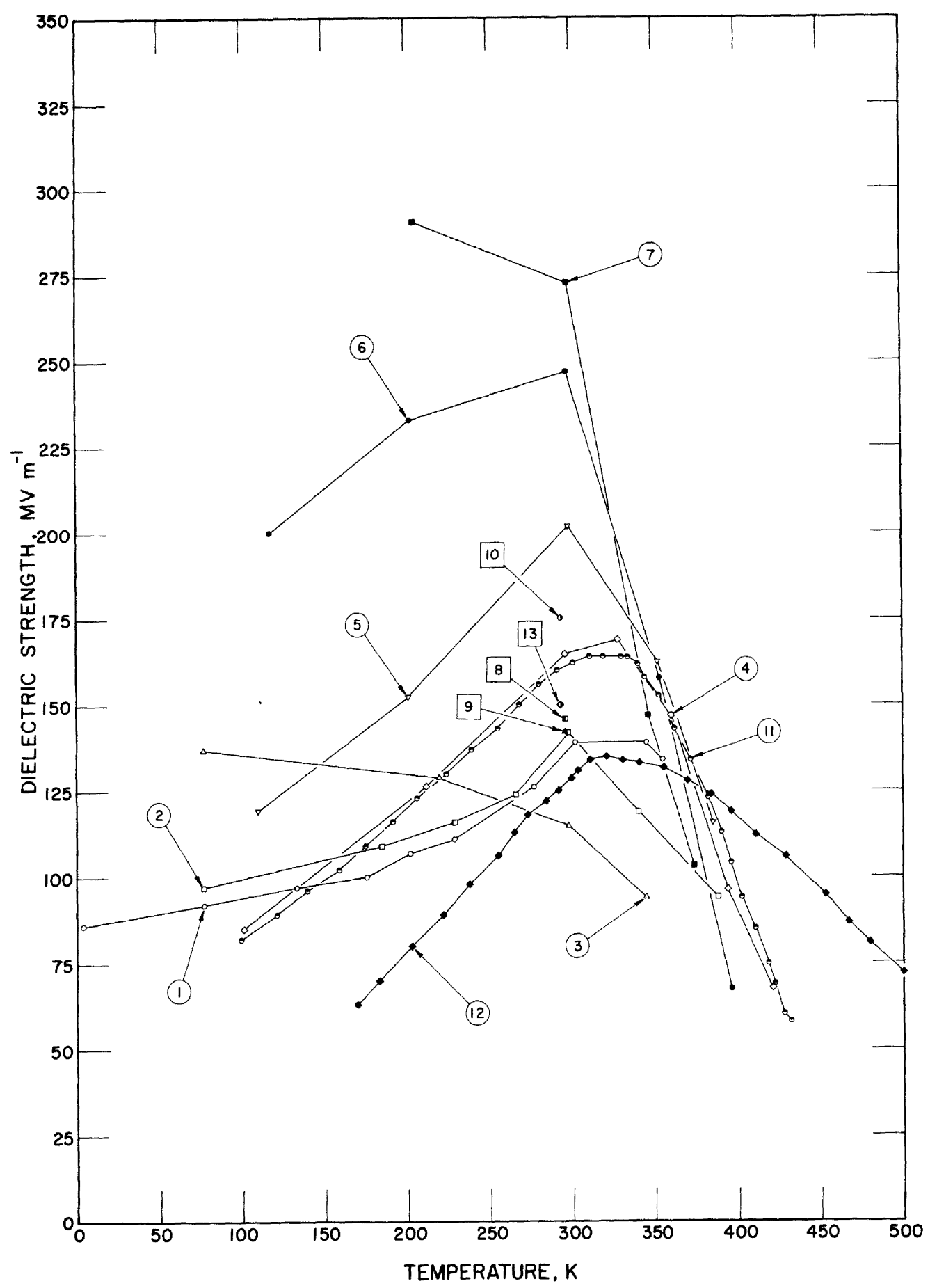

FIGURE 6.8. Dielectric strength of sodium chloride (temperature dependence). 


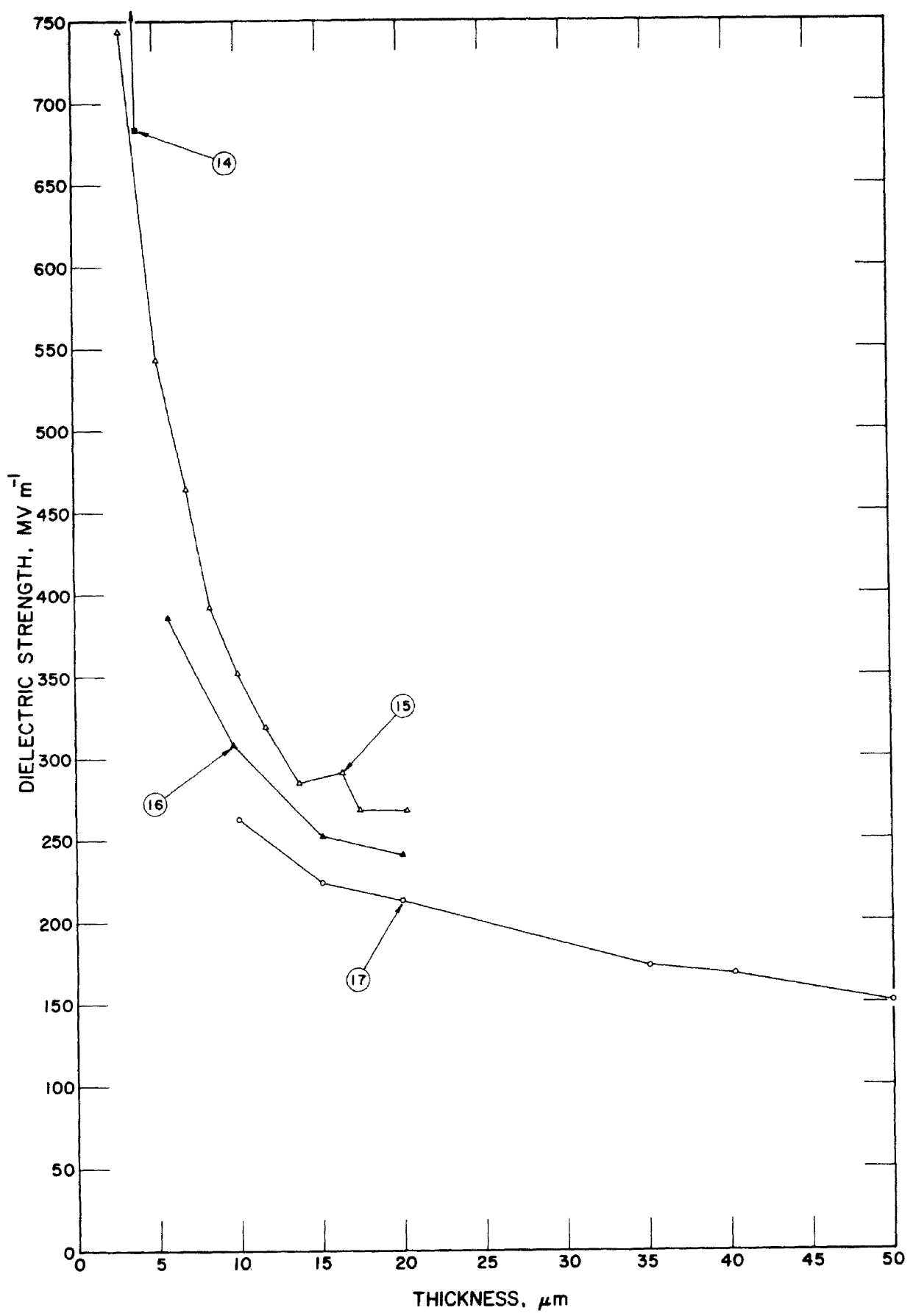

FIGURE 6.9. Dielectric strength of sodium chloride (thickness dependence). 
TABLE 6.9. EVALUATED DATA FOR THE DIELECTRIC STRENGTH OF BULK, PURE, UNSTRAINED SODIUM CHLORIDE

[Temperature, $\mathrm{T}, \mathrm{K}$; Dielectric Strength, $\mathrm{MV} \mathrm{m}^{-1}$ ]

T Dielectric Strength

$293 \quad 125-175$

TABLE 6.10. EXPERIMENTAL DATA FOR THE DIELECTRIC STRENGTH OF SODIUM CHLORIDE

[Temperature, T,K; Thickness, $t, \mu \mathrm{m}$; Dielectric Strength, MV $\mathrm{m}^{-1}$ ]

\begin{tabular}{|c|c|c|c|c|}
\hline $\begin{array}{l}\text { Data } \\
\text { Set }\end{array}$ & Author(s), Year [Ref.] & $\mathrm{T}$ & $\begin{array}{l}\text { Dielectric } \\
\text { Strength }\end{array}$ & Remarks \\
\hline 1 & Nevald, R., 1964 [81] & $\begin{array}{r}4 \\
77 \\
133 \\
176 \\
202 \\
229 \\
277 \\
302 \\
345 \\
355\end{array}$ & $\begin{array}{r}86 \\
92 \\
97 \\
100 \\
107 \\
111 \\
126 \\
139 \\
139 \\
134\end{array}$ & 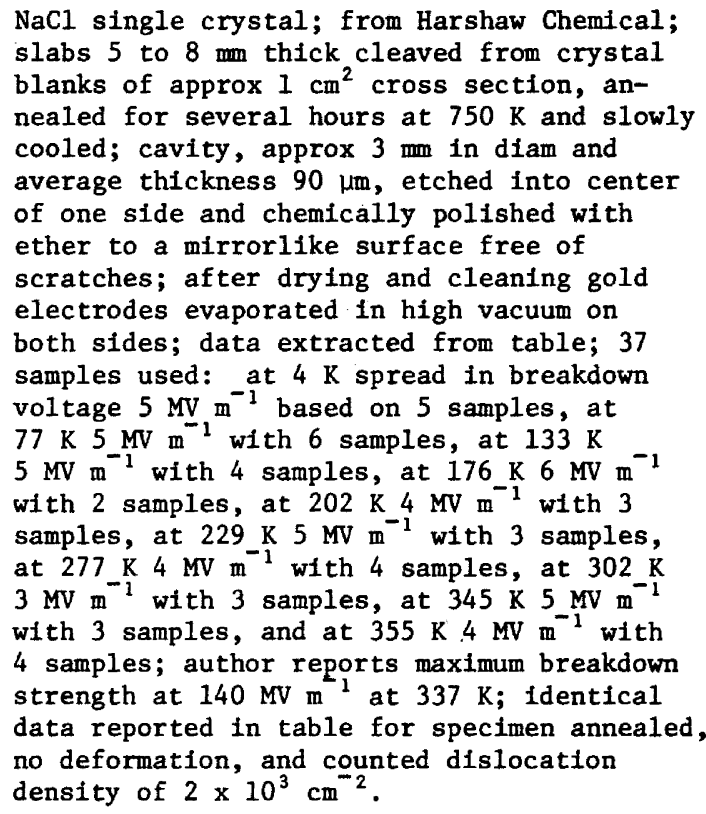 \\
\hline 2 & Nevald, R., 1964 [81] & $\begin{array}{r}77 \\
185 \\
229 \\
266 \\
298 \\
340 \\
388\end{array}$ & $\begin{array}{r}97 \\
109 \\
116 \\
124 \\
142 \\
119 \\
94\end{array}$ & 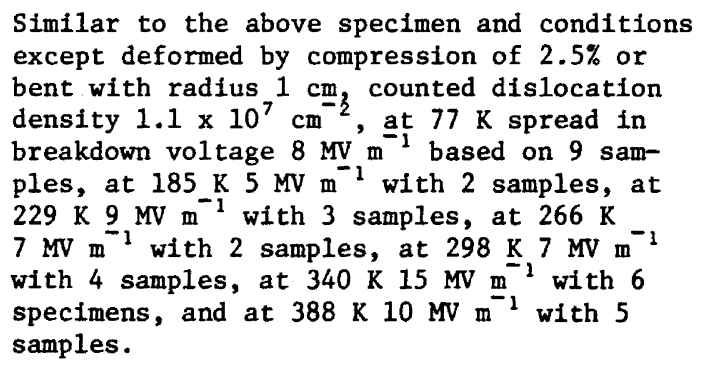 \\
\hline 3 & Nevald, R., 1964 [81] & $\begin{array}{r}77 \\
220 \\
298 \\
345\end{array}$ & $\begin{array}{r}137 \\
129 \\
115 \\
94\end{array}$ & $\begin{array}{l}\text { Similar to the above specimen and conditions } \\
\text { except deformed by compression } 10 \% \text {, counted } \\
\text { dislocation density } 1.0 \times 10^{9} \mathrm{~cm}^{-2} \text { at } 77 \mathrm{~K} \\
\text { spread in breakdown voltage } 12 \mathrm{MV} \mathrm{m}^{-1} \text { based } \\
\text { on } 11 \text { samples, at } 220 \mathrm{~K} 7 \mathrm{MV} \mathrm{m}-1 \text { with } 7 \\
\text { samples, at } 298 \mathrm{~K} 8 \mathrm{MV} \mathrm{m}^{-1} \text { with } 7 \text { samples, } \\
\text { and at } 345 \mathrm{~K} 10 \mathrm{MV} \mathrm{m} \text { with } 4 \text { samples. }\end{array}$ \\
\hline 4 & $\begin{array}{l}\text { von Hippel, A. and } \\
\text { Lee, G.M., } 1941 \text { [90] }\end{array}$ & $\begin{array}{l}100.7 \\
211.8 \\
295.5 \\
328.4 \\
360.0 \\
394.4 \\
420.5\end{array}$ & $\begin{array}{r}85.0 \\
126.2 \\
164.7 \\
168.8 \\
146.9 \\
96.3 \\
67.6\end{array}$ & $\begin{array}{l}\text { Pure } \mathrm{NaCl} \text { (rock salt); data points extracted } \\
\text { from figure. }\end{array}$ \\
\hline 5 & $\begin{array}{l}\text { von AIppe1, A. and } \\
\text { Lee, G.M., } 1941 \text { [90] }\end{array}$ & $\begin{array}{l}110.2 \\
200.8\end{array}$ & $\begin{array}{l}119.2 \\
152.2\end{array}$ & $\begin{array}{l}0.004 \text { at. } \% \text { AgCl in rock salt; data points } \\
\text { extracted from figure. }\end{array}$ \\
\hline
\end{tabular}


TABLE 6.10. EXPERIMENTAL DATA FOR THE DIELECTRIC STRENGTH OF SODIUM CHLORIDE (continued)

\begin{tabular}{|c|c|c|c|c|}
\hline $\begin{array}{l}\text { Data } \\
\text { Set }\end{array}$ & Author (s), Year [Ref.] & $\mathrm{T}$ & $\begin{array}{l}\text { Dielectric } \\
\text { Strength }\end{array}$ & Remarks \\
\hline $\begin{array}{c}5 \\
\text { (cont.) }\end{array}$ & $\begin{array}{l}\text { von Hippel, A. and } \\
\text { Lee, G.M., } 1941 \text { [90] }\end{array}$ & $\begin{array}{l}298.2 \\
351.7 \\
384.8\end{array}$ & $\begin{array}{l}201.7 \\
167.5 \\
115.5\end{array}$ & \\
\hline 6 & $\begin{array}{l}\text { von HippeI, A. and } \\
\text { Lee, G.M., } 1941 \text { [90] }\end{array}$ & $\begin{array}{l}117.0 \\
202.1 \\
296.7 \\
353.1 \\
395.8\end{array}$ & $\begin{array}{r}200.1 \\
233.0 \\
246.9 \\
157.9 \\
67.5\end{array}$ & $\begin{array}{l}0.017 \text { at. } \% \mathrm{AgC1} \text { in rock salt; data points } \\
\text { extracted from figure. }\end{array}$ \\
\hline 7 & $\begin{array}{l}\text { von Hippel, A. and } \\
\text { Lee, G.M., } 1941 \text { [90] }\end{array}$ & $\begin{array}{l}204.7 \\
298.1 \\
346.3 \\
373.8\end{array}$ & $\begin{array}{l}290.6 \\
272.9 \\
146.9 \\
103.1\end{array}$ & $\begin{array}{l}0.046 \text { at.\% } \mathrm{AgCl} \text { in rock sa1t; data points } \\
\text { extracted from figure. }\end{array}$ \\
\hline 8 & Caspari, M.E., 1955 [91] & 296 & 146 & $\begin{array}{l}\text { NaCl single crystal from Harshaw Chemical } \\
\text { Co.; crystal plates of }<0.25 \mathrm{~mm} \text { thickness } \\
\text { and about } 1 \mathrm{~cm}^{2} \text { area cut from same single } \\
\text { crystal, ground to proper thickness, and } \\
\text { polished on soft silk moistened with } \mathrm{NaC1} \\
\text { solution; evaporated gold electrodes applied } \\
\text { to flat specimens; direction of applied } \\
\text { field [100]; data reported is average for } 5 \\
\text { specimens; data extracted from table; max } \\
154 \mathrm{MV} \mathrm{m}^{-1} \text {, min } 135 \mathrm{MV} \mathrm{m}^{-2} \text {, standard devia- } \\
\text { tion } 0.064 \text {; max deviation about } \pm 7.5 \% \text {, } \\
\text { about } 2.5 \% \text { of this may be due to random } \\
\text { errors in voltage and thickness determina- } \\
\text { tion. }\end{array}$ \\
\hline 9 & Caspari, M.E., 1955 [91] & 296 & 142 & $\begin{array}{l}\text { Similar to the above specimens and conditions } \\
\text { except direction of applied field }[110] \text {, } \\
\text { max dielectric strength } 151 \mathrm{MV} \mathrm{m}^{-1} \text { min } \\
138 \mathrm{MV} \mathrm{m}^{-1} \text {, and standard deviation } 0.048 \text {. }\end{array}$ \\
\hline 10 & Caspari, M.E., 1955 [91] & 293 & 175 & $\begin{array}{l}\text { Crystal between glass slides; approximate } \\
\text { values reported; data extracted from table; } \\
\text { measurement temperature specified as room } \\
\text { temperature, } 293 \mathrm{~K} \text { assigned. }\end{array}$ \\
\hline 11 & $\begin{array}{l}\text { von Hippel, A. and } \\
\text { Alger, R.S., } 1949 \text { [92] }\end{array}$ & $\begin{array}{r}99 \\
121 \\
138 \\
159 \\
175 \\
191 \\
206 \\
224 \\
239 \\
255 \\
268 \\
280 \\
291 \\
303 \\
311 \\
319 \\
330 \\
334\end{array}$ & $\begin{array}{r}82 \\
89 \\
96 \\
102 \\
109 \\
116 \\
123 \\
130 \\
137 \\
143 \\
150 \\
156 \\
160 \\
162 \\
164 \\
164 \\
164 \\
164\end{array}$ & $\begin{array}{l}\text { Pressed-on ball bearing electrodes; dc } \\
\text { dielectric strength; data extracted from } \\
\text { figure. }\end{array}$ \\
\hline
\end{tabular}


TABLE 6.10. EXPERIMENTAL DATA FOR THE DIELECTRIC STRENGTH OF SODIUM CHLORIDE (continued)

\begin{tabular}{|c|c|c|c|c|}
\hline $\begin{array}{l}\text { Data } \\
\text { Set }\end{array}$ & Author(s), Year [Ref.] & $\mathrm{T}$ & $\begin{array}{l}\text { Dielectric } \\
\text { Strength }\end{array}$ & Remarks \\
\hline $\begin{array}{c}11 \\
\text { (cont.) }\end{array}$ & $\begin{array}{l}\text { von Hippel, A. and } \\
\text { Alger, R.S., } 1949 \text { [92] }\end{array}$ & $\begin{array}{l}340 \\
344 \\
352 \\
362 \\
372 \\
382 \\
390 \\
396 \\
402 \\
410 \\
418 \\
422 \\
428 \\
432\end{array}$ & $\begin{array}{r}162 \\
158 \\
153 \\
143 \\
134 \\
123 \\
113 \\
104 \\
94 \\
85 \\
75 \\
69 \\
60 \\
58\end{array}$ & \\
\hline 12 & $\begin{array}{l}\text { von Hippe1, A. and } \\
\text { Alger, R.S., } 1949 \text { [92] }\end{array}$ & $\begin{array}{l}170 \\
183 \\
203 \\
222 \\
238 \\
255 \\
265 \\
273 \\
284 \\
292 \\
300 \\
304 \\
311 \\
321 \\
331 \\
341 \\
356 \\
370 \\
384 \\
396 \\
411 \\
429 \\
453 \\
467 \\
480 \\
500 \\
522 \\
540 \\
559 \\
575 \\
585 \\
601\end{array}$ & $\begin{array}{r}63 \\
70 \\
80 \\
89 \\
98 \\
106 \\
113 \\
118 \\
122 \\
125 \\
129 \\
131 \\
134 \\
135 \\
134 \\
133 \\
132 \\
128 \\
124 \\
119 \\
112 \\
106 \\
95 \\
87 \\
81 \\
72 \\
62 * \\
53 * \\
44 * \\
36 * \\
31 * \\
24 *\end{array}$ & $\begin{array}{l}\text { Cavity, evaporated metal electrodes; dc } \\
\text { dielectric strength; data extracted from } \\
\text { figure. }\end{array}$ \\
\hline & & $* \mathrm{~N}$ & lown in $\mathrm{fi}$ & \\
\hline 13 & $\begin{array}{l}\text { von Hippe1, A., } 1932 \\
\text { [93] }\end{array}$ & 293 & 150 & $\begin{array}{l}\text { Results of. measurements on several natural } \\
\text { crystals and a synthetic } \mathrm{NaCl} \text { specimen; } \\
\text { max deviation } \pm 10 \mathrm{MV} \mathrm{m} \text { or } \pm 6.6 \% \text {; measure- } \\
\text { ment temperature not given explicitly, } \\
\text { assumed to be } 293 \mathrm{~K} \text {. }\end{array}$ \\
\hline
\end{tabular}


TABLE 6.10. EXPERIMENTAL DATA FOR THE DIELECTRIC STRENGTH OF SODIUM CHLORIDE (continued)

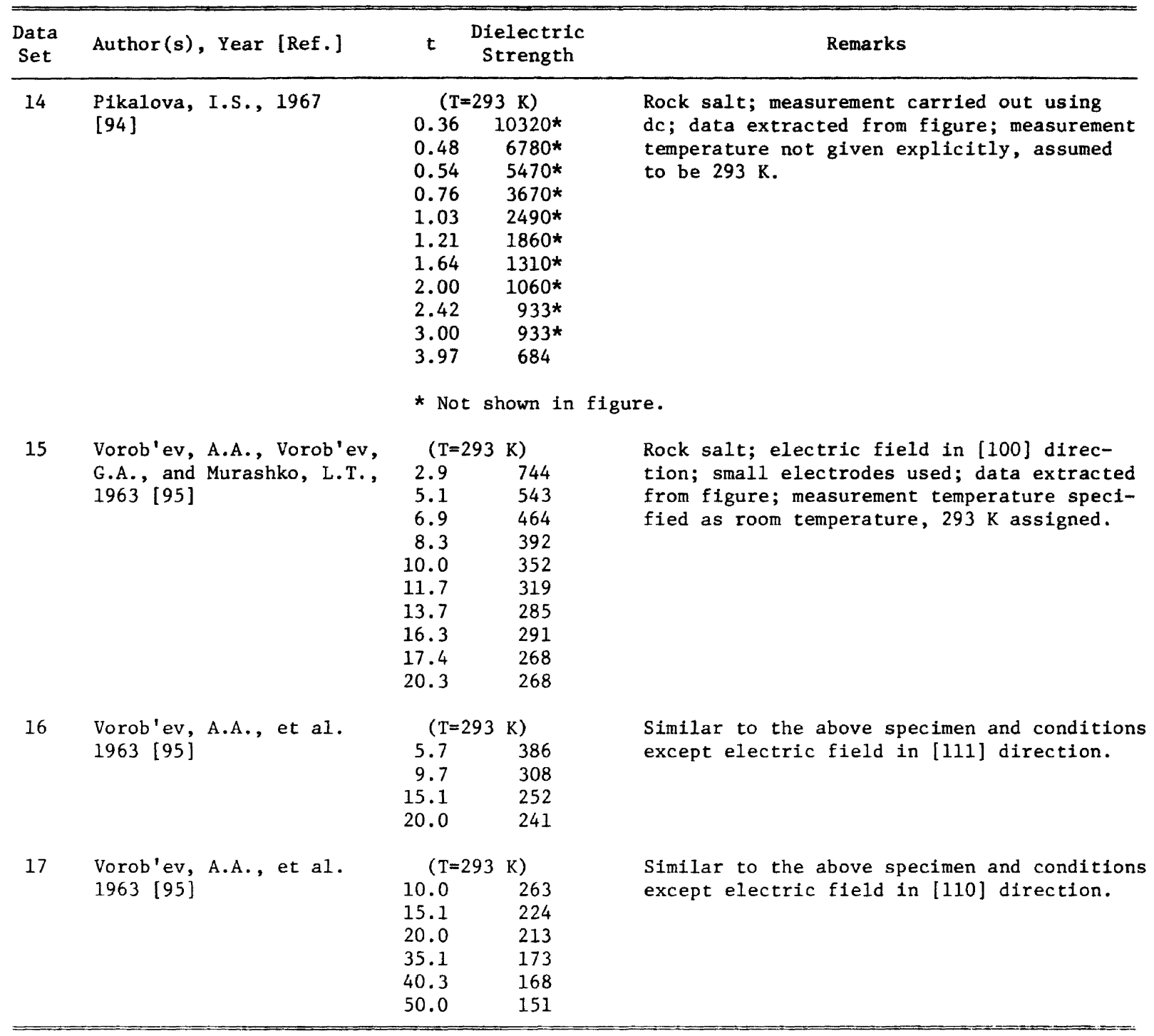


work of von Hippel and Alger [92] showed that the electrodes used to measure the dielectric strength have an effect on the numerical values. Data from press-on ball bearings (data set 11) resulted in a value of $160 \mathrm{MV}$ $\mathrm{m}^{-1}$ at $291 \mathrm{~K}$ while cavity, evaporated metal electrodes (data set 12) gave $125 \mathrm{MV} \mathrm{m}^{-1}$ at $292 \mathrm{~K}$. With a crystal between glass slides, Caspari [91] (data set 10) reported an approximate value of $175 \mathrm{MV} \mathrm{m}^{-1}$ at $293 \mathrm{~K}$. For results on several natural crystals and a synthetic one, von Hippel [93] (data set 13) reported a value of 150 MV $\mathrm{m}^{-1}$.

In contrast to pure material, data for specimens with impurities deliberately added or deformed show other features. In 1941, von Hippel and Lee [90] (data sets 4-7) presented data for the dielectric strength for varying amounts of silver chloride in sodium chloride. For temperatures below room temperature, the dielectric strength increases as the amount of silver chloride increases and the maximum in the dielectric strength shifts to a lower temperature. Above room temperature the slope of the decrease shows a tendency to become more pronounced as the amount of silver chloride increases. Nevald [81] (data sets 1-3) investigated the effect of deformation. A deformation by compression of $10 \%$ (data set 3 ) shows a curve decreasing in value form 77 to $345 \mathrm{~K}$.

Figure 6.9 for the thickness dependence shows the general features of the data. Of particular note is the orientation dependence shown by Vorob'ev et al. [95] (data sets 15-17) demonstrating that the dielectric strength increases as the electric field is in the [100], [111], and [110] directions.

The range of values at room temperature for the dielectric strength given in table 6.9 as the evaluated data is based on the lowest and highest values reported for bulk, pure, and unstrained sodium chloride; evaluated data are not given in addition to room temperature since several effects mentioned above lead to a variation in the dielectric strength and also data on wellcharacterized materials are lacking.

In addition to the data discussed above, data are contained in references $[91,96,97]$. A review article in which the author discusses many aspects of dielectric strength in alkali halide crystals is reference [98].

\subsection{Magnetic Susceptibility}

Evaluated data for the temperature dependence of the magnetic mass susceptibility of pure sodium chloride are given in table 6.11 and shown on figure 6.10 together with experimental data. Table 6.12 contains the numerical data, together with information on sample characterization, for the experimental data shown on figure 6.10. A discussion of the data is given before stating the basis of the evaluated data.

The data indicate that at room temperature and below the magnetic susceptibility is constant. In 1914, Ishiwara [99] (curve 1) reported data on a small crystal from Merck over the temperature range 123 to $291 \mathrm{~K}$, with the data showing a constant behavior. The data are negative making sodium chloride a diamagnetic substance. He also reported data on a large crystal of rock salt (curve 2), which are close to the data on the small crystal, and also showed constant behavior. Data on solid material at or near room temperature were reported by Hoare and Brindley [101,102] (curve 4) and by Kido [103] (curve 5) with the data of the latter differing from the data of Ishiwara by no more than 3.5\%. Data from measurements on aqueous solutions were given by Ikenmeyer [100] (curve 3). In 1974, Smirnov et al. [104] made the point that the temperature coefficient of the magnetic susceptibility, within the experimental error, was zero for crystals of sodium chloride.

The evaluated data were based on the data of Ishiwara (curve 1) for a solid sample and were arrived at by taking an average of that data. The uncertainty in the data is assigned a value of $3.5 \%$ since the data of Kido is within that percentage.

Additional data for the magnetic susceptibility appear in references [105,106, and 126]. A previous compilation of molar magnetic susceptibility values for sodium chloride in aqueous solutions appears in reference [107].

\subsection{Effect of Nuclear Irradiation on Electrical and Magnetic Properties}

\subsubsection{Effect of Nuclear Irradiation on Electrical Conductivity}

Pearlstein [108] studied the effect of proton bombardment on the electrical conductivity of sodium chloride. The material received a $350 \mathrm{MeV}$ fluence of $10^{15}$ protons $\mathrm{cm}^{-2}$ at room temperature and the conductivity was measured over the range of 398 to $743 \mathrm{~K}$. The conductivity was decreased by the bombardment. Upon heating the material the conductivity anneals in several distinct temperature ranges. At room temperature, the initial conductivity is restored after all the heat treatments; at higher temperatures it is only about $75 \%$ restored. Further work on proton bombardment was reported by Pearlstein and Ingham [109] in which sodium chloride was bombarded at $350 \mathrm{MeV}$ and several days later the conductivity was measured as the temperature was increased at a constant rate of $1.25 \mathrm{~K}$ $\min ^{-1}$. Three different proton fluences of $2.6 \times 10^{14}, 1 \times$ $10^{15}$, and $2.6 \times 10^{15}$ protons $\mathrm{cm}^{-2}$ were used. The 
conductivity decreased to a minimum at $423 \mathrm{~K}$ and increased to its pre-bombardment level at just below 623

K.

\subsubsection{Effect of Nuclear Irradiation on Dielectric Constant and Strength}

Ishiguro et al. [110] studied the effect of $x$-ray irradiation on $\tan \delta$. If a specimen is either plastically deformed or quenched, $\mathbf{x}$-rays darken the crystal and the anomalous dispersion peak at $393 \mathrm{~K}$ disappears. When the specimen undergoes either heating or illumination, the peak reappears.

Mineav et al. [111] exposed single-crystal sodium chloride whiskers to $x$-rays and found the dielectric strength decreased with an increase in the concentration of $\mathrm{F}$-centers that were produced by the irradiation.

TABLE 6.11. EVALUATED DATA FOR THE MAGNETIC MASS SUSCEPTIBILITY OF PURE SODIUM CHLORIDE

[Temperature, T, K; Magnetic Mass Susceptibi]ity, $X_{M}$, mass, $10^{-9} \mathrm{~m}^{3} \mathrm{~kg}^{-1}$ ]

$\begin{array}{cl}\mathrm{T} & \mathrm{X}_{\mathrm{M}, \text { mass }} \\ 125 & -6.28 \\ 150 & -6.28 \\ 200 & -6.28 \\ 250 & -6.28 \\ 291 & -6.28\end{array}$

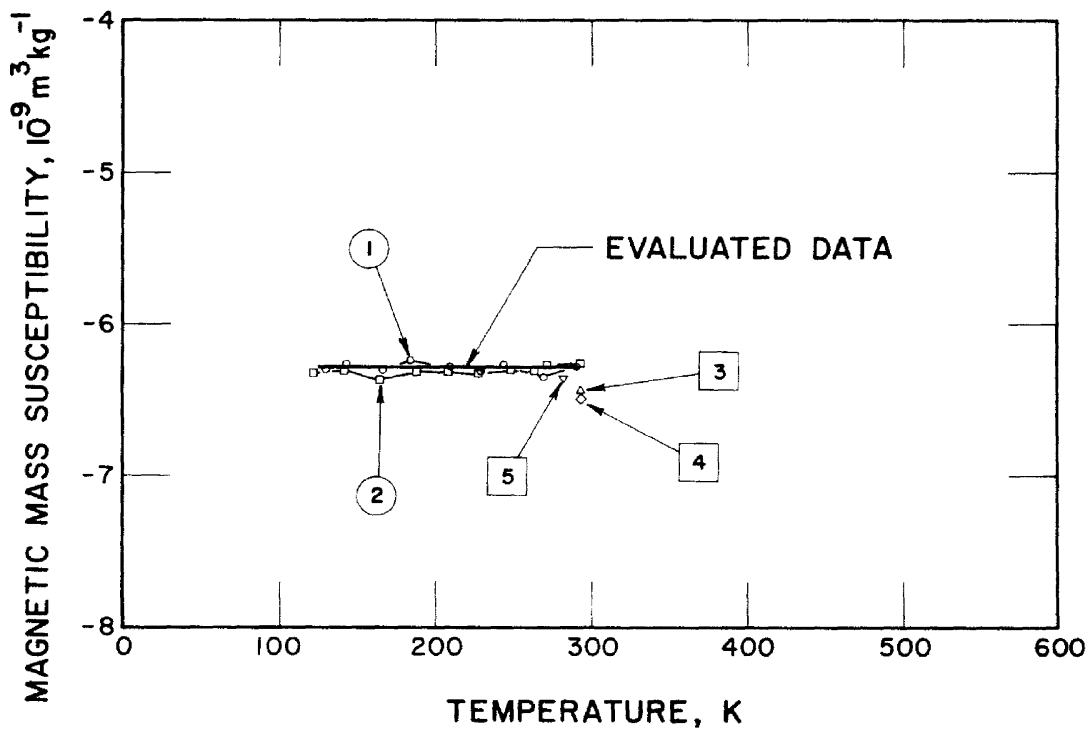

FiguRE 6.10. Magnetic mass susceptibility of sodium chloride. 
TABLE 6.12. EXPERIMENTAL DATA FOR THE MAGNETIC MASS SUSCEPTIBILITY OF SODIUM CHLORIDE [Temperature, T,K; Magnetic Mass Susceptibility, $X_{M}$, mass, $10^{-9} \mathrm{~m}^{3} \mathrm{~kg}^{-1}$ ]

\begin{tabular}{|c|c|c|c|c|}
\hline $\begin{array}{l}\text { Data } \\
\text { Set }\end{array}$ & Author(s), Year [Ref.] & $\mathrm{T}$ & $X_{M, \text { mass }}$ & Remarks \\
\hline 1 & Ishiwara, T., 1914 [99] & $\begin{array}{l}123.2 \\
143.4 \\
165.6 \\
183.8 \\
210.2 \\
229.0 \\
244.2 \\
269.2 \\
291.4\end{array}$ & $\begin{array}{l}-6.30 \\
-6.26 \\
-6.30 \\
-6.22 \\
-6.28 \\
-6.31 \\
-6.27 \\
-6.35 \\
-6.27\end{array}$ & $\begin{array}{l}\text { From Merck; small crystal, data extracted } \\
\text { from table. }\end{array}$ \\
\hline 2 & Ishiwara, T., 1914 [99] & $\begin{array}{l}122.2 \\
142.2 \\
165.0 \\
188.8 \\
207.6 \\
227.8 \\
248.8 \\
263.8 \\
271.2 \\
292.4\end{array}$ & $\begin{array}{l}-6.32 \\
-6.31 \\
-6.37 \\
-6.31 \\
-6.32 \\
-6.32 \\
-6.30 \\
-6.31 \\
-6.27 \\
-6.26\end{array}$ & $\begin{array}{l}\text { Rock salt; large crystal; data extracted } \\
\text { from table. }\end{array}$ \\
\hline 3 & $\begin{array}{l}\text { Ihenmeyer, K., } 1929 \\
\text { [100] }\end{array}$ & 293 & -6.438 & $\begin{array}{l}\text { From measurements on aqueous solutions; mea- } \\
\text { surement temperature assumed to be } 293 \mathrm{~K} \text {; } \\
\text { data extracted from table. }\end{array}$ \\
\hline 4 & $\begin{array}{l}\text { Hoare, F.E. and } \\
\text { Brindley, G.W., } 1934 \\
{[101,102]}\end{array}$ & 293 & -6.49 & $\begin{array}{l}\text { Material supplied by British Drug Houses, } \\
\text { Ltd., of grade A.R. standard; measurement con- } \\
\text { ducted on crystalline material; number of } \\
\text { samples used was } 4 \text {; Gouy method used; temper- } \\
\text { ature specified as room temperature, } 293 \mathrm{~K} \\
\text { assigned; data of molecular diamagnetic sus- } \\
\text { ceptibility ( } 30.2 \pm 0.14 \times 10^{-6} \text { ) extracted } \\
\text { from table; average deviation from mean of } \\
\text { molecular diamagnetic susceptibility } \pm 0.14 \mathrm{x} \\
10^{-6} \text {; molecular weight of NaCl } 58.44277 \mathrm{from} \\
1971 \text { atomic weights of the elements. }\end{array}$ \\
\hline 5 & Kido, K., 1932 [103] & 282 & -6.36 & Solid material; data extracted from table. \\
\hline
\end{tabular}

\subsection{References}

[1] Torkar, K., "Studies of Preparation and Properties of Active Alkali Azides and Barium Azide and Effects of this Activity on Thermodynamic and Thermochemical Data," Graz Univ., Austria, 12 pp. (1965). [AD 463 784]

[2] Radhakrishna, S. and Karguppikar, A.M., "Defect Centers in Antimony Doped Sodium Chloride Crystals," J. Phys. Chem. Solids, 34(9), 1497-505 (1973).

[3] Phipps, T.E., Lansing, W.D., and Cooke, T.G., "Temperature Conductance Curves of Solid Salts. I. The Halides of Sodium," J. Amer. Chem. Soc., 48, 112-25 (1926).

[4] Jain, S.C. and Dahake, S.L., "Ionic Conductivity of Sodium Chloride Crystals Doped with Nickel and Other Impurities," Indian J. Pure Appl. Phys., 2, 71-9 (1964).

[5] Etzel, H.W. and Maurer, R.J., "The Concentration and Mobility of Vacancies in Sodium Chloride," J. Chem. Phys., 18(8), 1003-7 (1950).

[6] Seelen, D., "On the Electrical Conductivity of Rock Salt Crystals,"'Z. Phys., 29, 125-40 (1924).
[7] Dreyfus, R.W. and Nowick, A.S., "Ionic Conductivity of Doped Sodium Chloride Crystals," Phys. Rev., 126(4), 1367-77 (1962).

[8] Trnovcova, V., Mariani, E., and Polak, K., "Association Reactions Between Nickel Ions and Vacancies in Sodium Chloride Crystals," Czech. J. Phys., B, 24, 765-73 (1974).

[9] Lehfeldt, W., "About the Electrical Conductivity of Single Crystals," Z. Physik., 85, 717-26 (1933).

[10] Melik-Gaikazyan, I.Ya., et al., "Effect of Annealing on the Absorption Spectra and Electrical Conductivity of Crystalline Lead Doped Sodium Chloride and Potassium Chloride," Opt. and Spectro., 9(1), 43-4 (1960).

[11] Trnovcova, V., Mariani, E., and Lebl., M., "Electrical Conductivity and Dielectric Relaxation of Sodium Chloride Crystals Doped with Vanadium," Phys. Status Solidi, A, 31(1), K43-K46 (1975).

[12] Westy.hal, W.B. and Sils, A., "Dielectric Report," Massachusetts Inst. of Tech., Cambridge, Mass., 243 pp. (1972). [AD $746686]$

[13] Shinizu, K., "Effect of Hydrostatic Pressure on Ionic Conductivity of Sodium Chloride," Rev. Phys. Chem., Jap., 31(2), 67-72 (1962). 
[14] Beyeler, M. and Lazarus, D., "Influence of the Hydrostatic Pressure on the Electric Conductivity of Sodium Chloride in the Intrinsic Domain," Solid State Commun. 7(20), 1487-9 (1969).

[15] Nadler, C. and Rossel, J., "Measurement and Interpretation of the Ionic Conduction in Alkali Halides," Phys. Status Solidi A, 18(2), 711-22 (1973).

[16] Dreyfus, R.W. and Nowick, A.S., "Energy and Entropy of Formation and Motion of Vacancies in Sodium Chloride and Potassium Chloride Crystals," J. Appl. Phys., 33(1), 473-7 (1962).

[17] Dryden, J.S. and Meakins, R.J., "Electrical Conductivity of Certain Crystalline Materials After Grinding," 171, 307-8 (1953).

[18] Kobayashi, K. and Tomiki, T., "Studies on the Preparation of Pure Alkali Chlorides," J. Phys. Soc. Japan, 15(11), 1982-90 (1960).

[19] Trnovcova, V., "Ionic Conductivity and Cation Self-diffusion in Sodium Chloride Crystals Doped with Calcium or Cadmium," Czech. J. Phys., B, 19, 663-76 (1969).

[20] Bhatia, R., "The Conductivity of Direct Compression Materials and Its Relation to Hardness in Aged Compacts," Rutgers University, New Brunswick, N.J., Ph.D. Thesis, 152 pp. (1976).

[21] Biermann, W., "The Pressure Dependence of Electrical Conductivity of Alkali Halides, I.," Z. Phys. Chem., 25, 90-107 (1960).

[22] Tammann, G. and Veszi, G., "Electrical Conductivity of Salts in Single Crystals and Crystalline Conglomerates," Z. Anorg. Allg. Chem., 150, 355-80 (1926).

[23] Benrath, A. and Wainoff, J., "On the Electrical Conductivity of Salts and Salt Mixtures," Z. Phys. Chem., 77, 257-68 (1911).

[24] Rautenfeld, F., "The Conduction of Electricity in Crystals," Ann. Physik, 72, 617-28 (1923).

[25] Rautenfeld, F., "Correction and Addendum to my Paper on the Conduction of Electricity in Crystals," Ann. Physik, 75(4), 848-50 (1924).

[26] Hochberg, B. and Walther, A., "Investigation of the Electrical Conductivity of Sodium Chloride Crystals," Z. Phys., 64, 392-401 (1930).

[27] Quittner, F., "Dependence of Electrical Ionic Conductivity of Single Crystals on Field Strength," Z. Physik., 56, 597-603 (1929).

[28] Gyulai, Z., "The Electrical Conductivity of Deformed Sodium Chloride Crystals and Their Crystalline Structure," Z. Physik, 96, 210-8 (1935).

[29] Gingold, J., "The Electricity Conduction in Solid Sodium Chloride at Room Temperature," Z. Physik, 50, 633-43 (1928).

[30] Tomka, P., "Contributions About the Electrical Conduction of Discolored and Nondiscolored Alkali-Halogenide Crystals," Acta Phys. Acad. Sci. Hung., 2, 209-22 (1952).

[31] Lidiard, A.B., "Ionic Conductivity," Encyclopedia of Physics, 20, 246-349 (1957).

[32] Van Artsdalen, E.R. and Yaffe, I.S., "Electrical Conductance and Density of Molten Salt Systems: Potassium ChlorideLithium Chloride, Potassium Chloride-Sodium Chloride and Potassium Chloride-Potassium Iodide," J. Phys. Chem., 59, 118-27 (1955)

[33] Ketelaar, J.A.A. and Maenaut, P.P.E., "Electrical Conductivity of Molten Sodium Chloride and Its Use as a Reference Salt at $1000^{\circ} \mathrm{C}$," Electrochim. Acta, 17(12), 2195-203 (1972).
[34] Huber, R.W., Potter, E.V., and St. Clair, H.W., "Electrical Conductivity and Density of Fused Binary Mixtures of Magnesium Chloride and Other Chlorides," U.S. Bureau of Mines, Washington, DC, 14 pp. (1952).

[35] Matiasovsky, K., Danek, V., and Lillebuen, B., "On the Frequency and Temperature-Dependence of the Conductivity of Molten Salts," Electrochim. Acta, 17(3), 463-9 (1972).

[36] Zuca, S. and Ionescu-Vasu, L., "Electrical Conductance of Binary Mixtures of Molten Salts with Common Cation," Rev. Roum. Chim., 12, 1285-93 (1967).

[37] Story, J.B. and Clarke, J.T., "Electrical Conductivity of Fused Sodium Chloride-Calcium Chloride Mixtures," J. Metals, 9, 1449-54 (1957).

[38] Arndt, K. and Gessier, A., "Conductivity Measurements of Molten Salts," Z. Elektrochem., 14(39), 662-5 (1908).

[39] Ryschkewitsch, E., "The Electrical Conductivity of Some Molten Salt Mixtures," Z. Elektrochem., 39(7), 531-7 (1933).

[40] Emons, H.H., Brautigam, G., and Vogt, H., "Electrical Conductivity of Molten Salt Mixtures of Alkaline Earth Alkali Metal Chloride," Z. Anorg. Allgem. Chem., 394(3), 263-70 (1972).

[41] Shabanov, O.M., Gadzhiev, S.M., and Tagirov, S.M., "Effect of High Fields on the Electric Conductivity of Alkali Metal Chloride Melts," Elektrokhimiya, 9(11), 1742 (1973); English translation: Sov. Electrochem., 9(11), 1638 (1973).

[42] Braun, F., "The Galvanical Conductivity of Molten Salts," Ann. Physik, 154(2), 161-96 (1875).

[43] Bizouard, M., "The Electrical Conductivity and Cryometry of Molten Salt Solutions," Ann. Phys. 6, 851-911 (1961).

[44] Shabanov, O.M., Gadzhiev, S.M., and Tagirov, S.M., "Depend. ence of the Conductivity of Molten Lithium, Sodium, and Potassium Chlorides on the Electric Field Strength," Elektrokhimiya, 9(12), 1828-32 (1973); English translation: Sov. Electrochem., 9(12), 1721-4 (1973).

[45] Janz, G.J., Dampier, F.W., Lakshminarayanan, G.R., Lorenz, P.K., and Tomkins, R.P.T., "Molten Salts: Volume 1, Electrical Conductance, Density, and Viscosity Data," NSRDS-NBS 15, 139 pp. (1968).

[46] Janz, G.J., Tomkins, R.P.T., Allen, C.B., Downey, J.R., Jr., Gardner, G.L., Krebs, U., and Singer, S.K., "Electrical Conductance, Density, Viscosity, and Surface Tension Data," J.Phys. Chem. Ref. Data, 4(4), $871-1178$ (1975).

[47] Pierce, C.B., "Effect of Hydrostatic Pressure on Ionic Conductivity in Doped Single Crystals of Sodium Chloride, Potassium Chloride, and Rubidium Chloride," Phys. Rev., 123(3), 744-54 (1961).

[48] Cleaver, B., Smedley, S.I., and Spencer, P.N., "Effect of Pressure on Electrical Conductivities of Fused Alkali Metal Halides and Silver Halides," J. Chem. Soc., Faraday Trans. 1, 68(9), 1720-34 (1972).

[49] Yoon, D.N. and Lazarus, D., "Pressure Dependence of Ionic Conductivity in Potassium Chloride, Sodium Chloride, Potassium Bromide, and Sodium Bromide," Phys. Rev. 3B, 5(12), 4935-45 (1972).

[50] Kolrausch, F.W., Holborn, L. and Diesselhorst, H., "New Basis for the Values of Thermal Conductivity of Electrolyte," Ann. Physik., 63(3), 417-55 (1898).

[51] Henderson, W.E., and Kellogg, D.A., "The Hydrolysis of Ethyl Acetate by Neutral Salt Solutions," J. Amer. Chem. Soc., 35, 396-418 (1913). 
[52] Gunning, H.E. and Gordon, A.R., "The Conductance and Ionic Mobilities for Aqueous Solutions of Potassium and Sodium Chloride at Temperatures from $15^{\circ}$ to $45^{\circ} \mathrm{C}$," J. Chem. Phys., 10, 126-31 (1942).

[53] Lorenz, R. and Michael, W., "Concerning the Conductivity of Single Binary Electrolytes," Z. Angor. Allg. Chem., 116, 161-82 (1921).

[54] Walden, P. and Ulich, H., "Conductivity Measurements on Dilute Aqueous Salt Solutions at $0^{\circ}, 18^{\circ}$, and $100^{\circ} \mathrm{C}, " \mathrm{Z}$. Phys. Chem., 106, 49-92 (1923).

[55] Kohlrausch, F. and Grotrian, 0., "Part III: The Electric Conductivity of the Alkali and Alkaline Earth Fluorides as Well as Electrical Conductivity of Metric Acids and Aqueous Solutions," Ann. Physik, 154, 215-39 (1875).

[56] Noyes, A.A. and Coulidge, W.D., "The Electrical Conductivity of Aqueous Solutions. Part II. Original Apparatus and Method. Conductivity and Ionization of Sodium and Potassium Chlorides up to $360^{\circ} \mathrm{C}$," Carnegie Inst. of Washington, Publ. 63, 7-55 (1907).

[57] Noyes, A.A. and Falk, K.G., "The Properties of Salt Solutions in Relation to the Ionic Theory. III. Electrical Conductance," J. Amer. Chem. Soc., 34, 454-85 (1912).

[58] Washburn, E.W. and Klemens, P., "Electrical Conductivity of Aqueous Solutions. Part I. Conductivity of Neutral Halides, Nitrates and Sulfates," in International Critical Tables of Numerical Data, Physics, Chemistry and Technology (Washburn, E.W., Editor-in-Chief), Vol. 6, McGraw-Hill Book Co., Inc., New York, 230-40 (1929).

[59] Murri, W. and Doran, D.G., "Electrical Effects of Shock Waves: Conductivity in Cesium Iodide, Potassium Iodide and Sodium Chloride," Stanford Research Inst., Menlo Park, Calif., 79 pp. (1965). [AD 625 568]

[60] Laboratory for Insulation Research, Massachusetts'Institute of Technology, "V Tables of Dielectric Materials," in Dielectric Materials and Applications (von Hippel, A.R., Editor), The Technology Press of M.I.T. and John Wiley and Sons, Inc., New York, 291-433 (1954).

[61] Breckenridge, R.G., "Low Frequency Dispersion in Ionic Crystals," J. Chem. Phys., 16(10), 959-67 (1948).

[62] DiGiura, V. and Spinolo, G., "Measurement of the Low Frequency Dielectric Constant in Some Alkali Halides," Nuovo Cimento, B, 56(1), 192-4 (1968).

[63] Lowndes, R.P., "The Temperature Dependence of the Static Dielectric Constant of Alkali, Silver, and Thallium Halides," Phys. Lett., 21 (1), 26-7 (1966).

[64] Haussuhl, S., "The Dielectric Constant of Alkali Halides of the Rock Salt Type," Z. Naturforsch., A, 12, 445-7 (1957).

[65] Jones, B.W., "The Dielectric Constant of Ionic Solids and Its Change with Hydrostatic Pressure," Phil Mag., 16, 1085-96 (1967).

[66] Eucken, A. and Buchner, A., "The Dielectric Constant of Weak Polar Crystals and Their Temperature Dependence," Z. Phys. Chem., (Leipzig), 27(5-6), 321-49 (1935).

[67] Matsonashvili, B.N., "Dielectric Constant, Dielectric Loss and Electric Conductivity of Alkali Halide Single Crystals," Izv. 4kad. Nauk, SSSR, Ser. Fiz., 22(3), 296-310, 1958; English translation: Bull. Acad. Sci., USSR, Phys. Ser., 22(3), 294-307 (1958).

168] Kosman, M.S. and Petrova, N.A., "Dielectric Constant of Rock Salt at High Temperature," Bull. Acad. Sci., USSR, Phys., Ser. 22(3), 308-11 (1958).

[69] Young, K.F. and Frederikse, H.P.R., "Compilation of the Static Dielectric Constant of Inorganic Solids," J. Phys. Chem. Ref. Data, 2(2), 313-409 (1973).
[70] Kyropoulos, S., "Dielectric Constants of Regular Crystals," Z. Physik, 63, 849-54 (1930).

[71] Schupp, P., "Measurement of the Dielectric Constants of Salts," Z. Physik, 75, 84-104 (1932).

[72] Pauley, J.L. and Chessin, H., "A Mixed-Liquid Method for the Determination of the Dielectric Constant of Solids," J. Amer. Chem. Soc., 76, 3888-90 (1954).

[73] Errera, J., "Relations Between Dielectrical and Optical Properties in Bodies with a Sodium Chloride-Lattice," Z. Elektrochem., 36(9), 818-22 (1930).

[74] Owens, J.C., "Phonon Anharmonicity and Microwave Absorption in Alkali Halide Crystals," Cruff Lab., Harvard Univ., Cambridge, Mass., (1964). [AD 610 689].

[75] Bretscher, E., "The Temperature Variation of the Dielectric Constant of Ionic Crystals," Trans. Faraday Soc., 30, 684-7 (1934).

[76] Bosman, A.J. and Havinga, E.E., "Temperature Dependence of Dielectric Constants of Cubic Ionic Compounds," Phys. Rev., 129(4), 1593-600 (1963).

[77] Mayburg, S., "Effect of Pressure on the Low Frequency Dielectric Constant of Ionic Crystals," Phys. Rev., 79(2), 375-82 (1950).

[78] Fleming, J.A. and Dewar, J., "On the Dielectric Constants of Certain Frozen Electrolytes at and above the Temperature of Liquid Air," Proc. Roy. Soc. (London), A61, 299-317 (1897).

[79] Parker, T.J., Ledsham, D.A., and Chambers, W.G., "Dispersive Reflection Spectroscopy in the Far-Infrared," Infrared Physics, 16, 293-7 (1976).

[80] Scaife, B.K.P., Scaife, W.G.S., Mahmud, K.R., and Kamath, K., "Pressure Dependence of the Dielectric Properties of Some Organic Liquids and of Fifteen of the Alkali Halides," Trinity College, Dublin (Ireland), AFOSR-TR-69-0383, 175 pp. (1968).

[81] Nevald, R., "Breakdown Strength of Alkali Halides as a Function of Temperature and Dislocation Density," LIR-TR-193, Lab. for Insulation Res., Massachusetts Inst. Tech., Cambridge, 22 pp. (1964). [AD 608 827].

[82] Haven, Y., "Dielectric Losses of Sodium Chloride Crystals," Chem. Phys., 21, 171-2 (1953).

[83] Haven, Y., "Concentration and Association of Lattice Defects in Sodium Chloride," Defects Cryst. Solids, Rep. Conf., 261-72 (1955).

[84] Bayley, P.L., "Dielectric Losses in Rock Salt," Phys. Rev., 43, 355-7 (1933).

[85] Vodop'ianov, K.A. and Galibina, G.I., "Dielectric Loss at High Frequencies in Pure and Mixed Alkali Halide Crystals," Bull. Acad. Sci., USSR, Phys. Ser., 22(3), 287-93 (1958).

[86] Breckenridge, R.G., "Low Frequency Dispersion in Ionic Crystals Containing Foreign Ions," J. Chem. Phys., 18(7), 913-26 (1950).

[87] D'yachenko, N.G., Tyurin, A.V., and Sheveleva, A.S., "Short Term Electrical Relaxation in Alkali Halide Crystals," Izv. Vyssh. Ucheb. Zaved., Fiz., 16(6), 101-6 (1973); English translation: J. Sov. Phys., 16(6), 824-8 (1973).

[88] Jacobs, G., "Dielectric Relaxation in Sodium Chloride Crystals," Naturwiss., 42, 575-6 (1955).

[89] Lal, K. and Pahwa, D.R., "Determination of Vacancy Jump Frequencies from Dielectric Loss Measurements on Ni++ Doped NaCl Crystals," Phys. Rev. B, 4(8), 2741-5 (1971).

[90] von Hippel, A. and Lee, G.M., "Scattering, Trapping, and Release of Electrons in Sodium Chloride and in Mixed Crystals of Sodium Chloride and Silver Chloride," Phys. Rev., 59, 824-6 (1941).

[91] Caspari, M.E., "Directional Breakdown in Alkali Halide Crystals," Phys. Rev., 98(6), 1679-91 (1955). 
[92] von Hippel, A. and Alger, R.S., "Breakdown of Ionic Crystals by Electron Avalanches," Phys. Rev., 76(1), 127-33 (1949).

[93] von Hippel, A., "Electrical Strength and Crystal Structure," Z. Physik., 75, 145-70 (1932).

[94] Pikalova, I.S., "Investigation of the Breakdown of Rocksalt in the Micron and Submicron Range of Thicknesses," Fiz. Tverd. Tela, 8(7), 2242-4 (1966); English translation: Sov. Phys. Solid State, 8(7), 1784-5 (1967).

[95] Vorob'ev, A.A., Vorob'ev, G.A., and Murashko, L.T., "Anisotropy of the Electric Strength of Rocksalt." Fiz. Tverd. Tela, 4(7), 1967-8, 1962; English translation: Sov. Phys. Solid State, 4(7), 1441 (1963).

[96] Vorob'ev, G.A. and Shirokov, V.A., "Question of the Temperature Dependence of the Electrical Strength of Solid Dielectrics," Izv. Vyssh. Ucheb. Zaved., Fiz., 15(11), 141-3 (1972).

[97] Turner, L.A., "The Propagation of Electron Waves in Ionic Single Crystals," Phys. Rev., 57, 156-7 (1940).

[98] Cooper, R., "The Electric Breakdown of Alkali Halide Crystals." in Progress in Dielectrics (Birks, J.B., General Editor), Vol. 5, Academic Press, Inc., New York, NY, 95-141 (1963).

[99] Ishiwara, T., "On the Thermomagnetic Properties of Various Compounds at Low Temperatures," Sci. Rept. Tohoku Imp. Univ., 3(1), 303-19 (1914).

[100] Ikenmeyer, K., "The Magnetic Susceptibility of the Alkali and Earth Alkali Halogenides," Ann. Physik, 1(2), 169-91 (1929).

[101] Hoare, F.E., "The Diamagnetic Susceptibilities of Salts Forming Ions with Inert Gas Configurations. Part I. The Halides of Sodium and Potassium," Proc. Roy. Soc. (London) A, 147, 88-100 (1934).

[102] Brindley, G.W. and Hoare, F.E., "The Diamagnetic Susceptibilities of Salts Forming Ions with Inert Gas Configurations. II. The Alkaline Halides," Proc. Roy. Soc. (London) A, 152, 342-3 (1935).

[103] Kido, K., "Diamagnetic Susceptibilities of Inorganic Compounds. Part I. Acids, Alkali and Alkali-Earth Salts," Sci. Rept. Tohoku Imp. Univ., 21, 149-70 (1932).

[104] Smirnov, M.V., Kudyakov, V.Ya., and Zyryanov, A.S., "Variation in the Magnetic Susceptibility of Alkali Halides on Melting," Teor. Eksp. Khim., 10(6), 829-32 (1974); English translation: Theor. Exp. Chem., 10(6), 685-7 (1974).

[105] Voigt, W. and Kinoshita, S., "Determination of the Absolute Values of Magnetisation Numbers, Especially for Crystals," Ann. Phys., 24(4), 492-514 (1907).

[106] Arendt, R.H. and Nachtrieb, H., "The Magnetic Susceptibility of Molten Sodium-Sodium Chloride Solutions," AFOSR-TR-1107, Dept. of Chemistry, Chicago Univ., Ill., 20-53 (1970). [AD 705 676]

[107] Hoare, F.E. and Brindley, G.W., "The Diamagnetic Susceptibilities of Dissolved and Hydrated Salts," Proc. Phys. Soc. (London), 49, 619-28 (1937).

[108] Pearlstein, E.A., "Change of Electrical Conductivity of Sodium Chloride Upon Bombardment with High-Energy Protons," Phys. Rev., 92(4), 881-2 (1953)

[109] Pearlstein, E. and Ingham, H., "Changes of Electrical Conductivity of Alkali Halides Upon Irradiation with HighEnergy Protons and Gamma Rays," in Conference of Effects of Radiation on Dielectric Materials, Office of Naval Research, Department of the Navy, Washington, DC, 31-6 (1954). [PD 111 863]
[110] Ishiguro, M., Oda, F., and Fujino, T., "Plastic Flow and the Low-Frequency Dispersion in the Alkali Halide Crystal," Phys. Rev., 95, 1347-8 (1954).

[111] Minaev, S.M., Lebedinskaya, E.N., and Melik-Gaikazyan, I.Ya., "Electrical Breakdown of Alkali Halide Whisker Crystals as Affected by Temperatures and F-Centre Concentration," Izu. Vuz. Fiz., USSR, 19(9), 124-6 (1976); English translation: J. Sov. Phys., 19(9), 124-6 (1976).

[112] Mapother, D., "Self Diffusion and Ionic Conductivity of the Sodium Ion in Sodium Chloride," Carnegie Inst. of Technology, Pittsburgh, PA, 89 pp. (1949). [AD 49 215]

[113] Whitham, W. and Calderwood, J.H., "Electrode Behavior and the Determination of Defect Energies from Measurements of Ionic Conductivity in Sodium Chloride Crystals," IEEE Trans. Elec. Insul. 8(2), 60-8 (1973).

[114] Janz, G.J., Gardner, G.L., Krebs, U., and Tomkins, R.P.T., "Molten Salts: Volume 4, Part 1, Fluorides and Mixtures Electrical Conductance, Density, Viscosity, and Surface Tension Data," J. Phys. Chem. Ref. Data, 3(1), 1-115 (1974,

[115] Janz, G.J., Krebs, U., Siegenthaler, H.F., and Tomkins, R.P.T., "Molten Salts: Volume 3, Nitrates, Nitrites, and Mixtures. Electrical Conductance, Density, Viscosity, and Surface Tension Data," J. Phys. Chem. Ref. Data, 3(1), 581-746 (1972).

[116] Scaife, B.K.P., Complex Permittivity: Theory and Measurement, The English Universities Press Ltd., London, England, 170 pp. (1971).

[117] Anderson, J.C., Dielectrics, Reinhold Publishing Corporation, New York,171 pp. (1964).

[118] von Hippel, A.R., Dielectrics and Waves, John Wiley and Sons, Inc., New York, 284 pp. (1954).

[119] von Hippel, A.R. (Editor), Dielectric Materials and Applications, The Technology Press of MIT and John Wiley and Sons, Inc., New York, 438 pp. (1954).

[120] Vaughan, W.E., Smyth, C.P., and Powles, J.G., "Determination of Dielectric Constant and Loss," in Physical Methods of Chemistry, Vol. 1, Part IV of Techniques of Chemistry (Weissberger, A. and Rossiter, B.W., Editors), WileyInterscience, New York, 351-95 (1972).

[121] O'Dwyer, J.J., The Theory of Electrical Conduction and Breakdown in Solid Dielectrics, Clarendon Press, Oxford, England, 326 pp. (1973).

[122] Kittel, C., Introduction to Solid State Physics, Third Edition, John Wiley and Sons, Inc., New York, 648 pp. (1966).

[123] Selwood, P.W., Magnetochemistry, Second Edition, Interscience Publishers, Inc., New York, NY, 435 pp. (1956).

[124] Mulay, L.N., "Techniques for Measuring Magnetic Susceptibility," in Physical Methods of Chemistry, Vol. 1, Part IV of Techniques of Chemistry (Weissberger, A. and Rossiter, B.W., Editors), Wiley-Interscience, New York, 431-553 (1972).

[125] Homan, C.G., Rich, F.J., and Frankel, J., "Pressure Effect on Ionic Conductivity in NaCl," Phys. Rev. B, 14(6), 2672-80 (1976).

[126] Korovkin, K.N., Oks, N.A., Bylyna, E.A., and Evdokimov, V.B., "Magnetic Torsion Balance," Russ. J. Phys. Chem., 35(3), 330-2 (1961).

[127] Olhoeft, G.R., "Electrical Properties of Salt Cored from Carlsbad, New Mexico," U.S. Geological Survey Open File Report 78-463, 4 pp. (1978).

[128] Olhoeft, G.R., Private communication, Geological Survey, U.S. Dept. of the Interior, July 11, 1979. 
Symbols and Units

\begin{tabular}{lll}
\hline \hline Symbol & Name & Unit \\
\hline tan $\delta$ & Tangent of the loss angle & dimensionless \\
$T$ & Temperature & $\mathrm{K}$ \\
$\epsilon$ & Real part of the dielectric constant & dimensionless \\
$\nu$ & Frequency & $\mathrm{Hz}$ \\
$o$ & Electrical conductivity & $\mathrm{S} \mathrm{m}^{-1}$ \\
${ }_{\text {intrinsic }}$ & Intrinsic electrical conductivity & $\mathrm{S} \mathrm{m}^{-1}$ \\
$\chi_{\text {M, mass }}$ & Magnetic mass susceptibility & $\mathrm{im}^{3} \mathrm{~kg}^{-1}$ \\
$\rho$ & Electrical resistivity & $\Omega \mathrm{m}$ \\
\hline
\end{tabular}

Conversion Factors

\begin{tabular}{|c|c|c|}
\hline \multicolumn{3}{|l|}{ Temperature } \\
\hline $\begin{array}{c}\text { To convert from } \\
\mathbf{K} \\
\mathbf{K}\end{array}$ & $\begin{array}{l}\text { to } \\
{ }^{\circ} \mathrm{C} \\
{ }^{\circ} \mathrm{F}\end{array}$ & $\begin{array}{l}\text { Use } \\
\mathrm{K}-273.15 \\
(\mathrm{~K}-273.15) 9 / 5+32\end{array}$ \\
\hline \multicolumn{3}{|c|}{ Electrical Conductivity } \\
\hline To convert from & to & Multiply by \\
\hline$S \mathrm{~m}^{-1}$ & $\Omega^{1} \mathrm{~cm}^{-1}$ & $10^{-2}$ \\
\hline$S \mathrm{~m}^{-1}$ & $\Omega{ }^{1}$ in $^{-1}$ & $2.54 \times 10^{-2}$ \\
\hline$S \mathbf{m}^{-1}$ & $\Omega{ }^{1} \mathrm{ft}^{-1}$ & $3.048 \times 10^{-1}$ \\
\hline$S \mathrm{~m}^{-1}$ & $\Omega{ }^{1} \mathrm{cmil}^{-1} \mathrm{ft}$ & $1.66243 \times 10^{-9}$ \\
\hline$S \mathrm{~m}^{-1}$ & $(\mu \Omega \mathbf{c m})^{-1}$ & $1 \times 10^{-8}$ \\
\hline
\end{tabular}


NBS-114A (REV, 9-7B)

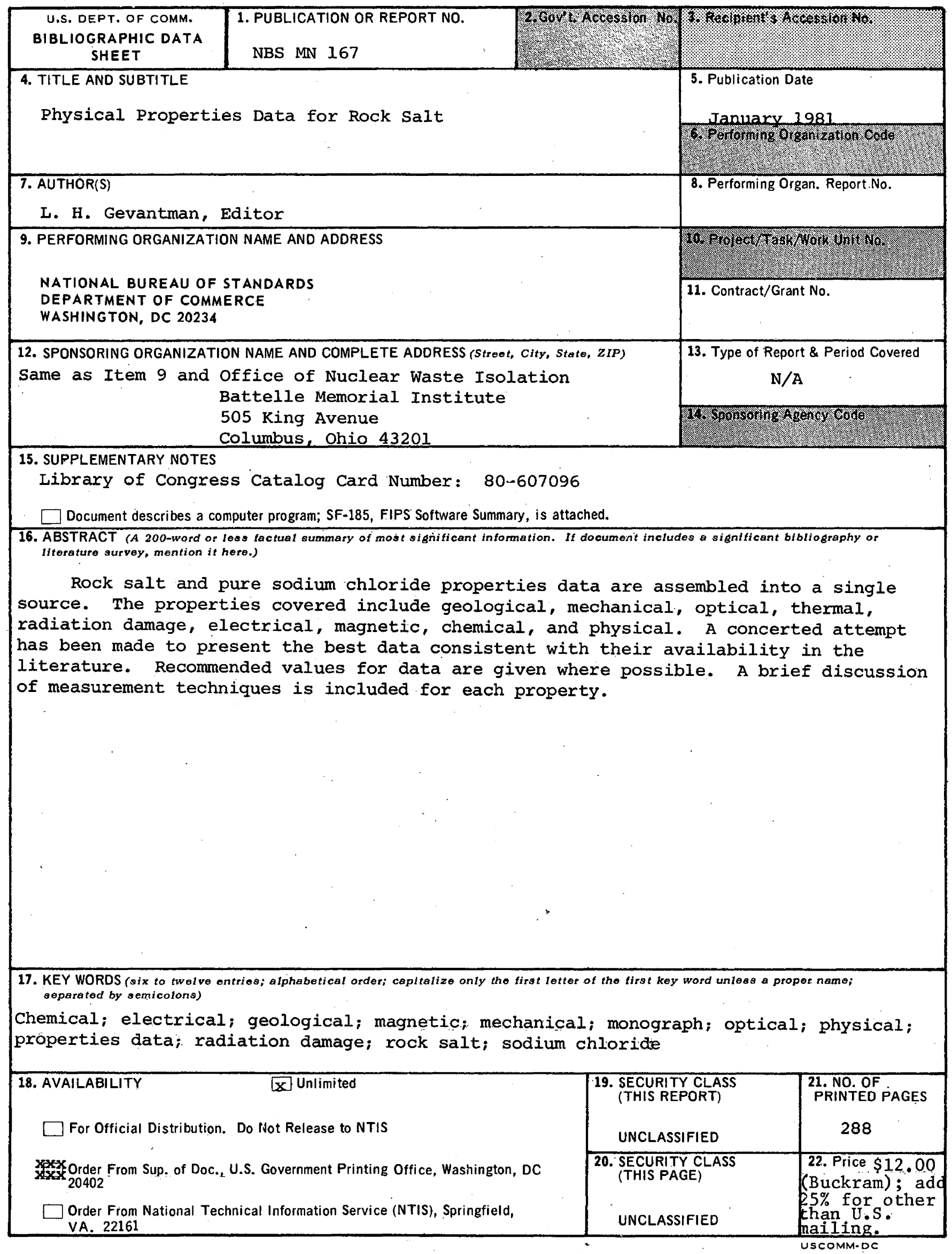




\section{Where can you find all the reference data you need?}

Right in the Joumal of Physical and Chemical Reference Data!

Now in its sixth year, this valuable publication has proved that it fills the important gaps for you in the literature of the physical sciences.

Published by the American Institute of Physics and the American Chemical Society for the National Bureau of Standards, this quarterly gives you quantitative numerical data, with recommended values and uncertainty limits chosen by experts in the field.

Critical commentary on methods of measurement and sources of error, as well as full references to the original literature, is an integral part of each of your four issues a year.

Can you afford to be without this prime source of reliable data on physical and chemical properties? To start receiving your copies, just fill in the order form and drop into the mail. If you do use a purchase order, please attach the printed form as this will help us to expedite your order. Send for complete list of reprints!

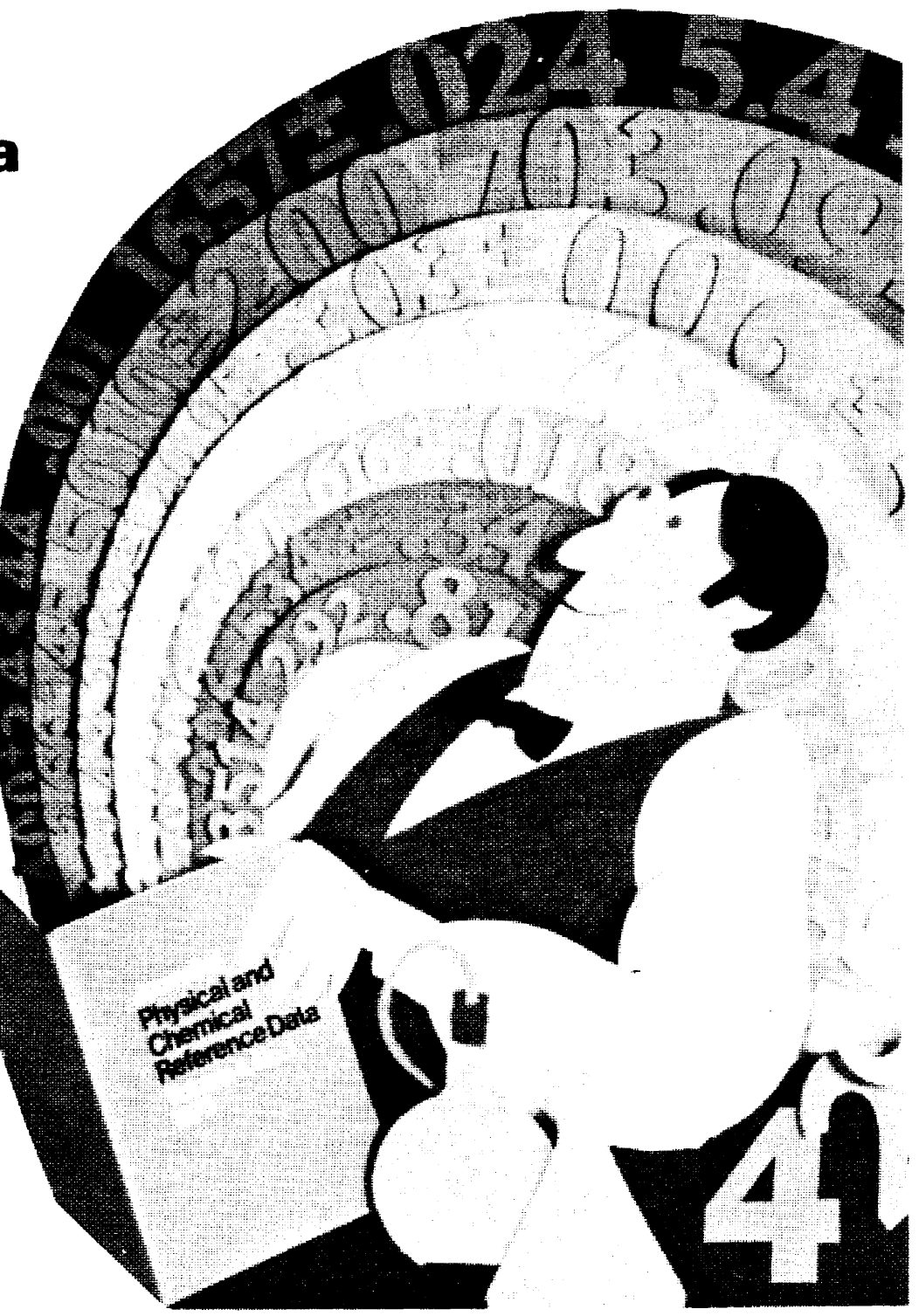

Journal of Physical and Chemical Reference Data American Chemical Society

1155 Sixteenth Street,N.W., Washington, D.C. 20036

Yes, I would like to receive the JOURNAL OF PHYSICAL AND CHEMICAL REFERENCE DATA at the one-year rate checked below:

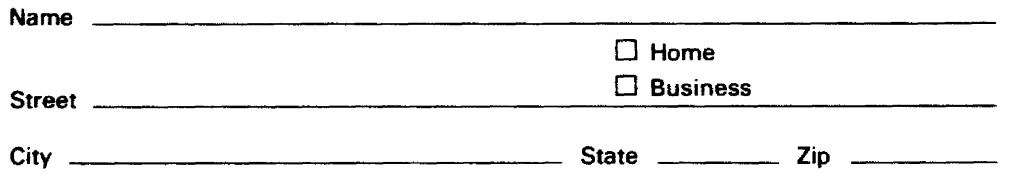

Bill me $\square \quad$ Bill company or school $\square \quad$ Payment enclosed $\square$

$\begin{array}{ll} & \text { Members Nonmembers } \\ \text { M.S., Canada, } & \square \$ 25.00 \square \$ 100.00 \\ \text { Maxico } & \square \$ \$ 29.00 \square \$ 104.00\end{array}$

Please Attach This Order Form To Purchase Order. 


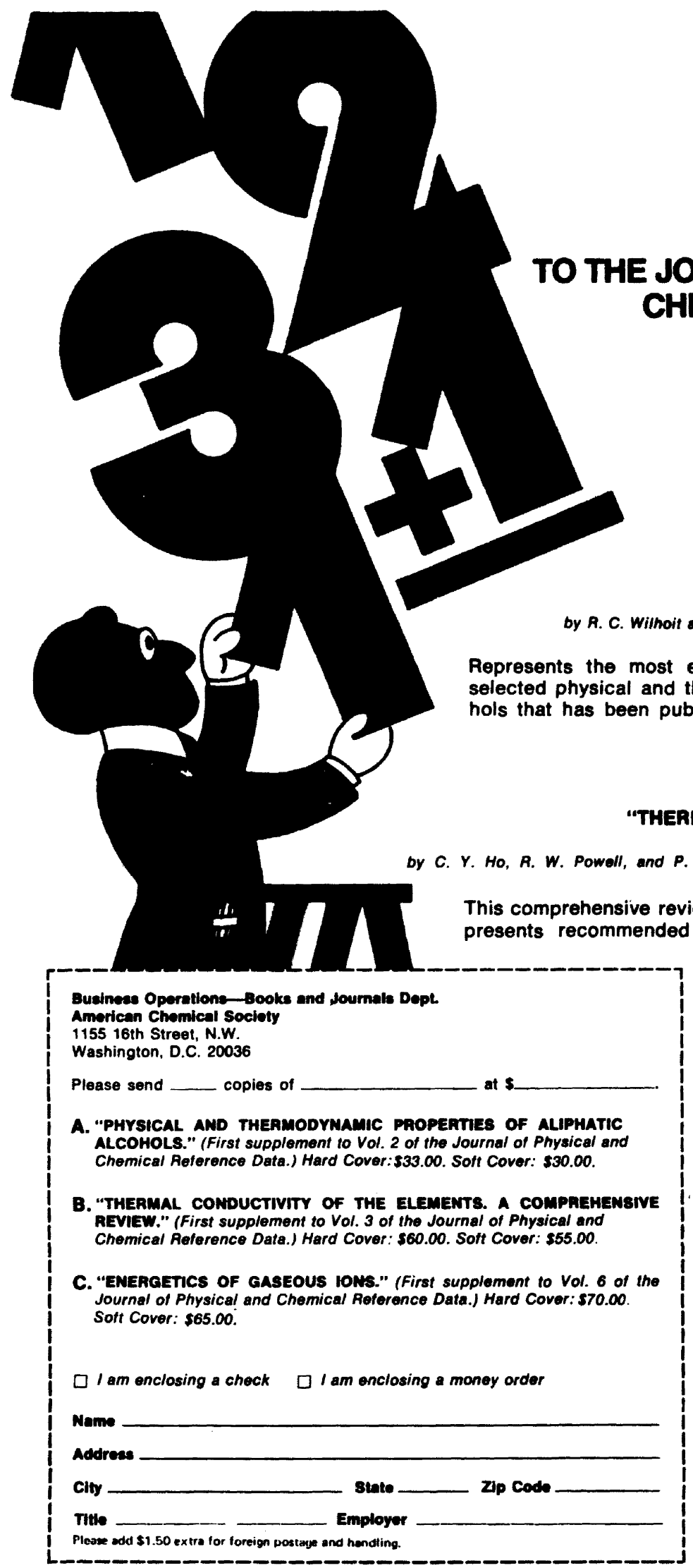

Three comprehensive reference volumes, each, as the Journal itself, published by the American Institute of Physics and the American Chemical Society for the National Bureau of Standards ... your triple assurance of their accuracy, immediacy. and usefulness.

Supplement No. 1 to $\mathrm{Vol} .2$

"PHYSICAL AND THERMODYNAMHC PROPERTIES OF AUPHATIC ALCOHOLS" d B. J. Zwolinski, Thermodynamics Aosearch Center, Department of Chemistry. Texas A \& M University Represents the most exhaustive review and critical analysis of selected physical and thermodynamic properties of aliphatic alcohols that has been published in the world literature of chemistry.

\section{A COMPREhENSIVE REVIEW"}

Supplement No. 1 to Vol. 3 A Cormophysal Properties Research Center, Purdue University, West Lalayette, Indiane

This comprehensive review of the world's thermal conductivity data presents recommended or estimated values for all 105 elements.

Busineas Oparations-Books and soumals Dept ican Chomical Socioty

Please send _ copies of at $\mathbf{s}$

"PHYSICAL AND THERMODYMAMIC PROPEATIES OF ALIPHATIC ALCOHOLS." (First supplement to Vol. 2 of the Journal of Physical and

A COMPAEHENSIV REVIEW." (First supplement to Vol. 3 of the Journal of Physical and

"ENERGETICS OF GASEOUS IONS." (First supplement to Vol. 6 of the Journal of Physical and Chemical Reference Data.) Hard Cover: $\$ 70.00$. Sott Cover: $\$ 65.00$

I am enclosing a check

I am enclosing a money order

City

Zpp Code

ad hendting.
Supplement No. 1 to Vol, 6 ENERGETICS OF GASEOUS IONS

by H. M. Rosenstock, K. Draxl, B. Steiner, ano J. T. Herron, National Bureau of Standarde

Provides a comprehensive body of critically evaluated information on ionization potentials, appearance potentials, electron affinities and heats of formation of gaseous positive and negative ions. It is a complete revision and extension of the earlier reference work, "Ionization Potentials, Appearance Potentials and Heats for Formation of Gaseous Positive lons," NSRDS-NBS 26. 


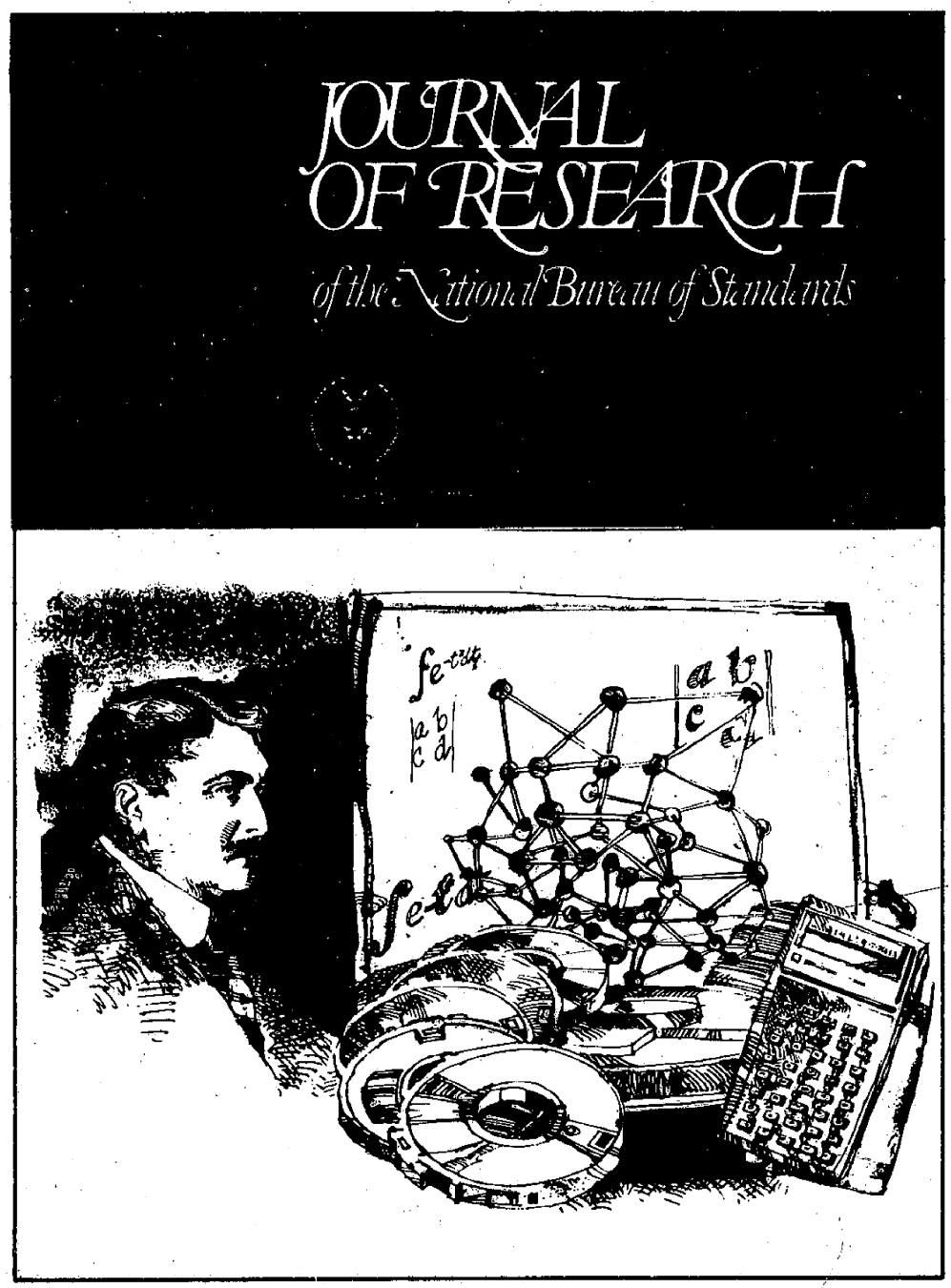
The new Clational Burean of Standards Journal

The expanded Journal of Research of the National Bureau of Standards reports NBS research and development in those disciplines of the physical and engineering sciences in which the Bureau is active. These include physics, chemistry, engineering, mathematics, and computer sciences. Papers cover a broad range of subjects, with major emphasis on measurement methodology, and the basic technology underlying standardization. Also included from time to time are survey articles on topics closely related to the Bureau's technical and scientific programs. As a special service to subscribers each issue contains complete citations to all recent NBS publications in NBS and nonNBS media. Issued six times a year. Annual subscriptions: domestic $\$ 17.00$; foreign $\$ 21.25$. Single copy, $\$ 3.00$ domestic; $\$ 3.75$ foreign.

- Note: The Journal was formerly published in two sections: Section A "Physics and Chemistry" and Section B "Mathematical Sciences."

\section{NBS Board of Editors}

Churchill Eisenhart,

Executive Editor (Mathematics)

John W. Cooper (Physics)

Donald D. Wagman (Chemistry)

Andrew J. Fowell (Engineering)

Joseph O. Harrison (Computer Science)

Howard J. M. Hanley (Boulder Labs.)

\section{Subscription Order Form \\ Enter my subscription to NBS Journal of Research \\ at $\$ 17.00$. Add $\$ 4.25$ for foreign mailing. No additional postage is required for mailing within the United States or its possessions. (S.JAA-File Code 2N)}

Send Subscription to:

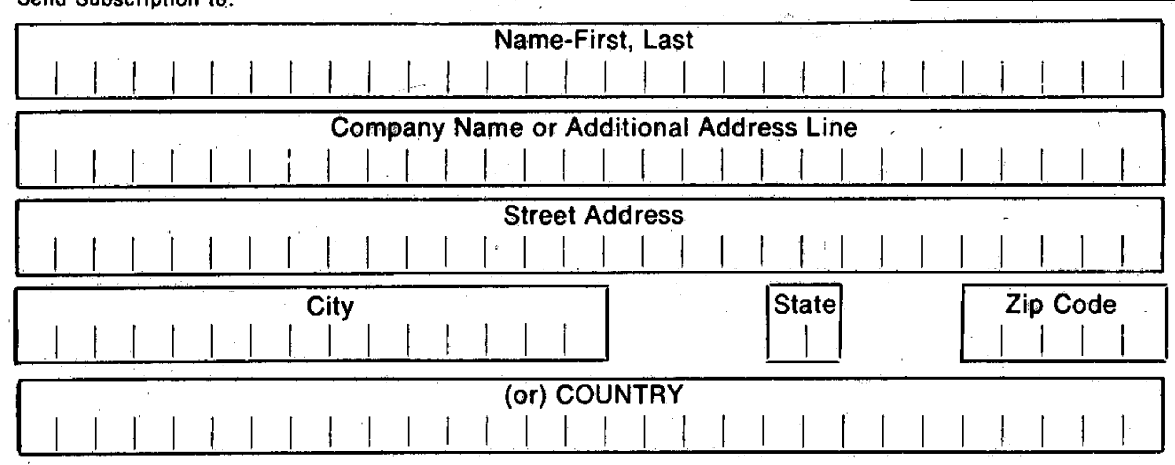

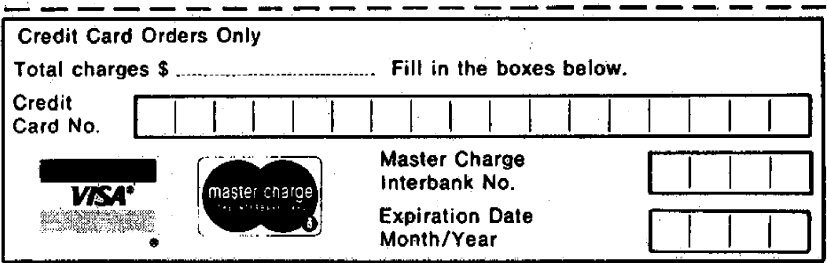

$\square$ Remittance Enclosed. Domestic: Check or money order. Foreign International money order, draft on an American or Canadian Bank, or by UNESCO coupons, Made payable to the Superintendent of Documents. Charge to my Deposit Account No.

MAIL ORDER FORM TO: Superintendent of Documents Government Printing Office Washington, D.C. 20402 